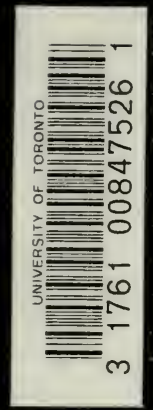


Digitized by the Internet Archive in 2008 with funding from Microsoft Corporation 


25

MORPHOLOGY OF ANGIOSPERMS 
(14. 


\section{MORPHOLOGY \\ OF ANGIOSPERMS}

(MORPHOLOGY OF SPERMATOPHYTES. PART II)

BY

JOHN MERLE COULTER, Ph. D.

HEAD OF DEPARTMENT OF BOTANY, THE UNIVERSITY OF CHICAGO

AND

CHARLES JOSEPH CHAMBERLAIN, PH. D. INSTRUCTOR IN BOTANY, THE UNIVERSITY OF CHICAGO

\section{ILLUSTRATED}
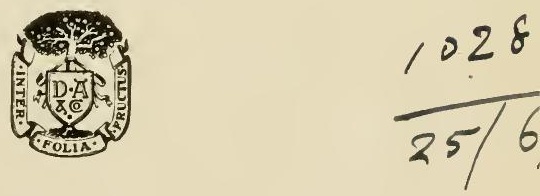

NEW YORK

D. APPLETON AND COMPANY

I 909 
COPYRIGHT, 1903

BY D. APPLETON AND COMPANY 


\section{P R E F A C E}

Is 1901 we published the first part of a work entitled Morphology of spermatophytes, containing an account of the Gymnosperms. At that time it was our purpose to issue as a second part an account of the Angiosperms, which would also contain a complete index of the whole work. We have become convinced, however, that such an association of these two great groups would help to emphasize a relationship that does not exist, and that Gymnosperms and Angiosperms should be treated as independent groups, coordinate with Pteridophytes. Therefore, the present rolume is issued, not as Part II of Morphology of Spermatophytes, but as an independent volume entitled Morphology of Angiosperms: and any subsequent edition of the previous volume will be entitled Morphology of Gymnosperms.

This volume, as the preceding, has grown out of a course of lectures accompanied by laboratory work, given for several successive years to classes of graduate students preparing for research. It seeks to organize the vast amount of scattered material so that it may be available in compact and related form. While careful attention has been given to citations, so that the student may know the groups that have been investigated, and be put in touch with the original papers, the work is in no sense a compilation. The ground has heen traversed repeatedly, for several rears, by various members of the botanical staff and by numerous students, and their results have served to check current statements, as well as to contribute no small amount of new material. 
Any one who has attempted to review the literature of the morphology of Angiosperms will appreciate the great amount of labor it involves, as well as the chaotic condition of terminology and citations. There is nothing more baffling than the attempt to follow the guidance of the meager, indefinite, and often incorrect citations of the standard texts. It is believed. therefore, that the attempt to reduce the numerous contributions to a consistent terminology and to make the citations fairly representative of the subject as well as definite and accurate will be of some real serrice to students of morphologr. 'The volume, therefore, seeks to give to the advanced student a continuous account of the structures involved, and to the research student the details of groups and bibliography that he needs.

In every case where figures have been copied, acknowledgment is made and a reference is given to the original paper containing the illustration. It should be noted that much information included in the legends does not appear in the text, so that in any thorough reading of the book the legends should be included. The bibliography pertaining to each subject is printed in chronological order at the end of each chapter containing numerous citations. At the close of the volume all of the cited bibliographr is brought together, arranged alphabetieally by authors.

It would be too large a task to include a complete bibliography of such a subject, but we have presented what may be regarded as a full representative bibliography, containing. so far as we know, all of the most important contributions. In the very nature of things, some citations mar have been omitted that should have been included, but there has been no intentional neglect.

No attempt is made to present the details of floral structure. so fully described by the earlier morphologists and taxonomists. since they are easily accessible in numerous texts. Nor have we rentured to enter the old and extensive field of anatomr, although many of its details are pertinent to morphology. In 
its later development, however, it has contributed so many important data essential in any discussion of phylogeny that we hare asked Professor E. C. Jeffrey to present the general outlines of the subject in the last two chapters of this volume, a discussion which includes both Gymnosperms and Angiosperms. It is hoped that this presentation will help to stimulate the cultivation of an important field of research too much neglected in this country.

It did not seem necessary to treat the two great groups of Angiosperms separately. They are so similar in their essential norphological features that their separate presentation would have involved a needless amount of repetition. The have also continued to regard the spore mother-cell as the end of the sporophytic generation, and its division as the beginning of the gametophyte. The reasons for this are more fully presented in the present rolume than in the preceding.

In the chapters upon classification we have presented the scheme elaborated by Professor Engler, believing that it is the best expression of current knowledge of relationship applied to the whole group, and that it is suggestive of the most critical regions for research. This has not been pressed to the dreary details of minor groups, for these are easily accessible. It has rather been our intention to present the general ideas involved in the alliances of first rank, so that principles rather than details may be prominent. We have also thought that the special student should be somewhat familiar with the history of the group, so far as known, its geographic distribution, and the current notions as to its phrlogeny. The last subject may be regarded as more theoretical than profitable, but the final aim of morphology is a definite phylogeny, and advance toward it must be made by a succession of theoretical conclusions.

Johy M. Coulter.

Charles J. Chamberlain.

The University of Chicago, January, 1903. 



\section{CONTENTS}

CBAPTER

\section{I.-IXTRODUCTORY}

Angiosperms and Gymnosperms contrasted, 1-Spermatophrtes not a natural group, 3-Monocotyledons and Dicotyledons contrasted, 4.

\section{II.-The Flower}

Definition of a flower, 9-Origin of floral leares, 9-Tendencies in the evolution of the flower, 10-Organogeny of the flower, 16 -Dioecism, 20-Morphology of floral members, 22-Stamen, 23 - Carpel, 24.

III.-The Microsporaxgiux

Origin from periblem, 27 -Cauline microsporangia, 28-Number of microsporangia, 29-Time of formation, 30-Development, 32-Archesporium, 32-Parietal layers, 34-Tapetum. 36Mother-cells, 38-Dehiscence, 41-Line of demarcation between sporophyte and gametophyte, 41 .

\section{IV.-The Megasporangiem}

Origin from periblem, 46-Cauline ovules, 46 -Foliar orules, 50 -Morphological nature of ovule, 51-Time of development of megasporangia, 52-Development of ovule, 53-Archesporium, 57-Parietal cells, 62-Mother-cell, 66.

V.-The Female Gametophyte

The tetrad, 71-Number of megaspores, 76-Reduction of chromosomes, 80-The functioning megaspore, 84-Number of embryo-sacs, 86-Germination of megaspore, 8i-Tariations in history, 89-Egg-apparatus, 93-Synergids, 94-Fusion of polar nuclei, 95-Antipodal cells, 96-Enlargenent of embryo-sac, 103 -The nutritive jacket, 103-Haustoria, 104-The mechanism for nutrition, 108.

VI.-The Male (iametophyte.

The tetrad. 121-Number of microspores. 125-The nuclear divisions of the pollen mother-cell, 126-The microspores. 131-Germination of microspore, 132-Division of generative cell, 135The male nuclei, 136. 
CHAPTER

VII.-Fertilization

Historical résumé, 143-Development of pollen-tube, 146-Chalazogamy, 14y-The pollen-tube within the embryo-sac, 151-Discharge of pullen-tube, 152-Fusion of male and female nuclei, 153-Centrosomes, 153-Double fertilization, 155-Male cell and male nucleus, 160.

VIII.-The ExdosperM

Contrast between Gymnosperms and Angiosperms, 165-The fusion nucleus, 166-Endosperm without fusion, 166-Endosperm and pollination, 16\%-Division of fusion nucleus, 169Two methods of endosperm-formation, 171-Function of endosperm, 179-Xenia, 179-Morphological character, 181-Nature of triple fusion, 182 .

IX.-Тне Емвrтo . . . . . . . . . . .

Monocotyledons, 188-Alisma type, 188-Pistia type, 192-

Lilium type, 19:-Orchid type, 194-Dicotyledons, 196-Capsella type, 199-Uther types, 200-Degree of development, 205

—"Pseudo-monocotyledons," 206-Phylogeny of the cotyledon, 208-Parthenogenesis, 210-Polyembryony, 213.

\section{X.-Classification of Monocotrledons}

Spiral series, 228-Cyclic series, 234.

Xi.-Classification of Archichlayideae

XII.Classification of SrMpetalae . . . . . . . 253

Xili.-Geographic Distribution of Axolosperis . . . . . . 261

Monocotyledons, 262-A rchichlamydeae, 266-Sympetalae, 268.

XIV.-Fossil ANgiosperis

Monocotyledons, 2テ2-Dicotyledons, $2 \approx 6$.

XV.-Phylogexy of Axgiosperys

Are Angiosperms monophyletic? 280-Relation to Gymnosperms, 283-Relation to Pteridophytes, 285-Theories of alternation of generations, 288-Theory of the strobilus, 288-The mutation theory, 292.

XTI.-Comparative Axatony of the GrmxosperMs aNd their AlLies

Pteridophỵtes, 296-Cycadofilices, 300-Cycadales, 304-Bennettitales, 306-Cordaitales, 30\%-Ginkgoales, 30\%-Coniferales, 308-Gnetales, 310.

XVII.-Comparative Axatomy of Axglosperys

Dicotyledons, 311-Monocotyledons, 314. 


\section{MORPHOLOGY OF ANGIOSPERMS}

\section{CHAPTER I \\ INTRODUCTORY}

THERE is a very large element of uncertainty in a presentation of the special morphology of Angiosperms, chiefly because of the vast amount of unstudied material, but also because of the inequality in the accuracy and definiteness of the work done. Howerer, the general outlines seem to be fairly well established, and their filling in must long occupy morphologists.

Although two rery distinct groups of Angiosperms are recognized, the Monocotyledons and the Dicotrledons, their essential morphologr is so similar that separate treatment would involve needless repetition. The chief differences between them have to do with the structure of the regetative bodr of the sporophrte. A general treatment of these differences is not neeessary in a book dealing with special morphology, for it belongs to elementary instruction; while a special treatment would lead into the immense field of anatomy, which it is not the purpose of this book to present. So far as anatomieal studies have a conspicuous bearing upon the phrlogens of the great groups, they are presented hy Professor E. C. Teffrey in the last two eliapters.

In eontrasting Angiosperms with Grmnosperms, one is impressed by the fact that a group of plants eomprising more than one hundred thousand known species can not be presented with the same confidence and detail as can a group represented by a scant four hundred species. And ret. what have been agreed upon as the essential morphological features of these groups appear to be more uniform in Angiosperms than in Gymnosperms. In our treatment of the latter group, the great 
divisions were presented separately because of the diversities; but the morphological diversities among Angiosperms seem to be not so much those of groups as of habit and habitat. While it is generally agreed that the seed-bearing habit was dereloped independently in more than one phylum, and that the Grmnosperms and Angiosperms have probably no immediate phylogenetic relation to one another, it is of interest to note the essential contrasting features of the two great seed-bearing groups.

The chief contrast in the sporophyte is that in Grmnosperms pollination results in bringing the pollen in contact with the orule, while in Angiosperms the result of pollination places the pollen in contact with a receptive surface developed by the carpel. This contrast inrolves great differences in morphological structure, so great, in fact, that it is hard to imagine one of these conditions as having been derived from the other. The method of pollination might also be mentioned as a contrasting feature, since the primitive anemophilous habit seems to be universal among the Gymnosperms, while among Angiosperms it prevails only among those groups that may be regarded as primitive. There accompanies this contrast a similar one in connection with the flower. Just how this structure may be defined is considered in the next chapter, but the characteristic flowers of Angiosperms have no representative among Grmnosperms, howerer much the older morphologs felt compelled to homologize them. However, the method of pollination and the flower are but corollaries to the fundamental contrast involved in the contact of the pollen with the orule in the one case, and with the carpel in the other.

A second fundamental distinction in connection with the -porophyte is to be found in the embryogeny of the two groups. In the Gymnosperms, the free nuclear division within the fertilized egg, and the use of the bulk of the egg as a food re-erve in most forms are in sharp contrast with the absence of free nuclear division in the Angiosperm egg, a character appearing, however, in Gnetum and Tumboa.

If the contrast between the sporophytes of Grmnosperms and Angiosperms be pressed into anatomical details, the differences are found to be quite as striking, though perhaps a little more nerplexing. 
The contrast between the gametophytes of the two groups, especially the female gametophytes, is even greater than that shown by the sporophytes. The male gametophytes of Gymnosperms when contrasted with those of heterosporous Pteridophytes present a much shorter history ; and the gametophytic structure produced by the Grmnosperm microspore involves the formation of two or three times as many cells as are formed in the germination of the Angiosperm microspore. The female gametophytes of the two groups, however, are in the main strikingly different. As is well known, the female gametophytes of Gymnosperms in general, with their well-organized tissue and archegonia, are almost the exact counterparts of those of Selaginella and Isoetes; while the female gametophyte of Angiosperms remains a morphological puzzle, made still more perplexing by the discovery of the wide-spread phenomenon styled " double fertilization." It is a rery significant fact, howerer, that in spite of the difficulties of the female gametophrte of Angiosperms in the way of interpretation and of origin, it is one of the most remarkably consistent structures known to morphologr, the sequence of events in its history representing an almost unvarying schedule, and supplying one of the strongest arguments in faror of the monophyletic origin of Angiosperms.

In riew of these and other differences between Angiosperms and Grmnosperms, the question is raised whether we have not been too narrow in the conception of the seed-bearing habit in compelling these two groups to remain as subdivisions of a group Spermatophytes coordinate with Pteridophytes and Bryophytes. In a certain sense, to select a single character, such as seed-bearing, as a basis for the union of two groups otherwise dissimilar is suggestive of artificial classification. Furthermore, to separate the female gametophytes of Gymnosperms from those of the heterosporous Lxcopodiales, and to associate them with those of Angiosperms, is certainly to do violence to a most important suggestion of natural relationships. In our judgment, therefore, the designation Spermatophrtes should be used in a general way, as a term of convenience rather than of classification, only less extensive in its application than "vascular plants"; and Gymnosperms and Angiosperms should be recognized as two groups coordinate 
with Pteridophytes and Bryophytes. In fact, Pteridophytes and Grmmosperms together form a much more natural group than do Grmnosperms and Angiosperms; and this fact should be emphasized by treating Grmnosperms and Angiosperms as groups of the first rank.

Although it is a question whether Grmnosperms and Angiosperms should be so closely associated as to form the tro subdivisions of a great group, there can be no question that Monocotyledons and Dicotyledons are naturally and intimately associated. This proposition is not affected by the question of their common origin, but is based upon their essential morphological features, whatever may have been their origin. The character's that separate Monocotyledons and Dicotyledons are cumulative rather than specific, and although the character of the embryo is held to be the decisive one in every case, there is danger of using it with umatural rigidity. When a decision between two groups is reduced to a single character, there is a suspicion either that the groups can only be separated artificially or that too much stress is laid upon the character. Monocotyledons and Dicotyledons are best distinguished br certain tendencies that involve sereral characters, and if these tendencies are supported by the character of the embryo the case is clear. A brief statement of the conspicuous differences may be of service.

1. In the embrso of Monocotyledons the cotyledon is terminal and the stem tip lateral in origin: while in Dicotyledons the stem tip is terminal and the cotyledons lateral in origin. This character seems to be fundamental, and at the present time is the only one that may be regarded as decisive. That the difference indicated will alwars be expressed in the abore terms is not likels, for the nature of the cotsledon is in question, and the significance of this relation of parts has yet to be determined.

2. The development of the vascular bundles in the stele is rery different in the two groups. This difference involves not only the arrangement of the bundles, but also the presence or absence of fascicular cambium, and is far-reaching in its re-ults upon the habit of the body. In the case of perennial stems it involres the general ability to increase in diameter, and this affects the power of branching, and this in turn deter- 
mines the question of an annual increase in the display of foliage, which means the working power of the body. This character can not be used as a specific test for the two groups; nor must it be pressed in certain features alone or too rigidly. When intelligently applied, it is probably only second in importance to the character supplied by the embryo; but it must be remembered that these prevailing tendencies of the two groups are in some instances exchanged.

3. The characteristic foliage leaves of Monocotyledons have a closed renation, while in Dicotyledons the renation is open. This character involves many differences in detail. For example, as a result the Monocotrledon leaf is entire, while the Dicotyledon leaf, with reins ending freely in the margin, is inclined to branch more or less, this tendencr expressing itself in the greatest variety of ways from simple teeth to the socalled "compound leaves." * It is also true in general that in Monocotyledons there is a sharp contrast in size betreen the principal veins of the leaf and the reticulating reinlets; while in Dicotyledons the gradation is so gradual that the reticulation becomes very evident. It may be well to call attention to the fact that while the so-called "parallel" renation may be of service in distinguishing the majority of Monocotyledons in temperate regions, as contrasted with the "pinnate" or "palmate" venation of Dicotyledons, it loses its significance when the tropical Monocotyledons are included. The distinctive character of closed or open renation can not be applied to all Monocotyledons and Dicotrledons, and is certainly less general in its application than the two characters already giren. As a. character to be used in a cumulative way, however, it deserres prominent mention.

4. Among Monocotyledons and Dicotyledons with cyclic flowers the establishment of three as the cycle number of the former, and of five or four as the cycle number of the latter is quite distinctive. In fact, the constancy with which these numbers appear is more remarkable than the exceptions. Of necessity, this character is of comparatively limited use, but it is of service among the crclic families, and also among those families some of whose floral parts are in crcles. The persist-

* This term should be abandoned for leaves, as has the term " compound flower" for the characteristic head of Compositae. 
ent tendency of the spiral groups of Monocotyledons and Dicotyledons to express the appropriate cyclic number, when the conditions seem to favor indefinite numbers, is even more remarkable than the constant reappearance of the cyclic number in families in which it has become established. Just what has determined these numbers for the two great groups is an interesting but unanswered question. The problem is confused by the fact that certain plants, undoubtedly Monocotyledons or Dicotyledons by all the usual tests, have the cycle number of the other group.

In addition to the distinguishing characters enumerated above, others of much less general application have been suggested, but it is not clear that any of them are really significant group characters.

There are certain general differences in the leaves of the two groups that deserve mention, since they come as near representing group tendencies as any of the secondary characters just enumerated. Among Dicotyledons the foliage leaf is generally more differentiated than among Monocotyledons, including a petiole and often stipules. In fact stipules would be quite characteristic of Dicotyledons were they not lacking in so many, for Monocotyledons possess no such structures. Among the latter, however, there is the almost equally characteristic leaf-sheath from which the blade directly arises. This general distinction between the leaves of the two groups must have some unappreciated significance, and suggests that it may represent something as fundamental as do the differences in the embryo and the stele.

The so-called "germination" of the seed is suggestive of different tendencies in the two groups, but the data seem to be too scanty and indefinite as yet for safe generalization. So far as they do exist, they indicate a tendency in Monocotyledons to free the stem and root tips by the elongation of a portion of the cotyledon, the other portion remaining in contact with the endosperm as a digesting and absorbing organ, very suggestive of the "font" of Pteridophytes; while in Dicotyledons the tendency is to liberate the growing points and cotyledons by the elongation of the hypocotyls and even hypogean cotyledons are not related to endosperm as digestive and absorbing organs. 
It is caimed that the prophyllum * of Monocotyledons is solitary and posterior, while in Dicotrledons there are two opposite and lateral prophylla. If such structures generally oceurred, or even if this distinction were generally true when they do occur, such a character would be significant, for the prophyllum certainly has a definite connection with the position of the successire floral parts in relation to the main axis.

It has been urged also that the Monocotyledons are characterized by a small embryo embedded in an abundant endosperm, and that in Dicotyledons the tendency is to derelop larger embryos at the expense of the endosperm. This involves so many and such important exceptions that it can hardly be regarded as a distinction between these two great groups.

The roots of Monocotyledons are said to differ from those of Dicotyledons in that the primary roots are short-lived and there is no persistent root-system as in many Dicotyledons. While this may be true of Monocotyledons in general, it is also true of many Dicotyledons, and can not be used as a distinctive character.

All the characters enumerated above, both those of primary and those of secondary importance, are to be considered in any general characterization of the two groups; but it must be remembered that most of them await confirmation as essential group characters. It is of interest to note that they are all characters of the regetative sporophyte, and that the sporangia and gametophytes of Monocotyledons and Dicotyledons have thus far giren no tangible eridence of group differences.

* Translated into German as Torblatt, and into English as fore-ltaf. The first leaf on a branch, but used only in connection with the bractlets of a flower cluster. 


\section{CHAPTER II}

\section{THE FLOWER}

THE morphology of the flower of Angiosperms has an enormous literature, much of which is now more curious than valuable. It is not the purpose of this book to present the numerous details and extensive terminology that were so conspicuous a feature of the older morphology, dominated as it was by the doctrine of metamorphosis. For these the student is referred to Eichler's Blïthendiagramme (1875-'78), in which may be found the most complete account of the flower of Angiosperms from this standpoint. The English student will also find an admirable short account of the same subject from the same standpoint in Gray's Structural Botany (1579). A presentation that combines much of the older method of treatment with newer points of view appears in Goebel's Outlines of Classification and Special Morphologr of Plants (English translation, 1857). Among the later important literature the following may be consulted: Goebel's Vergleichende Entwicklungsgeschichte der Pflanzenorgane in Schenck's Handbuch der Botanik (3 ${ }^{1}: 99-432$. figs. 126. 18s4); Celakorsky's Teber den phylogenetischen Entwicklnngsgang der Bliite und ïber den Lrsprung der Blumenkrone. I and II (Sitzher. Königl. Böhm. Gesell. W'iss. 1896 and 1900); Familler's Biogenetische Untersuchungen ïber verkiimmerte nder umgebildete Sexualorgane (Flora 82:133-168. figs. 10. 1896); Engler and Prantl's Die Natiirlichen Pflanzenfamilien; Goehel's Organographie der Pflanzen (rol. ii, 1901).* These works and others like them must be consulted for the details of the structure of angio-

* It should be understood that in this mention of the literature of the flower only certain important works are cited, and that only in the subsequent chapters is there any attempt at presenting fairly complete lists of the important literature. 
spermous flowers, for in this chapter only certain of the broader morphological features will be discussed.

Any strict definition of a flower seems to be impossible. That the morphological precursor of the angiospermous flower was some such structure as the strobilus of Pteridophytes seems reasonably clear. In fact, the strobilus is plainly continued among the Angiosperms in spiral flowers and spirally arranged members. The appearance of distinet floral leaves associated with sporophylls, however, is characteristic of the ligher Angiosperms. If a flower is essentially a sporophyll or a set of sporophylls, as the older definition insists, Pteridophytes must be included among flowering plants. If, on the other hand, a flower is characterized by floral leaves, many Angiosperms are not flowering plants. In any erent, the term flower is of indefinite application, and is incapable of sharp definition. It is a term of convenience among Angiosperms, where it also includes strobili. The attempt of the older morphology to establish a definite conception for a flower, and to force all of the sporophyll-bearing structures of Seed-plants into this conception was exceedingly unfortunate.

The development of floral leaves among Angiosperms seems to be connected with the evolution of entomophily, which has resulted in immense diversity in the details of floral structure, but snch details are quite foreign to the purpose of this book. The origin of floral leaves, however, is a question that must be considered.

That all floral leaves are derived from sporophylls may be said to be the current view, as stated by $\mathrm{A}$. P. De Candolle in 1817 , and by many subsequent writers, notably Celakorsky in 1896 and 1900. Gocbel, however, in his recent Organographie der Pflanzen, claims that while in a large number of eases floral leaves may be derived from sporophylls, as in Nymphaea, etc., they are often derived from "bracts." For example, he calls attention to certain ancmones in which the involucre becomes the calyx and this in turn may beeme petaloid. In other words, he claims a doulble origin for floral leaves, namely, sporophylls and foliage leaves, and whicherer their origin the result is the same. It may he of interest to note that Goebel's definition of a flower, a definition originally proposed by Schleiden, is " a shoot beset with sporophylls," which of course 
includes certain Pteridophytes among flowering plants. It is certainly more in aecord with present morphological conceptions not to limit ton rigidly the possible origin of a structure, and from this point of riew it seems reasonable that floral leaves in general may have been derived from contiguons structures both above and below.

It is not always easy to delimit a flower exactly from the regetative shoot, for there are numerous illustrations of gradations between foliage and floral leaves: but for all ordinary purposes four different organs are readily recognized as entering into the structure of a highly developed flower. The discarded doctrine of metamorphosis assumed that such a flower is the trpe, from which all others are the modified deseendants, and this conception is perpetuated in terminology. The same conception dominates also in nearly all presentations of floral diversities, as it is well-nigh impossible to abandon at once all the terms of an obsolete conception and remain intelligible. It has been a very prevalent conception, therefore, that flowers of simpler structure than the assumed type are reduced forms. There are certain cases in which this seems clear, as in the relation of Lemna to the Araceae; but the rast majority of simpler flowers are better regarded as primitive than as reduced forms. At present this is at least a raluable working hypothesis, for it coincides in general with the morphological and historical evidence concerning relationships, as well as -with the doctrine of erolution.

Accepting the evidence that the simpler flowers are for the most part the more primitive forms rather than reduced ones, certain prominent tendencies in the erolution of the flower, adnairably presented by Engler, may be discussed. It must be understood, howerer, that only general tendencies are traced, for the actual lines of descent can not be determined by our present knowledge.

The naked fowrer with one or more free sporophylls may be regarded as the most primitive form. In fact, it is an angiospermons flower without the characteristic floral leares. Such a flower may sometimes represent a case of reduction, but its persistent association with plants recognized as primitive from other testimony is rery strong evidence that it is a primitive condition of the flower. From this stage a series 
can be arranged illustrating the gradual derelopment and differentiation of the two floral envelopes. Foliar members, whether derived from foliage leares or sporophylls, become more and more definitely associated with the sporophylls, until they may be regarded as constituting an inconspicuous, bractlike perianth. They gradually appear in two definite sets and become more conspicuous, and sooner or later show the petaloid texture and coloration. The final stage is a completely differentiated calyx and corolla, with their characteristic differences. This tendency to produce a completely differentiated calyx and corolla has resulted in its attainment by most flowers, but there are numerous cases in which even near relatives have not made the same progress in this regard. For example, the phenomenon styled apetaly may be observed in flowers whose nearest relatives have a distinct calyx and corolla. While some cases of apetaly may be explained as the suppression of a set of floral envelopes, there are certainly cases in which it means that the two sets have never become differentiated. This indicates that progress made in a single direction can not be used as a criterion of relationship. In general, however, it must remain true that a flower with completely differentiated calyx and corolla, other things being equal, is of higher rank than a flower which has not attained this differentiation.

Among the most primitive flowers the floral axis tends to elongate, and the members appear in indefinite numbers along a low spiral. In more highly developed flowers the growth of the axis in length is checked at a very early period, so that the spiral along which the members successively appear becomes lower and lower, until it has only a theoretical existence, passing into successive cycles, which eventually become limited in number. With the appearance of definite cycles the number of members appearing in each one becomes limited, the limit in Monocotyledons being prerailingly three, and in Dicotyledons five or four. It is to he noted that the cyclic arrangement is not attained simultaneously by all the sets of a single flower. For example, in many species of Ranunculus the sepals and petals are erclic, or approximately sn, while the stamens and earpels are distinctly spiral. This tendency is so well-marked and so uniformly displayed that Engler has used it as a basis for dividing Monocotyledons into two great series, the "spiral 
series" comprising all those families that show the spiral tendency in any of the floral sets, and the "cyclic series" comprising all those whose flowers are completely crelic, the former series including all the more primitive families. There is no reason why this same distinction can not be applied also in a general way to the Archichlamydeae. This gradual transition of flowers from the spiral to the cyclic condition is one of the best-marked tendencies in their evolution, and has the adrantage of being represented by innumerable intermediate stages. All of those families which are recognized as being of the lighest rank have completely crelic flowers, witl members appearing in definite and low numbers, notably illustrated by the whole group Sympetalae.

There is a marked tendency in flowers for the members of a single set to lose their identity and to develop en masse, a phenomenon called "coalescence" by the older morphologists, under the impression that separate members had united. This congenital union is to be distinguished from such a mechanical union as is shown br the anthers of Compositae. In the organogeny of such a flower it is to be observed that in the meristematic zone from which a certain set is to levelop, the different members first appear as separate primordia, but sooner or later the whole zone shares in the growth and, the axial growing point being checked, an annular structure arises that gradually. assumes the size and form of the mature organ (Fig. 1). It has been claimed that this is a toral uprising and that. for example, the tubular portion of a sympetalous corolla is morphologically torus, but there seems no more reason for this supposition than to regard an individual petal as a toral uprising. It is merely the difference between development from the meristematic zone at certain points and at all points. Is is well known, this derelopment of the whole zone mar begin almost at once, or may be deferred until the set is nearly mature, resulting in every stage of separation in the members, from a completely tubular structure to one that is tubular only at base. Or the zone may develop for a time in tro sections and later en masse, resulting in the so-called bilabiate structure. Further inequalities in the time and rate of derelopment result in various irregularities. In any erent, this tendency to zonal derelopment rather than the maintenance of separate points of 
derelopment is persistent among flowers, the first set showing it being the carpels, resulting in syncarpy. The zonal derelopment of the corolla, however, or sympetaly, accords with so many other characters indicating natural relationships that it has been used to designate and even to define the great group Sympetalae. This is probably pressing a single character too far, for there is evidence that the result has been to do violence to certain natural relationships, and to make certain unnatural groupings. This tendency to zonal development is found in every floral set, and those flowers that show it are certainly to be regarded as of higher rank than those that do not.

Among the more primitive flowers each cycle arises separately from the growing point, its members remaining separate or the whole meristematic zone entering more or less completely into the outgrowth. The insertion of each cycle is definitely below that of the next inner eycle, resulting in an hypogynous Hower (Fig. 1, A). That hypogyny is a primitive condition of the flower is a statement that does not seem to need discussion. The tendency to zonal derelopment, however, is carried farther when a whole region arising en masse produces two or more cycles of floral members. In the simplest cases two cycles are thus produced, as is illustrated by the strong tendency of the petaliferous and staminiferous cycles to have a common origin in sympetalous flowers, resulting in the appearance of "stamens inserted on the tube of the corolla." The same tendency is shown among orchids, in which the whole region for the development of stamens and carpels arises in a single body, forming the characteristic gynostemium or " column." While these may be regarded as special tendencies of certain groups, rather than of fiowers in general, there are other instances that seem to belong to the general erolution of the flower. In certain cases the region of the growing point belonging to the carpels ceases to derelop, while the rest of the growing point continues to develop en masse, forming a cup or urn-like outgrowth, from the rim of which the three onter sets develop separately, forming the perigynous flower (Fig. $1, B$ ). In this case the carpels arise from what scems to be a depression in the center of the torus, but which, of course, is the region of checked growth. Perigyny is chictly displayed among families of the Archichlamydeae. 
Far more general is the tendency to epigyny, in which the checking of apical growth and the continued growth of the rest of the growing point results in an ovule-bearing cavity grad-
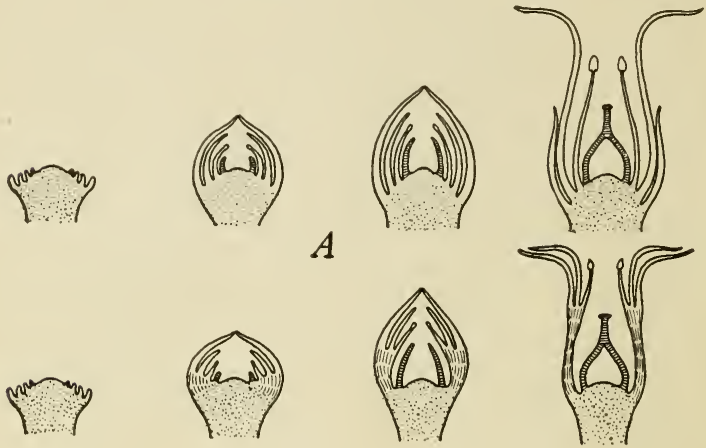

$B$
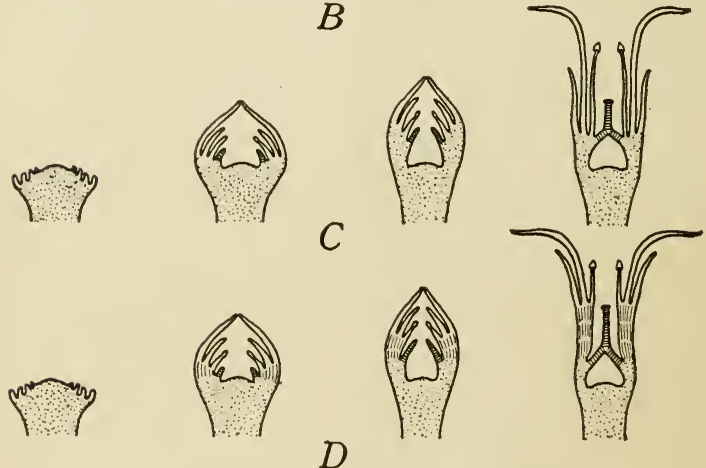

Fig. 1.- "Diagram to illustrate the morphology of typical flowers. $A$, hypogynous; $B$, perigynous; $C$, epigynous: $D$, epigynous with prolonged 'calyx tube.' Receptacle is dotted; carpels are cross-lined; 'perianth tube,' or 'calyx tube,' vertically lined; sepals, petals, and stamens are unshaded, but may be distinguished by their relative positious." - After GANovg.*

ually roofed over by the carpels. From the top of the ovary thus developed the four sets of floral members develop as usual, those of each set remaining independent, or a crcle dereloping 
cn masse, or two cycles (especially petaliferous and staminiferons) having a common origin (Fig. 1, C, D). Goebel holds (Organographie) that at least in some epigynous flowers (as Pirus Malus) the carpels do not merely roof the orular cavity but also line it, basing the claim upon a study of the meristematic tissue; in which case the wall of the so-called " ovary" is toral without and carpellate within. It is to be expected that numerous intermediate stages between complete hypogyny and extreme epigyny will be displayed, as may be inferred even from the doubtful phrases employed by taxonomists to describe them. It also seems to be a safe conclusion, since epigrny is constantly associated with the most specialized groups of each great dirision, as Orchidaceae among Monocotyledons, Umbelliferae among Archichlamydeae, and Compositae among Sympetalae, that it is a mark of higher rank than hypogyny in any evolutionary series.

The tendency for the members of a floral set to derelop unequally, resulting in zrgomorphy or various forms of "irregularity," is not general, and can not be applied so broadly as can the tendency to the cyclic arrangement or to epigyny. In certain groups, howerer, it is rery pronounced as a special character, as Orchidaccae among Monocotyledons, Leguminosae among Archichlamydeae, and Personales among Srmpetalae. The occurrence of zrgomorphy in relatively primitive as well as in highly specialized gromps indicates that it is to be regarded as a special rather than a ceneral tendency; and ret, other things heing equal, the zygomorphic flower is to be regarded as of higher rank in any given erolutionary series than the actinomorphic flower. Diversities resulting from inequalities of growth are often described in terms of symmetry, a term that unfortmately has two applications in connection with the flower, for its well-known hiological use br Sachs found it already used to designate a flower "in which the members of all the creles are of the same number." In its biological sense a srmmetrical flower is one "that can be divided into two similar halves, or the parts of which are radially disposed around a central point." The terms " monosymmetrical" and "polysrmmetrical" are logical, but not hetter than the older terms of Eichler, "zyomorphic" and " actinomorphic." However, the phenomena of floral symmetry are not well expressed 
in two categories, and three have been proposed, as follows: (1) actinomorphic, in which the planes of symmetry are as numerous as the members of a cycle; $(2)$ isobilateral, in which there are two planes of srmmetry, but the halves produced by one plane are unlike those produced by the other (Dicentra, Cruciferae, etc.): and (3) zygomorphic, in which there is only one plane of simmetry (Fig. 2). These eategories are expressions of certain laws of growth, and that they are somewhat funda-
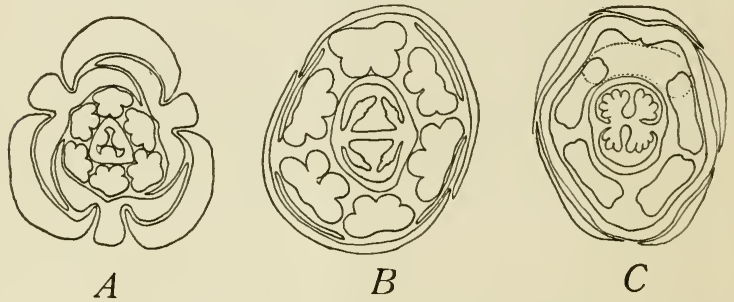

FIG. 2.-A, radial symmetry (Lilium tigrinum); $B$, isobilateral symmetry (Capsella Bursa-pastoris); C, zygomorphic symmetry (Scrophularia nodosa).

mental may be inferred from the fact that they are persistent through great groups of plants.

While these and other evolutionary tendencies are to be observed among flowers, it is evident that they are not necessarily expressed simultaneously. For example, the spiral and crclic arrangements are associated in Ranunculus, zrgomorphy is associated with polypetaly and hypogyn among the papilionaceous Leguminosae, epirny is associated with polrpetaly among the Lmbelliferae, and srmpetaly and zrgomorply are associated with hypogrny among the Labiatae. It is among the Compositae that practically erery erolutionary tendency mentioned finds its highest expression. It is onle by striking an average that sueh characters mar be used in roughly placing a family in its evolutionary position, commonly called its "relative rank."

The clas-ic memoir on the organogeny of the flower is Payer's Traité d'organogénie de la fleur (1957). but the subject has not heen developed sinee as it deserves. In the case of spiral flowers, in which the torus elongates more or less, the 

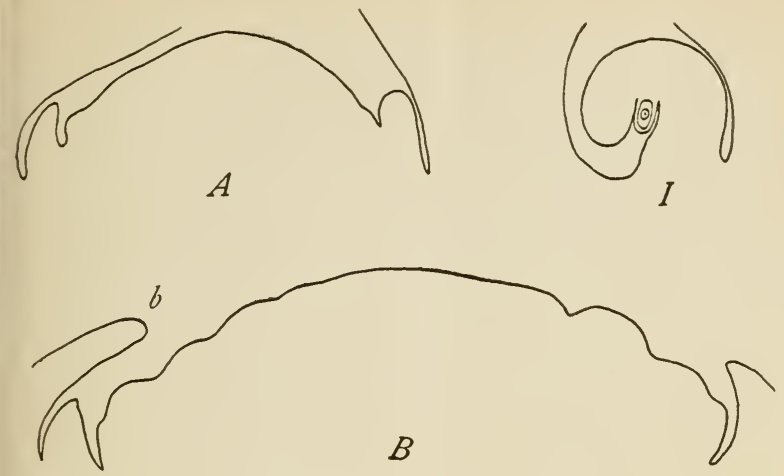

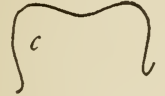

C

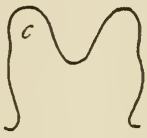

D
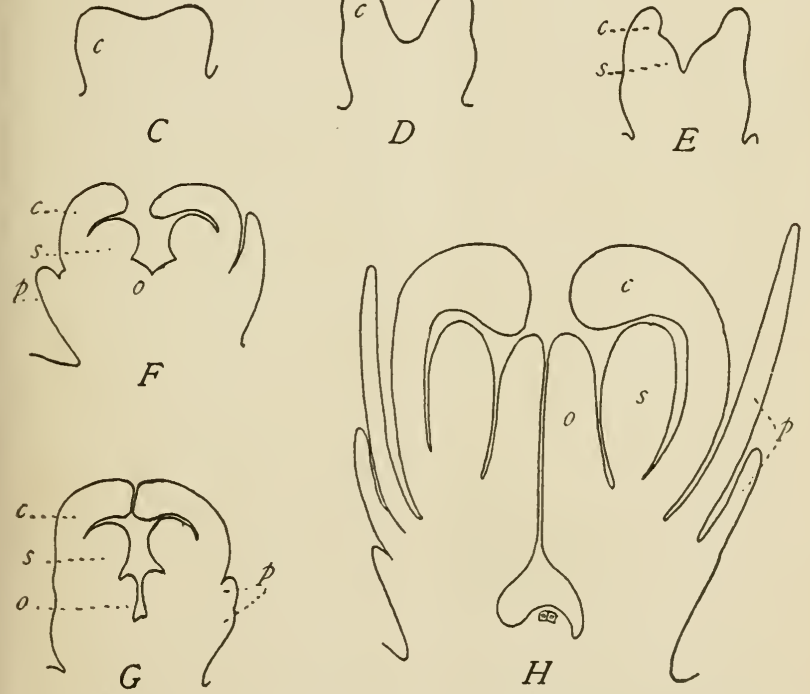

Fio. 3.-Cnicus arvensis. Floral development: $A$, receptacle almost evenly convex; $B$, appearance of papillæ to becone flowers; $C$, a single papilla more advanced, showing beginning of corolla; $I$, corolla more prominent: $E$, stamens distinguishable; $F$, carpels and pappus (calyx) evident; $G$, carpels beginning to form eavity of ovary; $H$, ovule readil $y$ distinguishable; $I$, ovule showing megaspore mother-cell and single thick integument: $b$, bract of involucre; $c$, corolla; $s$, stamen; $o$, carpel; $p$, pappus (calyx). $A-H \times 50 ; I \times 100$. 
members appear in acropetal suecession along a continuous low spiral, and just when one set of members stops and the next begins is indefinite within eertain usual limits. There seems no doubt in this case that the primordia are indifferent up to a certain stage of development, and that the particular organ produced depends upon something outside of the essential constitution of the primordim itself. In the case of cyelie flowers, in which toral growtl in length has been cheeked and there has been growth in diameter, the aeropetal suecession of members is often very much interfered with. The "disturbances" that arise in the torus by substituting growth in diameter for growth in length aceount not only for the breaking up of the acropetal suecession, but also for the inequality of members of the same cyele, or of different regions of the eycle. It is evident that in the case of cyelic flowers organogeny must deal not only with the suceession of eycles, but also with the suceession of members in each eycle. Definite data in reference to these points are not so available as they should be, but a few illustrations may be cited.

For the majority of evelic flowers it seems to be assumed that the eyeles appear in acropetal suecession-namely, sepals, petals, stamens, carpels-and that the members of each ercle are practically synchronous in origin, but it is probable that this assumption is gratuitous. While theoretically it may be assumed that the ercles should arise in acropetal succession, the fact that they do not in many observed cases indieates that they may not in many more cases; and the synehronous appearance of the members of a single cycle is unsound as a theoretical assumption. Infmeister * records that in Rosa, Potentilla, and Rubus the primordia of the carpels appear before those of the stamens have reached the full number, and that in Hypericum calycimum the primordia of the sepals appear after those of the stamens. It is also generally known that among the Compositae (Fig. 3), Dipsaceae, Valerianaceae, and Rubiaceae, in which the sepals are much reducer or modified, their primordia do not appear until after those of the stamens and earpels; and that amone the Crueiferae (in Capsclla, at least) (Fig. 4) the petals are the last members to

* Hofmeister, W. Allgemeine Morphologie der Gewäehse. Leipzig. 1868. p. 462 . 
appear. Webb * has recently observed in Astilbe that the order of succession of floral creles is sepals, inner stamens, carpels, onter stamens, and petals. In this case there is an acro-

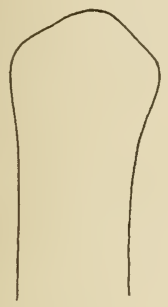

$A$
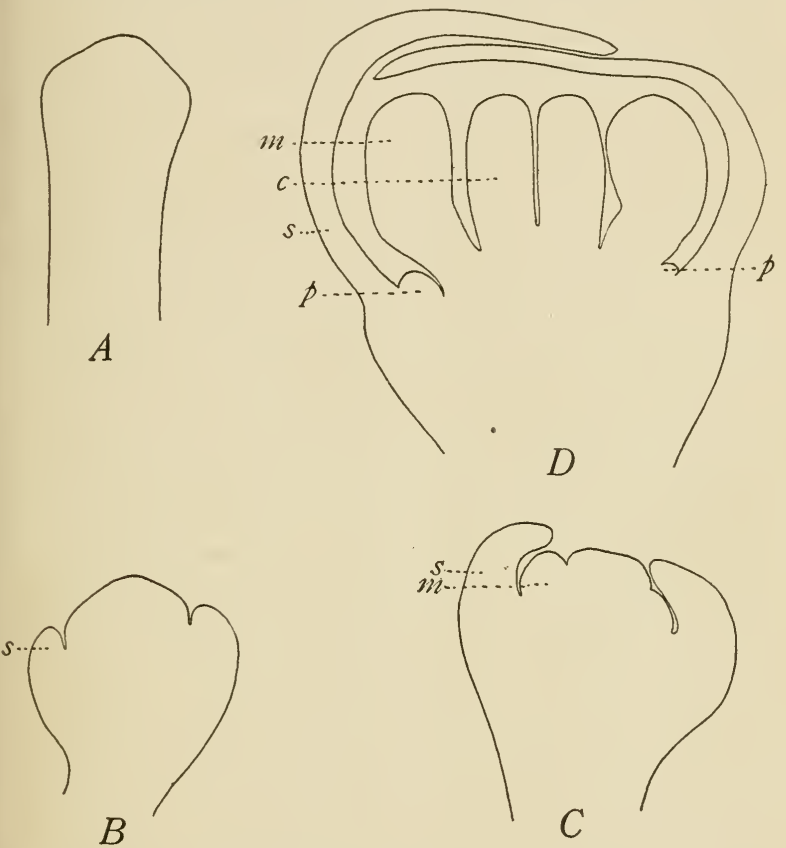

Fio. 4.-Capsella Bursa-pastoris. Floral development: $A$, floral axis before appearance of floral organs; $B$, appearance of sepals; $C$, appearance of stamens ; carpels barely distinguishable; $D$, appearance of petals : 8 , sepals ; $m$, stamens ; $c$, carpels ; $p$, petals $\times 130$.

petal sucession of certain cycles, followed by a basipetal sucession of the remaining ones. The remarkable case of the flower of the Primulaceae, noted by Pfeffer, $\nmid$ is also familiar, in

* WeBr, J. E. A Morpholngical Study of the Flower and Embryo of Spi raea. Bot. Gazette 33: 451-460. figs. 2\%. 1902. For correction of names, see REHDER in Bot. Gazette 34: 246. 1902.

† Pfeffer, W. Zur Blïthenentwicklung der Primulaceen und Ampelideen. Jahrb. Wiss. Bot. 8: 194-215. 18\%2. 
which the primordia of the petals appear after those of the stamens, andeach apparently from the dorsal surface of a young stamen. The conclusion that the so-called petals of this family are not morphologically petals, but stamineal outgrowths, is unnecessary, since the phenomenon can be more logically interpreted as a case in which the primordia of stamen and petal have a common origin, entirely analogous to the srmpetalous corolla with stamens " inserted on its tube," but in which the separate primordia of the petals have been delayed in their appearance. Such examples as those enumerated abore simply serve to emphasize the desirability of a more serious and systematic inrestigation of the whole subject.

In the case of members of a single crele, it is a question whether their primordia erer appear simultaneously, although they may appear in rapid succession. In zygomorphic flowers, however, the succession is probably always evident. For example, Goebel * cites the case of the papilionaceous Leguminosae, in which the anterior median sepal first appears, then those to the right and left of it simultaneously, and finally the two obliquely posterior ones: but before these last are erident the two obliquely anterior petals appear, and after them the other three in the same order as the corresponding sepals. This succession proceeds right and left from the anterior member to the posterior. In other known cases, however, as in Reseda, according to Parer, the succession is right and left from the posterior nember to the anterior.

It nust also be noted that a meristematic zone giving rise to a set of members mar add to the set later or even duplicate it, giving rise to the well-known interposition of new members or new sets. For example, it is stated that among the Geraniaceae, Rutaceae, and Zrgophyllaceae a new cycle of fire stamens is interposed among the fire already formed; and that in Aceraceae and Sapindaceae two to four stamens are intercalated in the complete crele of fire previously formed. This later interposition of new sets or new members has been recorded chiefly for stamens, and is a prolific source of interference with the "symmetry" of numbers.

All seed-bearing plants are necessarily dioecious since they

* Goebel, C. Outlines of Classification and Special Morphology. English translation. 1887 . p. 424 . 
are heterosporous. So far as there is any advantage in this habit, however, it is practically lost if stamens and carpels are present in the same flower or upon the same plant. Morphologically the gametophytes are misexual, but in fact they are dependent upon the same individual. Any physiological adrantage, therefore, that comes from the crossing of individuals must be secured by pollination or by the separation of stamens and carpels upon different individuals. It is unfortunate that the term "dioecious" has two distinct morphological applications, referring to the sexual differentiation of individuals among the lower plants, and to the sporangial differentiation of individuals among seed-bearing plants; but from the physiological standpoint the distinction probably does not exist. As a consequence, the dioecious habit in effect is secured in certain seed-plants by the development of monosporangiate individuals, and it is perhaps significant that this habit not only prevails among the more primitive seed-bearing plants, but is associated in the main with wind-pollination. Among the higher Angiosperms the effect of the dioecions habit is secured for bisporangiate plants by means of insect-pollination. It follows from this point of view that neither the monosporangiate nor the bisporangiate habit can be regarded as in itself the more primitive. The former habit prevails among the more primitive families because they are necessarily anemophilous: while the latter prevails among the higher families because insect pollination does not necessitate the monosporangiate habit. It should be noted that Goebel (Organographie) regards the bisporangiate condition as primitive, the monosporangiate heing derived from it by reduction. This can be demonstrated in certain cases, but the monosporangiate condition is probably the primitive one in many of the more primitive angiospermons families. In any event, the monosporangiate and bisporangiate habits are not always settled ones. For example, in the monosporangiate Amarantus retroflexus there are occasional bisporangiate flowers: while in monosporangiate and dioecious willows both catkins may appear on the same individuals, and the catkins themselves may be mixed (staminate, pistillate, and bisporangiate). It follows also that there mar he monosporangiate members in all great groups (as Ranunculaceae), or eren in bisporangiate genera (as Rumex and Lychnis), for this habit 
is probably not a hindrance to any form of pollination, and certainly prevents self-pollination. C'ross-pollination by wind or by insects, therefore, appears as an offset to the loss of any adrantage originally gained by the dioecious habit; and the appearance of monosporangiate individuals in any Angiosperm group does not imply a tendency toward a more primitive or more advanced condition. For example, the monosporangiate habit of poplars is no more indicative of a primitive condition than is the monosporangiate habit of certain Compositae of an adranced condition.

The older morphologists considered the floral members as morphologically leares, and presented proofs which to them seemed decisive, such as the leaf-like position and intergrading of members, and varions malformations, among which are the so-called " reversions." This conclusion was controlled by the prevailing doctrine of metamorphosis, and under its guidance nothing seemed clearer than that stamens and carpels are transformed leares. While sepals and petals may be regarded as often leares more or less modified to serve as floral enrelopes, and are not so different from leaves in structure and function as to deserve a separate morphological category, the same claim can not be made for stamens and carpels. They are very ancient structures, of uncertain origin, for it is quite as likely that leares are transformed sporophylls as that sporophylls are transformed leares. It is a rigid morphologr, howerer, dominated by the doctrine of "trpes," that denies to an organ so thoroughly established as the stamen of Angiosperms a morphological individuality. One might almost as well deny to the leaf itself a morpliological individuality becanse it did not always exist as a distinct organ. Just how long an organ must maintain its independence before it can be recognized as a morphological unit is not easr to say, but stamens and carpels seem to have earned the right. To call a stamen a modified leaf is no more sound morphology than to eall a sporangium derived from a single superficial cell a modified trichome. The cases of "reversion" cited are easily regarded as eases of replacement. Lateral members frequently replace one another, but this does not mean that one is a transformation of the other. For example, in 1ss? Barher * observed a Nymphaea in which

* Barber, C. A. On a Change of Flowers to Tubers in Nymphaea Lotus. var. monstrosa. Annals of Botany 4: 105-116. pl. 5. 1889. 
foliage leaves had replaced all the floral members within the calyx and the end of the axis had become much swollen. It is probable that the latter fact was responsible for the former, and that a growing axis put forth leares, as it usually does; but the inference that these leaves represent the replaced floral members in any morphological sense has no logical comnection with the facts observed. Such cases as that of the ordinary flowers of Nymphaea, in which stamens seem to be gradually differentiated from petals, present no difficulty when one notes the remarkable indifference of sporangia to the nature of the member upon which they appear. Because microsporangia appear occasionally upon an axial structure it might as well be argued that stamens are transformed stems. The stamens and carpels are just as definite morphological structures as are foliage leaves, with just as distinct functions, and should be so regarded, whatever may have been their historical origin. Stamen and leaf probably merge into one another in history, and so do stem and leaf, but all have become established as distinct organs.

Further details as to the varying form and structure of sepals and petals are of no special morphological significance, and are of interest chiefly to the taxonomist and the ecologist. The stamens and carpels, however, are so intimately associated with essential morphological structures that some further details in reference to them are necessary.

The stamen set has been called collectively the "androecium," a name so objectionable to the morphologist on account of its sexual significance that it should be abandoned. The stamen is an organ devoted to the production of microsporangia, and its endless diversity of form and position is related more or less directly to the needs of pollination. The term " anther" is one of convenience, but represents a morphological complex made up of sporangia and more or less sporophyll tissue. The cooperation of sporophyll and sporangia in the dehiscence of, the latter will be included in the discussion of the microsporangium, as well as those various differences among anthers that have to do with the number and behavior of their sporangia. It is important to note that stamens have the power of branching, and can thus multiply sporangia. Well-known cases are Callothamnus, in which the branching is like that of a pinnate 
leaf: Ricinus, in which repeated forking results in a stamen bearing very numerous sporangia; and Hypericum, in which the primordium branclies, that is, produces secondary primordia, the common base of the tufted cluster not being recognized in the mature condition. The case of zonal derelopment, that is, an uprising from the whole staminiferous zone, and also the case of stamen and petal or stamen and carpel regions rising en masse, have already been noted in connection with the general tendencies of the flower. The tendency of stamens and of carpels to become more or less coalescent through pressure is also well marked, as in the anthers of Compositae and Lobeliaceae, and in some cases that have been called svncarpy. It remains to note the fact that stamens occur in all stages of abortion, especially to be observed among the Personales, from the absence of sporangia to that amount of abortion that is only short of suppression. Stamens that have lost their normal function are generally called "staminodia," but they may assume various forms and serve a rariety of purposes. In certain cases, as notably among the Labiatae, the claim that one or more stamens have been suppressed is justified by their presence in near relatives, combined with the occurrence of unoccupied points where stamens ordinarily appear.

The carpel set has been called collectively the "grnoecium," a term that also should be dropped from morphological terminology on account of its implication of sexuality. The carpel is the organ most intimately related to the megasporangia, inresting them more or less completely, but not alwars producing them, and giving name to the Angiosperms. Its history is unknown, for although it is easy to imagine it derived from such open carpels as are found among Grmmosperms, no clear intermediate stages have been found. At all erents, it is a thoroughly established and characteristic organ. The term "ovary" for the sporangium-bearing cavity is particularly unfortunate on account of its very different application among animals. To aroid this confusion Barnes * has proposed the term "orulary," but even this contains in its stem the sexual implication. The strle is definitely related, in its varving form and length, to the problem of pollination, and upon it the stig-

* Barxes, C. R. Plant Life. 1898. p. 240. 
matic surface is developed in various ways. This surface is increased in area by the enlargement of the apex of the style, by its branching, or by being developed laterally upon the style.

One of the essential features of the structure of the carpel is the provision for the progress of the pollen-tube from the receptive surface to the sporangium or even to its micropyle. A specialized and continuous nutritive tissue connects these two extremes, often confused in the sporangial chamber with the "placenta," in the style called "conducting tissue," and upon its surface the "stigma," but forming one continuous tissue system, well named the conducting tissue. It is unfortunate that the terminology of taxonomy has somewhat diverted attention from the continuity of this tissue, for in it the "stigma" is an organ distinct from the style, rather than a display upon the surface, often modified to receive it, of a special tissue of the style. While the placenta is the point or line of sporangium origin, and may be said to consist of sporangiogenic tissue, it is probably true that much of the outgrowth that stands for the placenta to many is conducting tissue. In the case of hollow styles, as in Lilium, Butomus, Agave, Erythronium, Tiola, Campanula, Sarcodes, etc., the conducting tissue lines the canal as a glandular laver, or in some cases, as in Anagallis, fills up a hollow style; but in most cases the style is solid, with the conducting tissue as an axial strand. In case a single style is connected with two or more sporangial chambers, the strand of conducting tissue branches into each chamber. This suggests the possibility that the stylar canal, with its lining of conducting tissue, may represent a primitive angiospermous condition, and that the larger development of this tissue has resulted in the prevailing solid strle, a view that is also suggested by the development of the style. Of course the reverse may be true, and the stylar canal a result of the breaking down or rupture of the axial strand of conducting tissue.

The strong tendency to a congenital development of carpels has been previonsly noted, and this justifies the use of the term "pistil" as one of convenience, although it does not stand for a morphological unit. It is applied to any organization of carjels that appears as a single organ with one ovary, whether one or more carpels are involved. It is to be noted that the term 
"ovary" also, as usually applied, has no definite morphological significance, referring to a morphologically single sporangial chamber or to a combination of several such units, and these chambers may be of axial as well as of carpellary origin. The various ways in which the congenital carpels are related to one another in a compound pistil are of great serrice in taxonomy, as the particular structure of such a pistil is usually characteristic of great families, or even of groups of higher rank. These details of structure are too fully presented in various texts, however, to justify their repetition here. The relation of sporangia to carpels is an important subject to the morphologist, and will be considered in connection with the derelopment of the sporangia. 


\section{CHAPTER III}

THE MICROSPORANGIUM

The microsporangia of Angiosperms are embedded structures, and are derived from the outermost layer of the periblem. Thus far, the only recorded exceptions to this origin are Naias flexilis, and probably Zannichellin ${ }^{15}$ and Lilaea subulata, ${ }^{13}$ whose microsporangia are claimed by Campbeil to be derived from the plerome (Fig. $5)$. The periblem origin of the sporangia seems to account for the fact that the archesporium is superficial in Pteridophytes and hypodermal in Spermatophirtes. It also accounts for the indifference of the sporangia to the morphological nature of the organ upon which they appear. In general, they occur upon a lateral member that holds the same relation to the axis as do the leaves, and in this sense it may be called a leaf-like member. Such sporangia, therefore, may be called foliar, and the structure that bears them a sporophyll. In certain cases, however, the sporangia are derived from the periblem of the axis, and such may be called cauline. In each case the resulting nrran is a stamen, whether in the po-

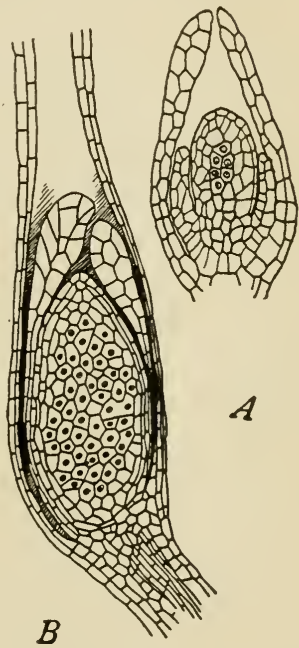

F16. 5.-Naias flexilis. A, young stamen showing "integument" and plerome origin of archesporium ; sporogenous cells represented with nuclei: $\times 200$. $B$, later stage; $\times 70 .-$ After CAMPBELL. ${ }^{16}$ s' " $n$ of a leaf or of an axis. The freedom with which microporangia are sometimes produced may be illustrated by the 
willows, notably Salix petiolaris, in which Chamberlain ${ }^{16}$ found microsporangia in the " placenta" of the ovary, the carpel sometimes being wide open and bearing both microsporangia and
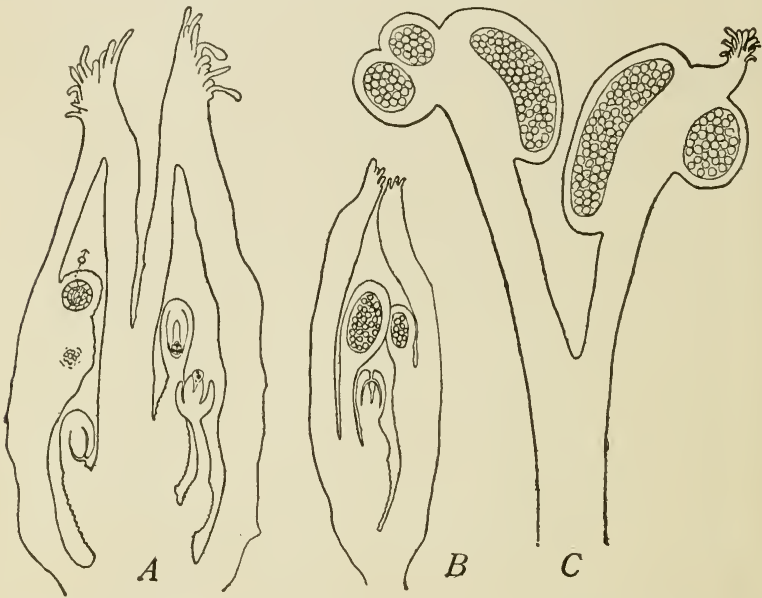

Fi@. 6.-Salix petiolaris. $A$, microsporangia in wall of ovary; both anatropous and orthotropous ovules. $B$, microsporangia with long stalks within the ovary; pollen normally developed; ovule orthotropous. $C$, branching stamen, each anther with four microsporangia; anther on right terminated by a stigma; $\times 50$ - After СнамBERLAIN. ${ }^{16}$

megasporangia, and in some cases stigmas dereloping on stamens (Fig. 6).

The cauline origin of microsporangia seems to have been recorded first in 1868 in the case of Casuarina, by Kauffmann; ${ }^{6}$ and then in 1869 for the species of Naias, by Magnus. ${ }^{7}$ confirmed in 1897 by Campbell. ${ }^{15}$ In 1573 Warming ${ }^{8}$ made a similar record for Cyclanthera, and was confirmed by Engler ${ }^{9}$ in 1876 . Rohrbach ${ }^{5}$ discovered cauline microsporangia in Typha; Goebel ${ }^{11}$ (p. 353) states that they occur in the " unbranched stamens"; and their occurrence in T. latifolia was confirmed by Schaffner ${ }^{17}$ in 1897 . In 1897 Campbell ${ }^{15}$ added to the list Zannichellia, and in 1598 Lilaea. ${ }^{18}$ In 1900 Lotsy ${ }^{30}$ suggested that the curious stamen of Rhopalocnemis phalloides (Balanophoraceae) is an axial structure. 
It is reasonably assured, therefore, that cauline microsporangia occur in at least seven genera, both Monocotyledons and Dicotyledons being represented. Epon the whole, they seem more characteristic of the primitive members of these two groups than of the more highly specialized members, but this impression may disappear with further investigation. If the cauline origin of megasporangia be considered, the primitive character of this feature becomes increasingly uncertain, for cauline megasporangia are common eren in the highest groups. It seems probable, therefore, that the cauline or foliar origin of sporangia among Angiosperms is not to be taken as an argument for or against the primitive character of the group in which they occur. The particular organ dereloping microsporangia was probably determined not by its morphological nature, but by what may be called its physiological relations (Fig. 6). Even among Pterirlophytes, the sporangia of Lycopodium are foliar, and those of the nearly allied Selaginella cauline; and anong Grmnosperms sporangia have both origins. It is erident, therefore, that the distinguishing morphological

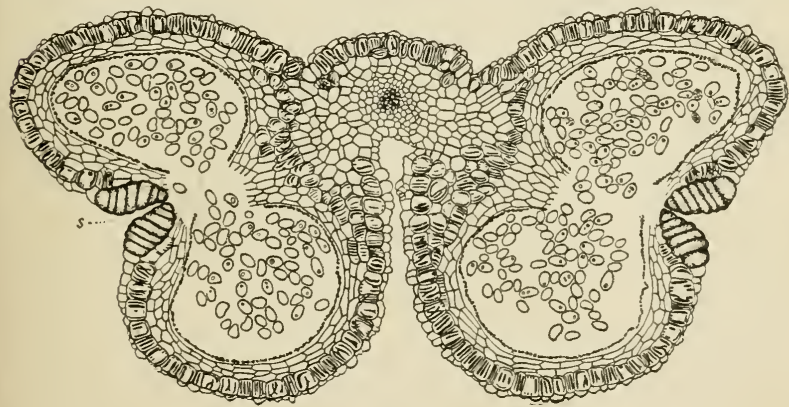

FIG. 7.-Lilium philadelphicum. Transverse seetion of almost mature anther; nearly all the walls separating the microsporangia have broken down; highly dereloped stomium $(s)$ and endothecium (with its rib-like thickenıngs very prominent; $\times 25$. -From a drawing by IV. J. G. Laxd.

structure is the sporangium rather than any member of the plant body from which it may arise.

In niost cases the stamen produces four microsporangia (Fig. 7 ), and the exceptions noted thus far are by no means 
numerous. Caldwell ${ }^{23}$ lias called attention to the occurrence of what might be regarded a single microsporangium in Lemna; it is well known that the stamens of Asclepiadaceae produce only two microsporangia; and in Hamamelis (Shoemaker ${ }^{35}$ ) there is a single sporangium to each "pollen-sac." Eight microsporangia had long been observed among the Mimoseae when Engler ${ }^{9}$ reported a still larger number. Among the Orchidaceae Guignard ${ }^{10}$ reports eight microsporangia in the stamen of Calanthe veratrifolia; and among the Onagraceae, as in Gaura, more than four microsporangia are suggested by the pollen-sacs (see Groebel, ${ }^{11}$ p. 36!, foot-note 2). Among Loranthaceae Van Tieghem ${ }^{13}$ says that the number of pollensacs is exceedingly variable, ranging from one to an indefinite number; and the same is true of the Balanophoraceae, as reported by several investigators. Attention should be called to the fact, howerer, that the number of sporogenous masses finally dereloped may not necessarily determine the number of sporangia, for plates of sterile tissue, derived from sporogenous tissue, have been observed to divide a single mass of sporogenous tissue into two or more. This has been made out clearly by Caldwell ${ }^{23}$ in the case of Lemna (Fig. 1t); and in those cases in which more than four microsporangia are reported a detailed study of their origin is desirable. In the case of branching stamens, referred to on p. 23 , the microsporangiz may become very numerous.

The time for the formation of mierosporangia in relation to what is usually called "the growing season" has not received the attention it deserves. In 1896 Arma Smith $^{14}$ reported that she had discovered the pollen mother-cells of Tritlium dividing in the spring beneath frozen soil. In 1897 Chamberlain ${ }^{16}$ called attention to the fact that the microsporangia of Salix glaucophylla are in the mother-cell stage in October, and that they pass the winter in this condition. In 1898 the same investigator ${ }^{20}$ reported that this is true of other species of Salix; that in Corylus americana (Fig. 8, B) and Alnus glutinosa the midwinter catkins contain pollen ready for shedding with the generative cell formed; that in Populus monilifera (Fig. \&, A) the primary sporogenouts cells are found in July and the mother-cell stage in October, the latter condition persisting through the winter; and that in Hepatica 
the mother-cell stage was found in September, and fully formed pollen in the spring while the ground was still frozen. Duggar ${ }^{27}$ has also observed that the microsporangia of Symplocarpus pass the winter in the mother-cell stage. The pollen mother-cells of Podophyllum peltatum are forming the tetrads when the young plant has reached the surface of the ground, so that in all probability the winter is passed in the mother-cell stage. Although Conrad 29 found stamens well formed in the winter buds of Quercus velutina, the tissue of the anther was still homogeneous. These records merely serve as an indication of what may be expected when the subject is really investigated. It is evident that the time elapsing between the differentiation of the archesporium and pollination is often much longer than has been ordinarily supposed. It would seem probable that in general those plants whose flowers open early in the season, as most trees and the vernal herbs, develop their microsporangia before the end of the "growing season," and that the mother-cell stage is the usual winter condition. In the case of such plants, therefore, the earliest stages in the history of the microsporangia must be looked for during the latter half of the growing season that precedes the season of "blooming."
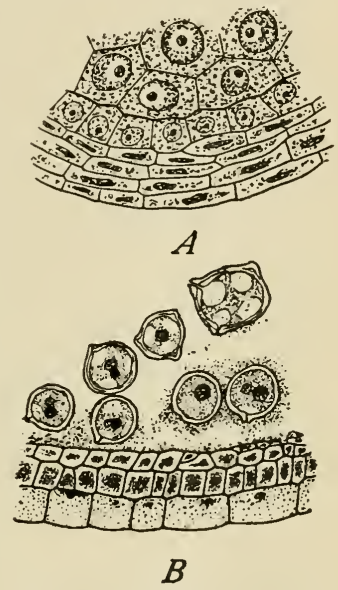

Fio. 8. - A, Populus monilifera, probably spore mother-cell stage, Jan. 25,$1895 ; \times 600$. B, Corylus americana, pollen ready for shedding, Dec. 7, $1897 ; \times 400$.-After Chamberlain.20

This suggests that the natural end of a growing season for the sporophyte is the attainment of the mother-cell stage by its sporangia, which is really the limit of the sporophyte in the alternation of generations; and the natural beginning of the next season is the reduction division and the beginning of the gametophyte. Of course such a distinction disappears in many plants whose seasonal habits are different from those we have been considering, but it suggests a natural division of growth between seasons, and even in annuals the mother-cell stage is a prolonged one. 
The development of the microsporangia began to be described by Nigeli ${ }^{2}$ in 1842 , and was continued by Hofmeister ${ }^{3}$ in $185 !-61$ : but the first detailed account from the standpoint of modern morphology is that of Warming ${ }^{8}$ in 1873, which has been marle the basis of all subsequent accounts. This was supplemented in 1676 by Engler, ${ }^{9}$ and since then numerous investigators have added extensively to the literature of the subject.

The anther at first is a homogeneous mass of small meristematic cells corered by an epidermis (Fig. 9). Tery early it
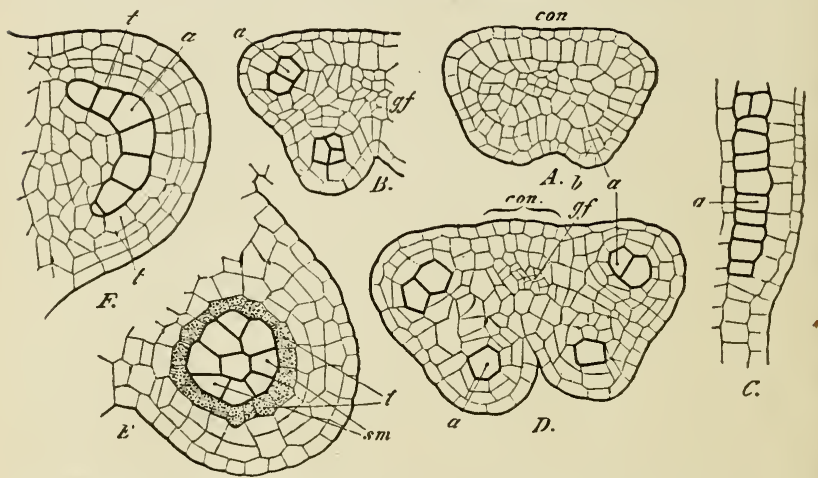

FIG. 9.-Derelopment of the microsporangium. A-D, Doronicum macrophyllum: $A$, transverse section of very young anther, showing primary sporogenous cell $(a)$ and primary parietal eell $(b) ; \dot{B}$, slightly older stage; $C$, longitudinal section of anther in same stage as that shown in $B: I$, later stage; $a$, sporogenous eells. $E$, Menyanths trifoliata, transverse section of a nierosporangium at a still later stage showing tapetum $(t)$ and mierospore mother-cells $(s m)$. F, Mentha aquatica, transverse section showing tapetum $(t)$ and sporogenous cells $(a)$.- After W ARMING, from Goebel's Outlines of C'lassifieation and Special Morphology.

becomes faintly four-lobed in cross-section, and the differentiation of the rascular strand of the connective outlines the general plan of the structure. The whole hypodermal laver of cells, representing the outermost laver of the periblem, is probably to be regarded as archesporial in its possibilities, and one region of it is just as likely as another, under similar conditions, to develop into actual archesporial cells. The farorable conditions for this development, however, are under the lobes; so that almost simultaneously with their appearance, a plate 
of hrpodermal cells becomes differentiated in each lobe, distinguished from the adjacent cells by their larger size, their usual radial elongation, their larger nuclei, and their different reaction to stains. In cross-section this plate is a single row of cells of rariable number, sometimes almost equaling in extent the contour of the lobe, as in Mentha aquatica (Tarming ${ }^{8}$ ); sometimes consisting of four to six cells, as in Orchis maculata (Guignard ${ }^{10}$ ); sometimes three or four cells, as in Hemerocallis fulia (Fullmer ${ }^{24}$ ); sometimes one or two cells, as in C'onvallaria majalis and Potamogeton foliosus (Wiegand ${ }^{25}$ ): and sometimes constantly one cell, as long known in Malraceae and most Compositae, and recently reported in Avena fatua by Cannon. ${ }^{26}$ In longitudinal section the plate extends approximately the length of the anther, being' a single row of cells in case the cross-section consists of a single cell: but in Mimoseae the whole archesporium is reported by Rosanoff ${ }^{4}$ as being a single cell, as is also the case in Euphorbia corollata, as reported by Miss Lyon. ${ }^{22}$ The general fact becomes elear, therefore, that an exceedingly rariable amount of the hypodermal layer may become archesporium, from nearly all of it to a single cell; and further, that this amount usually raries within certain limits in the same species, and that the extent of the archesporium is in no way related to the primitive or highly specialized eharacter of plant groups.

The subsequent divisions to the mother-cell stage usualls follow one another rapidly (Fig. 10). Following the history of a single sporangim, the radially elongated archesporial cellsall divide equally and almost simultaneously by periclinal walls, forming an outer layer (primary parietal," Fig. 9, $A, b$ ) and an inner layer (primary sporogenons, + Figs. 9, $A$, $a$, and 10 ,

* This has been commonly called the "primary tapetal layer," on the ground that the tapetum is one of its derivatives. At most only a part of the tapetum can be derived from it, and in some cascs none of the tapetum is so derived. Besides, the tapetum is a phrsiological layer of variable morphological origin. The essential morphological feature of this onter sterile layer is that it develops the wall of the embedded sporangium, and hence we have I,referred to designate it as the primary parietal laser.

+ This is the "archesporium" of Gochel's Outlines of Classification and of other texts. With such an application of the term the archesporium of the microsporangium of Angiosperms does not homologize with that of the megasporangium, and is of indefinite application among the Pteridophytes. $\mathrm{By}$ 
A). The names used to designate these two layers indicate their subsequent history, the former producing the wall of the embedded sporangium, and the latter the sporogenons tissue.

The cells of the primary parietal layer divide by periclinal walls, so that usually a definite series of concentric parietal lavers appears (Fig. \&, A). Walls in other directions also extend the parietal laver's uniformly with the rapidly enlarging anther. The number of parietal layers is variable, but in most cases there are from three to fire. Sometimes there are only two lavers, as in Silphium (Nerreli ${ }^{25}$ ) and in Quercus (Conrad ${ }^{29}$ ); and anong the Pontederiaceae Smith ${ }^{21}$ has regularly found six. Even higher numbers have been reported, and Goebel ${ }^{11}$ (p. 365 ) cites Agave americana as dereloping eight to twelve fibrous or endothecial lavers. In Rhopalocnemis phalloides (Balanophoraceae) Lotsy ${ }^{30}$ has shown that the sporangia of the curions axial stamen do not organize definite parietal layers and have no method of dehiscence, although the microspores are fully matured.

The outermost parietal layer usually develops very differently from the others, and has been called the "endothecium." This name was giren by Purkinje ${ }^{1}$ to designate all the layers of the dehiscing anther wall within the epidermis, which latter he named the "exothecium." Since in most cases the outermost parietal layer is the only one represented in Purkinje's "endothecium," the name has come to be restricted to it, which seems to us unfortunate, for it should be retained in its original application and used only in connection with the dehiscing anther-wall. It remains true, however, that the outermost parietal layer generally becomes the endothecium, and in the following account this condition will be presented. If the anther does not dehisce, the endothecial cells do not become specially modified; but if the anther dehisces, the cells develop thickening bands in various ways, the position and extent of these banded cells being directly related to the method of dehiscence (Fig. 7).

Between the outermost and innermost parietal layers there are usually one to three "middle layers," and this amount of

applying the term to the first cell or group of cells differentiated from the ordinary vegetative cells to produce sporogenous tissue, it is easy of application and the homologies are definite. 

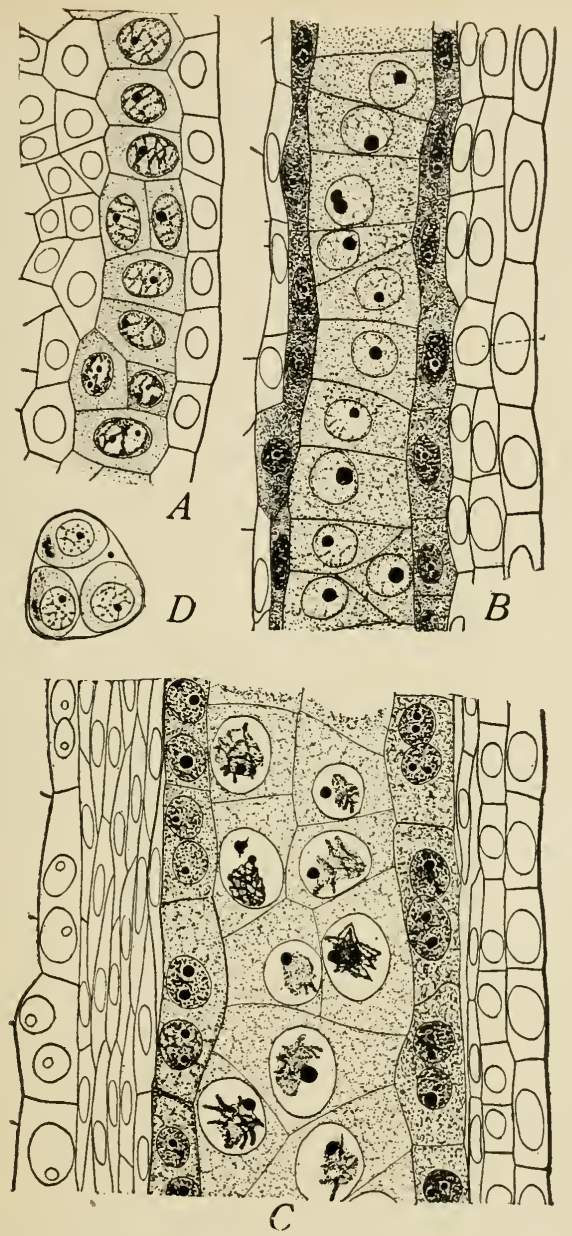

F10. 10.-Silphium integrifolium. Longitudinal sections of mierosporangia; $\times 520$. $A$, single row of archesporial cells; in two cells division into primary sporogenous and primary parietal cells has already taken place. $B$, sporogenous and tapetal cells sharply differentiated. $C$, later stage showing spore mother-cells in synapsis. $D$, a tetrad (only three microspores shown) formed within the spore mother-cell.-After Merrelt. 29 
variation may oceur in the same wall, as noted by Coulter ${ }^{19}$ in Ranunculus. The cells of these layers are usually tabular, and gradually become flattened and disorganized; but in sone cases the one or two innermost middle layers become prominent as a part of the tapetum; in others the outer ones may become a part of the endothecium; and occasionally there is no disorganization of parietal layers.

The innermost parietal layer, as a rule, becomes part of the tapetum, which is a jacket of nourishing cells in inmediate contact with the sporogenous tissue (Figs. 9, 10). The tapetum has
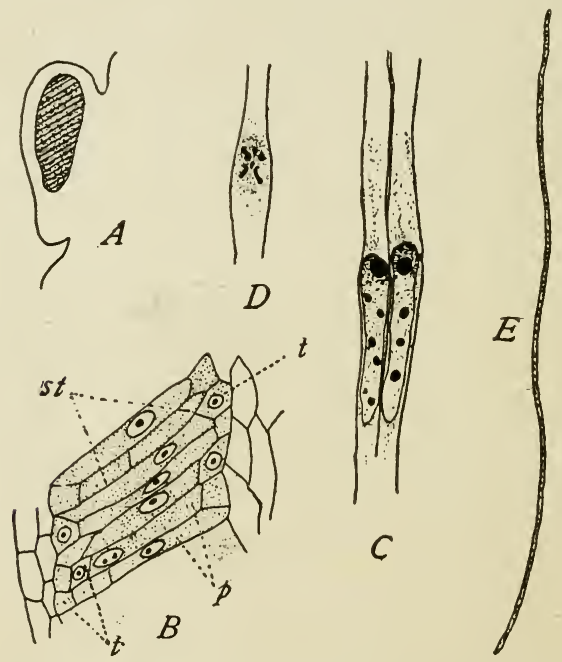

Fio. 11.-Zostera marina. A, young microsporangium with archesporial cells shaded. $B$, later stage showing tapetum derived from sporogenous cells; $t$, tapetum; $p$, pollen mother-cells; st, sterile cells, as shown by transverse wall. $C$, portions of the two long cells resulting from the first division of the pollen mother-cell. $D$, portion of a microspore showing the nuclear division that gives rise to the generative and tube nuclei; there are six chromosomes. $E$, the filiform pollen grain.-After Rosenberg. 32

no definite morphological boundary or origin, but results from pressing into special physiological service the sterile cells, of whatever origin, contiguous to the sporogenous tissue. While one 
layer of cells is the rule, the tapetum may inclnde two or more lavers, as pointed out by Frye ${ }^{33}$ in Asclepias. The same investigator has also followed the origin of that portion of the tapetuin next the connective from the plate of cells immediately within the archesporium; and in a recent paper Rosenberg ${ }^{32}$ de-cribes and figures the much elongated archesporial cells of Zostera as cutting off isodiametric cells at each end, that divide more or less and form the tapetum on the onter and inner surfaces of the sporogenous mass (Fig. 11, $B, t)$. There is evidence, therefore, that in certain

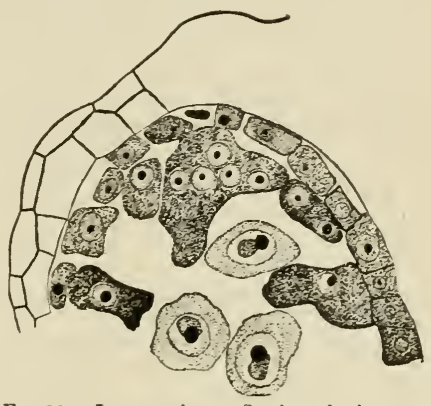

Fig. 12.-Lemna minor. Section of microsporangium showing some of the spore mothercells broken down and functioning as tapetum; $\times 1100 .-$ After Caldwell. ${ }^{23}$ cases the tapetum, or at least part of it, may be derived from sterile cells cut off from: the periphery of the sporogenous mass. Such a probability is also reported by Coulter $^{19}$ in Ranunculus, and by Webb $^{34}$ in Astilbe. Enough is known, at least, to lead to the conclusion that any sterile cells in contact with the sporogenous tissue assume the tapetal function. This is a well-known fact in connection with sterile mother-cells, which in this sense are a part of the tapetum. Among the Pontederiaceae Smith ${ }^{21}$ found that the tapetal cells, closely adherent to the mother-cells, are often wedged among them; and in Lemna Caldwell ${ }^{23}$ observed that the cells of the regular tapetal jacket often divide and form groups of celis projecting deep among the mother-cells, sterile mother-cells also disintegrating (Fig. 12): while in Symplocarpus. Duggar ${ }^{27}$ reports that the tapetal cells become free and "wander" among the mother-cells. It seems clear, therefore, that the tapetum is a set of sterile cells that nourish the functioning mother-cells, and that while ordinarily it is a definite layer none of which is derived from the primary sporogenous cells, it may include a variety of morphological elements.

As a rule, the complete organization of the tapetal jacket is 
coincident with the mother-cell stage, but the greatest derelopment of the tapetal cells is during the formation of tetrads. During this process they may increase greatly in size, this being associated with the disorganization of the cells of one or more of the middle lavers. It is very common for the enlarged tapetal cells, filled with food material, to become binucleate (Fig. 10,C), and later even multinucleate, as in Typha (Schaff-

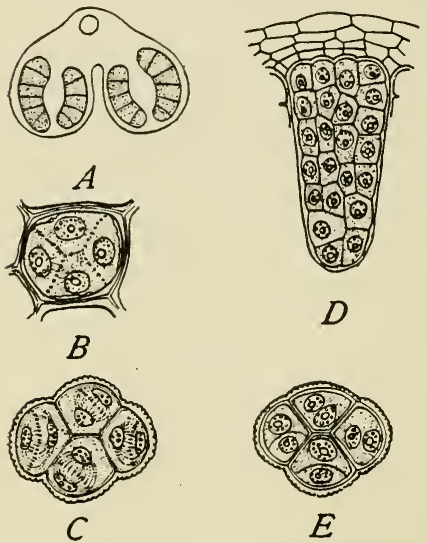

Fig. 13.- $A$ and $D$, Orchis maculata: $A$, transverse section of an anther with four microsporangia, each showing five or six cells, each of which gives rise to a "massula" as shown in $D . B, C$, and $E$, Neottia ovata: $B$, a tetrad; $C$, the four mierospores within the common wall dividing to form tube nucleus and generative cell; $E$, the division completed; two of the microspores show the generative cell cut off by a lenticular wall. $A \times 25 ; D \times 240 ; B, C, E \times 365$.-After Guignard. 10 ner ${ }^{17}$ ) and Hepatica (Coulter $\left.{ }^{19}\right)$, in the latter genus six to thirteen nuclei having been observed in a single cell. At the end of the tetrad division the tapetal cells usually become disorganized,-also such of the middle lavers as have not disorganized previously, and the outermost parietal layer begins to develop the thickenings characteristic of the endothecium. The fact that the endothecium may consist of additional layers of cells has already been mentioned.

During the derelopment of the parietal layers the primary sporogenous cells either directly or by division produce the mothercells. When division occurs, it is in every direction, so that all appearance of layers is lost. Perhaps

the usual case is for the primary sporogenous cells to divide two or three times, but there are sometimes more divisions, and a number of cases are known in which the primary sporogenous cells, without dirision, become mother-cells, as has been long known in Malva, Datura, Mentha, and Chrysanthemum, and recently reported for several species of Asclepiadaceae by Stras- 
burger ${ }^{31}$ and by Frye. $^{33}$ The ease of certain orchids, such as U:chis maculata, Calanthe veratrifolia, and Neottia ovata, investigated by Guignard, ${ }^{10}$ and their allied forms, deserve special mention. Each primary sporogenous cell gives rise to a welldefined mass of mother-cells known as a massula (Fig. 13, A, $D)$, and separated from its fellows by thieker walls.

The mother-eells and their nuelei usually increase very much in size, and differ from the adjacent cells in their reaction to stains. This growth is usually aceompanied by a rounding of the cells and their separation from one another, and also by a thickening of the wall; but in many Dicotyledons (Tropaeolum, Althaea, ete.) the mother-cells do not become isolated, and remain packed closely together in the sporangium, due probably to the tardy disorganization of the tapetum or its failure to disorganize.

The time relations of the events described to those that form the history of the corresponding megasporangimm are exceedingly variable, but the case of Astilbe, as described by Webb, ${ }^{34}$ may be taken as an illustration, especially as it probably represents an average case. The microsporangia develop rapidly, maturing in one or two weeks, and preeede the megasporangia stage for stage. The anthers are rounded and enlarged before the carpellary cavity is closed over; the four microsporangia are well marked when the "placentae" are wholly undifferentiated; the tapetum is organized and the mother-eell stage reached when the integuments have not appeared; during the tetrad stage the integuments appear, while the microspores are "rounded off" before the functional megaspore is determined. The most extreme eases are probably certain orehids in which pollination oecurs before orules are formed; and oaks (Con$\operatorname{rad}^{29}$ ), in which pollination oceurs one spring and the ovules do not develop until the next.

The case of Lemna, as reported by Caldwell, ${ }^{23}$ deserves separate mention (Fig. 14). In the naseent anther a single hypodermal group of cells appears as an archesporium and enters upon the usual history, a wall of several layers and a broad sporogenous mass being formed. A plate of sterile cells gradually divides this sporogenous mass into two, each of which continues to divide as the anther inereases in size. Fach of these two sporogenous masses is divided by a plate of sterile cells, so that 
four distinct sporogenous groups are formed, each surrounded by its own tapetum. As a result, the mature anther seems to contain the usual four sporangia. Such a case makes the definition of a sporangium difficult. If a single archesporium is the criterion, Lemna has a single sporangium; if a group of mother-cells invested by a tapetum is the criterion, it has four sporangia. The explanation probably lies in the fact that the whole outer layer of the periblem is capable of becoming trans-
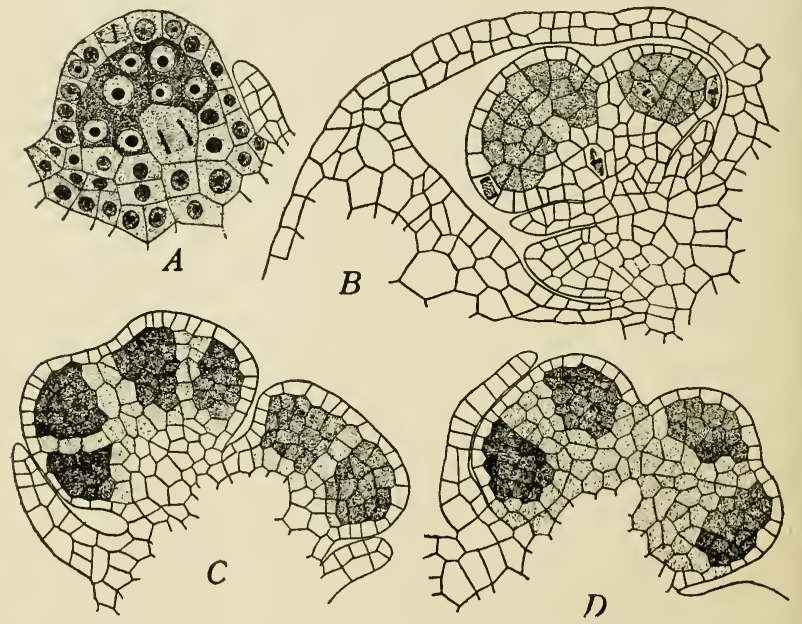

Fiø. 14.-Lemna minor. Development of microsporangium and sporogenous tissue. A young stamen with sporogenous cells. $B$, two young stamens; in the one at the left the sporogenous tissue is becoming divided by a sterile plate. $C$, a more advanced stage than $B$. D, a single stamen showing the four masses of sporogrenous tissue well separated by sterile plates. $A \times 1100 ; B, C, D \times 712$-After CAl,1)WELL. ${ }^{23}$

formed into an archesporium, and that while in ordinary cases archesporial tissue is developed in four separate regions, in Lemna the conditions favor a more general development. To livide a large sporogenous mass by sterile plates for better nutrition is too common to call for any special remark. As for the definition of a sporangim, it is probably not best to define it too rigidly, but to use the term as one of convenience. From 
this standpoint, there is no objection to speaking of the four groups of mother-cells in Lemna as four sporangia, which have had quite an exceptional origin. The phenomenon is too unique as yet among Angiosperms to justify any generalization.

The growth of mother-cells and the enlargement of the sporangial cavities usually result in reducing to a thin plate the sterile tissue separating the two sporangial cavities on each side of the anther. As dehiscence approaches, this plate usually disappears, and the two sporangial cavities become fused into a single loculus of the anther (Fig. 7). In the mature condition, therefore, such an anther contains two loculi or "pollensacs." While this represents the ordinary condition of the mature anther, among the Araceae it is reported that the single loculus of the anther is formed by the fusion of four sporangial cavities, and in Sassafras it is well known that the four remain separate. In case an anther contains only two sporangia, as among Asclepiadaceae, there is no fusion, and each loculus is a single sporangial cavity.

The mechanism for the dehiscence of anthers is extremely varied (Fig. 15), and needs much more investigation than it has received. By far the most common method is by means of a longitudinal fissure, a definite stomimm dereloping, as in Lilium (Fig. 7), and opening by means of the drying of the anther-walls, the contraction of the epidermal cells being greater than that of the endothecial cells with their thick bands. There is also dehiscence by a short apical fissure, as in Solanum and certain Ericaceae; by a terminal pore, formed by the disorganization of a small portion of tissme, as in certain Ericaceae; by hinged valves, as in Berberis, Sassafras, and Hamamelis; and by irregular breaking and exfoliating of superficial tissues, as in the axial stamens of Naias. The details of these methods, and of others, shonld be investigater from the standpoint of the development of the mechanism, for such as we have are too rague and superficial to be of much significance.

The mother-cell stage of the microsporangium is regarded as the end of the history of the sporophyte in this direction, chiefly because the division of the mother-cell, preceded by a more or less prolonged rest, is a reduction division, and in consequence the resulting cells have the feature most characteristic 
of gametophrtic tissue-namely, the reduced number of chromosomes (Fig. 53). With this division, therefore, the history of the male gametophyte begins. This line of demarcation between sporophyte and gametophyte is easy to define, but does

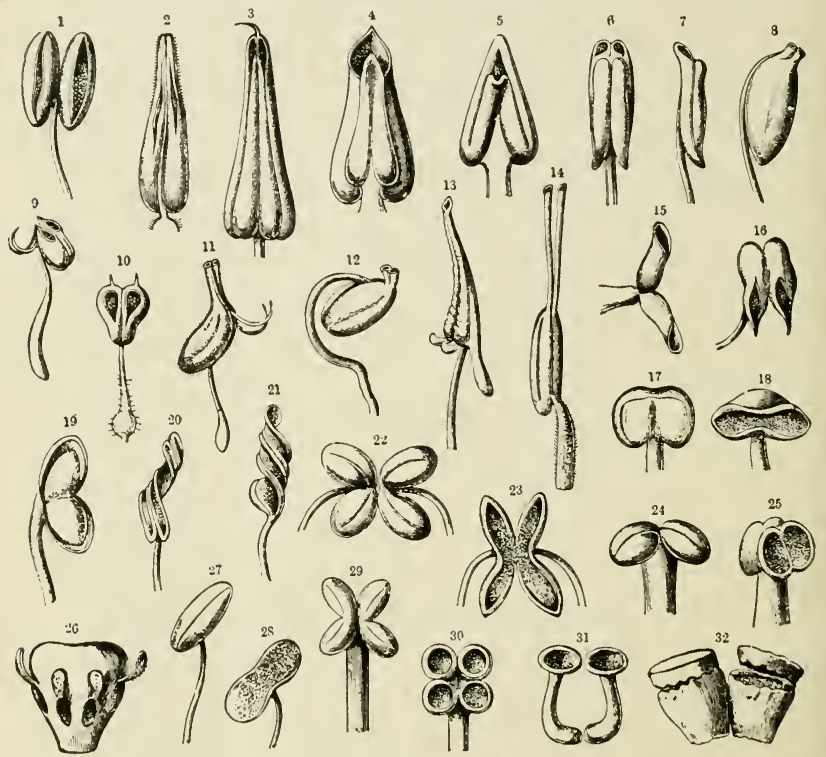

Fı. 15.-Forms of stamens. 1, Calandrinia compressa; 2, Solanum Lycopersicum; 3 , Galanthus nivalis; 4, Cyclamen europaeum; 5, Rtmondia pyrenaica: 6. 7, Cassia lenitiva: 8, Pyrola rotundifolia; 9, Arctostaphylos Cva-ursi; 10, A. alpina: 11, Vaccinium uliginosum: 12, Pyrola unitlora; 13, Hedinilla (after Baillov); 14, Vaccinium Oxycoccus; 15, Calceolaria Pnvonii; 16, Tozzia alpina; 17, 18, Sihballia procumbens; 19, Galeopsis angustifolia; 20, 21, Erythraea Centaureum; 22, 23, Melissa officinalis; 24, 25, Calla palustris: 26, Nyctandra (after Balloos); 27, 28, Globularia cordifolia; 29, 30, Thenbroma Cacao: 31, Pingnicula vulgaris; 32, Garcinia.-From Kerver's PHanzenleben.

not result in so simple a conception of the alternating generations as to begin the gametophrte with the germinating spore, for it involves the simultaneous origin of four gametophrtic generations from the mother-cell through an intermediate division. The claim that the reduction division must be regarded 
as ushering in the gametophyte was first urged by Strasburger, ${ }^{12}$ whose paper closes as follows:

" The reduction in number of the chromosomes takes place, among the higher plants, in the mother-cells of the spores, and it is consequently these which must be regarded as the first term of the new generation. They as-ert this their true significance in that they usually isolate themselves from cohesion with other cells and become indepentent, although this independence is only of practical utility in the case of the products of their division-that is, of the spores. Hence the center of gravity of the derelopmental processes which take place in both micro- and macrosporangia of Creptogams and Phanerogams does not lie in those cells, cell-rows, or cell-aggregates which give rise to the sporogenous tissue and have been designated 'archesporium' by Goebel. The archesporium still belongs to the sexually dereloped asexual generation; it is only the spore mother-cells which initiate the new sexual generation; consequently the presence or absence of a rell-clefined archesporium is not a matter to which importance should be attached."

\section{LITERATURE CITED}

1. Purkinje. J. E. De cellulis antherarum fibrosis nec non de granorum pollinarium formis commentatio phytotomica. Tratislaviae. 1830.

2. N̈̈GELI, C. Zur Entwicklungsgeschichte des Pollens. Zïrich. 1842.

3. Hofmeister. W. Nenere Beobachtungen über Embryobildung der Phanerogamen. Jahrb. Wiss. Bot. 1: 82-188. pls. ґ-10. 1858 .

4. Rosaxoff, S. Zur Kenntniss des Banes und der Entwicklungsgeschichte des Pollens der Mimoseae. Jahrb. Wiss. Bot. 4: 441450. pls. 81-32. 1865 .

5. Rohrbach, P. Die Samenknospe der Typhaceen. Bot. Zeit. 27 : 479-480. 1869.

6. Kauffyasx. N. Ueber die männlichen Blïthe von Casuarina quadrivalvis. Bull. Soc. Nat. Moscou 41:374-382. 1869.

7. Marixts. P. Zur Morphologie der Gattung Naias L. Bot. Zeit. 27: 769-773. 1869. Also Beiträge zur Kenntniss der Gattung Naias L. Berlin. 1870.

8. Warmisc, E. Untersuchungen ïber pollenbildende Phyllome und Kaulome. Hanstein's Bot. Abhandl. 2: 1-90. pls. 1-6. 1873. 
9. Exgler, A. Beiträge zur Kenntniss der Antherenbildung der Metaspermen. Jahrb. Wiss. Bot. 10: 275-316. pls. 20-24. 1876.

10. Guigrard, L. Recherches sur la développement de l'anthère et du pollen des Orchidées. Ann. Sci. Nat. Bot. VI. 14: 26-45. pl. 2. 1882.

11. Goebel, C. Outlines of Classification and Special Morphology. English translation. 1887.

12. Strasburger, E. The Periodic Reduction of Chromosomes in Living Organisms. Annals of Botany 8: 281-316. 1894.

13. Van Tieghem, Ph.: Observations sur la structure et la dehiscence des anthères des Loranthacées, etc. Bull. Soc. Bot. France 42 : 363-368. 1895 .

14. Suith, Arma. Abortive Flower Buds of Trillium. Bot. Gazette 22: $402-403,1896$.

15. Campbell, D. H. A Morphological Study of Naias and Zannichellia, Proc. Calif. Acad. Sci. III. 1: 1-62. pls. 1-5. 1897.

16. Chamberlain. C. J. Contribution to the Life History of Salix. Bot. Gazette 23: 147-179. pls. 12-18. 1897.

17. Schaffyer, J. H. The Development of the Stamens and Carpels of Typha latifolia. Bot. Gazette 24: 93-102. pls. 4-6. 1897.

18. CAmpbell, D. H. The Development of the Flower and Embryo in Lilaea subulata H B K. Annals of Botany 12 : 1-28. pls. 1-3. 1898.

19. Coulter, J. M. Contribution to the Life History of Ranunculus. Bot. Gazette 25: 73-88. pls. 4-

20. Chamberlain, C. J. Winter Character's of Certain Sporangia. Bot. Gazette 25 : 124-128. pl. 11. 1898.

21. Sirtr, R. W. A Contribution to the Life History of the Pontederiaceae. Bot. Gazette 25 : 324-337. pls. 19-20. 1898.

22. Lyox, Florence M. A Contribution to the Life History of Euphorbia corollata. Bot. Gazette 25: 418-426. pls. 2?-24. 1898.

23. Caldwell, O. W. On the Life History of Lemna minor. Bot. Gazette 27: 37-66. figs. 59. 1899.

24. Fulluer, E. L. The Development of the Microsporangia and Nicrospores of Hemerocallis fulva. Bot. Gazette 28: 81-88. pls. $\tilde{\imath}-8.1899$.

25. WiEgaNd, K. M. The Development of the Microsporangium and Microspores in Convallaria and Potamogeton. Bot. Gazette 28: 328-359. pls. 24-25. 1899.

26. Canvon, W. A. A Morphological Study of the Flower and Embryo of the Wild Oat, Avena fatua. Proc. Calif. Acad. Sci. III. 1 : 329-364 pls. 49-53. 1900.

27. Duggar. B. M. Studies in the Development of the Pollen Grain in Symplocarpus foetidus and Peltandra undulata. Bot. Gazette 29: 81-98. pls. 1-2. 1900. 
28. Merrell. W. D. A Contribution to the Life History of Silphium. Bot. Gazette 29: 99-133. pls. 3-10. 1900.

29. Conrad, A. H. A Contribution to the Life History of Quercus. Bot. Gazette 29: 408-418. pls. 28-29. 1900.

30. Lotsy, J. P. Rhopalocnemis phalloides Jungh., a Morphologicalsystematical Study. Ann. Jard. Bot. Buitenzorg II. 2: 73-101. pls. 3-14. 1900.

31. Strasblrater, E. Einige Bemerkungen zu der Pollenbildung bei Asclepias. Ber. Deutsch. Bot. Gesell. 19: 450-461. pl. 24. 1901.

32. Roserberg, O. Ueber die Pollenbildung von Zostera. Meddel. Stockholms Högsk. Bot. Inst. pp. 21. 1901.

33. Frye, T. C. Development of the Pollen in some Asclepiadaceae. Bot. Gazette 32: 325-331. pl. 13. 1901.

34. WebB. J. E. A Morphological Study of the Flower and Embryo of Spiraea. Bot. Gazette 33: 451-460. figs. 28. 1902. For correction of names see REHDER in Bot. Gazette 34: 246. 1902.

35. Shommaker. D. $\mathrm{X}$. Notes on the Development of Hamamelis virginiana L. Johns Hopkins Univ. Circ. 21: 86-87. 1902. 


\section{CHAP'TER IV \\ THE MEGASPORANGIUM}

THE megasporanginm, just as the microsporangium, is hypodermal in origin, being derived from the outermost layer of the periblem. Although strictly an embedded organ, it becomes superficially very distinct throngh the growth of cells beneath and around it, the whole structure constituting the ovule. Althongh in a strict morphological sense the ormle is more than a megasporanginm, just as the ordinary anther is more than four microsporangia, the distinction is theoretical rather than practical, and in the following discnssion will be disregarded.

Although the carpels are concerned in forming all or a part of the encasement of the orules, they do not always produce them. Just as in the case of the microsporangia, and in the same sense, there are cauline as well as foliar orules, and the former are much more common than are cauline microsporangia. This is probably due to the fact that the ornles are much more closely associated with the growing point of the axis than are the microsporangia, and hence the former are much more likely to be borne by a lateral member than the latter.

Cauline ornles are either terminal or lateral. In the former case the apex of the axis becomes the nucellus, as is probably true of most orthotropons orules, certainly in Naias, Zannichellia, Lilaea, Piperaceae, Juglandaceae, Polygonaceae, and others. In the case of laterally canline ovules apical growth of the axis may be checked, so that the lateral orule appears to arise in a terminal position from the bottom of the sporangial chamber, as among the Compositae; or the apical growth may be continued into the sporangial chamber as a dome-shaped (Anagallis arrensis) or columnar (Spergularia rubra, Amarantaceae, etc.) structure mpon which numerous lateral orules are 
borne, giving rise to the so-called " free central placentation" of the older botanists. Cauline orules have also been reported


Fio. 16.-A, Balanophora polyandra, with archegonium-like megasporangia; $\times 15$. $B, B$, dioica, a younger stage showing the mother-cell just after the first division; $\times 200$. C , B. polyandra, "style" with a pollen-tube growing down into the "stylar canal"; $\times 105$. D, $B$. dioica, longitudinal section of a nearly ripe seed; the suspensor is not shown in this section. $E$, a similar section through the endosperm and embryo, showing the suspensor.-After HoFME1ster. ${ }^{5}$

in Myzodendron punctulatum by Johnson, ${ }^{22}$ and they doubtless occur in other Santalaceae; and in Sparganium simplex, Lilaea 
subulata, and eertain of the Araceae by Campbell ${ }^{37,4 i, 49}$; and there is no doubt that numerous other cases await diseovery. It should be remembered also that in many cases of epigyny the

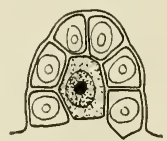

A



B

Fig. 17.-Balanophora globosa. A, nucellus with mother-cell of embryosac (shaded); the epidermal cells above the mother-cell give rise to the outgrowth resembling the neck of an archegonium. $B$, later stage in which the mother-eell has divided into two cells, both of which "very often develop into embryo-saes"; $\times$ 166.After Lotsy. ${ }^{48}$ orules are probably to be regarded as cauline, and if these be added to the cases already indicated, it becomes erident that cauline orules are exceedingly common and occur in all grades of Angiosperms.

In this connection the curious condition in Loranthaceae and Balanophoraceae may be consiclered, a condition that may have some connection with their peculiar habits. In 185s Hofmeister ${ }^{4,5}$ studied various species and outlined the prominent feature: of these groups, describing and illustrating sereral stages in the development of the archegoniumlike megasporangium, and also of the endosperm and embryo of Balanophoraceae (Fig. 16), and also the puzzling "mamelon" in Loranthaceae. Subsequent investigators have in the main confirmed and extended this work, the most important modification being in the interpretation of the embryo; and eren here Hofmeister's figures are nearly identical with those of the most recent papers ( $c f$. Fig. 16 with Fig. 10\%). In 1882 Treub ${ }^{18}$ described the development of the pistil of Loranthus sphaerocarpus (Fig. 19). A strueture (" mamelon") arises from the bottom of each of the three or four sporangial chambers and grows until it completely fills it, and in this structure hypodermal archesporia appear and derelop megaspores in the usual way. It is a fair question whether the "mamelon" is a growth of the axis, whose orules, represented by separate archesporia, are mechanically hindered from any superficial development; or whether it is an ovule 
without an integument, in which there are several archesporia. Hofmeister farored the latter view, while Treub inclined to the former, as his explanation of it as a fusion of rudimentary orules and placentas would seem to indicate. In 1883 Treub ${ }^{19}$ discovered exactly the same structure in Loranthus pentandrus. In 1895 the same investigator ${ }^{29}$ described Balanophora elongata as having no orule or placenta. In 1896 this was confirmed by Tan Tieghem ${ }^{34}$ for $B$. indica; and in 1899 by Lotsy 48 for $B$. globosa (Fig. 17). Lotsy claims that in $\dot{B}$. globosa there are no flowers, carpels, placenta, or orules; but that a hypodermal cell in a protuberance of the floral axis gives rise to the embryo-sac, while the epidermal cells over it develop a long, style-like organ resembling the neck of an archegonium. Hofmeister describes and figures the pollentube of $B$. polyandra as growing down into this "stylar caual," as he called it (Fig. $16, C)$. It would appear from the figures that the "protuberance of the floral axis" is a megasporangium without integuments, and that the socalled "style" is a remarkable outgrowth of the nucellus. The pollen-grains, as figured by Hofmeister, therefore, come in contact with the nucellus, as in Gymnosperms. In this connection attention may be called to the remarkable beak developed by the nucellus of Euphorbia corollata as described by Miss L y.on ${ }^{41}$ (Fig.



Fiब. 18.-Euphorbia corollata. Longitudinal section showing an excessive prolongation of the nucellus; $\times 650 .-$ After LYoN.41 18), a beak which suggests the same general tendeney of the nucellus which has reached such an extreme expression in Balanophora. The investigation of Phopalocnemis phalloides (Balanophoraceae) by Lotsy, ${ }^{52}$ however, as well as the case of Balano- 
phora, suggests the explanation. Lotsy finds that the enlarged tip of the flower axis soon completely fills the carity of the orary,
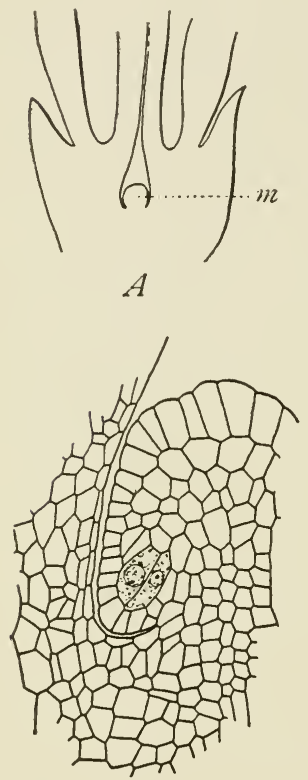

$B$

Fis.19.-Loranthus sphaerocarpus. $A$, longitudinal section of a young flower showing the "mamelon" $(m) ; \times 25$. $B$, longitudinal section of a "mamelon" at a later stage showing two hypodermal archesporial cells ; $\times 300$. - After TREUb. ${ }^{18}$ and that one or more hypodermal cells of this axis form the megaspores (Fig. 20). This is exactly the case of Loranthus, and suggests that in the allied Balanophora the same "manelon" is present, but with no carpellary investment, the naked nucellus (as the "mamelon" would seem to be in this case) dereloping the remarkable neck-like outgrowth of sterile tissue. In both families it seems certain that the megasporangia are cauline.

Foliar orules are related to the carpels in a variety of ways. By far the most common position is for the orules to arise in a line along each side of one of the two prominent rascular bundles of the carpel, a very common position for the sporangia of ferns. In the older morphology this line was thought to represent the abutting margins of the infolded carpellary leaf, and hence such orules were called "marginal." In fact, this double line of orules, and the dehiscence of many carpels along it, seemed to the supporters of metamorphosis to prove the foliar nature of the carpel. As might be expected from the behavior of sporangia in ferns, there are cases in which orules arise without such close counection with a prominent vascular bundle. For example, in Butomus, Nymphaea, Nuphar, Obolaria, Bartonia, and many species of Gentiana, the orules arise from the whole inner surface of the carpel. In the older terminology these were called "superficial" orules, and associated with them, curiously enough, were 
the occasional cases in which the orules arise from the other vascular bundle (the "midrib" of the infolded leaf theory), as in Brasenia, Cabomba, and Astrocarpus (Eichler, ${ }^{8}$ 2: 17). According to $\mathrm{Warming}^{7}$ a third category is necessary to include such cases as Zannichellia, Ranunculus, and Sedum, in which he says the ornles are " basal or axillary."

The general conclusion seems evident that orules may arise from any free surface within the cavity of the ovary, whether it be morphologically carpel or axis; and further, that if the carity of the orary becomes obliterated by the enlarged tip of
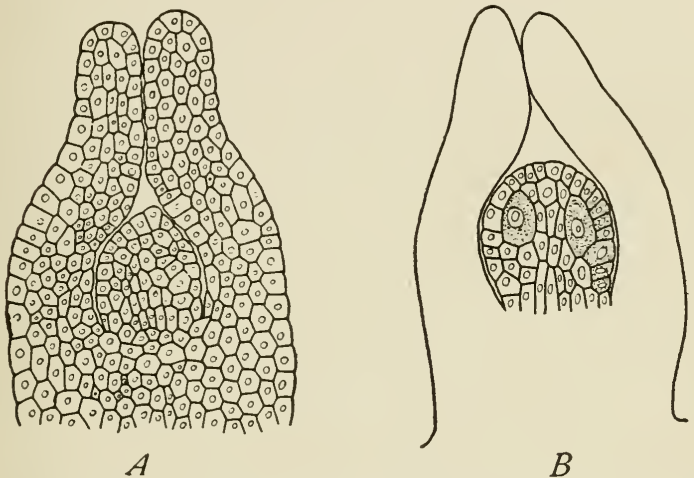

Fig. 20.-Rhopalocnemis phalloiles. A, longitudinal section through the "mamelon" before the appearance of archesporial eells. $B$, later stage showing the two megaspore mother-eells which develop directly into embry 0-sucs. $\times$ 116.-After Lotsr. ${ }^{62}$

the axis, as probable in Loranthaceae and Balanophoraceae, megasporangia arise from the hypodermal cells of the axis without the definite organization of ovules.

The morphological nature of the ovule was much discussed by the older morphologists. According to the theory of metamorphosis it was necessary to interpret it as a transformation of some one or more of the vegetative members. The most prevalent view was that it is a transformed leaf-bud arising from the margin of the carpellary leaf, as in the well-known case of Bryophyllum; and Hofmeister claimed that the orule of Orchis is a trichome because it arises from a single epidermal 
cell. When cauline orules came to notice, Schleiden, Endlicher, and others took the extreme position that all ovules are cauline, even those evidently parietal upon carpels. This view was opposed by Van Tieghem, ${ }^{6}$ Celakorsky," and especially by Warming. ${ }^{10}$ The last-mentioned paper is noteworthy for its presentation of the origin and derelopment of the ovule, as well as for its discussion of its morphology. These writers maintained that the ovule is always foliar in origin, and their explanations of cauline ovules are interesting on account of their ingenuity. This view was also maintained by Eichler in his Bliuthendiagramme, where an historical résumé of the whole subject may be found. The most interesting feature of the whole discussion, however, is the persistent idea that ovules could not be both foliar and cauline. These last observers, having established the foliar origin, disproved the bud character of ovules, since the members of leaf-buds arise in acropetal succession, while the nucellus and integuments are basipetal. It was urged that the ovule is a transformed leaf-lobe or leafoutgrowth, and that this view homologized them with the sporangia of ferns. This was a decided step in advance, and it only remained to abandon the doctrine of metamorphosis, and to see that the orules (sporangia) hold no necessary relation to either leaf or stem, but are themselves long-established and independent members of the plant bodr, with a history that antedates that of either stem or leaf.

The length of time from the beginning of megasporangia to their maturity is very indefinitely known, as most investigators do not seem to have kept such a record. It must be extremely variable, as in the case of the microsporangia, and related to the seasonal habit of the plant. In Salix and Populus Chamberlain ${ }^{39}$ found that the megaspore mother-cells are not distinguished until the renewal of growth in the spring, although the microsporangia pass the winter in the mother-cell stage; and this lateness of development may be usual in the megaspore series. Enough cases have been observer, however, to show that a much earlier development may often oceur. For example, in Acer rubrum Mottier ${ }^{27}$ discovered the mother-cell stage in March or earlier, the indication heing that this is the winter condition; Chamberlain ${ }^{39}$ found the four megaspores of Tritlium recurvatum fully formed early in April, when the plants 
were not more than 5 centimeters high, and the embryo-sac of Hepatica ready for fertilization while the ground was still frozen; we have seen embryo-sacs of Epigaea ready for fertilization in the autumn, pollination probably occurring the following spring; and Schaffner ${ }^{56}$ has found that in Erythronium the archesporial cell begins to enlarge about the first of October and nuclear changes oceur, and that by the first of December the nucleus is very large and the mother-cell stage reached, which persists until early spring. The subject should be investigated especially in connection with vernal herbs and early blooming shrubs and trees.

The details of the derelopment of the orule have been admirably given by Warming ${ }^{10}$ and Strasburger, ${ }^{13}$ supplementing and correcting the earlier observations of Hofmeister, ${ }^{4} 5$ and the literature since has grown so extensively that full citation is impossible (Fig. 21). At first the epidermis of the member upon which the ovule is to appear is even, and in the hypodermal layer the archesporium may or may not be evident. A slight protuberance is developed by cell-dirisions, which are usually only radial in the epidermal laser, resulting in a more extended plate of cells; but in the hypodermal laver they are variable, resulting in a mass of tissue, or in many cases in but a single axial row of cells. In any event, the protuberance becomes more and more prominent and constitutes the nucellus of the nascent ovule.

After the nucellus has become prominent, an annular outgrowth begins at its base, and with greater or less rapidity develops into the inner and often only integument, in most cases overtopping the nucellus (Fig. 3, I). In case there is an outer integument, its annular primordium becomes visible soon after the inner integument is well under way (Fig. 21). If the aril be placed in this category, it has been observed that this third integument arises much later than the other two, usually after fertilization, as in Asphodelus, Aloe, Nymphaea, Podophyllum, Euonymus, Celastrus, Myristica, etc., although in all these cases its point of origin does not seem to be well established. Disregarding the aril, two integuments-seem to be the rule among Monocotyledons, the only recorderl exception we have noted being Crinum, although, donbtless, there are others. Two integuments prevail among the Archichlamydeae also, the 

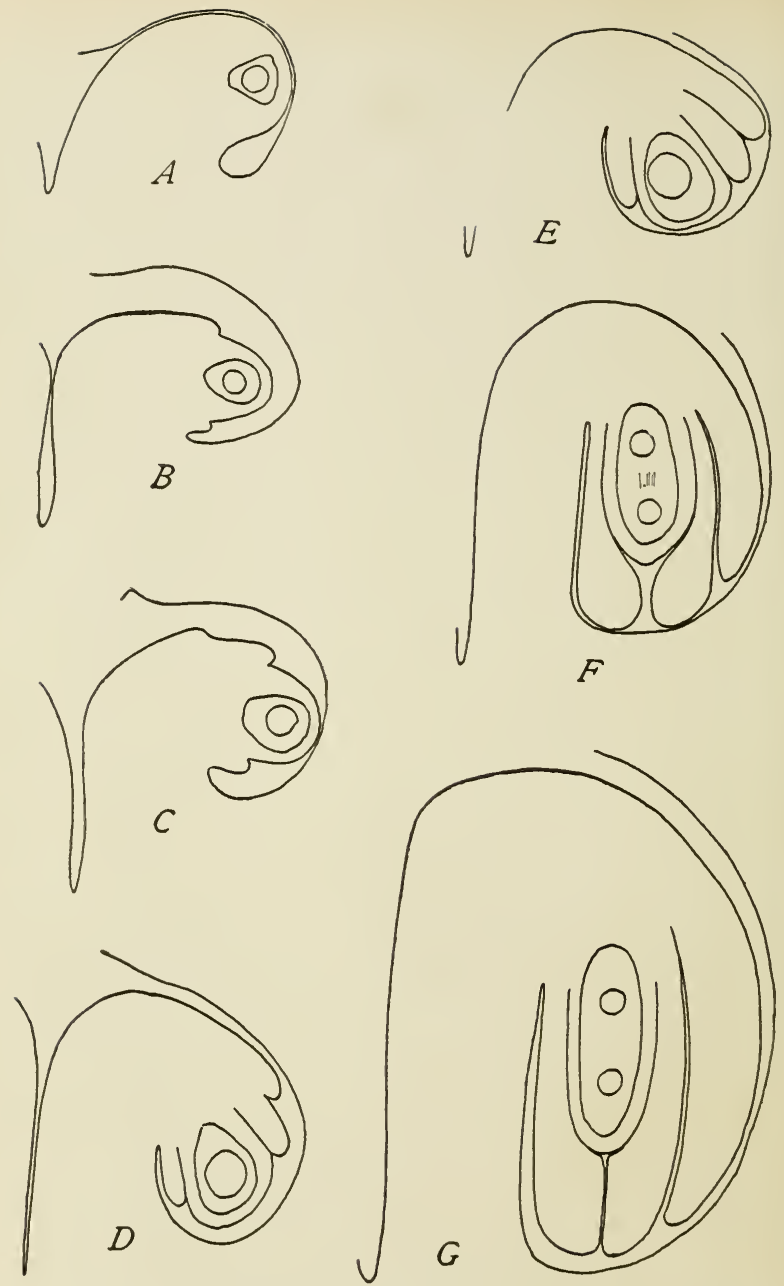

Fig. 21.-Lilium philadelphicum. A, ovule before the appearance of integuments, showing a single hypodermal archesporial cell which is also the megaspore mothercell. $B$, beginning of inner integument. $C$, beginning of outer interument. $I, E$, later stages. $F, G$, the orule anatropous and the megaspore germinating. $\times 175$. 
Umbelliferae being the most notable exception. On the other hand, a single integument is characteristic of the ovules of the Srmpetalae, as well as of the Lmbelliferae, and some other Archichlamrdeae, such as species of Ranunculus, Leguminosae, etc., the integument being very massive and in comparison with the rery small nucellus constituting the bulk of the orule. There seems to be erery indication that two integuments are characteristic of the orules of the more primitive Angiosperms; that they persist among Monocotyledons even among the most highly specialized families; but that among Dicotyledons they are replaced in the higher groups by the single massive integument. The fact that the single integument is more massive eren than both integuments when there are two suggests that it represents two integuments in the sense that their primordia are no longer differentiated. This is very far from meaning that two integuments have fused to form the single one, but that a single integument is dereloped by the same region that in other cases produces two.

Certain exceptional cases in the derelopment of integuments may be noted. Among the Loranthaceae and Balanophoraceae no integuments are formed: and the same claim is made by Chaureaud 24,65 for ('ynanchum (Asclepiadaceae), perhaps to be explained by Asclepias (Frre ${ }^{66}$ ), in which the integument might be mistaken for part of a naked nucellus. The same claim is made for Santalaceae, and it may be true of most of them; but in Myzodendron punctulatum Johnson 22 has described a single-layered integument that does not corer the free end of the embryo-sac. This suggests an abortion of the integument, which in other members of the family may not have been recognized or may eren hare been suppressed. The orule of Houstonia is said by Lloyd ${ }^{61}$ to have no integument. The orule of IIippuris long had the reputation of having no integument, as reported by Schleiden, ${ }^{1}$ Unger, ${ }^{2}$ and Schacht. ${ }^{3}$ In 1 sso, howerer, Fischer ${ }^{15}$ in reinvestigating it discorered that a single integument is formed, but closes orer the nucellus so tightly as to give the appearance of a naker nucellus. Oliver ${ }^{21}$ discorered exactly the same behavior in his new genus Trapella, except that the integument is rery massive. The same thing has also been observed br Murbeck ${ }^{\text {si }}$ in the parthenogenetic Alchemilla alpina, in which the single 
integument so completely coalesces with the nucellus and closes the micropyle that the ovule resembles a naked nucellus. Zinger ${ }^{43}$ observed that the massive inner integument in Cannabineae is completely coalescent with the thick outer one orer the apex of the nucellus, and the micropylar canal becomes entirely closed by the derelopment of tissue. In eases of chalazogamy and persistent parthenogenesis such behavior of the integuments may be expected, as well as in other cases whose habits do not suggest it.

In most cases, the orule does not merely become distinct from the surface of the member that produces it, but is borne upon a stalk-like base or funiculus. It is generally stated that
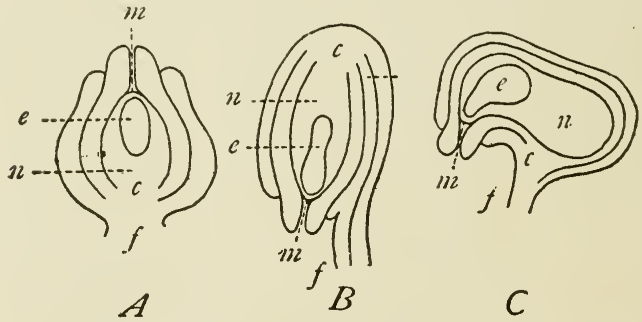

Fre. 22.-Forms of ovules (diagrammatic). $A$, orthotropous; $B$, anatropous; $C$, campylotropous ; $m$, nicropyle; $e$, embryo-sac ; $n$, nucellus; $c$, chalaza ; $f$, funiculus.After Prantl in Engler aud Prantl's Nat. Pflanzenfam.

the orules of Gramineae have no funiculus, but it would be impossible to draw an exact line between its presence and absence.

The direction of growth of the ovule seems to be related to the orientation of the micropvle in reference to the pollentube. Nirbel gave to the resulting forms the names orthotropous, campylotropous, and anatropous (Fig. 22). In the first case the growth continues without the development of any curvature, a fact generally true of terminal cauline ovules. Orthotropous orules are quite common, being found among Monocotyledons in the Restiaceae, Eriocaulaceae, Xyridaceae, certain Araceae, Commelinaceae, etc. ; and among Dicotyledons in the Piperaceae, Urticaceae, Polrgonaceae, Cistaceae, etc. These are relatively primitive families of $\mathbf{M}$ onoentyledons and Archichlanydeae, and confirm the natural impression that the 
original angiospermons ovules were straight. The camprlotropous orule, in which the whole body of the orule curres, is the rarest type, among Monocotyledons characterizing the Gramineae, Scitamineae, etc., and among Dicotyledons the Chenopodiaceae, Caryophyllaceae, Cruciferae, Capparidaceae, Reserlaceae, etc. These families are more or less specialized members of their alliances, and none of them belong to the Sympetalae. $\mathrm{By}$ far the most common form of orule is the anatropous, and although it is extensively displayed among Monocotyledons and Archichlamydeae, it is present almost without exception among the Srmpetalae, and may be regarded as the most highly specialized type of orule. In its derelopment an anatropous orule is at first straight or nearly so, but very early develops a curvature at a level with the origin of the first or only integument. As the integuments grow the curvature increases, and usually before the outer integument is complete the nucellus is inverted against the funiculus (Fig. 21). For this reason, in anatropous orules with two integuments the outer one is not developed on the side toward the funiculus. In abnormal material of Salix petiolaris both anatropous and orthotropous orules have been observed in the same ovary (Fig. 6).

The archesporium, as in the microsporangia, is recognized by the increasing size and the different reaction to stains of one or more hypodermal cells. Doubtless all of the hrpodermal cells are potentially archesporial, and there is reason for believing that the deeper cells of the nucellus, most of which are probably derivatives from the original hypodermal layer, may be also. In the rast majority of cases, howerer, only cells of the hypodermal layer show those changes that are characteristic of archesporial cells. It is not always easy to determine just how many hypodermal cells are to be included in the archesporium, for there is often complete gradation from cells with the size and staining reaction of undoubted archesporial cells to those showing neither increase in size nor the characteristic staining reaction. This is to be expected in case all the hypodermal cells are potentially archesporial, and there is no definite point in its history when such a cell ceases to be merely hypodermal and becomes clearly archesporial. For this reason, the number of cells recorled as constituting the archesporium in many plants can not be regarded as precise, but as approxi- 
mate. The prevailing habit, however, is to limit the archesporium to the single hypodermal cell that terminates the axial row of the nucellus. This seems to have resulted in the more
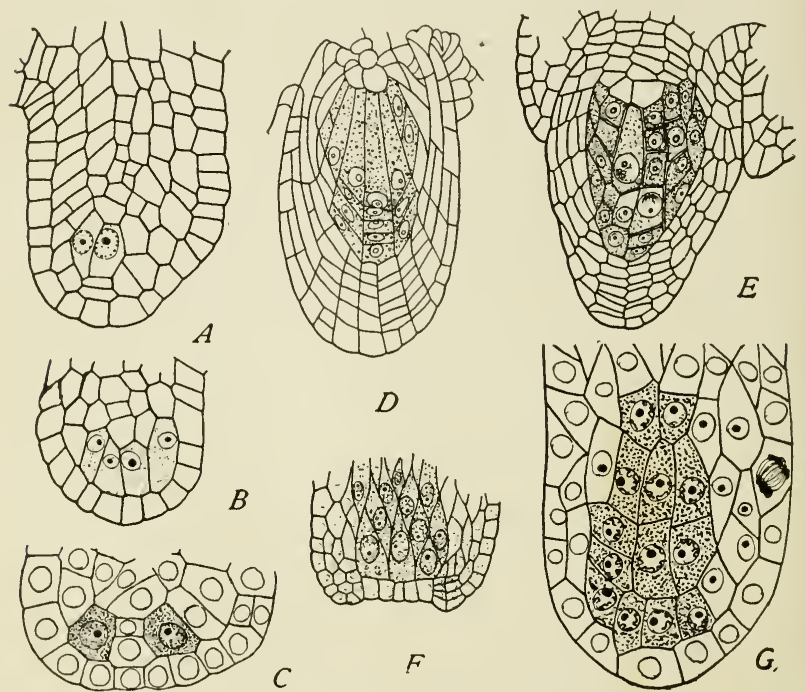

D
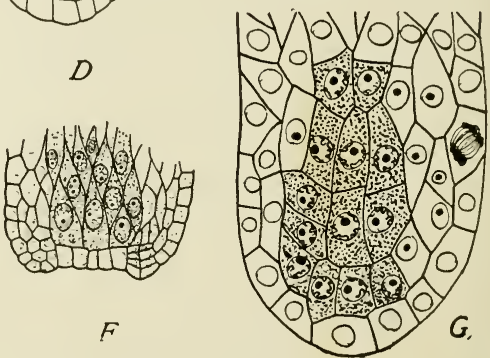

Fro. 23.-Longitudinal sections of ovules showing multicellular arehesporia. $A . B$, Astilbe japonica, $\times 550$; after $W_{\text {Евв, }}{ }^{60} \quad C$, sulix glaucophylla, $\times 600$; after C'намberlain. ${ }^{35}$ I, Rosa livida, $\times 224$; after Strasburger. ${ }^{13}$ E, Alchemilla alpina, $\times 275$; after Murвеск.67 $F$, Callipeltis cucullaria; after Lloyd. ${ }^{61} G$, Quercus velutina, $\times 720 ;$ after Conrad.63

highly specialized groups in reducing the nucellus within the epidermis to this axial row, as Litium, many Orchidaceae (Dumcé ${ }^{44}$ ), Lobeliaceae (Marshall-IVard ${ }^{14}$ ), Rubiaceae (Lloyd ${ }^{61}$ ), Compositae, and many other sympetalous groups. In such cases the nucellus in longitudinal section shows only three rows of cells.

It is of interest to note the recorded cases in which the archesporium is said to consist of more than a single cell (Fig. 23). In 1879 Strasburger ${ }^{13}$ described the several-celled archesporium of Rosa livida, and in 1580 Fischer ${ }^{15}$ reported a similar archesporium in Geum, Sanguisorba, Agrimonia, Ru- 
bus, and Cydonia, indicating that this is the prevailing tendency among the Rosaceae. In 1882 Guignard ${ }^{17}$ added Eriobotrya to the list, and in 1901 Murbeck ${ }^{57}$ found an archesporial group in Alchemilla alpina. Recently, however, Péchoutre ${ }^{63}$ has made a general survey of the Rosaceae, and in all of the fourteen genera studied, well distributed among the tribes, there was found a many-celled archesporium, showing a remarkable persistence of this character throughout a large family. Among the closely allied Saxifragaceae also, $\mathrm{Webb}^{60}$ has found in Astille this same type of archesporium.

In 1591 Treub $^{23}$ published his account of Casuarina, reporting that the archesporium is a group of hypodermal cells, and that the derived sporogenous tissue forms a large central mass within the nucellus (Fig. 24). The account and the fig-
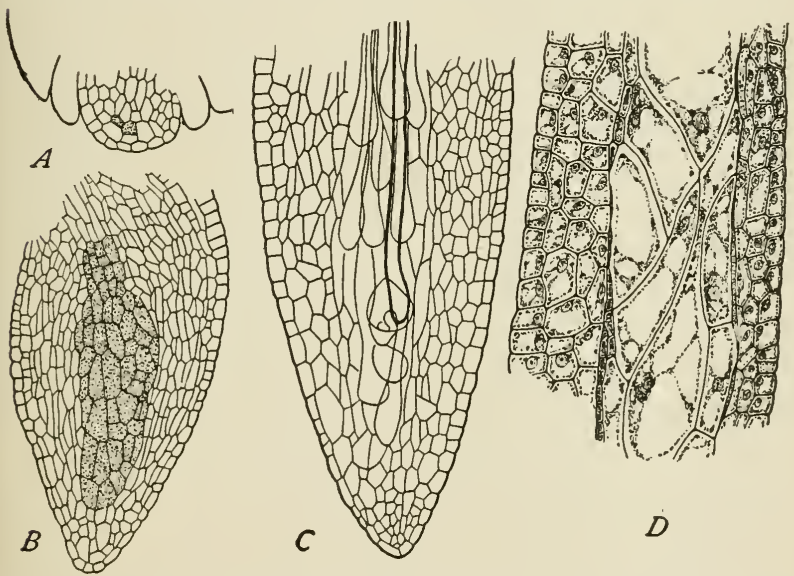

Fia. 24-Casuarina. Longitudinal sections of nucellus. $A$, section slowing two primary sporogenous cells (shaded); $\times 190$. $B$, later stage showing extensive sporogenous tissue: $\times 190 . C$, pollen-tube (with heavier walls) among the elongated sterile megaspores; $\times 67$. $D$, portion of nueellus at a much earlier stage than $C$, showing numerous megaspore mother-cells; $\times$ 157.-After Tвеvв. ${ }^{23}$

ures suggest that all of the sporogenous tissue may not be derived from the hypodermal layer. In 1894 Miss Benson ${ }^{28}$ discovered that a several-celled archesporium is present in $\mathrm{Fa}$ - 
The archesporial cells behave as do those of the microsporangium, and in case the archesporium is a plate of cells, the resemblance is striking. In the large majority of cases, however, the archesporim is a single cell, and often by transverse division it gives rise to a primary parietal cell and a primary sporogenous cell (Fig. 26). That the former cell, or plate of cells, as it is in the case of a several-celled archesporium, represents the primary parietal layer of the microsporangium seems

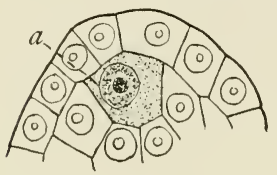

A

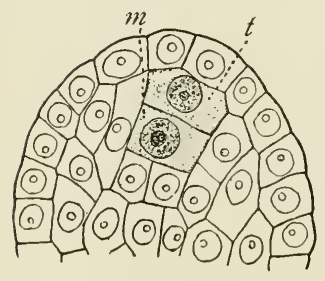

$B$

Fig. 26.-Salix glaucophylla. Longitudinal sections of nucellus, $\times 631$. A, single hypodermal archesporial cell $(a)$. $B$, archesporial cell has given rise to primary parietal cell $(t)$ and primary sporogenous cell $(m)$.After Chamberlain.95 clear. In recognition of this fact Strasburger called it the "tapetal cell," but for reasons given under the microsporangium we shall call it the parietal cell-that is, a cell that develops in part the wall of the embedded sporangium. Mottier ${ }^{25}$ has reported a very peculiar case in $\mathrm{Ar}$ saema, in which the single archesporial cell divides by anticlinal walls into three or four cells, each of which then cuts off a parietal cell. Just how far this is exceptional behavior remains to be seen, but it introduces an interesting problem as to the application of the term archesporium.

The behavior of the primary parietal cell is exceedingly raried. An extreme case is for a series of periclinal divisions to oceur, resulting in a long row of parietal cells, corresponding to the parietal layers of the microsporangium. In case there is a plate of archesporial cells the radial rows of parietal cells are very conspicuous, as in the Rosaceae and many of the Amentiferae (Figs. 23, $B, D, E$ ). In other cases the parietal rows become lost by the formation of anticlinal walls. If the mother-cell broadens rapidly, the first divisions of the primary parietal cell may be anticlinal, followed by periclinal divisions, as in Ruta graveolens (Guignard ${ }^{17}$ ) and Potamogeton foliosus (Wiegand ${ }^{54}$ ). The deep-placing of the sporoge- 
nous cells beneath parietal tissue occurs in Potamegeton (Wiegand, ${ }^{5+}$ Holferty ${ }^{55}$ ), Triticum (Koeruicke ${ }^{33}$ ), Agraphis (Tesque ${ }^{12}$ ), Triglochin (Tesque ${ }^{12}$ ), Lysichiton (Campbell ${ }^{4 i}$ ), Rosaceae, Saxifragaceae, many Leguminosae (as Lupinus, Cercis, Acacia), Euphorbiaceae, C'uphea (Guignard ${ }^{17}$ ), Fuchsia (Tesque ${ }^{12}$ ), Mesembrianthemum (Guignard ${ }^{17}$ ), and doubtless many other Monocotyledons and Archichlamydeae.

From a conspicuous development of parietal tissue there is a complete gradation to its entire suppression. A few periclinal divisions of the parietal cells may oceur or none at all. Sometimes in case the periclinal divisions have been abandoned, one or more anticlinal divisions may be induced by the broadening of the mother-cell, as the single periclinal division in Typha (Schaffner ${ }^{36}$ ) and Lemna (Caldwell ${ }^{46}$ ), and the series of such divisions in Convallaria (Wiegand ${ }^{54}$ ) and Butomus (Ward ${ }^{1+}$ ).

The gradation toward the suppression of parietal tissue is further illustrated in cases where the primary parietal cell divides or not in the same spccies, as in the grass Cornucopiae (Guignard ${ }^{17}$ ), Pontederiaceae (Smith ${ }^{40}$ ), Yucca (Guignard ${ }^{17}$ ), and Thalictrum (Overton ${ }^{59}$ ). The next stage is represented by the constant failure of the parietal cell to divide, as in Alyssum (Miss Riddle ${ }^{42}$ ) and Limnocharis (Hall ${ }^{58}$ ). The last case is of special interest from the fact that in the cutting off of the primary parietal cell no wall is formed, and the cell speedily disappears through the growth of the mothercell.

The transition from an incomplete and ephemeral primary parietal cell to none at all is natural, and this final stage, in which there is complete suppression of the parietal tissue, has been reached by many plants. It may be of interest to consider how far this condition has been reached by the great groups.

Among Monocotyledons the suppression of parietal tissue occurs in all the higher families, but it is usually associated also with the greater or less development of this tissue. Among Gramineae, Cannon ${ }^{50}$ reports Avena fatua as having no parietal cell, although other Gramineae are known to possess it, and in Triticum (Koernicke ${ }^{33}$ ) it develops an extensive tissue. Among Commelinaceae, Guignard ${ }^{\mathbf{1 7}}$ records Commelina stricta as without a parietal cell, and Strasburger ${ }^{13}$ figures Trade- 
scantia virginica as having one. Among Liliaceae, Allium, IIemerocallis, Lilium, Erythronium, and Tricyrtis have no parietal cell; and C'onvallaria, Funkia, Scilla, Omithogalum, Tritlium, and Yllecu are known to have one. Among Iridaceae, the only records we have been able to find are those of Sisyrinchium iridifolium (Strasburger ${ }^{13}$ ) and Iris stylosa (Guignard ${ }^{17}$ ), in neither of which is there a parietal cell; but it would be very unsafe to predicate this condition for the whole family. Among the Cannaceae, Guignard ${ }^{17}$ reports Canna indica as sometimes having a parietal cell and sometimes not, but Wiegand 54 finds in it only an abundant parietal tissue; and the other Scitamineae are reported by Humplirey ${ }^{32}$ with parietal tissue. Among Orchidaceae, Crymnadenia conopsea (Strasburger ${ }^{13}$ ) and Orchis pallens (Goebel, ${ }^{\circ}$ p. 391) were long ago reported as without a parietal cell, but recently Dumée, ${ }^{4+}$ examining a number of genera and species of orchids, reports them all as having parietal cells. This record probably fairly represents the condition of the parietal tissue among Monocotyledons. It indicates a general tendency to suppress it, which has been successful in certain members of the higher and more specialized families.

Among the Archichlamydeae approximately the same condition prevails. The Ranunculaceae exhibit a surprisingly uniform suppression of the parietal tissue, this condition having been found in Anemone, Caltha, Clematis, Delphimium, Myosurus, and Ranunculus (Fig. 27); while in Aquilegia a parietal cell may or may not appear. Only IIelleborus (Guignard ${ }^{1 \tau}$ ) and Thalictrum (Overton ${ }^{59}$ ) have thus far been reported as having a parietal cell, and this may or may not divide. It is to he noted that in Delphinium, Caltha, and Jeffersonia the absence of parietal tissue is compensated for by numerous periclinal and anticlinal divisions of the orerlying epidermal cells; and in the Balanophoraceae this epidermal growth reaches so remarkable a development that Treub at first called it a style. The same development is seen in II ippuris ( Fischer ${ }^{15}$ ), in which the apical epidermal cell divides by anticlinal and periclinal walls and forms a small, werlge-shaped cushion that prevents the micropyle from heing entirely obliterated by the closing in of the integument. Among the Berheridacese, Jeffersonia (Andrews ${ }^{31}$ ) has no parietal cell, and Mahonia indica (Guig- 
of Angiosperms the primary sporogenous cell is the mother-cell. The only possible exception to this is the case of such sporogenous masses as occur in the orules of C'asuarina (Treub ${ }^{23}$ ), C'arpinus (Miss Benson ${ }^{28}$ ), and Quercus (Conrad ${ }^{53}$ ). If the whole sporogenous mass in these forms is derived from a hrpodermal archesporium, then of course the primary sporogenous cells divide to form additional sporogenous cells. But if all the sporogenous tissue is an archesporium, in this case contributed to by cells deeper than the hypodermal layer, the primary sporogenous cells do not divide, nor do all the archesporial cells give rise to parietal cells. In any event, the cells of the completed sporogenous mass, whether archesporial or not, are mother-cells.

The history of the development of the microsporangia and megasporangia is strikingly similar. In both cases the archesporium is hypodermal; in the microsporangium it is usually a plate of cells and exceptionally a single cell, while in the megasporangium it is usually a single cell and exceptionally a plate of cells. In both each archesporial cell divides by a periclinal wall, cutting off a peripheral parietal cell that takes part in dereloping a sporangium wall of a variable number of layers. In the development of the megasporangium, however, there is a strong tendency to suppress the wall layers, probably as of no significance or even a hindrance in the process of fertilization. While in the microsporangium the primary sporogenous cells often divide a few times before the mother-cell stage is reached, this is by no means alwars the case; and although in the megasporangium the primary sporogenous cells usually do not divide to form mother-cells, this is probably not always true. In both sporangia the mother-cells, reached by the same sequence of events, are recognized by the fact that their division is the reduction division.

It is at this point that the history of the megasporangium closes, for the reduction division is the beginning of the female gametophyte (see p. 41).

\section{LITERATURE CITED}

1. Schleides, M. J. Ueber Bildung des Eichens und Entstehung des Embryo's bei den Phanerogamen. Nova Acta Leopoldina 19: 27-58. 1839; Ann. Sci. Nat. Bot. II. 11: 129-141. 1839. 
2. Unger, D. F. Die Entwicklung des Embryo's von Hippuris vulgaris. Bot. Zeit. 7: 329-339. pls. 3-4. 1849.

3. Sснаснт, H. Entwicklungsgeschichte des Pflanzen-Embryon. Amsterdam. 1850; Ann. Sci. Nat. Bot. III. 15: 80-109. 1851.

4. Hofyeister, W. Neuere Beobachtungen über Embryobildung der Phanerogamen. Jahrb. Wiss. Bot. 1: 82-188. pls. $\gamma-10$. 1858 .

5. - Neue Beiträge zur Kenntniss der Embryobildung der Phanerogamen. Abhandl. Königl. Sächs. Gesell. Wiss. 6: 533672. pls. 1-27. 1859.

6. Tieghey, Ph. vas. Structure du pistil des Primulacées et des Theophrastées. Ann. Sci. Nat. Bot. V. 12: 329-339. 1869.

7. WARMing, E. Recherches sur la ramification des Phanérogames. Copenhagen. 1872.

8. Eichler, A. W. Blüthendiagramme. 2 vols. Leipzig. 1875-1878.

9. Celakovsky, L. F. Tergleichende Darstellung der Placenten i. d. Fruchtknoten d. Phanerogamen. Abhandl. Königl. Böhm. Gesell. Wiss. Prag. VI. 8: 187\%.

10. Warming, E. De l'ovule. Ann. Sci. Nat. Bot. VI. 5: 177-266. pls. 7-13, $187 \%$.

11. Vesque, J. Développement du sac embryonnaire des Phanérogames Angiospermes. Ann. Sci. Nat. Bot. VI. 6: 23r-285. pls. 11-16. 1878.

12. - - Nouvelles recherches sur le développement du sac embryonnaire des Phanérogames Angiospermes. Ann. Sci. Nat. Bot. VI. 8: 261-390. pls. 12-21. 1879.

13. Strasberger, E. Die Angiospermen und die Gymnospermen. Jena. 1879.

14. Ward, H. Marshall. A Contribution to Our Knowledge of the Embryo-sac in Angiosperms. Jour. Linn. Soc. Bot. London 17: 519-546. pls. 1\%-25. 1880.

15. Fischer, E. Zur Kenntniss des Embryosackentwicklung, etc. Jenaisch. Zeitsch. Naturwiss. 14: 90-132. 1880.

16. GUIGNARD, L. Recherches d'embryogénie végétale comparée. I. Légumineuses. Ann. Sci. Nat. Bot. VI. 12: 5-166. pls. 1-8. 1881.

17. $\ldots$. Recherches sur le sac embryonnaire des Phanérogames Angiospermes. Ann. Sci. Nat. Bot. VI. 13: 136-199. pls. 3-7. 1882.

18. Treub, M. Observations sur les Loranthacées. Ann. Sci. Nat. Bot. VI. 13: 250-282. pls. 13-20. 1882; reprinted in Ann. Jard. Bot. Buitenzorg 3: 1-12. pls. 1-2. 1883, and 2: 54-76. pls. 8-15. 1885.

19. - Observations sur les Loranthacées. IV. Ann. Jard. Bot. Buitenzorg 3: 184-190. pls. 28-29. 1883.

20. Goeber, C. Outlines of Classification and Special Morphology of Plants. English translation. 1887. 
21. Oliver, F. W. On the Structure, Derelopment, and Affinities of Trapella, a New Genus of Pedalineae. Annals of Botany 2: 75-115. pls. 5-9. 1888.

22. Johrsox, T. The Nursing of the Embryo and some Other Points in Myzodendron punctulatum Banks et Sol. Annals of Botany 3: 179-206. pls. 13-14. 1889.

23. Trecb, M. Sur les Casuarinées et leur place dans le système naturel. Ann. Jard. Bot. Buitenzorg 10: 145-231. pls. 12-32. 1891.

24. Chatreacd, G. L. Sur la fécondation dans les cas de polyembryonie. Compt. Rend. 114: 504. 1892.

25. Mottier, D. M. On the Development of the Embryo-sac of Arisaema triphyllum. Bot. Gazette 17: 258-260. pl. 18. 1892.

26. - On the Embryo-sac and Embryo of Senecio aureus L. Bot. Gazette 18: 245-253. pls. 2\%-29. 1893.

27. - Development of the Embryo-sac in Acer rubrum. Bot. Gazette 18: 375-37\%. pl. 34. 1893.

28. Bexsox, Margaret. Contributions to the Embryology of the

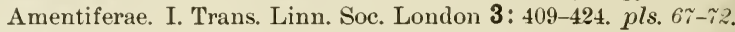
1894 .

29. Treub, M. L'organe femelle et l'apogamie du Balanophora elongata. Ann. Jard. Bot. Buitenzorg 15: 1-22. pls. 1-8. 1898.

30. Mottier, D. M. Contributions to the Embryology of the Ranunculaceae. Bot. Gazette 20: 241-248, 296-304. pls. 1\%-20. 1895.

31. Axprews, F. M. Development of the Embryo-sac of Jeffersonia diphylla. Bot. Gazette 20: 423-424. pl. 28. 1895.

32. Humphrey, J. E. The Development of the Seed in Scitamineae. Annals of Botany 10: 1-40. pls. 1-4. 1896.

33. KoERxicke. M. Untersuchungen über die Entstehung und Entwickelung der Sexualorgane von Triticum mit besonderer Berücksichtigung der Kerntheilung. Verhandl. Naturhist. Ver. Preussen Rheinl. 53: 149-185. 1896.

34. Vax Tiegheir, Ph. Sur l'organisation florale des Balanophoracées. Bull. Soc. Bot. France 43: 295-309. 1896.

35. Chamberlaix, C. J. Contribution to the Life History of Salix. Bot. Gazette 23: 147-179. pls. 12-18. 1897.

36. Schaffier, J. H. The Development of the Stamens and Carpels of Typha latifolia. Bot. Gazette 24: 93-102. pls. 4-6. 1897.

37. Campbell, D. H. The Development of the Flower and Embryo in Lilaea subulata HBK. Annals of Botany 12: 1-28. pls. 1-3. 1898.

38. Coclter. J. M. Contribution to the Life History of Ranunculus. Bot. Gazette 25: 73-88. pls. 4-\%. 1898 .

39. Chamberlaix. C. J. Winter Characters of Certain Sporangia. Bot. Fazette 25: 124-128, pl. 11. 1898.

40. Smith, R. W. A Contribution to the Life History of the Pontederiaceae. Bot. Gazette 25: 324-337. pls. 19-20. 1898. 
41. Lyon, Florexce May. A Contribution to the Life History of Euphorbia corollata. Bot. Gazette 25: 418-426. pls. 22-24. 1898.

42. Riddle, Lumiva C. The Embryology of Alyssum. Bot. Gazette 26: 314-324. pls. 26-28. 1898.

43. Zixger, N. Beiträge zur Kenntniss der weiblichen Blüthen und Inflorescenzen bei Cannabineen. Flora 85: 189-253. pls. $6-10$. 1898.

44. Domée et Malinvadd. Un Vicia nouveau pour le flore francaise. Bull. Soc. Bot. France 46: (Sess. Extraord.) xxx-xxxii, 263-266. pls. 2. 1899.

45. Lloyd, F. E. The Comparative Embryology of the Rubiaceae. Bull. Torr. Bot. Club 28: 1-25. pls. 1-3. 1899.

46. Caldwell, O. W. On the Life History of Lemna minor. Bot. Gazette 27: 37-66. figs. 59. 1899.

47. Campbell, D. H. Notes on the Structure of the Embryo-sac in Sparganium and Lysichiton. Bot. Gazette 27: 153-166. pl. 1. 1899.

48. Lotsy, J. P. Balanophora globosa Jungh. Eine wenigstens örtlich-verwittwete Pflanze. Ann. Jard. Bot. Buitenzorg II. 1: 171186. pls. 26-29. 1899.

49. Caxipbell, D. H. Studies on the Araceae. Annals of Botany 14: 1-25. pls. 1-3. 1900.

50. Canson, W. A. A Morphological Study of the Flower and Embryo of the Wild Oat, Avena fatua. Proc. Calif. Acad. Sci. III. 1: 329-364. pls. 49-5.3. 1900.

51. Bervard, C. H. Recherches sur les sphères attractives chez Lilium candidum, etc. Jour. Botanique 14: 118-124, 177-188, 206-212. pls. 4-5. 1900.

52. Lotsy, J. P. Rhopalocnemis phalloides Jungh., a Morphologicalsystematical Study. Ann. Jard. Bot. Buitenzorg II. 2: 73-101. pls. 3-14. 1900.

53. Conrad, A. H. A Contribution to the Life History of Quercus. Bot. Gazette 29: 408-418. pls. 28-29. 1900.

54. Wiegand. K. The Development of the Embryo-sac in some Monocotyledonous Plants. Bot. Gazette 30: 25-47. pls, 6-7. 1900.

55. Holferty. G. M. Ovule and Embryo of Potamogeton natans. Bot. Gazette 31: 339-346. pls. 2-3. 1901.

56. Schaffier. J. H. A Contribution to the Life History and Cytology of Erythronium. Bot. Gazette 31: 369-387. pls. 4-9. 1901.

57. Mtrbeck, S. Parthenogenetische Embryobildung in der Gattung Alchemilla. Lunds Univ. Arsskrift. 36: No. 7, pp. 46. pls. 6. 1901: Bot. Zeit. 59: 129. 1901.

58. Hall, J. G. An Embryological Study of Limnocharis emarginata. Bot. Gazette 33: 214-219. pl.9. 1902. 
59. Overton, J. B. Parthenogenesis in Thalictrum purpurascens. Bot. Gazette 33: 363-375. pls. 12-13. 1902.

60. Wевв, J. E. A Morphological Study of the Flower and Embryo of Spiraea. Bot. Gazette 33: 451-160. figs. 28. 1902. For correction of name see REHDER in Bot. Gazette 34: 246. 1902.

61. Lloyd, F. E. The Comparative Embryology of the Rubiaceae. Mem. Torr. Bot. Club 8: 27-112. pls. 8-15. 1902.

62. Ducamp, L. Recherches sur l'embryogénie des Araliacées. Ann. Sci. Nat. Bot. VIII. 15: 311-402. pls. 6-18. 1902.

63. Péchoutre, F. Contribution a l'étude du développement de l'ovule et de le graine des Rosacées. Ann. Sci. Nat. Bot. VIII. 16: 1-158. figs. 166. 1902.

64. KARstev, G. Ueber die Entwicklung der weiblichen Blüthen bei einigen Juglandaceen. Flora 90: 316-333. pl. 12. 1902.

65. Chauveaud, G. L. De le reproduction chez le dompte-venin. Diss. Paris. 1902.

66. FrYt, T. C. A Morphological Study of Certain Asclepiadaceae. Bot. Gazette 34: 389-413. pls. 13-15. 1902. 


\section{CHAPTER V}

\section{THE FEMALE GAMETOPHYTE}

The literature relating to the female gametophyte of Angiosperms is so extensive that one can not hope to compass all of its details. We have selected for eritical examination numerous examples, well distributed throughout the great groups, and the conclusions from these must fairly represent the present state of knowledge. Eren in these cases it would be hopeless to attempt the presentation of all the details to which attention has been called, and only those will be considered that seem most significant. There is a prevalent impression that with very few exceptions the history of the female gametophyte is rigidly uniform, but an examination of the literature reveals considerable variation. This impression has doubtless arisen from the fact that the standard texts have almost uniformly selected a single trpe of history for deseription.

The important literature of the subject dates from Hofmeister, ${ }^{1,2}$ whose work was supplemented and correeted by Warming, ${ }^{3}$ Tesque, ${ }^{4}$ Strasburger, ${ }^{5}$ Fiseher, ${ }^{6}$ Marshall-IVard, Treub and Mellink, ${ }^{10}$ Guignard, ${ }^{11,12}$ and others. During the last twenty years numerous investigators have added to the literature, and much of their work will be referred to later.

It was stated in the previous chapter that we regard the history of the female gametophyte as beginning with the division of the mother-cell. The ordinary product of this division is an axial row of cells whose morphological nature was long a subject of discussion (Figs. 28, 29). By many they were regarded as mother-cells that do not divide, but at present there is general agreement with the view, stated by Orerton ${ }^{28}$ (p. $172)$ in 1893 , that they are megaspores. This means that the usual row of four cells produced by the mother-cell represents 
the tetrad usually formed by the microspore mother-cell. The first mitosis in the megaspore mother-cell always shows the
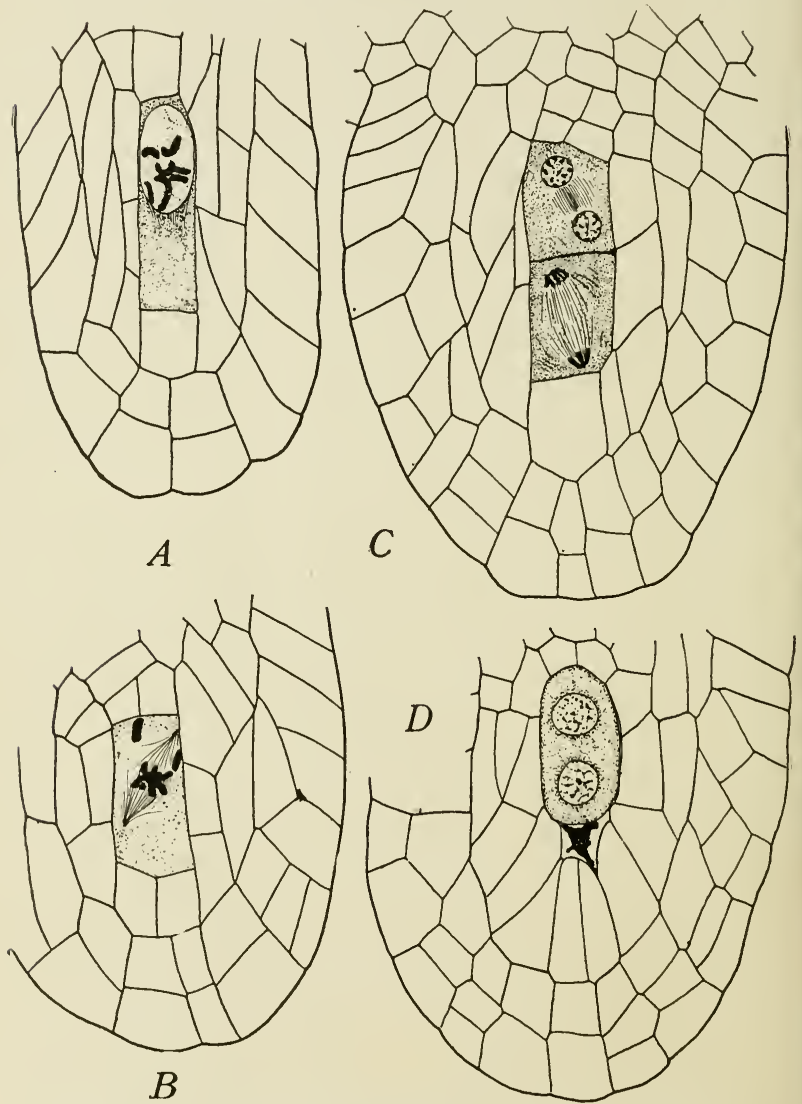

Fia. 28.- Trillium recurvatum. Longitudinal sections of nucellus, showing some early stages in the development of the female gametophyte: $\times 500 . A$, megaspore mothercell; nucleus shows six chromosomes, the gametophyte number. $B$, first division of nucleus of mother-cell. $C$, second division of nucleus of mother-cell; mitosis nearer chalaza much further advanced than that at micropylar end. $D$, germinaticn of megaspore nearest chalaza; the other three megaspores represented only by a dense, shapeless mass. 
recluced number of chromosomes, and this is true whether a row of two, three, or four megaspores is to be produced, or the mother-cell is to derelop directly into the embryo-sac, as in Litium. In such forms as Lilium the second mitosis also corresponds in all essential details with the second division that is to result in a row of four megaspores. The third mitosis differs
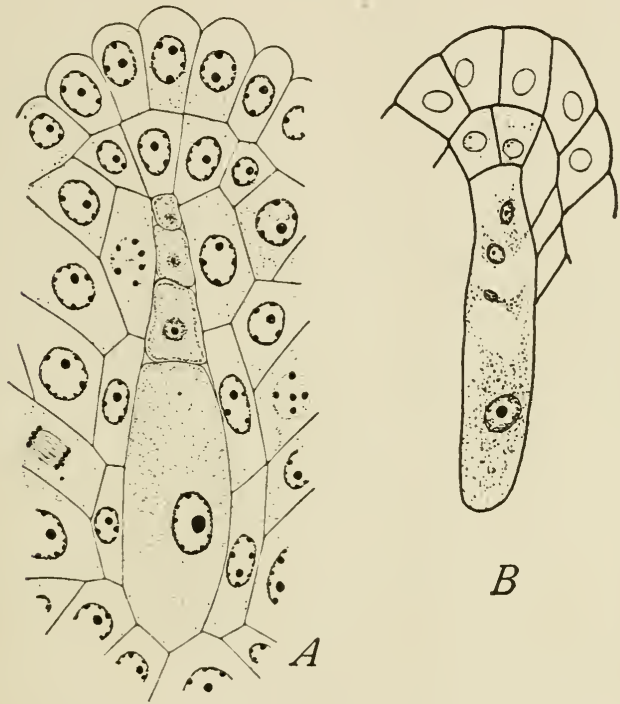

Fig. 29.-A, Canna indica; axial row of four megaspores, the innermost one beginning to germinate and the other three disintegrating; after W1EGAND. ${ }^{80}$ B, Eichhornia crassipes: portion of nucellus showing four megaspores, the innermost one germinating. and the other three, which are not separated by walls, disintegrating; $\times 1100$; after SMitu. ${ }^{53}$

from the nsual sporophytic mitosis only in the reduced number of chromosomes ( Miss Sargant, ${ }^{41}$ Straslourger, ${ }^{72}$ Juel ${ }^{88}$ ). Not only do the first two divisions agree in the various types, but they correspond minutely with the two divisions with which the microspore mother-cell gives rise to the tetrad. That the megaspores do not occur in tetrahedral or hilateral arrangement does not involve their morphological nature, for in the 
pollen mother-cells of Typha (Schaffner ${ }^{49}$ ) (Fig. 5i) the microspores are formed in rows of four as well as tetrahedrally, while in Asclepias (Strasburger, ${ }^{96}$ Frre ${ }^{99}$ ) the microspores

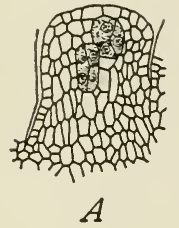

A

FIG. 30.-A, Fatsia juponica. Longitudinal section of nucellus showing two tetrads; $\times 175$. $B$, similar section of Aralia racemosa, in which the nucellus bears a strong resemblance to a nicrosporangium; $\times 340$ -After Decayp:i12

constantly appear in rows of four (Fig. 5s); and in t!.e pollen mother-cells of $\mathrm{Zos}$ tera (Rosenberg ${ }^{93}$ ) the four elongated microspores lie side by side in the same plane. Nor is it a criterion of a tetrad that all of its spores shall mature, for in Carex acuta (Juel ${ }^{8 s}$ ) (Fig. 59) only one spore of the tetrad functions, a habit to be observed also among the Pteridophrtes, as in Marsilea and Azolla. Even the rare ease of more than four megaspores in a row is met by the occasional occurrence of more than four microspores in the pollen mother-cells of Hemerocallis fulva (Juel, ${ }^{50}$ Fullmer ${ }^{65}$ ) and of Euphorbia corollata (Miss Lyon ${ }^{54}$ ) (Fig. 60). The usual tetrad arrangement, howerer, is not lacking among megaspores, as observed by Dueamp ${ }^{112}$ in Fatsia japonica (Fig. 30), in which after the mother-cell had divicled transrersely the two daughter-cells were obserred to divide longitudinally: and in one preparation, in which two mother-cells had thus divided, the nucellus looked verr mueh like an ordinary sporangium. In another case the middle cell of a row of three had dirided longitudinally. The parallel seems still more striking. when microspores germinate like megaspores, even reaching the stage with eight free nuclei, as observed by Nêmee ${ }^{5 s}$ in the petaloid anthers of Iyacinthus orientalis, whose mierospores sometimes show three suceessive mitoses, giving rise to four nuclei at each end of the pollen-grain (Fig. 31). Eren the formation of three cells at one end, and the wandering of one polar nucleus toward the middle were observed, although fusion did not oceur. Xêmee did not hesitate to homolngize these dirisions with those oceurring in the embryo-sac. There seems to be no longer any reasonable objection to the view that this row of cells, whose formation is initiated by the reduction division, is the homo- 
logue of the tetrad formed by the microspore mother-cell. The most recent suggestion as to the nature of the embryo-sac is that made by Atkinson, ${ }^{101}$ who claims that in the orule there do not exist spores " in the sense in which they are represented in the Pteridophytes, or in the microspores of the Spermatophytes," but that the angiospermous embryo-sac arises directly from nucellar tissue without the interrention of spores. Is spores are not needed for distribution they are " cut out of the cycle of development, and the embryo-sac or gametophyte arises directly from the tissue of the sporophyte."

In our own judgment it seems clear that the cells in questicn are morphologically megaspores, and if so it would follow that the natural tendency of the megaspore mother-cell is to form a tetrad. The fact that the spores form a row may be due to the

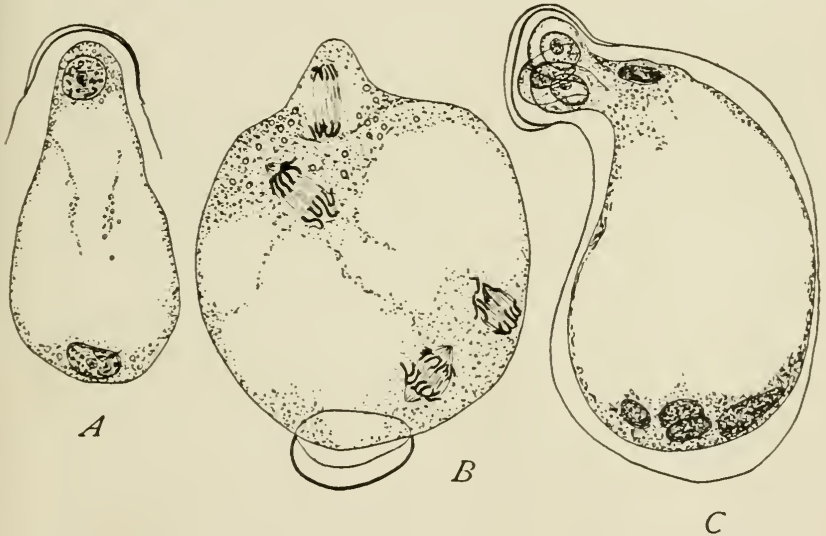

F1G. 31.-Hyacinthus orientalis. Abnormal germination of microspores in jetaloid anthers. $A$, the mierospore has formed a sac-like tube showing definite polarity; $B$. a short pollen-tube resembling an embryo-sac at the third nuclear division; the heary line below represents the thick wall of the pollen-grain; $C$, a later stage, showing four nuclei at each end of the sac-like pollen-tube-After NêMEc.58

pressure of the surrounding tissue, there being no opportunity for early isolation and rounding off as in microsporangia. It may be of interest to note that sometimes after the first division of the mother-cell the outer daughter-cell divides by an anticlinal rather than a periclinal wall, as observed in Butomus 
(Marshall-ITard ${ }^{\mathbf{s}}$ ), Jeffersonia (Indrews ${ }^{37}$ ), and Potamogeton (Holferty ${ }^{97}$ ). In the case of (ynomorium (.Juel ${ }^{121}$ ). the two cells resulting from the first division of the mother-cell are very unequal, the micropylar one being the smaller. This smaller cell divides longitudinally and the larger one transrersely. Transitions to this condition in the formation of oblique walls sometimes occur, as in Delphinium (Mottier ${ }^{36}$ ). The case of Fatsia japonica has been referred to above. As already indicated, the completion of a tetrad is by no means always attained, for there is every gradation between a row of four megaspores and an undividing mother-cell that functions directly as a megaspore. The explanation of this tendency to shorten the megaspore series is probably connected with the fact that only one megaspore of the tetrad functions. The number of megaspores formed by the mother-cell has been reported for very many plants, but the records are by no means of equal value. The reasons for this are obrious. One is that the sterile axial cells of the nucellus often simulate megaspores, so that too large a number might easily be reported, and great care is necessary to distinguish them; and another is that the technique of the earlier observer's did not alwars permit certainty. By far the most important source of inaccuracy, however, is the hasty examination of a great number of forms by a single investigator. Two megaspores might be reported, when the same orule collected a few hours later might have shown four megaspores. As a consequence, much of the arailable data can be used only in a very general way as indicating tendencies of gioups.

Among the Monocotyledons, about one-third of those inrestigated are reported as forming complete tetrads, in another third the mother-cell does not divide, while the remaining forms show every intergradation. Although one might expect the complete tetrads to be characteristic of the more primitive Monocotyledons, and the undividing mother-cell characteristic of the higher families, there is as ret no such evidence, both conditions occurring in all grades of Monocotrledons.

The greatest variability is formd among the Liliaceae, possibly because more of the species have been investigated (compare Fig. 2s with Figs. 3.5 and 36). For example, without attempting to include all the recorded cases, in Hemerocallos (Stras- 
burger ${ }^{5}$ ), Trillium (Chamberlain ${ }^{52}$ ), and Galtonia (Schniewind-Thies ${ }^{95}$ ) four megaspores are reported, although in the last genus only two may appear; in Anthericum (Strasburger $^{5}$ ), and Tricyrtis and Yucca (Guignard ${ }^{12}$ ) three; in Allium (Strasburger ${ }^{5}$ ), and Agraphis and Ornithogalum (Guignard ${ }^{12}$ ) two; while in Lilium, Fritillaria, Funtia, Tulipa, Convallaria (Wiegand ${ }^{80}$ ), and Erythronium (Schaffner ${ }^{98}$ ) the mother-eell does not divide. It may be of interest to note the records of other investigators in reference to some of these genera. For example, Ikeda ${ }^{106}$ reports four megaspores in Tricyrtis hirta, and Tesque ${ }^{4}$ three in Hemerocallis, Allium, and Convallaria.

Among the more primitive aquatic families, Zostera (Rosenberg ${ }^{92}$ ) and Potamogeton (Wiegand, ${ }^{66}$ Holferty ${ }^{97}$ ) have three or four megaspores; in Typha (Schaffner ${ }^{49}$ ) there is no dirision of the mother-cell; and among the Alismaceae, Alisma (Schaffner ${ }^{44}$ ) and Limnocharis (Hall ${ }^{109}$ ) have an undividing mother-cell, while Butomus ( $\mathrm{Ward}^{8}$ ) has three and sometimes four megaspores.

Among the Gramineae the complete tetrad is common (Fischer ${ }^{6}$ ), but Guignard ${ }^{12}$ reports only two megaspores in Cornucopiae.

Among the Araceae Nottier ${ }^{27}$ reports two megaspores in Arisnema, and Campbell ${ }^{75}$ the same number in Dieffenbachia, while in the allied Lemna (Caldwell ${ }^{62}$ ) the mother-cell does not divide.

Among the Pontederiaceae (Smith ${ }^{53}$ ) there are four megaspores, while Guignard ${ }^{12}$ reports only two in Commelina.

Among the higher families, Narcissus (Guignard ${ }^{12}$ ) has an undividing mother-cell; Iris (Guignard ${ }^{12}$ ) has three megaspores (Tesque ${ }^{4}$ reports four), and Tritonia and Sisyrinchium (Strasburger ${ }^{5}$ ) four; the Scitrmineae have three or four, excepting Costus (Humphrey ${ }^{40}$ ), in which the mother-cell does not divide; while the orehids Gymnadenia (Strasburger ${ }^{5}$ ) and Orchis (Vesque ${ }^{*}$ ) have a row of three or four megaspores.

That detailed study would show that many of these numbers are not constant is indicated in sereral instances. In Arisaema, in which two megaspores are customary, Mottier ${ }^{27}$ found one case in which the transverse wall did not form, the elongated mother-cell appearing with a nueleus at each end; while in Dief- 
fenbachia, of the same family, Camplell ${ }^{75}$ states that the inner one of the two cells may divide, forming a row of three megaspores. Among the Pontederiaceae, Simith ${ }^{53}$ found great rariation in the development of the megaspores. While sometimes the row of four is formed by equal successive divisions, it is more common for the mother-cell to elongate greatly, with its nucleus near the micropylar end. In this position two successive and rapid dirisions of the nucleus oceur in any order or direction, and four usually naked cells are the result, the innermost being much the largest and speedily obliterating the others, becoming the functioning megaspore (Fig. 29, $B$ ). In Arena fatua, Cannon ${ }^{86}$ found that four cells are formed: or the mother-cell may contain four nuclei without any cell walls, the three outermost disappearing, the innermost forming the nucleus of the functioning megaspore. In Potamogeton foliosus, Wiegand ${ }^{66}$ found that the second divisions in forming the row of four are not accompanied by walls, and Holferty ${ }^{97}$ found in Potamogeton natans that the outermost wall may not appear even when there is nuclear division. Such cases emphasize the fact that there may often be the greatest variation in the derelopment of megaspores, and that a number reported for a species by a hasty observer should not be regarded as a fixed one, or eren possibly the customary one.

The only generalization that seems to be safe in reference to the Monocotyledons, aside from the fact of their great irregularity, is that more of them than of the Dicotrledons have reached the condition of an undividing mother-cell.

Among the Archichlamrdeae, nearly all the species investigated have three or four megaspores, and both of these numbers are represented in ahmost every family in which more than one species has been studied. Tpon the whole, however, a row of three megaspores seems to be more common than one of four. For example, among the Rammculaceae, of eleven genera studied only four have been reported as having four megaspores, and in all of these cases three megaspores have also been observed. The four genera referred to are Aquilegia, in which fire megaspores were also observed, Delphinium, Ranunculus (Fig. 27), and Thalictrum, and in each of these cases different observers have given different numbers. In Caltha, which ordinarily has three megaspores, Mottier ${ }^{36}$ occasionally found nuclear divi- 
sion, unaccompanied by a wall, in the outermost cell of the row of three. Theie is every evidence that in this family the inner cell of the first division always divides, and the other one may or may not divide, resulting in three or four megaspores. Almost the only exception to three or four megaspores, in case the mother-cell divides, noted among Archichlamydeae is Tiscum articnlatum ( Trenb ${ }^{13}$ ), in which the four or five mothercells divide only once, the inner cell becoming the functional megaspore.

This same rariation is found in at least twenty other families of the Archichlamrieae. Probably the most rariable case recorded is that of Salix glaucophylla (Chamberlain ${ }^{46}$ ), in which there may be three megaspores, or two, or the mother-cell may not divide.

The few cases among Archichlamydeae in which the mothercells are not known to divide are three genera of Piperaceae (Peperomia, Piper, Hecheria) investigated by Johnson, ${ }^{79,11+}$ but the allied Saururus (Johnson ${ }^{\mathrm{s}}$ ) has a row of three megaspores; Alchemilla alpina (Murbeck ${ }^{94}$ ), but this is associated with the occurrence of a large mass of archesporial tissue: the Cactaceae (D'Hubert ${ }^{32}$ ); and at least Sium cicutaefolium among the Umbelliferae. In Juglans cordiformis Karsten ${ }^{115}$ finds great variability, the mother-cell functioning directly as the megaspore or giving rise to a row of three or four megaspores, the two outer ones never functioning, the two inner ones apparently having an equal chance, and in many cases dereloping two sacs. Among the Iraliaceae also, Dncamp ${ }^{112}$ reports that the mother-cell becomes the megaspore directly or produces a row of three or four megaspores. The same is true of the Balanophoraceae, as shown by Lotsy 82 in Rhopalocnemis, and by Chodat and Bemard ${ }^{83}$ in Helosis; but the conditions in this family are so peculiar that the phenomenon does not seem significant. In ('asuarina (Treub ${ }^{25}$ ) (Fig. 24) and Quercus (Conrad is), in which there is a large mass of sporogenous cells, there is no division of mother-cells to form spores. The behavior of the numerous mother-cells of Casuarina is remarkable, a certain number developing as embrro-sacs, a larger number remaining sterile and hecoming verr much elongated, and still others becoming tracheid-like cells.

It is apparent, therefore, that among the Archichlamydeae 
the mother-cell very rarely fails to divide, but that there is a strong tendeney to suppress one of the divisions and form a row of three megaspores.

Among the Sirmpetalae the complete tetrad appears with remarkable uniformity. This is associated with a rery small nucellus, most frequently only the epidermal layer investing the tetrad row, and the suggestion is erident that there may be some causal relation between these two facts. Occasionally, however, one of the divisions is suppressed, and a row of three megaspores is the result, the only cases we have found being Taccinium and Lycium (Vesque ${ }^{4}$ ), Lobelia (MarshallWard ${ }^{8}$ ), Lonicera and Nicotiana (Guignard ${ }^{12}$ ), and Trapella and Sarcodes (Oliver ${ }^{21,24}$ ). Among the Rubiaceae Llovid ${ }^{105}$ reports that while each mother-cell forms a tetrad there are usually no walls (Fig. 33), as in Avena (Cannon ${ }^{86}$ ) and Eichhornia (Smith ${ }^{53}$ ). Among the Verbenaceae Treub ${ }^{1+}$ reports that in Aricemia officinalis the mother-cell does not divide: in Aphyllon uniflorum Miss Smith ${ }^{102}$ reports that the mothercell does not divide, although Koch ${ }^{19}$ figures a row of four megaspores in Orobanche; in the parthenogenetic Antennaria alpina Juel it finds that the mother-cell does not divide, however, in A. dioica, in which fertilization regularly oceurs, a row of four megaspores is formed. Undoubtedly more numerons exceptions will be found, but the evidence seems elear that the complete row of four megaspores is almost universally present among the Srmpetalae.

As has been stated, the reduction in the number of chromosomes oeeurs during the first mitosis in the megaspore-mothercell, whether a row of four, or three, or two megaspores is to be formed, or the mother-eell is to function direetly as a megaspore. In Litium, the first described form in which the mothercell does not divide to form megaspores, the beginning of a cell-plate is elearly visible in the spindle during the first mitosis, and at the second mitosis there is also a rudimentars cellplate. Since the other cytological characters of these two mitoses are identical with the first two mitoses in forms that have the row of four megaspores, it might be suggested that the rudimentary plate is a survival, indicating that the ancestors of Litium once produced the row of four, and making Lilium in this respect a specialized rather than a primitive form. This 
seems reasonable, but it must be noted that the rudimentary plate occurs also at the third mitosis, and so may be a reminiscence of a much more remote ancestry with cellular prothallia.

In connection with the reduction dirision it is of interest to note the number of chromosomes found among Angiosperms. The following table, arranged in the Engler sequence of families, although more extensive than any hitherto published, is far from complete. The numbers in parentheses were inferred rather than actually counted:

The Number of Chromosomes recorded for Certain Angiosperms

\begin{tabular}{|c|c|c|c|c|}
\hline \multirow[b]{2}{*}{ Plant. } & \multicolumn{2}{|c|}{ CHROMOSOME NCMBERS. } & \multirow[b]{2}{*}{ Observer. } & \multirow[b]{2}{*}{ Year. } \\
\hline & $\begin{array}{l}\text { Ganieto- } \\
\text { phyte. }\end{array}$ & Sporophyte. & & \\
\hline Zostera marina. & 6 & 12 & Rosenberg 92 & 1901 \\
\hline Taias major. . & 6 & 12 & Guignard 71 & 1899 \\
\hline Triticum vulgare. & 8 & (16) & Overton 28 & $1 \times 93$ \\
\hline 4 & 8 & 16 & Koernicke ${ }^{4}$ & $1 \times 96$ \\
\hline Tradescantia.... & 12 & mostly 16 & Strasburger 20 & 1889 \\
\hline Eichhornia crassipes & 16 & (32) & Smith 53 & 1899 \\
\hline Pontederia cordata. & 8 & 16 & . & $1 \times 99$ \\
\hline Chlorophytum Stembergianum. & 12 * & $?$ & Strasburger ${ }^{20}$ & 1889 \\
\hline Funkia Sieboldiana........... & 24 & $(48)$ & Strasburger 72 & 1900 \\
\hline Allium fistulosum........... & 8 & 16 & Strasburger 20 & $18 x$ \\
\hline "ursinum... & 8 & (16) & Guignard 26 & $1-91$ \\
\hline "Cepa... & (8) & . 16 & Schaffner ${ }^{55}$ & 1895 \\
\hline Lilium ..... & 12 & mostly 16 & Strasburger 20 & $1 \times x$ \\
\hline "Martago & 12 & 24 & Guignard 16 & $18 \times 4$ \\
\hline ") & 12 & 24 & Sargant 41 & $1 \times 96$ \\
\hline candidum. & 12 & 24 & Strasburger 20 & $1 \times-8$ \\
\hline croceum. & 12 & 24 & .. & $1 \times-y$ \\
\hline " philadelphicu & 12 & 24 & Schaffner 43 & $189 \%$ \\
\hline " tigrinum....... & 12 & 24 & *. & $1 \times 9 \%$ \\
\hline Fritillaria imperialis. & 12 & 24 & Strasburger 20 & $1 \times 89$ \\
\hline " Meleagris & 12 & 24 & Guignard 26 & $1 \times 91$ \\
\hline Tulipa Gesneriana. . & 8 & 16 & Schn.-Thies ${ }^{95}$ & 1901 \\
\hline Erythronium americanum. & 12 & 24 & Sehaffner ${ }^{98}$ & 1901 \\
\hline Graltonia candicans... & 8 & 16 or less & Sehn.-Thies ${ }^{95}$ & 1901 \\
\hline Scilla non-seripta.. & 8 & (16) & Orerton 28 & $1 \times 93$ \\
\hline " sibirica. & 8 & variably $8-16$ & Sichn.-Thies ${ }^{95}$ & 1901 \\
\hline Wuscuri neglectum..... & 24 & $4 \dot{0}$ & Strasburger 20 & $1 \times 54$ \\
\hline Conrallaria majalis. & $16 ?$ & more than 16 & “" & $18 \times 8$ \\
\hline & 18 & $(36)$ & Wiegand ${ }^{80}$ & 1900 \\
\hline Trillium grandiflorim & 6 & 12 & Atkinson 64 & $1<99$ \\
\hline " recurvatum. & 6 & 12 & The author:- & 1902 \\
\hline Leucojum rernum... & 12 & $(2 t)$ & Overton 23 & $1+9 ?$ \\
\hline Alstroemeria. & 8 & mostly 16 & Strasburger 20 & $1 \times 58$ \\
\hline " psit & 8 & 16 & Guignard 26 & 1891 \\
\hline Iris squalens.... & 12 & 24 & Strasburger ${ }^{72}$ & 190 \\
\hline ranna indica... & 3 & 6 & WViegand 80 & $191) 0$ \\
\hline Cypripedium barbatur & 16 & 32 & itrasburger 20 & 18,85 \\
\hline
\end{tabular}

* One anther constantly 14. 
The Number of Chromosomes-Continued

\begin{tabular}{|c|c|c|c|c|}
\hline \multirow[b]{2}{*}{ Plant. } & \multicolumn{2}{|c|}{ CHROMOSOME NUMBERS. } & \multirow[b]{2}{*}{ Observer. } & \multirow[b]{2}{*}{ Year. } \\
\hline & $\begin{array}{l}\text { Gameto- } \\
\text { phyte. }\end{array}$ & Sporophyte. & & \\
\hline 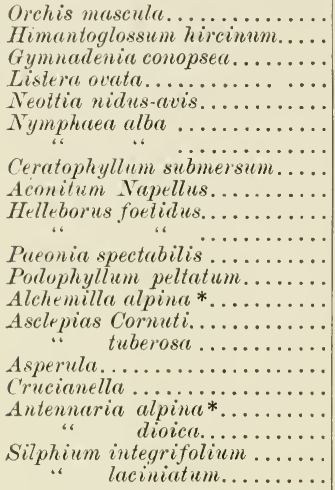 & $\begin{array}{l}16 \\
16 \\
16 \\
16 \\
16 \\
32 \\
48 \\
12 \\
12 \\
12 \\
12 \\
12 \\
8 \\
32 \\
10 \\
10 \\
12 \\
10 \\
40-50 \\
12-14 \\
8 \\
8\end{array}$ & $\begin{array}{c}(32) \\
(32) \\
(32) \\
(32) \\
(32) \\
(64) \\
(96) \\
24 \\
(24) \\
24 \\
\text { mostly } 16 \\
(24) \\
16 \\
32 \\
20 \\
20 \\
24 \\
20 \\
40-50 \\
\text { counted } 20 \\
(16) \\
16 \dagger\end{array}$ & 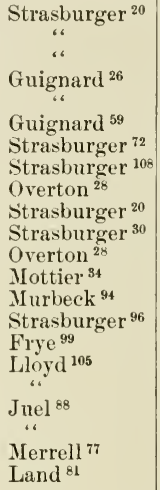 & $\begin{array}{l}1888 \\
1888 \\
1888 \\
1891 \\
1891 \\
1898 \\
1900 \\
1902 \\
1893 \\
1888 \\
1894 \\
1893 \\
1895 \\
1901 \\
1901 \\
1901 \\
1902 \\
1902 \\
1900 \\
1900 \\
1900 \\
1900\end{array}$ \\
\hline
\end{tabular}

It is evident from the table that Strasburger and Guignard were pioneers in this work and that they still remain the most active contributors. It is of interest to note that when attention was first directed to this subject, the number of chromosomes reported for the sporophyte, while exceeding that of the gametophyte, was not precisely twice that number. The subject is one of great difficulty, and doubtless the countings of competent investigators have often been influenced by their theories, while their followers have been content too often with confirming a reported number. Variations from the characteristic number are numerous. In the gametophyte the number of chromosomes in the antipodals is frequently irregular, with a tendeney to higher numbers : but an explanation may be found in the irregular nuclear divisions which present some of the characters of amitosis (Miss Sargant ${ }^{41}$ ). Variations are even more frequent in the sporophyte, but it is well known that mitoses are frequently irregular, and it is easy to imagine that a chromosome may fail to split or that an unequal distribu- 
tion to the daughter nuclei may oceur. The high numbers reported for the endosperm are doubtless to be explained by the triple fusion.

In the great majority of cases the gametophyte number has been counted only in the mother-cells, and the sporophyte number in the tissues of the ovule or young embryo. Still, occasional counts throughout the entire life-history show that the reduced number that occurs in the division of the mother-cell is maintained up to the time of fertilization, whether the interval be short, as in Angiosperms, where only from three to fire nuclear divisions intervene between reduction and fertilization, or long, as in the liverworts, where the gametophyte is the more permanent generation and the sporophyte is a comparatively temporary structure.

Why the number of chromosomes should be so constant, and why a reduction in number should take place, are the most important questions in this connection. The constancy of the numbers has led many to believe that the chromosome is a permanent organ of the nucleus, just as the latter is a permanent organ of the cell; but no one would assign such a reason for the constant recurrence of six stamens in a lily. There is other evidence in faror of the individuality of the chromosomes, but it does not seem to be sufficient. The physiological adrantages are evident, for the constancy in number enables each parent to transmit an equal number of chromosomes to the offspring, and the reduction prevents the constant geometrical increase in the number of chromosomes which would otherwise occur. Strasburger ${ }^{108}$ says: "The morphological cause of the reduction in the number of the chromosomes and of their equalit $y$ in number in the sexual cells is, in my opinion, phylogenetic. I look upon these facts as indicating a return to the original generation from which, after it had attained sexual differentiation, offspring were developed having the donble number of chromosomes. Thus the reduction by one-half of the number of chromosomes in the sexual cells is not the outcome of a gradually evolved process of reduction, but rather it is the reappearance of the primitive number of chromosomes as it existed in the nuclei of the generation in which sexual differentiation first took place. . . The reduction in the number of chromosomes takes place, in the higher plants, in the mother-cells of 
the spores, and it is consequently these which must be regarded as the first term of the new generation."

In case the mother-cell dirides, only the innermost megaspore functions, its growth involving the digestion and absorption of the other megaspores, as well as more or less of the surrounding sterile tissue. Ordinarily the elongating megaspore encroaches upon the others until they become merely a cap upon it; but among the Ranunculaceae Guignard ${ }^{12}$ found in Clematis and ILelleborus, and Mottier ${ }^{36}$ in Delphinium, that the nucellus elongates so rapidly that the sterile megaspores are not crowded into a cap, but their disorganization leaves a narrow cavity. The same thing occurs in Jeffersonia, as shown by Andrews, ${ }^{37}$ and doubtless among many other Archichlamydeae. The known exceptions to the functioning of the innermost megaspore are so few that they deserve special mention, as possibly indicating some peculiar condition.

Among the Monocotyledons, Agraphis (scilla) and Dieffenbachia are the only exceptions we have noted. In the former, Treub and Mellink ${ }^{10}$ observed that the outer one of the two megaspores becomes the embryo-sac, but the inner one also derelops a sac to the four-nucleate stage, an observation later confirmed by Guignard ${ }^{12}$ for other species of the genus. In Agraphis nutans Vesque ${ }^{4}$ observed the uppermost of a row of three megaspores functioning, but the ordinary dirisions within the embrvo-sac, up to four nuclei, were also observed in two or even all of the megaspores. The same observer also reports that in Yucca gloriosa all four megaspores show sac tendencies, while in Lvularia each spore in a row of two developed an embryo-sac to the four-nucleate condition. In Dieffenbachia, Campbell ${ }^{75}$ says that the mother-cell divides very unequally, the outer one being the larger and developing the embrro-sac. In Galtonia candicans (Liliaceae) Schniewind-Thies ${ }^{95}$ has observed an interesting transition to the condition of Litium and similar forms. The mother-cell usually gives rise to a row of four megaspores, but oceasionally only two spores appear, one of which may pass orer direetly into the embryo-sac.

Among the Archichlamyleae, in Juglans cordiformis (Karsten ${ }^{115}$ ), the two chalazal megaspores may both develop embryo-sacs; the outermost megaspore of the row often functions in Stellaria IIolostea (Vesque ${ }^{4}$ ) and in Rosa, and sometimes 
in the latter the two outer begin the formation of embrys-sacs; and in Eriokotrya Guignard ${ }^{12}$ found that while ordinarily the innermost megaspore of three functions, the middle or the outer one may form the embryo-sac, and even all three may begin its formation. The same author ${ }^{11}$ also reports great irregularity in Acacia, in some species the innermost of four megaspores functioning, in others the next outer one, and in still others the middle one of a row of three. In Loranthus also, Treub ${ }^{13}$ finds that the outermost megaspore of three persistently functions. Among the Araliaceae (Ducamp ${ }^{112}$ ) usually the innermost of four megaspores functions, but occasionally one of the middle cells may become the embryo-sac. Such cases serve to emphasize the megaspore character of all the cells of the row.

Among the Sympetalae, the only well-established exception is that of Trapella, in which Oliver ${ }^{21}$ finds that the outermost of four megaspores functions, and in one case the next cell, while the innermost megaspore develops the remarkable haustorium (Fig. 32). In Asclepias tuberosa, although the innermost of the row of four megaspores ordinarily functions, Frye ${ }^{118}$ has observed cases in which the outermost megaspore functions, and others in which the two innermost derelop together; while V'esque ${ }^{4}$ reports that in Salvia pratensis the outermost of the four megaspores functions. In Crucianclla (Lloyd ${ }^{105}$ ) all four megaspores, which in this case are not separated by cell-walls, may begin to germinate (Fig. 33). Guignard 12 also includes Pyrethrum as among the forms whose outermost megaspore functions, but it needs further investigation. It should be noted in this connection that when a row of four megaspores is to be formed, the nucleus nearest the chalaza almost invariably shows a more advanced stage in mitosis than 
the nucleus nearer the micropyle, as shown for Trillium in Fig. 25. Hence the negaspore at the chalazal end of a row is formed a little earlier than the one at the micropylar end.


FIG. 33.-Crucianella macrostachya. A, four-nucleate embryo-sac and three disintegrating megaspores; the four megaspores of this axial row not separated by cell-walls. $B$, axial row of four megaspores which are not separated by cell-walls ; each megaspore has germinated and is in the binucleate stage. $C$, an embryo-sac (with two nuclei) and four sets of megaspores; the megaspores of one set germinating.-After LLOYD, 105

A still more important reason for the selection of the chalazal megaspore is doubtless its more immediate relation to the nutritive supplies coming through the base of the orule, a fact which may also account for the earlier mitosis at the chalazal end of the row.

In case there is more than one mother-cell, two or more megaspores may begin the development of embryo-sacs, which may even attain the fertilization stage, but in almost every case one embryo-sac prevails orer the others. Among the Monocotyledons two embryo-sacs are reported as sometimes occurring in Lilium candidum (Bernard ${ }^{84}$ ): and in Agraphis (Vesque, Guignard ${ }^{12}$ ) and L'vularia (Tesque ${ }^{4}$ ), as referred to above, all of the two or three megaspores of the single row derelop embryo-sacs to the four-nucleate stage. Among the Archichlamydeae, five to eight sacs begin to develop in Loranthus 
(Treub ${ }^{15}$ ) and in ('asuarina (Treub ${ }^{25}$ ); in Tiscum articulatum (Treub ${ }^{13}$ ) all of the four or five megaspores reach the two-nucleate stage; in Salix (Chamberlain ${ }^{46}$ ) occasionally two embryo-sacs are found in the fertilization stage; in Fagus, Corylus, and Carpinus (Miss Benson ${ }^{31}$ ) two or more completed sacs have been observed; in Juglans cordiformis (Karsten ${ }^{115}$ ) two embryo-sacs often occur; in Delphinium (Mottier ${ }^{36}$ ) two completed embryo-sacs have been found (Fig. 3t), and in $R a$ munculus (Coulter ${ }^{51}$ ) several sacs develop to the two or fournucleate stage (Fig. 25) : among the Rosaceae, sereral embryosacs have been observed to start in Rosa (Strasburger ${ }^{5}$ ), Eriobotrya (Guignard ${ }^{12}$ ), and Alchemilla (Murbeck ${ }^{94}$ ); and the same is true of Astilbe (Webb,111). Among the Compositae, Marshall- IVard ${ }^{8}$ observed three sacs enlarging side by side in Pyrethrum, and Mottier ${ }^{29}$ reports two completed sacs in Senecio.

The history of the gametophrte from the megaspore to the completion of the ego-apparatus is remarkably uniform. Attention has been focused upon it for many rears, and almost every description is a reiteration of the preceding one. The megaspore and its mucleus usually enlarge very much before division, and the daughter nuclei migrate, one to each end of the sac (Figs. $35-37)$. The subsequent divisions proceed rapidly and simultaneously, resulting in a group of four nuclei at each end of the embryo-sac. The antipodal polar nueleus and the micropylar polar nucleus (sister to the $\mathrm{egg}$ )

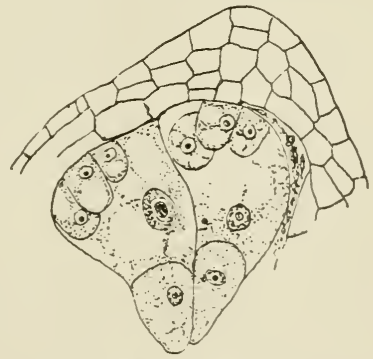

FIG. 34.-Delphinium tricorne. Two mature embryo-sacs lying side by side in one ovule; $\times 250$.-After Hotrier. ${ }^{36}$ then move toward one another and fuse in the general central region of the sac, forming the primary endosperm nuclens." The three remaining micropylar nuclei enter into the formation of the cells of the ego-apparatus, while the three remaining antipodal nuclei enter into the formation of the antipodal cells. Such

* A discussion of the participation of one of the male cells in the formation of this nucleus will be found in Chapter VII. 
is in bricf outline a history whose begimnings are entirely conjectural. Its uniformity throughout so vast a group of plants testifies to its long establishment. The eranescent cell-plate frequently observed during the three free nuclear divisions by
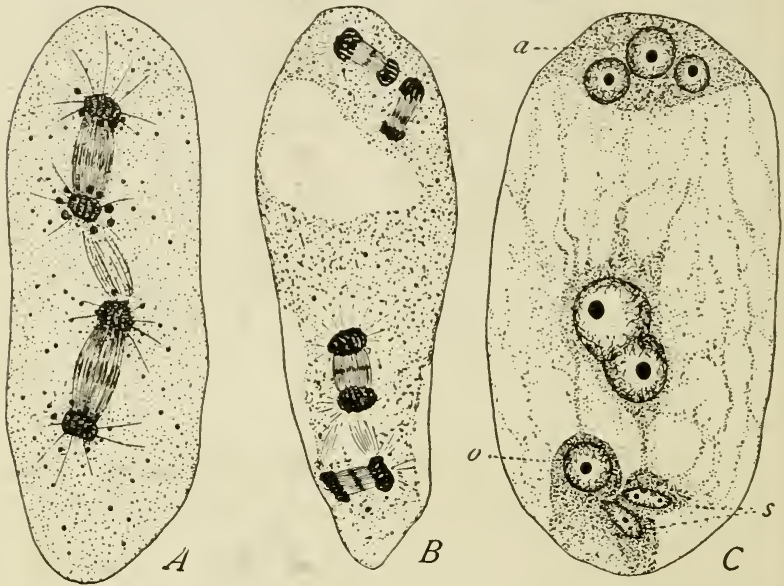

F16. 37.-A, Lilium philadelphicum, seeond nuelear division in the embryo-sac: the persistenee of the spindle from the first division indieates that the second division has followed very rapidly; $\times 450$; after Schaffier.48 $B, L$. philadelphicum, third nuclear division; two of the spindles show the beginning of a cell-plate; $\times 450$; after Coclter.48 C, Ranunculus multifidus, fusion of polar nuelei to form endosperm nucleus; $\times 600$; after Cocltes ${ }^{2} ; 8$, synergids; 0 , oosphere, fusing polar nuclei in central region: $a$, antipodals.

which the eight-nucleate stage of the embryo-sac is reached, the frequent organization of cells about the three antipodal nuclei, the frequent division of the antipodal cells resulting in a more or less extensive tissue, and the additional nuclear dirisions observed in Peperomia and other forms, are evidences that the present female gametophrte of Angiosperms is a much reduced descendant from multicellular ancestral forms, with forms like Fnetum as the nearest approach to the present conditions; but there seem to he no nearer records of its connection with the histories of other female gametophrtes. The female gametophyte of Ingiosperms, therefore, is a morphological problem of 

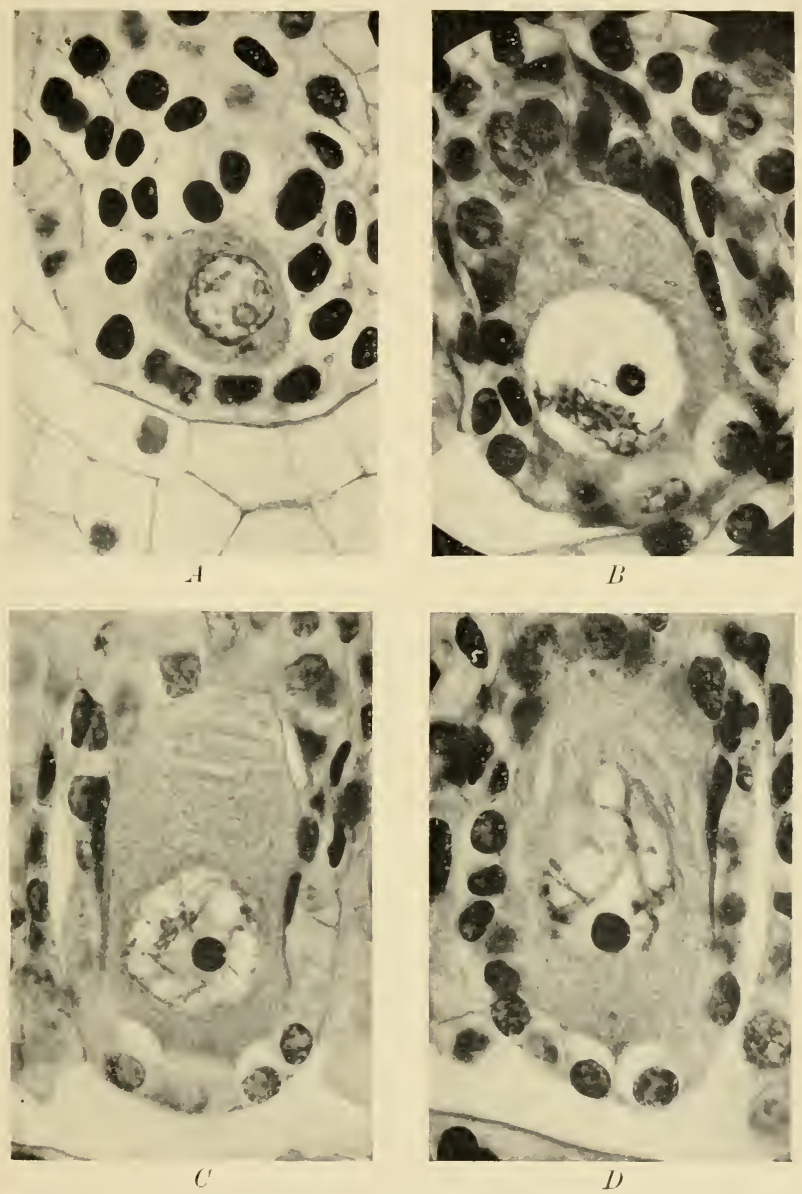

Fig. 35.-Litium phitaltphicum. A, arehesporial eell which is also the megaspore mother-eell; $B$, synapsis: $C$. stage just hetore splitting of spirem ; $I$. longitulinal -plitting of spirem (best seen in threads at the left); $\times 466 .-$ Negatives by W.J. (i. LAXD. 

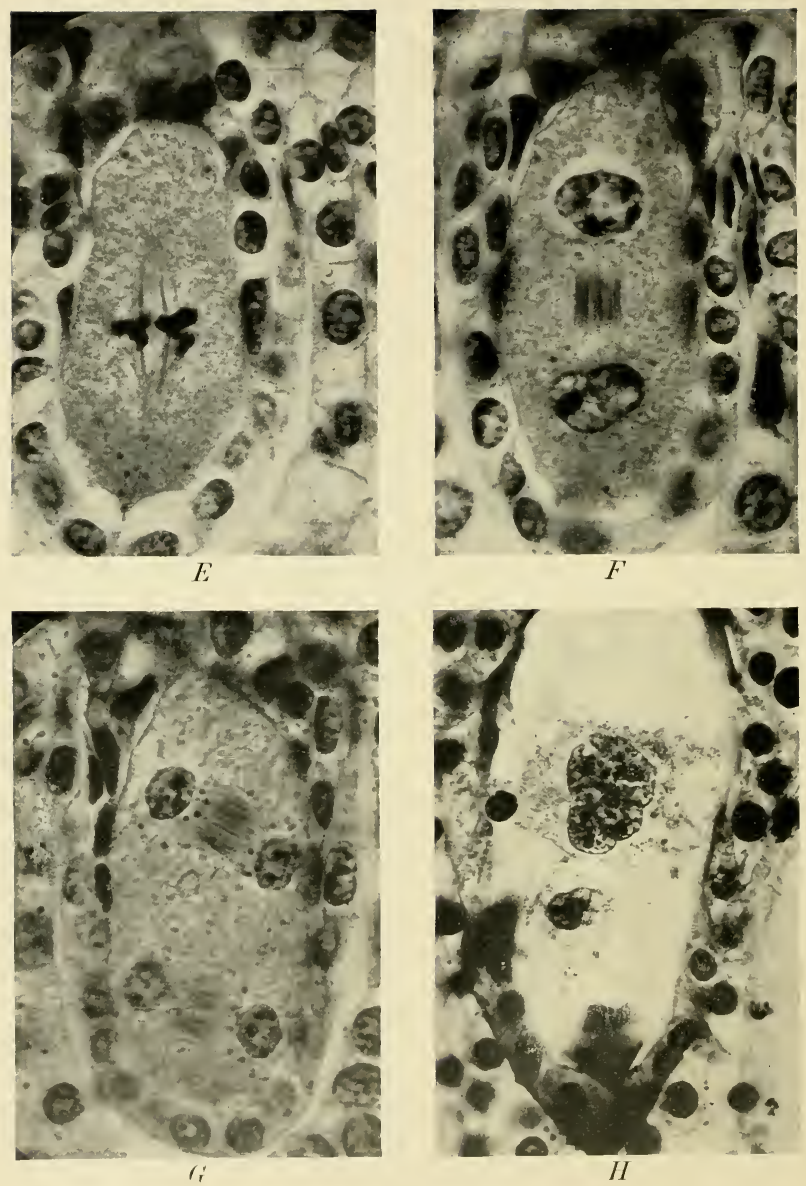

FIG. 3h.-Lilium philadelphicum. E. mitotic figure of the reduction dirision showing the short, thick chromosomes charactoristic of this stage: $F$. binucleate embrrosac; $G$, four-nueleate embryo-sac: $/ I, \cdots$ louble tertilization $*$ : in the egg the darker nucleus is the male and the lishter one the female: just berom the egg three nuclei are fusing: the antipodal polar nucleus forms about one-half of the complex, while the mieroprlar polar nucleus and the male nueleus form the other half, the male. meleus beine on the risht and touching both polar uuclei. $E-G \times 466$; $I I \times 520$ ).-Neratives by W. J. (i. Laxd. 
great obscurity, and very little has been added to the original suggestions concerning it.

The most important departure from the ordinary history is that shown by Peperomia pellucida, as described by Campbell ${ }^{70}$ and Johnson ${ }^{79}$ (Fig. 3s), Gunnera (Schnegg ${ }^{103}$ ), Trillium (Ernst ${ }^{116}$ ), and Tulipa as described by Guignard. ${ }^{89 a}$ In Peperomia the nuclei of the embryo-sac do not show any of the polarity that is so marked a feature in other forms. The first four nuclei are large, and arranged peripherally like the spores of a tetrad. Divisions continue until sixteen parietal nuclei, rather evenly distributed, are found in the sac. One of the muclei at the micropylar end of the sac becomes somewhat larger and is surrounded by a fairly defined mass of cytoplasm with a limiting membrane, this cell functioning as the egg. Another micropylar cell is similarly organized, and from its position

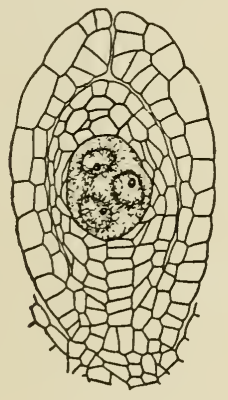

A
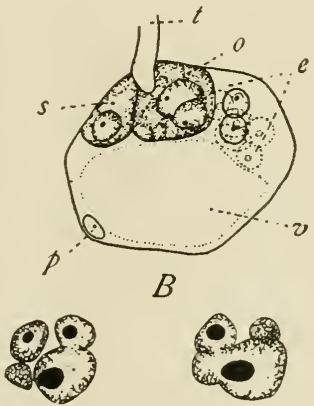

C

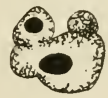

D

Fis. 38.-Peperomia pellucida. A, longitudinal section of an ovule with a four-nucleate entbryo-sac showing no polarity ; $\times 295 . \quad B$, embryo-sac at tine of fertilization; $t$, pollen-tube: $o$, oospore; $e$, group of nuclei fusing to form endosperm nucleus: $p$, peripheral nucleus of embryo-sac; $s$, synergid; $v$, vacuole: $\times 520 . C, D$, groups of nuclei fusing to form endosperm nucleus; $\times 520$.-After Johxsox. ${ }^{79}$

mar be called a synergid. Eight of the remaining nuclei mass tonether, are surrounded by a common eytoplasmic investment, and after fertilization unite to form a great fusion-nucleus that functions as the primary endosperm nucleus. The remaining six nuclei remain in their parietal position and are finally cut 
off by walls, showing no tendener to migrate toward the position of antipodal cells. This remarkable history is regarded by

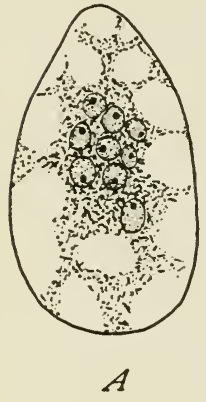

Fis. 39.-Gunnera. A, embryo-sae with nine nuclei, showing no polarity. $B$, later stage showing sixteen nuclei; $s$, synergid nuclei ; $o$, oosphere nucleus; near center, a group of six nuclei fusing to form endosperm nucleus; near base, seven antipodal nuclei.-After SCHNEGG. ${ }^{103}$

Camplell as representing a primitive phase of the embryosac of Angiosperms; a riew from which Johnson dissents, and in a more reeent paper ${ }^{114}$ he shows that in the allied Piper and IIecheria the eight-nucleate stage of the embrro-sac is reached in the usual war. It is tempting to conneet such a sac as that of Peperomia with such as that of Gnetum, and theoretically it represents what one might expect to be an earlier condition of the female gametophyte among Angiosperms: but .Johnson infers from the testimony of Piper and ILecheria, just referred to, that this particular sac of Peperomia is specialized rather than primitive.

In Gumnera, aceording to Schnegg, ${ }^{103}$ there is no polarity in the early stages of the embrro-sac, and the melear divisions are not simultaneous but irregular, so that there is no definite eight-nucleate stage of the sac. Before fertilization there are " at least" eight nuelei, and rerr commonly one or moie of the nuclei diride so that nine or ten and sometimes eren sixteen nuelei are found (Fig. 39) : in which ease, as in Peperomia, the primary endosperm nucleus is formed by the fusion of a considerable number of nuclei. A similar lack of polarity has been observed in Tulipa sylvestris by Guignard, ${ }^{\mathrm{s} a}$ and in Tritlium grandiflorum by Ernst ${ }^{116}$; in the latter case at least two of the nuclei of the eight-nucleate sac have heen known to divide, giving rise to a sac with ten nuclei.

In the embryo-sac of Juglans regia Nawaschin ${ }^{38}$ has indi- 
cated a lack of the usual definite organization, the male cells being described as "wandering" in the cytoplasm of the sac and fusing with one of several free nuclei which function as eggs but have not organized into an egg-apparatus. This loosene-s of organization in the cells of the embryo-sac has also been observed by Karsten ${ }^{115}$ in several species of Juglans, and he emphasizes the resemblance to Grmnosperms, believing that Angiosperms are derived from them, with such forms as Gnetum as the point of origin.

What may be called minor irregularities in the structure of the female gametophyte have been described in a number of forms. The reported occurrence of only one synergid in Orni-
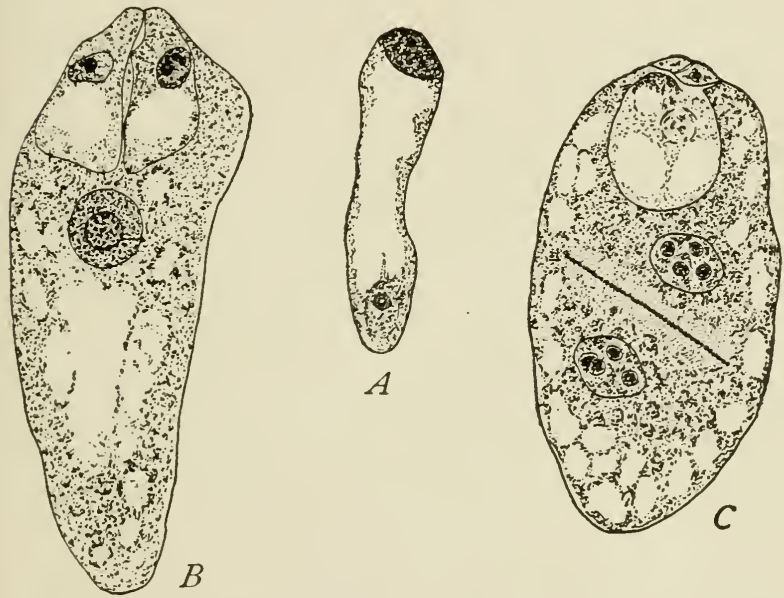

Fio. 40.-Helosis guyanensis. A, binucleate embryo-sac with antipodal nucleus already disintegrating. $B$, later stage; micropylar nucleus has divided twice, giving rise to two synergids, an egg (not shown), and the mieropylar polar nucleus which gives rise to the endosperm; no antipodals. $C$, remains of synergids and egg; the "pseudo-endosperm" nucleus dividing; no trace of antipodals.-After CHоDAт and Bernard.es

thogalum nutans, Santalum, Gomphrena, and Loranthus, bas long been known. In Loranthus Treub ${ }^{13}$ says that this is due to the fact that the primary micropylar nucleus divides only once, but it is also possible that the mother-nucleus of the 
synergids may not always divide. In the same category Casuarina, as reported by Treub, ${ }^{25}$ has long been included; but a recent study of the genus by Frye ${ }^{119}$ has shown that the usual



Fro. 41.-Antennaria alpina.

Egg-cell much extended and polar nuclei about to divide; $a$, antipodal cells; $e$, egg; $p$. polar nuclei ; $s$, synergid; $m$, micropyle; $\times 250 .-$ After JUEL.74

three micropylar nuclei occur. Fischer ${ }^{6}$ reports the occurrence of two eggs in Gomphrena, which Strasburger suggests may have come from division of the normal egg.

In Loranthus and Casuarina Treub also states that there are no antipodals; but Frye's ${ }^{119}$ recent investigation of the latter form has resulted in the discovery of three antipodals, which occur either at the chalazal extremity of the expanded portion of the sac, or in the tubular haustorial elongation.

In Helosis guayanensis (Balanophoraceae) Chodat and Bernard ${ }^{83}$ state that the primary antipodal nucleus (binucleate stage) rarely divides, but soon degenerates, which means also the absence of an antipodal polar nucleus (Fig. 40). The same phenomenon has been observed by Hall ${ }^{109}$ in Limnocharis, the primary antipodal nucleus remaining undivided. Several cases have also been reported in which regularly formed polar nuclei approach one another but do not fuse before endosperm formation, as in Balanophora elongata (Treub ${ }^{32}$ ), confirmed also in B. indica by Tan Tieghem, ${ }^{45}$ and in $B$. globosa by Lotsy ${ }^{69}$; but in the allied Rhopalocnemis (Lot$\mathrm{sy}^{82}$ ) the polar nuclei fuse. In the orchid Gymnadenia also, Marshall- Ward $\bar{T}$ states that the polar nuclei do not fuse: in the parthenogenetic Antennaria alpina .Juel ${ }^{57}$ (Fig. 41) observed the same phenomenon; in Lemna Caldwell ${ }^{62}$ reports that the polar nuclei often do not fuse; and in Juglans nigra Karsten ${ }^{115}$ states that there is probably no fusion of polar nuclei, or 
if it takes place at all it is very late. In parthenogenetic species of Alchemilla (Murbeck ${ }^{113}$ ), not only the two polar nuclei have the power of motion, but the synergid and antipodal nuclei may also move toward the center of the sac, forming groups of three, four, or five "polar nuclei" surrounded by a common mass of protoplasm. In the case represented in Fig. 42, Murbeck interprets the antipodals to be lacking, although, according to his own account, their nuclei are in the group of what he calls " polar nuclei."

Notwithstanding some such irregularities, however, the normal history of the female gametophyte is so remarkably constant that none of them can be regarded as of special significance.

The cells of the egg-apparatus are alike in being pyriform and bounded by a membrane which, for the lack of an accepted English equivalent, is commonly designated the Hautschicht; the egg, however, is racuolate toward the micropyle, its nuclens lying at its broad extremity, while in the scrnergids the reverse is true (Fig, 43). The size of these cells, as compared with the other cells of the embryo-sac, is exceedingly variable, sometimes being much the largest and sometimes eren the smallest. The morphological nature of this group of cells has been much discussed in the attempt to relate it to the archegonium of the lower plants. There seems to be no serious objection to regarding all three cells as potential eggs, only one of which usually functions as such. Whether they

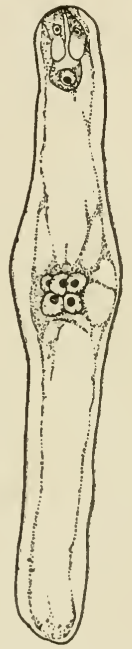

Fig. 42.-Alchemilla sericata. "Embryo-sac with complete egg-apparatus and tive polar nuclei; in agreement with this, no antipodals are present." -After MLRBEC. ${ }^{113}$ represent three archegonia, or the $\mathrm{egg}$ and canal cells of one archegonium, seems to be pressing morphology to an absurdity. The lack of any compact tissue precludes the formation of an archegonium, and hence frce cells organize as eggs. There seems to be no need to relate them to archegonia. but merely to regard them as eggs produced by a gametophrte that can not form archegonia. If a rigid morphology is to be applied, it 
may be said that these eggs appear earlier in the history of the gametophyte than is possible for archegonia, which are relatively late structures.

The character and behavior of the egg will be discussed under fertilization, but the synergids present certain peculiarities that may be considered here. The name "synergid," given

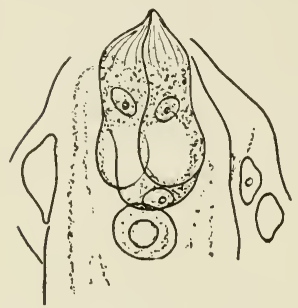

Fig. 43.- Polygon um divaricatum. Embryo-sac ready for fertilization: showing synergids with "filiform apparatus," egg, and primary endosperm nucleus; $\times 540 .-$ After StRASBUROER. ${ }^{\circ}$

by Strasburger, has proved most appropriate, for it is usually both a nutritive and mechanieal "helper" in the process of fertilization, although it does not " serve to convey the fertilizing substance from the pollentube to the oosphere," as once supposed. The two synergids follow the configuration of the apex of the sac, which is usually rounded, and hence they are pyriform for the most part. In certain cases, however, the sac becomes pointed or even much elongated, and the synergids develop beak-like extensions of more or less prominence, which in many cases have been found to pierce the wall of the embryo-sac and extend into the micropyle (Fig. 44). Oceasionally the beaks show delicate longitudinal striations, and were ealled by Schacht the "filiform apparatus." Such beak-like extensions of the sac and synergids are usually associated with narrow and long micropyles, and doubtless are of assistance in the progress of the pollen-tube. Among the Nonocotyledons they are by no means so common as among Dicotyledons, but are well scattered among the families. For example, they oceur in sorghum and Zea (Guignard ${ }^{71}$ ), Eichhornia (Smith ${ }^{53}$ ), Crocus (Hofmeister ${ }^{\mathbf{1}}$ ), Romulea (Ferraris ${ }^{\mathbf{1 2 0}}$ ), and Gymnadenia (MarshallWard ${ }^{7}$ ), and doubtless in others. Among the Archichlamy they are more numerous, having been noterl in Salix (Chainberlain ${ }^{46}$ ), Quercus (Conrad ${ }^{78}$ ), Santalum, Polygonum (Strasburger $^{5}$ ), Hepatica (Mottier ${ }^{36}$ ), Thalictrum (Overton ${ }^{110}$ ), Silene and Capsella (Guignard ${ }^{12}$ ), and becoming very long in Euphorbia (Miss Lyon ${ }^{54}$ ) and Sium. They are eren more common among the Sympetalae, a fact perhaps to be associated with the 
very hear integument. They have been noted, for example, in Campanula, Jasminum, and Salvia (Guignard ${ }^{12}$ ), and in almost all the species of Compositae investigated. In Calendula lusitanica Billings ${ }^{100}$ reports a very conspicuous synergid haustorium, the synergids developing into the micropyle and much enlarging. Synergid haustoria have been reported in other forms, which are probably outgrowths of the sac. The behavior of the synergids of Trapella, as described by Oliver, ${ }^{21}$ is remarkable, after fertilization increasing much in size, and in the mature seed forming a conspicuous tubercle-like body (Fig. 32).

It has been generally assumed that the polar nuclei fuse as soon as formed, which is perhaps generally true. If the time of fusion be related to the act of fertilization, however, it will be found to vary from before pollination to long after fertilization, and in some cases, already mentioned (Lemna, Gymnadenia, Balanophora, Antennaria alpina), the polar nuclei seldom if
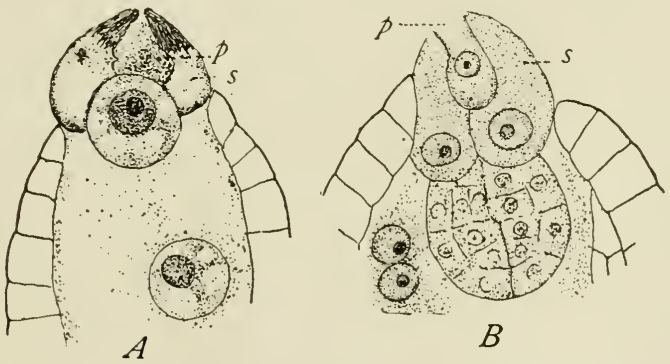

FIG. 44.-A, Salix petiolaris, upper end of embryo-sae soon after fertilization: $p$, pollentube: $\varepsilon$, synergid : the synergids, whieh are beaked and have the "filiform apparatus," have broken through the embryo-sac into the mieropyle; $\times 694 . \quad B, S . g l a u$ cophylla, synergids not disintegrating after the formation of the embryo; polar nuclei have not fused: $\times$ 694.-After ChamberLain. ${ }^{46}$

ever fuse. In this connection it may be noted that there is no antipodal polar nucleus in Limnocharis (Hall ${ }^{109}$ ) and Helosis (Chodat and Bernard ${ }^{83}$ ). Fusion of the polar nuclei at any time from before pollination, as in Eichhornia (Smith ${ }^{53}$ ), to the moment of sexual fusion, as in Litium, may be regarded as normal. Later fusion of the nuclei has been noted in the 
Nyctaginaceae and Conyza by Guignard, ${ }^{12}$ in Alchemilla by Murbeck, ${ }^{94}$ in Sium, in which case they are relatively small and remain near one another in a parietal position until the embryo-sac has become much enlarged, in Nicotiana by Guignard, ${ }^{10}$ and in Juglans nigra by Karsten, ${ }^{115}$ in which there may be no fusion. In this connection the recent experiments of Shibata ${ }^{122}$ upon Monotropa uniflora are of interest. He found that the polar nuclei may fuse in the absence of pollination, but that fusion is hastened by pollination. For example, when pollination occurs the polar nuclei fuse in about fire days, but when pollination is prevented the fusion does not oceur for ten days or more.

It seems to be generally true that the polar nuclei either fuse in contact with the egg, as observed by Guignard ${ }^{12}$ in Eriobotrya, C'mphea, Nicotiana, ${ }^{10 \pi}$ and other forms, or the fusion-nucleus migrates to that position just before fertilization, as in Tricyrtis (Ikeda ${ }^{1065}$ ), or after fertilization, as reported by Balicka-Iwanowska ${ }^{68}$ for the Scrophulariaceae and allied families. The last observer suggests that this position of the primary endosperm nucleus has to do with the nutrition of the fertilized egg; but the case of Tricyrtis suggests a function during fertilization. It is certainly true that in most cases this muclens is finally either in contact with the egg or very near to it. In Sagittaria (Schaffner ${ }^{47}$ ) and Potamogeton (Holferty ${ }^{97}$ ) the polar nuclei fuse in the antipodal end of the sac, but at the first division of the fusion-nucleus one daughternucleus mores toward the egg-apparatus. The evidence seems to show that the polar nuclei and the fusion-nucleus have freedom to "wander" "through the sac, and that there is at some time a relation in position to the egg. For example, in Tricyrtis Ikeda ${ }^{106}$ has described the fusion-nuclens as passing first to the antipodals, and then passing to the egg just before fertilization.

The antipodal cells are either naked or inrested br walls, and are exceedingly rariable as to their arrangement, umber, and persistence. The ordinary statement that the number of cells is limited to the three primary ones, and that they are more or less ephemeral, taking no part in the actirities of the embrrosac, has proved to be far from true in the majority of cases investigated. It is impossible to classify them as ephemeral 
and inactive, or relatively persistent and active, for the gradations between these two extreme conditions are complete. It is noticeable, however, that the two conditions are apt to be characteristic of families, and that the most extensive development of the antipodal cells is found in comparatively few families.

It is needless to attempt to give a complete list of those families in which the antipodal cells are ephemeral, disorganizing with more or less rapidity, and apparently taking no part in the activities of the embryo-sac. The following data will serve to illustrate that this condition is found in groups of every rank. Among Monocotyledons, ephemeral antipodals are found in Typhaceae, Naiadaceae (Potamogeton), Alismaceae, Pontederiaceae, Liliaceae (except Ornithogalum), Scitamineae, and Orchidaceae; among Archichlamydeae, in Saururaceae, Salicaceae, probably Casmarinaceae, Cupuliferae, Loranthaceae (Loranthus), Carrophrllaceae, Cruciferae, Saxifragaceae, Leguminosae, Euphorbiaceae, Aceraceae, Cactaceae, Onagraceae, and Umbelliferae; and among the Srmpetalae, in Oleaceae, Bignoniaceae, Pedaliaceae, Scrophulariaceae and their allies, and certain Rubiaceae. A certain amount of variation in these families has been found, as will be noted later, and doubtless much more will be found as other species are investigated. It will also be noted that this condition is probably not so prevalent in the Srmpetalae as in the other groups.

In those antipodal cells that function more or less there is every degree of prominence. It should also be noted that antipodals of the same sac often differ very much in prominence. For example, in Litium the innermost antipodal is often the most prominent, in Nicotiana (Guignard ${ }^{107}$ ) they are often unequal in size, among the Galieae (Lloyd ${ }^{105}$ ) one of the three is much elongated, and among the Compositae the one nearest the chalaza is often very much enlarged (Fig. 4 7 ). The simplest cases are those in which the cells do not grow very large or divide, but by their prominence and persistence indicate that they are taking some part in the actiritics of the embryo-sac, as in Tiscum, Nyctaginaceac, Puta, Polygala, Borago, Salvia, Ticotiana, and Sarcodes, as well as certain members of families characterized by a striking derelopment of the antipodal cells. 
In other instances the activity of the antipodal cells is shown by their great inerease in size and nswally multiuucleate eondition, and also by their more or less extensive division. Among the Monocotyledons, the Sparganiaceae, Gramineae, and Araceae are conspienous for their strongly developed antipodal cells. In Sparganium simplex Campbell ${ }^{63}$ describes the

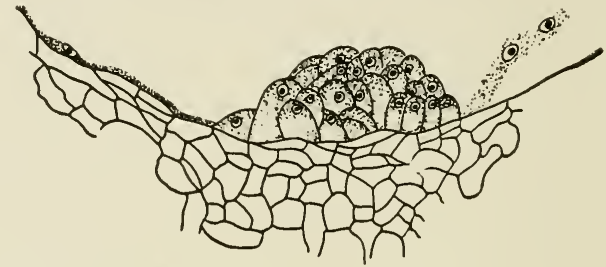

Fic. 45.-Sparganium simplex. Lower end of embryo-sac showing a large mass of antipodal cells.-After CAMPBELL. ${ }^{63}$

antipodal cells as at first very small, but immediately after fertilization they enlarge to several times their original size, their nuelei dividing. Finally, a conspicuous hemispherical mass of 100 to 150 uninucleate cells is formed, at this stage the endosperm having hardly at all developed (Fig. 45). The strong development of antipodal cells among the Gramineae has long been known, Fischer ${ }^{6}$ having reported in 1880 that each antipodal cell of Ehrarta panicea divides once, and of Alopecurus pratensis three or more times. More recently Cannon ${ }^{86}$ found in Arena fatua that the antipodal cells become thirty-six or more in number before fertilization, and begin to disorganize with the beginning of endosperm development. Westermaier ${ }^{\mathbf{2 3}}$ has described a growth of antipodal tissue in Zea and other grasses before fertilization, and Guignard ${ }^{90}$ has found as many as twelve multinueleate cells in the much narrowed antipodal end of the embrro-sac of Zea. It is of interest to note in this connection that in $18 \mathrm{~s} 2$ the same investigator ${ }^{12}$ found in Cornucopiae undivided but prominent and often binucleate antipodal cells. Among the Araceae Campbell ${ }^{75}$ states that there is a general tendeney for the antipodals to develop strongly, often dividing and forming a tissue, and in Lysichiton kamtschatcense the same observer ${ }^{63}$ finds that at the time of fertilization the antipodal nuclei have 
increased remarkably in size, and after fertilization the cells increase rapidly and divide, forming a group of eight or more cells with remarkably large nuclei. In addition to these three monocotyledonous families, a prominent antipodal region has been found in Triglochin maritima (Hill ${ }^{76}$ ), in which there are three to fourteen cells; verv large but undivided antipodals have been found in Lilaea (Campbell ${ }^{56}$ ), Commelina (Guignard ${ }^{12}$ ), Ornithogalum, Gladiolus, and Crocus (Mottier ${ }^{36}$ ), Narcissus and Iris (Guignard ${ }^{12}$ ), and Romulea (Ferraris ${ }^{120}$ ); and Ikeda ${ }^{106}$ reports that in Tricyrtis the antipodals fill up the "chalazal protuberance," become elongated with it, and reach their maximum length just before fertilization.

Among the Archichlamydeae, the Ranunculaceae are especially characterized by the activity of the antipodal cells, shown both by their great size and multinucleate condition, and also by their dirisions. We have records of twelve genera, and in all of them the antipodals are conspicuous. In 1879 Strasburger 5 reported the antipodals of Myosurus as very prominent, and in 1 s.2 Guignard ${ }^{12}$ described the antipodals of Erianthis as large, those of Clematis as verr large and binucleate, and those of Ilepatica as forming a great group and becoming multinucleate after fertilization. In 1s90 Westelmaier ${ }^{23}$ reported large antipodals in Ranunculaceac, among them Nigella; and in 15,5 Mottier ${ }^{36}$ investigated a number of genera and described the antipodals of Delphinium trirorme as rery large, growing with the embrro-sac, and persisting till after fertilization; those of Caltha palustris as large, prriform, and multinucleate; those of Aquilegia canadensis as growing enormously 
before and after fertilization and becoming multinueleate; those of various species of Ranunculus, Anemonella, and Thal-

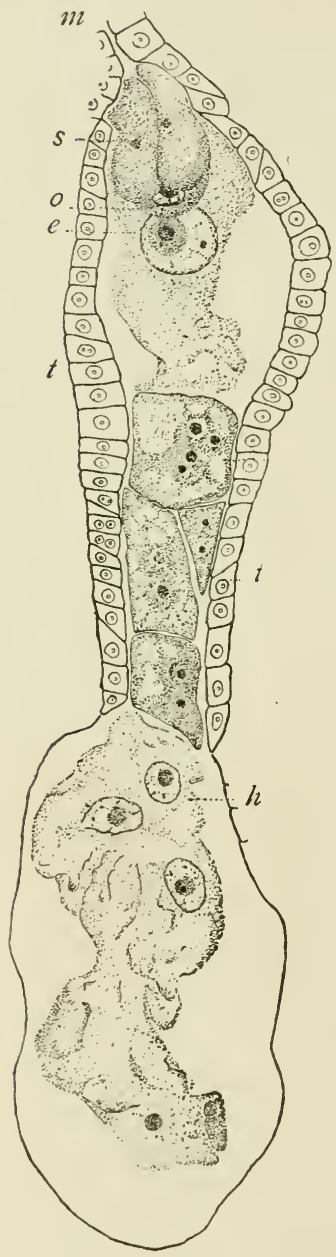
ictrum dioicum as very large; and those of Hepatica as growing very much until after fertilization. Sinee then Orerton ${ }^{110}$ has found that the antipodals of Thalictrum purpurascens become remarkably large, reaching the eenter of the sac; Miss Dumn ${ }^{89}$ has reported that in Delphinium exaltatum three very large antipodals persist even in the oldest seeds with no indication of degeneration; Miss Lyon has noted as many as twenty-five antipodal cells in Hepatica; and Osterwalder ${ }^{60}$ has figured exceedingly large antipodals in Aconitum Napellus (Fig. 46). The whole family is characterized, therefore, by the actirity of its antipodal cells, exhibited more bs their great increase in size than by dirision. Among the Amentiferae Miss Benson ${ }^{31}$ reports a row of six or more superposed nntipodals in the very narrow antipodal end of the sae in Castanea vulgaris, the lowest one being figured as the largest and multinucleate, the whole structure resembling the antipodal region of many Compositae. Around the base of this elongated antipodal region there are developed sueh tracheidlike cells as ocemr in the nucellus

Fug. 47.-Aster novae-nngliae. Longitudinal section of embryo-sac just before fertilization:

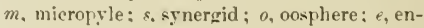
dosperm nucleus: $t$, jacket: $h$. lower antipodal cell: tour nther antipndal cell- shown, the upper with four nuclei und the others with two: $\times$ 407.-After ChaMBerLais.95 
of Casuarina, but in this latter instance they are derived from mother-cells. Other Archichlamrleae with active antipodals are ILechiria (Johnson ${ }^{114}$ ), in which they are sometimes six to eight in number; Asarum (Hofmeister ${ }^{2}$ ), in which they are very long, extending at fertilization from onethird to one-half the length of the embryo-sac, and sometimes dividing; Jeffersonia diphylla (Andrews ${ }^{37}$ ), in which they become about one-half as long as the embryo-sac; Eriobotrya (Guignard ${ }^{12}$ ), in which they are large; and Anoda (Guignard ${ }^{12}$ ), in which they are prominent and often binucleate.

Among the Sympetalae the Compositae are especially noteworthy for the extensive development of the antipodal region (Fig. 47 ). In this family the chalazal end of the elongated sac is rery narrow and the antipodals are superposed. In a number of cases, as in Doronicum, Petasites, and Taraxacum, there are usually only three antipodals, but they remain active: while in Tussilago (Guignard ${ }^{12}$ ) there are usually four; in Senecio (Mottier ${ }^{29}$ ) two to six; in Silphium (Merrell ${ }^{77}$ ) three to eight; in Conyza (Guignard ${ }^{12}$ ) eight to ten; in Aster novae-angline (Chamberlain ${ }^{35}$ ) three to thirteen: and in Antennaria (Juel ${ }^{57}$ ) they continue to divide until quite a tis-

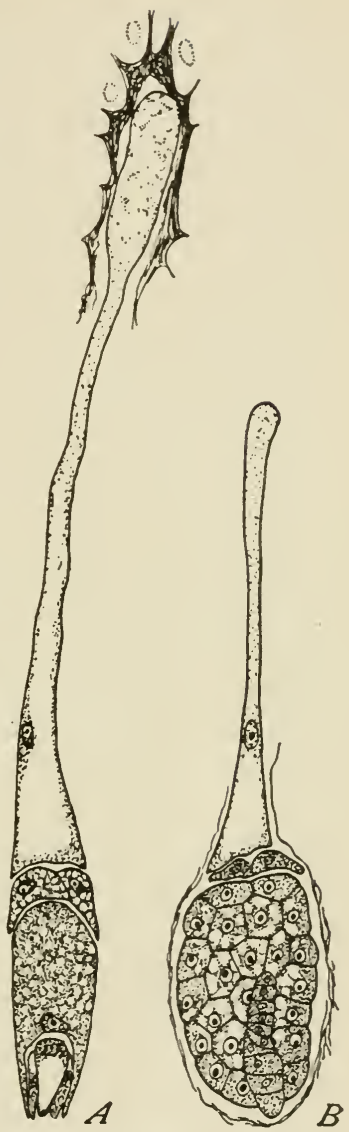

Fio. 48,-A, Sherardia arvensis. Em-0 bryo-sac before fertilization: lower antipodal acting as an haustoriun. $B$, Callipeltis cucullaria, showing lower antipodal still active after embryo and endosperm are considerably advanced.-After LLOYD. ${ }^{106}$ 
sue is formed (Fig. 41). This record indicates that the divisions are variable in number even in the same species, and it may be noted in this connection that while Schwere ${ }^{+2}$ states that there are only three antipodals in Taraxacum, Hegelmaier ${ }^{9}$ had previously reported four or five, and more than three have been obscrved frequently in this laboratory. In many of these cases all the cells usually contain two or more nuclei, and the end cell toward the chalaza often becomes resicular and multinucleate, breaking through the sac and encroaching upon the chalazal tissue. It seems to be clear that in the Compositae this derelopment of antipodals is practically an aggressive haustorium for the embryo-sac; while in the Ranunculaceae the antipodals doubtless serve as an haustorium, but do not invade the neighboring tissue. Certain Rubiaceae also contain active antipodals, since Lloyd ${ }^{6}$ has found that in Taillantia hispida while two of the antipodals are insignificant, the third is very prominent and remains active for a long time. The same author ${ }^{105}$ has more recently found the same to be true of the Galieae (Fig. 4s), and he also has found four to ten antipodals in Diodia virginiana. Balicka-Iwanowska ${ }^{68}$ has also noted enlarging and persistent antipodals in Plantaginaceae and Campanulaceae, and their dirision in Dipsaceae as in the Compositae. In Asclepias, althongh three active antipodals are usual. Frye ${ }^{11 s}$ has observed compact antipodal tissue consisting of seren or eight cells; and in A. Cormuti he has noted the occurrence of tracheid-like cells at the base of the embrro-sac, such as oceur in C'asuarina and Castanea.

There seems to be no reason to question the ordinary view that the antipodal cells are regetative cells of the gametophrte. Their polarity as contrasted with that of the egg-apparatus, and their behavior when they function confirm it. The oceasion for their activity seems to be to supply the embryo-sac with nutritive material ahsorhed from withont at a time when the endosperm has not been organized or other means of obtaining nutrition are not available. In Wonotropa uniflora Shibata ${ }^{122}$ has found that the three small antipodals disintegrate after fertilization, but that when fertilization is prevented they may enlarge enormously and fill a considerable portion of the sac. The character of the active antipodals among the more primitive Monocotrledons and in the Ranunculaceae may be 
regarded as indicating a primitive condition of the nutritive tissue in the female gametophytes of Angiosperms; but the antipodals of many of the Compositae are organized into an aggressive haustorium which can only be regarded as a very specialized organ.

The enlargement of the embryo-sac and the nature of its derelopment, both before and after fertilization, are extremely varied. The enlargement is directly related to the digestion of the contiguous tissue. In a few eases this destruction is not extensive, and more or less of the nucellar tissue is permanent (perisperm) and is used for the storage of reserve food, as in the Scitamineae, Piperaceae, Chenopodiaceae, Phytolaceaceac, Caryophyllaceae, Nymphaeaceae, etc. In most cases, however, the destruction of the nucellar tissue is complete to the integument, and even that is sometimes involved, as in Allium odorum, certain orchids, and lstilbe (Webb ${ }^{111}$ ). Frequently the tissue at the apex of the nucellus remains as a cap on the embryo-sac, as in Arisaema (Mottier ${ }^{27}$ ) and other Araceae, Lemna (Caldwell ${ }^{62}$ ), Liliaceae, Silphium (Merrell ${ }^{i t}$ ), and many other forms, and this is frequently accompanied by more or less elongation and even division of the capping cells.

Frequently a definite nutritive jacket invests the embryosac, consisting of one or more layers of cells with deeply staining contents (Figs. 47, 50). For the most part this is a single layer derived from the integument, but in Armeria it is derived from the nucellus, and in Erodium one layer is derived from the nucellus and the other from the integument. This jacket has been called a tapetum, and such it is in function. In using the term, howerer, there is danger of confusing it with the tapetum of ordinary sporogenous tissue. This jacket has been definitely observed as conspicuous in Helosis (Chodat and Bernard ${ }^{83}$ ), Sium, many Scrophulariaceae (Balicka-Iranowska ${ }^{68}$ ), Campanula (Barnes $\left.{ }^{18}\right)$, Stylidaceae (Burns ${ }^{85}$ ), and certain Compositae, and by Billings ${ }^{100}$ in numerous srmpetalous forms, among the most conspicuous being Lobelia, Primulaceae (except Leptosiphon), Linum, Forsythia, Amsonia, Venyanthes, Polemoniaceae, Myoporum, Globularia, Scaevola, Calendula, etc.

In many cases the mieropylar end of the sac destroys all of the nucellar tissue capping it, and protrudes more or less 
into the micropsle, as in Hemerocallis, Crocus, Gladiolus, Romulea (Ferraris ${ }^{120}$ ), Alchemilla (Murbeck ${ }^{94}$ ), in which the sac pushes through to the tegumentary tissue closing the microprle, Medicago, Torenia asiatica (Strasburger ${ }^{5}$ ), Labiatae, Taillantia (Lloyd ${ }^{6 \pi}$ ), Diodia and the Galieae (Lloyd ${ }^{105}$ ), and many other forms. In Vaillantia the mother-cell migrates into the micropyle and derelops there.

While ordinarily the embryo-sac is relatively broad and rounded at its micropylar extremity, this is by no means so

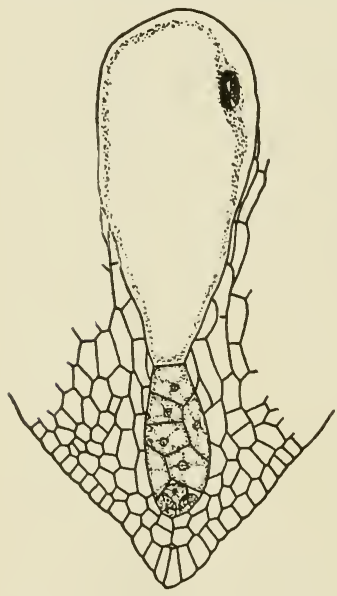

Fig. 49,-Saumurus cernuus. Longitudinal section of eubryo-sac; after the first division of the endosperm nucleus the micropylar cell has given rise to endosperm tissue, while the other cell has beeome a large resieular haustorium.-After Jowxson.87 commonly true of the antipodal end. If the antipodals are ephemeral, the growth of the antipodal region is frequently checked after the first division of the megaspore nucleus, and through the growth of the rest of the sac it becomes a very small pocket, as in Typha, Potamogeton, Sagittaria, certain Gramineae, Pontederia, Litium, Oenothera, etc. (Fig. 79). It is generally true that the antipodal region of the sac is narrower than the micropylar, but its growth is not often checked so completely and so early as in the cases cited.

In other cases, the antipodal region of the sac grows very actively, elongating toward the chalazal region and penetrating it more or less deeply, resulting in a very narrow and elongated sac. Such an antipodal region must be regarded as an haustorium that digests and absorbs its way into the chalazal tissue. Illustrations of this are very numerous, as in Gramineae, Tricyrtis (Ikeda ${ }^{106}$ ), Scitamineae, Samruraceae, Loranthaceae, Polygalaceae, Lythraceae, Aceraceae, and most Srmpetalae. In penetrating the chalaza the antipodal tip usually remains narrow, but in Saururus (Johnson ${ }^{87}$ ), Scitamineae (Humphrey ${ }^{40}$ ), Cuphea (Guignard ${ }^{12}$ ), Campanula (Barnes ${ }^{18}$ ), etc., 
it has been observed to enlarge more or less abruptly, forming a bulbous chalazal haustorium. In Canna indica this becomes much larger than the rest of the embryo-sac; and in Saururus cernuus Johnson st describes the embryo-sac as elongating rapidly, broadening below, the upper part remaining narrow, the completed sac resembling a long-necked flask (Fig. 49).

In addition to the various forms of haustorial apparatus described above as developed in comnection with the embryo-sac, certain extreme cases leserve special mention. It has long been known that among the Santalaceae (Santalum, Thesium, Osyris, etc.) the embryo-sac derelops a micropylar tube that passes through the micropyle and enters the cavity of the orary, and that in some of them (Thesium, etc.) there is also an antipodal tube (see Guignard ${ }^{17}$ ). These remarkable tubular or rerniform haustoria obtain nutritive material beyond the orule. Later, Johnson 22 described in detail the hanstorial apparatus of Myzodendron, another genus of Santalaceae. The young sac is broad abore and narrowed toward the antipodal end. After fertilization the antipodal region develops rapidly, penetrates the chalaza, enters the placental axis, and curving passes dorn it to the base of the flower. where its tip dilates and becomes embedded in the "rascular eup" formed by the three direroing carpellary bundles. Rigidity is given to this remarkably eloncated tube by numerous cross-walls, but these are lacking in the placental region.

Among the Amentiferae ( $M i s s$ Benson ${ }^{31}$ ) rermiform caeca are often sent out from the embryo-sac. In Fagus sylvatica this tubular outgrowth penetrates to the base of the nucellus, the primary endosperm nuclens passing into it, but not the antipodals, which are anchored by thick walls. In Castanea inlgaris the caccum derelops from the sicle of the sac just above the narrow antiporlal prolongation, is entered by the endosperm nucleus, and passes down between the nucellus and the integument. In Crapinus Betulus the chalazal region is sometimes riddled by the long eaeca from the sereral embryo-sacs; and in Corylus Avellana a short caecum appears after fertilization.

In Casuarima. as shown by Frye, ${ }^{119}$ a conspieunus rermiform raecum is developed much as among the Imentiferar. Finm the antipolal extremity of the sac a long tube penetrates the chalazal region, into which the endosperm nucleus passes 
and sometimes the antipodals. This haustorial tube was observed to begin its development at different stages in the history of the sac, sometimes being erident in the two-nucleate stage of the sac, sometimes not laving begun in the seren or eightnucleate stage.

One of the strangest cases is that of Trapella, as described by Oliver. ${ }^{21}$ In this the innermost megaspore of a row of four becomes extremely elongated, penetrates the chalaza, and divides longitudinally, the two cells being very active, as indicated by their contents and numerous starch grains. In this form the synergids enlarge and persist on the apex of the sac (Fig. 32).

Among the Scrophulariaceae, such as Pedicularis, Rhinanthus and its allies, etc., Tulasne, Hofmeister, Tschirch, Schlotterbeck, and others have described the numerous vermiform tubes that develop from the embryo-sac and "ruminate" the integument and destroy its tissue, although they did not recognize their origin; and similar tubes have been found in certain Labiatae. Recently Balicka-Iwanowska ${ }^{68}$ has investigated the embryo-sacs of many Scrophulariaceae, as well as other allied Sympetalae, and has discovered a remarkably constant occurrence of haustorial outgrowths from the sac at both micropylar and chalazal ends, filled in later by endosperm cells. The common case is for the broad micropylar end of the sac to develop four prongs, and for the narrower chalazal end to fork, as seen not merely among Scrophulariaceae, but also among Utriculariaceae, Pedaliaceae, and Plantaginaceae. The development of these haustoria is related to the thickness of the integument, which in these groups seems to be a source of nutritive supply. There are all stages in the development of the haustoria, but the general tendency in this region of the Srmpetalae is very marked. A striking case is that of the well-known Torenia asiatica, mentioned above, in which the sac does not derelop outgrowths, but protrudes bodily beyond the micropyle, touching the funiculus, and even reaching the ovary wall. All of these haustorial outgrowths are supplied with active endosperm cells or nuclei.

It is stated that all species of Campanulaceae (BalickaIwanowska ${ }^{68}$ ), Lobeliaceae (Billings ${ }^{100}$ ), and Stylidaceac (Burns ${ }^{85}$ ) develop both micropylar and chalazal haustoria, and 

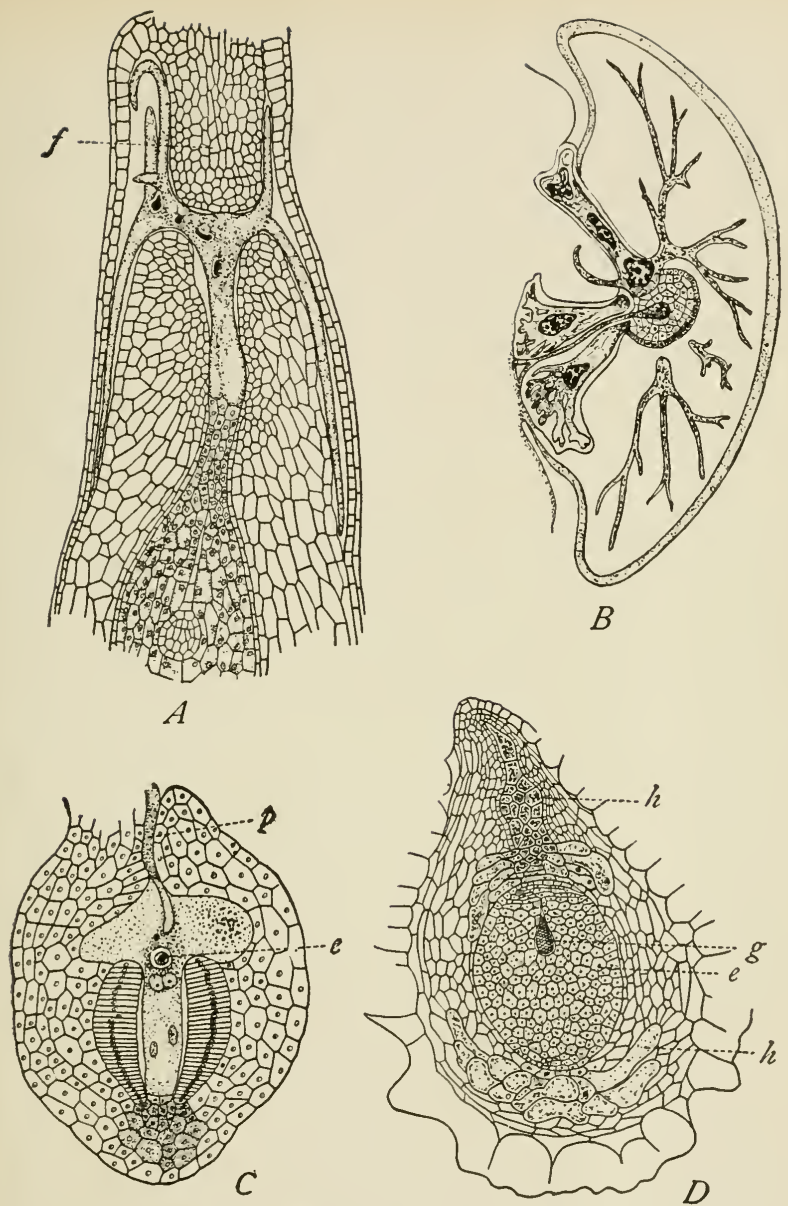

Fio. 50.-A, Globularia cordifolia, the micropylar end of the embryo-sac has grown out into an extensive haustorium furnished with nuelei from the endosperm: $f$, funiculus; after Brlzivos. ${ }^{200} \quad B$, Plantago lanceolati, longitudinal section of ovule after embryo is somewhat advanced, showing extensive haustorial system: after Baticka-Iwanowska.68 $C$, Stylidium squamellosum, embryo-sae after seeond division of endosperm nucleus: $e$, egg: $p$, pollen-tube: after Burss. ${ }^{85} \quad I$, Byblis giqantea, longitudinal section of seed with branching haustoria in both micropylar and antipodal regious; $h$, haustorium; $g$, embryo,$e$, endosperm; after L.s. $\theta^{01}$ 
that often finger-like processes are put out at the side or base of the sac, extending toward the vascular bundles; and in Stylidaceae, immediately after the entrance of the pollen-tube, the micropylar part of the embryo-sac grows out into an enormons haustorium much larger than the rest of the sae (Fig. 50). As a result of his investigations of Polypompholyx and Byblis, Lang ${ }^{91}$ not only discovered conspicuous haustoria, but used this character, along with others, such as the nucellus with a single

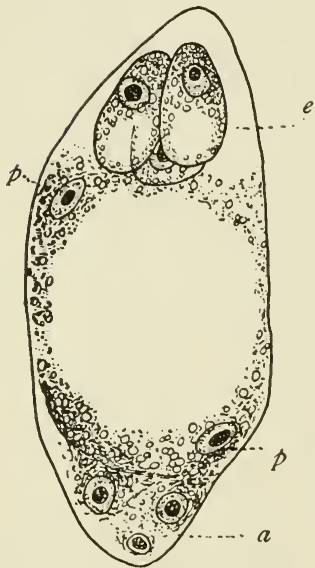

F19. 51.-Phyllocactus. Stareh disappearing from antipodals and accumulating in other portions of the embryo-sac: $a$, antipodals; e, eirg-apparatus; $p$, polar nucleus; $x$ tiffi. - After DHeВегт. 33 row of axial cells, the tapetum derived from the single integument, and the united petals, to remore these genera from the archichlamydeous Droseraceae to the sympetalous Lentibulariaceae.

The whole subject of the mechanism for the nutrition of the enbryosac deserves more detailed attention than it has received. In his studr of the Hleshy plants, D'Hubert, ${ }^{33}$ on the basis of the appearance and disappearance of stareh, concludes that the antipodals nourish the sac before fertilization, the srnergids nourish the muclei of the pollen-tube and then the nucleus of the egg at the time of fertilization, and the polar nuclei nourish the fertilized $\mathrm{eg}$ and give rise to the endosperm (Fig. 51). Such details mar prove true for the Cactaceae and other fleshy plants, but the larger field is to be traversed first, which embraces all of the morphologieal structures used in obtaining nutritive supplies for the structures within the embryo-sac, both before and after fertilization. Just what mechanism supplies what structure is a subordinate detail and very difficnlt to prove, besides being an exceedingly improbable division of labor among structures so

* D'Hubert enneludes that starch is characteristic of fleshy plants, hut there is a large display of stareh in Astilbe (Webb, ${ }^{111}$ ) and Galium (Lloyd ${ }^{105}$ ). and doubtless in many other non-fleshy plants. 
closely associated. From the data more or less scattered through the preceding and following pages, the rarious methods by which nutritive supplies are brought into the sac may be grouped together as follows, although the subject is in no condition as ret for satisfactory organization.

The digestion and absorption of adjacent tissue by the enlarging sac is the most general method of obtaining nutritive supplies. It always occurs to a certain extent, and often is the only observed method. The varying amount of tissue destroyed in this way is a thing of common observation.

The organization of a definite layer or lavers of cells about the embryo-sac in its later stages, which we have called the "nutritive jacket," has not been reported for the Monocotyledons, occurs in comparatively few Archichlamydeae, while it seems to be common among the Sympetalae. For the origin and occurrence of this jacket see page 101. Its appearance and function is that of a tapetum, and there seems to be no good reason why it should not receive the name.

Tracheid-like cells have been reported in the nucellar tissue of Casuarina, Castanea, and Asclepias, but this meager list will doubtless be much increased. That such cells are connected with a nutritive mechanism seems clear, but their rare and feeble development suggests a relic of an efficient ancestral mechanism. The recent discovery (Oliver ${ }^{104}$ ) of a Palaeozoic fern with certain resemblances to the Cycadofilices, in which tracheids replaced the tapetum in the sporangium, may be another indication of the former somewhat extensive nse of this special form of mechanism. Thick-walled cells often appear in the chalazal region, especially in connection with the penetration of the sac. Some are as hard as tracheids, while in other cases the walls have become mucilaginous and swollen. Similar cells also oceur wherever haustoria invade tissue in any other region of the orule or outside of it.

The aggressive penetration of the chalazal region by the elongation of the antipodal extremity of the sac is very common. This definite antipodal haustorium seems to be nearly always developed when a more or less prominent mass of chalazal tissue occurs. Among Monocotyledons such haustoria are recorded among the Gramineae, Tiliaceae, and Scitamineae; among the Archichlamydeae they are known to occur among the Sauru- 
raceae, Loranthaceae, Nymphaeaceae, Polygalaceae, Lythraceae, and Aceraceae, while they seem to be almost unirersal among the Sympetalae. In most cases the adrancing tip remains narrow, but sometimes it becomes enlarged, in certain cases rery much so. For example, in Canna the antipodal hanstorium becomes a bulbous structure larger than the rest of the sac, while in sumurus the narrow micropylar end and the bulbous antipodal haustorium form a flask-shaped sac.

Among the Santalaceae the rermiform haustoria sent from the micropylar extremity of the sac into the cavity of the orary have been noted. Perhaps the most remarkable member of the family in this regard, however, is Myzodendron, as described above. In this case the haustorium is really an extreme derelopment of the antipodal extremity of the sac, but the elongation is so excessive that it has been included in this rather than in the preceding category. Among the Fagales vermiform haustoria are more or less prominent, in this case being sent out laterally from near the antipodal extremity and penetrating the chalazal tissue, and being entered by the endosperm nucleus. Conspicuons haustoria of this type are reported, as noted abore, in Fagus and Castanea. while in ('arpinus the chalazal region is sometimes riddled by the haustoria from the sereral sacs. Among the Sympetalae vermiform haustoria are common, being well known among Scrophulariaceae and their allies, as well as among the Campanulaceae, Lobeliaceae, and Stylidaceae. In addition to the penetration of the chalazal tissue by haustoria from the antipodal region of the sac, micropylar haustoria are often sent into the tissue of the massive integument. Four such micropylar haustoria, more or less prominent, and alwars associated with active endosperm cells, seem to be common among the Scrophulariaceae. Such haustoria are apt to be coenocrtic, the endosperm ennsisting of large and densely staining nuclei rather than of walled cells as in other parts of the sac. The haustorial mechanism is evident even when it consists only of groups of active endosperm cells in contact with definite regions of the sac wall.

In this connection the remarkable case of Trapella (Pedaliaceae) may be mentioned, in which the innermost megaspore of the linear tetrad becomes modified into an active haustorium that penetrates the chalazal region (Fig. 32). 
The protrusion of the sac bodily into or through the micropyle nuy be regarded as only a more extensive derelopment of the rermiform nicropylar haustorium, but it deserves separate mention. Torenia is the oldest and most conspicuous illustration of this phenomenon, the sac passing beyond the micropyle and even reaching the wall of the ovary. The phenomenon also occurs among the Rubiaceae, the sac entering the microprle in Diodia and the Galieae, while in Taillantia the megaspore mother-cell parses into the micropyle and divides there.

The projection of the svnergid as an hanstorium has becn observed by Billings ${ }^{100}$ in Calendula lusitanica, in which the synergid develops into the micropyle and enlarges greatly: and in Trapella (Oliver ${ }^{21}$ ), large. persistent svnergids occur, which are evilently haustorial. Other ssnergid haustoria have been reported, as in Lobelia, but they prove to be merely haustoria from the sac, containing endosperm.

The antipodal cells are often very prominently associated with the haustorial apparatus for obtaining nutritive supplies from or throngh the chalazal region. The nutritive function of the antipodals seems to have been claimed first by Westermaier 23,39 in his studies of the prominent antipodals of the Ranunculaceae. This was confirmed by Osterwalder ${ }^{60}$ in his study of Aconitum Napellus: and also by Mlle. Goldflus ${ }^{61}$ in connection with the Compositae. The latest contribution to the subject is that by Ikeda, ${ }^{106}$ in connection with Tricyrtis hirtr, who claims that the antipodals in that species are nutritively active from the full maturation of the sac to the formation of endosperm, after which they change in structure and gradually weaken; and that during that period they not only elaborate food for endosperm-formation, but also for the growth of the egg-apparatus. The cutinization of the integument prevents the passage of materials except by way of the chalaza, and hence much of the nutrition must pass through the antipodals. Ikerla describes and figures the position of starch, dextrine, and cutinized membranes at rarions stages in the development of the ovule and embrro (Fig. 52). From this point of riew antiporlals are of two general types, that may be spoken of as the passive and agcressive types. In the passive trpe the antiporlals remain active, often become rery much enlarged (as among Ranunculaceac), or even form a mass of tissue (as in 
Sparyanium), but they are not associated with an invasion of the chalazal region, and simply receive material from it. This type is characteristic of Monocotyledons (except Gramineae)
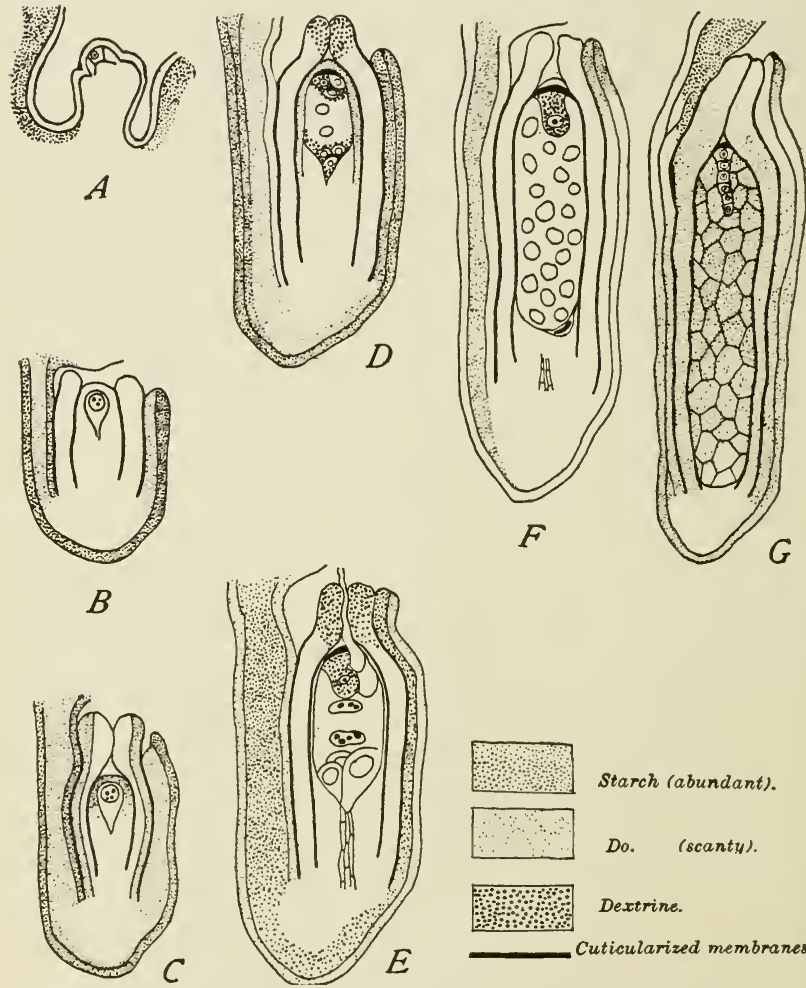

Starch (abundant).

Do. (scanty).

\section{Dextrine.}

Fic. 52.-Tricyrtis hirta. Various stages in development of ovules, embryo-sac, and embryo, showing the starch, dextrine, and cutinized membranes at different periods, the sequence being indieated by the letters $A-G,-A$ fter IKEDA. ${ }^{108}$

and Archichlamydeae (except many Amentiferae). In the aggressive type, active and often multiplring antipodal are associated with the penetration of the chalazal region by the 
antipodal portion of the sac. This type is characteristic of Sympetalae, perhaps being especially prominent among the Rubiaceae and Compositae; but it is also conspicuous among the Gramineae and Amentiferae. Anong the Amentiferae it is noteworthy that an antipodal hanstorimm oceupied by active antipodal cells and a special rermiform haustorinm oceupied by endosperm cells are often both present.

That every suspensor is an haustorium for the embryo seems evident, but aside from this general fact special outgrowths from the suspensor are developed to reach a wider range of nutritive supplies. The case of certain orchids whose suspensor's develop rermiform haustoria that envelop the embryo, or grow through the micropyle and embed themselves in the wall of the ovary, has long been known; and it has been recently found that among certain Rubiaceae (Galieae) the filamentous suspensor sends out conspicuous lateral processes or branches that penetrate the endosperm (Lloyd ${ }^{105}$ ).

In some cases a complex mechanism for nutrition has been described, and numerons others will be discovered when attention is given to the subject. The case of Phlox Drummondii, as described by Billings, ${ }^{100}$ may be used as an illustration. The wall of the ovary adjacent to the micropyle develops a papilla of special structure consisting of elongated cells. This presses against the micropyle, which becomes closed and resembles conducting tissue. A papilla of small cells develops from the adjacent integument in contact with the sac, and pressing into it is put in connection with the suspensor. In testing this mechanism for starch, Billings found stareh in the ordinary tissue of the ovary wall, no starch in the wall-papilla, and abundant starch again in the integument bordering the old micropyle. This seems to establish a definite passage of nutritive supplies from the ovary wall, through a series of specially dereloped tissues, to the suspensor.

In Stylidium squamellosum (Burns ${ }^{85}$ ) there is a remarkable combination of nutritive structures (Fig. 50). The micropylar end of the sac enlarges enormously and spreads out through the thick integument, a remarkable nutritive jacket of radially elongated cells invests the lower part of the sac, and a distinct gland-like nutritive tissue is developed in the chalaza adjacent to the antipodal end of the sac. 


\section{LITERATURE CITED}

1. Hofmeister, W. Neuere Beobachtungen über Embryobildung der Phanerogamen. Jahrb. Wiss. Bot. 1: 82-188. pls. 7-10. 1858 .

2. - Neue Beiträge zur Kenntniss der Embryobildung der Phanerogamen. Abhandl. Königl. Sächs. Gesell. Wiss. 6: 533672. pls. 1-2\%. 1859.

3. Warmixg, E. De l'ovule. Ann. Sci. Nat. Bot. VI. 5: 177-266. pls. $\tau-13.18 \% 7$.

4. Vesque, J. Déreloppement du sac embryonnaire des Phanérogames Angiospermes. Ann. Sci. Nat. Bot. VI. 6: 237-285. pls. 11-16. 1878; 8: 261-390. 1879. Compt. Rend. 88: 1359-1361. 1879. Bot. Zeit. 37: 505-509. 1879.

5. Strasberger, E. Die Angiospermen und die Gymnospermen. Jena. 1879.

6. Fischer, A. Zur Kenntniss der Embryosackentwicklung einiger Angiospermen. Jenaisch. Zeitsch. Naturwiss. 14: 90-132. 1880.

7. Ward, H. Marshall. On the Embryo-sac and Development of Gymnadenia conopsea. Quart. Jour. Micr. Sci. 20: 1-18. pls. 1-3. 1880 .

8. - - A Contribution to Our Knowledge of the Embryo-sac in Angiosperms. Jour. Linn. Soc. Bot. London 17: 519-546. pls. 17-25. 1880.

9. Hegelyaier, F. Ueber aus mehrkernigen Zellen aufgebaute Dikotyledonen-Keimträger. Bot. Zeit. 38: 496-506, 513-522. 1880.

10. Tredb, M., and Mellisk, J. F. A. Notice sur la développement du sac embryonnaire dans quelques Angiospermes. Archives Néerlandaises 15: Oct. 1880.

11. GuigraRd, L. Recherches d'embryogénie végétale comparée. I. Légumineuses. Ann. Sci. Nat. Bot. VI. 12: 5-166. pls. 1-8. 1881.

12. — Recherches sur le sac embryonnaire des Phanérogames Angiospermes. Ann. Sci. Nat. Bot. VI. 13: 136-199. pls. 3-7. 1882.

13. Trecb, M. Observations sur les Loranthacées. Ann. Sci. Nat. Bot. VI. 13: 250-282. pls. 13-20. 1882; reprinted in Ann. Jard. Bot. Buitenzorg 3: 1-12. pls. 1-2. 1883 and 2: 54-76. pls. $8-15.1885$.

14. - Notes sur l'embryon, le sac embryonnaire, et l'ovule. I and II. Ann. Jard. Bot. Buitenzorg 3: 76-87. pls. 13-15. 1883.

15. - - Observations sur les Loranthacées. IV. Ann. Jard. Bot. Buitenzorg 3: 184-190. pls. 28-29. 1883.

16. Guignard, L. Structure et division du noyau cellulaire. Ann. Sci. Nat. Bot. VI. 17: 5-59. pls. 1-5. 1884. 
17. Guigrard, L. Observations sur les Santalacées. Ann. Sci. Nat. Bot. VII. 2: 181-202. pls. 12-14. 1885.

18. BARNes, C. R. The Process of Fertilization in Campanula americana. Bot. Gazette 10: 349-354. pl. 10. 1885.

19. Косн, L. Entwicklungsgeschichte der Orobanchen, pp. 389. pls. 12. Heidelberg. 188\%.

20. Strasburger, E. Ueber Kerntheilung und Zelltheilung im Pflanzenreich. Hist. Beitr. I. Jena. 1888.

21. Oliver, F. W. On the Structure, Development, and Affinities of Trapella, a New Genus of Pedalineae. Annals of Botany 2: 75-115. pls. 5-9. 1888.

22. Johrsox, T. The Nursing of the Embryo and some other Points in Myzodendron punctulatum Banks et Sol. Annals of Botany 3: 179-206. pls. 13-14. 1889.

23. Westervaier, M. Zur Embryologie der Phanerogamen, insbesondere ïber die sogenannten Antipoden. Nova Acta Leopoldina 57: 1890.

24. Oliver, F. W. On Sarcodes sanguinea. Annals of Botany 4: 303-326. pls. 17-21. 1890.

25. Treub, M. Sur les Casuarinées et leur place dans le système naturel. Ann. Jard. Bot. Buitenzorg 10: 145-231. pls. 12-32. 1891.

26. Guigrard, L. Nouvelles études sur la fécondation. Ann. Sci. Nat. Bot. VII. 14: 163-296. pls. 9-18. 1891.

27. Mottier, D. M. On the Development of the Embryo-sac of Arisaema triphyllum. Bot. Gazette 17: 258-260. pl. 18. 1892.

28. Overtos, E. Ueber die Reduktion der Chromosomen in den Kernen der Pflanzen. Vierteljahrssch. Naturf. Gesell. Zürich 38: 1893.

29. Mottikr, D. M. On the Embryo-sac and Embryo of Senecio aureus L. Bot. Gazette 18: 245-253. pls. 2\%-29. 1893.

30. Strasburger, E. The Periodic Reduction of Chromosomes in Living Organisms. Annals of Botany 8: 281-316. 1894.

31. Bexson, Margaret. Contributions to the Embryology of the Amentiferae. I. Trans. Linn. Soc. Bot. London 3: 409-424. pls. 6\%-7. 1894.

32. TrevB, M. L'organe femelle et l'apogamie du Balanophora elongata. Ann. Jard. Bot. Buitenzorg 15: 1-22. pls. 1-8. 1898.

33. D'Hubert, E. Recherches sur le sac embryonnaire des plantes grasses. Ann. Sci. Nat. Bot. VIII. 2: 37-128. pls. 1-3. figs. 66. 1896.

34. Mottier, D. M. Beiträge zur Kenntniss der Kerntheilung in den Pollenmutterzellen einiger Monokotylen und Dikotylen. Jahrb. Wiss. Bot. 30: 169-204. pls. 3-5. 1895.

35. Chamberlais, C. J. The Embryo-sac of Aster novae-angliae. Bot. Gazette 20: 205-212. pls. 15-16. 1895. 
36. Mottier, D. M. Contributions to the Embryology of the Ranunculaceae. Bot. Gazette 20: 241-248, 296-304. pls. 17-20. 1895.

37. Andrews, F. M. Development of the Embryo-sac of Jeffersonia diphylla. Bot. Gazette 20: 423-424. pl. $\approx 8.1895$.

38. Nawaschis, s. Ein neues Beispiel der Chalazogamie. Bot. Centralbl. 63: 353-35\%. 1895 .

39. Westermaier, M. Zur Physiologie und Morphologie der Angiospermen-Samenknospen. Beitr. Wiss. Bot. 1: 2. 1896.

40. Humphrey, J. E. The Development of the Seed in Scitamineae. Annals of Botany 10: 1-40. pls. 1-4. 1896.

41. Sargant, Ethel. The Formation of Sexual Nuclei in Lilium Martagon. I. Oogenesis. Aunals of Botany 10: 445-477. pls. 22-23. 1896.

42. Schwere, S. Entwickelungsgeschichte der Frucht von Taraxacum officinale Web. Ein Beitrag zur Embryologie der Compositen. Flora 82: 32-66. pls. 2-5. 1896.

43. Koersicke, M. Untersuchungen über die Entstehung und Entwickelung der Sexualorgane ron Triticum mit besonderer Berücksichtigung der Kerntheilung. Terhandl. Naturhist. Ver. Preussen Rheinl. 53: 149-185. 1896.

44. Schaffier, J. H. The Embryo-sac of Alisma Plantago. Bot. Gazette 21: 123-132. pls. 9-10. 1896.

45. Vax Tiegheu, PH. Sur l'organisation florale des Balanophoracées. Bull. Soc. Bot. France 43: 295-309. 1896.

46. Chamberlain, C. J. Contribution to the Life-History of Salix. Bot. Gazette 23: 147-179. pls. 12-18. 1897.

47. Schaffner, J. H. Contribution to the Life-History of Sagittaria variabilis. Bot. Gazette 23: 252-273. pls. 20-26. 1897.

48. Coulter, J. M., Chamberlain, C. J., Schaffner, J. H. Contribution to the Life-History of Lilium philadelphicum. Bot. Gazette 23: 412-452. pls. 32-39. 1897.

49. Schaffier, J. H. The Development of the Stamens and Carpels of Typha latifolia. Bot. Gazette 24: 93-102. pls. 4-6. 1897.

50. Juel, H. O. Die Kerntheilungen in den Pollenmutterzellen von Hemerocallis fulva und die bei denselben auftretenden Unregelmässigkeiten. Jahrb. Wiss. Bot. 30: 205-226. pls. 6-8. 1897.

51. Collter, J. M. Contribution to the Life-History of Ramunculus. Bot. Gazette 2J: 73-8s. pls. 4-\%. 1s9s.

52. Chamberlais, C. J. Winter Characters of Certain Sporangia. Bot. Gazette 25: 124-128. pl. 11. 1s98.

53. Sirth, R. W. A Contribution to the Life-History of the Pontederiaceae. Bot. Gazette 25: 324-337. pls. 19-20. 1898 .

54. Lyox, Florexce M. A Contribution to the Life-History of Euphorlia corollata. Bot. Gazette 25: 418-426. pls. 2?-24. 1898.

55. Schaffier, J. H. Karyokinesis in the Root Tips of Allium Cepa. Bot. Gazette 26: 225-238. pls. 21-2?. 1898. 
56. Campbell, D. H. The Development of the Flower and Embryo in Lilaea subulata HBK. Annals of Botany 12: 1-28. pls. 1-3. 1898.

57. Juel, H. O. Parthenogenesis bei Antennaria alpina (L.) R. Br. Bot. Centralbl. 74: 369-372. 1898.

58. NêMec, B. Ueber den Pollen der petaloiden Antheren von Hyacinthus orientalis. Bull. Int. Acad. Sci. Bohême. 1898.

59. Guigrard, L. Les centres cinetiques chez les vegetaux. Ann. Sci. Nat. Bot. VIII. 6: 177-220. pls. 8-10. 1898.

60. Osterwalder, A. Beiträge zur Embryologie von Aconitum Napellus L. Flora 85: 251-292. pls. 11-15. 1898.

61. Goldflus, Mlle. M. Sur la structure et les fonctions de l'assise épithéliale et des antipodes chez les Composées. Jour. Botanique 12: 374-384. pls. 1-6. 1898; 13: 87-96. 1899.

62. Caldwell, O. W. On the Life-History of Lemna minor. Bot. Gazette 27: 37-66. figs. 59. 1899.

63. Canpbell, D. H. Notes on the Structure of the Embryo-sac in Sparganium and Lysichiton. Bot. Gazette 27:153-166. pl. 1. 189.9.

64. Athinson, G. F. Studies on Reduction in Plants. Bot. Gazette 28: 1-26. pls. 1-6. 1899.

65. Flllyer, E. L. The Development of the Microsporangia and Microspores of Hemerocallis fulva. Bot. Gazette 28: 81-88. pls. 7-8, 1899 .

66. WiEgand, K. M. The Development of the Microsporangium and Microspores in Convallaria and Potamogeton. Bot. Gazette 28: 328-359. pls. 24-25. 1899.

67. Lloyd, F. E. The Comparative Embryology of the Rubiaceae. Bull. Torr. Bot. Club 28: 1-25. pls. 1-3. 1899.

68. Balicka-Iwanowska, G. P. Contribution à létude du sac embryonnaire chez certaines Gamopetales. Flora 86: 47-71. pls. 3-10. 1899.

69. Lotsy, J. P. Balanophora globosa Jungh. Eine wenigstens örtlich-verwittwete Pflanze. Ann. Jard. Bot. Buitenzorg II. 1: 174-186. pls. 26-99. 1899.

70. Campbell, D. H. Die Entwicklung des Embryosackes von Peperomia pellucida Kunth. Ber. Deutsch. Bot. Gesell. 17: 452-456. pl.31. 1899: also, A Peculiar Embryo-sac in Peperomia pellucicla. Annals of Botany 13: 626. 1899.

71. GuigraRD, L. Le développement du pollen et la reduction dans le Naias major. Arch. Anat. Micr. 2: 455-509. 1899.

72. Strasburger, E. Ueber Reduktionstheilung, Spindelbildung, und Cilienbildner im Pflanzenreich. Hist. Beitr. VI. Jena, 1900.

73. Goebel, C. Organography of Plants. Translated by I. B. Balfour. Oxford. 1900. 
74. JUEL, H. O. Vergleichende Untersuchungen über typische und parthenogenetische Fortpflanzung bei der Gattung Antennaria. Handl. Svensk. Vetensk. Akad. 33: no. 5. pp. 59. pls. 6. figs. 5. 1900; review in Bot. Zeit. 59: 131. 1901.

75. Campbell, D. H. Studies on Araceae. Annals of Botany 14: 1-25. pls. 1-3. 1900.

76. Hill, T. G. The Structure and Development of Triglochin maritimum L. Annals of Botany 14: 83-107. pls. 6-7. 1900.

77. Merrell, W. D. A Contribution to the Life-History of Silphium. Bot. Gazette 29: 99-133. pls. 3-10. 1900.

78. Conrad, A. H. A Contribution to the Life-History of Quercus. Bot. Gazette 29: 408-418. pls. 28-29. 1900.

79. Johnson, D. S. On the Endosperm and Embryo of Peperomia pellucida. Bot. Gazette 30: 1-11. pl. 1. 1900.

80. WiEgand, K. M. The Development of the Embryo-sac in some Monocotyledonous Plants. Bot. Gazette 30: 25-47. pls. 6-7. 1900.

81. LAND, W. J. G. Double Fertilization in Compositae. Bot. Gazette 30: 252-260. pls. 15-16. 1900.

82. Lotsy, J. P. Rhopalocnemis phalloides Jungh., a Morphologicalsystematical Study. Ann. Jard. Bot. Buitenzorg II. 2: 73-101. pls. 3-14. 1900.

83. Chodat, R., and Bernard, C. Sur le sac embryonnaire de l'Helosis guayanensis. Jour. Botanique 14: 72-79. pls. 1-2. 1900.

84. Bernard, C. H. Recherches sur les sphères attractives chez Lilium candidum, etc. Jour. Botanique 14: 118-124, 177-188, 206-212. pls. 4-5. 1900.

85. Burss, G. P. Beiträge zur Kenntniss der Stylidiaceen. Flora 87: 313-354. pls. 13-14. 1900.

86. Canson, W. A. A Morphological Study of the Flower and Embryo of the Wiid Oat, Avena fatua. Proc. Calif. Acad. Sei. III. 1: 329-364. pls. 49-53. 1900.

87. Johnson, D. S. On the Development of Saururus cernuus L. Bull. Torr. Bot. Club. 27: 365-372. pl. 23. 1900.

88. JuEL, H. O. Beiträge zur Kenntniss der Tetradenbildung. Jahrb. Wiss. Bot. 35: 626-659. pls. 15-16. 1900.

89. Dunn, Louise B. Morphology of the Development of the Ovule in Delphinium exaltatum. Proc. Amer. Assn. Adv. Sci. 49: 284. 1900.

$89 a$. Guignard, L. L'appareil sexuel et la double fécondation dans les Tulipes. Ann. Sci. Nat. Bot. VII. 11: 365-387. pls. 9-11. 1900.

90. —. La double fécondation dans le mais. Jour. Botanique 15: $37-50.1901$.

91. LANG, F. X. Untersuchungen über Morphologie, Anatomie, und Samenentwicklung von Polypompholyx und Byblis gigantea. Flora 88: 149-206. pl. 12. figs. 80. 1901. 
92. Rosexberg, O. Ueber die Embryologie von Zostera marina. Bil. Handl. Srensk. Vetensk. Akad. 273: no. 6. pp. 26. pls. 2. 1901.

93. —_ Ueber die Pollenbildung von Zostera. Meddel. Stockholms Högsk. Bot. Inst. pp. 21. 1901.

94. Murbeck, S. Parthenogenetische Embryobildung in der Gattung Alchemilla. Lunds Univ. Arsskrift 36?: no. 7, pp. 46. pls. 6. 1901.

95. Schriewixd-Thies, J. Die Reduktion der Chromosomenzahl und die ihr folgenden Kerntheilungen in den Embryosackmutterzellen der Angiospermen. Jena. 1901.

96. Strasblrger, E. Einige Bemerkungen zu der Pollenbildung bei Asclepias. Ber. Deutsch. Bot. Gesell. 19: 450-461. pl. 24. 1901.

97. Holferty, G. M. Ovule and Embryo of Potamogeton natans. Bot. Gazette 31: 339-:16. pls. 2-3. 1901.

98. Schaffrer, J. H. A Contribution to the Life-History and Cytology of Erythronium. Bot. Gazette 31: 369-38\%. pls. 4-?. 1901.

99. Frre, T. C. Derelopment of the Pollen in some Asclepiadaceae. Bot. Gazette 32: 325-331. pl. 13. 1901.

100. Billixgs, F. H. Beiträge zur Kenntniss der Samenentwicklung. Flora 88: 253-318, 1901.

101. Atkisson, G. F. On the Homologies and Probable Origin of the Embryo-sac. Science 13: 530-538. 1901.

102. Syith, Ayelia C. The Structure and Parasitism of Aphyllon uniflorum Gray. Contrib. Bot. Lab. Univ. Penn. 2: 111-121. pls. 13-15. 1901 .

103. Schisga, H. Beiträge zur Kenntniss der Gattung Gunnera. Flora 90: 161-208, figs. 28, 1902.

104. Olver, F. W. On a Vascular Sporangium from the Stephanian of Grand Croix. New Phytologist 1: 60-6r. pl. 1. 1902.

105. Lloyd, F. E. The Comparative Embryology of the Rubiaceae. Mem. Torr. Bot. Club 8: 27-112. pls. 8-15. 1902.

106. InEDA, T. Studies in the Physiological Functions of Antipodals and Related Phenomena of Fertilization in Liliaceae. 1. Tricyrtis hirta. Bull. Coll. Agric. Imp. Univ. Tokyo 5: 41-7\%. pls. 3-6. 1902.

107. Grigrard, L. La double fécondation chez les Solanées. Jour. Botanique 16: 145-167. figs. 45. 1902.

108. Strasberger, E. Ein Beitrag zur Kenntniss von Ceratophyllum submersum und phylogenetische Erörterungen. Jahrb. Wiss. Bot. 37: 477-526. pls. 9-11. 1902.

109. HaLl. J. G. An Embryological Study of Limnocharis emarginata. Bot. Gazette 33: 214-219. pl. 9. 1902.

110. Orertox, J. B. Parthenogenesis in Thalictrum purpurascens. Bot. Gazette $33: 363-3 \% 5 ., 1 / s .12-13.1902$. 
111. Wевв. J. E. A Morphological Study of the Flower and Embryo of Spiraea. Bot. Gazette 33: 451-460. figs. 28. 1902. For correction of names see REHDER in Bot. Gazette 34: 246. 1902.

112. Ducanp, L. Recherches sur l'embryogénie des Araliacées. Ann. Sci. Nat. Bot. VIII. 15: 311-402. pls. 6-13. 1902.

113. Murbeck, S. Ueber Anomalien im Baue des Nucellus und des Embryosackes bei parthenogenetischen Arten der Gattung Alchemilla. Lunds Univ. Arsskrift 38*: no. 2. pp. 10. pl. 1. 190\%.

114. Johnson, D. S. On the Development of Certain Piperaceae. Bot. Gazette 34: 321-340. pls. 9-10. 1902.

115. Karstex, G. Ueber die Entwicklung der weiblichen Blüthen bei einigen Juglandaceen. Flora 90: 316-333. pl. 12. 190:.

116. Errst, A. Chromosomenreduction, Entwicklung des Embryosackes und Befruchtung bei Paris quadrifolia L. und Trillium grandiflorum Salisb. Flora 91: 1-46. pls. 1-6. 1902.

117. Endriss, W. Monographie von Pilostyles ingae (Karst.) (Pilostyles Uiei Solms-Laub.). Flora 91: 209-236. pl. 20. figs. 29. 1902.

118. Frye, T. C. A Morphological Study of Certain Asclepiadaceae. Bot. Gazette 34: 389-413. pls. 13-15. 1902.

119. - - The Embryo-sac of Casuarina stricta. To be published in Bot. Gazette 35: 1903.

120. Ferraris, T. Ricerche embriologiche sulle Iridaceae. I. Embriologia del G. Romulea Maratti. Ann. R. Istit. Bot. Roma 9: 221-241. pls. 6-\%. 1902.

121. Juel, H. O. Zur Entwicklungsgeschichte des Samens von Cynomorium. Beih. Bot. Centralbl. 13: 194-202. figs. 5. 1902.

122. Shibata, K. Experimentelle Studien über die Entwickelung des Endosperms bei Monotropa. (Vorläufige Mitteilung.) Biol. Centralbl. 22: 705-714. 1902. 


\section{CHAPTER VI}

\section{THE MALE GAMETOPHYTE}

THE reduced number of chromosomes appears at the first mitosis in the pollen mother-cell, which is therefore the first gametophytic cell (Fig. 53). In every case, so far as known, two divisions oceur in rapid succession, giving rise to four microspores. Strasburger ${ }^{8}$ lras called attention to the two modes of division. In one case, most frequent among Monocotyledons, a wall follows the first nuclear division, dividing the mother-cell into two hemispherical cells; the second nuclear division is also followed immediately by the formation of a wall, making two equal cells from each of the hemispheres (Fig. $54)$. In the other case, more characteristic of the Dicotyledons, the two nuclear divisions occur before any walls are formed, all the walls being then formed simultaneously and in such a way that each of the four cells has the form of a triangular prramid with a spherical base - that is, each cell is the quadrant of a sphere (Figs. 55, 56). The former method has been called successive, the latter simultaneous division. The two modes are not sharply characteristic of the two great groups of Angiosperms, but the successive method is dominant among Monocotyledons and the simultaneous among Dicotyledons. In any erent the result is a tetrad, a group of four cells each of which $i=$ a microspore. In successive division there is a bilateral arrangement of the microspores, and in simultaneous division the arrangement is tetrahedral; but both arrangements sometimes oceur in the same sporangium.

The arrangement of the tetrad is not always restricted to these two methods (Fig. 55). Wille ${ }^{15}$ has described varying arrangements of microspores in the tetrads of species of Juncus and Orchis mascula; and in Typha Schaffner ${ }^{34}$ not only found 
the tetrads indiscriminately tetrahedral or bilateral, but frequently the four spores are in a row. A tetrad consisting of four spores in a row has also been found by Strasburger ${ }^{54}$ and
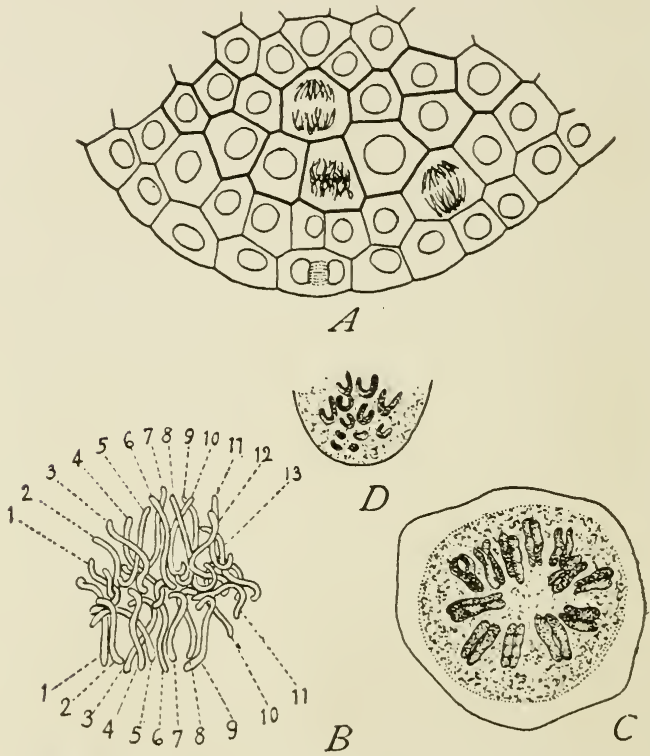

Fiя. 53.-Litium Ifartagon. A, transverse section of young microsporangium, showing two nuclear mitotic figures in sporogenous cells and one in a hypodermal cell; such figures show 24 ehromosomes, the sporophyte number; $\times 200$. B. chromosomes of a mitotic figure in the wall of a mierosporangium, showing 24 ehromosomes; $\times 601$. $C$, pollen mother-cell : polar view of the first mitosis, showing 12 chromosomes, the gametophyte number, in the suclear plate; the sesments are double, one-half of each segment will pass to each pole $\times \quad 625$. $D$, later stage in first mitosis showing 12 chromosomes, each chromosome representing oue-halt of one of the 12 segments shown in $C ; \times 625$.-After Gilgxard.19

by Frye ${ }^{56}$ to occur regularly in Asclepias and allied genera; by Rosenberg ${ }^{57}$ in Zostera; and Teottia nidus-aris is cited by Goebel ${ }^{16}$ (p. 36s).

It has been claimed that in Zostera. Crperaceae, Clematis, Hetianthemum. Epitobium, Asclepias, and Lappa, only one microspore is formed by a mother-cell. In every case except 
Zostera, Crperaceae, and Asclepias the claim was disproved long ago; and eren these hare now been cleared up, so that no case is known in which a pollen mother-cell becomes a microspore directly without the tetrad divisions. It does not seem improbable that such a case may exist, for cases of oogenesis

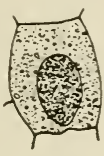

A

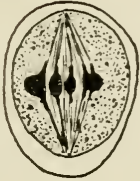

$D$

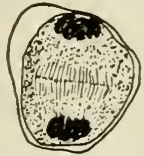

G

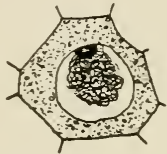

B

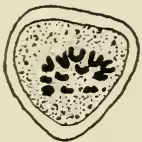

$E$

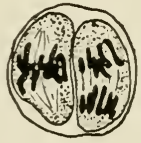

H

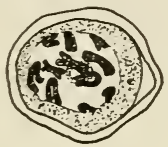

C
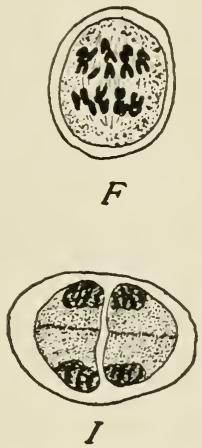

Fia. 54,-Fritillaria persica. Sections showing the two nuclear divisions by which four microspores are formed in the mother-cell by the successive (bilateral) method; $\times 530$. $A$, very young mother-cell ; $B$. nucleus in synapsis; $C, 12$ chromosomes, one of them rather indistinct. within the nucleus; $D$, mitotic figure of the first division showing the short, thick chromosomes characteristic of the reduction division; $E$, later stage of first division, showing vertical view of the 12 chromosomes; $F$, side view of same stage showing 12 chromosomes passing to the upper pole, only 10 for the lower pole being in sight; $G$, formation of wall between daughter nuelei; $I$, second division; $I$, formation of walls.-After STRAsBtrger.10

like that of Lilium are not rare, where the mother-cell gives rise directly to a single megaspore. As stated, in $1886 \mathrm{Wille}^{\mathbf{1 5}}$ found no tetrad in Asclepias syriaca; and in 1892 Chauveaud ${ }^{20}$ observed the reduction division of the pollen mother- 
cells of Cynanchum, but seems not to have noted the formation of a tetrad; but the tetrad, consisting of a row of four microspores, and referred to above as discovered by Strasburger and by Frye in 1901 in a number of species of Asclepias and in Cynanchum, was so unusual as to disguise its tetrad nature, and
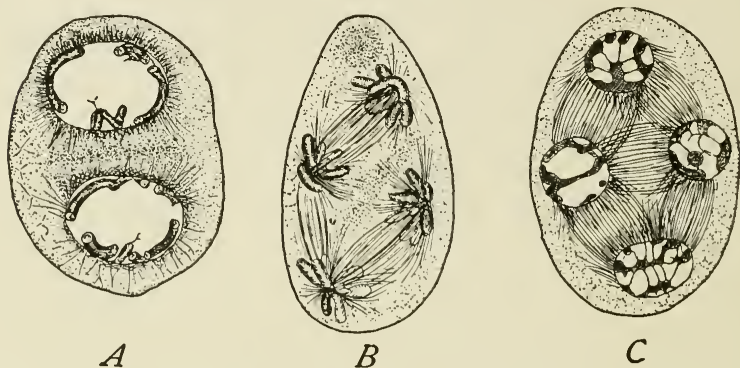

Fig. 55.-Podophyllum peltatum. Mitosis in pollen mother-cell. $A$, telophase of first division; $B$, late anaphase of second division; $C$, telophase of second division; the nuclei of the four nicrospores are formed, but the cell walls, as is characteristic of simultaneous division, have not yet appeared.-Atter Motrier. ${ }^{26}$

besides, the enlargement and consequent readjustment of the spores soon break up the row (Fig. 5s). The first record of the ocenrrence of a tetrad in Asclepias seems to have been made by Stevens ${ }^{41}$ in 1898; and the fourth independent discovery of it was by Gager ${ }^{58}$ in 1902 . Elving, ${ }^{7}$ Wrille, $^{15}$ and Strasburger $^{12}$ showed that in various species of the Crperaceae a tetrad is formed althongh only one microspore becomes functional, the other soon disorganizing. Juel ${ }^{50}$ has recently made a thorough study of Carex acuta (Fig. 59). He finds that the two characteristie nnclear clivisions take place, and that a cell-plate is formed at each division. The cell-plates are soon resorbed, howerer, so that the four nuclei lie free within the wall of the mother-cell. Three of the nuclei then disintegrate, while the fourth beeomes the nucleus of the single functional microspore; and the wall of the mother-cell, inclosing the four nuclei, becomes the wall of the microspore. In Zostera marina Rosenberg ${ }^{5 i}$ has described the tetrad division of the remarkably elongated mother-cell (Fig. 11). The divisions are longitudinal and in parallel plames, resulting in four remarkable filiform 
microspores lying side by side, and measuring 3 by $2,000 \mu$ when mature. That this is a tetrad is evident from the rapid succession of the divisions, the reduction of chromosomes, and the formation of four spores from a mother-cell.

In some cases a mother-cell may give rise to less than four microspores, or may produce more than the normal number (Fig. 60). In 1ss6 Wille $^{15}$ summarized the work of previous investigators, notably of Hofmeister, Tangl, Wimmel, and Tschistiakoff, and added the results of his own investigations. The following lists are made up largely of forms investigated by Wille himself:

Two microspores from a mother-cell are occasionally found in Convallaria multiflore, Asparagus officinalis, 1 conitum Napellus, Euphorbia Lathyrus, Begonia sp., Saxifraga caespitosa, Azalea indica, and Syringa vulgaris.

Three microspores were found in Begonia sp., Saxifraga caespitosa, dzalea indica, and Lonicera coerulea.

Five microspores were found in Funlia ovata, $F i$ caria ranunculoides, Stellaria glauca, sicleranthus anmus, Prumus Cerasus, Rumex Patientia, Azalea indica, Lonicera coerulea, Syringa persica, and Symphytum officinale.

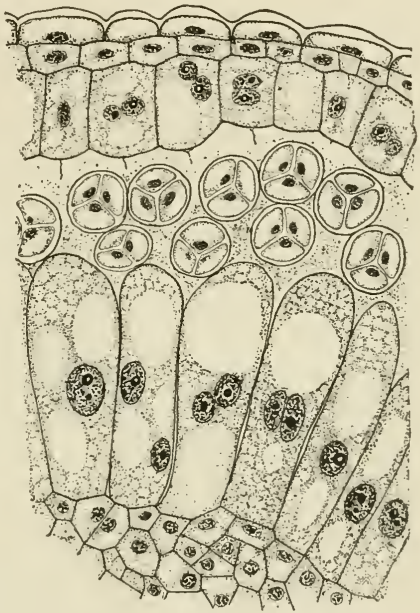

F16. 56.-Sicrophularia nodosa. Section of microsporangium showing appearance of spores formed by the simultaneous method; the inner tapetum of microsporangium consists of greatly elongated cells which are very glandular in appearance. $\times 275$.

Six microspores were found in Hemerocallis fulva, Ficaria ranunculoides, Elatine hexandra, Cornus sanguinea, Lonicera coerulea, and Fuchsia sp.

Seren microspores were counted with certainty in Fuchsia sp. and fourteen are reported rather doubtfully: eight is given for Azalea indica, and eight to twelve for Lonicera coerulea, 
but it was not absolutely certain that in case of the higher numbers all the microspores came from the same mother-cell. In Hemerocallis fulva Strasburger ${ }^{10}$ has counted nine microspores from a single mother-cell; and later Juel ${ }^{33}$ and Fullmer ${ }^{44}$ reported six to eight in the same species. More recently Miss Lron ${ }^{40}$ has found fire or six microspores of equal size produced by a single mother-cell of Euphorbia corollata.

According to Wille, two microspores result from a failure of the mother-cell to undergo the second division. When three are formed, the first dirision is unequal, and only the larger
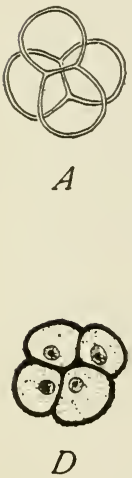

Fio. 57.-Variation in the arrangement of the spores of a tetrad. A-C, Orchis mascula, $\times 380$; after Wille.15 D-E, Typha latifolia, $\times 400$; after SCHAFFNER. ${ }^{34}$
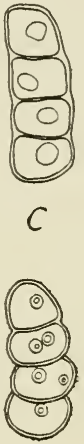

E cell divides. Five or more microspores are formed by subsequent division of one or more members of the tetrad.

Strasburger, ${ }^{10}$ Juel, ${ }^{33}$ and Fullmer, ${ }^{44}$ in their study of Hemerocallis fulva found an explanation of the irregular numbers. Strasburger found that chromosomes which fail to pass to either pole at the first mitosis give rise to small microspores. Juel in his more recent study confirms Strasburger, and finds that even single ehromosomes which become separated may divide and give rise to nuclei and organize cells. Fullmer attributes the supernumerary microspores to the division of one or more members of the tetrad.

Perhaps no phase of plant cytology has received so much attention as the nuclear divisions in the pollen mother-cell. It is an interesting fact that the eytological characters of these two mitoses agree minutely with those in the megaspore mothercell. The pollen mother-cell can be positively identified by the appearance of the synapsis stage (Fig. 54. B), even before any rounding off or separation takes place. While set in the spirem 

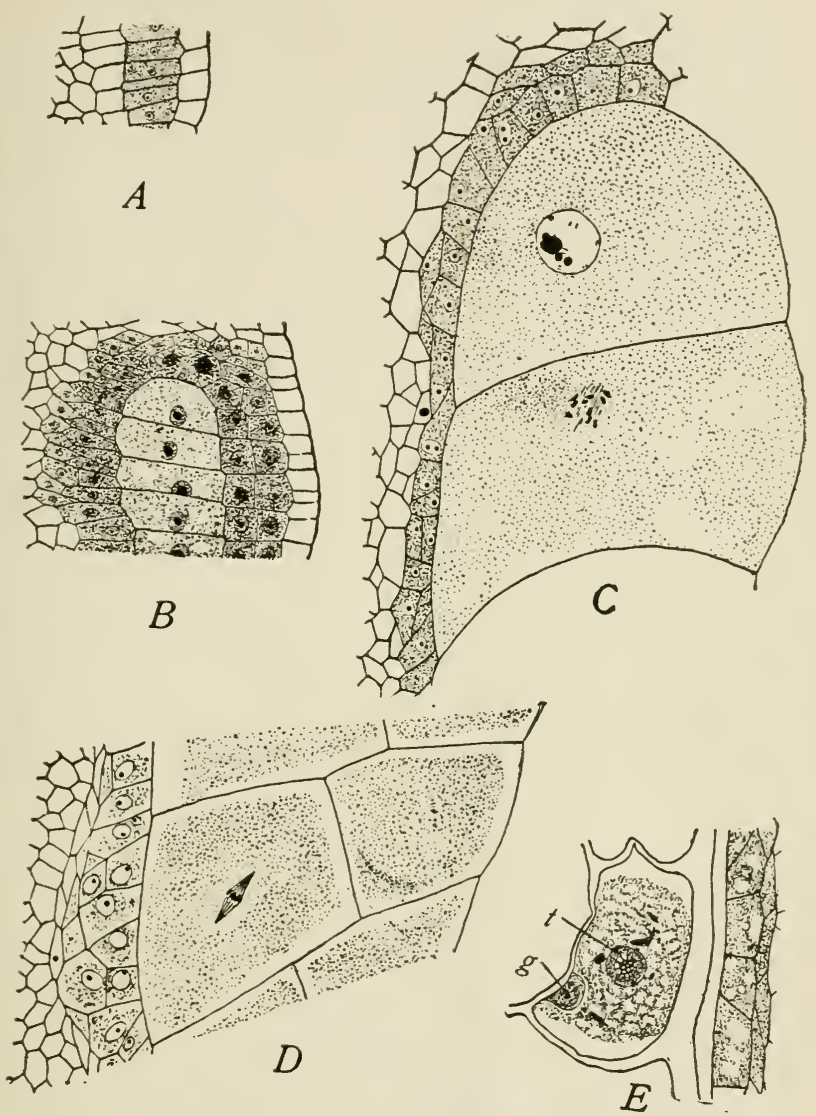

Fro. 58.-Development of male gametophyte in Asclepias. A-B, A. Cornuti; $C-E ; A$. tuberosa. $A$, section of young microsporangium showing archesporial cells: $B$. portion of the single layer of elongated mother-cells; $C$, later stage showing two mother-cells, the lower one dividing and showing 10 chromosomes, the gametophyte number: $D$, second division of mother-cell, by which the row of four microspores is formed: $E$, microspore showing tuhe nucleus $(t)$ and generative nucleus $(g) . A$, $\times 200 ; B-E, \times 800$, -After FRYE. ${ }^{*}$ 
stage the chromatin thread splits longitudinally throughout its entire length (Fig. 61, 1, B). The double thread then segments transversely into the number of chromosomes characteris-


C
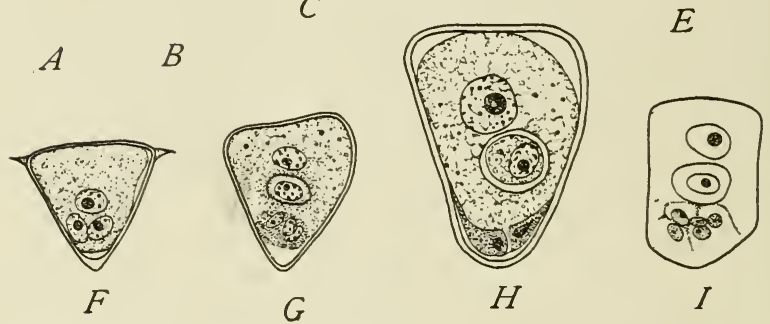

Fic. 59.-Development of mierospores in Heleocharis palustris and Carex acuta. $A-B$, Heleocharis, showing the single funetional microspore and three disorganizing microspores. $\times 399$; after Strasbtrakr. ${ }^{2} C-I$, Carex: C; mother-cell; $D$, second division; $F$, four nuelei, only three of which are shown within the mother-eell $E$ and $F$ should be reversed); $E$, later stage than $F$; the nuclens of the functional microspores is preparing for division; $G$, tube nueleus, generative cell, and lower down the nueles of the three non-functional microspores: $H$, nearly ripe pollen grain; $I$, irregular ease in which the nuclei of the three non-functional microspores have divided ; $\times 900$. - After J I'EL. $^{50}$

tic of the gametophyte of a given species, each chromosome thus being made up of two pieces (Fig. 5., C). According to sereral investigators, a second longitudinal splitting of the chromosomes may be seen during the anaphase of the first mitosis, so that the two mitoses merely distribute the rednced number of chromosomes which appear just after the segmentation of the spirem. In the subsequent mitoses the spirem segments into chromosomes which afterward split longitutinally as in regetative cells.

It is in the divisions of the pollen mother-cell that the problem of the reduction of chromosomes has been studied most thoroughly: but while it is asreed that the redueed number appears at the first mitosis, there is still some difference of 
opinion as to whether a qualitative division occurs. At present the weight of eridence is against such a division.

According to nearly all recent observers (Belajeff, ${ }^{24}$ Strasburger, ${ }^{25}$ Mottier, ${ }^{26}$ Lawson, ${ }^{35}$ Miss Byxbee ${ }^{52}$ ) the spindle in the first mitosis originates as a multipolar structure, which
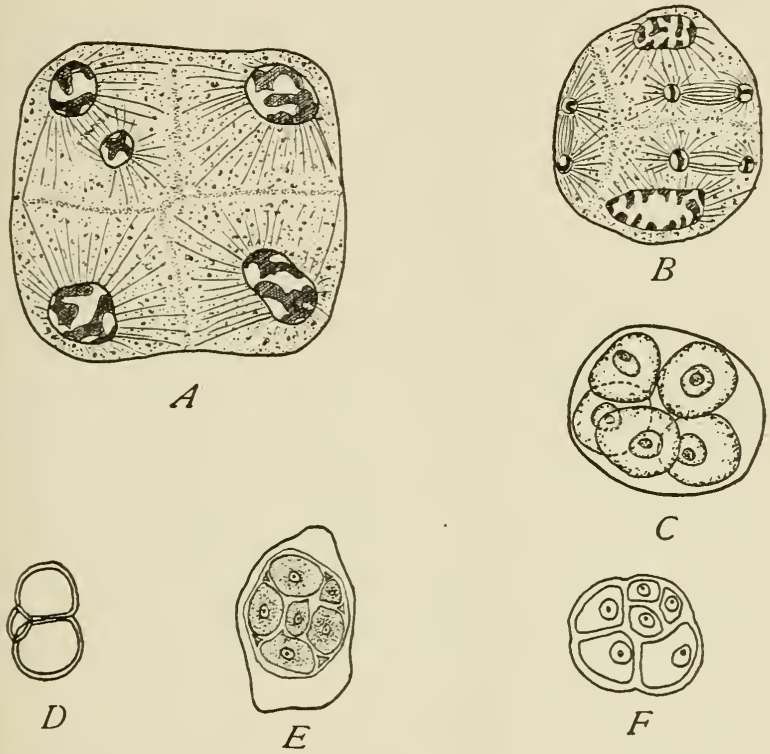

FIG. 60.-Microspore mother-cells producing more or less than four microspores. $A-B$, Hemerocallis fulva, with tive and eight microspores in process of tormation, $A \times 1000 ; B \times 625$; after JeEL. ${ }^{38} \quad C$, Euphorbia corollata, with five microspores of equal size within mother-celk; $\times 625$; after Lros.40 D, Begonia sp., with three microspores from a mother-cell; $\times 400$. E, Ficaria ranunculoides, with six microspores, $\times 400 . F$, Azalea indica, with six unicrospores, three having couse from the division of one of the spores of the tetrad, $\times 400$. D-E, after W ILLE.15

gradually becomes bipolar (Figs. 61, 61a). In a few cases multipolar spindles have been described for the second mitosis. In regetative cells the spindle first appears as a pair of domesliaped prominences or caps. Transitions between the two moles are not lacking. 
The number of chromosomes obserred in connection with the reduction division have been noted in the preceding chapter (p. s1).
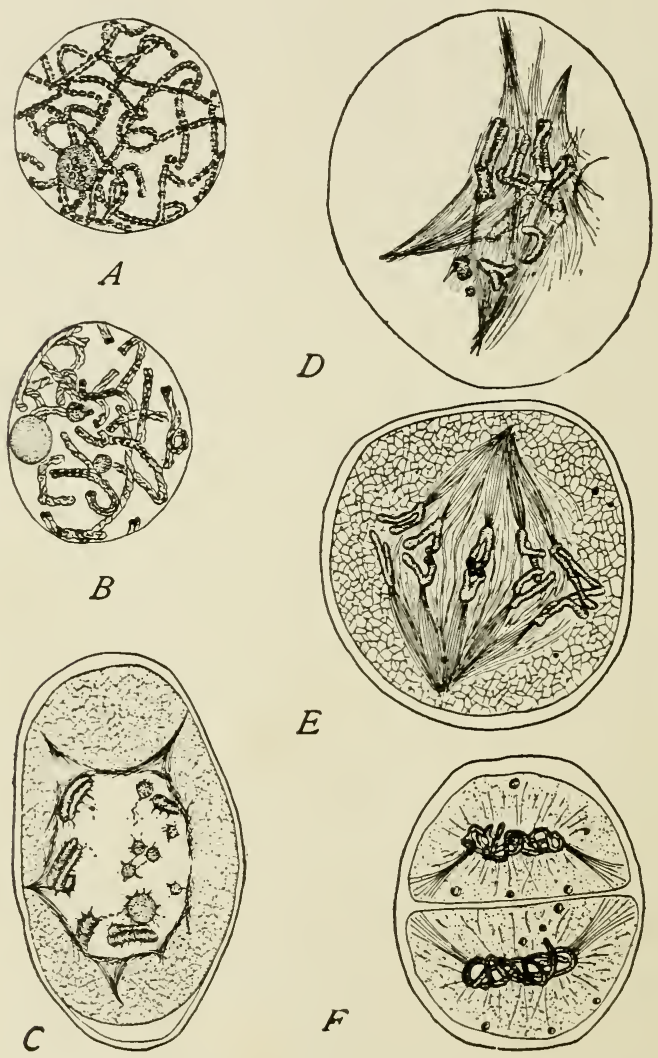

F16. 61.-First division of pollen mother-cell, showing formation of the bipolar from the multipolar spindle A, B. E, F, Lilium Martagon: C-I, L. candidum. A, double row of chromatin granules upon the linin thread; $B$. later stage in which the entire thread has split longitudinally; $C$, formation of a weft of fibers about the nueleus; $D$, multipolar spindle: $E$, bipolar spindle; $F$, telophase of first division showing that the division is of the successive type.-After Motrikr. 20 
After the two divisions, each of the four young microspores becomes invested by a delicate wall which is independent of the common wall of the mother-cell. This wall soon becomes differentiated into two layers, the inner one (intine) consisting of pure cellulose and later dereloping the pollen-tube.

The outer layer (exine) is cutinized, and especially among Dicotyledons becomes rariously sculptured, often being covered with ridges, warts, spines, etc., as fully described by Schacht ${ }^{2}$ and Luersen. ${ }^{5}$ For the most part, there are thin spots in the exine for the exit of pollen-tubes. It is interesting to note that only a single point of exit occurs in the microspores of most Monocotyledons and of a fer Iicotyledons; while in most Dicotyledons there are from two to many such points of exit. Goebel ${ }^{16}$ (p. $36 \tau$ ) has given the following illustrations from Schacht ${ }^{2}$ : two points of exit in Ficus, Justicia, etc.; three in Cupuliferae, Proteaceae, Geraniaceae, Onagraceae, Poraginaceae, and Compositae; four to six in Almus, C'arpinus, Astrapaea, and Impaticns; many in Alsineae, Malvaceae, Convolvulaceae, etc. Barnes ${ }^{13}$ records three to twelve thin spots in the exine of Campanula, and Coulter ${ }^{37}$ finds fifteen to thirty such areas in that of Ranunculus. In certain cases a much more specialized metliod for the exit of the pollen-tube is

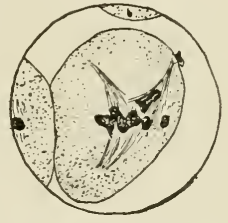

Fig. 61a.-Lilium candidum. Multipolar spindle at first division of pollen mother-cell; $\times 400 .,-$ After BeLAJEFF, ${ }^{24}$ providerl, as among the Cucurbitaceae and in Passiflora, in which romdish, lid-like, and often embossed pieces of the exine become detached; and in Thunbergia, in which the laver of exine splits into exfoliating spiral bands. Among those aquatics that pollinate under water, as well as in the pollinia-bearing forms, the exine is said to be lacking. The origin and development of the walls of spores is a problem that needs further investigation.

For the most part, the microspores become entirely free from one another at maturity, forming a pulverulent mass, but there are instances of micrnspores failing to become dissociated, giving rise to the so-called "compound grains" (Figs. 13, 57). In the simplest cases the four spores of a tetrarl cling together, as in Typha, certain orehids (as Neottia), Anona, Fourcroya, 
and Rhododendron; in other cases the whole product of a primary sporogenous cell, ranging from eight to sixty-four 'nicrospores, clings in a mass, as the massulae of certain orchids (Ophrveae) and the groups of pollen-grains found among the Ilimoseae; and in the most extreme cases, the whole product of a sporangium forms a single mass, the pollinium, characteri-tic of certain Orchids and of the Asclepiadaceae. It is of interest to note that all of these conditions occur among Orchiclaceae, from isolated microspores (Cypripedium) to the completely organized pollinium. Such variations and others have becn described in detail by Reichenbach, ${ }^{1}$ Hofmeister, ${ }^{3}$ Rosanoff, ${ }^{4}$ Corry, ${ }^{11}$ and others.

The older botanists were not able to recognize the structures developed within the mature pollen-grain, whose contents they called " forilla," regarding it as a fertilizing substance rich in food material. In 15 - 8 Strasburger ${ }^{6}$ discovered that structures are developed in the microspores of Angiosperms comparable to those already known in Gymnosperms, and this was confirmed by Elfving. ${ }^{7}$

The germination of the microspore begins with the division of its nucleus, and this always oceurs before dehiscence, sometimes long before, the two daughter nuclei having been found eren in midwinter, as in Alnus and Corylus (Chamberlain ${ }^{38}$ ) (Fig. s). When first formed, the daughter nuclei are usually alike in size and form, but in most cases the tube nucleus soon becomes much larger, the differentiation sometimes beginning, as in Cypripedium, before the mitosis is fully completed (Fig. (i2). In any case, the nuclei soon become differentiated, the tube-nucleus having a large nucleolus and a rather scanty chromatin network; while the generative nucleus is smaller, has a smaller nucleolus or none at all, and its chromatin is denser and less irregular. The nuclei also differ in their reaction to stains, a combination like cranin and erythrosin staining the tube-mucleus red and the generative nucleus blue.

At first Strasburger ${ }^{6}$ thought that the tube-nuclens was concerned not merely in developing the pollen-tube, but also in fertilizing the egg, and hence named it the "generative nurleus." The other nucleus, although seen to enter the tube and even divicle, was thought to take no part in the processes connected with fertilization, and was called the "vegetative" or 
"prothallial" muelens. This older view is the one given in Goebel's Outlines of Classification and Special Morphology. In 1sat Strasburger ${ }^{12}$ recognized the real natrire of the two nuclei and interchanged the names, applying them as they have been u-erl erer since. We have substituted the name " tube-nuclens" for " regetative nucleus," not only because the development of the tube is its most conspicuous function, but also because it is

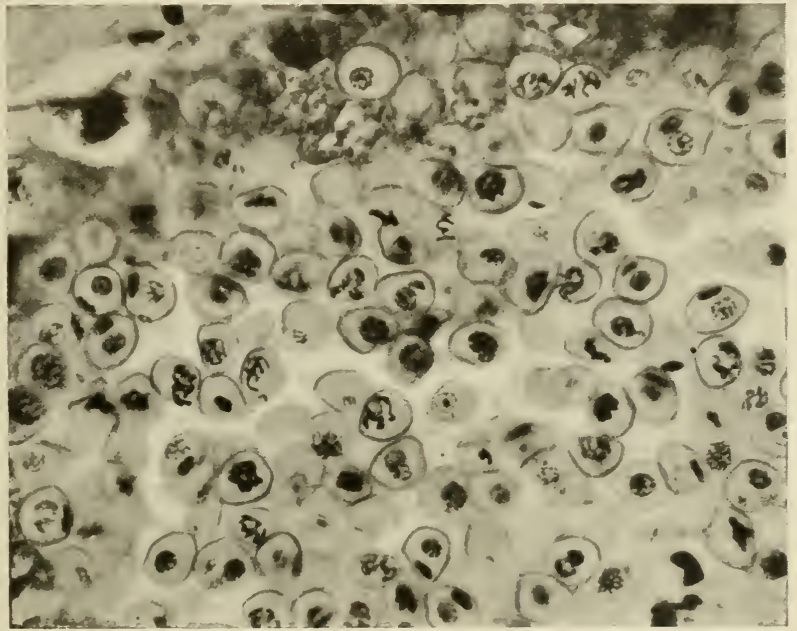

F1G. 62.-Cypripedium spectabile. Section of microsporangium, showing mierospores in various stages of division into tube and generative nuclei; although the divisions are nearly simultaneous throughout the microsporangium, it will be seen that in some cases the nuclei are in the spirem stage, while in others the tube and generative nuclei are easily distinguished; $\times 300$.

not the morphological equivalent of the regetative or prothallial cells of the Gymnosperms and heterosporous Pteridophytes.

A generative cell is formed by the more or less distinct organization of the eytoplasm about the generative nucleus. This cell usually lies free in the borly of the spore, but is often cut off by a distinct wall, as in Typha (Schaffner ${ }^{31}$ ). Sparganium (Campbell ${ }^{43}$ ), Nains (Camphell ${ }^{29}$ ), Convallaria (Wiegand ${ }^{45}$ ), Neottia (Guignard ${ }^{9}$ ), Populus (Chamberlain ${ }^{30}$ ), Asclepias 
(Free ${ }^{56}$ ), and Sarcodes (Oliver ${ }^{18}$ ). Both methods are often found in the same species and even in the same anther, as in Lilium (Fig. 63).

The free generative cell finally assmmes a variety of forms, the most common being lenticular, the cytoplasm massing chiefly
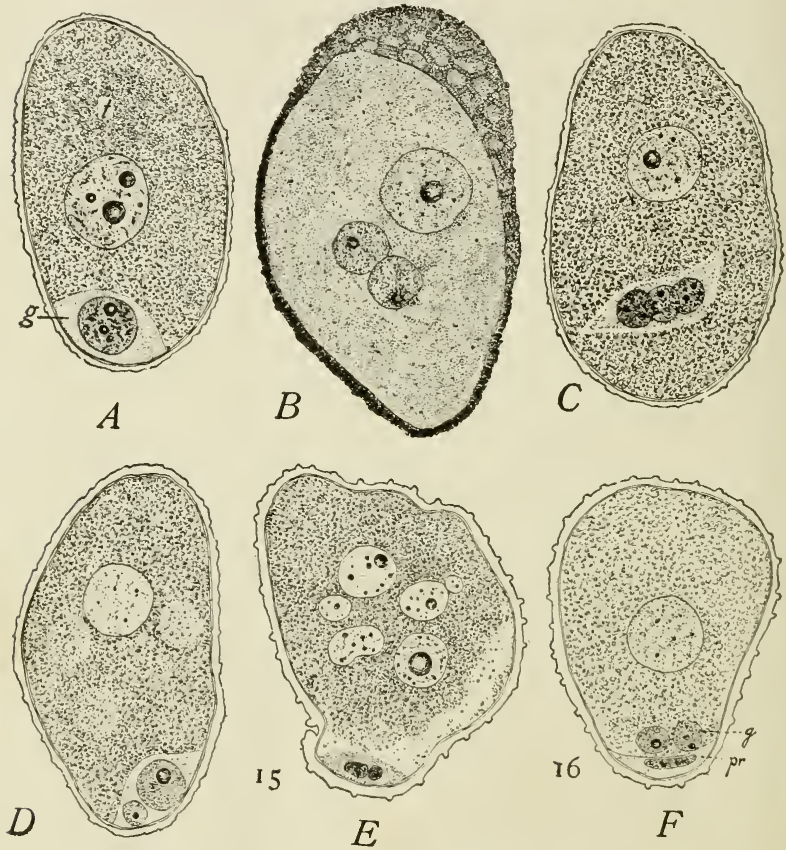

Fro. 63.-Male gametophyte at time of shedding. $B, C$, Lilium auratum; the others

L. tigrinum; $\times 500 . A$, generative cell against side of microspore; $B$, generative cell in body of microspore; the two male nuclei already formed; $C$, three male nuclei within generative cell, an unusual case; $I$, two male nuelei, differing in size, within generative cell; $E$, tubc-nucleus divided, giving rise to six nuclei; $F$. an unusual case, showing tube-nucleus, two generative cells (q), and a "prothallial" cell ( $p r$ i.-. After Chayberlain. ${ }^{32}$

at two opposite poles of the nucleus. In some cases a spherical form is maintained, as in Acer (Mottier ${ }^{22}$ ); in others the lenticular form passes into the rermiform, becoming elongated and 
even coiled or twisted, as in Tradescantia (Coulter and liose ${ }^{14}$ ) ; or the cytoplasm of the spindle-shaped generative cell may taper into elongated whip-like filaments that more or less encircle the tube-nucleus, as in Eichhornia (Smith ${ }^{39}$ ). In Erythronium Schaffner ${ }^{55}$ found that the generative nucleus is larger than the tube nucleus and is surrounded by a densely staining amoeboid-form mass of cytoplasm. It is altogether probable that the size and form of free generative cells varies with age and external conditions, so that they may be relatively large or small; or spherical, lenticular, spindle-shaped, or vermiform in the same species. It is very common to find them at first spherical and later lenticular, as has been frequently observed in Lilium.

In Litium tigrinum Chamberlain ${ }^{32}$ often found a small cell cut off by the microspore before the appearance of the tube and generative nuclei, and the same cell was noted after the division of the generative nucleus (Fig. 63). A similar cell was found by Smith ${ }^{39}$ in Eichhornia crassipes and by Campbell ${ }^{43}$ in Sparganium simplex. It is suggestive of a true vegetative or prothallial cell, two of which so commonly occur among the Grmnosperms; but the phenomenon is too unique as yet among Angiosperms to deserve more than a mention.

The tube-nucleus usually increases much in size, and under certain conditions has been found to fragment, as in Lilium, in which Chamberlain ${ }^{32}$ found four and in one case eight tubenuclei; in Eichhomia, in which Smith ${ }^{39}$ found two tube-nuclei in half the pollen-grains examined; in Hemerocallis, in which Fullmer ${ }^{4 t}$ reports the frequent oceurrence of two to six tubenuclei ; and in Asclepias, in which Frye ${ }^{56}$ observed a fragmenting nucleus. This phenomenon is doubtless not uncommon in certain conditions of nutrition.

The generative nucleus or cell may divide in the pollengrain, even long before dehiscence, as in Sagittaria (Schaffner ${ }^{31}$ ); or the generative cell may pass into the tube before division, sometimes not dividing until immediately before fertilization. The time of this division seems to hold no relation to the great plant groups, and may be rariable in the same genus or eren species. For example, in Lilium tigrimum it often takes place in the grain, but in L. philadelphicum rarely so; and in this last species it may occur either in the grain or at 
any time in the tube up to its completed growth. The variable relation of the time of this division to the great groups may be illustrated by the following record:

Among Nonocotyledons the generative nucleus divides in the pollen-grain in Potamogeton (Wiegand ${ }^{45}$ ), Alisma (Schaff${ }_{n e r}{ }^{28}$ ), Sagittaria (Schaffner ${ }^{31}$ ), Avena (Cannon $\left.{ }^{46}\right)$, Triticum and other grasses (Golinski ${ }^{21}$ ), Lemna (Caldwell ${ }^{42}$ ), and Litium (Chamberlain ${ }^{32}$ ); and in the pollen-tube in Symplocarpus (Duggar ${ }^{47}$ ), Tradescantia (Coulter and Rose ${ }^{14}$ ), Eichhornia (Smith ${ }^{39}$ ), Lilium (Chamberlain ${ }^{32}$ ), Convallaria (Weigand ${ }^{45}$ ), Erythronium (Schaffner ${ }^{55}$ ), and the Orchids (Guignard ${ }^{9}$ ). In examining this record it might be concluded that the early division of the generative cell within the pollengrain is a more primitive character in general than the later division in the pollen-tube. Even if this should prove to be true for the Monocotyledons, it can hardly be claimed for the Dicotrledons, as the following record shows:

Among Dicotvledons the generative nuclens or cell divides in the pollen-grain in Rhopalocnemis (Lotsy ${ }^{51}$ ), Papaver, Hesperis, Archangelica, and Mertensia (all by Strasburger ${ }^{12}$ ), Nicotiana Tabacum (Guignard ${ }^{59}$ ), Sambucus (Halsted ${ }^{17}$ ), and silphium (Merrell ${ }^{48}$ ): and in the pollen-tube in Peperomia (Johnson ${ }^{49}$ ), Salix (Chamberlain ${ }^{30}$ ), Ranunculus (Coulter $^{37}$ ), Lathyrus (Strasburger ${ }^{12}$ ), Enphorbia (Miss Lyon ${ }^{40}$ ), Staphylea (Strasburger ${ }^{12}$ ), Acer (Mottier ${ }^{22}$ ), Tinca, Temophila, Digitalis, and Torenia (all by Strasburger ${ }^{12}$ ), Campanula (Barnes ${ }^{13}$ ), and Datura laevis (Guignard ${ }^{59}$ ). It is evident that the two conditions are found among Dicotyledons in both primitive and high groups, and even in the same family (as Solanaceae), and that neither one has any claim to be regarded as an essentially primitive character.

The male nuclei, formed by the division of a generative nucleus, are possibly always associated with crtoplasm in such a way that definite male cells are organized. The nuclens is often the only conspicuons feature, and in every case it finally constitutes the bulk of the male cell. In fact, in most of the plants studied only the male nucleus has heen demonstrated in the pollen-tube and embryo-sac. In the following citations "male nucleus" and "male cell" are used to indicate whether cytoplasm was demonstrated or not. Tarious forms of male 
cells and nuclei have been described, but it is evident that the form as well as the size may change decidedly in the course of its hi-tory. For example, Schaffner ${ }^{31}$ notes that the male nuclei in Sagittaria are at first spherical, but after pollination become bean-shape or spindle-shape. In Silphium Merrell ${ }^{48}$ observed the originally spherical male nuclei become much elongated, more or less curved, and even spirally twisted while still within the pollen-grain (Fig. 6t) ; and in Triticum and other grasses Golinski 21 implies the same changes in form in describing the oceurrence of male nuclei within the pollen-grain as " not unlike the antherozoirls of a fern or of Chara." It has been repeatedly observed that the spherical nuclei of the oblong or lenticular male cells of Lilium increase in size and become vermiform and varionsly curved and coiled after discharge from the pollen-tube, and the same 1henomenon was observed by Miss Thomas ${ }^{53}$ in Caltha.

It seems to be generally true that the male cells when formed free in the body of the grain are at first -pherical, but soon become oblong or lenticular. In a fortheoming paper hy Koernicke it will he shown that in Lilinm only male nuelei are found in the pollen-tube; at least there are no male cells as ordinarily figured. This claim is of special interest, since in

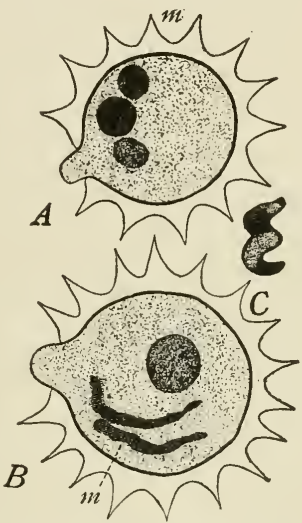

Fig. 64.-A, microspore of Silphium integrifolium, showing tubenucleus and two male nuclei. $B$, later stage in s. terebinthinaceum, showing the two male cells. $C$, single male cell of $s$. integrifolium, showing spiral form.-After Merrell.48

Lilium male cells are clearly organized in the pollen-grain. The increase in size and change of form so often described as taking place in the tube or sae are probably phenomena of the male nucleus rather than of the male cell. There are wellknown cases, however, in which the spherical or oblong form persists throughont the history of the nucleus. For example, in Pepromia (Johnson ${ }^{49}$ ) the male nucleus is spherical even in contact with the exw, and the same is true of several other forms recently investigated in connection with double fertilization. 
There is also indication that the two male nuclei may become differentiated in form, as in the case of Alisma, in which Schaffner ${ }^{25}$ found the upper male nucleus in the pollen-tube elongated or spindle-shaped, and the lower one spherical. It is also probable that in cases of double fertilization the two male nuclei often assume different forms in the embryo-sac. Four male nuclei have been reported by Strasburger ${ }^{12}$ as sometimes occurring in Camassia Fraseri, and Chamberlain ${ }^{32}$ has observed three nuclei within a single male cell in Lilium auratum (Fig. 63, $C$ ). This recalls the spermatogenesis of Grmnosperms, in which the generative cell gives rise to a stalk cell and two male cells, but it mar have no further significance than that any active cell may be induced to divide by farorable conditions.

The morphologr of the structures included in the male gametophyte of Angiosperms is obscure. In 1sst Strasburger 12 suggested that only an antheridium is developed within the pollen-grain, the regetative or prothallial tissue, represented in many Grmmosperms, having been entirely suppressed. The same riew has been dereloped in several papers from this laboratory, and in 1898 Belajeff ${ }^{36}$ reiterated it in a discussion including both Grmnosperms and Angiosperms. According to this riew, the larger tube-cell is the antheridium wall that derelops a tubular outgrowth, used at least in Angiosperms as the carrier of the male nuclei, while the generative cell and its product is the spermatogenous part of the antheridium. It is not exact to say that according to this riew the whole pollen-grain is an antheridium, but that in its germination the pollen-grain develops only an antheridium.

Another view, which seems to be the only alternative, is that while only an antheridium is present its sole representative is the generative cell, the tube-cell not being any more a part of the gametophrte than is the embryo-sac. The dirergence between the two riews, therefore, has to do only with the nature of the tube-cell. In any event, it is important to note, as contradicting a very common statement, that the pollen-tube is not the male gametophrte.

The derelopment of the pollen-tube and the passage of the male nuclei to the embrro-sac are so directly connected with fertilization that they will be considered in the next chapter. 


\section{LITERATLRE CITED}

1. Reichexbach, H. G. De pollinis Orchidearum genesi ac structura et de Orchideis in artem ac systema regigendis. Leipzig. 1852.

2. Sснаснт, H. Ueber den Bau einiger Pollenkörner. Jahrb. Wiss. Bot. 2: 107-168. pls. 14-18. 1860 .

3. Hofmister, IV. Neue Beiträge zur Kenntniss der Embryobildung der Phanerogamen. Abhandl. Königl. Sächs. Gesell. Wiss. 6: 533-672. pls. 1-27. 1859.

4. Rosaxof, S. Zur Kenntniss des Baues und der Entwicklungsgeschichte des Pollens der Mimoseae. Jahrb. Wiss. Bot. 4: 441450. pls. 31-32. 1865 .

5. Luerssen, C. Zur Controverse über die Einzelligkeit oder Mehrzelligkeit des Pollens der Onagrarieen, Cucurbitaceen und Corylaceen. Jahrb. Wiss. Bot. 7 : 34-60. pls. 3-5. 1869.

6. Strasburger, E. Befruchtung und Zelltheilung. Jena. 1877.

7. Elfixg, F. Studien über die Pollenkörner der Angiospermen. Jenaisch. Zeitsch. Naturwiss. 13: 1-28. 1879; Quart. Jour. Micr. Sci. $20: 19-35$. 1880.

8. Strasburger, E. Zellbildung und Zelltheilung. Ed. 3. Jena. 1880 .

9. Guiginard, L. Recherches sur le développement de l'anthère et du pollen des Orchidées. Ann. Sci. Nat. Bot. VI. 14: 26-45. pl. 2. 1882 .

10. Strasberger, E. Ueber den Theilungsvorgang der Zellkerne und das Verhältniss der Kerntheilung zur Zelltheilung. Archiv. Mikr. Anat. 21: 476-59u. pls. 25-2\%. 1882.

11. Corry, T. H. Structure and Development of the Gynostegium, etc., in Asclepias Cornuti. Trans. Linn. Soc. Bot. London 2: 173-207. pls. 24-26. 1884 .

12. Strasburger. E. Neue Untersuchungen über den Befruchtungsvorgang bei den Phanerogamen. Jena. 1884.

13. Barses, C. R. The Process of Fertilization in Campanula americana. Bot. Gazette 10: 349-354. pl. 10. 1885.

14. Coulter, J. M., and Rose, J. N. The Pollen Spore of Tradescantia virginica. Bot. Gazette 11: 10-14. pl. 1. 1886.

15 Wille, N. Ueber die Entwickelungsgeschichte der Pollenkörner der Angiospermen und das Wachsthum der Membranen durch Intussusception. Christiania. 1886.

16. Goebel, C. Outlines of Classification and Special Morphology. English translation. 1887.

17. Halsted, B. D. Three Nuclei in Pollen Grains. Bot. Gazette 12: 285-288. pl. 16. $188 \%$.

18. Oliver. F. W. On Sarcodes sanguinea. Annals of Botany 4: 303-326. pls. 17-21. 1890. 
19. Guignard, L. Nouvelles études sur la fécondation. Ann. Sci. Nat. Bot. VII. 14: 163-296. pls. 9-18. 1891.

20. Chauveaud, G. L. Sur la fécondation dans les cas de polyembryonie. Compt. Rend. 114: 504. 1892.

21. Golinski, St. J. Ein Beitrag zur Entwicklungsgeschichte des Androeceums und des Gynaeceums des Gräser. Bot. Centralbl. 55: 1-17, 65-72, 129-135. pls. 1-3. 1893.

22. Motrier, D. M. Development of the Embryo-sac in Acer rubrum. Bot. Gazette 18: 375-377. pl. 34. 1893.

23. Humphrey, J. E. Nucleolen und Centrosomen. Ber. Deutsch. Bot. Gesell. 12: 108-117. pl. 6. 1894.

24. Belajeff, W. Zur Kenntniss der Karyokinese bei den Pflanzen. Flora. Ergänzungsband, 1894.

25. Strasburger. E. Karyokinetische Probleme. Jahrb. Wiss. Bot. 28: 151-204. pls. 2-3. 1895.

26. Motrier, D. M. Beiträge zur Kenntniss der Kerntheilung in den Pollennutterzellen einiger Monokotylen und Dikotylen. Jahrb. Wiss. Bot. 30 : 169-204. pls. 3-5. 1897.

27. Campbell, D. H. The Structure and Development of the Mosses and Ferns. London and New York. 1895.

28. Schaffner, J. H. The Embryo-sac of Alisma Plantago. Bot. Gazette 21: 123-132. pls. 9-10. 1896.

29. Campbell, D. H. A Morphological Study of Naias and Zannichellia. Proc. Calif. Acad. Sei. III. 1: 1-62. pls. 1-5. 1897.

30. Chamberlain, C. .T. Contribution to the Life History of Salix. Bot. Gazette 23: 147-179. pls. 12-18. 1897.

31. Schaffner, J. H. Contribution to the Life History of Sagittaria variabilis. Bot. Gazette 23 : 252-273. pls. 20-26. 1897.

32. Chamberlain, C. J. Contribution to the Life History of Lilnum Philadelphicum; the Pollen Grain. Bot. Gazette 23: 42:3-430. pls. 35-36. 1897.

33. JuEL, H. O. Die Kerntheilungen in den Pollenmutterzellen von Hemerocallis fulva und die bei denselben auftretenden Unregelmässigkeiten Jahrb. Wiss. Bot. 30 : 205-226. pls. 6-8. 1897.

34. Schaffner, J. H. The Development of the Stamens and Carpels of Typha latifolia. Bot. Gazette 24: 93-102. pls. 4-6. 1897.

35. Lawson, A. A. Some Observations on the Development of the Karyokinetic Spindle in the Pollen Mother-cells of Cobaea scandens. Proc. Calif. Acad. Sci. III. 1: 169-184. pls. 33-36. 1898.

36. BeLaJefF, W. Die verwandtschaftlichen Beziehungen zwischen den Phanerogamen und den Cryptogamen in Lichte der neuesten Forschungen. Biol. Centralbl. 18: 209-218. 1898.

37. Coulter, J. M. Contribution to the Life History of Ranunculus. Bot. Gazette 25 : 73-88. pls. 4-7. 1898. 
38. Chamberlais, C. J. Winter Characters of Certain Sporangia. Bot. Gazette 25: 12t-128. pl. 11. 1898.

39. Suith, R. W. A Contribution to the Life History of the Pontederiaceae. Bot. Gazette 25: 324-33\%. pls. 19-20. 1898.

40. Lyon, Florexce M. A Contribution to the Life History of Euphorbia corollata. Bot. Gazette 25: 418-426. pls. 22-24. 1898.

41. Stevens, W. C. The Behavior of the Kinoplasm and Nucleolus in the Division of the Pollen Mother-cells of Asclepias Cornuti. Kansas Univ. Quarterly 7: 77-85. pl. 15. 1898.

42. Caldwell, O. W. On the Life History of Lemna minor. Bot. Gazette 27: 37-66. figs. 59. 1899.

43. Canpbell, D. H. Notes on the Structure of the Embryo-sac in Sparganium and Lysichiton. Bot. Gazette 27: 153-166. pl. 1. 1899.

44. Fullier, E. L. The Development of the Microsporangia and Microspores of Hemerocallis fulva. Bot. Gazette 28: 81-88. pls. 7-8. 1899.

45. WiEgaND, K. M. The Development of the Microsporangium and Microspores in Convallaria and Potamogeton. Bot. Gazette 28: 328-359. pls. 24-25. 1899.

46. CAnvon, W. A. A Mtorphological Study of the Flower and Embryo of the Wild Oat, Avena fatua. Proc. Calif. Acad. Sci. III. 1: 329-364. pls. 49-53. 1900.

47. DugGar, B. M. Studies in the Development of the Pollen Grain in Symplocarpus foetidus and Peltandra undulata. Bot. Gazette 29: 81-98. pls. 1-2. 1900.

48. Merrell, W. D. A Contribution to the Life History of Silphium. Bot. Gazette 29: 99-133. pls. 3-10. 1900.

49. Johnson, D. S. On the Endosperm and Embryo of Peperomia pellucida. Bot. Gazette $30: 1-11 . p l .1 .1900$.

50. JuEL, H. O. Beiträge zur Kenntniss der Tetradenbildung. Jahrb.

Wiss. Bot. 35: 626-659. pls. 15-16. 1900.

51. Lotsy, J. P. Rhopalocnemis phalloides Jungh., a Morphologicalsystematical Study. Ann. Jard. Bot. Buitenzorg II. 2: 73-101. pls. 3-14. 1900 .

52. Byxbee, Edith. The Development of the Karyokinetic Spindle in the Pollen Mother-cell of Lavatera. Proc. Calif. Acad. Sci. III. 2: 63-82. pls. 10-13. 1900.

53. Thonas, Ethel M. On the Presence of Vermiform Nuclei in a Dicotyledon. Annals of Botany 14: 318-319. 1900.

54. Strasburger, E. Einige Bemerkungen zu der Pollenbildung bei Asclepias. Ber. Deutsch. Bot. Gesell. 19: 450-461. pl. 24. 1901.

55. Schaffner. J. H. A Contribution to the Life History and $\mathrm{Cy}$ tology of Erythronium. Bot. Gazette 31: 369-3s7. pls.4-9. 1901. 
56. Frye, T. C. Development of the Pollen in some Asclepiadaceae. Bot. Gazette 32: 325-331. pl. 13. 1901.

57. Rosenbert, O. Ueber die Pollenbildung von Zostera. Meddel. Stockholms Högsk. Bot. Inst. pp. 21. 1901.

58. GAGER, C. S. The Development of the Pollinium and Sperm Cells in Asclepias Cornuti. Annals of Botany 16: 123-148. pl. \% 1902.

59. Guignard, L. La double fécondation chez les Solanées. Jour. Botanique 16: 145-167. figs. 45. 1902.

60. Cheauveaud, G. L. De la reproduction chez le dompte-venin. Diss. Paris. 1902. 


\section{CHAPTER VII}

\section{FERTILIZATION}

Is various ways the male gametophyte reaches the stigma. The literature dealing with pollination has become very extensive, and can not even be recapitulated here, especially as it is an ecological subject. The development of tubes from pollengrains lodged upon stigmas has long been known, but the relation of the tubes to fertilization was long misunderstood. An historical account of the early views of fertilization among Angiosperms, together with the citation of literature, was given by Schacht ${ }^{1}$ in 1850 , and by Hofmeister ${ }^{2}$ in 1851. A few notes from Schacht's account may not be without interest, and the reproduction of some of his figures will serve to show the technique of the time and to illustrate how theories may influence interpretation (Fig. 65).

In 1681 Malpighi discovered the ovule and the embryosac, and also examined the pollen, but regarded it as a useless secretion. No important advance was made until 1823, when Anici discovered the pollen-tube on the stigma of a Portulaca and succeeded in tracing the tube to the orule. In 1826 Brongniart traced the pollen-tube in many plants, and in Pepo macrocarpus saw hanging from the micropyle the end of the tube that had passed into the embryo-sac; "but," says Schacht, " he misinterpreted the phenomenon, for he regarded the pollen-tube as a fertilizing tube through which the fertilizing contents were bronght to the embryo-sac, there to be taken up by the 'embryonal vesicle,' a cell arising in the sac." In 1826 Rohert Brown described the development of the integuments, and later traced the pollen-tubes of orchids and asclepiads from the stigma to the nicropyle. In 1833 the knowledge of the subject may be summarized as follows: there had been observed 
the pollen-grain with its pollen-tube and some contents, as well as the ovule with its integuments and embryo-sae; and the pollen-tube had been traced from the stigma to the embryo-sac.


Fig. 65.-A-C, Orchis Morio; D, O. latifolia; $E$, O. maculata; F, Canna limbata. $A-B$, young ovules, $\times 150 ; C$, end of pollen-tube enlarging, $\times 100: D$, later stage with two nuclei visible in embryo, $\times 166: E$, more advanced embryo, $\times 20) ; F$, considerably later stage, $\times 125 .-$ After \$снаснт.1

In 1835 Schleiden, the founder of the cell-theory, traced the pollen-tube in a large number of widely separated families. He elaimed to have seen the tube enter the micropyle, press into the embryo-sac, and then beeome itself the embryonal vesicle, the beginning of the embryo. He thought that the contents of the pollen-tube not only give rise to the embrronal vesicle, but that the end of the tube, nourished by the embryo-sac, becomes the future plant. 
In 1 s 42 Hartig described an "egg" in the embryo-sac, and claimed that the pollen-tube carries a substance that fertilizes the egg, a view which Schleiden promptly opposed. In the same rear Amici reiterated his prerious views and claimed for Orchis and other plants the preexistence in the embrro-sac of a cell which, through the influence of the pollen-tube, becomes the embryo. Schacht opposed this claim, and suggested that such antiquated ideas be abandoned. At the same time, Hugo ron Mohl described the egg-apparatus in Orchis Morio, and warmly supported Amici's riews.

In his conclusion Schacht says: "The tendency to error is so bound up in human nature that the work of one's mind, like that of his hand, is never perfect, and consequently I do not consider my work free from error and misconception, but I have tried to minimize these as much as possible. In the chief
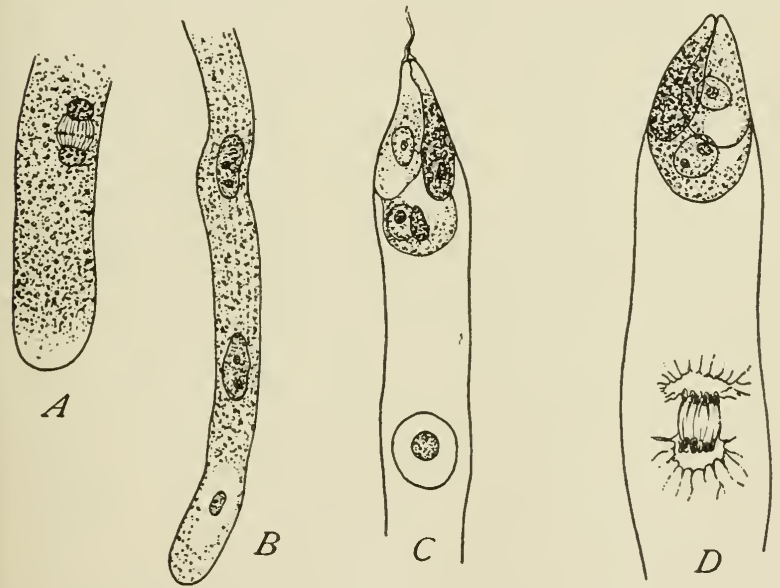

Fig. 66.-A, Staphylea; tip of pollen-tube showing division of generative nucleus. $B$, Orchis latifolia; end of pollen-tube showing tube nucleus (in advance) and the two male nuclei. C, Monotropa Hypopitys; fusion of sex nuclei, male nucleus more deeply shaded. $D$, the same stage just after fertilization, showing first division of endosperm nucleus, $\times 450 .-$ After Strasbirger. ${ }^{8}$

matter, the origin of the embryn from the pollen-tube, no one can convince me that there has been any error or misconcep- 
tion." Terertheless, in his text-book, published a few years later, he says that " fertilization" is accomplished in plants, as in animals, by the union of male and female elements.

It is only since 1875 that detailed information has gradually accumulated; and not until $188+$ (Strasburger $^{8}$ ) were the cells concerned in fertilization clearly pointed out (Fig. 66).

The tube-cell of the pollen-grain in various ways pushes through the exine a papillate protrusion of the intine that derelops into the pollen-tube with greater or less rapidity. Crowding among the loose papillate cells of the stigma, the elongating tubes enter the conducting tissue of the style. Ordinarily the style is solid, and the tubes grow along the conducting strand, which they disorganize more or less, obtaining from it their nutritive supply. In case there is a stylar canal the tubes either pass down it, as in Pontederia (Smith ${ }^{28}$ ) and Erythronium (Schaffner ${ }^{51}$ ), nourished by the lining glandular cells, or they may penetrate the stylar tissue about the tube, as in Campanula (Barnes ${ }^{9}$ ) and Juglans ( Tawaschin ${ }^{20}$ ). In many cases the tube enters the ovary carity close to the microprle; in others it must traverse more or less of the cavity, being "guided" to the micropsle by rarious mechanical and nutritive contrivances.

Although ordinarily pollen-tubes are developed only in contact with the stigma, in cleistogamous flowers tubes have been observed issuing from pollen-grains still in the anther, the tips being directed toward the stigma. In Asclepias also multitudes of tubes sometimes start from the unremoved pollinia.

The time elapsing between pollination and fertilization, as inferred from the presence of pollen-tubes in the embryo-sac, is extremely rariable, and seems to hold no relation to the distance traversed, as shown by Hofmeister, ${ }^{3}$ in comparing Crocus, in which a style 6 to $10 \mathrm{~cm}$. long was traversed in one to three dars, with 1 rum, in which a style only 2 to $3 \mathrm{~mm}$. long was traversed in five dars. The range in time is probably represented by the following illustrations: In Limnocharis emarginata. Hall ${ }^{57}$ found a two-celled embryo in material killed eighteen hours after pollination, and thinks that in this case fertilization probably occurs the first night after pollination. Probably the most accurate estimate of the time is that by Mottier ${ }^{26}$ for Lilium, in which the time between artificial pol- 
lination and fertilization (as shown by fusion) was sixty-five to seventy-two hours. Guignard ${ }^{56}$ has recorded an interval of two dars between pollination and fertilization in Nicotinana Tabacum. Juel ${ }^{63}$ found by artificial pollination that fertilization occurs in Cynomorium four days after pollination, sixteen days after pollination embryos of various sizes being found. Hofmeister ${ }^{2}$ noted the interval as one to three days in C'rocus, five days in Arum, from ten days to several months among the Orchidaceae, and in Colchicum autumnale not less than six months (November to May). In the last case, as is well known, pollination sometimes occurs before there is any appearance of ovules. Miss Benson ${ }^{15}$ found three weeks elapsing in Fagus syliatica between pollination and the entrance of the tube into the embryo-sac, and the same interval is reported by D'Hubert ${ }^{17}$ for certain Cactaceae. In Hamamelis virginiana Shoemaker ${ }^{62}$ has found that pollination occurs from October to December; that the tubes develop at once and grow rapidly until cold weather; that during January and February the tube may be found safely embedded in the hairy part of the carpel; and that growth is resumed in the spring, fertilization occurring about the middle of May, five to seven months after pollination. The pollen-grains of Hamamelis show great resistance to low temperature, Shoemaker citing cases in which they produced tubes after exposure to a week of cold, the temperature sometimes being as low as $-15^{\circ} \mathrm{C}$. Among the Amentiferae, however, the interval becomes even more extended. Miss Benson ${ }^{15}$ reports that it is one month in Betula alba, two months in Carpinus Betulus, three months in Aluus glutinosa, four months in Corylus Avellana and Quercus Robur, and as much as eleven months in certain other oaks; while in $Q$. velutina Conrad ${ }^{36}$ found the interval between pollination and fertilization to be thirteen months. Baillon had long before noted that no indication of orules is present in Quercus at the time of pollination. Goebel ${ }^{10}$ has associated these long intervals with the woody habit, citing $C$ lmus, Quercus, Fagus, Juglans, Citrus, Aesculus, Acer, Cormus, and Robinia as illustrations, and stating that the interval is almost a year in Imerican oaks that take two rears to ripen their seed. Such eases bear a striking resemblance in this regard to many Grmnosperms.

A recent study of Monotropa uniflora by Shibata ${ }^{65}$ indi- 
cates that the interval between pollination and fertilization in any given species may be dependent upon temperature. In the case of Monotropa, under normal conditions fertilization takes place about five days after pollination : but by lowering the temperature the interval is lengthened, and at $\mathrm{S}-10^{\circ} \mathrm{C}$. fertilization is prevented. In Shibata's experiments it was shown that light, atmospheric pressure, and mechanical injury seem to exert no influence upon fertilization and subsequent phenomena, but that the structures of the embryo-sac are very sensitive to temperature.

In a long pollen-tube, or in one that persists for a long time, it is common to observe the formation of successive cellulose plugs (Propfen) that shut off the growing tip, with its cells and nuclei, from the cavity behind, as fully described by Strasburger ${ }^{4}$ and Elfring. ${ }^{6}$ Sometimes the plugs are so large and persist in such a series that they become conspicuous objects, as in Gymnadenia conopsea (Marshall- Ward ${ }^{\mathbf{7}}$ ), Campanula americana (Barnes ${ }^{9}$ ), Sarcodes sanguinea (Oliver ${ }^{11}$ ), etc. In such forms as the Amentiferae and others, in which the tube and its contents remain imbedded in the stylar tissne for a period rarving from one month to over a vear, the tip of the tube is cut off br a plug, its wall thickens, and it passes into what might fairly be called an encrsted condition, as suggested by Miss Benson ${ }^{\mathbf{1 5}}$ in connection with Carpinus.

The branching of pollen-tubes, so conspicuous a phenomenon among Grmnosperms, is also found among certain Angiosperms. Hofmeister ${ }^{3}$ observed branching tubes among Monocotyledons in Pothos longifolia and II ippeastrum aulicum. Among the Amentiferae it seems to be rery common, Miss Benson ${ }^{15}$ observing forking tubes in several of the genera (Corylus, Carpinus, etc.) she studied, and in Quercus a cluster of short branches at the end of the tube; while Nawaschin 20,30 states that the tubes of Juglans and Tluus branch profusely, and recently a similar branching has been noted by Billings ${ }^{66}$ in Carya (Hicoria). Zinger ${ }^{31}$ also described the pollen-tubes of the Camnabineae as ending in numerous swollen sac-like liranches. The breaking up of the tip of the tube into short hranches is doubtless a common phenomenon, probably associated with the rhizoidal habit, but free branching seems to be characteristic chiefly of chalazogamic forms. 
In 1891 Treub $^{12}$ announced the phenomenon of chalazogany in casuarina. He found the pollen-tube penetrating the chalazal region of the ovule, instead of entering through the micropyle. In this case the pollen-tube becomes associated with the numerous elongated sterile megaspores, and doubtless they are of service in rendering the passage easy; and later it enters the antipodal region of the embryo-sac and approaches the eggapparatus from that direction (Figs. 67, 24C). In 1893 Nawaschin ${ }^{14}$ reported chalazogamy in Betula; and in 1594 IFiss Benson ${ }^{15}$ not only observed the phenomenon in Betula, but also added Alnus, Corylus, and Carpinus to the list of chalazogamic plants. In all of these cases Miss Benson observed the tubes following a course parallel with the vascular strands of the raphe, thus reaching and penetrating the chalaza. In Corylus and Carpinus the tube enters a more or less conspicuous caecum lereloped in the antipodal region of the sac, traverses it, and comes in contact with the egg: but in Alnus the tube traverses the nucellus to the micropylar region above the embryo-sac, and then turns and enters it as though it had come by way of the micropyle. In 1895 Tawasehin ${ }^{20}$ added Juglans cinerea and $J$ regia to the list. In the
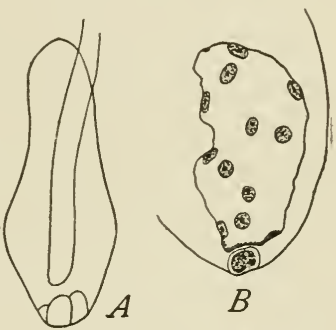

Fio. 67.-Casuarina suberosa. A, poll'n-tube entering chalazal end of embryosac, $\times 270 ; B$, stage showing (Treub's interpretation) formation of endosperm before fertilization, $\times 160$. Atter Trecb. ${ }^{12}$

latter species the tube does not pass down the stylar canal or traverse the carity of the ovary, but advances through the tissue of the strle and of the ovary wall until opposite the insertion of the single orule that fills the orary cavity. It then leares the ovary wall and pierces the chalaza, branching freely in the nucellus, which is described as "veined" by tubes surrounding the sac on all sides. The male nuclei discharged into the sac were seen "wandering" in its cytoplasm and fusing with one of several free cells that function as eggs but have not oroanized an eggapparatus. Recently Pillings ${ }^{66}$ has diseovered chalazogamy in Carya olivaeformis, the common pecan, the details conforming almost exactly to those given by Nawaschin for Juglans regia. 
In 1898 Nawaschin ${ }^{30}$ described some remarkable variations in the course of the pollen-tube in Llmus pedunculata and $U$. montana. In addition to tubes following the ordinary chalazogamic route, some instead of penetrating the chalaza pass from the funiculus across the short outer integument, and thence into and upward through the inner integument to the top of the nucellus, when they turn across to the bottom of the micropyle and so enter the nucellus from the usual direction; others follow the same route except that they pass directly from the funiculus into the inner integument; while still other tubes branch profusely and apparently with no definiteness within both the funiculus and integument. In the same species, therefore, pollen-tubes may enter the sac either at the antipodal or micropylar ends, and may either pass with great directness or branch profusely.

The behavior of the pollen-tubes in Ulmus suggested that there might be other routes than through the micropyle or through the chalaza, and this has been observed in other forms. In his study of the Cannabineae in 1895, Zinger ${ }^{31}$ discovered that the two thick integuments completely coalesce over the apex of the nucellus, and the micropyle is entirely closed by tissue. The pollen-tube either bores its way through the tissue filling the micropyle or pierces the two integuments, reaching the nucellus and branching about its apex, and finally sending one very slender branch into the embryo-sac.

With these facts before them, Pirotta and Longo ${ }^{41}$ proposed the term "acrogamy" for the entrance of the pollen-tube directly through the micropyle; "basigamy" for its entrance through the chalaza (Casuarina, Betula, Alnus, Corylus, Carpinus, Juglans, and sometimes (Tlmus); and "mesogamy" for its entrance by intermediate routes (sometimes UTmus, and Cannabineae). In the following year Longo ${ }^{49}$ described a case of mesogamy in Cucurbita, in which the pollen-tube traverses the tissues of the funiculus and outer integument before entering the micropyle. Practically the same phenomenon has been observed by Murbeck ${ }^{50}$ in Alchemilla arvensis, in which the micropyle is entirely closed by the growth of the integument, and the pollen-tube enters the orule at the chalazal end, trarcrses the entire length of the integument within its tissues, and thus enters the micropylar extremity of the embryo-sac. 
True chalazogamy, therefore, has as yet been found only among the Amentiferae, but such an intermediate condition as shown by Clmus, Cucurbita, and Alchemilla, in whieh the pollen-tube enters the ovule at the chalazal end, but traverses the integument instead of the nucellus, suggests that chalazogamy is an exceptional condition derived from the ordinary route of the pollen-tube through the micropyle. In certain cases the tube reaches the mieropyle by passing along more or less of the surface of the integument; in other cases it enters the tissues of the integument, and finally it penetrates deeper, entering the chalazal tissue. This seems to be a natural sequence of events that resulted in ehalazogamy, which therefore would hold no relation to a primitive condition of Angiosperms or to their elassifieation.

In passing through the micropyle the pollen-tube is more or less compressed, and upon reaching the wall of the embryosac may broaden out upon it. In some eases (p. 94) the synergids have already piereed the wall of the embryo-sac, but in most cases it must be pierced by the tube. Upon entering the sac the tube either passes between the srnergids, as in Pontederia (Smith ${ }^{28}$ ), Euphorbia (Lب̣on ${ }^{29}$ ), sometimes Satix (Chamberlain ${ }^{23}$ ), ete. (Fig. 44 ); or between the sac-wall and one srnergid, as in Alisma (Sehaffner ${ }^{22}$ ), Litium (Coulter ${ }^{25}$ ), Ranuinculus (Coulter ${ }^{27}$ ), Fagus (Benson ${ }^{15}$ ), Silphium (Merrell $^{35}$ ), etc. Riecently, howerer, Guignard ${ }^{56}$ has reported that in Nicotiana Tabacum and Datura laeris the tube passes into a srnergid and diseharges its contents into the broken-up body. So far as our own observation goes, the nsual route of the tube is between the sac-wall and one of the srnergids, but this mar well vary eren in the same species. Within the sac the tip of the tube usually becomes much swollen, often appearing pouch-like, as in Alisma, Erythronium, Ranunculus, Silphium, etc., due probably to the rapid absorption of material from the synergid. As a rule, one srnergid is disorganized by its contact with the tube: but in Salix (Chamberlain ${ }^{23}$ ) (Fig. 44), Sitphium (Merrell ${ }^{35}$ ), Nigella (Guignard ${ }^{53}$ ), ete., cases of fertilization have been observed in which both srnergids remained intact; while in Erigeron (Land ${ }^{38}$ ) both srnergids are frequently disorganized. $D^{\prime} H u b e r^{17}{ }^{1 \tau}$ has made the interesting observation in connection with his study of the Cactaceae that 
the nuclens of one synergid moves toward the tube upon its entrance into the sac, and that the nucleus of the other synergid moves toward the melens of the egg.

In case the tube passes between the srnergids it adrances direetly toward the egg-nuclens; but in case it passes along the wall of the sac the tip of the tube curves toward the egg-nuelens. In any event, the tip of the tube, in which a thin area (pit)

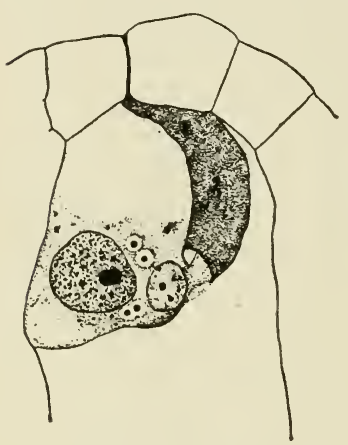

Fig. 68.-Sagittaria variabilis. Pollentube in the act of discharging; four centrosomes represented; $\times 900$.After SCHAFFNER. 24 is developed, is directed toward the egg-nucleus when the discharge takes place. Under the pressure dereloped by the turgor of the end of the tube, and resisted by the small caliber of the tube in its passage through the micropvle and sac-wall, the membrane of the pit is ruptured, and a discharge of the contents results. The perforated tip of the pollen-tube, after the discharge, has been demonstrated frequently, as seen by Schaffner ${ }^{4+}$ in Sagittaria (Fig. 68). The discharge seems to be forcible enough to empty the end of the tube of most of its contents, the most important ones being the two male nuclei. Cases have been reported in which only one male nucleus is said to be discharged, as in Alisma (Schaffner ${ }^{22}$ ) and Sagittaria (Schaffner ${ }^{24}$ ), the other being recognized as degenerating in the tube. However, the frequent presence of disorganizing bodies within the tube after fertilization (Fig. 71), and numerous observations of the discharge of both male nuelei, and especially the rapidly multiplying illustrations of "double fertilization," incline to the belief that the discharge of both male nuelei into the sac is usual.

The passage of the male nueleus through the cytoplasm of the egg toward the female nucleus may be attended by an increase in size and change in form, but the changes are not so ('onspienous as those that oceur in the male nucleus that passes deeper into the sac to fuse with the polar nuelei. For example, in Caltha palustris Miss Thomas ${ }^{44}$ found the male nuelei very 
-mall and oblong or lenticular on extrusion, the one passing to the polar nucles increasing very much in size, the other very little. In Tricyrtis hirta Ikeda ${ }^{58}$ found the male nucleus that passes to the polar nuclei showing "enormous change in size and shape" as it passes through the sac. There is usually more (1) less elongation of male nuclei at the time of discharge or afterward, but in Monotropa uniflora Shibata ${ }^{54}$ has seen them elongated when entering the sac, but becoming more nearly -pherical as fusion progresses. In the pollen-grain at the time of shedding the generative nucleus stains blue and the tube uncleus red with a combination like cyanin and erythrosin. This reaction is maintained, the male nucleus staining blue even after coming into contact with the nucleus of the egg which stains red; but as fusion proceeds the male nucleus takes less and less of the cyanin and finally stains with erythrosin like the nucleus of the egg.

The fusion of the male and female nuclei may be very rapid, as observed by Guignard 48,53 in Zea and Ranunculaceae; or the two may be long in contact without fusion, as noted by Johnson ${ }^{37}$ in Peperomia. The behavior of the chromatin during fusion has received but little attention. Mottier ${ }^{26}$ figures the chromatin when the nuclei are partly fused, and the -tatement is generally current that the nuclei fuse in the resting condition (Fig. 69). In view of the independence of the paternal and maternal chromatin during fertilization in Gymnosperms, as recently noted by -reral investigators, it would be well to reexamine the subject in Augiosperms, especially since most observers have paid little $\mathrm{r}$ no attention to this phase of the problem.

Since it has been in connection with fertilization and attendant phenomena that the centrosome problem has come into



Fro. 69.-Lilium candidum. Fusion of sex nuclei; the synergids appear as dense homogeneons masses.-After. MOTTIER, 26 greatest prominence, it may not be inappropriate to refer to the subject at this point. Guignard, Schaffner, and others have 
regarded the centrosome as a permanent organ performing an important function in mitosis and in fertilization. Even the "quadrille of the centers," described by the zoologist Fol, was identified by these observers. Centrosomes in the vascular plants have been figured by many other prominent botanists, including Humphrey, ${ }^{16}$ Strasburger, ${ }^{18}$ Campbell, ${ }^{19}$ and Mot-
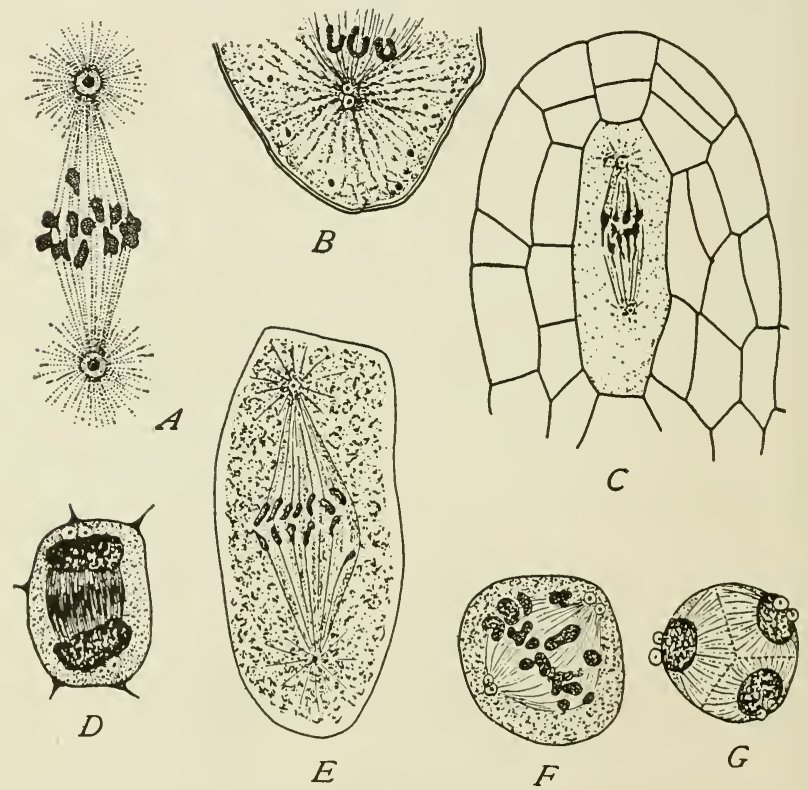

FIG. 70.-Figures of centrosomes in vascular plants. A, Lilium Lartagon, the reduction division at germination of megaspore; 12 chromosones may be counted: $\times 6 n 0$ : after GUlgNals, 13 B, Larix europaea, first division of pollen mother-cell: $\times 600$; after STRAsB'RGER 18 C, Delphinium tricorne, tirst division of megaspore mothercell; "at upper pole are centrospheres": × 55s; after Motriek.21 I), Sagittaria variabilis, first division of pollen mother-cell; $\times 640$; after ScHAFFNER ${ }^{24} E$, Lilium candilum, reduction division at germination of megaspore; after Bersarn, ${ }^{47} F$, Psilotum triquetrum, first division of spore mother-cell: $\times 800$; after Ht: $G$, Equisetum telemateia, tetrad of four spores $; \times 960$; after CAMPBelr. ${ }^{29}$

tier $^{26}$ (Fig. 70). Most botanists, following Strasburger, have publicly renounced any belief in the centrosome as an organ of 
vascular plants, and many others have made a tacit renunciation. To say that all the figures that have been drawn have
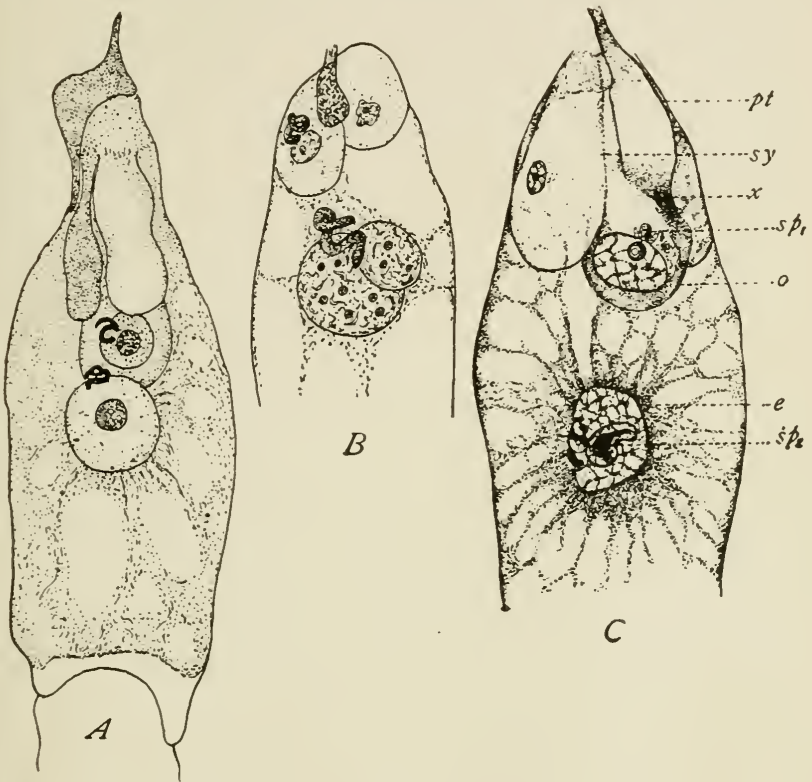

Fig. 71.-Double fertilization. A. Helianthus annuus, showing the two coiled male nuclei, one fusing with the egg-nucleus and the other with the endosperm nucleus; after NawAscus: 40 B, Iris, the two polar nuclei not yet fused; after GusGNaRd. ${ }^{32}$ $C$, Silphium laciniatum: $s p_{1}, s p_{2}$, nule nuelei: 0 , oosphere; e, endosperm nucleus; sy, synergid; $p t$, pollen-tube: $x$, two conjectural bodies often seen in the pollentube after the male nuclei have been discharged ; $\times 525$; after LAxD, ${ }^{38}$

been mere products of the imagination would be a radical statement, and one doubtless very far from the truth. In our opinion the observations, figures, and descriptions, like the pollen-tube embryos of Schleiden and Schacht, furnish an example of the extent to which eren a careful and conscientious scientist may be influenced by preconceived opinion.

Our knowledge of the phenomenon called "double fertilization" (Fig. 71) dates from 1898, when Nawaschin ${ }^{53,34}$ an- 
nounced at a meeting of the Russian Society of Naturalists in Angust that it oceurs in Lilium. Martagon and Fritillaria tenella. In 1899 Guignard ${ }^{32}$ observed the same phenomenon in Lilium pyrenaicum, Fritillaria meleagris, and Endymion nutans. During 1900 the literature of the subject increased rapidly. Nawaschin ${ }^{40}$ added Juglans, Delphinium elatum, Rudbeckia speciosa, and Helianthus annuus to the list, and in certain orchids (Arundina and Phajus) he found the second male nucleus consorting with the polar nuclei, but there was no fusion. Guignard ${ }^{39}$ described the phenomenon in species of Tulipa (Fig. 72), also ${ }^{42}$ in Scilla, Narcissus, Reseda, and Hibiscus; and Strasburger ${ }^{43}$ not only added Himantoglossum,
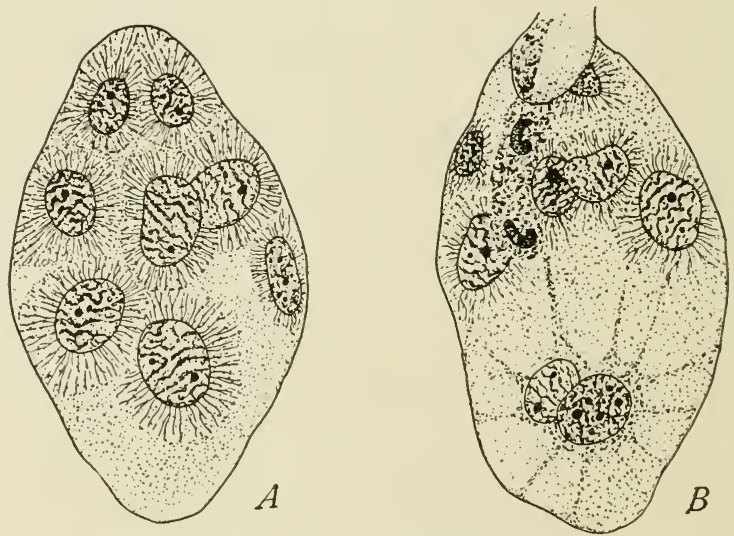

Fic. 72.-A, embryo-sac of Tulipa sylvestris, showing nuclei seattered irregularly, each nuclets surrounded by a rather definitely limited portion of the eytoplasm; $x 300$. B. T. Celsiana, showing double fertilization in sac like that shown in $A$; the male nuelei reeognized hy vermiform appearanee; $\times 338$. - After Guroxard. 39

certain species of Orchis, and Monotropa Mypopitys, but discussed the whole subject. Miss Thomas ${ }^{44,45}$ reported double fertilization in Caltha palustris: Guignard 42 announced it in Ramunculus Flammula, Helleborus foetidus, Inemone nemorosa, Clematis, Titicella, and Tigella sativa, and independentls confirmed its ocenrrence in Caltha palustris. Tand ${ }^{38}$ found it in species of Erigeron and Silphium; it was observed repeatedlr 
in this laboratory in Lilium philadelphicum (Fig. 36, H), L. trigrinum, and Anemone patens Nuttalliana; and at the close of 1900 Miss Sargant ${ }^{46}$ published a résumé and general discussion of the subject. Hore recently, Guignard ts has deseribed double fertilization in Zea and Naias major; Land has discorered it in Cnicus and possibly in Taraxacum; while Guignard ${ }^{53}$ has added Nigella damascena and Ranunculus Cymbalaria; and Frye ${ }^{60}$ has deseribed its occurrenee in Asclepias C'ornuti. Karsten ${ }^{55}$ has also confirmed the occurrence of double fertilization in Juglans, investigating several species; Shibata ${ }^{54}$ has added Monotropa uniflora, Ikeda ${ }^{58}$ Tricyitis hirta, Strasburger ${ }^{59}$ Ceratophyllum demersum, Guignard ${ }^{56}$ species of $\mathrm{Nico-}$ tiana and Datura, as well as of Capsella and Lepidium, ${ }^{64}$ Wylie ${ }^{67}$ Elodea, and Frye ${ }^{68}$ C'asuarina.

It will be scen that the phenomenon is not restricted to a few groups, but is widely displayed among both Monocotyledons and Dicotrledons; among the former having been observed in Naiadaceae, Hrilrocharitaceae, Gramineae, Liliaceae, Amaryllidaceae, and Orehidaceae; and among the latter in Juglandaceae, Ceratophyllaceae, Ranumeulaceae, Cruciferae, Resedaceae, Malraceae, Ericaceae, Asclepiadaceae, Solanaceae, and Compositae. Probably it is not safe to infer the general occurrence of double fertilization, although the observations already include sixteen families, about forty genera, and orer sixty species, besides inferential testimony in other species from the form and activity of both male nuclei and from the phenomenon of xenia. In any erent, it is common enough to demand a general explanation of its significance, its place in the history of Angiosperms, and especially whether it is really fertilization or merely triple fusion. It has certainly introduced among struetures already diffieult of interpretation a phenomenon that immensely increases the difficulty. The subject will be discussed briefly under endosperm (Chapter VIII), and only such general details presented here as have been observed in connection with the process.

It is claimed by Guignard for Litium, and confirmed br Miss Thomas in Caltha, that the first male nucleus extruded from the tube pasaes to the polar nuclei. The frequently rermiform and spiral cluaracter of this nucleus has sugqesterl the possibility of independent motion; but this form is lov no means con- 
stant, and Strasburger, ${ }^{43}$ in examining the process in living material of Monotropa, demonstrated the passage of the male nucleus in the streaming protoplasm of one of the eytoplasmic strands connecting the primary endosperm nucleus or the polar nuclei with the egg-apparatus. This is confirmed by Guignard, ${ }^{53}$ who has described and figured the very small male nucleus passing down the broad cytoplasmic strand that connects the egg-apparatus with the antipodals and envelops the primary endosperm nucleus in Nigella, Damascena, Ranunculus Cymbalaria, and Anemone nemorosa, and which is doubtless true of the other Ranunculaceae. It seems probable that the male nucleus is generally carried along one of these strands ; but it is not improbable that the rermiform nuclei occasionally acquire some pover of independent motion. It is during this passage that the male nucleus may increase much in size (Thomas, ${ }^{4+}$ Ikeda ${ }^{58}$ ) and may even assume the rermiform character; although all such changes mar have oceurred before discharge from the pollen-tube, eren in the pollen-grain, as observed by Merrell ${ }^{35}$ in silphium. The male nucleus, however, may retain its small size and oval form even in contact with the polar nuclei, as observed by Guignard ${ }^{32}$ in Endymion, and by other observers since. In Juglans Karsten ${ }^{55}$ believes that in all cases the polars are fertilized before the egg; but in Nicotiana Tabacum Guignard ${ }^{56}$ reports that sometimes the egg is fertilized first and sometimes the polars, so that probably there is no definite order in the two fusions.

Every possible order in the fusion of the three nuclei has been observed, so that the triple fusion is brought about in a variety of wars. As might be expected, it is often the case that the polar nuclei have already fused when the pollen-tube enters the embro-sac, and the male nucleus unites with the fusion nucleus, as in Tricyrtis, Ranunculaceae, Datura, Erigeron, Sitphium, etc.; although eren in this case the polar nuclei mar not always lose their individuality. The two polar nuclei and the male nucleus have also been observed to fuse all together, as in Zea (Guignard ${ }^{+8}$ ) and other plants, in which the rermiform male nucleus seems to bind the polar nuclei together. In Nicotiana (Guignard ${ }^{56}$ ) the male nuclens comes in contact with either polar nucleus or both. In Lilium Martagon the male nucleus usually fuses first with the upper polar nucleus, and later the 
lower polaw nucleus enters the combination, as was also observed by Shumia ${ }^{5+}$ in Monotropa uniflora; but in Litium it has been observed that if the lower polar nucleus happens to be the more farorably placed the male nucleus fuses with it first. In Asclepias Comuti (Frye ${ }^{60}$ ) both male nuclei are vermiform and more or less curved, and one of them was observed in contact with a polar nucleus near the antipodal cells, the microprlar polar nucleus being some distance away and nearer the eggapparatus. That the male nucleus may thus traverse much of the embryo-sac is also shown in Nigella damascena and Anemone nemorosa, in both of which Guignard ${ }^{53}$ observed the male nucleus uniting with the fusion nucleus near the prominent antipodal cells.

At present there is a decided tendency among botanists and zoologists to distinguish two distinct phenomena in fertilization-namely, the stimulus to growth and the mingling of ancestral qualities. Strasburger ${ }^{43}$ regards the latter process as the essential one, and the stimulus to growth as only providing the conditions which make it possible to obtain the advantages resulting from a mingling of ancestral plasma masses. In a later paper ${ }^{59}$ he makes the statement that fluctuating variations do not furnish a starting-point for the formation of new species, but that it is the principal function of fertilization, through the mingling of ancestral plasma masses, to keep the species characters constant. The essence of fertilization lies in the union of organized elements. It was to insure this essentially generative fertilization that, in the course of phylogenetic development, the inability of the sexual cells to derelop independently became more and more marked. The term generative fertilization is used in contrast with vegetative fertilization, which is merely a stimulus to growth. Hence Strasburger regards the fusion of the male nucleus with the polar nuclei as merely regetative fertilization, and lacking the essential feature of a sexual fusion. It is worthy of note that Ernst ${ }^{61}$ finds in Paris quadrifolia and Trillium grandiflorum a striking difference between generative and regetative fertilization, the fusion of the male nucleus with the egg-nucleus being complete, so that a trpical resting nucleus is formed: while the polar nuclei begin to form spirems even before the male nucleus arrives, and in the group of three nuclei-the two polar nuclei and the male 
nucleus - three spirems are distinguishable, a ease observed also in this laboratory by Miss Laetitia Snow in Lilium philadelphicum. In such eases it is very probable that there is no union of the chromatin (Fig. 73), and it is known that in Pinus there is no fusion of the chromatin of the two sex nuclei before the
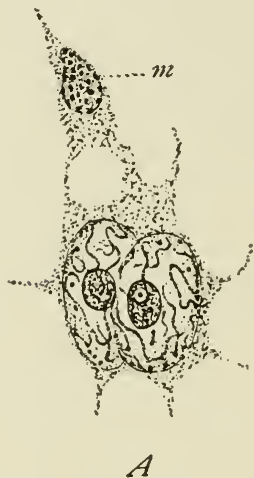

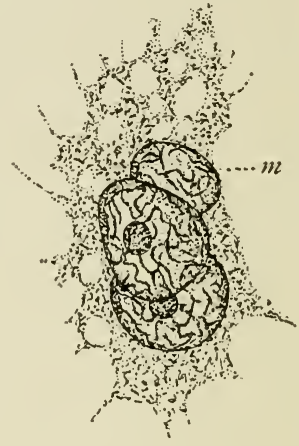

$B$

Fig. 73.-Paris quadrifolia. $A$, two polar nuclei in spirem stage; male nucleus $(m)$ shown just above; $B$, the two nuclei and male nucleus in spirem stage; $\times 1250$. After ERNst. ${ }^{61}$

binucleate stage of the proembryo is reached, and the majority of published figures show this mndition. However, Land ${ }^{38}$ describes a complete fusion of the polar nuclei of Silphium before the union with the second male nucleus.

On the whole, it is to be regretted that the phrase "double fertilization " has been applied to this phenomenon, since it is far from established that it is to be regarded as real fertilization. During this meertainty it would seem convenient and sufficient to speak of it as "triple fusion." It is also misleading to speak of the vermiform male muclei as "antherozoids" or "spermatozoids" in the sense that they are something morphologically distinet from the other male nuclei of Angiosperms. Whatever the ordinary male nuclei of Angiosperms may be these rermiform nuclei are. Probably male cells are alwars organized, and we con-iler them as morphologicalls sperm mothereells; but it is also probable that only the male nuclei become 
vermiform and take part in fusion. In preparations of Lilium we have seen a vermiform nucleus still enclosed by the crtoplasm of the male cell. It would be strange morphology to base the definition of a sperm-cell upon its form or power of independent motion.

\section{LITERATURE CITED}

1. Sснаснт, H. Entwickelungsgeschichte des Pflanzenembryon. Amsterdam. pp. 234. pls. 26. 1850.

2. Hofmeister, W. Vergleichende Untersuchungen der Keimung, Entfaltung und Fruchtbildung höherer Kryptogamen. Leipzig. 1851.

3. - Neue Beiträge zur Keuntniss der Embryobildung der Phanerogamen. Abhandl. Königl. Sächs. Gesell. Wiss. 6: 533672. pls. 1-27. 1859 .

4. Strasburger, E. Befruchtung und Zelltheilung. Jena. $187 \%$.

5. —. Die Gymnospermen und die Angiospermen. Jena. 1879.

6. Elfving, F. Studien über die Pollenkörner der Angiospermen. Jenaisch. Zeitsch. Naturwiss. 13: 1-28. 1879; Quart. Jour. Micr. Sci. 20: 19-35. 1880.

7. Ward, H. Marshall. On the Embryo-sac and Development of Gymnadenia conopsea. Quart. Jour. Micr. Sci. 20: 1-18. pls. 1-3. 1880.

8. Strasburger, E. Neue Untersuchungen über den Befruchtungsvorgang bei den Phanerogamen. Jena. 1881.

9. Barves, C. R. The Process of Fertilization in Campanula americana. Bot. Gazette 10: 349-354. pl. 10. 1885.

10. Gozbel, K. Outlines of Classification and Special Morphology. English translation. 188\%.

11. Oliver, F. W. On Sarcodes sanguinea. Annals of Botany 4: 303-326. pls. 1i-21. 1890.

12. Treub, M. Sur les Casuarinées et leur place dans le système naturel. Ann. Jard. Bot. Buitenzorg 10: 145-231. pls. 12-32. 1891.

13. Guigrard, L. Nouvelles études sur la fécondation. Ann. Sei. Nat. Bot. VII. 14: 163-296. pls, 9-18. 1891.

14. Nawaschix, S. Zur Embryobildung der Birke. Bull. Acad. Imp. Sci. St. Pétersbourg 13: $345-348$. 1892 ; reviewed in Bot. Centralbl. 54: 237. 1893.

15. Bexson, Marfaret. Contribution to the Embryology of the Amentiferae. I. Trans. Linn. Soc. Bot. London 3: 409-424. pls. 6\%-\%2. 1894.

16. Humphrey, J. E. Nucleolen und Centrosomen. Ber. Deutsch. Bot. Gesell. 12: 108-117. pl. 6. 1894. 
17. DHzbert, E. Recherches sur le sac embryonnaire des plantes grasses. Ann. Sci. Nat. Bot. VIII. 2: 3i-1:8. pls. 1-j. figs. 66 . 1896.

18. Strasburger, E. Karyokinetische Probleme. Jahrb. Wiss. Bot. 28: 151-204. pls. 2-3. 1895.

19. Canpbell, D. H. The Structure and Development of the Mosses and Ferns. London and New York. 1s95.

20. Nawaschis, S. Ein neues Beispiel der Chalazogamie. Bot. Centralbl. 63: 353-357. 1895.

21. Mottier, D. M. Contributions to the Embryology of the Ranunculaceae. Bot. Gazette 20: 241-248, 296-304. pls. 1\%-20. 1895.

22. Schaffier, J. H. The Embryo-sac of Alisma Plantago. Bot. Gazette 21: 123-132. pls. 9-10. 1896.

23. Chamberlaix, C. J. Contribution to the Life History of Salix. Bot. Gazette 23: 14i-179. pls. 12-18. 1897 .

24. Schaffyer, J. H. Contribution to the Life History of Sagittaria variabilis. Bot. Gazette 23: 252-273. pls. 20-26. 1897.

25. Collter, J. II. Contribution to the Life History of Lilium philadelphicum. Bot. Gazette 23: 412-422. pls. 32-34. 1897.

26. Mottier, D. M. Ueber das Verhalten der Kerne bei der Entwickelung des Embryosacks und die Vorgänge bei der Befruchtung. Jahrb. Wiss. Bot. 31: 125-158, pls. 2-3. 1898.

27. Coulter, J. M. Contribution to the Life History of Ranunculus. Bot. Gazette 25: 73-88. pls. 4- $\%$. 1898.

28. Suith, R. W. A Contribution to the Life History of the Pontederiaceae. Bot. Gazette 25: 324-337. pls. 19-20. 1898.

29. Lyon, Florexce M. A Contribution to the Life History of Euphorbia corollata. Bot. Gazette 25: 418-426. pls. 22-24. 1898.

30. Nawaschis, S. Ueber das Verhalten des Pollenschlauches bei der Ulme. Bull. Acad. Imp. Sci. St. Pétersbourg 8: 345-35\%. pl. 1 . 1898; reviewed in Bot. Centralbl. 77 : 26-30. 1899.

31. Zisger, N. Beiträge zur Kenntniss der weiblichen Blüthen und Inflorescenzen bei Cannabineen. Flora 85: 189-253. pls. 6-10. 1898.

32. Guignard, L. Sur les anthérozoides et la double copulation sexuelle chez les végétaux angiospermes. Compt. Rend. 128: 864871. figs. 19. 1899; Rev. Gen. Bot. 11: 129-135. pl. 1. 1899; also Les découvertes récentes sur la fécondation chez les végétaux angiospermes. Volume Jubilaire de la Société de Biologique. Paris. 1899.

33. Nawaschis, S. Resultate einer Revision der Befruchtungsvorgänge bei Lilium Martagon und Fritillaria tenella. Bull. Acad. Imp. Sci. St. Pétersbourg 9: 37т-382. 1898; reviewed in Bot. Centralbl. 78: 241-245. 1899.

34. - Neue Beobachtungen über Befruchtung bei Fritillaria tenella und Lilium Martagon. Bot. Centralbl. 77: 62. 1899. 
35. Merrell. W. D. A Contribution to the Life History of Silphium. Bot. Gazette 29: 99-133. pls. 3-10. 1900.

36. Coxrav, A. H. A Contribution to the Life History of Quercus. Bot. Gazette 29: 408-41s. pls. 28-29. 1900.

37. Johxsos, D. S. On the Endosperm and Embryo of Peperomia pellucida. Bot. Gazette 30: 1-11. pl. 1. 1900.

38. LAxD, IV. J. G. Double Fertilization in Compositae. Bot. Gazette 30: 252-260. pls. 15-16. 1900.

39. Guigrard. L. Lappareil sexuel et la double fécondation dans les Tulipes. Ann. Sci. Nat. Bot. VIII. 11: 365-38\%. pls. 9-11. 1900 .

40. Nawaschix, S. Ueber die Befruchtungsrorgänge bei einigen Dicotyledoneen. Ber. Deutsch. Bot. Gesell. 18: 294-230. pl. 9. 1900.

41. Pirotta, R. and Loxgo, B. Basigamia, mesogamia, acrogamia. Atti R. Accad. Lincei T. 9: 296-298. 1900; Bot. Centralbl. 86 : 93. 1901.

42. GuigraRD, L. Nouvelles recherches sur la double fécoudation chez les Phanerogames angiospermes. Compt. Rend. 131: 153160. 1900 .

43. Strasblrger, E. Einige Bemerkungen zur Frage nach der " doppelten Befruchtung " bei den Angiospermen. Bot. Zeit. 58: 293316. 1900.

44. Thomas, Ethel M. On the Presence of Vermiform Nuclei in a Dicotyledon. Annals of Botans 14: 318-319. 1900.

45. - Double Fertilization in a Dicotyledon-Caltha palustris. Annals of Botany 14: 527-535. 1,l. $\$ 0.1900$.

46. SARgaxt. Ethel. Recent Work on the Results of Fertilization in Angiosperms. Annals of Botany 14: 6s9- 12.1900.

47. BERxard, C. H. Recherches sur les sphères attractives chez Lilium condidım, etc. Jour. Botanique 14: 118-12t, 17-1ธง, 206-212. pls. $4-5.1900$.

48. Gigrard. L. La double fécondation dans le mais. Jour. Botanique 15: $3 \tilde{\tau}-50.1901$.

49. Losgo, B. La mesogamia nella commune zucca (Cucurbita Pepo Linn.). Rend. R. Accad. Lincei 10: 16s-1\%2. 1901.

50. Mrrbeck, S. Ueber das Terhalten des Pollenschlauches bei $A l$ chemilla arrensis und das Wesen der Chalazogamie. Lunds Univ. Arsskrift 36: pp. 19. pls. 2. 1901.

51. Schaffier, J. H. A Contribution to the Life History and Cytology of Erythromium. Bot. Gazette 31: 369-357. pls. 4-9. 1901.

52. Grigrard, L. Sur la clouble fécondation chez les Solanées et les Gentianées. Compt. Rend. 133: 126s-12:2. 1901.

53. - Double fécondation chez les Ranonculacées. Jour. Botanique 15: 394-40s. figs. 16. 1901.

54. Shibata. K. Die Doppelbefruchtung bei Monotropa uniflora L. Flora 90: 61-66. 1902. 
55. Karstex, G. Ueber die Entwickelung der weiblichen Blüthen bei einigen Juglandaceen. Flora 90 : 316-333. pl. 12. 1902.

59. Guignard, L. La double fécondation chez les Solanées. Jour. Botanique 16: 145-16\%. figs. 45. 1902.

57. HaLL, J. G. An Embryological Study of Limnocharis emarginata. Bot. Gazette 33: 214-219. pl.9. 1902.

58. Ineda, T. Studies in the Physiological Functions of Antipodals and Related Phenomena of Fertilization in Liliaceae. 1. Tricyrtis hirta. Bull. Coll. Agric. Inp. Univ. Tokyo 5: 41-72. pls. 3-6. 1902.

59. Strasburger, E. Ein Beitrag zur Kenntniss von Ceratophyllum. submersum und phylogenetische Erörterungen. Jahrb. Wiss. Bot. 37: 477-526. pls. 9-11. 1902.

60. Frye, T. C. A Morphological Study of Certain Asclepiadaceae. Bot. Gazette 34: 389-413. pls. 13-15. 1902.

61. Ensst, A. Chromosomenreduction, Entwickelung des Embryosackes und Befruchtung bei Paris quadrifolia L. und Trillium. grandiflorum Salisb. Flora 91: 1-46. pls. 1-6. 1902.

62. Shommaker, D. N. Notes on the Development of Hamamelis virginiana L. Johns Hopkins Univ. Circ. 21: 86-87. 1902.

63. Juel, H. O. Zur Entwicklungsgeschichte des Samens von Cynomorium. Beih. Bot. Centralbl. 13: 194-202. figs. 5. 1902.

64. Guignard, L. La double Fécondation chez les Crucifères. Jour. Botanique 16: 361-368. figs. 20. 1902.

65. Shibata, K. Experimentelle Studien über die Entwickelung des Endosperms bei Monotropa. (Vorläufige Mitteilung) Biol. Centralbl. 22: 705-714. 1902.

66. Billings, F. H. Chalazogamy in Carya olivaeformis. Bot. Gazette 35: 134-135. 1903.

67. Wylie, R. B. A Morphological Study of Elodea canadensis. To be published in Bot. Gazette 36: 1903.

68. Frye, T. C. The Embryo-sac of Casuarina stricta. To be published in Bot. Gazette 35: 1903. 


\section{CHAPTER VIII}

\section{THE ENDOSPERM}

ThE endosperm of Grmnosperms seems to be clearly the vegetative tissue of the female gametophyte, but the morphological nature of the endosperm of Angiosperms (Fig. 74) is not so clear. The germination of the megaspore begins, as in Gymnosperms, with free and simultaneous nuclear division. In Gymnosperms this continues for some time and is replaced by cell-formation, giving rise to an extensive tissue bearing archegonia, while in Angiosperms usually only eight free nuclei are formed before an egg is organized and fertilization takes place. In both cases endosperm is formed
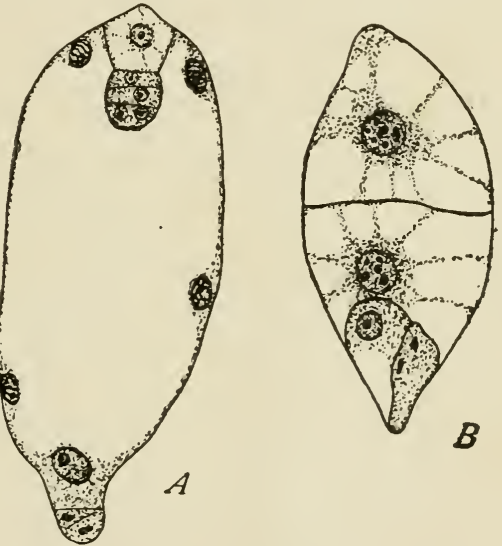

Fic. 74.-Two modes of initiating the formation of endosperm. A, Naias major, illustrating free nuclear division; there are four free nuclei belonging to the endosperm, the lower free nucleus being that of the upper antipodal ; $\times 175 . \quad B$, Datura laevis, nuclear division followed immediately by formation of wall ; $\times 225 .-$ After GLIGNARD،2, 48

after fertilization; but in Gymnosperms it is a continuation of cell division, while in Angiosperms it usually begins with muclear fusion followed by simultaneous and often free nuclear 
dirision. This nuclear fusion is one of the most striking features of the Angiosperms as contrasted with Gymnosperms, and especially since the discorery of so-called "double-fertilization" the morphological character of the endosperm of Angiosperns is in question. For this reason, we have preferred to discuss it apart from the gametophytic structures concerning which there is no question.

As has been said, the endosperm of Angiosperms is usually derived from a fusion nuclens, the constituent members being the micropylar polar nuclens, sister to the egg, and the antipodal polar nucleus. If the current homologies are true, this fusion is that of a female and a regetative nucleus. In many cases a male nucleus also joins in the structure of the primary endosperm nuclens, which is then the result of a triple fusion (Figs. 36, $I I$, and $71-73$ ). How far this male molens is an essential factor in the formation of the endosperm of Angiosperms is at present unknown, but the rapidly increasing number of plants in which triple fusion has been obserred leads to the belief that it may be of general occurrence. It should also bs remembered that in Peperomia pellucida (Johnson ${ }^{31}$ ) (Fig. 3s) the primary endosperm nucleus is the result of the fusion of no less than eight of the sixteen free nuclei of the embrrosac: and that in Crunnera (Schnegg ${ }^{4 \bar{i}}$ ) (Fig. 39) the same sort of multiple fusion occurs. The fusion-nucleus, therefore, mar be made up of a rariable number of constituents of rarious morphological character, and hence the significance of the fusion and the nature of the resulting tissue are peculiarly difficult to interpret.

While the fusion of these nuclei seems to result in what has been called a growth-stimulus, endosperm is sometines formed without any antecedent fusion. For example, in Balanophora (Treub, ${ }^{16}$ Lots ${ }^{26}$ ), the polar nuclei do not fuse, but divide independently, the embrco-sac becoming filled with endosperm tissue: and in Helosis (Chodat and Bernard ${ }^{33}$ ) after the first divi-ion of the nucleus of the megaspore the chalazal nucleudisintegrates so that antipodal cells, and hence an antipodal polar nuclens, are not formed, the endosperm being derived entirels from the micropylar polar nucleus. In Antennaria alpina Juel 22 found that the polar nuclei do not fuse, although they behare normally in $A$. dioica, as the same investigator ${ }^{35}$ has 
observed. In Lemna Caldwell ${ }^{2+}$ states that often the polar nuclei do not fuse, in which case he observed that the micropylar polar produced some free endosperm nuclei, and probably the antipodal one also. In Limnocharis, one of the Alismaceae, there is also no fusion ( Hall ${ }^{50}$ ), since no antipodal polar nucleus is formed, and all the endosperm, which eventually fills the sac, is derived fiom the micropslar polar nucleus. In Casuarina, according to Treub, ${ }^{12}$ there are no antipodals or polar nuclei, and the endosperm is formed before fertilization and independently of any fusion (Fig. $6 \tau, B)$. It should be stated, however, that in a recent study of Casuarina by Frye ${ }^{59}$ abundant endosperm was found before the first division of the egg, but probably not before fertilization. For example, the same investigator ${ }^{56}$ found in Asclepias sixteen and thirty-two endosperm nuclei before the first division of the egg, but not before fertilization (Fig. 75). In Piper and Heckeria the development of endosperm before the first division of the fertilized egg is even more extensive. Johnson ${ }^{55}$ represents twenty-two endosperm cells in a single section of Piper (Fig. 76) and the egg has not yet dirided. Not a little confusion has arisen by assuming that fertilization and the first division of the egg are

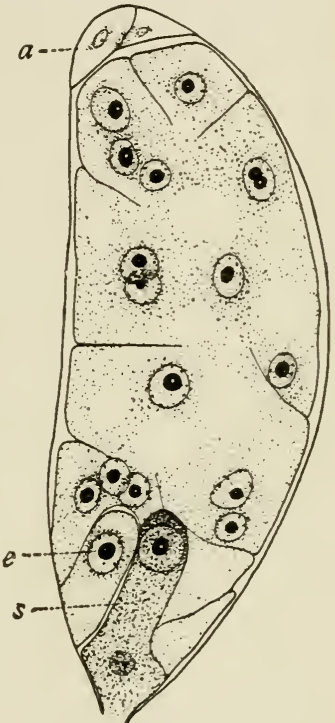

Fı. 75.-Asclepias Cornuti. Large development of endosperm before division of fertilized egg : $a$, antipodals; $e$, egy: 8 , synergids; $\times$ 750.-After FRY. 68 practically simultaneous. In any event, the formation of endosperm without antecedent fusion is clear enough in some cases, and indicates that while fusion usually serves to stimulate growth and cell division it is not an absolute prerequisite. In certain orchids Nawaschin ${ }^{36}$ states that the polar nuclei do not fuse, but in this case no endosperm is formerl.

In this connection the experiments of Shibata ${ }^{57}$ on Mono- 

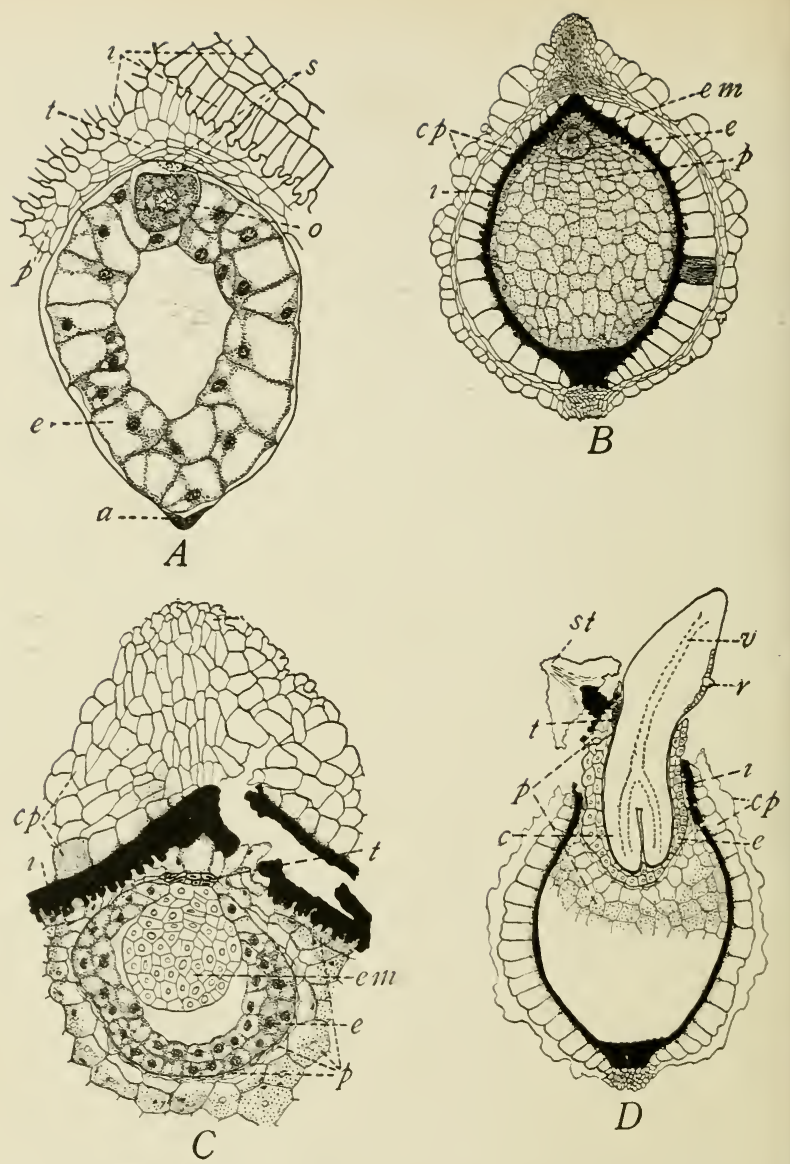

Frg. 76.-A, Piper medium, showing extensive development of endosperm before first division of fertilized egg: $\times 175 ; B-D$. Peperomia pellucida : $B$. longitudinal section of ripe seed, showing the small embryo, seanty endosperm, and abmidant perisperm; $\times 55 ; C$, terminal portion of a similar section at an early stage of germination; $\times 175 ; D$, longitudinal section of a germinating seed, showing the endosperm protruding with the embryo: $\times 55: a$, antipodals : $c$, eotyledons: $c p$, carpellary tissue; $e$, endosperm ; em, embryo: $i$, integument ; 0 , oosphere; $p$, perisperm ; $r$, rhizoid ; $s$, synergid ; st, stigma; $t$, tapetal cells.-After Jouxsox.ss 
tropa uniflora are of interest. In this case the polar nuclei may fuse in the absence of pollination, but the fusion may be hastened or regulated by pollination. In normal cases fusion of polar nuclei oecurs about five days after pollination, but when pollination is prevented the interval may be prolonged to ten days or even longer. Development of the endosperm was also induced experimentally in the absence of fertilization. When pollination is prevented, many of the ovules die within two or three weeks, hut in others the sac enlarges and beeomes filled with endosperm. This development of endosperm was observed in from three to five per cent of the orules, but at a temperature of $2 s^{\circ} \mathrm{C}$., or by using osmotic solutions, endosperm was developed by from six to twelve per cent of the seeds.

If a fusion nucleus is formed, as is certainly generally the case, it usually begins to divide before the fertilized $\mathrm{eg} g$ and with much greater rapidity. After fertilization, the egg usually seems to rest for a period while free endosperm nuelei are being formed. For example, among the Ranunculaceae (Guignard ${ }^{43}$ ) and in $A s$ clepias (Frye ${ }^{i 6}$ ) free en-


Fı. 77.-Erigeron philadelphicus. Longitudinal sections of embryo-sac after fertilization. $A$, fertilized egg dividing before primary endosperın nucleus; $B$, primary endosperm nucleus dividing before egg; $\times 550 .-$ After LAND. ${ }^{92}$ dosperm nimelei are scattered throngh the sac before the egg diviles. Put there is every gradation from an approximately :imultaneons division of primary endosperm nucleus and fertilized egg, as usually in Sagittaria (Schaffner ${ }^{18}$ ), Lilium (Coulter ${ }^{19}$ ), Nelumbo (Lxon $\left.{ }^{45}\right)$, Sarcodes (Oliver $\left.{ }^{11}\right)$, Senecio (Mottier ${ }^{15}$ ), and Erigeron (Land ${ }^{32}$ ) (Fig. $7 \%$ ), in which last alse sometimes the ego and sometimes the primary endosperm nucleus divides first, to a sac almost or even completely filled with 
endosperm before the fertilized egg seginents, as in Gonyanthes candida (Treub ${ }^{\mathbf{7}}$ ), Heckeria (Johnson ${ }^{\mathbf{5 5}}$ ), the Stylidaceae (Burns ${ }^{28}$ ), and A phyllon uniflorum (Smith ${ }^{46}$ ). Even though the primary endosperm nucleus and the fertilized egg divide simultaneously, the much more rapid divisions of the former result in numerous free endosperm nuclei before the first few segmentations of the egg have been completed.

In the cases just cited, in which the segmentation of the primary endosperm nucleus precedes that of the fertilized egg, the division does not begin until after fertilization, and probably this is true in the majority of plants. As a consequence, the impression is current that the act of fertilization is an essential stimulus to the division of the primary endosperm nucleus; and there seems to be no clear evidence to the contrary when fertilization occurs, unless it be the case of Ranunculus, as reported by Coulter, ${ }^{20}$ in which free endosperm nuclei were sometimes observed scattered through the embryo-sac before the entrance of the pollen-tube. To this same category belong those cases of habitual failure of fertilization in which endosperm formation may occur, as in the Balanophoraceae, Antennaria alpina (Juel ${ }^{22}$ ), Thalictrum purpurascens (Overton ${ }^{51}$ ), Eichhornia crassipes ( $S m i t h{ }^{21}$ ), etc. It seems to be very rare for the fertilized egg to divide before the primary endosperm nucleus, but in Naias major, in which triple fusion occurs, Guignard ${ }^{42}$ has observed that the fertilized egg divides immediately, and has figured a two-celled embryo by the side of a primary endosperm nucleus in the spirem stage. It is important to note also that in this same species Guignard observed that the male nucleus may fuse with the persistent synergid instead of with the primary endosperm nucleus, in which case there is no endosperm, but a second embryo (Fig. 103). Many cases of two embryos lying side by side with an " unfertilized" primary endosperm nucleus between them were observed. Recently Wylie ${ }^{60}$ has observed that in Elodea also the fertilized egg divides before the primary endosperm nucleus.

It is evident that the beginning of endosperm formation does not depend absolutely upon any of the causes usually assigned; and that while it is in general approximately coincident with the segmentation of the fertilized egg, this is merely a coincidence, for it may be independent of fertilization and 
even of fusion. Ordinarily it must be dependent upon polar fusion, and in some cases upon triple fusion, as indieated by the Lchavior in Naias cited above; but in the failure of these, other conditions may cause nuelear division and the formation of endosperm.

While in the majority of plants the endosperm may be regarded as fully developed, either to remain as a permanent tissue of the seed or to be more or less resorbed by the growing embryo, there are certain plants in which it is abortive or even suppressed. It consists of only a few scattered nuelei, or at most of a parietal layer of free nnelei, in Naiadaceae, most Alismaceae, Juneagineae, and Hydrocharitaeeae, all of which belong to the Helobiales among Monocotyledons. The tendency of the endosperm to become abortive in this particular alliance is evidently very strong, although, as Hall ${ }^{50}$ has shown in Limnocharis, the endosperm may finally develop and become packed about the embryo. With the exception of the Helobiales, disappearance of the endosperm seems to be very rare, having been reported in Tropaeolum and Trapa; and among the Orchidaceae the endosperm seems to be entirely suppressed, the polar nuclei, as a rule, neither fusing nor dividing.

Humphrey ${ }^{17}$ has ealled attention to what he calls a progressive series in the development of the endosperm anong the Scitamineae, but which seems to be best interpreted as a retrogressive series. In the Musaceae an abundant starch-bearing endosperm either fills the sac (IIeliconia) or nearly so (Strelitzia), the peripheral cells often forming an aleurone layer; in Zingiberaceae (Costus) the endosperm is several layers thick in the lower part of the sac and only aleurone-bearing; in Cannaceae $(C$. indica) the endosperm is a single aleurone-bearing layer lining the sac; while in Marantaceae (Thalia dealbata) the endosperm is probably not represented at all in the mature seed.

Strasburger ${ }^{4}$ has called attention to the two general methods of endosperm formation among Angiosperms. In the majority of plants observerl it begins with free nuclear division; but in many cases, chiefly among Dicotyledons, the first division of the primary endosperm nucleus is accompanied by a wall dividing the sac into two chambers (Fig. 74). While these two methods of initiating endosperm formation are quite dif- 
ferent, the subsequent stages of endosperm derelopment result in all kinds of intergrading conditions, as will be shown later. Even when the endosperm begins with free nuclear division, a rudimentary plate often appears, suggesting derivation from an endosperm in which nuclear division was followed by cellformation.

The history of the development of endosperm initiated br free nuclear division is nearly identical, in niost cases, with the history of the female gametophyte in Gymnosperms, modified, of course, by the presence of a developing embryo. It is an interesting fact, also, that the early stages in the development of the endosperm bear a striking resemblance to early stages in the derelopment of the embryo of Creadales and some other Gymnosperms. There is the same simultaneous nuclear division, often the parietal placing, and later the appearance of cell walls.

The primary endosperm nucleus, usually in contact with the egg, or nearly so, divides, and subsequent divisions follow with great rapidity, Guignard ${ }^{* 1}$ remarking that in Zea he was unable to follow the course of division, and other observers calling attention not only to the great rapidity with which one set of divisions is followed by another, but also to their simultaneous character. A common form of statement is that at first the free nuclei remain for a time in the ricinity of the $\mathrm{egg}$, but sooner or later migrate in every direction towarl the wall of the embryo-sac, where they become equally distributed and embedded in a lining crtoplasmic laver. The real fact, however, is that this apparent movement of the nuclei is due to the rapid enlargement of the sac, the cytoplasm becoming more and more vacnolate and finally occurring chiefly as a wall laver. $\mathrm{By}$ this increasing raculation the nuclei are naturally driven to the wall. In this parietal position free nuclear division continues, until finally walls are formed and a layer of parietal cells is organizcd.

These first walls usually " cut out" only one nucleus in each cell, but in some cases (Corydalis cava, Staphylea pinnata, Armeria rulgaris, ete.) Strasburger ${ }^{t}$ noted that two to four nuclei might be enclosed by a cell wall. but that they afterward fuse to form a single nucleus (Fig. 7s). Tischler ${ }^{38}$ has recently recxamined Corydalis cava and states that when septa 
appear many nuclei are always enclosed in each cell and subsequently fuse. In this particular case the free nuclear divisions are often irregular, and of course the number of chromosomes is exceedingly variable, a fact very common in all endo-
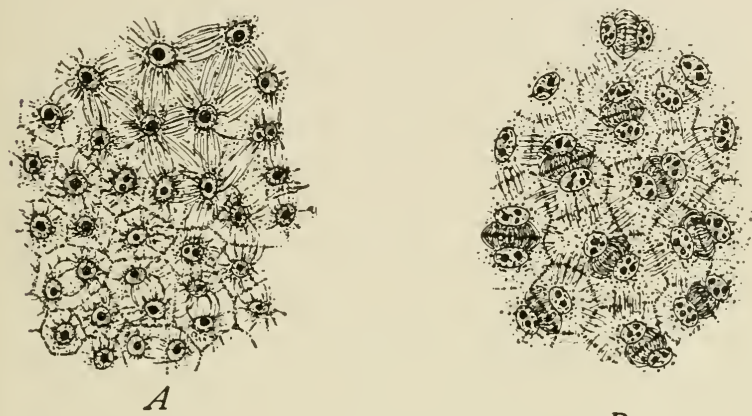

\section{B}


Fig. 78.-Advanced stages in development of endosperm. A, Reseda odorata, upper part of tigure showing frce nuclear division, while in lower part nuclear division is accompanied by formation of cell walls; $\times 860 ; B$, Caltha palustris, showing all nuclear divisions accompanied by formation of walls, $\times 155 ; C$, Corydalis cava, showing free nuclear division within cells of endosperm; $D$, the same, showing multinucleate endosperm; $\times 860$. -A fter STRAsBtrger. ${ }^{4}$

sperm. The same phenomenon was observed by Humphrey ${ }^{17}$ in Canna indica, in which the parietal laver of free nuclei becomes blocked out by walls, each "block" containing several 
nuclei that apparently fuse into one. The irregular and usually large number of chromosomes found in the nuclei of endosperm tissue is doubtless due to "double fertilization" and other nuclear fusions.

The parietal plate of cells by division gradually encroaches upon the general cavity of the embryo-sac, either filling it up compactly about the embryo, or leaving more or less of a carity containing cell sap, which in the coconut becomes of extraordinary size.

In many cases a fully developed endosperm is more or less displaced by the growing embryo, so that in the mature seed it may be mich reduced or even obliterated. Among the Monocotyledons the embryo of the Gramineae is at first completely invested by endosperm, but becomes eccentric by displacing it on one side; and the embryo in some Araceae finally replaces all the endosperm; but for the most part the Nonocotyledons are characterized by retaining the endosperm in the mature seed. Among the Dicotyledons, however, it is characteristic of certain families, among the important ones being Cupuliferae, Leguminosae, Cucurbitaceae, and Compositae, for the embryo to have entirely displaced the endosperm at the maturity of the seed, the gain in size being almost entirely in the cotyledons. It must not be supposed that in all cases the formation of endosperm continues from the first free molear division to a tissue filling the embryo-sac. Illustrations conld be introduced showing a cessation of endosperm formation at every stage. It may stop with a few free nuclei, or with the parietal placing of free nuclei, or with a parietal plate of tissue. An interesting case is that of Tricyrtis (Liliaceae), recently described by Ikeda, ${ }^{54}$ in which free endosperm nuclei are distributed through a sac full of cytoplasm, and assume very irregular and bizarre forms, the parietal position never being assumed.

The second general method of endosperm formationnamely, that in which the first division of the primary endosperm nucleus is accompanied by a wall dividing the sac into two chambers-is found chiefly among Dicotyledons, and among them it is especially characteristic of saprophytic and parasitic forms, Cuscuta being a marked exception in that its endosperm begins with free nuclear division. Usually the wall divides the sac into two approximately equal chambers, but naturally the 
relative size of the chambers depends upon the position of the dividing nucleus (Fig. 74).

Among Monocotyledons, the endosperm of Sagittaria (Schaffner ${ }^{18}$ ) develops rapidly in the micropylar chamber into a walled tissue, the endosperm nucleus of the antipodal chamber enlarging much but not dividing for a long time, when two or three nuclei may be formed, all of them increasing greatly (Fig. 79). Practically the same thing occurs in Limnocharis (Hall ${ }^{50}$ ), but the nucleus of the antipodal chamber enlarges without dividing. In Ruppia rostellata (Murbeck ${ }^{58}$ ) a

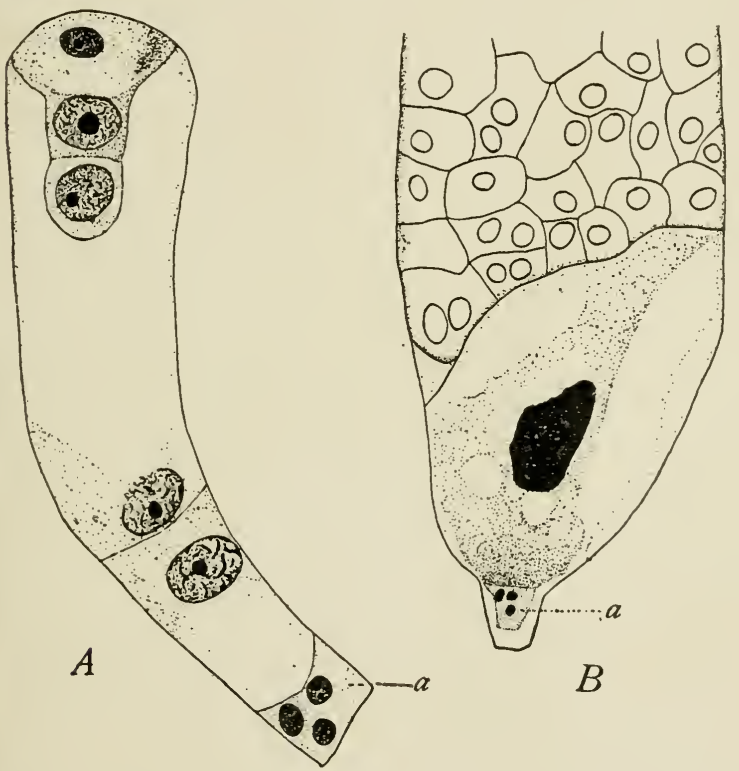

F16. 79.-Sagittaria variabilis. A, two nuclei of endosperm separated by wall : $a$, antipodals, $\times 200 ; B$, compact endosperm tissue developed from upper cell, the lower merely growing large without dividing; $\times$ 108.-After SCHAFFNER. ${ }^{18}$

wall is formed at the first division of the endosperm nucleus, the antipodal chamber remaining small and with undividing nucleus, but a large number of free nuclei being formed in the micro- 
pylar chamber. In Potamogeton (Holferty ${ }^{+4}$ ) the endosperm is dereloped only as a parietal layer of free muclei; but all of these seem to have come from the micropylar endosperm-cell of the first division, the lower one becoming very large but not dividing, a tendency similar to that in Sagittaria and Limnocharis, but without the formation of a transverse wall in the sac.

Among the Dicotyledons instances of a chambered embryosac are numerous. Hofmeister ${ }^{1}$ has given a long list of them, and these, with others added since, are approximately as follows: Among the Archichlamydeae they are the Saururaceae, Loranthaceae, Balanophoraceae, Santalaceae, Aristolochiaceae, Nrmphaeaceae, Ceratophyllaceae, Loasaceae, a list composed in the main of primitive or saprophytic and parasitic forms. In fact, the chambered sac is distinctly lacking in the more important and characteristic groups of the Archichlamydeae. Among the Sympetalae, chambered sacs occur in the Prrolaceae, Monotropaceae, Vacciniaceae, Hydrophyllaceae (Temophila), Solanaceae, Verbenaceae, Selaginaceae, Labiatae, Scrophulariaceae, Orobanchaceae, Bignoniaceae, Pedaliaceae, Acanthaceae, Plantaginaceae, and Campanulaceae. Although most largely represented among Srmpetalae, it will be noted that chambered sacs occur chiefly in saprophytic or parasitic forms, and among the Personales. The phenomenon seems thus to be associated with peculiar conditions of nutrition or a certain configuration of the embryo-sac.

In the case of two-chambered sacs among Dicotrledons, it does not seem to be common for endosperm to form in both chambers, although this is reported to be the case in Balanophoraceae, Aristolochiaceae, Pyrolaceae, and Monotropaceae. In the majority of cases the endosperm derelops only in the micropylar chamber, in connection with the embryo, as in Saururaceae, Tiscum (Loranthaceae), Santalaceae, Xrmphaeaceae, Globularia (Selaginaceae), Scrophulariaceae, and Orohanchaceae. In saururus (.Johnson ${ }^{34}$ ) the embryo-sac is flask-shaped, the wall cutting off the neck from the large venter, and the endosperm developing only in the former. In Nymphaca and Nuphar (Cook ${ }^{52}$ ) the endosperm derelops only in the micropylar chamber, while the antipodal chamber extends as an hanstorial tube to the chalazal extremity of the ovule. It is of interest to note that until Cook's work the endosperm of these genera was 
said to begin with free nuclear division, followed by a wall cutting off the micropylar end of the sac; and the same statement in reference to C'eratophyllum has been disproved recently by Strasburger. ${ }^{49}$ 'The endosper'm is said to develop only in the antipodal chamber in Lorunthus, Yacciniaceae, Verbenaceae, Mebenstreitia (Selaginaceae), Bignoniaceae, and Acanthaceae. In Trapella (Oliver ${ }^{10}$ ), a genus of the Pedaliaceae, although the sac is not chambered by a wall, the endosperm develops only in the lower two-thirds, a sort of diaphragm of thick-walled endosperm-cells cutting off the broad micropylar end of the sac.
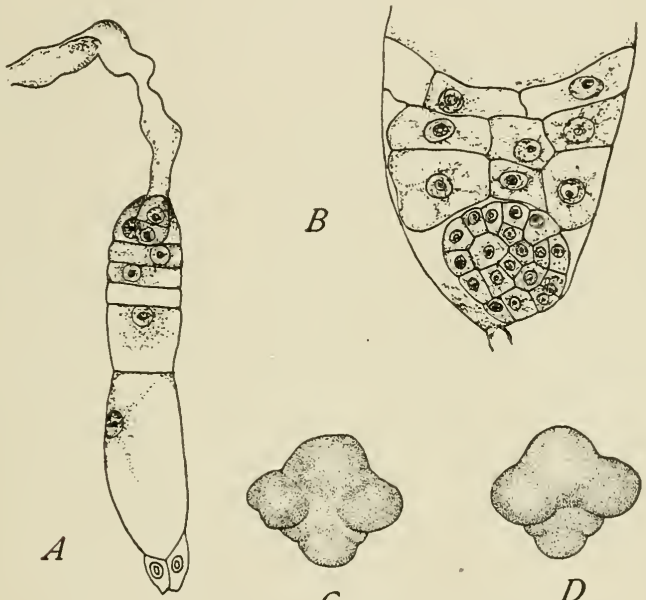

Fig. 80.-Ceratophyllum submersum. Development of endosperm and embryo. $A$, first division of embryo, six cells in endosperm $; \times 250 ; B$, embryo and endosperm more advanced; $\times 250 ; C$-D, entire embryo seen from opposite sides, $C$ showing the two cotyledons separate and $I /$ nearly united ; $\times$ 50.-After Strasburgen..40

Cases are also known in which more than two chambers are formed in the embryo-sac and followed by ordinary cell-formation. For example, in Ceratophyllum (Strasburger ${ }^{49}$ ) at the first division of the primary endosperm nuclens the sac is divided into two approximately equal chambers. The nucleus in the antipodal chamber does not divide again, but at the next division in the micropylar chamber another wall across the sac 
is formed, so that there are three superposed chambers, and only in the one nearest the micropyle does division proceed. As a result, a dense, small-celled tissue is formed near the embryo (Fig. $\$ 0$ ). In Datura laevis (Guignard ${ }^{48}$ ), after the first division into two chambers (Fig. 74), transverse walls are formed in each, resulting in four superposed chambers in which further division proceeds in rarious planes.

There are also cases in which each division of an endosperm nucleus is accompanied by a transverse wall across the sae, as in Sarcodes (Oliver ${ }^{11}$ ), in which the mature sac is severalchambered by a series of delicate transverse walls. The same is doubtless true of Pistia, whose narrow sac contains a row of broad discoid endosperm-cells that lie like transverse chambers. One of the most exceptional cases of wall-formation, however, is that of Peperomia pellucida (Johnson ${ }^{31}$ ), in which the first division of the very large primary endosperm nucleus, formed by the fusion of eight nuclei, is followed by a wall from the fertilized egg to the base of the sac, further divisions following until the sac is packed with forty or more endosperm-cells. In a recent study of Heckeria also, one of the Piperaceae, the same investigator ${ }^{55}$ has found the same general condition as in Peperomia, in that the endosperm is "cellular" from the first, filling the sac before the egg divides. It is worthy of note that the endosperm of Piper (Johnson ${ }^{55}$ ), on the other hand, begins with free nuclear division. It is evident from these differences in closely related genera, also noted by Hofmeister ${ }^{2}$ and Hegelmaier. ${ }^{8}$ that methods of endosperm formation ean not indicate relationship.

The mature and permanent endosperm is a tissue with no intercelhular spaces, whose cells are either thin-walled, forming an endosperm of delicate texture, or thick-walled, resulting in a horny endosperm, as in palms, umbellifers, etc. In case the thickening of the walls becomes excessive, the endosperm is stony, as in Phytelephas, the palm whose seeds furnish the so-called "regetable ivory."

The endosperm has sometimes been observed to continue its growth after it has filled the sac. Hofmeister describes the endosperm of Crinum capense and some other Amaryllidaceae as bursting the seed-coats, and even the orary wall, the cells developing chlorophyll, and the tissue remaining succulent and form- 
ing intercellular spaces. A similar extensive growth and escape of the endosperm is reported to occur during the germination of the seeds of Ricinus. In the germination of the seeds of certain Piperaceae (Peperomia and Heckeria) Johnson ${ }^{53,55}$ has described the endosperm as bursting out of the seed-coat, and continuing to jacket the embryo, which at germination is a globular undifferentiated mass of cells, until the root, hypocotyl, and cotyledons are organized. In the same papers Johnson calls attention to the fact that the endosperm of these Piperaceae is not a storage region, but digests, absorbs, and passes on food material to the embryo from the much more abundant perisperm, which is the real storage tissue. This restriction of the function of the endosperm Johnson ${ }^{34}$ had already pointed out in Saururus, and suggests the probability that this same relation between endosperm and perisperm obtains in all seeds with abundant perisperm as in Polygonaceae, Chenopodiaceae, Phytolaceaceae, Caryophyllaceae, ete. The following quotation ${ }^{55}$ will serve to make plain the author's point of view:

"Observations thus far made lead me to believe that in the perisperm-containing seeds mentioned the embryo sporophyte of the second generation is never nourished by the parent sporophyte directly, but always through the intermediate gametophyte. In general, then, we find that the food substance supplied to the embryo by the nucellus may pass through the endosperm and be stored in the embryo during the ripening of the seed, as in Cucurbita and Phaseolus; or, secondly, the food may be stopped in transit between the nucellus and the embryo and stored in the endosperm, there to be held during the resting period of the seed and delivered over to the embryo only at the time of sprouting, as in Ricinus, Zea, and apparently all Gymnosperms ; or, finally, the food supply for the developing embryo may be stored in the nucellus itself until the time of germination, when it is passed on to the embryo through the endosperm, as in Saururus, Peperomia, Phyto. lacca, Canna, and others."

The phenomenon of xenia has a direct bearing upon any discussion of the endosperm. The name was applied by Focke, ${ }^{5}$ in 1881 , to the direct effect of pollen on seeds and fruits ontside of the embryo, as shown in hybrids. The ease of peas has long been cited, but Giltay ${ }^{14}$ has shown that the effeets referred to occur in the cotyledons, and therefore can not be considered as xenia. So far as definitely known, the effect of foreign pollen outside of the embryo is observed only in the endosperm, 
as first pointed out by Körnicke, ${ }^{3}$ and this has been most clearly established in the crossing of races of corn. It also appears that this influence of foreign pollen extends only to the color of the endosperm and the chemical composition of the reserve materials, the size and form of the kernels remaining unchanged, as stated by Correns. ${ }^{25}$ For example, if white or yellow corn be crossed with pollen from a red corn, many of the lesulting kernels will be red or variously mottled; or if sweet corn, with its wrinkled and sugary endosperm, be crossed with pollen from dent or flint corn, the result is smooth kernels with starchy endosperm.

The possibility of such a direct effect of pollen was for a long time questioned, and the phenomenon remained inexplicable. With the discovery of "double fertilization" or triple fusion by Nawaschin 23 in 1898, the explanation of xenia occurred simultaneously and independently to Correns, ${ }^{25} \mathrm{De}$ Vries, ${ }^{27}$ and Webber, ${ }^{40}$ the paper of the last investigator being a very complete résumé and discussion of the subject based upon his own extensive experimental work. To claim that the phenomenon of xenia, as observed in corn, is due to the fusion of one of the male nuclei with the primary endosperm nucleus was an assumption, although an irresistible one, until such fusion was demonstrated by Guignard ${ }^{41}$ in 1901 . It has been proved repeatedly that when xenia ocenrs the embryo is a hybrid, so that we have in xenia not only a hybrid endosperm, but a gross demonstration of the oceurrence and effect of the triple fusion, and also an indication of the sort of eharacters that can be brought into a structure by a male nucleus.

In many cases of xenia following the erossing of races of different colors, the kernels are not of uniform color, but are parti-colored or varionsly mottled. The ingenious explanation suggested by Webber is that the male nucleus has failed to mite with the fusion-mucleus and may be able to divide independently. If so, there would result two cell-races of different characters that might be variously arranged with reference to one another in the endosperm. It is entirely conceivable that under favorable conditions of nutrition and phrsical environment an independent male nuelens may hegin divisions, especially as this has been observed in the case of certain animals; but it seems more probable that the independent appearance of 
these racial characters is due to the incompleteness of the trir fusion, snce it is well known that division of the primary es sperm nucleus often begins before the constituent nuclei nave lost their identity. In fact, Webber calls attention to the beginning of division before complete fusion in the case of the eggs of certain animals, and the same is true of the sexual fusionmucleus of some Grmnosperms. An alternative hypothesis suggested by Webber is that the male nucleus may fuse with one of the polar nuclei, the other remaining independent and dividing. These hypotheses are valuable in suggesting investigation as to whether the male nucleus ever divides independently in the embryo-sac, or whether it may unite with one polar nucleus, the other dividing independently.

It remains to consider the morphological character of the endosperm of Angiosperms. In view of the details as to its origin and beliavior given above, it is evident that it is a structure peculiarly difficult to interpret. The view has long been held, dating from Hofmeister, that the endosperm is belated regetative tissue of the female gametophyte, stimulated in a general way to develop by the act of fertilization, and in every way the morphological equivalent of the structure bearing the same name among Gymnosperms. Strasburger ${ }^{37}$ has suggested that this postponement of the formation of endosperm is of advantage in avoiding the waste that would follow its formation and separation from the parent plant with every unfertilized ovule. Of course the serious difficulty in this view of the nature of the endosperm was that it offered no historical explanation of the fusion of the polar nuclei. It conld only elaim that fusions of regetative nuclei, evidently resulting in growthstimulus, are by no means unknown, and in fact oecur in the endosperm itself. This riew does not appear to have been seriously disturbed by the claim of Le Monnier ${ }^{9}$ in $188 \%$, that the fusion of the polar nuclei is a sexual process, and that therefore the endosperm is a second embryo modified to serve as food tissue.

With the discovery of the fact that, at least in many cases, a male nucleus enters into the organization of the primary endosperm nucleus, the old view has been seriously menaced. The commonly used phrases "double fertilization" and "double fecundation" indicate general consent to the riew that this 
$f$ the male nucleus is a case of true fertilization, the inference weing that the endosperm is a second embryo or sporophyte, as Le Monnier had suggested.

Strasburger ${ }^{37}$ in discussing the whole subject concludes that the triple fusion is not real fertilization. Of course in such a discussion much depends upon the definition of fertilization. Strasburger distinguishes between "generative fertilization" and "regetative fertilization," the former being a definite union of parental qualities and resulting in an embryo, the latter a fusion resulting merely in a growth-stimulus. $\mathrm{He}$ thinks that the endosperm is historically a gametophyte, and that the fusion which initiates it has no origin in an act of fertilization.

Later, Miss Sargant ${ }^{38}$ published an admirable résumé of the subject, together with a clear statement of the problems involved and certain suggestions by way of interpretation. She very justly states that if the endosperm " arose from a belated formation of prothallus, we must trace the origin of the triple nuclear fusion which precedes its derelopment"; and if it is a modified embryo "we have to account for the interference of the lower polar nucleus with the act of fertilization, and for the subsequent development of a body unlike a normal embryo." Her suggested interpretation of the phenomenon is that the fusion of the male nucleus with the micropylar polar nucleus, an undoubted female nucleus, both containing the reduced number of chromosomes, is a typical sexual union; but that the antipodal polar nucleus, with its regetative character, and indefinite and usually increased number of chromosomes, is a disturbing factor, and the result is not a normal embryo but a small and short-lived mass of tissue. She aptly cites the experiments of Boveri ${ }^{13}$ with sea-urchins, in forcing more than one spermnucleus to unite with a single egg-nucleus and producing monstrous larval structures. "The presence of the third nucleus, therefore, with its redundant chromosomes, serves to secure the degeneracy of the resulting tissue." This means, of course, that the endosperm is a degenerate embryo, and that the triple fusion is a true sexual union whose normal result has been interfered with by the presence of a non-sexual nucleus in the combination.

It is impossible to solve such a problem by a discussion of 
the data we possess. The phylogeny of the endosperm must be traced, and the place of the polar fusion and of the triple fusion in its history determined before opinions cease to differ as to its morphological character. In view of such facts as we have, howerer, we are inclined to hold with Strasburger that the endosperm of Angiosperms is a gametophytic structure, and that the polar fusion and the triple fusion are interpolations in its history that do not change its essential character. The fact that endosperm sometimes forms before fertilization indicates that the triple fusion is not an essential prerequisite; the fact that endosperm forms without the polar fusion points at least to the conclusion that it was once developed without it; the indifference of the male nuclens as to which polar nucleus it fuses with (Lilium, Asclepias) does not show the selective attraction connected with sex-fusion; and the further fact that when an undoubted fertilization occurs, whether of egg, of synergid, or of upper polar nucleus, an embryo is the result, indicates that the presence of the male nuclens in triple fusion is of subsidiary rather than of dominating importance. That the fusing male nucleus does introduce parental characters that manifest themselves in the endosperm is proved br the phenomenon of xenia, but this does not seem necessarily to prove the sporophrtic character of the endosperm. In fact, the development and structure of the endosperm of Angiosperms is so much like that of Grmmosperms that it seems easier to regard the various fusions as merely resulting in a stimulus to growth than to imagine a degenerate embreco assuming this particular derelopment and structure. Of course one might go to the extreme, and regard the endosperm as neither gametophyte nor sporophrte, but as a composite tissue involving both, but this hardly seems to be necessary.

\section{LITERATURE CITED}

1. Hofmeister, W. Neuere Beobachtungen über Embryobildung der Phanerogamen. Jahrb. Wiss. Bot. 1: 82-188. pls. $\tilde{\imath}-10.1858$.

2. - Neue Beiträge zur Kenntniss der Embryobildung der Phanerogamen. Abhandl. Königl. Sächs, Gesell. Wiss. 6: 5336\%2. pls. 1-2\%. 1859.

3. Körsicke, F. Vorläufige Mittheilungen über den Mais. Sitzungsb. Niederrh. Gesell. Nat. Heilk. Bonn. 1872.

4. Strasberger, E. Zellbildung und Zelltheilung. Ed. 3. Jena. 1880. 
5. Focke, W. O. Die Pflanzen-Mischlinge. Berlin. 1881.

6. Guignard, L. Recherches d'embryogénie régétale comparée. I. Legumineuses. Amm. Sci. Nat. Bot. VI. 12: 5-166. pls. 1-8. 1881.

7. Trecb, II. Notes sur l'embryon, le sac embryonnaire, et l'ovule. III and IV. Ann. Jard. Bot. Buitenzorg 3: 120-128, pls. 18-19. 1883.

8. Hegeliaier. F. Untersuchungen über die Morphologie des Dikotyledonen-Endosperms. Nova Acta Leopoldina 49: 1-104. pls. 5. 1885 ; reviewed in Bot. Centralbl. 10: 302-304. 1886.

9. LE MIoxier, G. Sur la valeur morphologique de l'albumen chez les Angiospermes. Jour. Botanique 1: 140-142. 188\%.

10. Oliver, F. W. On the Structure, Development, and Affinities of Trapella, a New Genus of Pedalineae. Annals of Botany 2: 75115. pls. 5-9. 1888 .

11. —_. On Sarcodes sanguinea. Annals of Botany 4: 303-326. pls. 1\%-21. 1890 .

12. Trecb, M. Sur les Casuarinées et leur place dans le système naturel. Ann. Jard. Bot. Buitenzorg 10: 145-231. pls. 12-32. 1891.

13. Boveri, TH. Befruchtung. Anat. Hefte Ergebnisse 1: 386-485. figs, 15. 1891.

14. Giltay, E. Ueber den directen Einfluss des Pollens auf Fruchtund Samenbildung. Jahrb. WViss. Bot. 25: 459-509. pl. 23. 1893.

15. Mottier, D. M. On the Embryo-Sac aud Embryo of Senecio aurens L. Bot. Gazette 18: 245-253. pls. 27-29. 1893.

16. TREUB, M. L'organe femelle et l'apogamie du Balanophora elongata. Ann. Jard. Bot. Buitenzorg 15: 1-22. pls. 1-8, 1898.

17. Humphrey, J. E. The Development of the Seed in Scitamineae. Annals of Botany 10: 1-40. pls. 1-4. 1896.

18. Schaffner, J. H. Contribution to the Life History of Sagittaria variabilis. Bot. Gazette 23: 252-273. pls. 20-26. 1897.

19. Collter, J. M. Contribution to the Life History of Lilium philadelphicum. Bot. Gazette 23: 412-122. pls. 32-34. 1897.

20. Contribution to the Life History of Ranunculus. Bot. Gazette 25: 73-88. pls. 4-7. 1898.

21. Sirth, R. IV. A Contribution to the Life History of the Pontederiaceae. Bot. Gazette 25: 324-337. pls. 19-20. 1898.

22. Juel, H. O. Parthenogenesis bei Antennaria alpina (L.) R. Br. Bot. Centralbl. 74: 369-372. 1898.

23. Nawaschis, S. Resultate einer Revision der Befruchtungsvorgänge bei Lilium Martagon und Fritillaria tenella. Bull. Acad. Imp. Sci. St. Pétersbourg 9: 377-382. 1898; reviewed in Bot. Centralbl. 78: 241-245. 1899.

24. Caldwell, O. W. On the Life History of Lemna minor. Bot. Gazette 27: 37-66. figs. 59. 1899.

25. Correxs, C. Untersuchungen über die Xenien bei Zea Mays. Ber. Deutsch. Bot. Gesell. 17: 410-417. 1899. 
26. Lotsy, J. P. Balanophora globosa Jungh. Eine wenigstens - örtlich-verwittwete Pflanze. Ann. Jard. Bot. Buitenzorg II. 1: 174-186. pls. 26-29. 1899.

27. De Tries, H. Sur la fécondation hybride de l'albumen. Compt. Rend. 129: 973-975. 1899.

28. Burss, G. P. Beiträge zur Keuntniss der Stylidiaceen. Flora 87: 313-354. pls. 13-14. 1900.

29. Canpbell, D. H. Studies on the Araceae. Annals of Botany 14: 1-25. pls. 1-3. 1900.

30. Conrad, A. H. A Contribution to the Life History of Quercus. Bot. Gazette 29: 408-418. pls. 28-29. 1900.

31. Johrson, D. S. On the Endosperm and Embryo of Peperomia pellucida. Bot. Gazette 30: 1-11. pl. 1. 1900.

32. Laxd, W. J. G. Double Fertilization in Compositae. Bot. Gazette 30: 252-260. pls. 15-16. 1900.

33. Chodat, R., and Bernard, C. Sur le sac embryomaire de l'Helosis guayanensis. Jour. Botanique 14: 72-79. pls. 1-2. 1900.

34. Johnson, D. S. On the Development of Saururus cernuus L. Bull. Torr. Bot. Club 27: 365-372. pl. 23. 1900.

35. JUEL, H. O. Vergleichende Untersuchungen über typische und parthenogenetische Fortpflanzung bei der Gattung Antennaria. Handl. Svensk. Vetensk. Akad. 33 : no. 5. pp. 59. pls. 6. figs. 5. 1900 ; reviewed in Bot. Zeit. 59: 131. 1901.

36. Nawaschis, S. Ueber die Befruchtungsvorgänge bei einigen Dicotyledoneen. Ber. Deutsch. Bot. Gesell. 18: 224-230. pl. 9. 1900.

37. Strasburger, E. Einige Bemerkungen zur Frage nach der "doppelten Befruchtung" bei den Angiospermen. Bot. Zeit.

58: 293-316. 1900.

38. Sargant, Ethel. Recent Work on the Results of Fertilization in Angiosperms. Annals of Botany 14: 689-712. 1900.

39. Tischler, G. Untersuchungen über die Entwicklung des Endosperms und der Samenschale von Corydalis cava. Verhandl. Naturhist.-Ned. Ver. Heidelberg 6: 351-380. pls. 2. 1900.

40. Webber, H.J. Xenia, or the Immediate Effect of Pollen in Maize. Bulletin 22. Div. Veg. Path. and Phys. U. S. Dept. Agric. pp. 40. pls. 4. 1900.

41. Gugrard, L. La double fécondation dans le mais. Jour. Botanique 15 : 37-50. 1901.

42. —. La double fécondation dans le Naias major. Jour. Botanique 15: 205-213. figs. 14. 1901.

43. — Double fécondation chez les Renonculacées. Jour. Botanique 15: 394-408. figs. 16. 1901.

44. Holferty, G. M. Ovule and Embryo of Potamogeton natans. Bot. Gazette 31 : 339-346. pls. 2-3. 1901. 
45. Lyox, H. L. Observations on the Embryogeny of Nelumbo. Minn. Bot. Studies 2: 643-655. pls. 48-50. 1901.

46. Sirth, Amelia C. The Structure and Parasitism of Aphyllon uniflorum Gray. Contrib. Bot. Lab. Univ. Penn. 2: 111-121. pls. 13-15. 1901.

47. SchnegG, H. Beiträge zur Kenntniss der Gattung Gunnera. Flora 90: 161-208. figs. 28. 1902.

48. Guigrard, L. La double fécondation chez les Solanées. Jour. Botanique 16: 145-167. figs. 45. 1902.

49. Strasburger, E. Ein Beitrag zur Kenntniss von Ceratophyllum submersum und phylogenetische Erörterungen. Jahrb. Wiss. Bot. 37: 477-526. pls. 9-11. 1902.

50. Hall, J. G. An Embryological Study of Limnocharis emarginata. Bot. Gazette 33: 214-219. pl. \%. 1902.

51. Overton, J. B. Parthenogenesis in Thalictrum purpurascens. Bot. Gazette 33: 363-375. pls. 12-13. 1902.

52. Cook, M. T. Development of the Embryo-sac and Embryo of Castalia odorata and Nymphaea advena. Bull. Torr. Bot. Club 29: 211-220. pls. 12-13. 1902.

53. Johrsox, D. S. The Embryology and Germination of the Genus Peperomia. Abstract. Science 15: 408-409. 1902.

54. InEdA, T. Studies in the Physiological Functions of Antipodals and related Phenomena of Fertilization in Liliaceae. 1. Tricyrtis hirta. Bull. Coll. Agric. Imp. Univ. Tokyo 5: 41-72. pls. 3-6. 1902 .

55. Johxson, D. S. On the Development of Certain Piperaceae. Bot. Gazette 34: 321-340. pls. 9-10. 1902.

56. Frye, T. C. A Morphological Study of Certain Asclepiadaceae. Bot. Gazette 34: 389-413. pls. 13-15. 1902.

57. Shibata, K. Experimentelle Studien iiber die Entwickelung des Endosperms bei Monotropa. (Torläufige Mitteilung.) Biol. Centralbl. 22: 705-714. 1902.

58. Murbeck, S. Ueber die Embryologie von Ruppia rostellata Koch. Königl. Svensk. Tetensk. Akad. Handl. 36: 1-21. pls. 1-3. 1902.

59. Frye, T. C. The Embryo-sac of Casuarina stricta. To be published in Bot. Gazette 35: 1903.

60. Wrlie, R. B. A Morphological Study of Elodea canadensis. To be published in Bot. Gazette 36: 1903 . 


\section{CHAPTER IX}

\section{THE EMBRYO}

IT is perhaps impossible at present to formulate any definite laws for the development of the embryo of Angiosperms. The details recorded are very numerous and confusing, the greatest amount of variation occurring in allied forms and even in the same species. Undue attention probably has been given to the succession of cell divisions in the earliest stages of the embryo, for it is at this very period that the embryo seems to be peculiarly responsive to the conditions that surround it. What the conditions are that determine that a cell-wall in a given stage of the embryo shall run now in one plane, now in another, or even shall fa: to develop, are unknown; but the study of a large series of embryos makes it evident that if there is a normal sequence of cell divisions it is being eonstantly interfered with. It is probable that when these minor variations are neglected, certain laws of general development will appear that are concerned with

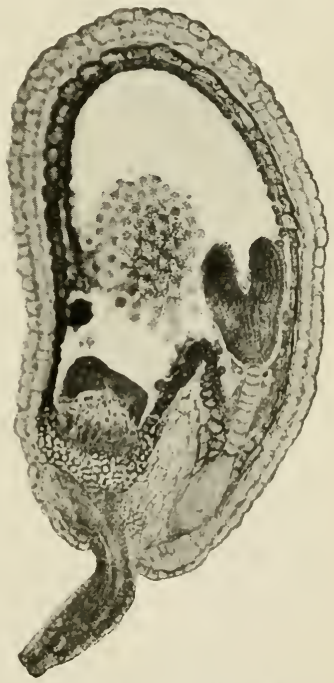

Fia. 81.-Capsella Bursa-pastoris. Photomicrograph of seed showing embryo, endosperm, and developing testa $; \times 125$. the organization of the great body regions rather than with the succession of cell divisions (Fig. 81). 
In general, the first division of the fertilized egg is transverse, and this is followed by one or more divisions in parallel planes, resulting in a row of cells. This undifferentiated group of cells is conveniently referred to as the proembryo. In general, the proembryo becomes differentiated into suspensor and embryo, which eventually become very distinct, although their origin is variable. This means that in general all the product of the fertilized egg does not enter into the structure of the embryo, a fact also true of most Grmnosperms. In general, the development of the embryo is initiated by the longitudinal division of the end-cell of the proembryo, and this is followed by divisions that result in the quadrant and then the octant stage. It is in the octant stage that periclinal walls may eut off the dermatogen, but this may be deferred to a later stage, and is often irregular. The cells of the dermatogen divide onls by anticlinal walls, but the inner cells continue divisions in the three dimensions, and soon the periblem and plerome become distinguishable. In general, the end-cell of the proembryo does not produce all of the embryo, but the next cell divides transrersely, and the daughter-cell adjacent to the embryo (hypophysis) fills out the periblem and dermatogen of the root-tip. The organization of the growing points of stem and cotrledon, in relation to the bodr of the embryo, are so radically different in Monocotrledons and Dicotrledons that no general statement concerning it is possible.

The fact remains that every general statement giren above is contradicted by well-known and by no means infrequent exceptions, and even the distinction between Monocotyledons and Dicotyledons is not always clear in the embryo. The subject will be treated in some detail under the titles Monocotyledons, Dicotrledons, Parthenogenesis, and Polyembryony.

\section{MONOCOTYLEDONS}

The embrro of Alisma Plantago, as described br Hanstein ${ }^{7}$ and Famintzin, ${ }^{17}$ has long been taken as a trpe of the monocotvledonous embryo. Among recent accounts Schaffner's ${ }^{43}$ description of the embryo of Sagittaria rariabilis, following his earlier study of $.17 i s m a{ }^{39}$ is the most complete, and while it confirms the principal features of the earlier accounts, the great improvement in technique since the time of Hanstein made it 


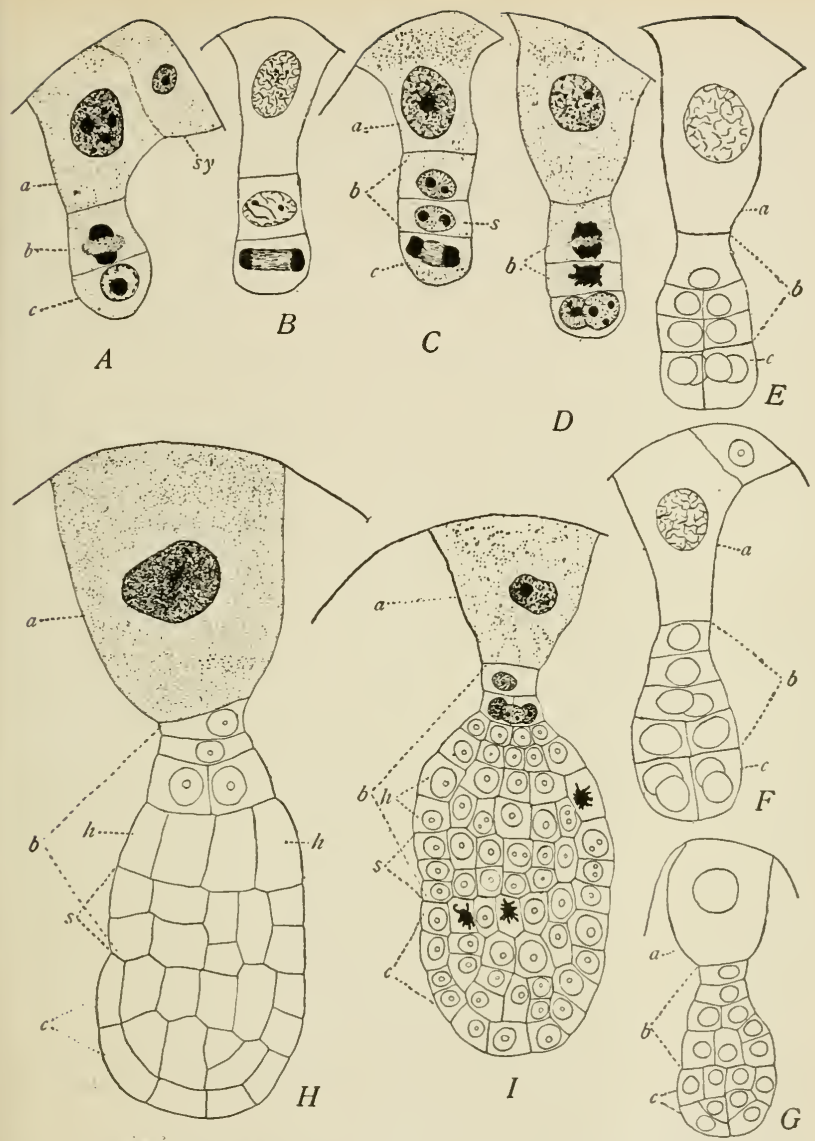

Fio. 82.-Sagittaria variabilis. Development of embryo. A, proembryo of three eells ; $a$, hasal cell (in all figures); $b$, mildle eell (dividing); $c$, terminal cell firom which the cotyledon is derived; $x y$, synergid: $B$, same stage, but terminal eell dividing; $C$, middle cell $(b)$ has divided, 8 being the cell from whose derivatives the stem-tip arises, and terminal eell (c) dividing; $D$, both cells derived from $b$ are dividing; $E$, terminal cell lias given rise to four cells $(c)$, and the region derived from the middle eell $(b)$ has developed further; $F$, showing further development of the middle cell region $(b)$, while the terminal cell region has made no further progress; $G$, dermatogen differentiated in the terminal eell region $(c)$, and the middle region $(b$ ) further developed: $/ I$, differentiation of dermatogen bevond the terminal region $(c)$, the middle region $h$, showing the differentiation between livpoeotyl $(h)$ and region producing stem-tip; $I$, more advaneed stage, showing same regions as in $H$, but the domatogen of the ront-tip not yet formed, and the plerome and periblem unditlerentiated. A-F, $\times 400 ; G, \times 260 ; I I, \times 400 ; I, \times 260 .-$ After S'CHAFFNER.43 
josible to correct some inaccuracies, and at the same time to show that the early divisions of the fertilized egg do not follow such a definite sequence as had been supposed. The following description is based upon his account. The fertilized egg divides by a transrerse wall, and the resulting basal cell becomes large and resicular, but does not diride. The apical cell dirides by a transverse wall and a proembryo of three cells is the result (Fig. -2 ). The terminal cell (Fig. 82, c) gives rise to the terminal cotyledon, and its first division, which may take place immediately or may be somewhat delayed, is always longitudinal. From the middle cell there are developed the lateral stem-tip, the root-tip, the hrpocotyl, and all of the suspensor except the resicular basal cell. The middle cell dirides transrersely, and of the two resulting cells the one next the terminal cell gives rise to the stem-tip (Fig. $-2, C, s$ ). In general, the differentiation is basipetal, proceeding from the cotyledon toward the suspensor. The terminal or cotyledon cell haring dirided by a longitudinal wall, the next division is transrerse, resulting in the quadrant stage, followed by the octant stage. At this stage the dermatogen begins to be differentiated, appearing first in the cotyledon and proceeding toward the root end of the embryo. While the cell from which the stem-tip arises can be identified in the four-celled proembryo, it is only in much later stages (as Fig. so, $I$ ) that it is readily recognized. In the four-celled proembryo ( $\mathrm{Fig}$. 8. $\mathrm{C}$ ) ) the cell next the resicular cell divides transversely; and of the two resulting cells the one nearest the resicular cell by one or more transrerse dirisions gives rise to a filamentous suspensor of two to six cells; from the other cell are dereloped the root and the hypocotyl. The dermatogen is usually developed, even around the root-tip, before any differentiation of periblem and plerome can be distinguished (Fig. 83).

This Alisma type has proved to be characteristic, not of Monocotyledons in general, but of the more primitive hydrophritic forms. Its main features are an undiriding and usually much enlarged and swollen basal cell cut off by the first division of the fertilized egg, and a proembryo of three cells whose middle cell divides basipetally to form the region of the embryo behind the cotyledon, and also forms more or less of a suspensor in addition to the large basal cell. As further illustrations of 

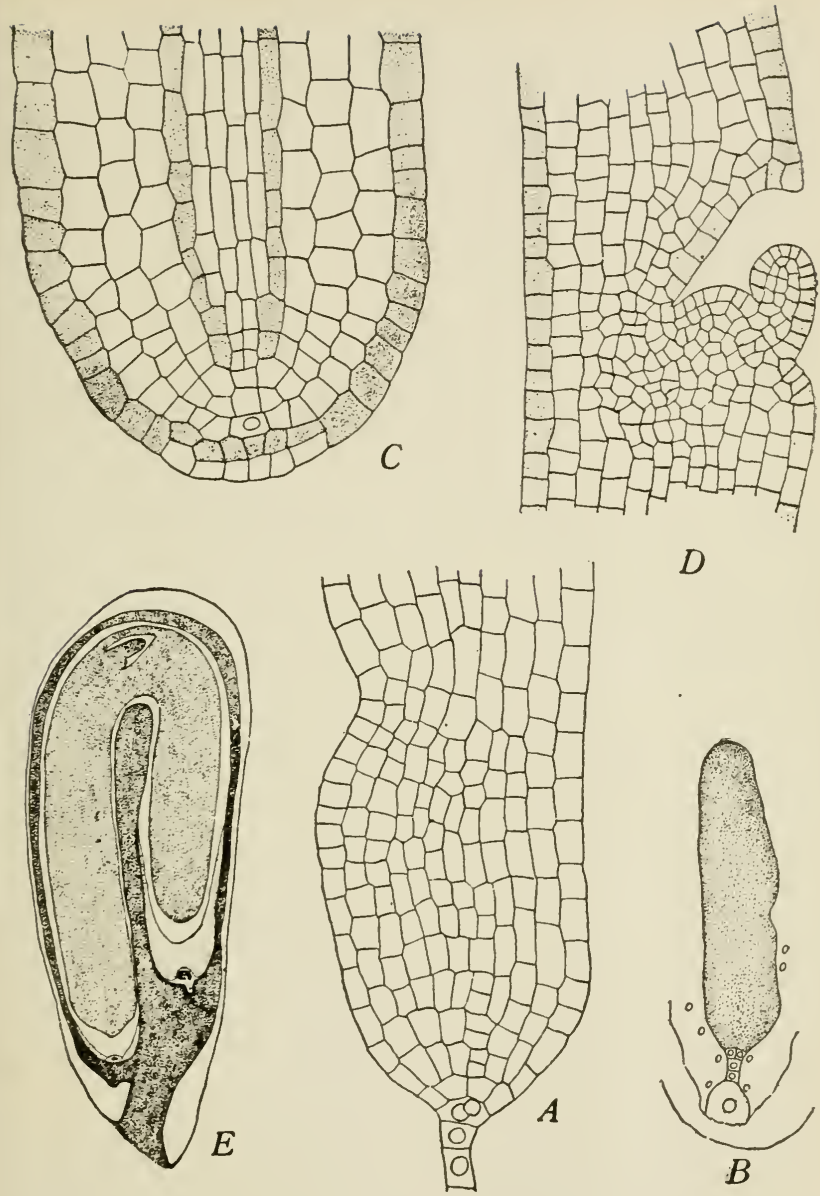

F16. 83.-Sagittaria variabilis. Development of embryo. $A$, somewhat advanced stage showing the depression in which the stem-tip develops; $\times 216 ; B$, about the same stage, showing the entire embryo; $\times 66 ; C$. later stage, with dermatogen, periblem, and plerome differentiated; $\times 216 ; I$, the lateral stem-tip; $\times 140 ; E$, longitudinal seetion of a ripe seed; $\times 26$.-After SCHAFFNER.49 
it we would cite Sparganium (Campbell ${ }^{55}$ ), Potumogeton (Wiegand, ${ }^{63}$ Holferty ${ }^{71}$ ), Zannichellia and Naias (Campbell ${ }^{41}$ ), Triglochin (Hill ${ }^{60}$ ), and Limnocharis (Hall ${ }^{82}$ ). The last-mentioned form well illustrates that the general type may be maintained, and at the same time there may be no regularity in the sequence of divisions after the first two. In fact, the apical cell of the proembry of Limnocharis may divide by a transverse, oblique, or longitudinal wall, and in the two latter cases the cotyledon and stem-tip are both terminal, as is the case also in Zannichellia.

Among the Gramineae the same general type of proembryo is formed, but if Avena fatua (Cannon ${ }^{65}$ ) be taken as representative of the general situation, the origin of the organs of the embryo in relation to the cells of the proembryo is quite different. In this species the cotyledon and stem-tip are both derived from the apical cell, the entire root-tip (including root(ap) from the adjacent cell, and the coleorhiza from the third cell, the suspensor consisting of only the primary basal cell.

Anong the Araceae a very different type of embryo is indicated, but so few forms have been investigated that no conclusion as to its prevalence in the family is safe. In 18 it Hegel-

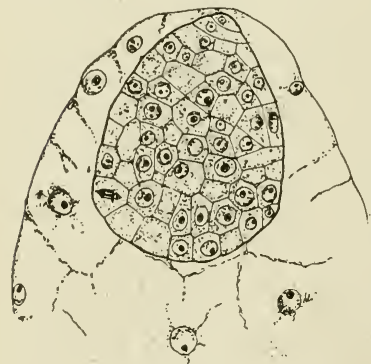

FIG. 84. - Lysichiton krmtschatcense. Longitudinal section of enthyo surrounded by endosperm, illustrating the Pistia type.-After Campbel. ${ }^{55}$ Araceae, it is not restricted to them, for IImphres ${ }^{38}$ las shown that the embryos of the Scitamineae have no suspensors: and the same is true at least of certain orchids, as shown by a suspensor in Pistia, the fertilized egg producing a spherical proembryo, all of which enters into the structure of the embryo. Campbell ${ }^{59}$ found the same trpe of embryo in Dieffenbachia, $\mathrm{I} g$ laonema, and Lysichiton (Fig. St), and states that in the segmentation of the egg there mar be two transcerse dirisions before any rertical dirision, or a regular quadrunt may be formed as in the ordinary fern embryo. Eren if this Pistia trpe should prove to be characteristic of the maier" described the absence of 
Treub ${ }^{18}$ for Listera ovata and Epipactis palustris, and by Leavitt ${ }^{i 3}$ for certain species of Goodyera and Spiranthes. It should be noted, however, that in Lemna (Caldwell ${ }^{54}$ ), the reduced aquatic ally of the Araceae, a multicellular suspensor is formed, the embryo resembling the Litium type described below.

Among the Liliaceae a third type of embryo - formation seemstoprevail. After the first segmentation of the fertilized egg, which is transverse, the subsequent divisions are very irregular, being transverse, oblique, or longitudinal in either cell, resulting in a massive proembryo. The differentiation into embryo and suspensor is late and irregular, the suspensor being massive, and inclined to eontinue active dirision until the end of the embryo-sac is occupied by a spreading suspensor tissue (Fig. 85). This is eharacteristic of Litium (Coulter ${ }^{44}$ ), Erythronium (Schaffner ${ }^{72}$ ), Tulipa (Ernst ${ }^{69}$ ), and probably all the allied forms, and the meristematic activity of the snspensor is apt to result in polyembryony (see below). Just how far this Litium type of embryo is represented among Liliales must be determined by future investigation, but it is distinct enough to deserve separate mention. 
Among the Orchidaceae there is the greatest amount of variation in the formation of the embryo. In general they are characterized by rery poorly dereloped embryos, the body regions not being differentiated, and by an extraordinary and raried derelopment of the suspensor as an haustorim. As already mentioned, howerer, some of them (species of Listera, Epipactis, Goodyera, Spiranthes) liare no suspensor (Fig.

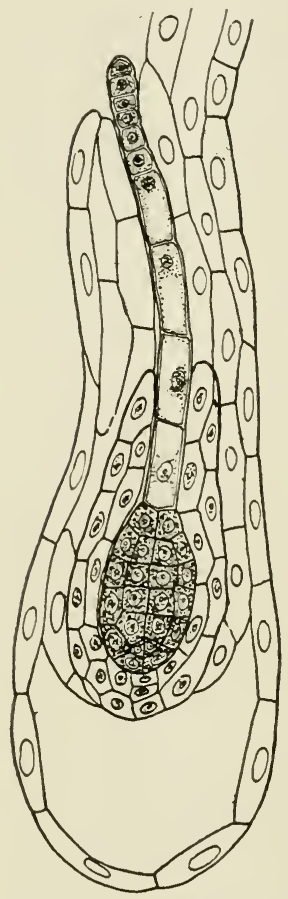

s6). Treub ${ }^{18}$ in 1579 described a number of forms in which the filamen-

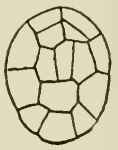

Fig. 86.-Listera ovata. Embryo at time of shedding seed. After Pritzer in Engler and Prantl's Iat. Itanzentamilien. tous suspensor grows out of the microprle, often branches, and embeds itself in adjacent nutritive tissue, such as the placenta. He found that in Phalaenopsis grandiflora branches of the suspensor not only turn toward the micropyle, but also toward the embryo and finally envelop it. Later the same investigator ${ }^{24}$ described the suspensor of Peristylis grandis as dividing transversely, growing out through the micropsle, and embedding itself by pseudopodium-like processes in the placenta. The embrro of Gymnadenia conopsea, as described by Marshall-Ward, ${ }^{20}$ is probably representative. The first division of the fertilized egg is transverse, the basal cell forming a chain-like suspensor of eight to ten more or less elongated cells that pushes through the micropyle into the ovary carity, and the apical cell producing a perfect octant stage, the dermatogen being cut off

FIG. 87.-Gymnadenia conopsea. Seetion of embryo with suspensor protruding from micropyle. -After Marsiall Ward.20 in the sixteen-celled stage (Fig. 87). Learitt ${ }^{73}$ has also described the suspensors of Aplectrum hiemale; of 
Corallorhiza multiflora, in which it consists of two very long cells and embeds its tip into the placenta; of Habenaria tridentata, and of $H$. blephariglottis, in which each of the six or seren cells of the suspensor usually sends out a branch, some of them short and reaching the integument, others elongated and passing parallel with the suspensor into the tissue at the base of the funiculis.

These four types of monocotyledonous embryos, which for convenience may be spoken of as Alisma, Pistia, Litium, and Urchid types, are, of course, related to one another in ways that suggest that they are all deriratives of one general monocotyledonous form. It is natural to assume that this primitive form is more nearly represented by the Alisma type than by any of
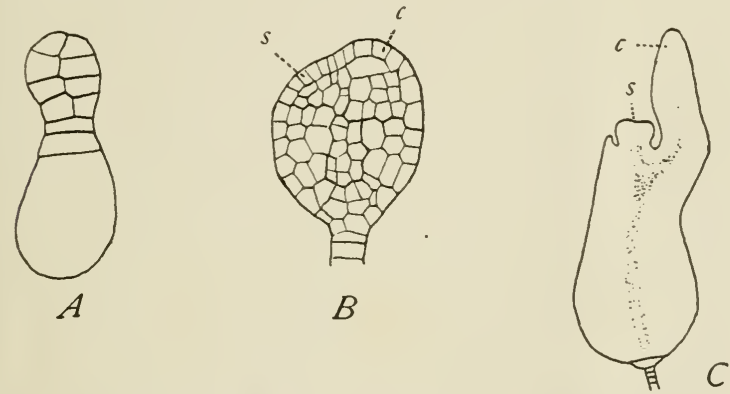

Fre. 89.-Zannichellia palustris. Development of embryo. A, young embryo; $\times 320$; $B$. later stage, showing beginning of differentiation into stem-tip $x$ ) and cotyledon (c), both coming from the cells derived from terminal cell of proembryo; $\times 160 ; C$, stemtip (s) and cotyledon (c) elearly differentiated; x 60.-After CAMPBELL.4?

the others, not merely because it characterizes the primitive hydrophytic forms, but also because it is the simplest type, and the others may well be modifications of it. In the Pistia type the suspensor is suppressed: in the Litium type it becomes massive and meristematic: in the Orchid type it is developed as a special haustorimm that passes ont of the orule on account of the lack of endosperm, and perhaps for the same reason the embryo does not reach the stage of differentiating organs.

There have been observed certain departures from the monocotyledonous type of embryo that deserve special mention. 
In 1s78 Solns-Lambach ${ }^{15}$ stated that in Dioscoreaceae and certain Commelinaceae the cotyledon is lateral in origin rather than terminal. The stem-tip is terminal in origin, but is later forced to one side by the strong growth of the cotyledon from beneath. Such a departure is, of course, fundamental, but before any generalization is rentured it should be subjected to the most critical investigation. Campbell ${ }^{41}$ finds that in Zannichellia the terminal cell of the proembryo gives rise to both cotyledon and stem-tip, the separation between the two organs being determined by the first vertical division of the terminal cell (Fig. ss). The same writer ${ }^{4} i$ has found another suggestive variation in Lilaea subulata, one of the Juncaginaceae. The embryonic root-tip, instead of being directed toward the suspensor, is directed to one side, almost in continuation of the axis of the stem-tip. This lateral origin of the root is regarded by Campbell as a primitive feature, and suggestive to him of Isoetes. In other particulars the embryo is of the Alisma type. In this connection the recent results of Murbeck ${ }^{95}$ with Ruppia are suggestive. He confirms the account of Wille that a primary root is formed at the base of the embryo, but soon disorganizes, and that a lateral root, formed very early, is the first functional one. This is very different from the account of Ascherson in Engler and Prantl's "Die Natürlichen Pflanzenfamilien," which is followed in Goebel's "Organography," according to which this lateral root is the primary root, its unusual position being due to displacement.

\section{DICOTYLEDONS}

The best-known dicotyledonous embryo is that of Capsella, as described by Hanstein ${ }^{7}$ and Famintzin, ${ }^{17}$ and it has been used as a basis of comparison ever since. To illustrate the earlier stages in the development of the embryo, therefore, we have made a rather complete series of camera drawings from sections of the embryo of Capsella (Figs. 89, 90; see also Fig. -1). The proembryo is a filament of cells of varying length. The apical cell divides first longitudinally, the next two divi-ions being longitudinal and transverse in either order and resulting in the octant stage. Whether the transverse division precedes or follows the second longitudinal division, it separates the cotyledonary and hypocotyledonary regions of the em- 


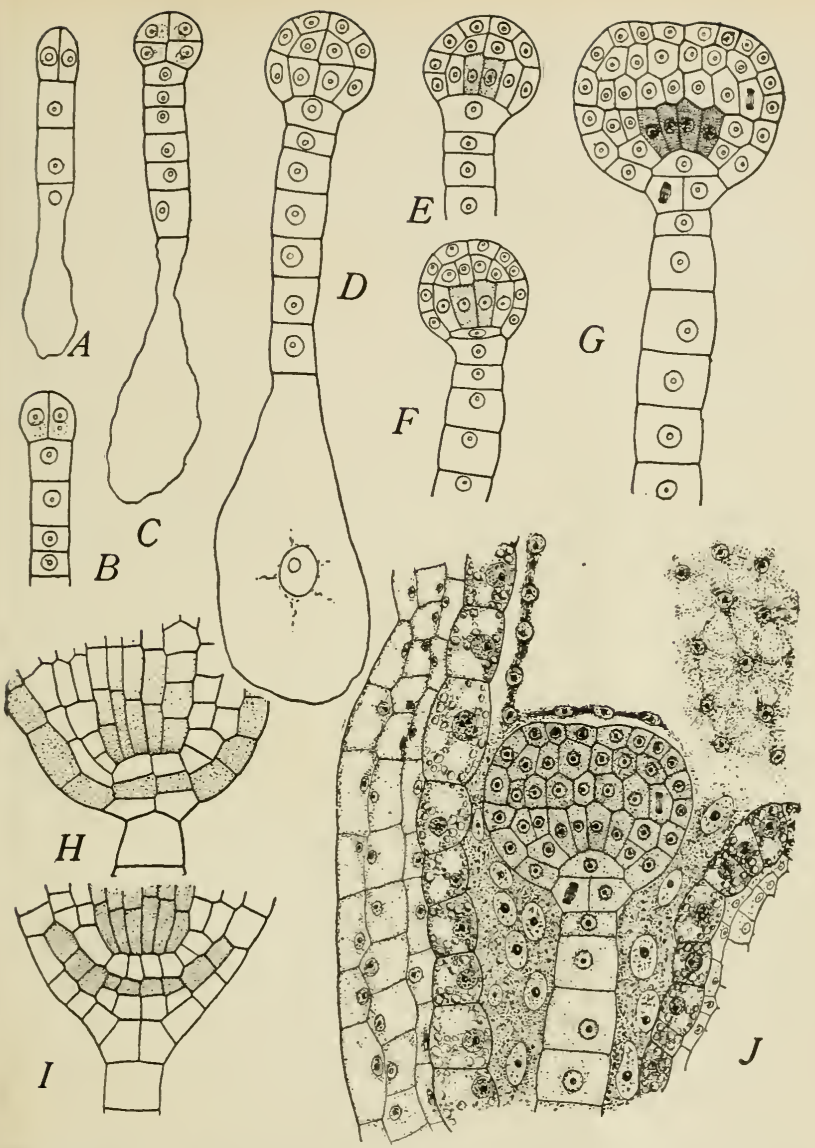

Fiє. 89.-Capsella Bursa-pastoris. A, first division of terminal (embryo) cell; $B$, quadrant stage: $C$, octant stage; $D$, differentiation of dermatogen; $E$, differentiation of periblem and plerome (latter shaded) $F$, completion of periblem of root; $G$, beginning of differentiation of dermatogen of root-tip (indicated by mitotie figure); $H$, later stage, showing plerome, periblem, dermatogen, and one layer of rot-cap (plerome and dermatogen shaded): $I$, two layers in root-cap (the plerome and portion of dermatogen derived from hypophysis shaded); $J$, young embryo surrounded by endosperm; walls of ovary also shown; $\times 400$. 
bryo. In the octant stage the dermatogen begins to be differentiated, the periclinal dirisions appearing first in the terminal octants and proceeding toward the root end of the embryo. The differentiation, howerer, is almost simultaneous, so that the dermatogen is soon completed except that of the root-tip, which is derived from the adjacent cell of the suspensor, and appears comparatively late. The periblem and plerome are differentiated early from the tissue within the dermatogen. The stemtip and cotyledons are derived from the four apical octants, and the bulk of the hypocotyl from the four basal octants. The root-tip, however, is completed by the adjacent cell of the sus-
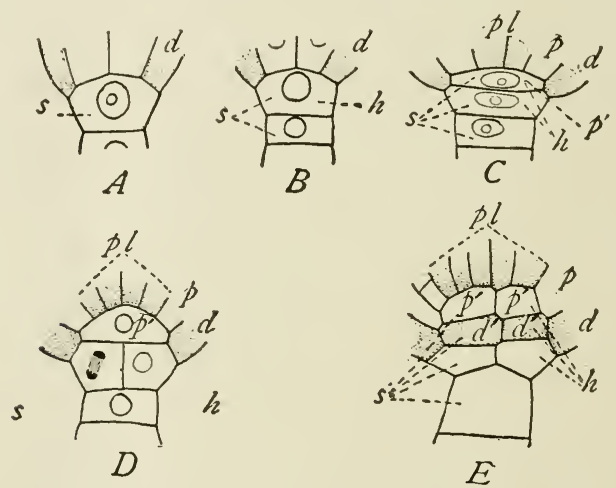

Fia. 90.-Cipsella Bursa-pastoris. Series showing contribution of upper cell of suspensor to embryo (plerome and dermatogen shaded): $s$, upper cell of suspensor; $h$, hypophysis; $d$, dermatogen; $d$, portion of dermatogen derived from hypuphysis; $p l$, plerome; $p$, periblem; $p^{\prime}$, portion of periblem derived from hypophysis; $\times 400$.

pensor (Fig. 90, s). This cell dirides transrersely, the basal daughter-cell taking no part in the formation of the embrro, but the other daughter-cell (hypophysis of Hanstein) filling out the periblem and dermatogen of the root-tip. The hypophrsis dirides transversely, the daughter-cell next the embryo completing the periblem of the root. The other daughter-cell by two longitudinal dirisions gires rise to a plate of four celli, each of which divides transversely, the plate of four cells torrard the embryo completing the dermatogen of the root-tip, and the other plate constituting the first layer of the root-cap. 
This type of embryo, called for convenience the Capsella type, is well represented throughout the Dicotyledons, and, so far as we have the means to judge, seems to be the prevalent type, subject, of course, to variation in detail. For example, it oceurs in Salix (Chamberlain ${ }^{42}$ ), in which it is questionable whether the hypophysis contributes to the periblem; in Ranunculus (Coulter ${ }^{48}$ ) and Thalictrum (Overton ${ }^{83}$ ), in the latter case the suspensor sometimes becoming a massive and twisted organ; in Alyssum (Riddle ${ }^{51}$ ), which almost exactly repeats the embryogeny of Capsella; in Sium, in which there is a rery long suspensor; in Sarcodes $\left(\right.$ Oliver $^{30}$ ); in Avicennia (Treub ${ }^{24}$ ); in Trapella (Oliver ${ }^{29}$ ), in which there is a remarkably long suspensor with an enormously elongated basal cell; and in Senecio (Mottier ${ }^{34}$ ), Silphium (Merrell ${ }^{61}$ ), and Taraxacum (Schwere ${ }^{40}$ ). Among the Rosaceae Péchoutre ${ }^{5 i}$ has recorded a wide variation in the structure of the suspensor, different genera showing every gradation between a simple filamentous suspensor (Fragaria, Geum) and one that is short and massive (Crataegus, Amygdalus). These examples represent all regions of Dicotrledons; and while there are differences as to the division of the basal suspensor-cell, the length of the suspensor, and the succession of walls in the apical cell (embryo-cell) of the proembryo, the general type remains the same, and resembles most nearly the Alisma type among Monocotyledons.

In addition to this prevailing type, there are modifications of it that sug-
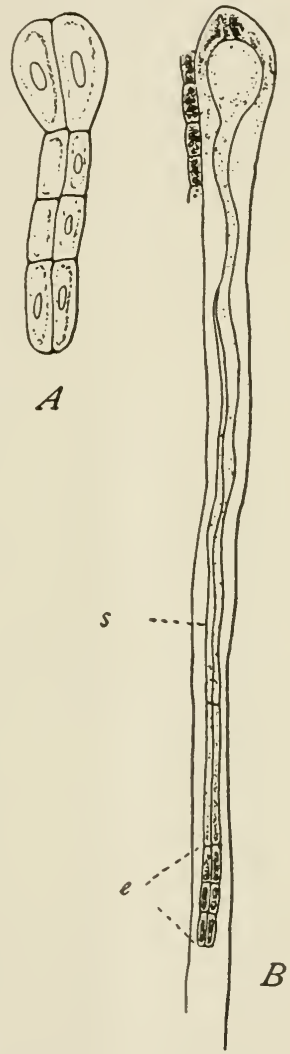

Fra. 91.-Loranthus sphaerocarpus. A, young embryo; $\times 190 ; B$, later stage, showing extreme lengthening of the two bulbous suspensorcells; $e$, eubryo; $s$, suspensor: $\times$ 120.-After Trevb. ${ }^{23}$ 
gest as wide a range of rariation as among Monocotyledons, though not so clearly related to great groups.

In Geranium, as has long been known, while the Capsella trpe is maintained in general, there is no hrpophrsis, the roottip being covered by the tissue of a massive suspensor.

In Peperomia pellucida Campbell ${ }^{56}$ and Johnson ${ }^{62}$ have both observed that the first segmentation of the fertilized egg is rertical, followed by a transverse division, and that there is no indication of a suspensor.

In Loranthus sphaerocarpus Treub ${ }^{22}$ has described the first division of the fertilized egg as vertical, as in Peperomia, but followed by transverse divisions, so that the proembryo resembles two filaments lying side by side (Fig. 91). The two basal cells elongate enormously, forming a suspensor as in Grmnosperms, whose length is increased by the moderate elongation of the second pair of cells, and which becomes more or less tortuous, the cells twisting about one another. In L. pentandrus (Treub ${ }^{26}$ ) the elongating suspensor early forces the embryo against the resistant base of the sac, where it becomes much flattened out, and for a time bear's little resemblance to an em-
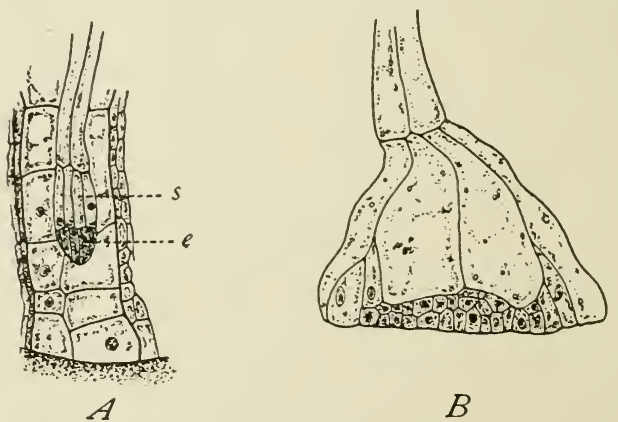

Fig. 92.-Loranthus pentandrus. A, young embryo advaneing into endosperm; thickwalled tissue at base of sac deeply shaded: $e$, embryo; 8 , suspensor: $\times 88: B$. later stage, the embryo has reached the resistant base of the sac and has beeme flattened out; $\times$ 144.--After TrEe B. ${ }^{28}$

bryo (Fig. 92). In Myoporum, as described by Billings ${ }^{\top 0}$ the suspensor is also extremely long and filamentous, forcing the roung embryo down into the principal mass of endosperm, 
which is at a considerable distance from the micropylar end of the embrro-sac (Fig. 93).

In Telumbo Lron ${ }^{i 5}$ states that there is no suspensor, but that the divisions of the egg result in a large spherieal body

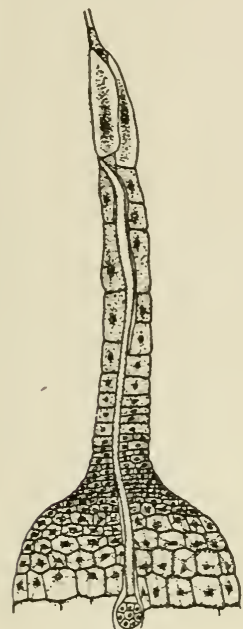

Fig. 93.- Hyoporum serratum. Young embryo with very long suspensor eniticelded in endosperm. - After BiLlixg. 70 that is still undifferentiated when consisting of sereral hundred cells, recalling the Pistia type among Monocotyledons. In Ceratophyllum demersum Strasburger ${ }^{8 t}$ has found the same undifferentiated

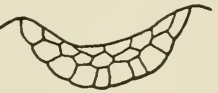

A

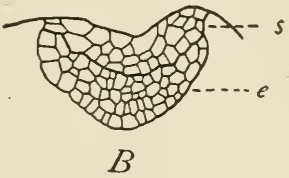

F1G. 94.-Barringtonia Vriesei. A, young proembryo; $B$, later stage, showing differentiation into embryo $(\epsilon)$ and suspensor $(x) ; \times 104 .-A$ fter Tretb. ${ }^{27}$

spherical embryo of hundreds of cells and with no suspensor; while in Nymphaea Conard ${ }^{81}$ finds the same type, but associated with it is a suspensor consisting of a row of three to five cells. In Hecheria (Piperaceae) Johnson ${ }^{86}$ has described the early stage of the embro as a globular mass composed of several hundred cells undifferentiated except for a rudimentary suspensor: and in Cynomorium (Balanophoraceae) Juel ${ }^{63}$ describes the embryo as a small spherical mass of cells with no suspensor and no differentiation into body legions.

In Baringtonia Triesei, one of the Mrrtaceae, Trenb ${ }^{2 \pi}$ has described a broad mass of tissue almost filling the micropylar end of the embryo-sac. At first the mass is homogeneous, 
and it is only late that the embryo becomes differentiated from the massive suspensor (Fig. 94).

In the Rubiaceae Lloyd ${ }^{57,85}$ has described a remarkable development of the suspensor, which in many members of the group
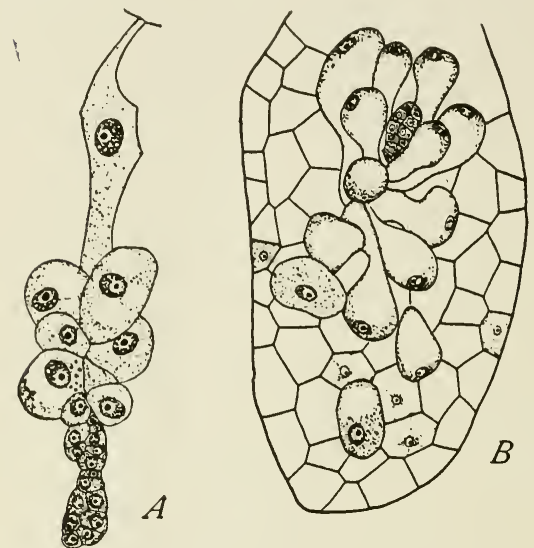

F16. 95,-A, Vaillantia hispida. Young embryo showing haustorial suspensor; $\times 375$; atter L LoYv. ${ }^{.57} B$, Asperula azurea. Young embryo with haustoria from suspensor highly developed; after LLoYD. ${ }^{56}$ acts as a haustorium (Fig. 95). In Vaillantia hispida the large suspensor cells near the embryo are clustered like "a 'bunch of grapes," while farther down a single elongated cell forms a point of attachment. In Asperula the scanty cytoplasm and the nucleus are found at the distal ends of the haustorial cells of the suspensor, recalling a condition which has been described for root hairs. It is worthy of note that among the Spermacoceae and in Houstonia there is a complete absence of these striking adaptive characters of the suspensor.

It is among the Leguminosae, however, that the greatest amount of rariation in embryogeny exists and the most unusual forms appear, as shown by Guignard 21 (Figs. 96-9s). It is impossible to give in a brief account any adequate idea of the amount of variation displayed by the nearly forty species Guignard has described, involving in the main the character of the proembryo and the final condition of the suspensor. In 1880 Strasburger ${ }^{19}$ had called attention to the fact that the cells of the rery long suspensor of Lupinus separate early, leaving the embryo free and some distance from the micropylar extremity of the sac. This, however, is but one phase of the embryogeny of the Leguminosae. In every case the first segmentation of the 
egg is transverse, but this may be followed either by longitudinal or transverse divisions, in the former case generally resur.ing in a massive and often globular proembryo, in the latter resulting in an extraordinarily long and conspicuous filamentous proembryo. In almost every case the suspensor-cells are more or less swollen and bladdery and surcharged with nutritive material, forming a conspicnons nutritive tissue for the cmbryo. The two types of proembryo may be illustrated as follows:

As illustrations of the massive proembryo, in which the suspensor and embryo are gradually differentiated, but are never very distinct externally except by a constriction between them, may be cited species of Acacia and Mimosa; Cercis siliquastrum, in which the oblong proembryonic mass broadens at each end to form the embryo and suspensor ; Caesalpinia mimosoides, in which the embryo becomes distinct rather early as the region of more actively dividing cells; Cytisus Laburnum, in which the suspensor becomes a great mass of loose rounded cells reseinbling a globular cluster of berries; Anthyllis tetraphylla, in which the suspensor is like that of Cytisus, but the clustered
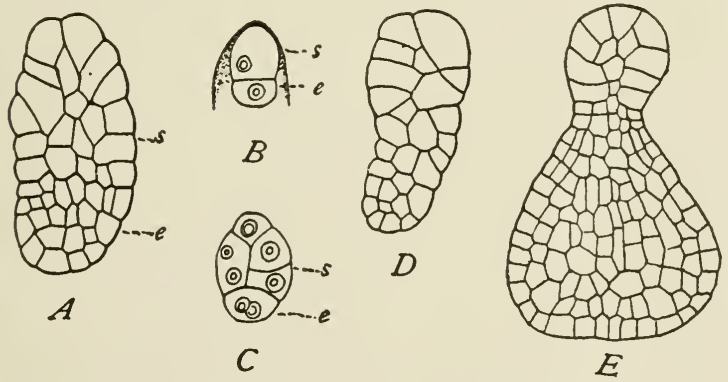

Fig. 96.-Embryos of Leguminosae. A, Cercis siliquastrum, with suspensor and enibryo developing about equally $\times 270 ; B-E$, Spartium junceum : $e$, embryo; 8 , suspensor; $\times$ 300.-After GujgnaRd. ${ }^{21}$

cells are much fewer in number; Spartium junceum and Trifolium resupinatum, in which the massive proembryo seems to constrict as in Cercis, but the suspensor as the cotyledon stage approaches is smaller than the embryo; Tetragonolobus purpureus, in which the larger part of the massive proembryo becomes the suspensor; Hedysarum coronarium and Arachis hypo- 
gaea; Onobrychis petraea, in which the proembryo is a globular mass of cells; and Phaseolus multiflorus and Erythrina crista-
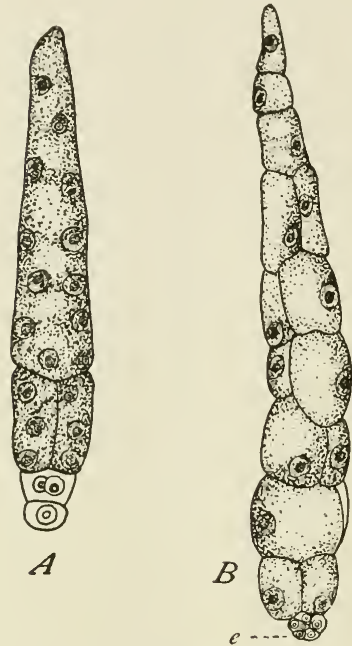

Fı. 97.-Embryos of Leguminosae. $A$, Orobus angustifolius, with suspensor of three multinucleate cells; $\times 336$. $B$, Cieer arietinum, with large multicellular suspensor and small embryo (e); x 160.-After GU1G:ARD.21 galli, in which the massive proembryo is elongated and there is no superficial separation between embryo and suspensor.

In case two or more of the first divisions are transverse, forming a filamentous proembryo, the end-cell forms the entire embryo, the suspensor-cells becoming relatively extremely large and bladdery inflated. Two general types may be noted. In Orobus angustifolius, O. aureus, Pisum sativum, Lathyrus heterophyllus, L. odoratus, Ervum Ervilia, and Ticia narbonnensis, a proembryo consisting of a row of three cells divides longitudinally: the two basal cells become much elongated, bladdery inflated, and multinucleate; the middle pair become bladdery inflated and multinucleate; and at the end of such a suspensor the terminal pair of cells organize a small round, oral, or elongated embryo. In Cicer arietinum it is interesting to note that the same huge suspensor and small embryo appear, but the suspensor-cells instead of hecoming multinucleate divide, forming a many-celled massive suspensor. In the other type, transverse divisions continue until the proen. brvo consists of a long filament of cells, all of which, excepting the end-cell; form a suspensor, as in Medicago falcata; Galega orientalis, in which the long suspensor finally becomes massive by longitudinal divisions; and Ononis fruticosa, in which the suspensorcells become very large and rounded, forming a chain that finally breaks up. In Ononis alopecuroides, however, the suspensor is reduced to a single cell. The genus Lupinus is espe- 
cially characterized by its extensive, worm-like, and large-celled suspensors, whose cells often break apart. The suspensor may consist of twenty pairs of elongated cells, forming a tortuous filament extending the entire length of the embryo-sac, with a very small embryo at the tip, as in L. subcarnosus; or it may be a filament of short, rery broad cells, suggesting a leech in appearance, as in $L$. pilosus; or it may be a loose, large-celled tissne lying along the cavity of the embryo-sac, actively dividing and more or less surrounding the late-forming embryo with its rounded cells, that finally break apart and become disorganized, as in L. polyphyllus, L. mutabilis, L. truncatus, etc.

The degree of development of the embryo is extremely variable. In some cases a plumule with several leaves is formed, and


Fro. 98.-Embryos of Leguminosae. A, Lupinus subcarnosus, with long sinuous suspensor and small four-celled embryo $(e) ; \times 2 \% 0$. B, L. luteus, with many suspensorcells binucleate; $\times 160 . \quad C, L$. pilosus, with some basal suspensor-cells isolated; $\times$ 80.-After (ivignard. 21

even lateral roots appear, as in Gramineac. Impatiens, Cucurbita, Trapa, ete. ; while in many parasites and saprophytes the embryo is represented only by an undifferentiated mass of cells. 
Among the Monocotyledons such undifferentiated embrros appear among Orchidaceae and Burmanniaceae, in the former family the primary root nerer appearing; but they are eren more numerous among Dicotyledons. Goebel ${ }^{28}$ states that the embryo of Monotropa consists of fire to nine cells, and that of Pyrola secunda, quoting from Hofmeister, of eight to sixteen cells. The entirely undifferentiated embryo of Aphyllon uniflorum has been noted by Miss Smith ${ }^{\mathrm{i}}$; and the embryos of Orobanchaceae ( $\mathrm{K}_{\mathrm{och}}{ }^{14}$ ), and of Balanophoraceae and Cytinaceae (Solms-Laubach ${ }^{8}$ ), consist of a rery small mass of tissue. In this connection it should be noted, howerer, that in Cuscuta and Tiscum the embryos are large and well developed. In some non-parasitic forms also poorly dereloped embryos occur, as in Ctricularia (Kamienski ${ }^{11}$ ), in which the embryo develops no root-tip but produces a large number of peculiar leaves.

The appearance of a single cotyledon in the embryos of certain Dicotyledons has naturally attracted attention. As a prefatory illustration, it may be observed th.s in Trapa natans, one cotyledon is much smaller than the other, and this suggests the possibility of further abortion and even of suppression of one of the cotyledons. In Ranunculus Ficaria Irmisch ${ }^{1}$ long ago reported the occurrence of a single cotyledon sheathing below, and Erianthis hiemalis, Corydalis cara, and Carum (Bunium) bulbocastanum have also been included in the list of "pseudo-monocotyledons." In the case of $C$. bulbocastanum Hegelmaier ${ }^{10}$ discovered that the apparently single and terminal cotyledon is accompanied br a second almost completely aborted and lateral cotyledon. All of these forms have been investigated recently by Schmid, ${ }^{91}$ who discovered that in Erianthis hiemalis the two cotyledons are of unequal size; that in Ranunculus Ficaria there is hardly a trace of a second cotrledon, and that this trace was probably mistaken by Irmisch ${ }^{1}$ for a sheathing base; and that in Corydatis cava there is only a slight protuberance to represent the second cotyledon, the functioning one in its growth gradually assuming a more terminal position and thrusting the stem-tip to an apparently lateral position, but in $C$. nobitis and $C$. Tutea the normal derelopment of cotyledons is foumd. In Cyclamen persicum, also, Schmid found embryos in ripe seeds with no trace of a second cotyledon. From these cases it is evident that in certain dicotyled- 
onous forms there may be early abortion, which may eren approach suppression, of one of the cotyledons; and that in consequence of this the single functional cotyledon may appear terminal and the stem-tip lateral. To call such cases "pseudomonocotyledons," however, is not consistent with the real nature of the monocotyledonous embryo. It is of interest to note, howerer, that Mis-s Sargant, ${ }^{\text {,-4 }}$ in her recent study of the "monocotyledonous Dicotyledons," a special case being made of Ranunculus Ficaria, has concluded that the apparently single cotrledon is a fusion of two.

The peculiar derelopment of the cotyledons of Nelumbo has suggested to Lyon ${ }^{i t,} i 5$ that they represent a single two-lobed cotyledon, and that this fact, along with certain anatomical details, should place Telumbo among the Monocotyledons. In its early stage he represents the proembrro as being a manycelled spherical bods, that later becomes a flattened mass filling the microprlar extremity of the sac. The stem-tip arises from the free surface toward one side, and a cotrledonary ridge arises behind it as a crescentic mound of tissue, whose wings finally extending around form a sheath about the stem-tip. $\mathrm{By}$ the development of two groẉing points on this cotyledonary sheath two lobes appear and develop rapidly, the two becoming concare and surrounding the plumule as a tube. The eridence in favor of a single cotyledon seems convincing until this embryogeny is compared with that of Nymphaea, as has been done by Conard. ${ }^{81}$ In this genus the same spherical multicellular proembryo appears, two opposite and symmetrical cotyledons with the stem-tip between them arising from the free side, and the basal portion forming the hrpocotyl. At maturity the cotyledons become concave and inclose the plumule, just as in Nelumbo. There can be no question that the two genera are closely related: and since the embryogeny of Nymphaea is trpically dicotyledonous, it follows that that of Nelumbo must be only a modification of it, and that for some reason the stemtip does not occupy its usual central position, and the two cotyledons arise for a time en masse, as in the case of petals in sinpetaly. Conard calls attention to such behavior on the part of the cotyledons of Tropacolum, which appear " connateperfoliate" about the hypocotyl; and also to the fact that Hegelmaier noted the complete fusion of the cotyledons along one 
edge in Tuphar lutea. In his recent study of Ceratophyllum Strasburger st fincs that the embryo in its earlier stages bears a striking resemblance to that of Nelumbo, there being a large spherical mass of cells with no suspensor (Fig. so). The embryo of Nelumbo has the rudiment of a root, although it nerer derelops, the first functional roots coming from the stem abore the cotyledon (Fig. so, s). In Ceratophyllum the reduction due to the water habit has gone further, not even the rudiment of a root appearing in the embryo. The two cotyledons of Ceratophyllum so strongly resemble the condition in Nelumbo, that Strasburger, after examining the embryo of the latter, was forced to helieve that here also, as in Ceratophyllum, there are two cotyledons.

The occasional occurrence of a whorl of three cotyledons has been reported for Quercus, Amygdalus, Phaseolus, etc., and many other cases are given by Bram. ${ }^{6}$

In this connection, recent sngestions as to the phrlogeny of the cotyledon may be referred to. The current opinion regards it as a modified foliage leaf, and this is borne out in the majority of Dicotrledons by the assumption of the foliage function. The terminal cotyledon of Monocotyledons, however, seems to belong to a different category, and to hold no relation to a foliage leaf or to a foliar member of any description. In a recent paper H. L. I, ron ss derelops the idea that the cotyledon of Angiosperms is phrlogenetically related to the sucking organ known as the "foot" among Brrophytes and Pteridophytes. IIis own summary makes his position clear:

(1) The typical embryos of the Pteridophytes and Angiosperms differentiate into three primary members, the cotyledon, stem. and root; (2) cotyledons are not arrested leaves, but are primarily haustorial organs originating phylogenetically as the nursing-foot in the Bryophytes and persisting throughout the higher plants; (3) the monocotyledonous condition is the primitive one and prevails in the Bryophytes, Pteridophytes, Monocotyledons, and some Gymnosperms; the two (sometimes more) cotyledons of the Dicotyledons are jointly the homologue of the single cotyledon of the Monocotyledons; (4) the cotyledon always occurs at the base of the primary stem; (5) the hypocotyl is a structure peculiar to the Angiosperms, being differentiated between the primary stem and root; (6) the so-called cotyledon of the Pteridophytes and Gymnosperms, with the probable exception of Ginkgo and the Cycads, are true foliage leaves. 
The same general idea has been expressed by Balfour, ${ }^{80}$ as the following quotations show:

"We ought, I think, to look upon the embryo as a protocorm of embryonic tissue adapted to a seed-life. Under the influence of its heterotrophic nutrition and seed-environment it may develop organs not represented in the adult plant as we see in, for instance, the embryonal intraovular and extraovular haustoria it often possesses. There is no reason to assume that there must be homologies between the protocorm and the adult outside an axial part with its polarity. There may be homologous organs; but neither in ontogeny nor in phylogeny is there sufficient evidence to suow that the parts of the embryo are a reduction of those of the adult."

- That the cotyledons, primarily suctorial organs, should change their function and become leaf-like under the new conditions after germination is no more peculiar than that the hypocotyl should take the form of an epicotylar internode, from which it is intrinsically different as the frequent derelopment upon it of hypocotylar buds throughout its extent shows."

"The protocorm has, I believe, developed along different lines in the Dicotyledons and Monocotyledons. This has been to the adrantage of the former in the provision that has been made for rapid as opposed to sluggish further development. Confining ourselves to the general case, the axial portion of the protocorm of the Dicotyledon, the hypocotyl, bears a pair of lateral outgrowths, the cotyledons, and terminates in the plumular bud and in the primary root respectively. The cotyledons are its suctorial organs, and the hypocotyl does the work of rupturing the seed and placing the plumular bud and root by a rapid elongation which commonly brings the plumular bud above ground, protected, it may be, by the cotyledons. These latter may then become the first assimilating organs unlike or like to the epicotylar leaves. In the Ionocotyledons the axial portion of the protocorm has usually no suctorial outgrowths. Its apex and usually its base also are of limited growth. The plumular bud is a lateral derelopment, and the primary root of ten an internal one. The suctorial function is performed by the apex of the protocorm, termed here also the cotyledon."

"I use the term purely as an objective designation, and in the original meaning of the suctorial organ in the embryo. This terminal cotyledon in the Monocotyledons is not a leaf nor the homologue of the lateral cotyledons in the Dicotyledons."

In explanation of the terminal cotyledon of Monocotyledons has been suggested by Miss Sargant ${ }^{89}$ in her study of the seedlings of Liliaceae. In Anemarthena she finds the cotyledon 
trarersed by two opposed vaseular bundles, which suggest the fusion of two organs and a derivation from the dicotyledonous condition. This position is further strengthened by the wellknown tendeney among eertain Dicotyledons for the cotyledons to become more or less completely fused (see Chapter $X V^{r}$ ).

'The whole problem, however, is too indefinite as yet, and the data are too few to permit well-grounded conclusions, but it is well worth consideration.

\section{PARTHENOGENESIS}

The term parthenogenesis was once very loosely applied, incuding all cases of the appearance of embryos without fertilization. Strictly, however, it includes only those eases in which the normal egg produees an embryo without fertilization, and this phenomenon has thus far been demonstrated in only three angiospermous genera, to be deseribed below. Apogamy, being the production of a sporophyte by a gametophyte without the act of fertilization, of course inchudes parthenogenesis, but the production of sporophytes by gametophytic struetures other than the egg may for convenience be distinguished as vegetative apogamy. In this category would be included all cases of embryos derived from unfertilized synergids, antipodals, and endosperm, the last-named strueture being included or not dependent upon one's view as to its morphological charaeter. When an unfertilized synergid produces an embryo, it might be claimed that it is not a ease of regetative apogamy but of parthenogenesis, since the synergid is to be regarded as a non-funetioning egg. This simply serves to illustrate the fact that eategories are essentially arbitrary and artificial. A third category includes those eases in which embryos are produced by the tissue of the nucellus or of the integument. This is not apogamy, although it has often been so called, for it is a case in which a sporophyte is produced by sporophytic tissue, and can be ineluded under the general name of budding. In addition to the normal method, therefore, embryos appear among Angiosperms in three ways, namely, by parthenogenesis, by regetative apogamy, and by budding. In most cases regetative apogamy and budding are assoeiated with polyembryony, and they will be considered under that head. The three well-authenticated cases of parthenogenesis among Angiosperms are as follows: 
In $1898 \mathrm{Juel}^{53,66}$ reported parthenogenesis in Antennaria alpina, and two years later published a very full account of this species and also of A. dioica, in the latter of which fertilization occurs regularly. In the parthenogenetic 1. alpina usually only pistillate plants are found, and in the staminate plants that do occur the pollen is either lacking or feebly developed. Juel was able to show conclusirely that the embryo develops from the unfertilized egg. He was also able to satisfy himself that the number of chromosomes (about fifty) remains unchanged throughout the entire life history, no reduction taking place in the formation or germination of the megaspore. The first division of the nucleus of the megaspore mother-cell is like the divisions in vegetative cells, and neither in the form of chromosomes nor in the character of the spindle does it resemble the heterotypic division that is so constantly associated with the reduction of chromosomes. The mother-cell gires rise to only one megaspore, not forming a tetrad. In A. dioica, in which fertilization regularly occurs, the megaspore mother-cell gives rise to a tetrad, the first division being accompanied by a reduction in the number of chromosomes (from about twenty-four to about twelve). While the number of chromosomes was not determined with absolute accuracy for either species, the numerous countings prove the principal point, namely, that in 1 . dioica a reduction occurs at the beginning of the gametophyte generation, but in the parthenogenetic $A$. alpina the number remains unchanged throughout the life history. In the latter also the polar nuclei do not fuse to form a primary endosperm nucleus, but each divides independently and forms a mass of endosperm, showing, like the egg, an ability to divide without previous fusion.

In 1901 Murbeck ${ }^{\tau 6}$ discovered that parthenogenesis is more or less constant in all the species of Alchemilla belonging to Evalchemluta but he succeeded in finding a species (A. arvensis) in which fertilization regularly occurs. In the structure of the nucellus Alchemilla differs decidedly from Antennaria, there being a large number of megaspore mother-cells, many of which form tetrads; and it is not uncommon for several of the resulting megaspores to germinate. The general appearance of the embryo-sac is normal, and the polar nuclei usually fuse to form a primary endosperm nucleus. Since this 
fusion was observed in several parthenogenetic species of $A l$ chemilla (A. sericata, A. "hybrida," A. pubescens, A. pastoralis, A. acutangula, A. alpestris, and A. speciosa), its failure, as in Antennaria alpina, can hardly be regarded as characteristic of parthenogenetic forms. In the parthenogenetic species of Alchemilla, as Antennaria alpina, the number of chromosomes remains unchanged throughout the life-history. Although the number was not positively established, the counting never showed less than thirty-two or more than forty-eight. In Alchemilla arensis, in which fertilization regularly occurs, the numbers are sixteen and thirty-two. Aside from the more difficult cytological evidence, a convincing proof of the existence of parthenogenesis in Alchemilla alpina is found in the fact that the segmenting embryos are often obtained from unopened buds in which no pollen has been dereloped. In A. arensis (Murbeck ${ }^{i \tau}$ ), in which fertilization occurs, the pollen-tube enters the chalaza and traverses the integument.

In 1902 Overton ${ }^{83}$ discovered parthenogenesis in Thalictrum purpurascens, the investigation having been suggested by an early observation that Thalictrum Fendleri set seed freely in the absence of staminate plants. Only orulate plants were brought into the greenhouse and forced. These set seed containing good embryos several weeks before the staminate plants of the ricinity had dereloped pollen. Investigation showed berond a peradrenture that these embryos were derived from unfertilized eggs. He also compared normal and parthenogenetic embryos, and found that the latter are noticeably slower in starting, though the two kinds become exactly alike at maturity. The eytoplasm is rery dense about the unfertilized egg, and when a zone in contact with the egg changes in appearance the first segmentation occurs. He suggests that there is a reaction of some kind between the egg and the contiguous crtoplasm that brings about the change in the phrsical constitution of the egg that induces segmentation. This is conceirable from the fact that artificial parthenogenesis has been induced in the unfertilized eggs of certain low animals br changing the osmotic pressure. Orerton finds that in nature this species probably produces normal and parthenogenetic embryos in about equal numbers.

Still more recently Treub ${ }^{92}$ has concluded that Ficus hirta 
produces parthenogenetic embryos. The observation was not direct or conchisive, the inference being based upon the failure to discover pollen-tubes although embryos were common, the feeble development of endosperm, and the poorly developed srnergids, all of which is negative evidence. Treub suggests that the stimulus that induces the egg to diride in this case is the puncture made by the pollinating wasp Blastophaga.

There seens to be no doubt that other cases of parthenogenesis will be discovered among Angiosperms, and that many embryos supposed to be normal are parthenogenetic. There seems to be no reason to doubt that if an envelop of eytoplasm may result in the segmentation of the egg in Thalictrum, it may often have the same result in other cases. For example, Treub ${ }^{25}$ observed that in certain Burmanniaceae (Gonyanthes candida and Burmannia jaranica) the egg does not segment until the embryo-sac is packed full of endosperm. Such a condition might well repeat the results in Thalictrum. In fact, all cases in which there is a long delay before the egg segments may be suspected of oceasional parthenogenesis.

\section{POLYEMBRYONY}

Polyembryony in Angiosperms; while not so prevalent as in Gymnosperms, is by no means a rare or recently discovered phenomenon. Is early as 1719, Leeuwenhoek found two embryos in orange seeds. In Euonymous latifolius polyembryony was discovered three times independently; hy Petit-Thonars in $1>07$, br Grebel in 1820, and by Treviranus in 1s.9. In this species about one-lialf of the ripe seeds are said to contain more than one embryo. A. Braun in 15.59 gave an historical résumé of the subject, and cited sixty cases as known at that time. The first demonstration of the real nature of certain cases of polyembryony was made by Straburger ${ }^{12,16}$ in $15-5$. He found that in Fumlia ovata, Nothoscordon fragrans, Citrus Aurantium, and Coelebogyne ilicifolia the cells of the nucellus above the apex of the embry-sac become rich in contents, divide and grow, and form sereral embryos that push the sac wall hefore them and become placed in the seed like normal emhryos. In Funkia the egg is fertilized, but seldom or perhaps never produces an embryo, diriding a few times and then disorganizing (Fig. 99). When pollination is prevented artificially, 
the adventitious embryos begin to derelop but nerer mature. In Citrus the embryos are derived not only from the cells of the

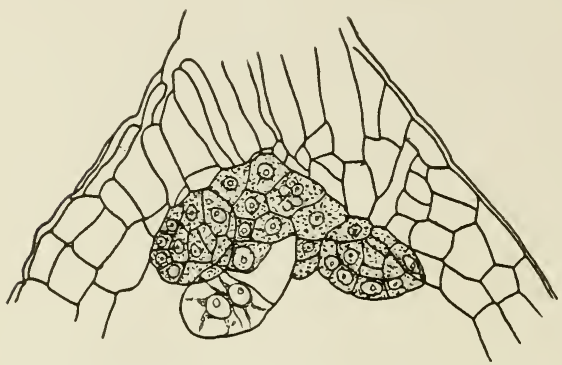

Fı. 99.-Funkia ovata, showing adventitious embryos; fertilized egg has given rise to weak proembryo of three cells; $\times$ 190.-After STrasBtrger. ${ }^{16}$ nucellus capping the sac, but also from those lower down, which may be separated from the sac by several cells. In Coelebogyne, long supposed to be parthenogenetic, fertilization nerer occurs in Europe, since only pistillate plants are cultivated. These are not cases of apogamy, as often stated, but are evidently cases of regetative multiplication or budding, since the embryos arise from sporophytic tissue. In Opuntia vulgaris (Ganong ${ }^{49}$ ) the ripe seed contains one large embryo and sereral smaller ones pressed to one side. Half ripe seeds generally show that the large embryo comes from the micropylar end of the sac, while the small ones arise from nucellar tissue. Among Cactaceae the only previously known case of polvembryony is that of Opuntia tortispina.

The multiplication of embryos by budding from a massive suspensor also occurs, and is especially common in the Litium type of embryogens, in which the suspensor is strongly meristematic. In 1895 Jeffrey ${ }^{35}$ called attention to the fact that in Erythronium americanum the suspensor is a massive and lobed tissue on whose

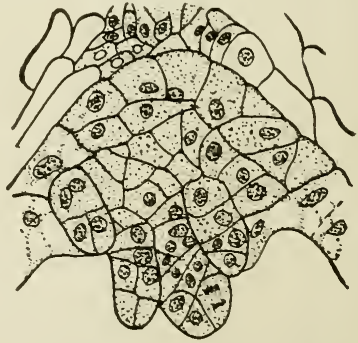

FIG. 100. - Erythronium americanum. Four embryos derived from fertilized egg; $\times 144$. - After JEFFREY ${ }^{36}$

free surface two to four embryos appear, only one persisting (Fig. 100). As in Funtia, the cells of the nucellus are 
rich in protoplasmic contents, and this led Jeffrey to suspect that a reinrestigation of Funkia with the aid of modern technique would reveal a similar condition. The examination, however, confirmed Strasburger's account, so that while the general appearance of sections is much the same in the two cases ( $c f$. Figs. 99 and 100), it is established that in Funkia the embryos come from the nucellus, while in Erythronium they come from the fertilized egg. In Erythronium albidum Schaff-
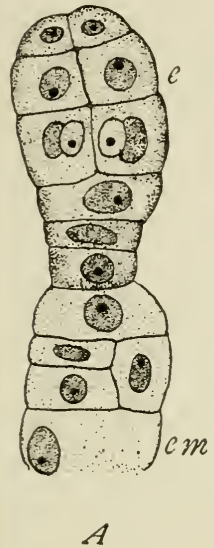
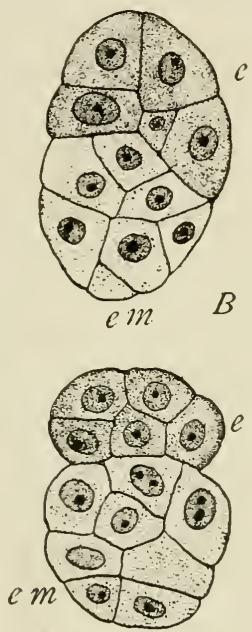

C

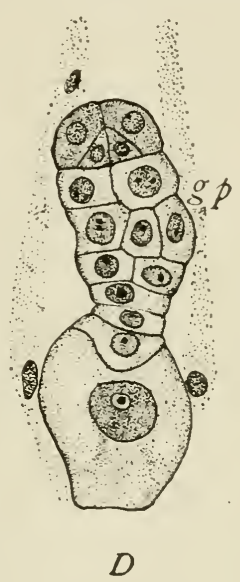

Fig. 101.-Limnocharis emarginata. A-C, three sections of one embryo, showing embryo proper (e) and embryo-buds from suspensor $(e m) ; D$, appearance of growing point of stem $(g p)$. - After HALL. ${ }^{82}$

ner ${ }^{72}$ found the same large, irregular, and much-lobed suspensor, but it was associated with only one embryo. In Tulipa Gesneriana Ernst ${ }^{69}$ also observed the phenomenon of a massive suspensor associated with one to six embryos, only one of which usually persists. In these cases the Litinm type of embryogeny is obscured by the early and rapid growth of the suspensor region of the proembryo, the embryonal cell appearing hardly more than one of the cells of its free surface. In these cases 
of polrembryony, therefore, one of the embryos is to be regarded as normal, and the others as secondary or adrentitions. Exactly the same thing sometimes occurs in Limnocharis emarginata, one of the Alismaceae, as observed by Hall \$2 (Fig. 101).

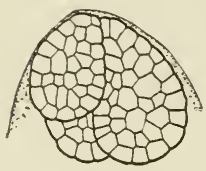

Fig. 102.-Jimasa Denhartii. Three embryos occupying position of egg-apparatus ; $\times 384$. -After Gigiand, 21

In this species the basal suspensor-cell may increase very much in size and remain undirided, as is most common in the Alisma type; or it may divide extensively, forming a massive tissue from which several embryos bud. It was not observed whether more than one embryo matures, but presumably not. This case is interesting not only on account of the polvembrrony, but also because it emphasizes the relation between the Alisma and Lilium types of embryogenr.

Illustrations of ordinary apogamy are relatively numerous, apparently every cell within the embryo-sac being able under certain conditions to produce an embrro. In some cases a svnergid is fertilized, and then the resulting embryo should probably be regarded as normal; it certainly is not apogamous. For example, Schwere ${ }^{40}$ discovered svnergid fertilization in Taraxacum officinale; and Guignard ${ }^{68}$ has observed that in Naias major the persistent synergid instead of the primary endosperm nucleus may be fertilized by the second male nucleus, resulting in two embryos lying side by side (Fig. 103). An embryo from a svnergid in addition to a normal embry from the egg has been reported by several observers. In $\mathbf{M} i$ mosa Denhartii Guignard ${ }^{21}$ has found cases which suggest the development of embryos from all three cells of the egg-apparatus. Sometimes two simi-

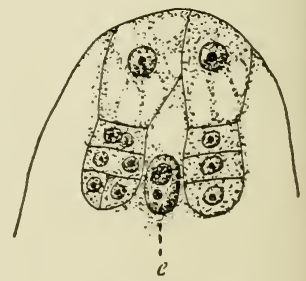

Fig. 103.-Naias major. Two embryos, one from fertilized egg, the other from fertilized synergid, a malc nucleus having fused with nucleus of synergid instead of polar nucleus; e, endosperm nucleus: $\times 176$.-After GcignaRD. ${ }^{\circ 8}$ lar embrros appear, one in the position of the egg and the wher in that of a svuergid; sometimes a group occurred con-isting of one unchanged srnergid, one embryo in the egg position, and a second embryo in the position of the second 
svnergid; and in one case three embryos were seen occupying the position of the egg-apparatus (Fig. 102). Although faroring this interpretation, Guignard mentions the possibility that the extra embryos may have come from the separation of early segments of the egg: a riew doubtless suggested by the separation of the cells of the suspensor in certain of the Leguminosae.

In Tincetoxicum nigrum and T. medium (haureaud ${ }^{33}$ finds that polvembryony is a regular phenomenon, one, tro, three, four, and even five embryos appearing, more than one of which may reach maturity. The scnergids are doubtless involved. Chaureaud found four or fire bodies in the pollentube which he thought might be interpreted as male nuclei, and responsible for polyembryony. He also concludes that polyembryony is a primitive feature of Angiosperms, the number having been reduced in the interest of one strong embryo. In describing srnergid fertilization in Iris sibirica, Dodel ${ }^{31}$ implies a somewhat similar view, when he interprets the synergids as partially aborted eggs. In this form more than one pollentube may enter the micropsle.

In certain orchids, as Gymnadenia conopsea (Strasburger ${ }^{16}$ ), two embryos sometime oceur in the same sac, but their origin is uncertain, although it is rery probable that one of them is derived from a synergid, either apogamonsly or by fertilization.

In a preliminary paper, Hegelmaier ${ }^{79}$ states that polyembryony is habitual in Euphorbia dulcis, two to nine embryos appearing at the micropylar end of the sac. One of the embryos, which certainly eomes from the egg and may be distinguished from the others by the presence of a suspensor, becomes the functional embrro. Fertilization was not studied, and so the origin of some of the embryos is in doubt, although it is certain that some come from the nucellus. Two embryos often reach the cotyledon stage, with tissue systems differentiated, while the others appear as irregular masses.

Allium odorum presents a remarkable case of polyembryony. In 1895 Tretjakow ${ }^{36}$ reported one to three embryos from the antiporlal cells (Fig. 104), the fertilized egg and sometimes a synergid forming additional embryos. In the same species Hegelmaier ${ }^{45}$ observed fire embryos in a single embryo-sac; 
one normal, one from a synergid, two from antipodal cells, and one from the inner integument (Fig. 105). It is interesting to note that while polyembryony is so frequent in Allium odo-

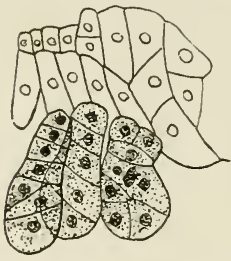

Fra. 104.-Allium odorum.

Three embryos derived from the three antipodal cells; $\times$ 116. - After TRETdAKOW. ${ }^{36}$ rum, it has not been observed in other species of the genus. Hegelmaier examined A. fistulosum and A. ursinum, and Elmore $^{50}$ made a thorough study of $A$. cernuum, A. tricoccum, and A. canadense, without discorering a single extra embryo, reporting also rery small and eranescent antipordals. In parthenogenetic species of Alchemilla Murbeck ${ }^{\tau 6}$ found embryos from the egg, from the synergids, and from the nucellar tissue (Fig. 106).

In Balanophora elongata and B. globosa fertilization is known not to oceur, and both Treub ${ }^{46}$ and Lotsy ${ }^{58}$ state that the embryo is formed by the upper polar nucleus. In addition to this, a cell in the midst of the endosperm is said to develop into a five to tencelled "pseud-embryo," whose significance and history we are
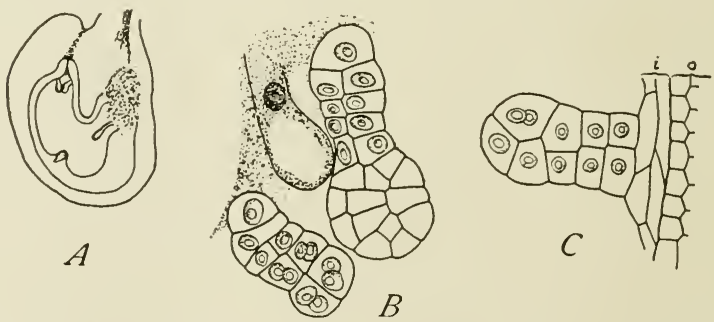

Fig. 105.-Allium odorum. A, seetion of ovule with four embryos, one from eqg. one from a synergid, ore from an antipodal cell, and one from the wall : $\times 15: B$, tro embryos, one from egg and one from a synergid: the other synergid somewhat enlarged and lying between the two embryos; $\times 246: C$, embryo derived from inner integument : $i$, inner integument: $o$, outer integument: $\times 246 .-$ After Heg FLAAIER ${ }^{45}$

at a loss to understand (Fig. 107). In the allied Helosis guaynnensis, also, Chodat and Bernard ${ }^{64}$ think that fertilization does not occur, and that the embryo arises apogamously from the endosperm.

It is evident that polyembryony is by no means so rare a 
phenomenon as many may have supposed. The cases on record are already sc numerous that only an exhaustive study of the literature would make it safe to renture an estimate of the number. Since in nearly all the cases described this phenomenon is rare rather than habitual, it is probable that under conditions not yet understood a large number of plants may exhibit polyembryony occasionally.
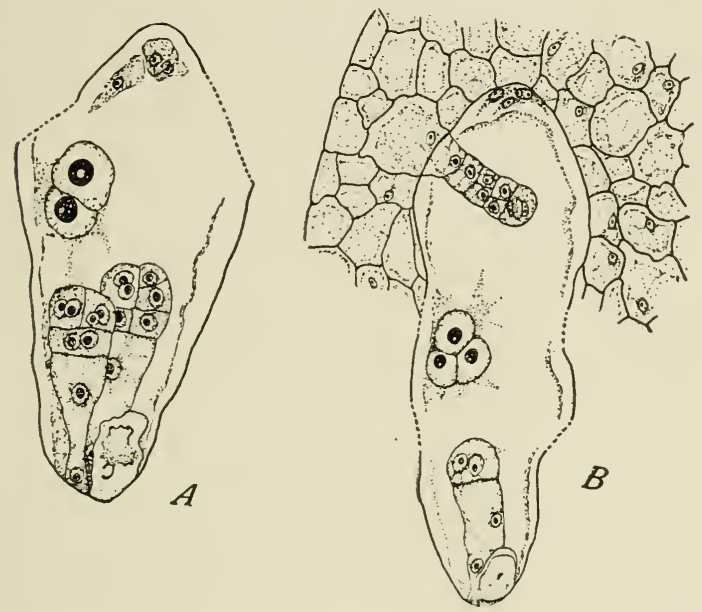

Fio. 106.-Embryos in parthenogenetic species of Alchemilla. A, A. sericata, one parthenogenetic embryo from egg and one from synergid, the other synergid breaking down: the two polar nuclei and antipodal celis also shown: $\times 284 ; B, A$. pastoralis, showing one syuergid partly disorganized, one embryo of four cells from unfertilized egg, one embryo from nucellus, two polar nuclei and one synergid nucleus forming group at middle of sac, also three disorganizing antipodal cells; $\times 190$. After M TRBECK. 90

The scattered literature of the subject is admirably summarized by Erust ${ }^{69}$ in his presentation of polyembryony in Tulipa Gesneriana. The following synoptical statement is taken from Ernst, and supplemented by the more recent additions. In case the same form is treated in sereral accounts, there is no attempt to cite all of them or eren the first reference, but a selection is made of those citations that direct to 

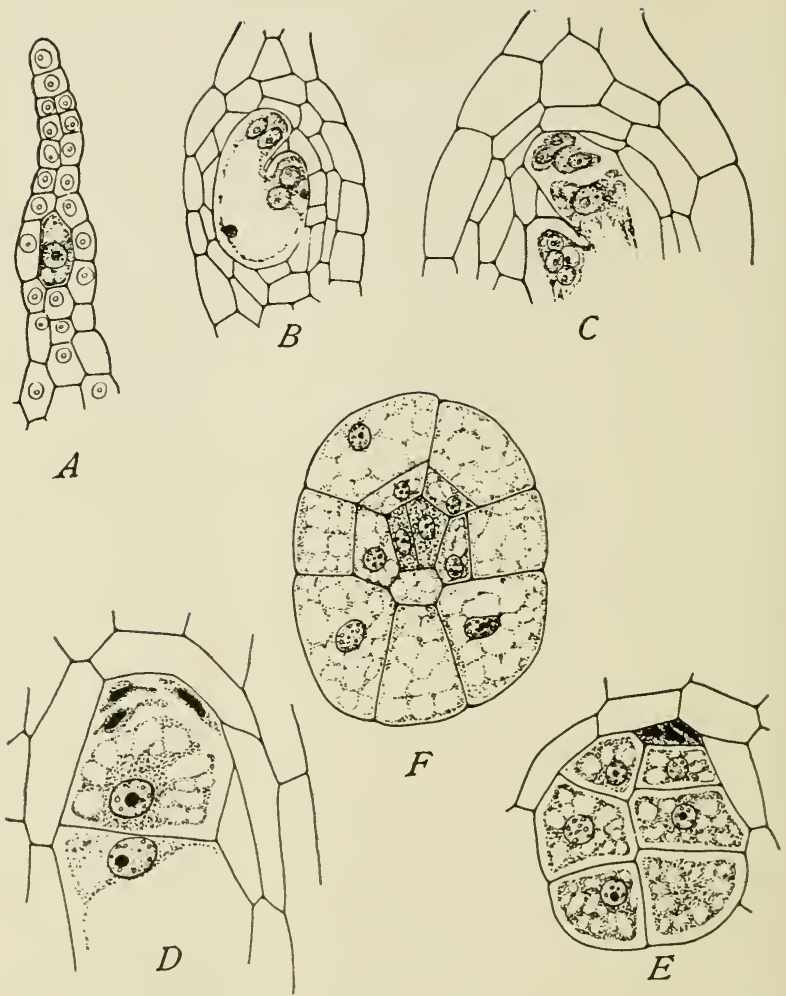

Fig. 10\%.-Balanophora elongata. Stages in development of embryo-sac, endosperm, and embryo. A, archegonium-like megusporangium with mother-cell that become. megaspore directly without forming tetrud; $\times 145 ; B$, quadrinucleate stage of embryo-sac: $\times 200 ; C$, nearly mature sac showing abore the two synergids and oosphere, just beneath the mieropylar polar nueleus, and at opposite end of sac a group of four nuelei, the three antipodals, and the lower polar nucleus: $\times 280 ; D$, at upper end the synergids and egg are disorganizing, just beneath are two cells resulting fron first division of upper polar nuelens : $\times 280: E$, six cells of endosperm shown; synergids and egg still visible at upper end of sac; $\times 300 ; F$, two-celled embryo formed from an inner cell of the endosperm; $\times$ 300.-After TRELB. ${ }^{46}$ 
the most complete descriptions. The forms that Ernst includes under "pseuca-polyembryony" are not treated in our discussion of the subject.

\section{Pseudo-polyembryony.}

1. Ovules Grown Together. Pirus Malus, Loranthus europaeus, Viscum album (all A. Braun $\left.{ }^{4}\right)$.

2. Division of Necelles. Morus albus (Hofmeister ${ }^{2}$ ). Orchis Morio (Braun 4), Gymnadenia conopsea (Strasburger ${ }^{16}$ ), Coffea arabica (Hanausek ${ }^{37}$ ).

3. Detelopyent of Several Eybryo Sacs in the saye NtCelles. Cheiranthus Cheiri (Schacht ${ }^{3}$ ), Rosa sp. (Hofmeister ${ }^{2}$ ), Rosa livida (Strasburger ${ }^{12}$ ), Trifolium pratense (Jönsson ${ }^{23}$ ), Taraxacum officinale (Schwere ${ }^{40}$ ).

\section{True Polyembryony.}

A. Embryos derived from cells outside the sac, hence from sporophytic tissue (vegetative multiplication or budding).

1. Exbryos Derived frod Cells of the Nucelles. Funkia ovata (Strasburger ${ }^{12}$ ), Nothoscordon fragrans (Strasburger ${ }^{12}$ ). Citrus A urantium (Strasburger ${ }^{18}$ ), Mangifera indica (Strasburger ${ }^{16}$ ). Euonymus americamus (Braun $\left.{ }^{4}\right)$. Coelebogyne ilicifolia (Braun. ${ }^{4}$ Strasburger $\left.{ }^{16}\right)$, Clusia alba (Goebel ${ }^{67}$ ), Opuntia vulgaris (Ganong ${ }^{43}$ ), Alchemilla pastoralis (Murbeck ${ }^{90}$ ).

2. Eybryos Fron Cells of the INtegryent. Allium odorum (Tretjakow, ${ }^{36}$ Hegelmaier ${ }^{45}$ ).

B. Embryos derived from cells within the sac (parthenogenesis and vegetative apogamy); although not in the same morphological category, embryos from the suspensor are also included in the list (vegetative multiplication or budding).

1. Normal Occerrexce of Two Eggs. Santalum album and Sinningia Lindleyana (both Strasburger ${ }^{22}$ ).

2. Eubryos Froy SYxergids. Glaucium luteum (Hegelmaier ${ }^{13}$ ), Mimosa Denleartii and Schrankia meinata (Guignard ${ }^{21}$ ), Iris sibirica (Dodel ${ }^{13}$ ), Lilinm Martagon (Overton ${ }^{32}$ ), Tincetoxicum nigrum and $T$. medium (Chaureaud ${ }^{39}$ ), Allinm odorum (Tretjakow, ${ }^{30}$ Hegelmaier ${ }^{45}$ ). Taraxacum officinale (Schwere ${ }^{40}$ ), Aconitum Napellus (Osterwalder ${ }^{62}$ ), Alchemilla sericata (Murbeck $\left.{ }^{90}\right)$, Naias majir. (Guignard ${ }^{68}$ ).

3. Splitixg of Embryo Derived from EgG. Loranthus europaeus (Braun 4).

4. Exbryos from Axtipodal Cells. Allium odom (Tretjakow, ${ }^{36}$ Hegelmaier ${ }^{13}$ ).

5. Eybryos froy Exdospery Cells. Balanophora elongata $\left(\right.$ Treub $\left.{ }^{46}\right)$. 
6. EybRYOS FROX THE SUSPENSOR. Erythronium dens-canis (Hofmeister $\left.{ }^{5}\right), \quad$ E. americanum (Jeffrey ${ }^{36}$ ), Tulipa Gesneriana (Ernst $\left.{ }^{80}\right)$, Limnocharis emarginata (Hall $\left.{ }^{82}\right)$.

\section{LITERATURE CITED}

1. Inмisch, T. Beiträge zur vergleichenden Morphologie der Pflanzen. Abhandl. Natur. Gesell. 2: 30-43. 1854; 3: 63-102, 107-137. 1855 .

2. Hofmeister, W. Neuere Beobachtungen über Embryobildung der Phanerogamen. Jahrb. Wiss. Bot. 1: 82-188. pls. $\gamma-10.1858$.

3. Аснаснт, H. Ueber Pflanzen-Befruchtung. Jahrb. Wiss. Bot. 1: 193-232. pls. 11-15. 1858.

4. Bracx, A. Ueber Polyembryonie und Keimung von Coelebogyne, ein Nachtrag zur der Abhandlung ïber Parthenogenesis bei Pflanzen. Abhandl. Königl. Akad. Wiss. Berlin, pp. 109-2us. 1859.

5. Hofueister, W. Neue Beiträge zur Kenntniss der Embryobildung der Phanerogamen. II. Monocotyledonen. 1861.

6. Braun, A. Pflanzenmissbildungen. 1869.

7. Haxstein, J. Entwickelungsgeschichte der Keime der Monocotyledonen und Dicotyledonen. Bot. Abhandl. Bonn, pp. 112. 1870.

8. Solms-Lacbach, H. Graf zu. Ueber den Bau der Samen in den Familien der Rafflesiaceae und Hydnoraceae. Bot. Zeit. 32: 337-342, 353-358, 369-374, 385-389. pl. s. 1874.

9. Hegeldaier, F. Zur Entwickelungsgeschichte monocotyledoner Keime nebst Bemerkungen iiber die Bildung der Samendeckel. Bot. Zeit. 32: 631-639, 648-671, 673-686, 689-700, 705-719. 1874.

10. - Vergleichende Untersuchungen. Stuttgart. 1875.

11. Kavienski, F. Vergleichende Untersuchungen iiber die Entwickelungsgeschichte der Utricularien. Bot. Zeit. 35: 761-775. pl. 14. $187 \%$.

12. Strasberger, E. Befruchtung und Zelltheilung. Jena. 187\%.

13. Hegelmaier, F. Vergleichende Untersuchungen über Entwickelung dicotyledoner Keime. Stuttgart. 1878.

14. Косн, L. Ueber die Entwickelung des Samens der Orobanchen. Jahrb. Wiss. Bot. 11: 218-261. pls. 8-10. 1878.

15. Solms-Latbach, H. Graf zu. Ueber monocotyle Embryonen mit scheitelbürtigen Vegetationspunkt. Bot. Żeit. 36: 65-74, 81-93. figs. 37. 1878.

16. Strasburger. E. Ueber Polyembryonie. Jenaisch. Zeitsch. Naturwiss. 12: 647-670. 1878 .

17. Famintzin, A. Embryologische Studien. Mem. Acad. Imp. Sci. St. Pétersbourg 26: 10. 1879.

18. Treub, M. Notes sur l'embryogénie de quelques Orchidées. Naturkund. Verhandl. Königl. Akad. Deel 21: 1879. 
19. StrasbCrger, E. Einige Bemerkungen über vielkernige Zellen und über Embryogenie von Lupinus. Bot. Zeit. 38: 845-854, 857-868. figs. 64. 1880.

20. Ward, H. Marshall. On the Embryo-sac and Development of Gymnadenia conopsea. Quart. Jour. Mier. Sci. 20: 1-18. pls. 1-3. 1880.

21. Guignard, L. Recherches d'embryogénie végétale comparée. I. Légumineuses. Ann. Sci. Nat. Bot. VI. 12: 5-166. pls. 1-8. 1881.

22. Trecb, M. Observations sur les Loranthacées. Ann. Sci. Nat. Bot. VI. 13: 250-282. pls. 13-20. 1882; reprinted in Ann. Jard. Bot. Buitenzorg 3: 1-12. pls. 1-2. 1883, and 2: 54-76. pls. 8-15. 1885. 23. Jössson, B. Polyembryonie hos Trifolium pratense L. Bot. Centralbl. 16: 171. 1883.

24. Treub, M. Notes sur l'embryon, le sac embryonnaire, et l'ovule. I and II. Ann. Jard. Bot. Buitenzorg 3: 76-87. pls. 13-15. 1883. 25. - Notes sur l'embryon, le sac embryonnaire, et l'ovule. III and IV. Ann. Jard. Bot. Buitenzorg 3: 120-128. pls. 18-19. 1883.

26. - Observations sur les Loranthacées. IT. Ann. Jard. Bot. Buitenzorg 3: 18t-190. pls. 28-29. 1883.

27. - Notes sur l'embryon, le sac embryonnaire, et l'ovule. $\mathrm{V}$. Ann. Jard. Bot. Buitenzorg 4: 101-106. pl. 8. 1884.

28. Goebel, C. Outlines of Classification and Special Morphology. English translation. Oxford. 1887.

29. Oliver, F. W. On the Structure, Development, and Affinities of Trapella, a New Genus of Pedalineae. Annals of Botany 2: 75115. pls. 5-9. 1888 .

30. - On Sarcodes sanguinea. Annals of Botany 4: 303-326. pls. $1 \%-21.1890$.

31. Dodel, A. Beiträge zur Kenntniss der Befruchtungserscheinungen bei Iris sibirica. Festschrift (Nägeli und Kölliker). Würzburg. 1891.

32. Overtox, E. Beitrag zur Kenntniss der Entwickelung und Vereinigung der Geschlechtsprodukte bei Lilium Martagon. Festschrift (Nägeli und Kölliker). Würzburg. 1891.

33. Chatveatd, G. L. Sur la fécondation dans les cas de polyembryonie. Compt. Rend. 114: 504-506. 1892.

34. Mottier, D. M. On the Embryo-sac and Embryo of Senecio aureus L. Bot. Gazette 18: 245-253. pls. 27-29. 1893.

35. Jeffrey, E. C. Polyembryony in Erythronium americanum. Annals of Botany 9: 53\%-542. pl. 19. 1895.

36. Tretjakow, S. Die Betheiligung der Antipoden in Fällen der Polyembryonie bei Allium odorum L. Ber. Deutsch. Bot. Gesell. 13: 13-17. $p l$. 2, 1895 .

37. Haxalsek, T. F. Ueber symmetrische und polyembryonische Samen von Coffea arabica L. Ber. Deutsch. Bot. Gesell. 13: 73-78. pl. 6. 1895 . 
38. Humphrey, J. E. The Development of the Seed in Scitamineat. Annals of Botany 10: 1-40. pls. 1-4. 1896.

39. Schaffier, J. H. The Embryo-sac of Alisma Plantago. Bot. Gazette 21: 123-132. $p l s .9-10.1896$.

40. SCHWERE, S. Zur Entwickelungsgeschichte der Frucht vou Taraxacum officinale Web. Ein Beitrag zur Embryologie der Compositen. Flora 82: 32-66. pls. 2-5. 1896.

41. CAmpbell, D. H. A Morphological Study of Naias and Zannichellia. Proc. Calif. Acad. Sc1. III. 1: 1-62. pls. 1-5. 1897.

42. Chamberlaix, C. J. Contribution to the Life History of Salix. Bot. Gazette 23: 147-179. pls. 1z-18. 1897.

43. Schaffiner, J. H. Contribution to the Life History of Sagittaria variabilis. Bot. Gazette 23: 252-273. pls. 20-26. 1897.

44. Coulter, J. M. Contribution to the Life History of Lilium illiladelphicum. Bot. Gazette 23: 412-422. pls. 32-34. 189\%.

45. Hegelmaier, F. Zur Kenntniss der Polyembryonie von Allium odorum. Bot. Zeit. 55: 133-140. 1897.

46. Trecb, II. Lorgane femelle et l'apogamie du Balanophora elongata. Ann. Jard. Bot. Buitenzorg 15: 1-22. pls. 1-8. 189s.

47. Caypbell, D. H. The Development of the Flower and Embryo in Lilaea subulata HBK. Annals of Botany 12: 1-28. pls. 1-3. 1898.

48. Collter, J. II. Contribution to the Life History of Ranunculus. Bot. Gazette 25: 73-85. pls. 4-\%. 1898.

49. GAxoxg, W. F. Upon Polyembryony and its Morphology in Opuntia rulgaris. Bot. Gazette 25: 221-228. pl. 16. 1898.

50. Elyore, C. J. Some Results from the Study of Allium. Bot. Gazette 26: 2ส-278. 1895.

51. Riddle, Lumixa C. The Embryology of Alyssum. Bot. Gazette 26: 314-324. pls. 26-28. 1898.

52. Osterwalder. A. Beiträge zur Embryologie von Aconitum Nupellus. Flora 85: 254-292. pls. 11-15. 1898.

53. Jckl, H. O. Parthenogenesis bei Antennaria alpina (L.) R. Br. Bot. Centralbl. 74: 369-37\%. 1898.

54. Caldwell. O. W. On the Life History of Lemna minor. Bot. Gazette 27: 37-66. figs. 59. 1899.

55. Canpbeld, D. H. Notes on the Structure of the Embryo-sac in Sparganium and Lysichiton. Bot. Gazette 27: 153-166. pl. 1. 1899.

56. ——. Die Entwickelung des Embryosackes von Peperomia pellucida Kunth. Ber. Dentsch. Bot. Gesell. 17: 452-456. pl. 31. 1899; also, A Peculiar Embrro-sac in Peperomia pellucida. Annals of Botany 13: 696. 1899.

57. Llovd, F. E. The Comparative Embryology of the Rubiaceae. Bull. Torr. Bot. Club 28: 1-25. pls. 1-3. 1899.

58. Lotsy, J. P. Balanophora globosa Jungh. Eine wenigstens örtlich-rerwittwete Pflanze. Ann. Jard. Bot. Buitenzorg II. 1: 17t-186. pls. 26-39. 1899. 
59. Campbell, D. H. Studies on the Araceae. Annals of Botany 14: 1-25. pls. 1-3. 1900.

60. HiLL, 'I'. G. The structure and Development of Triglochin maritimum L. Annals of Botany 14: 83-10\%. pls. 6- . 1900.

61. Merrell, W. D. A Contribution to the Life History of Silphium. Bot. Gazette 29: 99-133. pls. :-10. 1900.

62. Johxson, D. S. On the Endosperm and Embryo of Peperomia pellucida. Bot. Gazette 30: 1-11. pl. 1. 1900.

63. WiEgaxd, K. M. The Development of the Embryo-sac in some Monocotyledonous Plants. Bot. Gazette 30: 25-4\%. pls. 6-i. 1900.

64. Chodat, R., and Bernard, C. Sur le sac embryomaire de l'Helosis guayanensis. Jour. Botanique 14: 72-79. pls. 1-2. 1900.

65. Caxion, W. A. A Morphological Study of the Flower and Embryo of the Wild Oat, Avena fatua. Proc. Calif. Acad. Sci. III. 1: 329-364. pls. 49-58. 1900.

66. JuEL, H. O. Tergleichende Untersuchungen über typische und parthenogenetische Fortpflanzung bei der Gattung Antemnaria. Handl. Svensk. Tetensk. Akad. 33: no. 5. pp. 59. pls. 6. figs. 5. 1900 ; reviewed in Bot. Zeit. 59: 131. 1901.

67. GokBEL, C. Bemerkung zu der vorstehenden Mittheilung (Möbius: Parasitismus und sexuelle Reproduktion im Pflanzenreiche). Biol. Centralbl. 20: 5ั1-5\%2. 1900.

68. Guigrard, L. La double fécondation dans le Naias major. Jour. Botanique 15: 205-213. figs. 14. 1901.

69. Erxst, A. Beiträge zur Kenntniss der Entwickelung des Embryosackes und des Embryo (Polyembryonie) von Tulipa Gesneriana L. Flora 88: 37-7r. pls. 't-8. 1901.

70. Billixgs, F. H. Beiträge zur Kenntniss der Samenentwickelung. Flora 88: 253-318. 1901.

71. Holferty, G. II. Orule and Embryo of Potamogeton natans. Bot. Gazette 31 : 339-346. pls. 2-3. 1901.

72. SCHAFFxer, J. H. A Contribution to the Life History and Cytol- ogs of Erythronium. Bot. Gazette 31: 369-3s\%. pls. 4-9. 1901.

73. LeavitT. R. G. Notes on the Embryology of some New England Orehids. Rhodora 3 : 202-205. pl. 33. 1901.

74. Lyox, H. L. Preliminary Note on the Embryogeny of Nelumbo. Science 13: 470. 1901.

75. - Observations on the Embryogeny of Nelumbo. Minu. Bot. Studies 2: 64:3-65.5. pls. 48-50. 1301.

76. MLRBEcK, S. Parthenogenetische Embryobildung in der Gattung Alchemilla. Lunds Univ. Arsskrift $3^{*}:$ no. 7. pp. 46. pls. 6. 1901 ; reviewed in Bot. Zeit. 59: 129. 1901.

77. - Ueber das Verhalten des Pollenschlauches bei Alchemilla arvensis und das Tesen der Chalazogamie. Lunds Univ. Arsskrift 36: pp. 19. pls. 2. 1901. 
78. Sinth, Amelia C. The Structure and Parasitism of Aphyllon uniflorum Gray. Contrib. Bot. Lab. Univ. Penn. 2: 111-121. pls. 13-15. 1901.

79. Hegelyaier, F. Ueber einen neuen Fall von habitueller Polyembryonie. Ber. Deutsch. Bot. Gesell. 10: 488-499. 1901.

80. Balfocr, I. B. The Angiosperms. Address to the Botanical Section, Brit. Assn. Adv. Sci. Glasgow. 1901.

81. Covard, H. S. Note on the Embryo of Nymphaea. Science 15: 316. 1902.

82. Hall, J. G. An Embryological Study of Limnocharis emarginata. Bot. Gazette 33: 214-219. pl.9. 1902.

83. Overton, J. B. Parthenogenesis in Thalictrum purpurascens. Bot. Gazette 33: 363-375. pls. 12-13. 1902.

84. Strasburger, E. Ein Beitrag zur Kenntniss von Ceratophyllum submersum und phylogenetische Erörterungen. Jahrb. Wiss. Bot 37: 477-526. pls. 9-11. 1902.

85. Lloyd, F. E. The Comparative Embryology of the Rubiaceae. Mem. Torr. Bot. Club 8: 27-112. pls. 5-15. 1902.

86. Johrsox, D. S. On the Development of Certain Piperaceae. Bot. Gazette 34: 321-340. pls. 9-10. 1902.

87. PÉchoutre, F. Contribution à l'étude du développement de l'ovule et de le graine des Rosacées. Ann. Sci. Nat. Bot. VIII. 16: 1-158. figs. 166. 1902.

88. Lyox, H. L. The Phylogeny of the Cotyledon. Postelsia 1901: 55-86. 1902.

89. Sargant, Ethel. The Origin of the Seed-leaf in Monocotyledons. The New Phytologist 1: 107-113. pl. 2. 1902.

90. Murbeck, S. Ueber Anomalien im Baue des Nucellus und des Embryosackes bei parthenogenetischen Arten der Gattung Alchemilla. Lunds Univ. Arsskrift 38?: no. 2. pp. 10. pls. 13. 1902.

91. Sснмі, B. Beiträge zur Embryo-Entwickelung einiger Dicotylen. Bot. Zeit. 60: 207-230. pls. 8-10. 1902.

92. Treub, M. L'organe femelle et l'embryogénèse dans le Ficus hirta Vahl. Ann. Jard. Bot. Buitenzorg II. 3: 12t-15\%. pls. 1625. 1902.

93. JuEL, H. O. Zur Entwicklungsgeschichte des Samens von Cynomorium. Beih. Bot. Centralbl. 13 : 194-202. figs. 5. 1902.

94. Sargant, Ethel. A Theory of the Origin of Monocotyledons, founded on the Structure of their Seedlings. Annals of Botany 17: 1-92. pls, 1-\%. 1903.

95. Murbeck, S. Ueber die Embryologie von Ruppia rostellata Koch. Handl. Srensk. Vetensk. Akad. 36: pp. 21. pls. 3. 1902. 


\section{CHAPTER $\mathrm{X}$}

\section{CLASSIFICATION OF MONOCOTYLEDONS}

A satisfactory classification of Angiosperms still remains an impossible task. The immense number of species and their entanglement of relationships, as well as our merely superficial knowledge of the great majority of forms, have made progress toward a natural classification very slow. Since the time of John Ray (1703) steps in this progress have been taken by De Jussieu (17ธ9), De Candolle (1^19), Endlicher (1\$361540), Brongniart (1s43). Braun (1s64). Bentham and Hooker (1862-1853), Eichler (1\$83), Engler (1592), and others. Naturally, the increasing knowledge of morphologr and the changed conception of species have gradually broken nip artificial assemblages, but much of classification is still artificial. It does not lie within the pmpose of this book to trace the historical development of classification, nor to present another scheme for consideration. We merely adopt the classification of Eichler as morlified by Engler, and elaborated in Engler and Prantl's Die Natïrlichen Pfanzenfamilien, as the best expression of our present knowledge of morphology as applied to the whole of Angiosperms. The special student of morphologr must have enongh knowledge of general relationships to enable him to select critical forms for investigation and to appreciate the bearings of his results. The purpose of the following presentation, therefore, is to trace in a general way the evolution of Angiosperms and to point out the greatest gaps in knowledge, using the classification mentioned as the best available hasis. No attempt is made to use the varying terminology of the larger groups of classification, but coordinate groups are indicated by common endings.

According to Engler, the general tendency among Monocot- 
Yledons is to adrance from naked flowers with parts spirally arranged and indefinite in number to pentacyclic trimerous flowers. There are also such lines of advance as from apocarpy to syncarps, from hrpogrny to epigyny, from actinomorphy to zygomorphy, etc. 'These tendencies are often rery unequally expressed even by different groups of the same alliance, one group developing chiefly along one line, and another group along another line, so that the results are very different. It is also often a question whether a simple floral structure is primitive or reduced. In the older morphology there was a trpical floral structure, and all simpler ones were regarded as reduced forms. There can be no doubt that there are reduced floral structures, as in Lemna; but the great majority of simple florers are probably primitive.

- Lpon these and other considerations, Engler has subdivided the Monocotyledons into ten great alliances. The first six constitute the more primitive Spiral series, and although the trimerous habit appears among them, the spiral arrangement and indefinite numbers oceur in one or more sets. The remaining four alliances constitute the Cyclic series, the highly specialized Monocotyledons.

I. Paxdaxales. - This includes the Pandanaceae, Typhaceae, and Sparganiaceae, together containing a little more than 100 species. The Pandanaceae (about so species), or screwpines, belong to the oriental tropics, chiefly the coasts and islands of the Indian and Pacific oceans; while the other families are mainly represented in temperate regions.

That these forms are primitive Monocotyledons is indicated by the following facts: there is nothing to represent a perianth unless the floral bracts of Sparganium be regarded as one; the sporophylls are mostly spiral and indefinite in number, the stamens of Pandanaceae often being very numerous and exhibiting the greatest rariation in arrangement: the species are all hydrophytic: and the plants are anemophilons. Such flowers as those of the Pandanaceae and Trphaceae are extremely simple, the peculiar hairs accompanying the sporophylls of the latter apparently representing sterile sporophylls: while the Sparganiaceae are the most advanced members of the alliance, a perianth probably heing represented hy a set of small bracts, and the trimerous character appearing. 
A well-marked feature of the group is the protection of the flower-clusters by a prominent leaf-sheath. The development of this sheath as a protecting organ before the appearance of a fully dereloped perianth is one of the constant features of the more primitive Monocotvledons, and in some of the following groups it becomes highly specialized.

The hydrophytic Pandanales, therefore, begin in the greatest simplicity, so far as floral structures are concerned, the Pandanaceae being the most primitive forms on account of the indefinite number of the sporophylls and the spiral arrangement of the stamens, and the series has not adranced rery far. It should be remembered, however, that the three existing families probably represent fragments of a formerly much larger alliance, so that the association of the temperate Typha and Sparganium with the tropical Pandanaceae may not be so unnatural in reality as it appears at present. It is extremely desirable to obtain some accurate knowledge of the essential morphology of the Pandanaceae.

II. Helobinles.-This includes the Potamogetonaceae, Naiadaceae, Aponogetonaceae, Juncaginaceae, Alismaceae, Butomaceae, and $\mathrm{H}_{y}$ drocharitaceae, together containing about 235 species. Engler has set apart the small family Triuridaceae, containing about 18 species, as representing a distinct series, Tricripales, but this can be disregarded in this very general presentation.

This is one of the most remarkable of the monocotyledonous lines in its extent, reaching from the greatest floral simplicity in Potamogetonaceae to highly developed flowers in Hydrocharitaceae. It has been called an unstable or plastic line, and may have given rise to higher forms; in any event it is probably to be regarded as one of the most important phylogenetic lines among the Monocotyledons. For this reason morphological investigation in recent rears has specially cultivated this series of forms, particularly the more primitive families. About the only taxonomic character that holds these direrse forms together is the fact that they are exceptional among Monocotyledons in the feeble derelopment of endosperm. Thes are characteristically aquatic, and sheathing bracts enclosing the flower-clusters are largely developed. In most of the forms the spiral arrangement and indefinite number of floral parts is very appar- 
ent, but the line as a whole presents almost a complete series from the simplest floral structure to one of the most highly developed.

The series of floral changes may be broadly indicated as follows. In Potamogetonaceae and Naiadaceae there is no perianth, and the stamens and carpels are indefinite in number; in Juncaginaceae a bract-like perianth is present, there is a distinct tendency toward the trimerous habit, and syncarpy may oceur; in Alismaceae the perianth is differentiated into calyx and corolla, and the trimerous tendency is very clear, though the carpels are usually indefinite in number; in Hydrocharitaceae, in addition to a differentiated perianth and a strong expression of the trimerous tendency (although the stamens and carpels are often indefinite in number), the flowers are epigrnous. The plants are chiefly anemophilous or hydrophilous, but the appearance of a differentiated perianth in the Alismaceae is probably associated with a certain amount of entomophily.

Heliobales, therefore, begin with as great simplicity of floral structure as do the Pandanales, but they hare adranced much further in floral development. That such an extensive line comprises so few species is probably associated with the uniformity of aquatic conditions. In the whole series, however, there is no distinct settling into a complete trimerous habit, which is intimated rather than established.

III. Glumales. *-In this alliance are the two great families Gramineae and Cyperaceae, the former including about 351 genera and 4,700 species, the latter 76 genera and about 2,300 species. In point of species this is one of the greatest of angiospermous alliances, and in display of individuals it is unquestionably the greatest. The common features of the two families are the absence of a perianth, the protection of the flowers by special bracts, the fluctuating of the stamens between one and many, the solitary carpel, and anemophily. It is not probable that the two families are related to one another genetically, but they represent approximately the same stage of floral development.

The peculiar features of the bract-protection, as contrasted

* Glumiflorae of Engler. 
with the preceding alliances, is that the bract does not ensheath a whole flower-cluster but individual flower.. It is this characteristic bract (glume, palct) that gives name to the alliance. The lodicules of Gramineae and certain hairs and bracts of Cyperaceae are regarded by some as representing a perianth. Even if this doubtful claim be allowed, such a perianth is better regarded as one that is very primitive rather than reduced.

The primitive character of Glumales is indicated by the characters given above, but contrasted with the Ifelobiales it is a rigid group that has not advanced far in floral development, but has proved to be a remarkably successful type of regetation. Moreorer, it is the primitive group of MIonocotyledons that seems to have been the first to establish itself upon the drier and more diversified land surface, and this fact may hold some relation to its structural stability and its great display of species. Eridence of its aquatic origin may be obtained not only from the numerous hydrophytic forms, but also from anatomical characters that relate it to Helobiales and Pandanales rather than to the terrestrial alliances.

Pandanales, Helobiales, and Glumales are the only three alliances of Monocotyledons that include the most primitive type of monocotyledonous floral structure. Their possible genetic relation to one another is entirely ohscure, and in their present display they seem to emerge from the beginnings of the history of Monocotyledons as independent lines. The remaining seven alliances are either derived from these three, or their primitive members have disappeared.

IV. Palmales. * The palms are the chief representatives of monocotyledonous trees, and are characteristic of all tropical regions. The single family Palmaceae includes about 150 genera and 1,100 species, though these numbers will doubtless be much increased when the palms are studied in their habitats. $\Delta$ knowledge of the essential morphology of this group is also much to be desired.

A perianth is always present, although it is rery "rudimentary" and hence doubtful in Phytelephas and Coryphanthe, but it is not differentiated into a distinct calyx and corolla. 
As there are no naked flowers, this group does not have as primitive members as do the three preceding ones. The stamens are extremely variable in number, ranging from three to indefinitely numerons, showing the primitive spiral character; while the carpels are usually three and sometimes form a syncarpous pistil. The enormous flower-cluster is ensheathed by a great bract (spathe) that is more or less tough and even woody, a feature recalling the same tendency in Pandanales and Helobiales. As the axis of inflorescence is sometimes thickened and the flowers more or less embedded in it, the inflorescence is often spoken of as a branching spadix.

These characters indicate a group as a whole considerably further adranced than the preceding ones in the constant presence of a definite perianth, although it is undifferentiated. The association of floral envelops with a spathe is of interest, but in such conditions a highly developed perianth conld not be expected. While there is doubtless anemophilous pollination, entomophily must exist to a certain extent. The whole structure suggests one that is intermediate between the dominance of bract and perianth, between anemophily and entomophily.

Palmales, therefore, differ from Glumales in the definite trimerous perianth, as well as in numerons other features; from the Helobiales in that the number of carpels is constant; but through Phytelephas and ('oryphanthe, with their rudimentary perianth, as well as through general habit, the connection with Pandanales seems clear. It sems probable, therefore, that the Palmales have been rlerived from the Pandanales, surpassing the Glumales in floral development, but not reaching the differentiation of calrx and corolla and epigrny attained by the higher members of the Helobiales.

T. Srxixpmates."-This includes a small family (Cyclanthaceae) of the American tropics, represented by about 45 species, and usually and naturally associated with the screwpines and palms. The flowers are in an unbranched spadix, either scattered or in a close spiral, and there is generally an evident bract-like perianth in one or two creles. The stamens range from six to indefinitely numerous, and the carpels are one to four. In the staminate flowers there is no trace of car-

* Srvaxthae of Engler. 
pels and the stamens are connate; while in the carpellate flowers there are very conspicuous and often branching staminodia. There is a strong tendency to " coalescence" in all the members, the perianth often being tubular, the stamens usually connate, and the carpels (if more than one) always forming a synearpous pistil. The group is also peeuliar in the very numerous ovules upon a single parietal placenta.

Too little is known of the morphology of the group to speak of its relationships with any definiteness, but it seems safe to regard it as another branch of the Pandanales stock. The Pandanales, Palmales, and Symanthales are thus referred to a common origin, with the Pandanales as the most primitive representative of the stock. This tropical association seens to be a strange one for Typha and Sparganium, but otherwise it seems to be entirely natural, and not clearly related to any other Monocotyledons.

VI. Ar.stes. *-This includes the Araceae with about 1,000 species, and the Lemmaceae with about 25. The Aroids form one of the most distinet and also diversified groups of Monocotyledons. The characteristic features are the spadix, the highly developed spathe, and the broad net-reined leaves. There is also probably greater anatomical differentiation than in any other monocotyledonous group, which is taken advantage of in their classification. The floral structure is of three general tryes: (1) the C'alamus type, in which the flowers are bisporangiate, pentacyclic, 2 to t-merons, and syncarpous; $(2)$ the Calla trpe, in which the flowers are bisporangiate, with no perianth, (j) to !) stamens, and 1 carpel; (3) the Arum type, in which the flowers are monosporangiate (staminate flowers above and carpellate flowers below on the same spadix), and with no perianth.

It is evident that the floral structure is extremely fluctuating, and that this is probably associated with the extreme sperialization of the spathe. Engler has ealled attention to the fact that the flowers with a perianth are associated with a bract-like spathe; while those without a perianth (the great majority) are associated with a petaloideous spathe. In any event, the bract reaches its highest specialization in this group,

* Spathiflorae of Engler. 
being not merely a protecting organ, but immensely raried in form, texture, and color to secure entomophily. In other words, the conspicuous function of the perianth in the petaloideous groups is here assumed by the spathe, and the flowers retain for the most part the primitive character.

There are many features of the Aroids that suggest the Helobiales, especially the Potamogetonaceae, so that Engler inclines to the belief that they have been derived from that stock. If this be true, they represent a strong terrestrial branch from the aquatic Helobiales, that in tropical conditions has become extremely varied in form and structure, and that has assumed the erect, climbing, and epiphytic habits. It does not seem probable that any other monocotyledonous alliance is associated with these two in origin; but the suggestion has been made that from the Aroids the Dicotyledons, or at least some of their phyla, may have been derived. One of the most promising fields of morphological research is among the tropical Aroids.

The Lemnaceae represent a distinct reduction series, being Aroids adapted to the free-swimming habit, and remarkably reduced in structure, Irolffia being the smallest known seedplant.

The six great alliances just considered constitute the Spiral series of Engler, with inconstant number of floral nembers, with mostly no perianth or one not adapted to entomophily, and with a striking development of sheathing leaves or bracts in connection with the inflorescence or the individual flowers.

The four remaining alliances constitute the Cyclic series, in which the almost constant floral formula is perianth $3+3$, stamens $3+3$, carpels 3 and forming a syncarpons pistil. The two perianth sets may be variously modified, but there runthrongh the series an increasing specialization of the perianth for entomophily, which reaches its extreme expression in the Orchidaceae. Is a consequence, the perianth rather than bracts becomes the conspicuns floral feature. The pentacyclic trimerous habit having beeome established, the erclic groups have largely differentiated in the direction of a conspicuons perianth, epigrny, and zyomorphy. The number of speeies involved is so great that only the broadest outlines ean be considered. 
VII. Farmals." - The eleven families of this alliance are Flagellariaceae, liestionaceae, ('entrolepidaceac, Maracaceae, Xiridaceae, Eriocaulaceae, Rapateaceae, Bromeliaceae, Commelinaceae, Pontederiaceae, and Philydraceae, together containing a little more than 2,000 species. The large families are Bromeliaceae with over 900 species, Eriocaulaceae with 460 , Commelinaceae with more than 300 , and Restionaceae with nearly 250. The chief character that holds these diverse families together and separates them from the Liliales is the thinwalled endosperm rich in starch, whose cells become easily broken up and dissociated, resulting in a "mealy" or "crumbly " endosperm.

From the evolutionary standpoint the following facts are of importance: for the most part the forms are grass-like herbs, with all habits from aquatic to xerophytic and epiphytic; they are mostly bracteate forms, the upper bracts showing a decided tendency to ensheath the inflorescence: they are mostly anemophilous, but some forms have a perianth adapted to entomophily; the perianth ranges from scarions to petaloid, from undifferentiated to a distinct calyx and corolla, from polypetaly to srmpetaly; the flowers are syncarpous and, with the exception of a few Bromelias, hypogrnous.

Such evidence indicates a relatively primitive cyclic alliance with many charaeters recalling the spiral forms, the bract-protection and anemophily not being definitely replaced by a highly dereloped perianth and entomophily. The origin of the series is of conrse obscure, but the evidence seems to faror the Ghmales as the original stock. As illustrating the construction of a natural sequence of families, those of this alliance may be used as follows:

The Flagellariaeeae, Restionaeeac, and Centrolepidaceae, belonging to the oriental tropies ehiefly of the Sonthern Hemisphere, have a bracteate undifferentiated perianth and are anemophilons, in habit and general character resembling the Spiral series.

The Maracaceae, Xrrilaceae, ant Eriocaulaceae have a differentiated calyx and corolla, and orthotropus orules with very small embryos. These three familis, together with Restiona- 
ceae and Centrolepidaceae, constitute the main part of the old group Enantioblastae, characterized by the orthotropous orules.

The Rapateaceae, chiefly South American, have a distinct calyx and corolla, anatropous orules, and small embryos.

The Bromeliaceae, the great epiphytic family of the American tropics, have a distinct calyx and corolla, anatropous orules, and larger elongated embryos.

The Commelinaceae, in addition to the distinct calyx and corolla, show a tendency to zrgomorphy. This family has the orthotropous ormles and small embryos of the Enantioblastae, but the characters given, as well as the habit and inflorescence, seem to forbid that alliance.

The Pontederiaceae and the Australasian Philydraceae have long cylindrical embryos, a general tendency to a reduced number of stamens and carpels, and in the latter family sympetaly.

VIII. Lildales. *-The nine families of this alliance are Juncaceae, Stemonaceae, Liliaceae, Haemodoraceae, Amaryllidaceae, Velloziaceae, Taccaceae, Dioscoreaceae, and Iridaceae, together comprising almost 5,000 species. The largest families are Liliaceae with nearly 2,500 species, Iridaceae with more than 1,000, and Amaryllidaceae with nearly 900 .

This great alliance may be regarded as containing the trpical highly dereloped Monocotyledons. It is characterized by a conspicuous development of the perianth and a prevailing entomophilous habit. The endosperm cells are thick-walled and in general contain oil rather than starch, resulting in an endosperm that is not "mealy," as in the Farinales. The Juncaceae, Haemoloraceae, and Velloziaceae are exceptions in producing a starch-containing endosperm, but the cells do not become dissociated. In passing from the lower members of the series to the higher there is a transition from an undifferentiated scarions perianth to a differentiated and petaloideous one: and from hypogrny to epigrny, the four lower families being hypogynous and the five higher epigrnous.

The sequence of families hegins with the Juncaceae, which with their grass-like habit, scarious perianth, and starchy endosperm, may be fairly regarded as intermediate between Fari- 
nales and Liliales. The Liliales are midway in the series, having attained a petaloideous perianth and entomophily, and having become so diversified in structure and habit as to raise a question as to their monophyletic origin. The Amaryllidaceae introluce epigyny, and the highly specialized Iridaceae complete the series. The last six families are in great need of morphological investigation in the tropics where they are chictly massed.

The genetic connection between Liliales and Farinales seems clear, so that if the latter are regarded as derived from the Glumales, the former must be referred to the same stock, probably dissociating early from the Farinales.

The two remaining alliances are characterized by epigrny and zygomorphy, highly specialized entomophilous structures, reduction and modification of stamens, and very small and undifferentiated embryos. In all probability they are not genetically related, but they resemble one another more than they do the other alliances.

IX. Scrtamrates. *-The four families of this alliance are Musaceae, Zingiberaceae, Cannaceae, and Marantaceae, together comprising nearly s00 species, 500 belonging to the Zingiberaceae. The four families are undoubtedly genetically related, although the first two are restricted to the oriental tropics, and the last two to the occidental. In addition to the characters mentioned above, the replacing of functional stamens by petaloid staminodia is rerr characteristic, commonly only one stamen being functional and even this one being petaloid. In nearly every case, also, there is a labellum, formed either by the perianth or the staminodia. The habit of the regetative body, howerer, is most peculiar. The real stem is a rhizome, but the enormous leares, differentiated into sheath, petiole, and pinnately reined blade, build up a false stem br means of their very large and closely orerlapping sheaths.

The temptation is to derive this alliance from the Dracaena region of the Liliaceae, but important anatomical features that are common to all four families are opposed to this riew. That it is connected in some way with the Glumales-Farinales-Liliales stock seems most probable: and if so the general structures

* Scitamineae of Engler. 
indicate a separate origin from Ghmales. A morphological investigation of these families in the tropies is greatly to be desired.

X. Orchidales. "-The two families of this alliance are Burmanniaceae and Orehidaceae, all but about 5j of the 7,000 species belonging to the latter family. These two mequal families are held together by the very numerous and small orules and by the extreme zygomorphism of the flower, but the Burmanniaceae have endosperm, often six stamens, and frequently connate perianth-segments, approaching the Amaryllidaceae.

The chief interest of the alliance centers abont the Orehidaceac, the greatest monocotyledonous family in point of species and the most highly specialized. The epiphytic habit is extensively dereloped, and the terrestrial forms are mostly saprophytic or parasitic. These habits have resulted in the development of eertain special structures, such as the bulbous leaf-bases and velamen of the epiphytic forms; and in the suppression of some normal structures, as the primary root, and sometimes all roots. The absence of endosperm, the poorly developed embryo, and the extensive use of the suspensor as a remarkably developed haustorial organ are probably but additional results of the unusual habits of the family. The notable floral structures are the modification of one of the petals to form the labellum and spur, the remarkable "gynostemium," the twisted ovary, and the pollinium-meehanism.

As an illustration of the rarying modifieations of floral structure, the ordinary orehid may be compared with the $C y$ pripedium type. The flowers are pentacyclic, and the eveles are developed in the two types as follows, beginning with the outermost. In both types the first eyele consists of three sepals, and the second of three petals, the posterior (made anterior by the twisting of the ovary) forming the labellum and spur. In the third cycle two lateral stamens are suppressed in both types, but in ordinary orchids the anterior one is functional, while in Cypripedium it is replaeed by a staminodium. In the fourth evcle the posterior stamen is suppressed in both types, but in ordinary orchids the two laterals are replaced by staminodia, while in Cypripedium they are funetional stamens. In the 
fifth cycle in ordinary orchids the two lateral carpels form the stigma, the anterior producing the disk-bearing " rostellum," while in ('ypripedium all three carpels form the stigma.

The origin of the Orchidaceae is very obscure. It is common to regard them as derived from the Liliales, but there are many objections to this hypothesis. In any event, it seems most natural to refer them to the same general stock.

According to the views presented in this chapter, there are three primitive monocotyledonous stocks-Pandanales, Helobiales, and Glumales-and they are connecter with the other alliances as follows: Pandanales-Palmales-Synanthales; Helobiales-Arales; Glumales-Farinales-Liliales-Scitaminales-Orchidales. 


\section{CHAPTER XI}

\section{CLASSIFICATION OF ARCHICHLAMYDEAE}

Two great divisions of Dicotyledons are erident, the Archichlamydeae and Sympetalae, although there is no sharp distinction between them. Sympetalous forms among the former and polypetalous forms among the latter occur, but in the main apetaly or polypetaly is a distinctive feature of the Archichlat mydeae, and sympetaly of the Srmpetalae. That the Archichlanydeae include the most primitive Dicotyledons is clear, but what forms are to be regarded as the most primitive is open to discussion.

The classification of the Archichlamydeae is an exceedingly puzzling problem, and the current schemes are far less definite and satisfactory than those for the classification of Monocotyledons and Srmpetalae. Questions of primitive and reduced characters, and of relative rank on the basis of combination of characters, are particularly involved among Archichlamydeae, and hence opinions vary widely as to the details of their classification. The difficulties arise from the fact that the characters of the group are extremely fluctuating, not being established as among the Srmpetalae. Add to this that more than 60,000 species* are recognized, orer three times as numerous as the species of Monocotrlerlons, included in 180 families, and it becomes evident that the confusion of relationships is berrildering.

Engler has arranged the Archichlamycleae in twenty-six al-

* The numbers of species given in this chapter must be regarded as approximate and conservative. They will vary with the increase of knowledge and the conception of species, but in this chapter they are only intended to indieate the relative display of different types of structure. 
liances, coordinate with the ten series of Monocotyledons. The general sequence of these alliances is based, as in Monocotyledons, upon the developnent of the perianth and of the floral axis, and the arrangement of floral members; but other character's, chiefly those derived from the orules, are also used to disentangle relationships. Of course there is no real sequence of these twenty-six alliances, for they represent, for the most part, parallel or divergent lines of development. The sequence of presentation is determined in the main by the relative adrancement of the lower members of each alliance, whose higher members may or may not have made great advancement and in many directions. Such an assemblage of forms may be conceived of as a tangled thicket, through which certain paths may be more or less evident, but in which no orderly arrangement is apparent. It would be confusing, even were it possible, to discuss the relationships of each of the twenty-six series. They ean only be presented as assemblages of families that seem to be natural, perhaps not so much on account of their common origin as on account of their approximately equal grade of adrancement, and hence "form-groups" rather than necessarily genetic groups.

The following presentation of the alliances of Archichlamydeae is largely based upon Engler's " Lebersicht über die Unterabteilungen, Klassen, Reihen, Enterreihen, und Familien der Embryophyta siphonogama," published in Engler and Prantl's Die Tatürlichen Pflanzenfamilien in 1897 (Lieferung 165).

The first twelre alliances are especially puzzling. Among them are evidently the most primitive forms in floral structure. They also include the chalazogamic forms, and ovules whose structure is unusual among Angiosperms. The families are practically those that were disposed of by Eichler as Amentiferae, together with miscellaneous groups of uncertain aftinity. That the so-called Amentiferae or Amentaceae represented a heterogeneous assemblage of forms has long been evident. It is a question whether Engler's splitting up into alliances has not been excessive in this part of his scheme, certain morphological characters sometimes being used that may not prove to be of first importance. In any event, the splitting up will serve to keep apart distinct groups until they can be recombined naturally. There is no region of the Archichlamydeae which has 
recently reeeived more deserved attention from morphologists, and which still so greatì neeils inrestigation.

I. Casuarixales. * - This includes the single family Casuarinaceac, containing about 25 species. Engler regards the alliance as the nost primitive because the ornle develops numerons megaspores. This particular character can not be regarded as distinctive, since among the Fagales the same character, associated also with chalazogany, oecurs, and numerous megasores are found among the Ranales, Rosales, ete. The low position, however, is justified by the primitive flowers, which are either naked or with a bract-like perianth.

The next two alliances are regarded as relatively primitive on account of their naked flowers, together with the Casuarinales being the only naked alliances.

II. Piper.ntes.-This includes the Samruraceae, Piperaceae, Chloranthaceae, and Lacistemaceae, together containing about 1,150 species, of which about 1,100 belong to the Piperaceae. The results of the inrestigation of Peperomia pellucida by Campbell and by Jolnson indieate that the tropical Piperaceae are probably most promising forms for morphological investigation, and are to be considered in any discussion as to. the most primitive Dicotyledons.

III. Sarrcates.-This ineludes the single family Salicaceae, containing about 180 species.

IV. Mrricales. - This includes the single family Mrricaceae, containing 40 species. The adrance in floral structure is shown by the fact that the several bracts near the flower may be regarded as an extremely primitive perianth.

I. Bataxopsidass.-This includes the single family $\mathrm{Ba}$ lanopsidaceae, containing 7 species. This is an meertain trpe, and raises the question of relnction. The staminate flowers have a rudimentary perianth and an indefinite number of stamens; and the carpellate flowers have a bracteate perianth. Engler calls attention, however, to the fact that there are no intermediate forms for a rednetion series, and that the indefinite number of stamens is a primitive character.

YI. Leitrerintes.- This ineludes the single family Leitneriaceae, containing 2 species. The primitive charaeter of this 
type, with its flowers naked or with a bracteate perianth, is very doubtful. Engler states that if any evidence of reduction is obtained, this family would be included among the Rosales, near the Hamamelidaceae.

VII. Juglaxdates. - This includes the single family Juglandaceae, containing about 30 species. This alliance is distinctly higher than the preceding ones in that there is nearly always a distinct perianth, which in the carpellate flowers is coalescent with the orary, so that there is a resemblance to epigrny. Disregarding the Balanopsiclales and Leitneriales as doubtful and possibly reduction alliances, the Juglandales are to be compared directly with the Mrricales. The two were formerly associated in a single alliance, but the listinct perianth, as well as chalazogamy, serve to distinguish the Juglandales. It is a question whether such differences, and the others associated with them, are incompatible in a single alliance.

VIII. Fagales. - This includes the Betulaceae and Fagaceae, together containing about 420 species, nearly 350 of which belong to the Fagaceae. This is a parallel alliance with Juglandales, having a distinct but bracteate perianth, which in the carpellate flowers is more or less coalescent with the orarr. Among Betulaceae, also, chalazogamy oceurs, as in Juglandaceae and Casuarinaceae.

IX. Urticares.-This includes the Clmaceae, Moraceae, and Crticaceae, together containing about 1.560 species, the large families being Moraceae with about 920 species, and the Lrticaceae with abont 520 . This is an alliance parallel with the Juglandales and Fagales, with the distinct and bracteate perianth, which, as in Fagales, is definitely cyclic.

X. Protenles.-This includes the single great Australasian family Proteaceae, with about 950 species. In this alliance the next stage in the derelopment of the cyclic perianth becomes erident. Although it is sometimes green and bract-like, in the majority of cases it is petaloid, but there is no differentiation of calyx and corolla. A character used to distinguish this alliance from the following is the single carpel with well-dereloped orvile.

XI. SAxtalıles.-This includes the Loranthaceae, Myzodendraceae, Santalaceae, Grubbiaceae, Opiliaceac, Olacaceae, and Balanophoraceae, together containing about 1,260 species, 
the large families being Loranthaceae with 800 species, Santalaceae with 246 , and Olacaceae with 150 . In this alliance, also, the cyclic perianth is for the most part petaloid, but there is advancement in the general differentiation of a calyx and corolla. For the most part, there is a syncarpous pistil of three carpels, but the carpels may be two or one; and a free central placenta develops ovules without an integument or no distinct ovules at all. There is much diversity within the alliance, at least three distinct lines being evident; but the rather remarkable morphological structures found in the alliance are probably related to their general parasitic or semi-parasitic habits.

XII. Aristolochines.-This includes the Aristolochiaceae, Rafflesiaceae, and Hydnoraceae, together containing about 235 species, of which 205 belong to the Aristolochiaceae. The members of this series are distinctly in advance of the preceding in the coalescence of the petaloid segments of the perianth, and especially in epigyny. The indefinite number of ovules is also a distinguishing feature.

The preceding twelve alliances represent a primitive complex, in which reduced forms may have been included. How they may be related to one another in origin is too obscure for profitable discussion, but it scems probable that they are not at all related to the following alliances. In other words, whether they represent a single genetic stock or several, they appear to be isolated from the ligher alliances.

XIII. Poirgonales. - This includes the single family Polygonaceae, with about 750 species. Its mostly cyclic flowers, with undifferentiated perianth or distinct calyx and corolla, puts it upon aboit the plane of adrancement attained by the preceding alliances; while its strong trimerous tendency and peculiar habit set it well apart. This is sometimes regarded as a transition group between the preceding alliances and the Centrospermales. In any erent, it may be regarded as fairly associated with the latter.

XIV. Cextrospermans. * - This includes Chenopodiacrae, Amarantaceae, Nrctaginaceae, Batidaceae, Crnocrambaceae, Phytolaccaceae, Aizoaceae, Portulacaceae, Basellaceae, and Caryophyllaceae, together containing about 3,320 species, the

* Centrospermae of Engler. 
large families being Caryophyllaceae with 1,420 species, Aizoaceae with 575, and Chenopodiaceae and Amarantaceae each with about 435 . In this alliance the floral characters range from the bracteate undifferentiated perianth of Chenopodiaceae to the distinct calyx and corolla of many Caryophyllaceae. In the alliance as a whole calyx and corolla are frequently rather than prevailingly distinct, and only the highest family has attained the conspicuous corolla associated with entomophily. A feature of the alliance is the conspicuous perisperm.

The Polygonales and Centrospermales may possibly have a closely related origin, but it does not seem probable that they are related in any way to the following alliance, but that they represent a general line of development whose highest expression is among the Caryophyllaceae.

XV. Raxales.-This includes Nymphaeaceae, Ceratophyllaceae, Trochodendraceae, Ranunculaceae, Lardizabalaceae, Berberidaceae, Menispermaceae, Magnoliaceae, Calycanthaceae, Lactoridaceae, Anonaceae, Mrristicaceae, Gomortegaceae, Monimiaceae, Lauraceae, and Hernandiaceae, together containing about 4,050 species, the large families being Lauraceae with 1,015 species, Ranunculaceae with 990, Menispermaceae with 390 , Anonaceae with 345 , Monimiaceae with 245 , Myristicaceae with 235, and Berberidaceae with 135 .

This great alliance introduces the prevailing habit of a distinct calyx and corolla, and is characterized by the prevalence of apocarpy and hypogyny. The primitive character of the flower is indicated not only by apocarpy and hypogrny, but also by the strong tendency to the indefinite repetition and spiral arrangement of the floral members. Were it not for the prevalence of a distinct calyx and corolla the alliance would not hold so high a rank. At least three prominent derelopmental lines are evident, riz., Nymphaeaceae to Ceratophyllaceae, Ranmnculaceae to Menispermaceare, and Magnoliaceae to Hernandiaceac. In each of these lines there is an advance from the spiral to the eyclic arrangement, and in the last line epigyny is reached. As is also known, zygomorphy oceasionally oceurs, being present in no preseding alliance except the Aristolochiales.

It seems probable that the higher alliances of the Archichlamydeae are related in some way to the Ranales, whose numerous lines of derelopment seem to have been taken up by other 
alliances. It follows that the subsequent alliances will touch the Ranales in various ways, the latter representing a plexus out of which varions divergent lines have become distinct. This conception of the genetic position of Ranales among Archichlamydeae has brought to them the attention of morphologists, and the results thus far have more than justified their investigation.

XYI. Rhoednes.-This includes Papareraceae, Cruciferae, Torariaceae, Capparidaceae, Resedaceae, and Moringaceae, together containing about 2,615 species, the large families being Cruciferae with 1,560 species, Capparidaceae with 425 , and Papareraceae with 2SO. There seems to be no question that this alliance is closely related to the Ranales. The connection seems to be through the Papareraceae, which exhibit structures resembling those of Nrmphaeaceae; while the transition from Papareraceae to Cruciferae throngh the Fumaria forms is plain, and the aftinity of Cruciferae and Capparidaceate is unquestioned.

XYII. Sarracexiales. - This includes Sarraceniaceae, Tepenthaceae, and Droseraceae, together containing 145 species, nearly 100 of which belong to the Droseraceae. The alliance is evidently parallel with Rhoedales, and both are certainly related to the Nymphaeaceae-region of the Ranales. In fact, the Nymphaeaceae, Papaveraceae, and Sarraceniales have many things in common in the arrangement of floral members and the spirocyclic character of the flowers. The distinctive character of Sarraceniales as compared with Rhoedales is the prevalence in the former of central placentation.

XYIII. Rosales.-This includes Podostemonaceae, $\mathrm{Hr}^{\mathrm{r}}$ drostachyaceae, Crassulaceae, Cephalotaceae, Saxifragaceae, Pittosporaceae, Brunelliaceae, Cunoniaceae, Mrrothamnaceae, Prumiaceae, Hamamelidaceae, Platanaceae, Crossosomataceae, Rosaceae, Comnaraceae, and Legmminosae, together containing about 14,270 species, the large families being Leguminosae with over 11,000 species. Rosaceae with 1,525, Saxifragaceae with 6:30. and Crassulaceae with 490 . Since this alliance contains ly far the greatest fanily of Archichlamydeae, in fact, with a single exception, the greatest family of Angiosperms, it may be regarded as the most representatire and dominant alliance.

The begimnings of this great alliance, with apocarpr, hypogrns, and indefinite repetition of certain floral members, have 
much in common with the Ranales, especially the line containing Ranunculaceae. However, it has reached a much higher development in the more frequent oceurrence of syncarpy, and also of perigyny and epigrny, and especially in the remarkable development of zygomorphy among the Leguminosae. Disregarding the smaller families, the Saxifragaceae may be regarded as the beginnings of the alliance, originating in the Ranales, and diverging toward Podostemonaceae in one direction and Rosaceae-Leguminosae in the other. It has long been known that there is no real distinctive character separating Saxifragaceae and Rosaceae; and the transition from the latter family to the Leguminosae is easy. Rosaceae are characterized by actinomorphic flowers and several carpels; while Lcenminosae have zygomorphic flowers and a single carpel; but there are members of the two families that exactly reverse these distinctions. There seems to be a general plexus formed by the Rosa tribe of Rosaceae and the Mimosa tribe of Leguminosae, which is not very far removed from the Ranunculaceae among Ranales. Ont of the Rosu tribe the two very distinet lines of drupe-forms and pome-forms have diverged; while the Mimosa tribe, with its actinomorphic flowers and numerous usually free stamens, leads throngh the Caesalpinia tribe, with its actinomorphic or zygomorphic flowers and free stamens, to the Papilio tribe with its strongly zygomorphic flowers and coaleseent stamens.

The culmination of the alliance is of course the elaboration of zygomorphy, the Leguminosae dominating in this regard among Archichlamrdeae, as do the Orehidaceae among Monocotrledons, and the Personales among Srmpetalae.

In the preceding related alliances, from Ranales to Rosales, the crelic character of the flower is not fully established, every line of development having spiral members. In the following alliances, however, the cyclic character is fully established.

XIX. Geraxiales. - This inchudes Geraniaceae, Oxalidaceae, Tropacolaceae, Linaceae, IIumiriaceae, Erythroxylaceae, Zygophyllaceae, (nopraceae, Rutaceac, Simarubaceae, Burseraceae, Meliaceae, Malpighiaceac, Trigoniaceae, Vochysiaceae, Tremandraceae, Polygalaeeac, Dichapetalaceae. Euphorbiaceae, and Callitrichaceae, together eontaining about 9,160 species, the large families heing Euphorhiaceae with 4.140 species, Rutaceae with 910, Meliaceae with 75.3 , Malpighiaceae with 700 , 
Polygalaceae with 667 , Geraniaceae with 455 , Oxalidaceae with $3: 0$, and Burseraceae with 320 .

This cyclic alliance begins with those families that are isocarpic and extends to those in which a reduction in the number of carpels is prevalent. It is ehiefly distinguished from the Sapindales, with which it is parallel and very closely allied, by the orientation of the orules, the raphe of the anatropous orules being ventral in Geraniales and dorsal in Sapindales. Just the significance of such a character in distinguishing great genetic alliances is not elear, but its constancy is in its faror. Three lines of development are evident, the most prominent begimning with Geraniaccae, including the zygomorphic and anisocarpic Tropaeolaceae and the completely syncarpic Linaceae and its allies, and ending in Cneoraceae to Neliaceae with oil-eclls and highly differentiated tissues. Another line is Malpighiaceae to Vochysiaceae, characterized by oblique zygomorphy; while Polygalaceae with its strongly zygomorphic flowers, Dichapetalaceae, and Euphorbiaceae, show no surviving features in common. The affinities of these last three families are extremely doubtful, and those of Callitrichaceae are even more so.

XX. S.rpindales.*-This includes Buxaceae, Empetraceae, Coriariaceae, Limnanthaceae, Anacardiaceae, Cyrillaceae, Pentaphylaceae, Corynocarpaceae, Aquifoliaceae, Celastraceae, Hippocrateaceae, Stackhousiaceae, Staphyleaceae, Icacinaceae, Aceraceae, Hippocastanaceae, Sapindaceae, Sabiaceae, Melianthaceae, and Balsaminaceae, together comprising about 3,125 species, the large families being Sapindaceae with 1,040 species, Celastraceae with 425 , Anacardiaceae with 395 , Balsaminaceae with 300 , and Aquifoliaceae with 285 .

As among Geraniales, the alliance begins with isocarpic forms and passes to those in which the number of carpels is reduced, and in the higher families zygomorphy is attained. The orientation of the orules that separates this alliance from the Geraniales was referred to under that alliance. Engler reeognizes so many lines of development among Sapindales that the alliance seems to be well broken up, and the different memhers not clearly related to one another. 
XXI. Rhasxat.es. - This includes Rhamnaceae and Vitaceae, together containing about 955 species, almost exactly equally distributed between the two families. The alliance is clearly parallel with the preceding one, but is distinctly set apart by its tetracyelic flowers with opposite stamens.

XXIl. Malvales. - This includes Elaeocarpaceae, Chlaenaceae, Gonystylaceae, Tiliaceae, Mfalvaceae, Triplochitonaceae, Bombacaceae, Sterculiaceae, and Scytopetalaceae, together containing about 1,740 species, the large families being Malvaceae with about 800 species, and Sterculiaceae with 750 . This alliance is rery uneven in the advancement of its characters, and in certain features would seem to precede Geraniales and Sapindales in any sequence; but it is so closely related to Parietales through Elaeocarpaceae and Chlaenaceae that it seems clear it should be placed near them.

Distinct or slightly united carpels are found, as among the Geraniales and Sapindales, but complete synearpy prevails. The inequality of advancement is shown in such families as Tiliaceae, in which there is complete synearpy associated with indefinite stamens; and Stereuliaceae, in which there is a complexity in the arrangement of stamens approaching that in Malvaceae, associated with a more or less incomplete union of carpels.

XXIII. Parietales.-This includes Dilleniaceae, Eucryphiaceae, Ochnaceae, Caryocaraceae, Maregraviaceae, Quiinaceae, Theaceae, Guttiferae, Dipterocarpaceac, Elatinaceae, Frankeniaceae, Tamaricaceae, Fonquieraceae, Cistaceae, Bixaceae, Cochlospermaceae, Koeberliniaceae, Canellaceae, Violaceae, Flacourtiaceae, Stachruraceae, Turneraceae, Malesherbiaceae, Passifloraceae, Achariaceae, Caricaceae, Loasaceae, Datiscaceae, Begoniaceac, and Ancistrocladaceae, together comprising about 4,225 species, the large families being Guttiferae with 760 species, Flacourtiaceae with 525, Begoniaceae with 405, Violaceae with 400, Dipterocarpaceae with 320, and Pas-ifloraceae with 315 .

The Parietales are prevailingly syncarpous, and have very erident connection with the Ranales through the Dilleniaceae, which were formerly included among the Ranales, and with the Rhoedales through the Flacourtiaceae and other families. The families from Dilleniaceae to Dipterocarpaceae, mainly 
tropical, are regarded as one line, characterized by an oily endosperm; and among them such primitive characters as the spiral arrangement and indefinite number of floral members oceur, and even apocarpy (Ochnaceae). Another line inclucles the Elatinaceae to the Frankeniaceae, chiefly a temperate group characterized by a starchy endosperm. The Fouquieraceae are regarded as independent of the last line on account of their sympetaly and oily endosperm. The Cistaceae and Bixaceae also form an independent line with starchy endosperm. The Cochlospermaceae and Koeberliniaceae are also regarded as independent and much resemble the Capparidaceae among the Rhoedales. The families from Canellaceae to Achariaceae form another line, all characterized by oily endosperm, starting with completely cyclic flowers, and leading to such special developments as a strong tubular development of the receptacle and even sympetaly (Achariaceae). Closely related to this line are the Caricaceae, with sympetalous corollas, but distinguished by their stamens and latex system. The last four families (Loasaceae to Ancistrocladaceae) are epigynous, but each one seems to be a peculiar and isolated type of derelopment. This complex alliance is a good illustration of divergent lines of derelopment within one general circle of affinity, and at the same time of a gradual increase in floral complexity.

XXIV. Opuntules.-This includes the single family Cactaceae, with about 1,000 species. This characteristic American family presents a strange mixtme of primitive and arlranced characters in the structure of the flower. The spiral arrangement and indefinite repetition of floral nembers are often as primitive as in the Nymphaeaceae, with which region of the Ranales the alliance may be eonnected. The tubular receptacle, however, enclosing the constantly syncarpous pistil relates the group to the Parietales.

XXY. Mrrtales. - This inchules the Geissolomaceae, Penaeaceae, Oliniaceae, Thrmelaeaceae, Elaeagnaceac, Lythraceae, Sonneratiaceae (Blattiaceae), Punicaceae, Lecythiclaceae, Rhizophoraceae, Combretaceae, Myrtaceae, Melastomataceae, Onagraceae, Iyvlrocaryaceae, Haloraghidaceae, and Cynomoriaceae, together containing abont 7,180 species, the large families being Melastomataceae with 2,750 species, Mrrtaceae with 2,565, Onagraeeae with 465, Thrmelaeaceae with 395, and 
Lythraceae with 340 . The high character of this alliance is indicated by the constantly perigrnous and epigrnous flowers, as wcll as by the constantly crelic stamens, and the tendency to tetramerous flowers is strong.

XXVI. Unbellales. *-This includes the Araliaceae, Lmbelliferae, and Cornaceae, together containing about 2,660 slecies, about 2,100 of which belong to the Umbelliferae. The series is clearly the ranking one among the Archichlam ydeae on account of its epigyny, crclic stanens, reduced number of carpels, and mostly reduced scpals, the floral formula being the same as that of the highest Srmpetalae. The three families constituting the alliance are rery closely related, and the alliance as a whole stands so stittly apart from other Archichlamydeae as to raise the question whether it does not really belong among the higher Sympetalae.

It will be noted that in a large sense, and with the exception of the last two alliances, the Archichlamydeae correspond to the Spiral series anong Monocotyledons, in which the cyclic arrangement, although it frequently appears, is not fully established in every set of floral members. In the same sense, therefore, the Mrrtales, Cmbellales, and Sympetalae, correspond to the Cyclic series among Monocotyledons.

* Uybelliflorae of Engler. 


\section{CHAPTER XII}

\section{CLASSIFICATION OF SYMPETALAE}

The Srmpetalae form a much better defined group than do the Archichlamydeae, from which they seem to have been derived. The srmpetalous character is almost universal, and justifies the name of the group. To regard it as the crucial test, howerer, is to introduce the flaror of an artificial srstem. Among the Arehichlamydeae srmpetalons forms were noted, and certain families of the Srmpetalae inchude polspetalous members. It would seem that such exceptions might apply to whole families, whose other characters wonld determine their affinities. For example, the Umbelliferae present the combination of characters that belongs to the Srmpetalae, excepting srmpetaly; and this exception does not scem to be a sufficient reason to exclude them from association among the epigrnous anisocarpic Srmpetalae, any more than the polypetaly of the Pirolaceae exchules them from the isocarpic Srmpetalae.

The general characters of Srmpetalae are (1) a complete crelic arrangement of the floral members, associated with definite numbers; (2) a srmpetalous corolla that usually has a common origin with the stamens; and (3) orules with a single massive integument and a rery small nucellus. The group contains fiftr-one families, the number varring with different authors, and about 42,000 species, or approximately two-thirds of the number included in the Arehichlamydeae. Eight alliances have been recognized by Engler, coordinate with the ten alliances of Monocotrledons and the twentr-six alliances of Archichlamydeae, the contrast with the latter group in uniformity of floral structure being very striking.

The natural sequence of the alliances is much more evident than among the Arehichlamrdeae. The first three alliances are 
pentacyclic and isocarpic, while the remaining fire are tetracrelic and anisocarpic; and of the anisocarpic alliances, the first three are hypogynous and the last two epigynous.

The three pentacyclic or isocarpic alliances are certainly most nearly allied to the Archichlamydeae, for among them polypetaly still occurs, the two cycles of stamens are characteristic, and occasionally the orule has two integuments. They may be regarded as lines from the Archichlamydeae in which srmpetaly has become prevalent. They are all hypogrnous and actinomorphic, and the floral formula is characteristically sepals 5, petals 5 , stamens $5+5$, carpels 5 . These comparatively primitive Sympetalae are not numerous, containing only about 3,500 of the 42.000 species, and hence they are not the representative Srmpetalae.

I. Ericales.-This includes the Clethraceae, Pirolaceae, Lennoaceae, Ericaceae, Epacridaceae, and Diapensiaceae, together containing a little more than 1,700 species, by far the largest family being Ericaceae with about 1,360 species. The group is characteristically dereloped in high latitudes and altitudes, and its special features are well marked. The stamens are usually quite free from the petals, and this in connection with occasional polypetaly gives a strong resemblance to the Archichlamydeae; while the peculiar dehiscence of the anthers and their frequent appendages are very characteristic. The stamens are by no means constantly in two cycles, or distinct from the corolla or one another. it single crele of functional stamens may be associated with staminodia, or only a single evcle may appear, or the stamen cycle may have a common origin with the corolla, or in some cases it may be monadelphork. In short, there are transition forms to the suppression of a crele of stamens, and to a common origin of stamen crcle and corolla. A multilocular ovary with numerons ovules is also a feature of the alliance.

The Epacridaceae, a well-dereloped Australian family of heath-like plants containing nearly 300 species, are quite exceptional in having only one cycle of stamens and anthers with longitudinal dehiscence. These exceptions seem quite fundamental, but they may be illustrations of the result of long and distant separation of allied families. In any erent, a comparative morphological study of Epacridaceac and Ericaceae 
is much needed; and the whole series of Ericales deserves attention on account of its possible genetic connections with some region of the Archichlamydeae.

II. Primclates. - This includes the Mrrsinaceae, Primulaceae, and Plumbaginaceae, together containing about 550 species, approximately equally distributed among the three families. The families are closely associated in structure, but widely separated in geographical distribution, the Mrrsinaceae being characteristically tropical trees and shrubs (chictly American), the Primulaceae north temperate and boreal herbs, and the Plumbaginaceae characteristically halophytic herbs and undershrubs of salt-beaches and steppes (chiefly Mediterranean and Caspian). That such dissociated families shonld have $=0$ much in common is a strong argmment against the older idea that similarity of structure proves common origin.

The two most eharacteristic features of the group are the single cycle of stamens opposite the petals, and the unilocular orary with its " free central placenta " bearing numerons orules. The single cycle of stamens and its opposition to the petals are explained by the frequent occurrence of rudiments representing an outer abortive cycle. The "free central placenta" of taxonomists is of course a continuation of the floral axis to bear orules, and is perhaps the most important morphological character of the series. It is in this gromp, also, that there has been noted a peculiar origin of the petals, which are said to arise late from the primordia that have already developed the stamens.

As compared with the Ericales, the Primulales may be regarded as somewhat more advanced toward the higher Sympetalae, but polypetaly still occurs anong them, and they give the impression of a somewhat divergent and specialized group. An investigation of the Mrrsinaceae will doubtless result in a much clearer understanding of the relationships.

III. Ebexules.-This includes the Sapotaceae, Ebenaceae, Styracaceae, and Symplocaceae, together containino nearly 900 species, the large families being Sapotaceae with abont, 3 so species, and Ehenaceae with 27.5 . The group is chiefly developed in the tropies and the species are all shrubs or trees.

The alliance is particularly puzzling in its affinities, since there is a combination of primitive and advanced characters. 
The primitive characters are the indefiniteness in the number of sepals and petals, ranging from $t$ to s, oceasional polypetaly, and the often numerous stamens and carpels. Consistency would seen to demand that the Ebenales be regarded as the most primitive of the Srmpetalae, even the definite cyclic number's not being established. At the same time, there is adherence of a single stamen erele to a srmpetalons corolla, and distinct epigyny. The stamen cycles are peculiarly fluctuating, ranging from three or four cycles, through all stages of suppression of the outer cycles, to a single opposed cycle. This latter feature is suggestive of the Primulales, but the multilocular ovary with usually large solitary orules is suggestive neither of Primulales nor Ericales. The tropical forms certainly descrve careful morphological investigation, and are doubtless related to the Myrsinaceae, and in our judgment are to be included in any discussion of the most primitive Sympetalae.

In the five following alliances the tetracyclic character seems to be well established, and the prevailing formula is sepals 5, petals 5 , stamens 5 , carpels 2 . In the three previous isocarpic alliances there is every transition from the pentacrelic to the tetracyclic condition, and among the more primitive anisocarpic families the carpels are often three before two becomes the established number. Of the remaining alliances the first three are hypogynous.

IV. Gextiaxales. * - This includes the Oleaceae, Salvadoraceae, Loganiaceae, Gentianaceae, Apocynaceae, and Asclepiadaceae, together containing about 4,200 species, the large families being Asclepiadaceae with about 1,720 species, Apocynaceae with 975 , and Gentianaceae with 725 .

With this alliance the grouping into developmental lines becomes indefinite and perplexing, for the numerous families intergrade in every direction. There is no distinctive character that separates this alliance from the great alliance Tubiflorales. The fact that the corolla is generally twisted in aestivation seems to be the most useful character, and has suggested a name for the series, and the constantly opposite leaves is a supplementary character.

The lower members of the alliance are the Oleaceae and 
Salvadoraceae, in which there is sometimes distinct polypetaly, but the reduction of the stamens to two in the former family is hardly to be regarded as a primitive character. The Loganiaceae are general in their resemblances, having features in common with the remaining families, and others suggestive of Tubiflorales and Rubiales. In fact, Engler suggests that the Loganiaceae may be an older type than any of the others, and may have given rise to the Gentianales and Rubiales, in which he might have included the Tubiflorales. If this family may hold any such position in reference to these great alliances it certainly deserves careful investigation. The alliance ends with the Apocrnaceae and Asclepialaceae, in which a latex-sytem is dereloped, and other evidences of high specialization occur ; but they are also characterized by distinct carpels, a feature regarded as primitive. The Asclepiadiaceae form a very peculiar and highly specialized offshoot, the elaboration of floral structures for entomophily reaching a degree of complexity only to be compared with that of the Orchidaceae.

T. Tubiflorales. *-This includes Convolrulaceae, Polemoniaceae, Hrdrophyllaceae, Borraginaceae, Verbenaceae, Labiatae, Tolanaceae, Solanaceae, Scrophulariaceae, Bignoniaceae, Pedaliaceae, Martýniaceae, Orobanchaceae, Gesneraceae, Columelliaceae, Lentibulariaceae, Globulariaceae, Acanthaceae, Myoporaceae, and Phrrmaceae, together containing orer 14,600 species, the large families being Labiatae with nearly 3,000 species. Scrophulariaceae with 2,400 , Leanthaceae with nearly. 2.000, Solanaceae with about 1,700, and Borraginaceae with about 1,550 .

This enormous assemblage of forms has been ordinarily considererl as representing at least two alliances, the Polemoniales or 'Tubitlorae inchuling the first four families of the list above, and the Personales or Labiatiflorae including the remaining fanilies. The tendencies of levelopment are so numerous and interworen that they are difficult to separate, but rather than merge two such alliances together it might have been better to have broken up the Personales into fire or six alliances, especially if the Plantaginaceae are to be set off as a coordinate alliance Plantaginales. To distinguish them definitely would

* Tlbiflorae of Engler. 
probably be impossible, but an alliance at best expresses only a general evolutionary tendency more or less completely worked out.

Taking the alliance as a whole, it represents the culmination of hypogrnous Sympetalae, and this culmination is shown not only in the conspicuous corolla but in highly developed zygomorphism. In fact, the Personales, with the Labiatae and Scrophulariaceat as centers of aggregation, represent the great zygomorphic group of the Srmpetalae, as Leguminosae do among the Archichlamydeae, and Orchidaceae among the Monocotyledons.

First in the alliance are the Convolvulaceae and Polemoniaceae on account of their actinomorphic flowers and sereraloruled carpels, in these and other features being, together with the Gentianales, the least modified of the tetracyclic families. From Gentianales they are easily distinguished by their lack of twisted aestivation and by their usually alternate leares, and also by their undoubted relation to the other families of Tubitlorales.

A second natural alliance is that formed by the Hydrophyllaceae and Borraginaceae, which leads from the preceding alliance through Hydrophyllaceae, with a generally unlobed ovary, to the Borraginaceae with a much modified ovary. In the latter family the two carpels are diviled by a false partition, each loculus contains a single ovule, and the ovary becomes so deeply lobed as to resemble a group of four nutlets. Further modifications of this peculiar fruit, familiar to taxonomists, make it the most specialized and diversified structure of this large family.

I third natural alliance is that formed by the Verbenaceae and Labiatae, with about 3,700 species. It is joined to the Convolvulaceate by the orientation of the orule, and has followed a developmental path parallel with that of the preceding alliance in the evolution of the carpel structures. The lobing of the ovary into four nutlet-like bodies in the Labiatae, however, is not accompanied hy such detailed specialization as in the Borraginaceae: but the whole line is dominated by the strong development of zyomorphy, reaching its culmination in certain groups of the Labiatae.

A fourth natural alliance, the greatest of all, includes the 
eleren families from Nolanaceae to Globulariaceae, grouping about the Solanaceae and Scrophulariaceac. This series connects with the C'oniolvulus forms through the Nolanaceae, but does not develop its carpel-structures as to the Borrage and Labiate lines, retaining capsules with numerous orules, but there is a strong development of zygomorphy.

To summarize at this point, the primitive stock of the series seems to be the Convolvulaceae-Polemoniaceae alliance, from which three distinct lines of development have diverged: the Hrdrophyllaceae-Borraginaceae line, with its modified carpelstructures; the Verbenaceae-Labiatae line, with its modified carpel-structures and zrgomorphy; and the Nolanaceae-Globulariaceae line, with its zygomorphy. It should be noted in passing that the zygomorphy is associated with a strong tendency to reduce the number of stamens.

The three remaining families are so peculiar in certain features that Engler regards them as representing separate lines of development, although the Acanthaceae are not easily separated from certain families of the last alliance. The Myoporaceae secm to be a reduced type with no clear affinities; and the Phrymaceae, with their achenes and orthotropous orules, have no evident connections in this alliance, in which their strong zygomorphy has retained them.

It wonld be our judgment, therefore, to break up this great alliance of Tubiflorales into at least four, which might be called the Polemoniales (Convolvulaceae and Polemoniaceae), Borraginales (Hydrophyllaceae and Borraginaceae), Labiatales (Terbenaceae and Labiatae), and Personales (Nolanaceae, Solanaceae, Scrophulariaceae, Bignoniaceae, Acanthaceae, Pedaliaceae, Marțniaceae, Orobanchaceae, Gesneriaceae, Columelliaceae, Lentibulariaceae, and Globulariaceae), the Mroporaceae and Phrymaceae being left undetermined or regarded as reduction forms of Personales.

YI. Plaxtarixales.- This includes the single family Plantaginaceae with about 200 species. This family, with its peculiar habit, 4-merous flower's, membranous corolla, and characteristic fruit, is certainly entitled to special consideration. If such a series as Tubiflorales he maintained, however, there is no good reason why Plantaginaceae should not form one of the seven or eight sections of it. If, on the other hand, the 
series be broken up as suggested abore, Plantaginales should certainly be coordinate with Polemoniales, Borraginales, Labiatales, and Personales.

The two remaining alliances are epigrnous and naturally form the culmination of the Srmpetalae. In both alliances there is actinomorphy and numerous orules, but in both there is more or less derelopment of zygomorphy: a tendeney to reduction in numbers of members, especially of the orules; and a tendency to reduce the flowers in size and to mass them, leading to a modification of floral structures and a differentiation of the functions of individual flowers.

VII. Rubines.-This includes the Rubiaceae, Caprifoliaceae, Adoxaceae, Valerianaceae, and Dipsaceae, together containing nearly 4,800 species, the large family being Rubiaceae with nearly 4,100 species.

The possible relationship of this alliance to the Gentianales, especially the Loganiaceae, has been mentioned, from which it seems to be an epigrnous offshoot. It the same time, relations to the epigrnous Lmbellales among the Archichlamrdeae are $n$ less erident. It may possibly be found, as intimated in the last chapter, that the Lmbellales should be associated with the Rubiales as two parallel alliances of epigrnous Sympetalae. Through the Caprifoliaceae the Talerianaceae and Dipsaceae are closely connected with the allianee: while the position of the Idoxaceae is altogether uncertain. The distinguishing character to separate Rubiales from the next alliance is not alwars clear, but in general the connivent and often united anthers of the C'ampanales are not present in the Rubiales; lont this character is fortified by distinet derelopmental tendencies.

VIII. Campaxales. - This includes the Cncurbitaceae, Campanmlaceae, Goodeniaceae. Candolleaceae, Calyceraceae, and Compositae, together containing more than 14,500 species, fully 12,500 of which are Compositae, the Campanulaceae containing nearly 1,100 .

Connirent and often nnited anthers, and sometimes monadelphous stamens, prerail in the series. The peenliar tropical Cncurbitaceae oceupy a special place in the alliance, and can not be related rlearly to the others: while the Campannlaceae seem to represent a remnant of the ancient stock of the alliance, from which the other families have arisen. 
The alliance culminates in the Compositae, the greatest of all angiospermous families, not only in rank, but also in the number of species, although not much exceeding the Leguminosae in this latter regard. There seems to be no question that the Compositae represent the highest expression of the various derelopmental lines we have been tracing through the Angiosperms. This is shown not merely in their combination of -rmpetaly, epigrny, and seed-like fruit, but also by such special structures as the pappus and the syngenesious anthers, by the complex organization of the head, the prevalence of diclinism, the dimorphism of corollas, ete. 


\section{CHAPTER XIII}

\section{GEOGRAPHIC DISTRIBUTION OF ANGIOSPERMS}

So vast a subject can be presented only in rery brief outline in a single chapter. In a certain sense it is not pertinent to a discussion of the special morphology of a group, but the student of special morphology is aided by certain general considerations connected with geographic distribution, especially in any discussion of phylogeny. The distribution of a group containing nearly 125,000 species includes a rast mass of details, and only certain salient features can be selected for presentation. Even when these are selected, the numerous exceptions to any general statement must be disregarded. It must be understood, therefore, that in the following account the statements are very general in their nature, expressing average conditions of distribution, under all of which exceptions may be cited. At the same time, it is the general tendency in the distribution of any large group that is of interest to the morphologist rather than the details of distribution of species and genera.

The subject of geographic distribution presents two aspects for consideration. One involves the determination of life-zones over the surface of the earth, which is a consideration of distribution from the standpoint of physiography. The other aspect disregards the life-zones, and considers distribution from the standpoint of plant-grours. What a given plant-group has been able to do in the occupation of the earth's surface is of more morphological interest than the physiographic features of the problem. and hence the following presentation will take the latter standpoint.

Including only the existing regetation gires a rery inadequate conception of the relation of any group to the earth's surface. The present distribution of a group is only the last 
stage in a long history of distribution, and a knowledge of this history is an es-ential factor in any explanation of the present distribution. Infortimately, very little of this history is arailable, and this presentation must content itself with indicating the present relation of groups to the earth's surface, without any attempt at explanation. This is particularly unfortunate, sinee a lack of historical evidence mar ritiate many conclusions. If this lack of historical testimony be added to the lack of ans adequate record of the geographic distribution of existing species, it becomes evident that the generalizations proposed must be of the most tentative character. With this explanation the following statements may be given their proper weight.

\section{MONOCOTYLEDONS}

It is possible to present the distribution of the ten alliances of Engler in the order of their supposed relationship, a method that may be of serrice in the subsequent consideration of the aneient history and phrlogeny of the group. One genetic group is supposed to include the three following alliances.

Paxdaxiles. - The Pandanaceae (screw-pines), apparently the most primitive of Monocotyledons, belong to the general region of the Indian Ocean. Associated with them in relationship are the Trphaceae, found in aquatic conditions throughout the world, but most abundant in the tropics; and the Sparganiaceae, restrieted to the temperate and boreal regions of the morthern hemisphere and also of the Australasian region, and not represented in the tropics. The series as a whole shows wide adaptations to temperature, but not to soil conditions, with the primitive forms massed in the oriental tropies.

Paldales.-The Palmaceae are about equally divided between the oriental and oceidental tropies, with no temperate outliers, but not a species or a genus is common to the two hemispheres. The geographieal association of the palms and serew-pines in the orient is in faror of their supposed relationship, but the palms of the occident need explanation, especially since Phytelephas, regarded as a genus intermediate between Pandanaceae and Palmaceae, is an American genus. The present distribution of palms is an excellent illustration of the derelopment of continental diversities, which in this case has 
resulted not only in distinct genera, but almost every tribe is either oriental or occidental. Furthermore, the much larger number of monotypic genera in the orient must be associated with its larger and more broken tropical area.

Srxanthales.- The Cyclanthaceae are as restricted to the American tropies as the Pandanaceae are to the oriental tropics.

If this general "pain" type, comprising these three alliances, was once connected in the two hemispheres by a northern distribution, the palms alone found both hemispheres congenial in the tropics, while the Pandanaceae disappeared from the western and the Cyclanthaceae from the eastern hemisphere.

Helobiales. - This primitive series is very widely distributed and contains relatively few species, probably on account of its aquatic character. Three of its families (Potamogetonaceae, Naiadaceae, and Hydrocharitaceae) have a world-wide distribution. The remaining five families are somewhat restricted as follows: Aponogetonaceae in the Indian Ocean region, Triuridaceae in the tropies of both hemispheres, Butomaceae extending from the tropics into temperate regions, while Juncaginaceae and Alismaceae are mostly outside of the tropics in the northern and southern hemispheres.

Arales. - The possible relationship of this group to the preceding one has been mentioned. The aquatic Lemnaceae are universally distributed, but 92 per cent of the Araceae are within the tropics, being massed chiefly in South America, India, and the East Indies. This family, as the palms, affords a good illustration of the development of continental diversities. In this case, however, the diversity has not reached so extreme a stage as in the palms, in which even the tribes of the orient and oceident are for the most part distinct. Among Aroids the tribes of the two hemispheres are by no means distinct, at least two tropical genera (Cyrtosperma and IIomalomena) have species in both hemispheres, and the monotypic Pistia is found in every tropical region. The species are more numerous in the Imerican tropics, but the number of genera is nearly twice as great in the oriental tropics. The Aroids differ further from the palms in having at least six genera characteristic members of north temperate regetation, and these for the most part are common to both hemispheres. 
Glualales. - The world-wide distribution of this great alliance, from tropical to boreal conditions, has resulted in no continental tribes, comparatively few continental genera, and very numerous cosmopolitan species. So far as geographic distribution is concerned, it may well represent the primitive stock from which the following alliances have branched.

FArixales.-This alliance is made up of a remarkable group of isolated families, apparently being poorly adapted for cosmopolitan distribution. Only three of the eleven families have a more extensive distribution than a hemisphere, Eriocaulaceae, the most cosmopolitan family, being massed in the tropics, Commelinaceae occurring everwhere except in boreal conditions, and Pontederiaceae being represented in all warmer regions. Four families (Flagellariaceae, Restionaceae, Centrolepidaceae, and Rapateaceae) belong to the southern hemisphere, three (Mavacaceae, Xrridaceae, and Bromeliaceae) are restricted to the western hemisphere, and Philydraceae are Australian.

Liliales. - This series, in contrast to the Farinales, is made up of characteristically cosmopolitan families. Liliaceae and Iridaceae are literally cosmopolitan, Amaryllidaceae and Taccaceae are massed in all tropical regions, Juncaceae are best dereloped in the cool temperates of the northern and sonthern hemispheres, Haemodoraceae are represented in tropical America and Australia, Stemonaceae are scattered in patches in Australia, Asia, and Torth America, and Dioscoreaceae are mainly tropical. Only Velloziaceae are restricted to a single hemisphere, and the restriction is remarkable, since all of the 70 species are credited only to Brazil.

Scitanirales. - The four families of this series are all tropical, two of them (Musacene and Zingiheraceae) being restricted to the oriental tropics, and two (Cannaceae and Marantaceae) to the occidental.

Orcmidates. - The massing of orehids in the tropies of both hemispheres is well known, but they are by no means restricted to tropical conditions. Is a rule, the numerous tropical genera are not only restricted to hemispheres, but are often very local; while the temperate genera are represented in both hemispheres, and the most northern genera eren contain cosmopolitan species. 
¿pon examining such data, certain generalizations in reference to the distribution of Monocotyledons become apparent. These will doubtless be modified by a fuller knowledge of the distribution of families, but they will serve to illustrate certain facts :

1. Four great terrestrial families (Gramineae, Cyperaceae, Liliaceae, and Iridaceae) of Monocotyledons are world-wide in their distribution. This means that they have been able to become adapted to every condition of soil and climate possible to high-grade vegetation.

2. The Monocotyledons include a remarkable number of purely hydrophytic families which also have a world-wide distribution so far as fresh and brackish waters are concerned. The families are Trphaceae, Potanogetonaceae, Naiadaceae, IIrdrocharitaceae, Lemnaceae, and Pontederiaceae, four of them belonging to the Helobiales. In spite of this wide distribution, these families contain less than 200 species. I'hen this fact is taken in connection with the 10,000 species belonging to the four cosmopolitan terrestrial families mentioned above, it becomes evident that the rery diverse conditions of the land surface are far more favorable to the production of species than the comparatively uniform aquatic conditions.

3. There is a decided massing of monocotrledonous families in the tropies. This is so marked as to suggest that Monocotyledons as a whole are essentially tropical.

4. Is a corollary to the last statement, the entire absence of boreal forms, excepting the few belonging to the families of universal distribution, is noteworthy.

5. The poor representation of Monocotyledons in the southern hemisphere, exclusive of the world-wide families, is remarkable. Especially is this true of Australia, a region prolific in endemic forms among Gymnosperms and Dicotyledons.

6. Very few families are characteristic of temperate regions, and these (Sparganiaceac, Juncaginaceae, Alismaceae, and Juneaceae) are represented in both the northern and southern hemispheres, and none of them are of the ligher petaloideous type.

7. The tropical representation of Monocotyledons is approximately equal in the two hemispheres, not merely in num- 
ber of species but also of families. The tropical families represented in both hemispheres are Butomaceae, Triuridaceale, Palmaceae, Araceae, Eriocaulaceae, Commelinaceae, Amaryllidaceae, Taceaceae, Dioscoreaceae, Burmanniaceae, and Orchidaceae. Those peculiar to the oriental tropics are Pandanaceac, Aponogetonaceae, Musaceae, and Zingiberaceae. Those peculiar to the oceilental tropies are Crclanthaceae, Mavacaceae, Xvridaceae, Bromeliaceae, Haemodoraceae, Velloziaceae, Cannaceae, and Marantaceae.

8. The great preponderance of epiphrtic forms in the American tropics is probably associated with the culmination of the rainy forest. The two great epiphytic families are Bromeliaceae and Orchidaceae, the former being restricted to the occidental tropics, and the latter much more abundant there than in the oriental tropics.

9. The peculiar distribution of the three genera of Stemonaceae is noteworthy and suggestive. Stemona, with four or five species, ranges from the Himalayas to southern Australia. Croomia has one of its species (C. pauciflora) in Florida, Georgia, and Japan; while the other ( $C$. japonica) is restricted to Japan. The monotypic stichneuron is restricted to the East Indies. The occurrence of a single species of this oriental family in Georgia and Florida, and that species native also to Japan, is difficult to explain.

\section{ARCHICHLAMYDEAE}

It is impossible to consider the geographic distribution of the Archichlamydeae in such detail as that of the Monocotyledons. The series are so numerous and indefinite that a presentation of their separate distribution would be confusing and not very significant. In examination of arailable but rery insufficient data has resulted in the following extremely general statements:

1. No family has dereloped a world-wide distribution as have sereral families of the Monocotrledons and Srmpetalae. It must be understood that this fact is related to the great diversities in the group, that have resulted in the recognition of numerous families. The famils differences recognized by taxonomists are perhaps not to he pressed too far in ans comparison of the geographic distribution of the three great Angio- 
sperm groups. If they are of equal value, the Arehichlamydeae respond more readily to geographic conditions than do the other grups. We suspect, however, that they are of very unequal value, and that the kind of response shown by the Archichlamydeae to changed conditions happens to concern the structures used for determining families more than in the other groups.

2. Among the Archichlamydeae no distinctly boreal family has been developed, as among the Sympetalae.

3. The great tropical family is the Leguminosae, by far the largest Angiosperm family excepting the Compositae. If the Mimosa forms are to be regarded as the primitive ones, it is interesting to note that they are massed in tropical Afriea and Australia, and that it is the highly specialized Papilio forms that have chiefly occupied the temperate regions.

t. Certain great families are characteristic of the north temperate regions, usually being comparatively insignificant in the tropies. These are the Polygonaceae, Caryophyllaceae, Ranunculaceae, Cruciferae, Saxifragaceae, Rosaceae, Onagraceae, and Lmbelliferae.

5. Is among the Monocotyledons, aquatic forms are common and cosmopolitan, but this habit does not characterize whole families so frequently as in the former group. The fact that the aquatic habit is found chiefly among the Monocotyledons and Archichlamydeae must be assoeiated with the fact that in these groups the most primitive Angiosperms oceur. The cosmopolitan charaeter of such forms may be illustrated by the Ceratophyllaceae, which with only three species extends from the arctic to the antaretic regions, oceurring even in Australia and the Fiji Islands.

6. There is a distinct pairing of continents especially in tropical display, as was noted among the Monocotyledons, in this case America usually being one member of the pair and Asia or Africa the other. In this pairing, what may be ealled the Pacific-distribution, involving Asia, the East Indies, or Anstralia on the one hand, and the Imericas on the other, is particularly prominent. For example, the Amarantaceae are massed in Sonth America and the Fast Indies, the Lardizabalaeeae in South America and southeastern Asia, the Calycanthaceae in North America and Japan, the Lauraceae in Ameriea and Asia, the Malvales chiefly in America and Asia, the 
Myrtaceae in South America and Australia, etc. This pairing is still more erident if closely related families are included, as the Sarraceniaceae in North America and the Nepenthaceae in tropical eastern Asia and the East Indies. The pairing of Australia and Ifriea is less notable, as the Mimosa tribe, massed in tropical Australia and Africa, and the Thrmelaeaceae, chiefly occurring in temperate Anstralia and the Cape region. The pairing of America and Africa, or the Atlantic-distribution, is quite rare.

7. The predominance of the American tropics in the derelopment of Archichlamydeae is marked, as might be inferred from the last paragraph, almost all of the tropical groups being represented there, and two great families (Cactaceae and Melastomaceae) being almost exclusirelr American.

8. As might be expected, there is a much greater display of Archichlamyleae in the north temperate regions than in the south. Two large families, however, are characteristic of the south temperate regions-namely, the Proteaceae, chiefly Australian, some South African, and a few South American; and the Thymelaeaceae, characteristic of Australia and the Cape region.

9. It is of interest to note that the dominant tree-groups, so characteristic of Archichlamydeae, are of different alliances in the different regions. For example, in north temperate regions the Juglandales, Fagales, etc., dominate; in the tropics the Lauraceae are the characteristic tree-forms: while in south temperate regions the Proteaceae are the prominent archichlam ydeous forest trees.

10. There is a notable diffusion of types into all regions, so that very few families are restricted in their representation, although most of them hare a fairly definite region of massing. Characteristic tropical families have representatives in the temperate regions, and families rhiefly developed in the temperate regions have tropical representatives.

\section{SYMPETALAE}

The alliances of Sympetalae are comparatively so few and well defined that they may be considered separately.

Ericales. - This alliance is peculiar in containing distinctly temperate and boreal forms. It includes an arctic family 
(Diapensiaceae), an Australian family (Epacridaceae), and a great massing of heath-forms in the Cape region.

Princlales. - The three families are very distinct in their geographic distribution, Mrrsinaceae being tropical, especially American, Primulaceae north temperate and boreal, and Plumbaginaceae characteristically oriental in the halophytic conditions of the Mediterranean and Caspian regions.

EbExales.-The alliance is almost exclusirely tropical, and in both hemispheres.

Gextinales.-The alliance as a whole is more largely massed in the tropies through the tropical display of its largest families, Ipocynaceae and Asclepiadaceae. It contains also a great liana group (Loganiaceae) characteristic of South America and Asia, and there is a pairing of Africa and Asia by the Salvadoraceae. The Gentianaceae have almost a worldwide distribution, but are notable in their numerous alpine species.

Tubiflorales.-This great series is in the main broken up into fairly well-restricted areas, and the chief features of their distribution may be stated as follows: The Labiatae are rorld-wide in their distribution, being notably massed in the Mediterranean region. The Borraginaceae and Scrophulariaceae are the great north temperate families. The Solanaceae are everswhere in the tropics, extending into temperate regions especially in America. The Convolvulaceae, Polemoniaceae, and Hydrophrllaceae are characteristically American, the first being chicfly tropical, and the other two characteristic of western North Ameriea. The Gesneraceae belong to all regionsof the southern hemisphere; while the Verbenaceae, Nolanaceac, and Acanthaceae are notabls in tropical South America. There are also two Mediterranean families, the Orobanchaceae and Globulariaceae. The pairing of South Imerica and Asia is shown in the display of Verbenaceae and Acanthaceae; and of tropical Asia and Ifrica in the display of Pedaliaceae.

Plaxtagixales. - The genus Plantago is cosmopolitan.

Rubiales.- The Rubiaceae are prominently tropical American: the Caprifoliaceae and Valerianaceae are north temperate throughout both hemispheres; while the Dipsaceae scem to be confined to the temperate regions of the eastern hemisphere. 
Canpanales. - The Cucurbitaceae are tropical; the Campanulaceae belong to the north and south temperate regions, with the lobelias as tropical representatives; the Goodeniaceae and Candolleaceae are Australian; the Calyceraceae are mainly tropical American; and the Compositae are world-wide in their distribution.

The main conclusions to be derived from the above facts are as follows:

1. The Sympetalae as a whole are better defined geographically than the Archichlamydeae. This probably follows from the fact that they are better defined structurally.

2. There is a much more even distribution between the tropics and temperates than among the Monocotyledons and Archichlamydeae. Of course the tropical display is the larger, but it is hardly more than might be regarded as the normal ratio of increase in passing from the temperates to the tropics.

3. The Sympetalae as a whole, the youngest of the Angiosperm groups, seem to have become prominently adapted to the relatively unoccupied temperate and boreal conditions, and to have made in them their most characteristic display. From this general point of view, the Monocotyledons and Archichlamydeae are characteristically tropical, and the Sympetalae as characteristically temperate.

4. There is a remarkable paucity of aquatic forms as compared with Monocotyledons and Archichlamydeae. This is probably associated with at least two facts-namely, the lack of primitive angiospermous types among the Sympetalae, and the previous occupation of the water conditions by the older Monocotyledons and Archichlanydeae.

5. The Sympetalae show no such notable continental pairing as is characteristic of the Archichlamydeae. It would seem that this may be related to the temperate and boreal development of the group, which would retain continental connections much longer than would be possible for a group of more tropical tendencies.

6. The dominance of America in the tropical display of Sympetalae is almost as notable as among the Archichlamydeae. The excessive rainfall is doubtless one factor in the explanation, but whether it is the chief one is uncertain. 
7. The sympetalous families of world-wide distribution are the Compositae, Labiatae, and Plantaginaceae.

s. The great north temperate families are the Borraginaceae and Scrophulariaceae.

9. The characteristic boreal group is the Ericales, a group that finds no parallel among the Monocotyledons and Archichlamydeae. 


\section{CHAPTER XIV}

\section{FOSSIL ANGIOSPERMS}

The importance of a knowledge of the ancient history of Angiosperms can not be overestimated. The morphological conclusions as to phylogeny that can be confirmed by historical evidence rest upon the securest available foundation. Unfortunately, the paleobotanical record of Angiosperms is very fragmentary and poorly understood. The published accounts are dominated mainly by stratigraphy rather than by plant-groups, and the named material is often so uncertain as to its affinitie: that the morphologist is extremely perplexed in drawing any conclusions. Even when all data are rejected excepting those that rest upon reasonably secure botanical eridence, any conclusions must be extremely tentative, not only because much of the evidence is negative, but also becanse much of the rejected material undoubtedly contains valuable testimony. In spite of this uncertaintry, it may be useful to put together such testimony as we possess. Even this may modify some conceptions as to phylogeny.

\section{MONOCOTYLEDONS}

When the parallel venation of leaves was taken to be a distinctive character of the Monocotyledons their presence in the Carboniferous was claimed. But since it has become known that such leaves are equally characteristic of the great Paleozoic group Cordaites, as well as of other Gymnosperms, and of certain heterosporous Pteridophytes, this claim rests upon no substantial basis. So far as we have been able to examine the testimony, it must be said that the existence of Paleozoie Monocotyledons has not been proved.

There is no historical evidence that the Monocotyledons have erer been a dominant race, as the Gymnosperms have 
been, and as the Dicotyledons now are, although they do not seem to be so abundant now as they were during the Tertiary. Trhen they do appear in undoubted forms, they are almost completely differentiated and widely distributed. Their ancestral forms are obseured in the maze of unintelligible forms that precede them. The only suggestion of paleobotany as to the origin of the Monocotyledons is that they are certainly a younger type than the Gymnosperms.

Rejecting the claim for Carboniferous Monocotyledons, we encomter one for their existence during the Jurassic. This rests upon the occurrence of certain forms of grass-like habit, which suggest Monocotyledons, but such evidence can not be accepted as conclusive. There is certainly no clear proof of the existence of Monocotyledons in any strata earlier than the Cretaceons. *

The probability of Monocotyledons during the Jurassic rests not upon positive discovery, but upon the fact that during the Cretaceous they were abundant everywhere, and give evidence of their long presence. The earliest history of the group, therefore, is an absolute blank, and we are introduced to it in an advanced stage of development.

The record can be consiclered under three general categories-namely, (1) those families represented during the Cretaceous, (2) those whose earliest representatives are in the Tertiary, and (3) those only known since the Tertiary. It must be observed that the second and third categories are based upon negative evidence-that is, representatives of these families have not been found as yet at any earlier period. It must also be remembered that many plants have a habitat and structure unfarorable to their preservation as fossils, so that failure to discover them in the geological series is no positive evidence that they did not exist. With the uncertainties understood it may be safe to present such evidence as we have.

C'retaceous Families.-There seems to be sure evidence of the existence of five families during the Cretaceous, and a possibility of the oceurrence of a sixth.

The Pandanaceae were present and were widely distrib-

* See Seward, A. C. : Notes on the Geological History of Monocotyledons. Annals of Botany 10: 205-220. pl. 14. 1896. 
uted. This fact seems to substantiate the claim as to the primitive character of this family, and to discount the theory of its origin as a reduction type. Sot only did the serew-pine exist, but the family was richer in forms than at present, all the living genera containing more numerous species than now, and at least one extinet genus having been recognized.

A little later in the Cretaceous the Palmaceae occurred abundantly, but in genera that are now for the most part extinct. Their distribution was very wide-spread, remains having been found in deposits from Greenland to Egypt. This early association of Pandanaceae and Palmaceae is corroborative of the idea of their genetic relationship, and the later appearance of the Palmaceae further confirms the morphological evidence that they may have been derived from the Pandanaceae.

The Potamogetonaceae were abundant, a fact that coincides well with their morphological position as the most primitive of the Helobiales, and controverts the idea that they are a reduced type. That they were more abundantly displayed during the Cretaceous than now is evidenced by the fact that the majority of our present genera were represented, and at least three extinct genera have been detected.

The above families would be expected by a morphologist to occur among the earliest Nonocotyledons, but the Cretaceous record also discloses the presence of the Liliaceae. However, they are comparatively few in number, occur in the upper members of the Cretaceous series, and do not fairly display themselves until the Tertiary, when numerous and now extinct genera appeared. These earlier liliaceons forms are of the Smilax type, but this negative evidence is very uncertain, as this type is peculiarly favorable for preservation.

The Dioscorcaceae also appeared along with the Liliaceae, and are so confused with the Smilax forms as to be difficult to disentangle.

The sixth family, whose existence during the Cretaceous is possible but far from certain, is the Araceae, to which certain doubtful forms have been referred. It may have been scantily represented, and its association with the Potamogetonaceae would be confirmatory of Engler's suggestion as to their genetic connection. 
Tertiary Families.-To the five monocotyledonois families represented during the Cretaceous the Tertiary adds at least fourteen, the older families also showing a largely increased development. It will be interesting to note how these additional families fill out the ten great series of Monocotyledons. In each case the Cretaceous representative is put in parenthesis.

1. Pandanales.-(Pandanaceae), Typhaceae, Sparganiaceae. This primitive series is thus completed as at present recognized.

2. Helobiales.-(Potamogetonaceae), Juneaginaceae, Butomaceae, Hydrocharitaceae. This series is completed by the appearance of its highest member, and the Butomaceae are fairly representative of the Alismaceae.

3. Glumales.-Gramineae, Crperaceae. The occurrence of grass-like forms during the Jurassic has been referred to, but the absence of grasses from the Cretaceous record seriously militates against the claim that these Jurassic forms were grasses. It is since the Tertiary that the Gramineae have become most richly developed and widely spread, numerons extinct genera having been described. Although it would seem impossible to determine the relationships of grasses from fragmentary material, and doubt must be expressed as to the relationships inplied in such names as Poacites, Arundinites, etc., there is good evidence for the statement that the earliest grass types were related to such tropieal forms as Arundo, Phragmites, Bambusa, ete.

4. Palmales.-(Palmaceae). The only family of the series became much more largely developed and wide-spread during the Tertiary.

5. Symanthales.-Cyelanthaceae. This family, the only member of the series, appeared during the Eocene Tertiary, and its early association with the serew-pines and palms confirms its supposed relationship to them.

6. Arales.-(Araceae?). The doubtful appearance of this family during the Cretaceous has been mentioned, and this claim is not helped by the fact that they are no better known during the Tertiary. Such forms as do oecur resemble Acorus and Pistia. The so-called "Protolemnas" seem too doubtful to be included. 
7. Farinales.-Restionaceae, Centrolepidaceae, Eriocaulaceae. Three of the eleren families of the series are thus introduced, the first two now being restricted to the southern hemisphere, but during the Tertiary ranging through Europe.

8. Litiales-(Liliaceae, Dioscoreaceae), Juncaceae, Iridaceae. The last family is the highest nember of the series, and its appearance before certain of the lower families is altogether doubtful.

9. Scitaminales.-Musaceae. The series consists of four families, and this one, now confined to the oriental tropics, is recognized as the most primitive.

10. Orchidales.- Not represented.

At the end of the Tertiary, therefore, there is reasonable evidence as to the existence of all the great series of Monocotyledons excepting the highest, and of nearly one-half the families.

\section{DICOTYLEDOXS}

Any evidence as to the comparative antiquity of Monocotyledons and Dicotyledons is much to be desired, but as ret the historical evidence is not definite, for no undoubted Monocotyledon has been recorded from strata older than those in which trpical Dicotrledons first oceur, and rice versa. The great and sudden prominence of the Dicotyledons in the Cpper Cretaceous and Tertiary was long a puzzle, only relieved by the solitary Populus primaera of the Lower Cretacens. Comparatively recent studies, however, of contemporaneous beds in the [nited States and Portugal now regarded as Lower Cretaceous have thrown much light upon the subject, and since 1 sss our knowledge of the origin of the Dientyledons has increased rapidly. It should be remembered that the group is largely composed of herhaceous plants, and could not have a fair representation among fossil forms.

Lower Cretaceocs Dicotyledoxs.-The dicotyledonous flora of the Lower Cretacenus was an abundant one, and is of great interest in the history of Dicotyledons. It consists of a plexus of forms. some of which are clearly related to existing Dicotyledons, others are clearly Dicotyledons but with no living representatives. while others are vague in their relationship to Dicotyledons. The few forms that can be referred with any 
definiteness to modern groups are fairly submerged by the extinct and rague types. Such a plexus is consistent with any rolutionary theory of the origin of Dicotyledons, and that it has been definitely discovered in the Lower Cretaceous is of great importanee.

Proangiosperms. - These are the rague forms referred to above as being not definitely Dicotyledons but suggestive of them. They are recognized by stem-structure and leaf-renation, and seem to be related to numerous modern families, being good illustrations of so-ealled " eomprehensive types." It is hardly to be doubted that many of them represent primitive Dicotrledons. If the Lower Cretaceous be divided into five periods, the Proangiosperms not suggestive of modern groups are the only dicotyledonous forms in the first. In the other periods they also oceur, but in diminishing importance as compared with the increasing number of reeognizable forms. These clearly antecedent and for a time assoeiated forms are very suggestive of their signifieant relation to modern Dicotyledons.

Forms suggestive of Modern Groups.-After the first period of the Lower Cretaceous, forms suggestive of modern groups appear. They are so elearly Dicotyledons as not to be included among the Proangiosperms, but they are just as distinetly not modern types. Their generic nanes suggest the modern resemblanees, but these inust not be taken to indicate relationships. For example, such names as Leguminosites, Menispermites, Myrsinophyllum, Protcophyllum, Peuccdanites, ete., tell of certain superfieial resemblances, but may be very far from indieating real relationships.

Modern Genera.-As already stated, no modern genera were associated with the Proangiosperms during the first period of the Lower Cretaeeons. In the seeond period, howerer, an extinct species of Populus has been recognized, the most aneient living genus of Dicotyledons known. In the third period $\mathrm{Hag}$ notin and Liriodendron are reeorded; in the fourth Salix, Aristolochia, sassafras, Idoxa, and Aralia appeared; and in the fifth Myrica, Laurus, Eucalyptus, and Viburnum are recorded.

In considering this reeord of the Lower Cretaceous the following things berome erident:

1. The genera, so far as they are identical with living gen- 
era, are practically all members of the Archichlamydeae. The case of Tibumum, and even of Aralia, is peculiar, and perhaps suggestive of a fir more complete development of the Dicotyledons than the records have shown.

2. The early appearance of Populus confirms the general primitive character of naked flowers and the anemophilous habit.

3. None of the known chalazogamic forms are represented in the above list, so that chalazogamy can hardly be regarded as a primitive character, as has been claimed, unless it be assumed that these earlier genera were chalazogamic and later became porogamic.

4. Of the twelve modern genera represented in the list, no less than eight are recognized by morphologists as primitive in character.

5. The oceurrence of one of the Sympetalae in the uppermost member of the Lower Cretaceous, and that an epigynous form, needs explanation. It leads to at least one of three conclusions. Either the determination is a mistake, or a large representation of sympetalous genera remain to be discovered in the Lower Cretaceous, or the present view as to the relative rank and phylogeny of sympetalous families must be modified. If the determination of Tiburnum is the correct one, its association with Aralia is confirmatory of a genetic connection which we have long maintained.

6. That epigrny had appeared among the undoubted Archichlanydeae during the Lower Cretaceous is seen by the existence of such a genus as Eucalyptus.

Upper Cretaceods Dicotrledoxs.-Much less is known of the flora of the Lpper Cretaceous than of the Lower Cretaceous. There must have been a large development of existing genera, such as Salix, Populus, and Liriodendron being well known, as well as an introduction of new ones.

Tertiary Dicotrledoxs.--The record of the dicotyledonous flora of the Tertiary is naturally made up of the trees and shrubs. The forest display was evidently as extensive and raried as now. In addition to the genera mentioned above, all of which show increasing development, there appeared the Betnlaceae, Fagaceae, Juglandaceae, Moraceae, Proteaceae, Berberidaceae, Staphyleaceae, Aceraceae, etc. This means an almost 
complete display of the more primitive Arehichlamydeae. A notable introduction during the Tertiary was that of the Leguminosae. That these appeared first only as Mimosa forms is a strong confinuation of the primitive character of this tribe, as well as of its possible relation to the liosaceae.

The above facts in reference to the early history of the Dicotyledons seem to warrant the following eonclusions:

1. The modern Dicotyledons were derived from a plexus of vague forms developed largely in the Lower Cretaceons and known as Proangiosperms.

2. The Cretaceous and Tertiary display is almost exclusively made up of Archichlamydeae, the dominant types being the more primitive Arehichlamydeae.

3. The Sympetalae are practically absent from the Cretaceous and Tertiary, and represent therefore a comparatively. recent type.

4. The possible appearanee of Tiburnum, associated with Aralia, at the close of the Lower Cretaceous suggests a connection of Umbellales with the Sympetalae not recognized by taxonomists.

5 . None of the highly specialized groups of the Archiehlamydeae are represented in the C'retaceous and Tertiary, such a family as the Leguminosae being represented by its most primitive type, and all the types being what may be ealled "comprehensive."

6. The identity of genera in the eastern and western hemispheres indicates the absence of continental diversities, which later became so striking a feature in geographical distribution.

7. The theory that simple flowers are necessarily reduced rather than primitive structures seems to have a complete refutation in the testimony of history. 


\section{CHAPTER XV}

\section{PHYLOGENY OF ANGIOSPERMS}

THE phrlogeny of any great group will probably alwars remain a battling problem. At the same time, theories of phylogeny serve to coordinate knowledge and stimulate investigation. The phylogeny of Angiosperms is an unusually obscure problem. The hrpotheses proposed seem to include almost every possibility, but thus far they have been more interesting than conrineing. When similaritr of structure was taken as a sure indication of genetic relationships, the problem promised an approximate solution. But since it has been proved that similar structures may develop independently, the difficulty of solution has apparently become insurmountable. Under such cirenmstances it is questionable whether a disenssion of the subject is profitable, but a statement of the problem mar not be out of place.

The first phase of the problem has to do with the common or independent origin of the Monocotyledons and Dicotyledons. It has been assumed generally that the two groups are monophyletic. The chief argument, and in fact the only morphological one for the monophyletic theory, lies in the great uniformity of the peculiar development of both the male and female gametophytes. It is argued that the independent origin of such exact details of development and structure is inconceirable, and this argument has been reenforced recently by the discovery in both groups of the peculiar phenomenon called "double fertilization." The argument is certainly a very strong nne, and yet there are rebutting propositions. Even such similarity in strueture mar be the natural outcome of the changes that resulted in the evolution of seeds, and these are now generally beliered to have appeared in inde- 
pendent lines. Again, the fundamental differences in the development of the embryos of the two groups are hard to reconcilc upon the theory of monophyletic origin. Add to this the fundamental differences in the structure of the stem and in the character of its rascular bundles, and the deriration of one group from the other seens more inconeeirable than the derivation of the Dicotyledons from the Gymmosperms. Still another argument against the monophyletic theory is furnished by the historical testimony. The Proangiosperms of the Lower Cretaceous, so far as known, appeared associated with undoubted Monocotyledons, and merged gradually into recognizable Dicotyledons, without indicating any relationship to the Monocotyledons. The emerging of Dicotyledons from this vague group either indicates that Monocotyledons and Dicotyledons originated independently, or that the Proangiosperms were transition forms between Monocotyledons and Dicotyledons. This latter alternative is in tum inconceivable, especially since the most primitive Dicotyledons are recognized to be even more primitive than any of the Nonocotyledons.

Recently, however, the morphological arguments in favor of the monophyletic origin of Angiosperms have been reenforced by anatomical investigations, which point to origin from a common proangiospermous stock, or the derivation of the Monocotyledons from the more primitive Dicotyledons. In the following chapters it will be noted that on anatomical grounds Jeffrey regards the Monocotyledons as strictly monophyletic and modern, derived from the Dicotyledons or their parent stock; and on the same ground Queva ${ }^{9}$ thinks that the Monocotyledons are derived from the lower Dicotyledons. In her study of the origin of the cotyledon in Monocotyledons, Miss Saroant ${ }^{18}$ consludes that the IIonocotyledons are a specialized lranch from the Dicotyledons. In Anemarhena, one of the Iiliaceae, she finds two opposed vaseular bundles in the terminal cotyledon. These run down into the short hypoeotyl, where each divides into two, and the four phloems so formed are continuous with those of the tetrarch primary root. This slogests that two cotvledons are represented, which were separate in some dieotrledonons ancestor. The same investigator also finds in Erianthis, one of the Ranunculaceae, a posible illustration of this dicotyledonous aneestor; for the petioles 
of the cotyledons are united throughout their length, showing two opposed bundles, as in the cotyledon of Anemarhena. Attention should be called to similar cotyledonary tubes in Dicotyledons, and since nearly all of these are geophilous plants Miss Sargant ${ }^{21}$ has inferred that the fused condition of the cotyledons in the monocotyledons has arisen in connection with the geophilous habit. We herewith reproduce Miss Sargant's list of dicotyledonous seedlings with a well-marked cotyledonary tube.

Anemone coronaria, A. alpina, A. blanda, A. narcissiflora, A. rupicola, Ranunculus parnassifolius, Trollius Ledebouri, Erianthis hiemalis, Delphinium nudicaule, D. hybridum and var's., Aconitum Anthora, Leontice vesicaria, L. altaica, Podophyllum peltatum, P. Emodi, Cardamine spp., Oxalis spp., Rhizophora Mangle, R. conjugata, Megarrhiza californica, Smyrnium perfoliatum, S. rotundifolium, S. Olusatrum, Bunium luteum, Chaerophyllum bulbosum, Prangos ferulacea, Serratula radiata, Dodecatheon Meadia, Polygonum Bistorta, P. spliaerostachyum, and Rheum Moorcroftianum.

IIolm ${ }^{7}$ has also studied the two completely united cotyledons of Podophyllum, which suggested to him the possibility that the "pair" may be regarded as a single cotyledon. In her study of the "monocotyledonous Dicotyledons," Miss Sargant 21 claims that the so-called single cotyledon is a fusion of two cotyledons, special reference being made to the well-known case of Ranunculus Ficaria. It may be noted also that in 1496 Delpino $^{2}$ urged the origin of the monocotyledonous phylum from Dicotyledons throngh Butomus. Recently Hallier, ${ }^{20}$ basing his phylogeny upon sporophylls and foliage leaves (" trophophylls"), has urged the origin of Monocotyledons from Dicotyledons, elaiming that they have arisen from the region of the Ceratophyllaceae and Ranunculaceae.

There can be no question that among the Xrmphaeaceae, Ranunculaceae, and Berberidaceae there cecur anatomical structures very suggestive of Monoentyledons, as Campbell ${ }^{15}$ has recently pointed out, but that this proves the origin of Monocotyledons from Dicotyledons rather than the reverse is not evident. Even the evidence derived from cotyledons has been taken by Lyon ${ }^{1+}$ as indieating that the dientyledonous eondition has heen derived from the gradual splitting of the single cotyledon of Monocotyledons. If the riew of the phylogeny of 
the cotyledon maintained by Lyon ${ }^{17}$ be true (see Chapter IX), the Monocotyledons are more primitive than the Dicotyledons and have given rise to them.

It is an old view, however, that the Dicotyledons are the more primitive, and that the Monocotyledons have been derived from them as a reduction series. Later the relatively primitive character of the Monocotyledons was maintained without serious opposition. A detailed presentation of the phylogeny of Angiospems from this point of view may be found in Bessey's 3 " Phylogeny and Taxonomy of the Angiosperms."

In our judgment the evidence is strongly in favor of the independent origin of the two groups, which have attained practically the same advancement in the essential morphological structures, but are very diverse in their more superficial features. Their great distinctness now indicates either that they were always distinet or that they originated from forms that were really Proangiosperms and neither Monocotyledons nor Dicotyledons. It may be well to state in this connection that in speaking of the origin of one great gromp from another, the former is not supposed to have arisen as a single branch. For example, to say that Monocotyledons have been derived from Dicotyledons does not imply that a single monocotyledonous branch arose from some definite group of the Dicotyledons, but that probably several monocotyledonous lines arose from one or more regions of the Dicotyledons, regions that may or may not be illustrated by living groups.

The next phase of the problem raises the question whether the Angiosperms have been derived from the Gymnosperms or lirectly from the Pteridophytes. The general question is the same whether one believes in their monophyletic character or not. The older view is that the Angiosperms have been derived from the Gymnosperms, and Fnetum has been regarded as the nearest living representative of a transition condition between Grmmosperms and Angiosperus. The argument is based upon certain resemblances of Gnetum to the Ingiosperms, chief among them being the absence of archegonia, the organization of eggs while the gametophyte consists of free cells, the presence of a perianth and true vessels, and the Dicotyledon-like leaves. Thi showing is strong but perhaps not ennelusive. If this origin be maintained, it is evident not only from the leaf char- 
acters, but still nore from the nature of the embryo and the structure of the stem, that the primitive Angiosperm stock would be the Dicotyledons. Strasburger recognized this necessity when proposing the theory, and regarded the Monocotyledons as a reduced branch from the Dicotyledons; which is another reenforcement of the argument derived from recent anatomical investigations. In fact, the Grmnosperm ancestry of Dicotyledons also gains a point in the entire absence of pteridophytic anatomical features in the shoots of Dicotrledons.

Latelr, also, Karsten, ${ }^{16}$ in a morphological studr of the Juglandaceae, emphasizes their resemblances to Gymnosperms, and concludes that the Angiosperms have been derived from such forms as Gnetum. The historical argument against such a claim is the absence of any certain eridence of the existence of Gmetum among the numcrous Ingiosperms of the Cretaceous and Tertiary. If it were related in any way to the origin of such a group as the Angiosperms, it scems probable that it would have left some evidence of its existence. Of course this is negative evidence, and remains of ancient Gnetales may be found in the tropics or in the sonthern hemisphere. The argument from the presence of a perianth is particularly rulnerable, since the so-called perianth merely represents the bracts common among Gymnosperms, and the most primitive Dicotyledons and Monocotyledons have no perianth. Further, the presence of true ressels is an argument as much in favor of the origin of the Angiosperms from certain heterosporous Pteridophrtes as from Gnetum. Althongh we regard the origin of Ingiosperms from Grmnosperms as very improbable, the embryo-sac structures of Gnetum are suggestive of the was in which the characteristic sac-structures of the Ingiosperms may have arisen from a compact gametophyte. This is all the more probable since the sac-structures of certain Juglandaceae and of Peperomia pellucida have been found to be suggestive of those of certain species of Gruetum.

If the Grmmosperms are not the ancestral forms of the Angiosperms, their direct derivation from the Pteridophytes becomes a matter of course. The Pterislophrte that has been most persistently associated with the origin of Angiosperms is Isoetes. Its resemblances to the Monocotyledons have suggested 
that it may be the nearest living representative of their ancestral forms. Isoetes is a remarkably isolated group among the Pteridophytes, with no clear affinities, so that its own connection with the Pteridophrte stock is not evident. The most striking resemblance to Monocotyledons occurs in the embryo, in which the single cotyledon is terminal and the stem-tip arises later as a lateral structure. The development of the male gametophyte resembles Angiosperms more than it does Gymnosperms, while the female gametophyte is equally suggestive. Howerer, these gametophyte characters are shared by selaginella. The general habit and vegetative structure of Isoetes bear some resemblance to those of an aquatic Monoeotyledon, and the anatomy of the stem is suggestive of such forms as I ucca and Dracaena. There can be no question that the resemblances of Isoetes to the Monocotyledons are more numerous than those of any other living Pteridophyte. The most telling resemblanee is the character of the embryo, but the fact that its axis is transverse to that of the suspensor is a serious obstacle. Campbell has called attention to the fact, however, that in the embryos of Lilaea subulata and Zannichellia the apex of the root is not directed toward the suspensor but to one side, so that the axis of the embryo is oblique to that of the suspensor. A possible explanation of these laterally directed roots, howerer, is suggested by Murbeck's recent account of Ruppia (page 196), in which a primary root is formed with the normal orientation, but soon disorganizes, while a lateral root, formed very early, is the first functional one. As between the Gnetum origin of Angiosperms and the Isoetes origin of Monocotyledons the latter view must be preferred. Such a riew, of course, does not imply that the present Monocotyledons have been derived from the present Isoetaceae, but that the ancestral forms of the two were probably genetically connected. If this be true, doubtless Isoetes represents a reduced branch of some old stock that gare rise to the more vigorous Monocotyledons. The only possible alternative as to the origin of Monocotyledons, in case they have arisen independently of the Dicotyledons, seems to be to regard them as the end of a heterosporous line that developed independently from the ensporangiate Filicales, whose Pteridophyte members are extinct. Such an hrpothesis is only necessary in the event that those based upon known 
structures prove to be insufficient; but the problem seems to have reached this contingency now.

To many, any conclusion as to the origin of the Monocotyledons involves that of the Dicotyledons, which they would regard as an ancient branch from the Monocotyledon stock. We have already cited reasons why such a view does not commend itself to us, and prefer to regard Dicotyledons as of independent origin. If the two lines have a common origin, it seems to us that the arguments in favor of the derivation of Monocotyledons from the more primitive Dicotyledons are the more convincing. Both lines to-day include very primitive forms, and the structure of the flower and character of the megasporangiate archesporium are more primitive among existing Dicotyledons than among Monocotyledons. Whether Dicotyledons represent an independent angiospermous line, as we prefer to believe, or the primitive Angiosperm stock, it remains to discuss their possible origin. The fact that they emerged from a primitive group called Proangiosperms, which was largely developed in the first period of the Lower Cretaceous, seems to be fairly well established by paleobotany. The question thus concerns the origin of the Proangiosperms. They do not seem to warrant the belief that they represent a common stock from which both Monocotyledous and Dicotyledons hare been derived, for the Monocotyledons are believed to have existed in ummistakable forms before the large assemblage of Proangiosperms gave rise to ummistakable Dicotyledons. Still less conceivable is it that the Proangiosperms represent the transition forms from Monocotylerlons to Dicotyledons, for nothing in their known structure seems to suggest such a view. That they were derived from Gnetum-like forms is discredited by the fact that there is no sure record of the existence of Gnetum at such an early period, and to have given rise to such an assemblage of forms it must liave been a conspicuous group.

If we turn to the earlier groups that were sufficiently prominent and at all suggestive of having given rise to the Proangiosperms, we encounter the Coniferales, Cycadales, Lycopodiales, and Filicales. The Gymnosperm-origin of Dicotyledons seems to be most unlikely with the exclusion of Gnetum. At the same time, it might be claimed that Dicotyledons represent 
an independent line from the Grmnosperm-stock, that advanced in the same direction and much farther than did the Gnetumline. At the same time, all the essential morphology of the Grmmosperms is less farorable to such an origin than is that of the heterosporous Pteridophrites.

The Lycopodiales certainly deserve serious consideration in this connection. The structures of Selaginella are about as suggestive of Dicotyledons as those of Isoetes are suggestive of Monocotyledons, the embryo being as distinctly dicotyledonous as that of Isoetes is monocotyledonons, and the seed-like character of the megasporangium supplies a still more striking resemblance. Such a view does not imply that the present comparatively modern genus Selaginella has given rise to the Proangiosperms, but that the latter may have been derived from the same ancient Lycopodium stock.

The only remaining alternative hypothesis is that mentioned in connection with the origin of the Monocotyledons, namely, the derivation of the Proangiosperms as an independent heterosporous line from the abundant ancient eusporangiate Filicales, and this riew is supported by anatomical testimony. It may be that further knowledge of the Proangiosperms will help to establish such an hypothesis.

It seems to us that the last two hypotheses deserve the most consideration, as likely to include the future results of investigation.

It should be noted in connection with the origin of Dicotyledons that there is much evidence in favor of the view that they include two independent lines. For example, Campbell inclines to the view that one line is derived from the Arales, passing by way of the Piperales and amentaceous groups to the isocarpous Sympetalae. while the other arises from the apocarpous Helobiales, and by way of the Ranales and later groups culminates in the anisocarpic Srmpetalae. Although not inclined to accept the origin suggested, the existence of two such independent lines of Dicotyledons has rery much in its favor, whether derived from the Monocotyledons or not.

A summary of our present riews, as developerl in the preceding pages, may be stated as follows: The Mnnocotyledons and Dicotyledons represent two independent lines derived directly from Pteridophyte stock, probably from the Filicales. At the 
same time, the arguments in faror of the monophyletic origin of Angiosperms are strong; and if this riew be accepted, the derivation of Monocotyledons from primitive Dicotyledons seems to rest on stronger evidence than the reverse relationship. It must also be said that the Gymnosperm origin of Angiosperms is not to be discredited so much now as formerly.

The student of the phylogeny of any group of vascular plants should be acquainted with certain general theoretical views. Among them the origin of the sporophytic generation is one of the most fumdamental. Two theories are under discussion, known as that of homologous origin and that of antithetic origin, names applied by Celakorsky. According to the former theory, the sporophyte is the lineal descendant of the sexless individuals common among Thallophytes and homolugous with the sexual individuals; according to the latter theory, the sporophyte is a new structure intercalated in the life history of plants and holding no phylogenetic relation to any preceding individuals. The theory of homologous origin is referred to Pringsheim in 1876 ; that of antithetic origin was formulated by C'elakovsky in 1877 , but was presented in detail by Bower in 1890. In 1596 the theory of homologous origin was again brought into prominent notice by Scott in a presidential addres before the British Association; and two rears later Bower, upon a similar occasion, defended the theory of antithetic origin. A general presentation of the subject by Klebs, ${ }^{4}$ Lang, ${ }^{5}$ and Hartog ${ }^{6}$ followed, including the testimony of recent investigations. Indoubtedly the strongest argument in favor of the homologous origin of the sporophyte is derived from the phenomena of apogamy and apospory; and among Ferns these have been coming to light so rapidly and are induced so readily that the powers of gametophyte and sporophrte, at least in this group, seem to be easily interchangeable, a fact most easily explained by their homologous character. It will be noted that in all this discussion there is no suggestion that sporophytes may have arisen in both of these ways, a possibility that will be considered a little later.

One of the most suggestive theories of recert rears is Bower's ${ }^{1}$ theory of the strobilus. No better statement of its main points can be made than that of the author himself in his summary. 
1. Spore-production was the first office of the sporophyte, and the spore-phase has constantly recurred throughout the descent of the Archegoniatae; the spore-bearing tissues are to be regarded as primary, the vegetative tissues as secondary, in point of evolutionary history.

2. Other things being equal, increase in number of carpospores is an advantage; a climax of numerical spore-production was attained in the homosporous Vascular Cryptogams.

3. Sterilization of potential sporogenous tissues has been a widespread phenomenon, appearing as a natural consequence of increased spore-production.

4. Isolated sterile cells or layers of cells (tapetum) served in many cases the direct function of nourishing the developing spores, being themselves absorbed during the process.

5. By formation of a central sterile mass (columella, etc.) the sporeproduction was, in more complex forms, relegated to a more superficial position.

6. In vascular plants, parts of the sterile tissue formed septa, partitioning off the remaining sporogenous tissue into separate loculi.

7. Septation to form synangia, and subsequent separation of the sporangia, are phenomena illustrated in the upward development of vascular plants.

8. Such septation may have taken place repeatedly in the same line of lescent.

9. The strobilus as a whole is the correlative of a body of the nature of a sporogonial head, and the ajex of the one corresponds to the apex of the other.

10. Progression from the simpler to the more complex type depended upon $(a)$ septation, and $(b)$ eruption to form superficial appendicular organs (sporangiophores, sporophylls) upon which the sporangia are supported.

i1. By continued apical growth of the strobilus, the number of sporophylls may be indefinitely increased.

12. The sporophylls are susceptible of great increase in size and complexity of form; in point of evolutionary history, small and simple sporophylls preceded large and complex ones.

13. In certain cases foliage-leares were produced by sterilization of sporophylls.

This theory means that the leafy sporophyte is derived from such a sporophytic structure as is displayed by the sporogonium of Bryophytes; but, as suggested by Klebs and Lang, it may have had an entirely independent origin, and may have no phrlogenetic connection with such a structure as a sporogonium. This view, together with its possible relations to the question of antithetic versus homologous origin of the sporophyte, has 
been discussed by Coulter $^{8}$ the substance of whose paper may be stated in the following extracts:

It has been common to regard the distinct sporophyte as having been established once for all by the Bryophytes, and the sporophytes of the higher groups to have been derived from those of the Bryophytes. In searching for the origin of the leafy sporophyte, therefore, attention has been focused upon the sporogonia of Bryophytes. . . . The doctrine that any plant structure, however important, can have but one phylogeny, is hardly tenable at present. . . . In contrasting the sporophytes of Bryophytes and Pteridophytes, they seem to have nothing in common except that they are usually derived from the oospore and represent an asexual generation. These facts are important, but so are the numerous other facts in which they differ sharply....

It may be well to contrast the leafless and leafy sporophytes. In the former case the structure is never independent of the gametophyte, develops no lateral members, has nothing comparable to sporangia, and its whole tendency is to render complex the spore-producing region. In the latter case the sporophyte is dependent upon the gametophyte only in its embryonic stage, develops prominent lateral members, has distinct simple sporangia, and its whole tendency is to render complex the sterile or nutritive tissues. As one traces the evolution of the Bryophyte sporogonia they give evidence of increasing complexity and hence rigidity, and little promise of originating such a diverse tendency as that shown by the sporophyte of Pteridophytes. ... The origin of leaves on the gametophore of mosses suggests that leaves may develop in response to more favorable conditions for their work, and such development may result in the great reduction of chlorophyll work done by the less favored region, and its consequent simplification. It is evident that with the exchange of an aquatic for a terrestrial habit the thallose body would not be a favorable type for chlorophyll work, and that the development of chlorophyll tissue upon erect structures of various kinds might follow. Among Bryophytes the erect structure laid hold of is the gametophore, and not the sporogonium. ...

In considering whether it is possible to disregard the Bryophytes in our search for the origin of the leafy sporophyte, we are largely influenced by the fact that the Bryophyte sporophyte, throughout its whole history, is dominated by a tendency which does not appear in the Pteridophyte sporophyte. Before the establishment of alternate generations the plant body may be said to have had three functions, namely, chlorophyll work, and the production of gametes and spores. The appearance of the Bryophyte sporogonium was dominated by the separation of spore-formation from the other functions, chlorophyll work being retained by the gametophyte, along with gamete-produc- 
tion. Attention has been focused so long upon the gametes and spores as the two dominant factors in differentlation that it is hard to conceive of the possibility of the domination of another factor. It is entirely conceivable, however, that another form of differentiation may have occurred, dominated by the needs of the chlorophyll work, and not by spore-production. Certainly a great need for change, when aquatic conditions were exchanged for terrestrial, was in connection with the display of chlorophyll tissue. It would seem as if the Bryophytes had laid emphasis upon spore-production, and therefore never became organized for the fullest use of terrestrial conditions, while the Pteridophytes laid emphasis upon chlorophyll work and became highly organized for terrestrial life. It would seem possible, therefore, with the three factors to take into account, that two distinct asexual lines may have been organized, distinct in the factor selected to dominate. ...

If more favorable structures can be developed in response to the needs of spores or gametes, there seems to be no good reason why more favorable structures may not be developed in response to the needs of chlorophyll work. If such a response in structure is possible, it would naturally express itself first in developing the largest display of chlorophyll tissue in the most favorable region of the body, which would gradually become differentiated more and more distinctly from the rest of the body. It does not seem clear why the appearance of an erect leafy axis, bearing neither gametes nor spores, is not quite as supposable as the appearance of a sporophore with neither gametes nor leaves, or a gametophore with neither spores nor leaves. . . .

With such an origin of the leafy sporophyte, it would follow that foliage leaves are not secondary but primary structures, and that sporophylls have arisen from the differentiation of foliage leaves bearing sporangia, a state of things certainly suggested by the most primitive Ptericlophytes known. It would further follow that the evolution of the strobilus has followed the development of foliage leaves, a view in accordance with the older morphology. Such a view would make intelligible the great "gap " recognized as existing between Bryophytes and Pteridophytes, as the two groups would not be phylogenetically comnected, and would have developed along very divergent lines from the first. It would mean that at least two independent sporophyte lines have appeared, the Bryophyte line probably with an antithetic origin, and the Pteridophyte line possibly with an homologous origin. The great prominence of the latter line, with its Spermatophyte sequence, is correlated with the development of a vascular system, and it would seem as though the evolution of an elaborate vascular system must have depended upon the domination of chlorophyll work.

Knowledge of the varions theories as to the origin of species is so much a part of the essential training of the morpholugist 
that no résumé of the subject is necessary. Until very recently, the rarions theories involve the idea that a species is produced as the cumulative result of slight rariations through successive generations. In sharp contrast to this De Vries has recently proposed what is called the mutation theory, a brief statement of which may be of service. The experimental work that furnishes a substantial basis for the theory was conducted with Angiosperus, and a special student of the group should be prepared to recognize any testimony for or against it. A suggestive feature of the work of De Vries is his attempt to break away from the speculative method and to subject the problem to experimental investigation. Whether his results indicate a general method of the origin of species in natmre or an occa-ional method, or are capable of an entirely different explanation and hold no relation to the normal origin of species, remains for future work to determine. In any erent, the theory will stimulate investigation and deserves consideration.

The occasional sudden appearance of what have been called "sports" is well known, but they have not been prominently associated with the origin of species. They have been referred to as cases of "saltatory evolution," and in 1864 Kölliker ceems to have been responsible for the term "heterogenesis" as applied to this phenomenon. Quite independently and simultaneously De Vries ${ }^{11}$ and Korschinsky ${ }^{12}$ have elaborated the same theory as to the origin of species, the former calling it the "mutation theory," the latter using Kölliker's name " heterogenesis." Korschinsky has bronght together a mass of data from the records of gardeners and horticulturists to show that most of the culture "varieties" have arisen through heterogenesis rather than by selection. De Tries, on the other hand, has experimented extensively with Enothera Lamarcliana, a species showing mutability in a high degree. This American species was found naturalized on an area in Holland about 18.5 , and afterward spread rapidly. When observed by De Vries, in $18 \varsigma 6$, two new species were detected among the normal forms, sind they have maintained themselves ever since. From 1ss6 until the publication of his book, De Vries made observations upon the naturalized areas and carried on cultures in the botanical garden at Imsterdam. As a general result, it may be stated that out of 50,000 seedlings of $E$. Lamarchiana $\$ 00$ were mu- 
tants. Of these 800 , about 200 were the new species named (E. lata; that is, the same new species appeared about 200 times. Various other new species appeared, and were preserved by eulture. The mutants also occurred in every direction in the same environment, showing no indieation of being responses to external conditions. In the great majority of cases the mutants were constant from the outset, there being no development and fixation of characters through selection, and no transition between parent and offspring. Experiments with other species seem to indicate that the majority of species are at present inmutable, varying within certain narrow limits, but not giving rise to mutants.

Solms-Laubach ${ }^{10}$ has shown that in all probability Capsella Heegeri has arisen in this way from $C$. Bursa-pastoris; and Carlson ${ }^{13}$ has suggested a sinilar origin for certain Swedish forms of Succisa pratensis; while Jordan's work with Draba verna has discovered about 200 immutable forms within the old species limits, that probably represent true species derived by mutation from a parent of great mutability.

The experiments of De V'ries seem to indicate that there is a definite limit to individual variability, beyond which selection can not go. Furthermore, it is claimed that selection never fixes a character, but reversion may oceur after any number of generations of culture. In short, natural selection can not create anything new, but ean modify within definite and narrow limits; while mutation brings into existence something new, which will continue as a new species if it ean survive the struggle for existence. There is thus drawn a sharp eontrast between mutability and ordinary variability, the latter being governed by environment, the former independent of it. Hence, while most species are immutable, all are more or less variable.

At its present stage such a theory can not be aceepted or rejected. Either alternative will demand a vast amount of carefully sifted experimental evidence. It should be remembered that the subject lends itself readily to observations that are really inferences, and a vast amount of data will doubtless be fortheoming that can not he regarded as testimony. The student of Angiosperms, however, is in a position to encounter useful data, for the group is a very modern one and seems to contain many mutable species. It should further be remem- 
bered that the whole theory is based upon the present conception of species, a conception so variable that it can not be defined. Furthermore, although there may be a fixed limit to ordinary variation, there must also be a fixed limit to the extraordinary rariation called mutation, and this remains to be defined. In fact, there is eridence that extreme mutation results in functional derangement of organs, and the result is a monstrosity, which may be regarded as an impossible new species. Finally, even if mutation be found to explain the origin of many new species, it does not follow that other processes also may not be working to the same result.

In a recent paper, Strasburger ${ }^{19}$ takes occasion to discuss the origin of species, taking the riew that the results of natural selection have been orerestimated, and that new species have arisen through mutation, due to internal causes alone, and throngh " use and disuse," by means of which a certain amrunt of adaptation to environment is secured. To him the only function of natural selection appears to be to remove the less raluable forms produced through mutation and "use and disuse." It follows that the ordinary physiological operations do not result in species, but affect them after they have appeared, and that the origin of species is a morphological rather than a phrsiological problem.

\section{LITERATURE CITED}

1. Bower, F. O. A Theory of the Strobilus in Archegoniate Plants. Annals of Botany 8: 343-365. 1894.

2. Delpivo, F. Applicazione de nuovi criterii per la classificasione delle piante. Mrem. Real. Accad. Sci. Bologna T. 6: 8.3-116. 1896 ; see review Bot. Centralbl. 67 : 370. 1896.

3. Besser, C. E. Phylogeny and Taxonomy of the Angiosperms. Bot. Gazette 24: 145-178. 1897.

4. Klebs, G. Alternation of Generations in the Thallophytes. Annals of Botany 12: 570-583. 1898.

5. LAxG, W. H. Altemation of Generations in the Archegoniates. Annals of Botany 12: 583-592. 1898.

6. Hartog, M. Alternation of Generations. Anmals of Botany 12: 593-594. 1898.

7. Holir, Theo. Podophyllum peltatum; a Morphological Study. Bot. Gazette 27: 419-433. figs. 10. 1898.

8. Collter. I. M. The Origin of the Leafy Sporophyte. Bot. Gazette 28: 16-59. 1899. 
9. Queva, C. Contributions à l'anatomie des Yonocotyledonées. I. Les Uvulariées tubereuses. Lille. 1899.

10. Solys-Latbach, H. Cruciferenstudien. 1. Capsella Heegeri Solms, eine neue entstandene Form der deutschen Flora. Bot. Zeit. 581: 16\%-190. pl. . 1900.

11. De Vries, H. Die Mutationstheorie, Versuche und Beobachtungen über die Entstehung von Arten im Pflanzenreich. Tol. I. Leipzig. 1901. See reviews: Biol. Centralbl. 21: 257-269, 289-305. 1901 ; Bot. Centralbl. 87: 170. 1901; Bot. Gazette 33: 236. 1902. Also The Origin of Species by Mutation, Science 15: $721-729$. 1902 .

12. Korschinsky, S. Heterogenesis und Evolution. Ein Beitrag zur Theorie der Entstehung der Arten. Translated from the Russian by S. Tschulok. Flora 89: 240-363. 1901; also review in Bot. Gazette 33: 396. 1902.

13. Carlsox, G. W. F. Ett par afvikande former af Succisa pratensis. Bot. Notiser 1901 : 224-226.

14. Lyox, H. L. Observations on the Embryogeny of Nelumbo. Minn. Bot. Studies 2: 643-655. 1901.

15. Campbelz, D. H. On the Affinities of Certain Anomalous Dicotyledons. Amer. Nat. 36: 7-12. 1902.

16. Karstex, G. Ueber die Entwickelung der weiblichen Blüthen bei einigen Juglandaceen. Flora 90: 316-333. pl. 1:. 1902.

17. Lyos, H. L. The Phylogeny of the Cotyledon. Postelsia 1901: 55-86. 1902.

18. Sargaxt, Ethel. The Origin of the Seed-leaf in Monocotyledons. New Phytologist 1: 107-113. pl. 2. 1902.

19. Strasburger, E. Ein Beitrag zur Kenntniss von Ceratophyllum submersum und phylogenetische Erörterungen. Jahrb. Wiss. Bot. 37: 47\%-526. pls. 9-11. 1902.

20. Hallier, H. Beiträge zur Morphologie der Sporophylle und des Trophophylls in Beziehung zur Phylogenie der Kormophyten. Jahrb. Hamburgischen Wiss. Anstalten 19: 1-110. 1902.

21. Sargant, Ethel. A Theory of the Origin of Monocotyledons, founded on the Structure of their Seedlings. Annals of Botany 17: 1-92. pls. 1-\%. 1903. 


\section{CHAPTER XVI}

\section{COMPARATIVE ANATOMY OF THE GYMNOSPERMS AND THEIR ALLIES *}

The skeletal structure of vascular plants has in the past been used for phrlogenetic purposes to a much smaller extent than that of the higher animals. During recent years, howerer, important advances in our knowledge of the anatomy of fossil plants have made it apparent that the primary fibrovascular skeleton of the vascular plants is eren more conservative than their reproductive organs, and consequently of great importance in arriving at the relationships of the larger groups. The most extreme ecological conditions, acting for long periods, seem to have little effect in modifying the essential features of the primary fibrorascular framework, so that, for example, the extremely xerophytic cactus and the hydrophytic water-lily have exactly the same type of skeleton from the standpoint of comparative anatomy. It sometimes happens, howerer, that the woody framework is extremely complex in the adult. Recent inrestigations which corer the whole field of living vascular plants make it clear that the study of the derelopment of the sporeling or seedling provides a satisfactory ker to the interpretation of the most intricate skeletal structures of maturity.

A brief account of certain general results of recent anatomical and developmental research in the rase of the rascular plants is accordingly necessary for an understanding of those skeletal features of the Grmnosperms and their allies which are of phylogenetic importance.

\section{PTERIDOPHYTES}

The simplest trpe of stem in the Pteridophytes is that in which there is present a single pithless fibrorascular conductive

* Contrihuted by Professor Edward C. Jeffrey, of Harvard University. 296 
strand embedded in the parenchyma of the fundamental tissue. Part of a transverse section of such a stem is seen in Fig. 10S, A. In the center is the concentric fibrorascular bundle or stele, which consists of a mass of xylem completely surrounded by phloem. The stele or central cylinder is bounded in turn by hrown sclerenchymatous fundamental tissue. This type of stem, since it is a very primitive one, may conveniently be called "protostelic" (Jeffrer ${ }^{19}$ ).

Inother common condition of the stem is seen in Fig. 10s, $B$, which represents a cross-section of the rhizome of Adiantum pedatum. In this case the central cylinder is not a solid fibrovascular strand as in the preceding example, but a hollow crlinder filled with funciamental tissue like that external to the stele. The plane of section is just above the point of origin of a leaf-trace, which may be distinguished as the smaller of the two concentric masses of fibrorascular tissue. At a higher level the gap in the canline central cylinder closes, and the stele becomes circular instead of crescentic in cross-section. Similar gaps appear above all the outgoing leaf-traces, and as a consequence the central cylinder is cssentially a concentric fibrorascular tube, with gaps in its walls corresponding to the leaftraces. The type of central erlinder which has just been described may appropriately be termed "siphonostelic" (Jeffier $\left.{ }^{19}\right)$.

Fig. 10s, C , is from a photograph of the adult stem of Pteris aquilina, the common bracken fern. In this case there are numerous concentric fibrorascular bundles present in the fundamental tissue of the rhizome, and accordingly stems of this trpe have been designated by Tan Tieghem "polystelic." It has been shown, however, that in such stems as are exemplified by $P$. aquitina the primitice condition of the central crlinder is a stelar tube with foliar lacmae (Jeffrer ${ }^{19}$ ). Fig. $10 s, D$, from the roung stem of $P$. aquitina, sufficiently demonstrates the truth of this statement. The roung stem gradually passes into the condition represented in Fig. 10s, $C$, first by the foliar caps hecoming so long as to orcrlap, and second by the derivation of the large central strands from the inner wall of the primitive stelar tube. Consequently the stem of $P$. aquilina may he regarded on ontogenetic grounds as siphonostelic and essentially similar to that of 1 diantum pedatum. 
Fig. $105, E$, shows a type of central cylinder which at first sight appears very like that of the adult stem of Pteris aquilina; above on the right is a gap in the tubular stele, which in this case corresponds to a branch. Laterally, on the left, a foliar trace is to be seen in the fundamental tissue. The leaftrace is very small, and there is no gap in the central cylinder corresponding to it. As in $P$. aquilina, there are two medullary fibrovasenlar strands. It has recently been shown (Jeffrey ${ }^{13,19}$ ) that in certain great groups of plants foliar gaps are constantly present, while in other great groups they are unfailingly absent. The type of tubular stele eharacterized by the presence of foliar gaps has been called "phyllosiphonic," and that possessing only gaps for the branches or ramular lacunae "cladosiphonic." These distinctions are extremely constant, and consequently of great phylogenetic value.

Fig. $108, F$, is from a photograph of a eross-section of the central cylinder of Osmunda Claytoniana. It is of special interest because it is obvionsly of the same type as the central cylinder of the living Gymnosperms, viz., a ring of collateral bundles surrounding a medulla and separated from each other by medullary rays. Yan Tieghem ${ }^{4}$ regards this type of stele as derived by dilatation from the prostostelic condition, with the formation of pith and medullary rays from the stelar parenchyma. According to this riew, the pith and rays are morphologically different from and have nothing in common with the fundamental tissue surrounding the stele.

Fig. 109, $G$, shows the forking of the central cylinder of Osmunda cinnamomea. In this example the pith is obviously continuous with the external cortex, and a strand of the very characteristic brown sclerenchymatous tissue of the cortex is passing down into the medullary parenchyma through the gap between the divisions of the fork. It is to be noted further that the phloem passes inward around the divisions of the fork for a considerable distance, and the endodermis is as well marked on the inside as on the out-irle of the erescentic zones of bundles. In Fig. 109, $I I$, there appears a not unusual condition of the central cylinder in $O$. cinnamomea. Unlike $O$. Claytoniana, there is present an internal endodermis along the inner margin of the bundles, and the mednlla is often characterized by the presence of a mass of brown selerenchyma similar 
to that which constitutes the external portion of the fundamental tissue of the stem.

Fig. 109, I, shows a central cylinder of Osmunda cinnamomea, where not only an internal endodernis is present but also internal phloem as well. In Fig. 109, $J$, a part of the wall of the same central cylinder is shown more highly magnified. The sieve-tubes are easily recognized as large, apparently empty elements. It has been suggested by Jeffrey ${ }^{19}$ and Faull, ${ }^{18}$ as a result of the study of the anatomy of the whole order, that the type of central cylinder found in the Osmundaceat is the result of reduction from a siphonostelic condition with internal phloem. This view of the matter is strengthened by the fact that brown sclerenchrma is sometimes found in the pith of Osmunda regalis and Todea barbara, although in these species there is no longer any communication between pith and cortex in the region of forking. Moreorer, exactly similar series of degeneration to that supplied by the Osmundaceae have been shown to exist in the case of certain polypodiaceous ferns. Hence it may be assumed, in the present connection, that the type of central cylinder exemplified by the Osmundaceae has arisen by degeneracy from the siphonostelic type with internal phloem; and that the medulla often shows signs of its origin by striking histological resemblance to the cortex, even when there is no longer any communication between the medullary and cortical fundamental tissues.

Fig. $109, K$, shows the structure of one of the tracheary strands of Osmunda cinnamomea. The protoxylem or primitire wood appears as a cluster of small elements, just external to a mass of wood-parenchyma. The protoxylem does not abut immediately on the pith, as in the seed-plants, but is separated from it by a considerable amount of wood-parenchyma and metaxylem - most of the metaxylen, howcrer, lies external to the protoxylem. This type of tracheary bundle is very characteristic of the ferns, and has been designated "mesarch."

In the casc of the Lycopodiales, the tracheary bundle is of still another type. If Fig. 10s, $E$, be examined, it will be seen that on the left of the central cylinder, opposite the leaf-trace in the cortex, is a cluster of protoxylem. The primitive wood in this case is extcrnal and next the phloem. This feature is very characteristic of the Lycopods and their allies. Bundles 
of the type just mentioned have been designated by Scott ${ }^{6}$ " exarch." Hence it may be stated that the bundles of the Fernlike plants are characteristically mesarch; that the Lycopods and their allies have exarch bundles; and that the prevailing type in the Spermatophytes is the endarch bundle, the primitive wood here coming next the medulla. These anatomical distinetions, however, are less trustworthy than those depending on the presence and absence of foliar gaps, for many Ferns hare endarch bundles, while some (Lygodium, etc.) have even exarch tracheary strands: on the other hand, Phylloglossum, a recognized Lycopod, has distinctly mesarch canline bundles. There are no known examples, howerer, of siphonostelic Lrcopods (Jeffrey ${ }^{10}$ ) with foliar gaps, or of siphonostelic Ferns without them.

\section{CYCADOFILICES}

Recently Potonié ${ }^{11}$ has established a group, the Crcadofilices, to include a number of fossil forms which are neither true Ferns nor typical Grmmosperms, but which possess to a large degree anatomical features of both alliances. These forms can now be more advantageously discussed after the general anatomical account presented in the foregoing paragraphs. The regetative anatomy of the Cycadofilices is of special importance, both because of our entire ignorance of their reproductive organs at the present time and because their anatomical structure presents such an interesting transition from the pteridophrtic to the grmnospermous trpe.

Heterangium.-Fig. 109, L, taken from Scott's admirable Studies in Fossil Botany, shows the structural features of the stem of ILeterangium Grierii, a primitive representative of the Creadofilices. The central eylinder is obriously protostelic and rery similar to that of Gleichenia flabellata of Fig. 10s, A. A striking difference, however, is the presence, on the outside of the pithless primary wool, of a narrow zone of secondary wood which is clearly distinguishable by reason of the regular radial arrangement of its elements. In the cortex may be seen leaf-traces and groups of sclerotic cells. The exterual cortex is bounded by a very characteristic hypodermal zone, which in transverse section appears to be made up of alternating stripes of parenchrmatous and sclerenchrmatous cells. Tiewed longi- 
tudinally, the hypoderma is seen to be composed of a tangential network of sclerenchymatous fibers having the meshes filled with parenchyma.

If edullosu.-Fig. 110, M, reproduces a diagrammatic transverse section of the stem of Medullosa anglica. On the outside of the stem can be distinguished the same curious hypoderma which is eharacteristic of the genus briefly deseribed above. The eentral cylinder in this case, however, is obviously not protostelic, but polystelic. Each of the large fibrovascular strands is characterized by the presence of a considerable zone of secondary wood, which is indieated in the diagram by radiating lines. There are no sclerifications in the cortex; but numeroms mucilage ducts, similar to those of the Marattiaceae and the Cycads, may be seen in the fundamental tissue, both outside and between the large fibrorascilar strands, although their oceurrence in the latter position is not shown in the diagram.

Very often the arrangement of the bundles in species of Medullosa was much more complex than that appearing in Fig. $110, M$. It has been shown recently that in ferns with even the most complex arrangement of the bundles in the adult, by following the development it is possible to arrive at the simple stelar tube as a starting-point (Jeffrey ${ }^{19}$ ). It is consequently extremely probable that the bundle system of the Medullosae is to be regarded as primitively siphonostelie, like that of Pteris aquilina.

In Fig. 110, $N$, is represented a eross-section of a part of the sten of Medullosa Solmsi. Here are to be seen numerous bundles, some of which are broad and plate-like and others small and rounded in outline. The broader bundles are known as "plate-rings," and the smaller ones as "star-rings." In intersting feature of the onter plate-rings is the fact that the zone of seeondary wool on the external face of the bundles is often very much thicker than that on the internal face. Thi: peculiarity is especially well marked in old stems of $M$. stellata.

Lyginodendron.-Fig. 110. O, taken from Williamson and Scott, ${ }^{6}$ reproduces admirably the general features of strueture of the stem Lyginodendron Oldhamium. On the ontside is the same eurious hypodermal layer which oceurs in Heteran. gium and Medullosn. There is present also a zone of periderm external to the fibrovascular tissues. In the eortex may be seen 
clusters of sclerenchrmatous tissue. These are also found in the foliar gaps and in the pith. In the case of Lyginodendron the primary wood is comparatively poorly developed and occurs as distinct islands along the margin of the medulla. The secondary wood is characterized by the regular radial seriation of its elements and is abundant, but, in common with many other fossil Pteridophytes with secondary growth, shows no indication of annual rings. The continuity of the woody zone is completely interrupted at intervals by the foliar gaps which subtend the outgoing leaf-traces.

Fig. $110, P$, is a photograph of part of the ligneous zone of L. Oldhamium. The protoxylem, distinguished by the small size of its elements, is seen to be embedded in the primary wood. Most of the primary metaxylem lies on the medullary side of the protoxylem, and a smaller portion between it and the secondary wood. Hence the primary bundle is mesarch, as is often the case in the Ferns and their allies. Another important filicinean feature is the presence of well-marked foliar gaps.

Fig. 110, Q, taken from Williamson and Scott ${ }^{6}$ shows an interesting departure from the usual state of affairs in $L$. Oldhamium; a primary wood-bundle is present, and external to it is the usual secondary wood. In this case, however, there is secondary wood and phloem on the medullary side of the bundle as well. The condition represented in the figure is quite unusual in L. Oldhamium; but, as has been shown br Seward, is of common occurrence in L. robustum. The facts just described are of particular interest, because $S \operatorname{cott}^{6}$ has made a specific comparison between the central cylinders of Lyginodendron and $O s m u n d a$ : and indeed, if we imagine a secondary zone of wood present in the latter genus and the primary wood-bundles correspondingly reduced in size, the resemblance becomes very close. The occurrence of internal phloem and secontary wood is paralleled by the discovery of internal phloem in $O$. cinnamomea.

The forms described abore sufficiently illustrate the rariety of structure in the stem of the Crcadofilices, and it now becomes necessary to discuss their phylogenetic significance. First if all is to he noted the fact that they represent the three types of stelar strueture described at the beginning of the chapter: Heterangium being protostelic like Gleichenia ; Medullosa sipho- 
nostelic like Adiantum pedatum and Pteris aquilina; and Lyginodendron siphonostelic, without internal phloem, as is generally the case in Osmunda, but resembling this genus in the occasional occurrence of internal sieve-tissue. The only striking anatomical difference between the creadofilicinean forms described above and the parallel cases from the ferns lies in the absence of secondary growth in the latter. This feature is now known to be of minor importance, although great weight was attached to it by the Brongniartian school of paleobotanists.

In regard to the particular type of the Cycadofilices which gave rise to the Grmnosperms there is some difference of opinion. Potonié, ${ }^{9,11}$ Worsdell, ${ }^{16,17}$ and Jeffrer ${ }^{19}$ consider the Creads to be derived from Medullosa-like ancestors through a Lyginodendron-like phase, by the gradual disappearance of the internal secondary wood, and the final suppression of the centripetal primary wood. Scott, ${ }^{6,15}$ on the other hand, regards Lyginodendron as the ancestral type, and as derived directly from Heterangium by the formation of an intrastelar pith, and not from medullosan ancestors by reduction. He further considers the Medullosae to constitute merely a side branch of the phylogenetic tree, and expresses the opinion that " we should involve ourselves in unnecessary complications if we endeavored to derive the simple primary structure of the crcadean stem from the more elaborate organization of a Medullosa." Howerer, examples of phrlogenetic progression from the complex to the simple are not at all uncommon. Striking illustrations of this principle are afforded by the derivation of the simple hyoid bone of the mammals from the complex hyoid apparatus of the lower vertebrates, and the evolution of the monodactyl horses of the present day from their fomr-toed ancestors of the Eocene. The histological structure of the medulla in Lyginodendron strikingly resembles that of the cortex in the presence of sclerotic nests. and this feature indicates strongly community of origin of the medullary and cortical tissues. Further, the oceasional necurrence of internal phlnem and internal secondary wond in Lyginodendron can most easily be explained as a restigial relic of a siphonostelic condition, in which internal phloem was normally present-i. e., a Medullosa with a single series of bundles.

In regard to the special pteridophytic ancestry of the Cyca- 
dofilices there now seems to be little doubt. Scott has pointed out that their fern-like foliage and usually mesarch bundles indicate strongly a filicinean as opposed to a lycopodinean origin. It has further recently been shown that they are phyllosiphonic (Jeffrer ${ }^{19}$ ), and since this feature is quite exclusively characteristic of the ferns, it seems impossible to derive the Cycadofilices from the Lycopods, as has been done by Renault. ${ }^{2}$

\section{CYCADALES}

The leaves and fern-like habit of the Cycads afford good external evidence of their filicinean origin, and their multiciliate sperms point in the same direction. The strongest evidence of their having come from the ferns, however, is supplied by their fibrovascular anatony.

Fig. 111, $R$, is from a photograph of a cross-section of the stem of Zamia floridana. Both pith and cortex are occupied, as in Medullosa, by numerous mucilage ducts. In the cortex sereral curred lines are present, which represent the curved course of the foliar traces and are known as "girdles." $\mathrm{Al}$ though some years old, the fibrovascular zone is quite narrow, and shows no evidence of amnual rings, a feature of resemblance to the Medullosae and Lyginodendron.

In Fig. 111, S, the central cylinder of the same species is shown more highly magnified. Its continuity is obviously broken by gaps, which subtend the outgoing leaf-traces. The mucilage ducts of the medulla join with those of the cortex through the foliar gaps. The central eylinder of Zamia, which is quite trpical of the Creads in this respect, is consequently phyllosiphonic. The mucilage ducts of the Cycads do not penetrate into the leaf-traces or root-steles. Hence it may be assumed that, as in the Marattiaceae and Medullosae, they are characteristic only of the extrastelar fundamental tissue. The pith of the Cyeads, which contains mucilage ducts continuous with those of the cortex, is to be compared, therefore, with the mucilaginous medulla of one of the Marattiaceac or of a Medul$\operatorname{los} a$, and is to be regarded as extrastelar.

The foliar traces of the Cycads are quite unique in structure and of considerable phỵgonetic importance. The first complete description of them was given by Mettenius. ${ }^{1}$ As has already been pointed out, the course of cycadean leaf-traces is 
peculiar; for, instead of passing directly from the central cylinder into the leaf, they usually pursue a circular eomrse, so that they reach their corresponding leaf on the opposite side of the stem from their point of origin. In Zamia I have observed this arrangement of the traces even in the seedling; but in Cycas, according to Mettenius, ${ }^{\mathbf{1}}$ the leaf-traces of the young plant at first pursue a direct course, althongh at a later stage girdles are present. During their cortical course the foliar traces often undergo more or less eomplex anastomoses. The structure of the strands in the cortex, and even in the base of the petiole, is often concentrie.

Fig. 111, $T$, is from a photograph of a cortical bundle of Cycas revoluta. The center of the bundle is composed almost entirely of the large tracheids of the primary wood, which is surrounded by the radially arranged secondary wood and phloem. Higher up, in the lower part of the petiole, the bundles lose most of their secondary wood and assume mesarch structure. This is well seen in Fig. 111, $L$, which may be compared with Figs. $109, K$, and $110, P$. A striking featme of the bundle at this stage is that the primary wood is mostly centripetal, and has consequently a markedly creptogamic appearance.

Before discussing further the significance of the peeuliar structure of the foliar traces of the Cycads, it will be conrenient to refer to an interesting discovery made by Scott. ${ }^{7}$ Mesarch bundles have been found by him in the central crlinder of the peduncte of the cone of Stangeria paradora and certain other Crcads. The conservatism of reproductive organs is recognized by the universal use made of them in botanical elassification. 'It is Sentt's opinion that in the conservative reproduetive branches (i. e., cones) of certain living Creads the ancestral type of bundle is retained. Hence he believes that the cauline central cylinder of the more or less remote ancestors of the living Cyeads must have had a strueture similar to that of the stem of Lyginodendron. This hypothesis is borne out by the fact that the course of the leaf-traces in the cones of Cycarls is the same as in the seedling of the genus Cycas, and in the regetative stems of the extinct gromp of Cycad-like Bennettitales; for they pass directly into the leares (snorophylls) and do not form girdles. Jeffrey ${ }^{10}$ has pointed ont a similar 
conservatiom in the structure and course of the bundles in the cones of Equisetum.

Leaf-traces are likewise extremely conservative in structure, for where cenogenetic modifications are present in the ordinary cauline strands, the primitive trpe of fibrovascular bundle is often retained in the leaf-traces, as well as in the reproductive axis and in the seedling. Incestral features are retained moreorer in the leaf-traces, especially those of the cotyledons, long after they have disappeared elsewhere. Hence it is assumed that the mesarch structure of the foliar bundles of the Creads - upplies a further argument for their derivation from ancestors like Lyginodendron.

The fact that cycadean leaf-traces are often conccntric in the lower part of their course has been used as an argument by Worsdell ${ }^{16}$ in favor of the hypothesis that the cauline bundles of the ancestors of the Creads were originally concentric. This argument seems to have the same force as the similar argument in the case of the mesarch collateral bundles; and the fact that concentric strands are comparatively rarely present in the living Cycads is probably due to the concentric condition being further in the phylogenetic background. The structure of the conservative tracheary strands of the leaves and peduncles of the Cycads would seem to point to a more immediate ancestry with the general organization of Lyginodendron, derived in the remoter past from forms like .Medullosa.

\section{BENNETTITALES}

The external vegetative features and the reproductive organs of this interesting group have already been dealt with in the companion volume treating of Gymnosperms (p. 142). Although their reproductive organs differ very strikingly from those of any living Cycads, the fibrovascular anatomy of the Bennettitales is strikingly cycallean (Scott ${ }^{15}$ ). They possessed a large cycadean pith penetrated by nucilage canals and bounded by a thin fibrorascular ring. The continuity of the fibrovascular zone was broken at interrals opposite the large leaftraces, which separated in the cortex into ares of bundles passing directly into the leaves. The direct course of the foliar bundles is to be compared with that present in the cones only of living Cycads. This condition is probably to be regarded 
as ancestral, because it occurs also in cycadean seedlings. The foliar bundles of the Bennettitales were characterized by the same peculiarities as those of the more modern Cycads.

\section{CORDAITALES}

On page 135 of the companion volume treating of Gymnosperms, the reproductive features and general morphology of this interesting alliance are sufficiently described. The central cylinder of the Cordaites enclosed a large pith, and was characterized by considerable secondary growth. Like the Cycads and unlike the Conifers of the present day, the secondary wood generally showed no annual rings. The wood of Cordaites, in some cases at least, is to be identified with Araucarioxylon and $D a$ doxylon, fossil woods which oceur as far down in the strata as the Devonian. Scott ${ }^{14}$ has shown that in some species of Araucarioxylon the primary wood of the stem was mesarch. In a good many cases, however, the primary cauline bundles of Cordaites are only distinguished by exceptionally large development as compared with those of the higher living Gymnosperms. The leaf-traces were mesarch like those of the Cycads, and Scott ${ }^{15}$ compares the structure of a cordaitean leaf to that of a pinna of Zamiu. Fig. 111, $\mathrm{T}$, shows the structure of a transverse section of part of a leaf of a species of Cordaites.

The organization of the cauline and foliar bundles of the Cordaites favors the view of their derivation from a pteridophytic ancestry quite as much as that of their reproductive organs. Their well-marked foliar gaps and their large leares clearly indicate their filicinean affinities. The thickness of the woody cylinder and the freely branching habit of the Cordaites indicates a greater proximity to the Coniferales than to the Cycadales.

\section{GINKGO.ALES}

The discovery of multiciliate sperms in Ginkgo is good evidence for the antiquity and the affinities of the group. Still, its pteridophytic features have suffered very considerable reduction as compared with the Cycadales. Evidences of mesarch structure are accordingly comparatively scanty. The bundles of the stem are throughout endarch, and even the leaf-traces show slight traces of the presence of centripetal wood. Wors- 
dell, ${ }^{8}$ however, has found that the bundles of the cotyledons show fairly well-developed cryptogamic wood. Fig. 111, W, taken from Worsdell, nakes the truth of this statement apparent. The anatomical evidence leads to the conclusion that we have in Ginkgo a comparatively modern genus as compared with the living representatives of the cycadean stock. Distinct foliar gaps are present, which, taken together with the large leares and the multiciliate sperms, point strongly to a filicinean ancestry.

\section{CONIFERALES}

The Coniferales are the prevailing Gymnosperms of the present day, and it is not surprising that they should present few anatomical features which can be considered ancestral. Their usually small acicular leaves offer a striking contrast to the large fern-like foliar organs of the older grmmospermous groups. On account of the peculiar appearance of their foliage it is not to be wondered at that they should have been associated by Renault, ${ }^{2}$ Campbell, ${ }^{5}$ and Potonié ${ }^{11}$ with lycopodineous ancestors. Recent work on the anatomy (Jeffrey ${ }^{19}$ ) of vascular plants in general appears to show that in the case of the Coniferales the microphyllous habit has merely an ecological interest; for, unlike all the Lycopodiales, they have well-marked foliar gaps in their cauline woody cylinder.

The researches of Worsdell ${ }^{s}$ on the foliar bundles of the Conifers have resulted in a clear demonstration of striking pteridophrtic features. Fig. $112, \mathrm{~T}$, represents a cross-section of the cotyledonary bundle of Cephalotaxus drupacea. On the lower side of the fibrovascular strand centrifugal wood, such as is ordinarily present in the bundles of the Conifers, can be made out. On the upper side of the bundle are large, thickwalled elements, which are to be compared with the centripetal tracheids of the creadean bundle in Fig. 111, $T$. Fig. 112, $Y$, shows a longitudinal section of a cotyledonary bundle of $C$. Fortunei. On the left are some pitted tracheids of the secondary wood. In the center of the bundle is the disorganized protoxylem, while on the right is a single reticulated tracheid of the ancestral centripetal wood. The cotyledonary bundles of C'ephalotaxus are consequently mesarch like those of the ordinary leaves in Cyeads, but show striking signs of degeneracy 
in the eentripetal eryptogamic wood. On the flanks of the bundle the centripetal wood is continnous with the short-pitted cells of the "transfusion tissue" discovered by Frank in 1864 . In the bundles of the adult leaves of most of the living Coniferales there are only the very slightest traces of centripetal wood. Worsdell has reached the interesting general conclusion that the "transfusion tissue which oceurs almost universally in the leares of grmmospernous plants as an auxiliary conducting system has been phylogenetically derived from the centripetally formed xylem of the vaseular bundle."

Fig. 112, $Z$, shows the topography of a cross-section of a branch of Thuja occidentalis. The leaves in this species are extremely reduced, especially those occurring on the upper and lower sides of the flattened branches. It might naturally be expected that under these circumstances the foliar gaps would be obscure or absent, but such is not the ease, for subtending the traces, which pass to the specially small leaves on the upper and lower sides of the flattened branch, are two distinct foliar lacunae. An examination of a large number of Conifers, some with a very considerable xerophytic reduction in the size of their leaves, has shown that the presence of foliar gaps is quite constant in the group (Jeffrey ${ }^{19}$ ). It is now known that foliar gaps are unfailingly absent in the tubular central eylinder of living and fossil Lyeopodiales and Equisetales, while on the other hand they are invariably present in the Filicales. Hence it may be assumed that the Coniferales, much as they resemble the Lycopods in external appearance, are really derived from filicinean ancestors by adaptation to a xerophytic mode of life. The mierophyllous habit is obviously a cenogenetic adaptation, for the strueture of the fibrovascular skeleton plainly indieates that the coniferous stock is palingenetically megaphyllous, and thus allied to the Ferns.

Fig. 112, AA, shows the strueture of the root of Pinus Strobus. The cortex and phloen surround a considerable mass of secondary wood, in the center of which may be distinguished the exarch primary wood. This feature is more clearly seen in Fig. 112, $B B$, which represents the center of the section shown in Fig. 112, 14 , more highly magnifiert. It is an interesting fact, to which Van Tieghem ${ }^{4}$ has drawn attention, that the mode of growth of the primary wood is the same in all 
the rascular plants, riz., exarch and centripetal. The root of the Spermatophytes is consequently conservative, and retains intact ancestral pteridophrtic features. It seems phylogenetically signiticant that the exarch trpe of wood, so trpical of the Lrcopods and their allies, is alwars present in roots, and nerer the mesarch trpe so characteristic of the Fern-alliance. This feature probably indicates that the Lrcopod stock is an extremely old one, a conclusion borne out by the fact that the Lycopsid series had alreads culminated in the Carboniferous age. It appears also not improbable that the Pteropsida, largeleared fern-like plants, took their origin from the microphyllous lycopodinean stock in remote antiquity, and still exhibit a trace of their origin in the primary structure of their roots.

\section{GNETALES}

This group is generally regarded as the highest of the Grmnosperms, a view which is borme out both by a consideration of its anatomy and its reproductive organs. The latter show in the case of Tumboa and Ginetum a considerable adrance toward the condition of true flowers, and this advance is paralleled by a reduction in the amount of female prothallial tissue antecedent to fertilization. The Gnetales on the anatomical side show indubitable evidence of grmnospermous relationship, in the presence of quite typical foliar transfusion tissue. They are distinguished anatomically from all other Grmnosperms, however, living or fossil, by the presence of rudimentary vessels.

Fig. 113, CC, shows the structure of the wood in Gnetum Gnemon. The secondary wood in this species consists of tracheids and ressels, the latter being easily distinguished by their larger size. In sorne cases the fact that direct communication between two contiguous ressels is merelr the result of the disappearance of the membrane of a bordered pit can be made out.*

* For list of literature cited see end of Chapter XrII. 


\section{CHAPTER XVII}

\section{COMPARATIVE ANATOMY OF ANGIOSPERMS *}

The question of the relationship of the two great dirisions of the Augiosperms has for many years been a matter of dispute. Anatomically the differences between the Dicotyledons and Monocotyledons are sufficiently well marked, but it has not been easy to decide from ordinary anatomical data which should be regarded as having the more primitive and antecedent organization. There ean be little doubt that the two groups are closely related, for in addition to the striking general resemblance of their sporophrtic tissues there is almost an identical organization of the male and female gametophytes. The Monocotyledons have by some been regarded as primitive on account of the absence of a cambium in their ordinarily closed bundles. This'view has heen strengthened by statements as to their appearing earlier in the geological strata than the Dicotyledons. It is now known beyond doubt, howerer, that many of the earlier errptogamous groups had well-marked secondary growth, so that the absence of cambial actirity is by no means necessarily a primitive feature. Further, a more careful study of plant fossits has made it clear that many of the remains formerly considered to be Monocotrledons are in reality Pteridophytes or Grmnosperms. Discussion of these interesting problems will be more profitable after the salient features of the anatomy and derelopment of the Angiosperms have been described.

\section{DICOTYLEDOXS}

It has been shown by Jeffrey ${ }^{13}$ that the primitive condition of the central evlinder in the Angiosperms is siphonostelic. The tubular central exlinder of the seedling of Ranunculus,

* Contributed by Professor Edward C. Jeffrey, of Harvard Lniversity. 
for example, is characterized by foliar gaps such as are found - in the Filicales and Gymnosperms. Often in the seedling of this genus there is present an internal limiting layer of the stelar tissue which degenerates in the adult. Hence it may be assumed, in the absence of negative evidence, that the pith of Ranunculus belongs to the same morphological category as the cortex. Marie, from a comparative study of the anatomy of all the Ranunculaceae, has reached the conclusion that the genus Ranunculus is the starting-point from which all the other genera of the order have been derived. It follows apparently that the central cylinder of the Ranunculaceae in general is susceptible of the same interpretation as that of Ranunculus. If the central cylinder of the Ranmeulaceae be siphonostelic with foliar gaps, i. e., phyllosiphonic, it nay fairly be assumed that the central cylinder of Dicotyledons in general is to be similarly interpreted, especially as foliar gaps are universally present, even in such extreme cases of xerophytic reduction as C'asuarina and the Cactaceae.

There are some instances of the occurrence of concentric bundles in the Dicotyledons, but they appear to be of cenogenetic origin, and consequently of no phylogenetic importance; for in the cases which have been investigated, the concentric condition is ordinarily absent in the seedling, the leaf-traces, and the reproductive axes. This feature is illustrated by Primula farinosa, in which the bundles of the seedling, the reproductive axis, and the leaves are always collateral; whereas those of the older vegetative stem are usually concentric. Similar phenomena have been observed in the Nymphaeaceae, Haloraghidaceae, etc.

In the older subterranean stem of Ranunculus acris the fibrovascular tube becomes broken up into a series of segments or bundles by the overlapping of the foliar gaps; quite often in the stouter subterranean axis of Ranunculus acris (Jeffrey ${ }^{13}$ ) the foliar bundles tend to rum in the pith before passing out to the leares, thus offering a striking feature of resemblance to the normal course of the leaf-traces in the Monocotyledons. In the aerial stem, howerer, this feature is not present, as may be seen in Fig. 113, DD, in which the arrangement of the bundles shown is the typical one for the Dientylednns. There are a good many exceptions to the rule, however, e. g., Podo- 
phyllum, Gunneru, the Irmphaeaceae, etc. In the last-mentioned cases, the sudy of seedlings shows that the circular disposition of the fibrovascular strands is primitive. In Podophyllum the scattering arrangement of the bundles is present only in the aerial stem, and is absent in the rhizome, as well as in the seedling.

Fig. 113, EE, is from a photograph of one of the bundles of Ranunculus acris. The bundle is surrounded by a sclerenchrmatons sheath, which is thickest externally. The xylem and phloem are separated from one another by a narrow zone of cells arranged in radial rows, indicating that a slight but unmistakable cambial actirity is present. The bundle is conecquently an open one. The protoxylem is obviously the innermost part of the primary xylem, so the bundle is endarch. Endarch fibrorascular strands with secondary growth by means of a cambium are characteristic of the Dicotyledons. In aquatic Dicotyledons (e. g., the Nymphaeaceae), however, secondary growth is frequently absent.

The tracheary tissue of Dicotyledons with considerable secondary growth shows a further division of labor orer the highest Grmnosperms. In the oak, for example, there are thinner and thicker-walled tracheids as well as ressels. The latter have practically lost their water-conducting function and have rery few extremely small pits in their walls. They have thus been differentiated for the purpose of support. In the beech this division of labor among the tracheids does not take place, for all the tracheids are of the same type and have well-dereloped bordered pits in their walls. Strasburger ${ }^{3}$ is of the opinion that the woosl-fibers of the Cupuliferae thronghont are modified tracheids, and hence merit the name of fiber-tracheids. Such fibers are present in a number of the dicotyledonous orders. In other cases, according to Strasburger, the wood-fibers are to he regarded as derived from wood-parenchyma and not from tracheids. In these instances they may properly be called libriform fibers. It is not clear, however, that a sharp distinction can alwars be drawn between the two sorts of wool-fibers.

The sieve-tis:ne of the Dicotyledons is also more highly specialized than that of the Grmuosperms, for the sieve-tubes have special accessory cells. These accessory cells are derived from the same mother-cells as the siere-tules, and are known 
as companion cells. Companion cells are quite absent in the Gymnosperms, but Strasburger has pointed out that here the $\sigma^{4}$ marginal cells of the medullary rays perform the physiological function of companion cells.

The Dicotyledons as a group are distinguished anatomically from the Gymnosperms by the entire absence of palingenetic pteridophytic features of any sort in the fibrovascular tissues of their stems and leaves. The bundles are throughout endarch collateral, except in the root, where they are exarch, as in all other rascular plants. The concentric bundles which occasionally occur in the Dicotyledons are obviously cenogenetic, and have no phylogenetic significance. Both the xylem and phloem of the Dicotyledons show a marked advance in differentiation over all the Gymnosperms. The central evlinder of the stem in the Dicotyledons is characterized by the presence of foliar gaps, and accordingly, if the Dicotyledons are to be regarded as derived ultimately from pteridophytic ancestors, as appears to be the case, their descent is apparently from the Filicales, either directly or through some living or extinct phylum of the Gymosperms. The argument for lescent from a grmnospermous ancestry seems to gain great force from the entire absence of pteridophytic features in the shoot or leaves of the dicotyledonous Angiosperms.

\section{MONOCOTYLEDONS}

The arrangement of the bundles in the adult stem of the Monocotyledons is very characteristic. Instead of being disposed in a circle, as in the Dicotyledons, they are scattered throughout the central cylinder. Fig. 113, FF, illustrates this peculiarity. Not infrequently, however, e. g., in the Liliaceae, the bundles are obviously segments of a fibrovascular tube, just as is typically the case in the Dicotyledons. Fig. 113, GG, shows this feature in the rhizome of Clintonia boreatis. Sulttending gaps between the bundles are to be seen smaller fibrovascular strands, which are leaf-traces. In this example we have obviously to do with a fibrovascular tube with foliar gaps: Interestingly enough, the tubular arrangement of the fibrorascular elements is frequently present in monocotyledonons seedlings, although eharacteristically absent in the adult. Hence it may be inferred that the tubular central cylinder with foliar 
gaps is the ancestral condition in the Monocotyledons. In some cases, e. g., symplocarpus foetidus, the pith and cortex are continnous in the seedling through the foliar gaps, although they no longer appear to be so in the adult. An internal endodermis or stelar boundary is also sometimes present in the young plant, but has usually quite disappeared in the adult.

The typical bundle of the Monocotyledons is amphirasal concentrie. Such a bundle is shown in Fig. 113, $H H$. In this type of bundle the tracheary tissue surrounds the phloem, and not the phloem the tracheary tissue, as is generally the case in the Pteridophyta. The amphivasal concentric bundle is characteristic of the Monocotyledons from the grasses (Zizania, etc.) to the orchids (IIabenaria, Cypripedium, etc.), and is quite as constant a feature as the seattering disposition of the fibrovaseular strands. This type of bundle resembles the amphicribral concentric bundles of the Pteridophytes in showing no evidence of secondary growtl. Amphivasal strands are absent in the leaves and reproductive axes of the Monocotyledons, and generally in the seedlings as well. Unlike the concentric strands of the Gymnosperms, they are accordingly a cenogenetic and not an ancestral feature, but on account of their widespread occurrence in the group have an important phylogenetic significance.

Secondary growth has been supposed to be entirely lacking in the collateral strands of the Monocotyledons, but Queva ${ }^{\mathbf{1 2}}$ has recently shown that eharacteristic secondary growth is present in the bundles of the tuberous base of the stem of the liliaceous genus Gloriosa. The activity of the cambium beromes apparent during the season after the formation of the tuber, when it is passing its reserve products into the aerial stem. From the ocenrence of a cambium in Gloriosa, etc., Queva has drawn the conclusion that the Nonoentyledons are derived from the lower Dicotyledons.

The most salient anatomical features of the Monocotyledons are the scattering disposition of their closed fibrovasular strands, and the presenee of amphivasal concentrie bundles. These features, although practically universal, are not primitive; for a study of the leares, reproductive axes, and scedlings shows often a dicotyledonous disposition of the generally collateral strands. Hence we may infer that the Monocotyledons 
are a strictly monophyletic and modern group, since they possess in common a rery characteristic mode of arrangement of bundles of a unique type, and since neither the structure of the bundles nor their mode of disposition is palingenetic. Further, the eridence of secondary growth in Gloriosa, etc., would seem to indicate that the Monocotyledons have come off somewhere from the Dicotyledons, which they resemble so closely in their essential reproductive organs. This view of the matter seems strengthened by the greater reduction of the sporogenous tissue in the megasporangium of the Monocotyledons as compared with the lower Dicotyledons, and by the entire absence of the probably primitive phenomenon of chalazogamy, which is so characteristic of the lower Dicotyledons. In the present state of our knowledge we are apparently justified in considering the Nonocotyledons to be a modern, strictly monophyletic and specialized group, derived from the Dicotyledons or their parent stock, possibly br adaptation in the first instance to an amphibious mode of life.*

\section{LITERATURE CITED}

1. Mettenius, G. H. Beiträge zur Anatomie der Cycadeen. 185\%.

2. Renault, B. Cours de Botanique Fossile. Paris. 1880-1854.

3. Strasbutrakr, E. Histologische Beiträge. III. 1891.

4. Tieghem, P. vax. Traité de Botanique. Paris. 1891.

5. Caypbell, D. H. Mosses and Ferns. New York. 189.

6. Williarsox and ScotT. Further Observations on the Organization of the Fossil Plants of the Coal-measures. Part. 3. Lyginodendron and Heterangium. Phil. Trans. Roy. Soc. London B. 186: 1 s 96 .

7. Scotr. D. H. The Anatomical Characters presented by the Peduncle of the Cycadaceae. Annals of Botany 11: 399-419. pls. 20-21. 1897.

8. Worsdell. W. C. On Transfusion Tissue; its Origin and Function in the Leaves of Gymnospermous Plants. Trans. Linn. Soc. London Bot. II. 5: 301-319. pls. 23-26. 1897.

9. Potosié, H. Metamorplose der Pflanzen im Lichte Palaeontologischer Thatsachen. Berlin. 189s.

10. Jeffrey, E. C. The Development, Structure, and Affinities of the Genus Equisetum. Mem. Boston Soc. Nat. Hist. 5: 155-190. pls. $26-30.1899$.

* It should be noted that the inanuscript of Chapters XVI and XVII was completed April 1, 1902. 

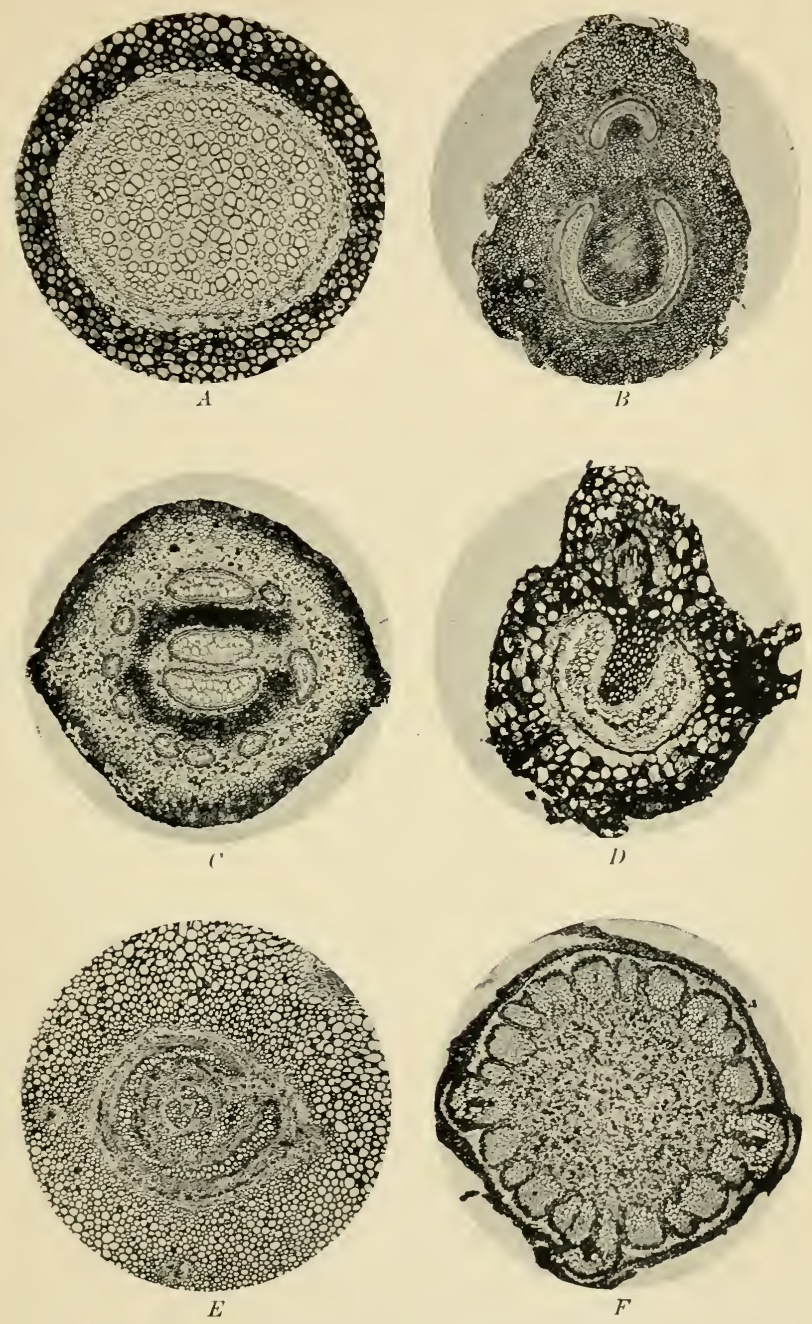

Fig. 108.- A, part of stem of Gleichenia Anbellata; $B$, stem of Adiantum pedutum: $C$, rhizome of Pteris aquilina: I, ynung stem of same; $E$, stem of Selaginella laevigata; $F$, central eylinder of Osmunda Claytoniana. 


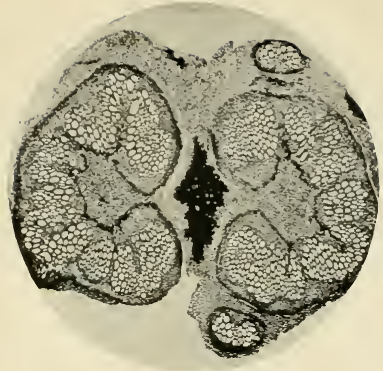

fi
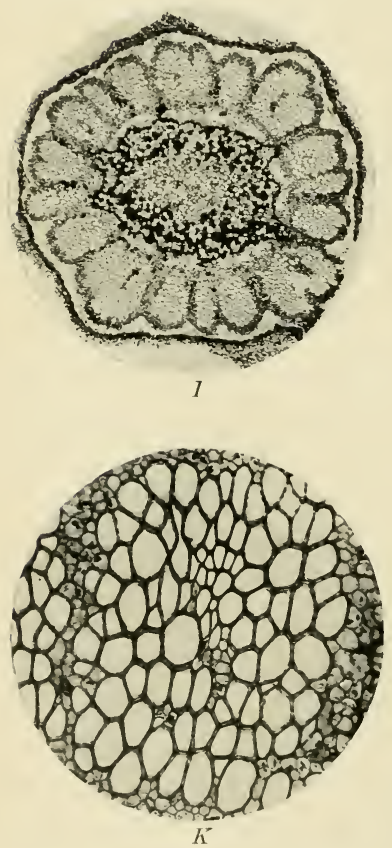
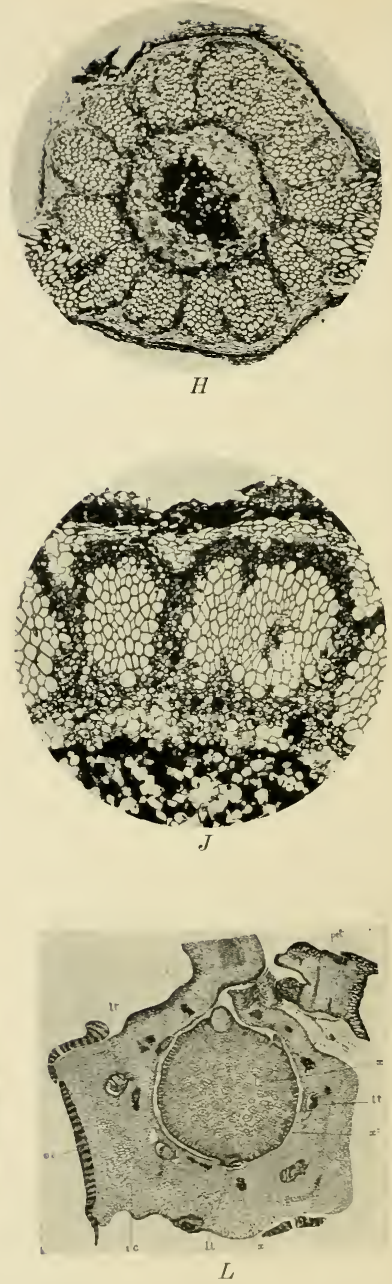

FIG. 109. - (r, forking central crlinder of (smunda cinuamomea: $H$, central exlinder of sane: $I$, same, showing presence of internal phloen: $J$. part of central cylinder shown in $I$. more highly marnified: $K$, mesarch bundle of same: $L$, stem of Heterangium Grievis, after Soust : $x \quad 5: x$, central mass of primary woml : $x^{2}$. sceondary wood: ic inner cortex; $l t$, leaf' trace; $r$, adventitious root : oc, outer cortex: pet, 

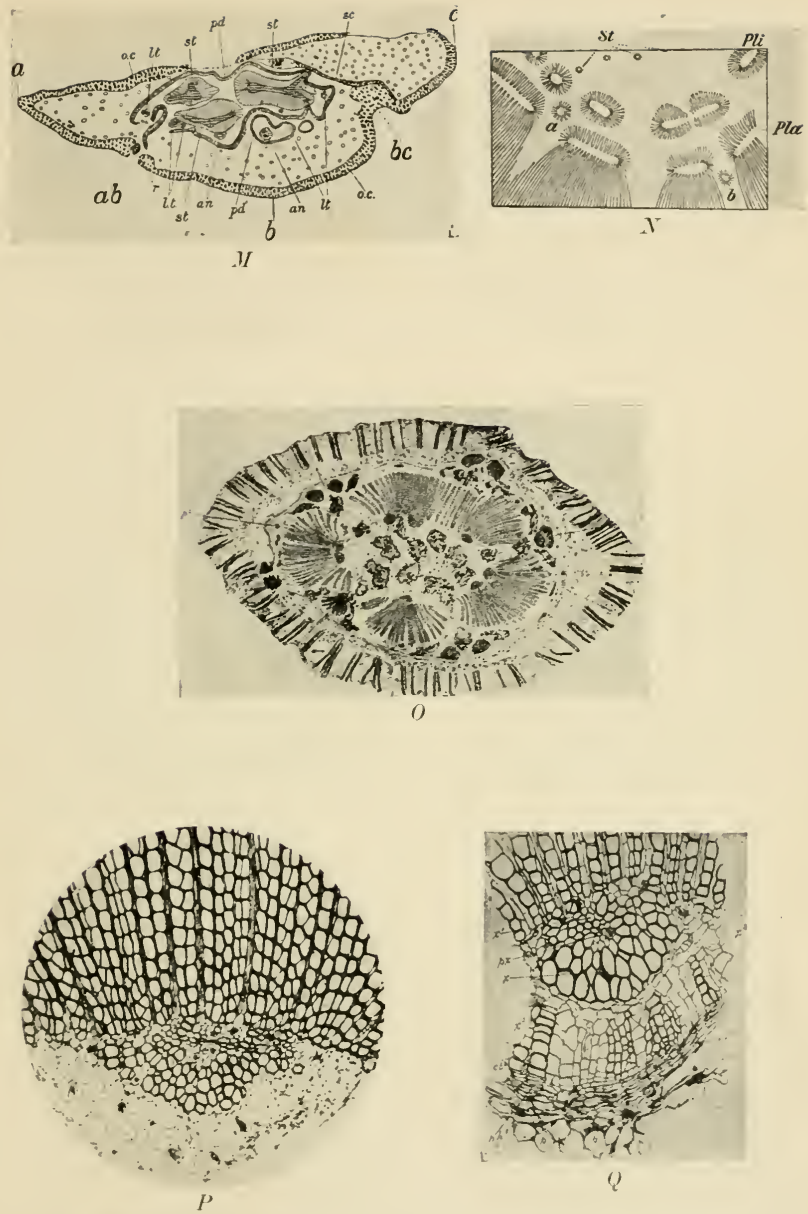

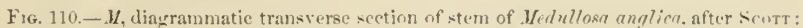
$s t$, concentric strands: $j u l$, periderm: lt. leaf trace; $Y$, diagram of part of transverse

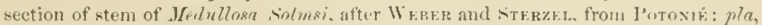
$p l i$, larcer enceutric strands; st. smaller enncentrie strands: O. transverse section of stem of Lyyimolendron Oldhumium, after Win.ususos and Scots; I?, part of woody zone of same; 4 , sane, showing internal seeondary wood and internal phloem. 

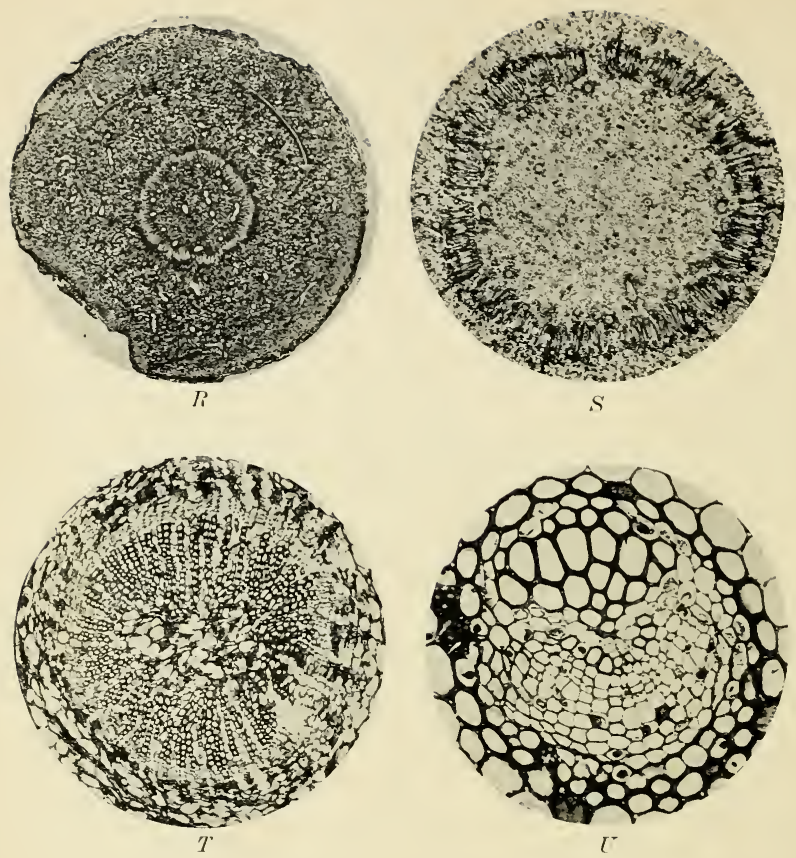



${ }^{*}$

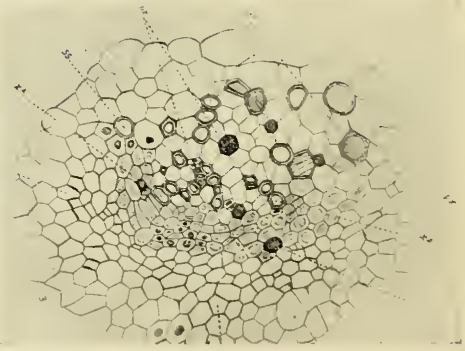

II

Fig. 111. - R. stem of Zamia floridana: S, central eylinder of same; T, eortical foliar bundle of Cycas revoluta; $I$, petiolar bundle of same; $I$, section of part of leaf of a species of Corlaitex: $W$, cotyledonary buudle of Ginkigo biloba: $p x$, protoxylem; $x^{1}$, centripetal wood; $x^{2}$, centrifugal wood. 



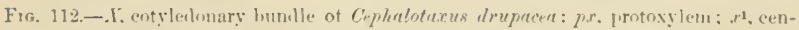
tripetal wool; $x^{2}$, centrifugal wool: $t f$, transfusion tisue: $Y$, Innuitudinal section of cotyledonary bundle of Crphelntarus Fortunei: phe phinem; otler lettering as in I: Z. small branch of Thuja occidentulis; A.I, root of P'luns strobles: BB. part of same. 

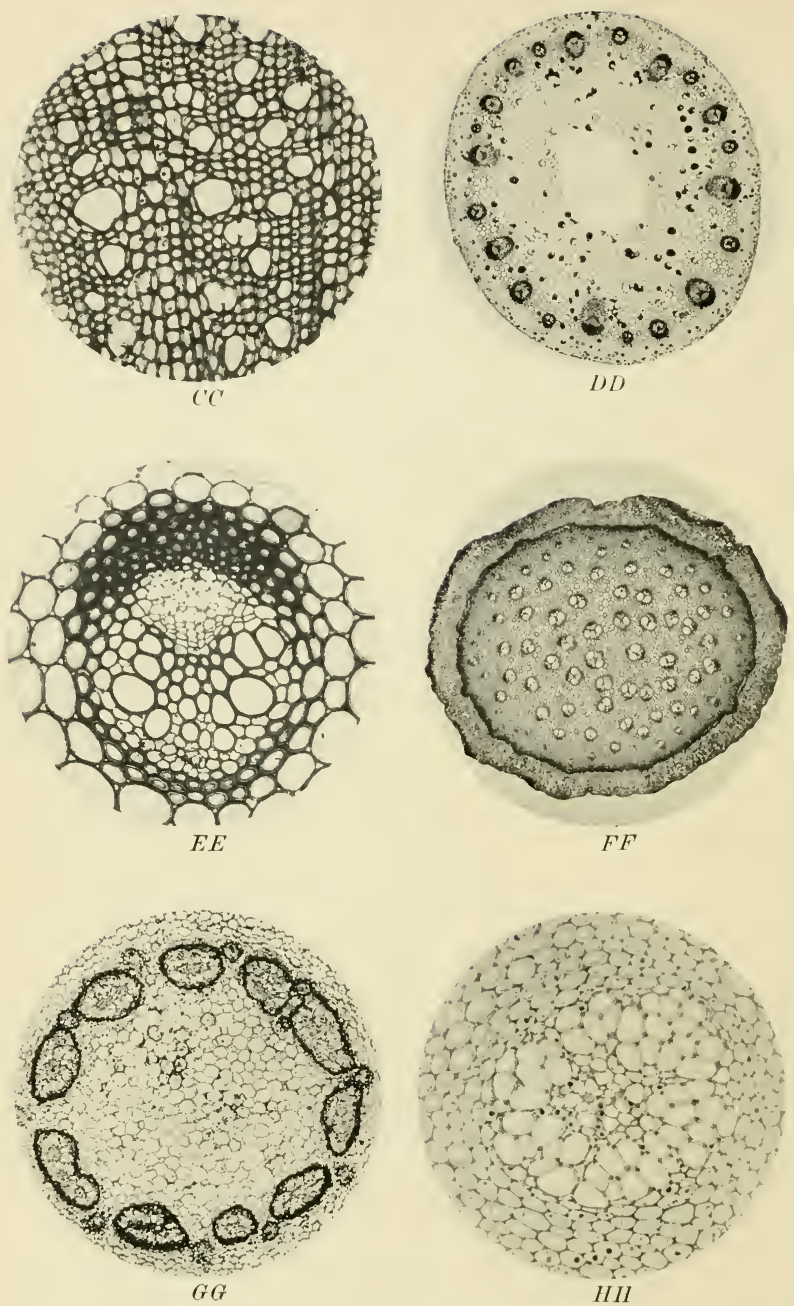

Fig. 113.-CC, wood of Gnetum Gnemon; ID), stem of Rimunculus acris: EE, bundle of same: $F F$, aerial stem of similax herbacea: $G(F$, part of subterranean stem of Clintonia borealis; $H H$, amphivasal eoneentrie bundle of the subterranean stem of Similax herbacea. 
11. Potonié, H. Pflanzenpalaeontologie. Berlin. 1899.

12. Queva, C. Contributions à l'anatomie des Monocotyledonées. I. Les Uvulariées tubereuses. Lille. 1899.

13. Jefremey, E. C. The Morphology of the Central Cylinder in the Angiosperms. Trans. Canadian Inst. pp. 40. pls. $\%-11.1900$.

14. Scotr, D. H. Trans. British Assil. Adv. Sci. 1900.

15. —. Studies in Fossil Botany. London. 1900.

16. Worsdell, W. C. The Comparative Anatomy of Certain Species of Encephalartos. Trans. Linn. Soc. London Bot. II. 5: 445459. pl. 43. 1900.

17. - Trans. British Assn. Adv. Sci. 1900.

18. Faull, J. H. The Anatomy of the Osmundaceae. Bot. Gazette 32: 381-420. pls. 14-1\%. 1901.

19. JefFrey, E. C. The Structure and Development of the Stem in the Pteridophyta and Gymnosperms. Phil. Trans. Roy. Soc. London B. 195: 119-146. pls. 6. 1902. 


\section{LITERATURE CITED}

ANDREws, F. M. Development of the Embryo-sac of Jeffersonia diphylla. Bot. Gazette 20: 423-424. pl. 28.1895 .

Atkissox, G. F. Studies on Reduction in Plants. Bot. Gazette 28: 1-26. pls. 1-6. 1899.

- On the Homologies and Probable Origin of the Embryo-sac. Science 13: 530-538. 1901.

Balfotr, I. B. The Angiosperms. Address to the Botanical Section, Brit. Assn. Adv. Sci. Glasgow. 1901.

Balicka-Iwaxowska, G. P. Contribution à létude du sac embryonnaire chez certaines Gamopetales. Flora 86: $4 \tau-i 1 . ~ p l s .3-10$. 1899.

Barber, C. A. On a Change of Flowers to Tubers in Nymphaea Lotus, var monstrosa. Annals of Botany 4: 105-106. pl. 5. 1889.

Barxes, C. R. The Process of Fertilization in Campanula americana. Bot. Gazette 10: 349-354. pl. 10. 1885.

—. Plant Life. New York. 1898.

BeLajefF, W. Zur Kenntniss der Karyokinese bei den Pflanzen. Flora. Ergänzungsband zum 1894.

- Die verwandtschaftlichen Beziehungen zwischen den Phancrogamen und den Cryptogamen in Lichte der neuesten Forschungen. Biol. Centralbl. 18: 209-218. 1898.

Bexsox, Margaret. Contribution to the Embryology of the Amentiferae. I. Trans. Linn. Soc. Bot. London 3: 409-424. pls. 6r-г2. 1894.

BERNARD, C. H. Recherches sur les sphères attractives chez Lilium candidum, etc. Jour. Botanique 14: 118-124, 1テ7-188, 206-212. pls. 4-5. 1900 .

Bessey, C. E. Phylogeny and Taxonomy of the Angiosperms. Bot. Gazette 24: 145-178. 1897 .

Billixgs, F. H. Beiträge zur Kenntniss der Samenentwickelung. Flora 88: 253-318. 1901.

Boveri, Tн. Befruchtung. Anat. Hefte Ergebnisse 1: 386-485. figs. 15. 1891.

Bower, F. O. A Theory of the Strobilus in Archegoniate Plants. Annals of Botany 8: 343-365. 1894. 
Bratr, A. Ueber Polyembryonie und Keimung von Coelebogyne, ein Nacistrag zur der Abhandlung über Parthenogenesis bei Pflanzen. Abhandl. Königl. Akad. Wiss. Berlin, pp. 109-263. 1859.

- Pflanzenmissbildungen. 1869.

Btrxs, G. P. Beiträge zur Kenntniss der Stylidiaceen. Flora 87: 313-354. pls. 13-14. 1900.

Byxbee, Edith. The Development of the Karyokinetic Spindle in the Pollen Mother-cell of Lavatera. Proc. Calif. Acad. Sci. III. 2: 63-82. pls. 10-13. 1900.

Caldwell, O. W. On the Life History of Lemna minor. Bot. Gazette 27: 37-66. figs. 59. 1899.

Caypbell, D. H. The Structure and Development of the Mosses and Ferns. London and New York. 1895.

A Morphological Study of Naias and Zannichellia. Proc. Calif. Acad. Sci. III. 1 : 1-62. pls. 1-5. 1897.

- The Development of the Flower and Embryo in Lilaea subulata HBK. Annals of Botany 12: 1-28. pls. 1-3. 1898.

- Notes on the Structure of the Embryo-sac in Sparganium and Lysichiton. Bot. Gazette 27: 153-166. pl. 1. 1899.

- Die Entwickelung des Embryosackes von Peperomia pellucida Kunth. Ber. Deutsch. Bot. Gesell. 17: 452-456. pl. 31. 1899 ; also, A Peculiar Embryo-sac in Peperomia pellucida. Annals of Botany 13: 626. 1899.

- Studies on the Araceae. Annals of Botany 14: 1-25. pls. 1-3. 1900.

- On the Affinities of Certain Anomalous Dicotyledons. Amer. Nat. 36: 7-12. 1902.

CAxxox, W. A. A Morphological Study of the Flower and Embryo of the Wild Oat, Arena fatua. Proc. Calif. Acad. Sci. III. 1: 329-364. pls. 49-53. 1900.

Carlson, G. W. F. Ett par afvikande former af Succisa pratensis. Bot. Notiser 1901 : 224-226.

Celakorsky, L. F. Vergleichende Darstellung der Placenten i. d. Fruchtknoten d. Phanerogamen. Abhandl. Königl. Böhm. Gesell. Wiss. Prag VI. 8: 18\%.

- Ueber den phylogenetischen Entwicklungsgang der Blïte und ïber den Ursprung der Blumenkrone, I und II. Sitzber. Königl. Böhm. Gesell. Wiss. 1896-1900.

Chamberlaix, C. J. The Embryo-sac of Aster novae-angliae. Bot. Gazette 20: 205-212. pls. 15-16. 1895.

- Contribution to the Life History of Salix. Bot. Gazette 23: 147-179. pls, 12-18. 1897.

. Contribution to the Life History of Lilium philadelphicum.

II. Bot. Gazette 23: 423-430. pls. 35-36. 1897.

- Winter Characters of Certain Sporangia. Bot. Gazette 25: 124-128. pl. 11. 1898. 
Chauveaud, G. L. Sur la fécondation dans les cas de polyembryonie. Compt. Rend. 114: 504-506. 1592.

De la reproduction chez le dompte-venin. Diss. Paris. 1902.

Chodat, R., and Bernard, C. Sur le sac embryonnaire de l Helosis gnayanensis. Jour. Botanique 14: 72-79. pls. 1-2. 1900.

Conard, H. S. Note on the Embryo of Nymphaea. Science 15: 316. 1902.

Conrad, A. H. A Contribution to the Life History of Quercus. Bot. Gazette 29: 408-41S. pls. 28-99. 1900.

Cook, M. T. Development of the Embryo-sac and Embryo of Castatia odorata and Nymphaea advena. Bull. Torr. Bot. Club 29: 211220. pls. 12-18. 1902 .

Correns, C. Untersuchungen iiber die Xenien bei Zea Mays. Ber. Deutsch. Bot. Gesell. 17: 410-417. 1899.

Corry, T. H. Structure and Development of the Gynostegium, etc., in Asclepias Cornuti. Trans. Linn. Soc. Bot. London 2: 1\%:207. pls. 24-26. 1884.

Coulter, J. M. Contribution to the Life History of Lilinm philadelphicnm. Bot. Gazette 23: 412-422. pls. 32-34. 1597.

Contribution to the Life History of Ranunculus. Bot. Gazette 25: 73-88. pls. 4-\%. 1898 .

The Origin of the Leafy Sporophyte. Bot. Gazette 28: 46-59. 1899.

, and Rose, J. N. The Pollen Spore of Tradescantia virginica. Bot. Gazette 11: 10-14. pl. 1. 1886.

Delpino, F. Applicazione de nuovi criterii per la classificasione delle piante. Mem. Real. Accad. Sci. Bologna T. 6: 83-116. 1896; see review Bot. Centralbl. 67 : 370.1896.

DE Tries, H. Sur la fécondation hybride de l'albumen. Compt. Rend. 129: 973-975. 1899.

- Die Mutationstheorie, Versuche und Beobachtungen über die Entstehung von Arten im Pflanzenreich. Tol. I. Leipzig. 1901. See reviews: Biol. Centralbl. 21: 257-269, 289-305. 1901; Bot. Centralbl. 87: 170. 1901; Bot. Gazette 33: 236. 1902. Also The Origin of Species by Mutation, Science 15: 721-729. 1902.

DODEL, A. Beiträge zur Kenntniss der Befruchtungserscheinungen bei Iris sibirica. Festschrift (Nägeli und Kölliker). Würzburg. 1891.

Ducàp, I: Recherches sur l'Embryogénie des Araliacées. Ann. Sci. Nat. Bot. T'III. 15: 311-402. pls. 6-13. 1902.

DugGar, B. M. Studies in the Development of the Pollen Grain in Symplocarpus foetidus and Peltandra undulata. Bot. Gazette 29: 81-98. pls. 1-2. 1900.

Dumée et Malinvaud. Un Vicia nouveau pour le flore francaise. Bull. Soc. Bot. France 46: (Sess. Extraord.) xxx-xxxii, 263-266. pls. ?. 189.9. 
Dunv, Louse B. Morphology of the Development of the Ovule in Delphininm exaltatum. Proc. Amer. Assn. Adv. Sci. 49: 284. 1900.

EICHLER, A. W. Blüthendiagramme. 2 vols. Leipzig. 1875-187s.

Elfvivg, F. Studien über die Pollenkörner der Angiospermen. Jenaisch. Zeitsch. Naturwiss. 13: 1-28. 1879; Quart. Jour. Micr. Sci. 20 : 19-35. 1880.

Elyore, C. J. Some Results from the Study of Allium. Bot. Gazette 26: $277-278.1898$.

ExDriss, W. Monographie vom Pilostyles ingue (Karst.) (Pilostyles Ulei Solms-Laub.). Flora 91: 209-236. pl. 20. figs. 29. 1902.

Exgler, A. Beiträge zur Kenntniss der Antherenbildung der Metaspermen. Jahrb. Wiss. Bot. 10: 275-316. pls. 20-24. 1876.

, and Praxtr, K. Die natürlichen Pflanzenfamilien. Leipzig. 1887.

Uebersicht über die Unterabteilung, Klassen, Reihen, Unterreihen, und Familien der Embryophyta siphonogama. In Engler and Prantl's Die naturlichen Pflanzenfamilien. 1897.

Ervst, A. Beiträge zur Kenntniss der Entwickelung des Embryosackes und des Embryo (Polyembryonie) von Tulipa Gesneriana L. Flora 88: 37-7\%. pls. 4-8, 1901.

—_. Chromosomenreduction, Entwickelung des Embryosackes und Befruchtung bei Paris quadrifolia L. und Trillium grandiflorum Salisb. Flora 91: 1-46. pls. 1-6. 1902.

Faniller, I. Biogenetische Unter'suchungen über verkümmerte oder umgebildete Sexualorgane. Flora 82: 133-168. figs. 10. 1896.

Fanistzis, A. Embryologische Studien. Mem. Acad. Imp. Sci. St. Pétersbourg 26: 10, 1879.

Fatll, J. H. The Anatomy of the Osmundaceae. Bot. Gazette 32: 381-420. pls. 14-1\%. 1901.

Ferra RIS, T. Ricerche embriologiche sulle Iridaceae. I. Embriologia del G. Romulea Maratti. Ann. R. Istit. Bot. Roma 9: 221-241 pls. $6-$. 1902.

Fischer, A. Zur Kenntniss der Embryosackentwicklung einiger Angiospermen. Jenaisch. Zeitsch. Naturwiss. 14: 90-132. 1880.

Focke, W. O. Die Pflanzen-Mischlinge. Berlin. 1881.

Frye, T. C. Development of the Pollen in some Asclepiadaceae. Bot. Gazette 32: 325-331. pl. 13. 1901.

A Morphological Study of Certain Asclepiadaceae. Bot. Gazette 34: 389-413. pls. 13-15. 1902.

. The Embryo-sac of Casuarina stricta. To be published in Bot. Gazette 36: 1903.

Fulluer, E. L. The Development of the Microsporangia and Microspores of Hemerocallis fulva. Bot. Gazette 28 : 81-88. pls. $\tau-8$. 1899 . 
GAger, C. S. The Development of the Pollinium and Sperm Cells in Asclepias Cornuti. Annals of Botany 16: 123-148. 11. \%. 1902. Ganong, W. F. Upon Polyembryony and its Morphology in Opuntia vulgaris. Bot. Gazette 25: 221-228. pl. 16. 1898.

- The Teaching Botanist. New York. 1899.

Giltay, E. Ueber den directen Einfluss des Pollens auf Frucht- und Samenbildung. Jahrb. Wiss. Bot. 25: 489-509. pl. 23. 1893.

GoEBel, C. Vergleichende Entwicklungsgeschichte der Pflanzenorgane. Schrenck's Handbuch der Botanik $3^{1}$ : 99-432. figs, 126. 1884.

translation. Oxford. 188\%.

- Organography of Plants. Translated by I. B. Balfour. Oxford. 1900.

- Bemerkung zu der vorstehenden Mittheilung (Möbius: Parasitismus und sexuelle Reproduktion im Pflanzenreiche). Biol. Centralbl. 20: 571-572. 1900.

-. Organographie der Pflanzen. Vol. ii. Jena. 1901.

Goldflus, MLle. M. Sur la strueture et les fonetions de l'assise épithéliale et des antipodes chez les Composées. Jour. Botanique 12: 374-384. pls. 1-6. 1898; 13: 87-96. 1899.

Golinski, ST. J. Ein Beitrag zur Entwicklungsgeschichte des Androeceums und des Gynaeceums des Gräser. Bot. Centralbl. 55: 1-17, 65-72, 129-135. pls. 1-3. 1893.

Gray, A. Structural Botany. New York. 1879.

GuignaRD, L. Recherches d'embryogénie végétale comparée. I. Légu mineuses. Ann. Sci. Nat. Bot. VI. 12: 5-166. pls. 1-8. 1881.

- Recherches sur le sac embryonnaire des Phanérogames Augiospermes. Ann. Sci. Nat. Bot. VI. 13: 136-199. pls. 3-\%. 1882.

- Recherches sur le développement de l'anthère et du pollen des Orchidées. Ann. Sci. Nat. Bot. VI. 14: 26-45. pl. . 1882.

- Structure et division du noyau cellulaire. Ann. Sci. Nat. Bot. VI. 17: 5-59. pls. 1-5. 1884 .

- Observations sur les Santalacées. Ann. Sci. Nat. Bot. VII. 2: 181-202. pls. 12-14. 1885 .

Nouvelles études sur la fécondation. Ann. Sci. Nat. Bot. VII. 14: 163-296. pls, 9-18. 1891.

- Les centres cinetiques chez les vegetaux. Ann. Sci. Nat. Bot. VIII. 6: 177-220. pls. $s-10.1898$.

- Le développement du pollen et la reduction dans le Naias major. Arch. Anat. Micr. 2: 455-509. 1899.

—. Sur les anthérozoides et la double copulation sexuelle chez les végétaux angiospermes. Compt. Rend. 128: 864-871. figs. 19. 1899 ; Rev. Gen. Bot. 11: 129-135. pl. 1. 1899; also Les découvertes récentes sur la férondation chez les végétaux augiospermes. Volume Jubilaire de la Société de Biologique. Paris. 1899. 
Guignard, L. L'appareil sexuel et la double fécondation dans les Tulipes. Amn. Sci. Nat. Bot. VIII. 11: 365-3s;. pls. 9-11. 1900.

- Nouvelles recherches sur la double fécondation chez les Phanerogames angiospermes. Compt. Rend. 131: 153-160. 1900.

. La double fécondation dans le mais. Jour. Botanique 15: 37-50. 1901.

. La double fécondation dans le Naias major. Jour. Botanique 15: 205-213. figs. 14. 1901.

Double fécondation chez les Renonculacées. Jour. Botanique 15: 394-408. figs. 16. 1901.

. Sur la double fécondation chez les Solanées et les Gentianées. Compt. Reud. 133: 1268-1272. 1901.

. La double fécondation chez les Solanées. Jour. Botanique 16: 145-167. figs. 45. 1902.

La double fécondation chez les Crucifères. Jour. Botaniqıe 16: 361-368. figs. 20. 1902.

Hall, J. G. An Embryological Study of Limnocharis emarginata. Bot. Gazette 33: 214-219. pl. 9. 1902.

Hallier, H. Beiträge zur Morphologie der Sporophylle und des Trophophylls in Beziehung zur Phylogenie der Kormophyten. Jahrb. Hamburgischen Wiss. Anstalten 19: 1-110. 1902.

Halsted, B. D. Three Nuclei in Pollen Grains. Bot. Gazette 12: 285-288. pl. 16. $188 \%$.

HANAUsek, T. F. Ueber symmetrische und polyembryonische Samen von Coffea arabica L. Ber. Deutsch. Bot. Gesell. 13: 73-78. pl. 6. 1895 .

Hanstein, J. Entwickelungsgeschichte der Keime der Monocotyledonen und Dicotyledonen. Bot. Abhandl. Bonn, pp. 112. 1870.

Hartog, M. Alternation of Generations. Annals of Botany 12: 593594. 1898.

Hegelmaier, F. Zur Entwickelungsgeschichte monocotyledoner Keime nebst Bemerkungen über die Bildung der Samendeckel. Bot. Zeit. 32 : 631-639, 648-671, 673-686, 689-700, 705-719. 1874.

Vergleichende Untersuchungen. Stuttgart. 1875.

Vergleichende Untersuchungen ïber Entwickelung dicotyledoner Keime. Stuttgart. 1878.

Ueber aus mehrkernigen Zellen aufgebaute DikotyledonenKeimträger. Bot. Zeit. 38: 496-506, 513-522. 1880.

Untersuchungen über die Morphologie des DikotyledonenEndosperms. Nova. Acta Leopoldina 49: 1-104. pls. 5. 1885; reviewed in Bot. Centralbl. 10: 302-304. 1886.

Zur Kenntniss der Polyembryonie von Allium odorum. Bot. Zeit. 55: 133-140. 1897.

Ueber einen neuen Fall von habitueller Polyembryonie. Ber. Deutsch. Bot. Gesell. 19 : 485-499. 1901. 
HiLL, T. G. The Structure and Development of Triglochin maritimum L. Annals of Botany 14: 83-107. pls. 6-\%. 1900.

Hofmeister, W. Vergleichende Untersuchungen der Keimung, Entfaltung und Fruchtbildung höherer Kryptogamen. Leipzig. 1851.

Neuere Beobachtungen über Embryobildung der Phanerogamen. Jahrb. Wiss. Bot. 1: 82-188. pls. \%-10. 1858.

- Neue Beiträge zur Kenntniss der Embryobildung der Phanerogamen. Abhandl. Königl. Sächs. Gesell. Wiss. 6: 533-672. pls. 1-27. 1859.

- Neue Beiträge zur Kenntniss der Embryobildung der Phanerogamen. II. Monocotyledonen. 1861.

- Allgemeine Morphologie der Gewächse. Leipzig. 1868.

Holferty, G. M. Ovule and Embryo of Potamogeton natans. Bot. Gazette 31: 339-346. pls. 2-8. 1901.

Hows, Theo. Podophyllum peltatum; a Morphological Study. Bot. Gazette 27: 419-433. figs. 10. 1898.

D'Hubert, E. Recherches sur le sac embryonnaire des plantes grasses. Ann. Sci. Nat. Bot. VIII. 2: 37-128. pls. 1-3. figs. 66. 1896.

Huxphrey, J. E. Nucleolen und Centrosomen. Ber. Deutsch. Bot. Gesell. 12: 108-117. pl. 6. 1894.

- The Development of the Seed in Scitamineae. Annals of Botany 10: 1-40. pls. 1-4. 1896.

IKEDA, T. Studies in the Physiological Functions of Antipodals and Related Phenomena of Fertilization in Liliaceae. 1. Tricyrtis hirta. Bull. Coll. Agric. Imp. Univ. Tokyo 5: 41-72. pls. 3-6. 1902.

IRMisch, T. Beiträge zur vergleichenden Morphologie der Pflanzen. Abhandl. Natur. Gesell. 2: 30-43. 1854; 3: 63-102, 107-137. 1855.

Jeffrey, E. C. Polyembryony in Erythronium americanum. Annals of Botany 9: 537-542. pl. 19. 1895 .

The Development, Structure, and Affinities of the Genus Equisetum. Mem. Boston Soc. Nat. Hist. 5: 155-190. pls. 2630. 1899.

- The Morphology of the Central Cylinder in the Angiosperns. Trans. Canadian Inst. pp. 40. pls. $\tau-11.1900$.

- The Structure and Development of the Stem in the Pteridophyta and Gymnosperms. Phil. Trans. Roy. Soc. London B. 125: 119-146. pls. G. 1902.

Johnson, D. S. On the Endosperm and Embryo of Peperomia pellucida. Bot. Gazette 30: 1-11. pl. 1. 1900.

- On the Development of Saururus cernuus L. Bull. Torr. Bot. Club 27: 365-372. pl. 23. 1900.

- The Embryology and Germination of the Genus Peperomia. Abstract. Science 15: 408-409. 1902. 
Johnson, D. S. On the Development of Certain Piperaceae. Bot. Gazette 34: 321-340. pls. 9-10. 1902.

Johssos, T. The Nursing of the Embryo and some other Points in Myzodendron punctulatum Banks et Sol. Annals of Botany 3: 179-206. pls. 13-1\%. 1889.

Jösssos, B. Polyembryouie hos Trifolium pratense L. Bot. Centralbl. 16: 171. 1883 .

JLEL, H. O. Die Kerntheilungen in den Pollenmutterzellen von Hemerocallis fulca und die bei denselben auftretenden Unregelmässigkeiten. Jahrb. Wiss. Bot. 30: 205-226. pls. 6-8. 1897.

- Parthenogenesis bei Antennaria alpina (L.) R. Br. Bot. Centralbl. 74: 369-372. 1898.

- Beiträge zur Kenntniss der Tetradenbildung. Jahrb. Wiss. Bot. 35: 626-659. pls. 15-16. 1900.

- Vergleichende Untersuchungen iiber typische und parthenogenetische Fortpflanzung bei der Gattung Antennaria. Handl. Svensk. Tetensk. Akad. 33: no. 5. pp. 59. pls. 6 . figs. 5. 1900 ; reviewed in Bot. Zeit. 59: 131. 1901.

- Zur Entwicklungsgeschichte des Samens von Cynomorium. Beih. Bot. Centralbl. 13: 194-202. figs. 5. 1902.

Kamienski, F. Vergleichende Untersuchungen ïber die Entwickelungsgeschichte der Utricularien. Bot. Zeit. 35: 761-775. pl. 14. $187 \%$.

KArstex, G. Ueber die Entwickelung der weiblichen Blüthen bei einigen Juglandaceen. Flora 90: 316-333. pl. 12. 1902.

KaUfFuans, N. Ueber die männlichen Blïthe von Casuarina quadrivalvis. Bull. Soc. Nat. Moscou 41: 374-382. 1869.

Kerner, A. Pflanzenleben. 2 vols. Leipzig and Wien. 1896-1898.

KLEBs, G. Alternation of Generations in the Thallophytes. Annals of Botany 12: 570-583. 1898.

Koch, L. Ueber die Entwickelung des Samens der Orobanchen. Jahrb. Wiss. Bot. 11: 218-261. pls. 8-10. 1878.

- Entwicklungsgeschichte der Orobanchen, pp. 389. pls. 12. Heidelberg. 188\%.

KörNicke, F. Torläufige Mittheilungen über den Mais. Sitzungsb. Niederrh. Gesell. Nat. Heilk. Bonn. 1872.

KoERsicke, M. Untersuchungen über die Entstehung und Entwickelung der Sexualorgane von Triticum mit besonderer Berücksichtigung der Kerntheilıng. Verhandl. Naturhist. Ver. Preussen Rheinl. 53: 149-185. 1896.

Korschissky, S. Heterogenesis und Evolution. Ein Beitrag zur Theorie der Entstehung der Arten. Translated from the Russian by S. Tschulok. Flora 89: 240-363. 1901; also review in Bot. Gazette 33: 396. 1902.

Laxi, W. J. G. Double Fertilization in Compositae. Bot. Gazette 30: 252-260. pls. 15-16. 1900 . 
LANG, F. X. Untersuchungen über Morphologie, Anatomie, und Samenentwicklung von Polypompholyx und Byblis gigantea. Flora 88: 149-206. pl. 12. figs. 80. 1901.

LANG, W. H. Alternation of Generations in the Archegoniates. Annals of Botany 12: 583-592. 1898.

LAwson, A. A. Some Observations on the Development of the Karyokinetic Spindle in the Pollen Mother-cells of Cobaea scandens. Proc. Calif. Acad. Sci. III. 1: 169-184. pls. 33-36. 1898.

LeavitT, R. G. Notes on the Embryology of some New England Orchids. Rhodora 3: 202-205, pl. 33. 1901.

LE Monnier, G. Sur la valeur morphologique de l'albumen chez les Angiospermes. Jour. Botanique 1: 140-142. 1887.

Lloxd, F. E. The Comparative Embryology of the Rubiaceae. Bull. Torr. Bot. Club 28: 1-25. pls. 1-3. 1899.

- The Comparative Embryology of the Rubiaceae. Mem. Torr. Bot. Club 8: 27-112. pls. 5-15. 1902.

Losgo, B. La mesogamia nella commune zucca (Cucurbita Pepo Linn.). Rend. R. Accad. Lincei 10: 168-1\%2. 1901.

Lotsy, J. P. Balanophora globosa Jungh. Eine wenigstens örtlichverwittwete Pflanze. Ann. Jard. Bot. Buitenzorg II. 1: 17t-186. pls. 26-29. 1899.

Rhopalocnemis phalloides Jungh., a Morphological-systematical Study. Ann. Jard. Bot. Buitenzorg II. 2: 73-101. pls. 3-14. 1900.

Luerssen, C. Zur Controverse ïber die Einzelligkeit oder Mehrzelligkeit des Pollens der Onagrarieen, Cucurbitaceen und Corylaceen. Jahrb. Wiss. Bot. 7: 34-60. pls. 3-5. 1869.

Lyon, Florence M. A Contribution to the Life History of Euphorbia corollata. Bot. Gazette 25: 418-426. pls. 22-24. 1898.

Lyos, H. L. Preliminary Note on the Embryogeny of Nelumbo. Science 13: 470. 1901 .

Observations on the Embryogeny of Nelumbo. Minn. Bot. Studies 2: 643-655. pls. 48-50. 1901.

—. The Phylogeny of the Cotyledon. Postelsia 1901: 55-86. 1902. MAgives, P. Zur Morphologie der Gattung Naias L. Bot. Zeit. 27: 769-773. 1869. Also Beiträge zur Kenntniss der Gattung Naias L. Berlin. $18 \bar{\pi} 0$.

Merrell, W. D. A Contribution to the Life History of Silphium. Bot. Gazette 29: 99-133. pls. 8-10. 1900.

Mettenius, G. H. Beiträge zur Anatomie der Cycadeen. 1857.

Mottier, D. M. On the Development of the Embryo-sac of Arisaema triphyllum. Bot. Gazette 17: 258-260. pl. 18. 1892.

- On the Embryo-sac and Embryo of Senecio aureus L. Bot. Gazette 18: 245-253. pls. 27-29. 1893.

- Development of the Embryo-sac in Acer rubrum. Bot. Gazette 18: 375-37\%. pl. 34. 1893 . 
Mottier, D. M. Contributions to the Embryology of the Ranunculaceae. Bot. Gazette 20: 241-248, 296-304. pls. 1\%-20. 1895.

- Beiträge zur Kenntniss der Kerntheilung in den Pollenmutterzellen einiger Monokotylen und Dikotylen. Jahrb. Wiss. Bot. 30: 169-204. pls: 3-5. 1897.

- Ueber das Verhalten der Kerne bei der Entwickelung des Embryosacks und die Vorgänge bei der Befruchtung. Jahrb. Wiss. Bot. 31: 125-158. pls. 2-2. 1898.

Murbeck, S. Parthenogenetische Embryobildung in der Gattung Alchemilla. Lunds Univ. Arsskrift 36: no. 7. pp. 46. pls. 6. 1901 ; reviewed in Bot. Zeit. 59: 129. 1901.

- Ueber das Verhalten des Pollenschlauches bei Alchemilla arvensis und das Wesen der Chalazogamie. Lunds Univ. Arsskrift 36: pp. 19. pls. 2. 1901.

- Ueber Anomalien im Baue des Nucellus und des Embryosackes bei parthenogenetischen Arten der Gattung Alchemilla. Lunds Univ. Arsskrift 382: no. 2. pp. 10. pls. 13. 1902.

- Ueber die Embryologie von Ruppia rostellata Koch. Handl. Svensk. Vetensk. Akad. 36: pp. 21. pls. 3. 1902.

NäGELI, C. Zur Entwicklungsgeschichte des Pollens. Zürich. 1842.

Nawaschin, S. Zur Embryobildung der Birke. Bull. Acad. Imp. Sci. St. Pétersbourg 13 : 345-348. 1892; reviewed in Bot. Centralbl. 54: 237. 1893.

—. Ein neues Beispiel der Chalazogamie. Bot. Centralbl. 63: 353-357. 1895.

- Ueber das Verhalten des Pollenschlauches bei der Ulme. Bull. Acad. Imp. Sci. St. Pétersbourg 8: 345-357. pl. 1. 1898; reviewed in Bot. Centralbl. 77 : 26-30. 1899.

- Neue Beobachtungen über Befruchtung bei Fritillaria tenella und Lilium Martagon. Bot. Centralbl. 77: 62. 1899.

- Resultate einer Revision der Befruchtungsvorgänge bei Lilium Martagon und Fritillaria tenella. Bull. Acad. Imp. Sci. St. Pétersbourg 9: 377-382. 1898; reviewed in Bot. Centralbl. 78: 241-245. 1899.

- Ueber die Befruchtungsvorgänge bei einigen Dicotyledoneen. Ber. Deutsch. Bot. Gesell. 18: 221-230. pl. 9. 1900.

NÊMEc, B. Ueber den Pollen der petaloiden Antheren von Hyacinthus orientalis. Bull. Imp. Acad. Sci. Bohême. 1898.

Oliver, F. W. On the Structure, Development, and Affinities of Trapella, a New Genus of Pedalineae. Annals of Botany 2: 75115. pls. 5-9. 1888.

- On Sarcodes sanguinea. Anuals of Botany 4: 303-326. pls. 1\%-21. 1890.

- On a Vascular Sporangium from the Stephanian of Grand 'Croix. New Phytologist 1: 60-67. pl. 1. 1902. 
Osterwalder, A. Beiträge zur Embryologie von Aconitum Napellus. Flora 85: 254-292. pls. 11-15. 1898.

Orerton, E. Beitrag zur Kenntniss der Entwickelung und Vereinigung der Geschlechtsprodukte bei Lilium Martagon. Festschrift (Nägeli und Kölliker). Würzburg. 1891.

Ueber die Reduktion der Chromosomen in den Kernen der Pflanzen. Vierteljahrssch. Naturf. Gesell. Zürich 38: 1893.

Orerton, J. B. Parthenogenesis in Thalictrum purpurascens. Bot. Gazette 33: 363-375. pls. 13-13. 1902.

PAYER, J. D. Traité d'organogénie de la fleur. Paris. 1857.

PÉchottre, F. Contribution à l'étude du développement de l'ovule et de le graine des Rosacées. Aun. Sci. Nat. Bot. VIII. 16: 1-158. figs. 166.1902.

Pfeffer, W. Blüthenentwicklung der Primulaceen und Ampelideen. Jahrb. Wiss. Bot. 8: 194-215. 1872.

Pirotta, R., and Loxgo, B. Basigamia, mesogamia, acrogamia. Atti R. Accad. Lincei V. 9: 296-298. 1900; Bot. Centralbl. 86: 93. 1901. Potoxí́, H. Metamorphose der Pflanzen im Lichte Palaeontologischer Thatsachen. Berlin. 1898.

- Pflanzenpalaeontologie. Berlin. 1899.

Prrkinje, J. E. De cellulis antherarum fibrosis nec non de granorum pollinarium formis commentatio phytotomica. Vratislaviae. 1830.

Queva, C. Contributions à l'anatomie des Monocotyledonées. I. Les Uvulariées tubereuses. Lille. 1899.

Reichenbach, H. G. De pollinis Orchidearum genesi ac structura et de Orchideis in artem ac systema regigendis. Leipzig. 1852.

Renault, B. Cours de Botanique Fossile. Paris. 1880-1884.

Riddle, Lumina C. The Embryology of Alyssum. Bot. Gazette 26: 314-324. pls. $26-28.1898$.

Rohrbach, P. Die Samenknospe der Typhaceen. Bot. Zeit. 27 : 479480. 1869 .

Rosaxoff, S. Zur Kenntniss des Baues und der Entwicklungsgeschichte des Pollens der Mimoseae. Jahrb. Wiss. Bot. 4: 441450. pls. 31-32. 1865 .

Rosenberg, O. Ueber die Embryologie von Zostera marina. Bih. Handl. Srensk. Vetensk. Akad. $27^{3}$ : no. 6. pp. 26. pls. 2. 1901.

- Ueber die Pollenbildung von Zostera. Meddel. Stockholms Högsk. Bot. Inst. pp. 21. 1901.

SARGayt, Ethel. The formation of Sexual Nuclei in Lilium Martagon. I. Oogenesis. Annals of Botany 10: 445-47\%. pls. 2223. 1896 .

- Recent Work on the Results of Fertilization in Angiosperms. Annals of Botany 14: 689-712. 1900.

- The Origin of the Seed-leaf in Monocotyledons. New Phytologist 1: 107-113. pl. 2. 1902. 
Sargant, Ethel. A Theory of the Origin of Monocotyledons founded on the Structure of their Seedlings. Annals of Botany 17: 1-92. pls. 1-\%. 1903.

Sснаснт, H. Entwicklungsgeschichte des Pflanzenembryon. pp. 234. pls. 26. Amsterdam. 1850; Ann. Sei. Nat. Bot. III. 15: s0-109. 1851.

Ueber Pflanzen-Befruchtung. Jahrb. Wiss. Bot. 1: 193-232. pls. 11-15. 1858.

- Ueber den Bau einiger Pollenkörner. Jahrb. Wiss. Bot. 2 : 107-168. pls. 14-18. 1860.

Schaffier, J. H. The Embryo-sac of Alisma Plantago. Bot. Gazette 21: 123-132. pls. 9-10. 1896.

. Contribution to the Life History of Sagittaria variabilis. Bot. Gazette 23 : 252-273. pls. 20-26. 1897.

- The Development of the Stamens and Carpels of Typha latifolia. Bot. Gazette 24: 93-102. pls. 4-6. 1897.

. Karyokinesis in the Root Tips of Allium Cepa. Bot. Gazette 26: 225-238. pls. 21-22. 1898.

A Contribution to the Life History and Cytology of Erythronium. Bot. Gazette 31: 369-387. pls. 4-9. 1901.

Schleidex, M. J. Ueber Bildung des Eichens und Entstehung des Embryo's bei den Phanerogamen. Nova Acta Leopoldina 19: 27-58. 1839 ; Ann. Sci. Nat. Bot. II. 11: 129-141. 1839.

SснміD, B. Beiträge zur Embryo-Entwickelung einiger Dicotylen. Bot. Zeit. 60: 207-230. pls, 8-10. 1902.

SchNeGG, H. Beiträge zur Kenntniss der Gattung Gunnera. Flora 90: 161-208. figs. 28. 1902.

Schviewixd-Thies, J. Die Reduktion der Chromosomenzahl und die ihr folgenden Kerntheilungen in den Embryosackmutterzellen der Angiospermen. Jena. 1901.

ScHwere, S. Zur Entwickelungsgeschichte der Frucht von Taraxacum officinale Web. Ein Beitrag zur Embryologie der Compositen. Flora 82: 32-66. pls. 2-5. 1896.

ScotT, D. H. The Anatomical Characters presented by the Peduncle of the Cycadaceae. Annals of Botany 11: 399-419. pls. 20-21. 1897.

\section{- Trans. British Assn. Adv. Sci. 1900.}

- Studies in Fossil Botany. London. 1900.

SEward, A. C. Notes on the Geological History of Monocotyledons. Annals of Botany 10: 205-220. pl. 14. 1896.

Shibata, K. Die Doppelbefruchtung bei Monotropa uniflora L. Flora 90: 61-66. 1902.

- Experimentelle Studien über die Entwickelung des Endosperms bei Monotropa. (Vorläufige Mittheilung) Biol. Centralbl.

22: 705-714. 1902.

Shomaker, D. N. Notes on the Development of Hamamelis rirginiana L. Johns Hopkins Univ. Circ. 21: 86-87. 1902. 
Syith, Axelia C. The Structure and Parasitism of Aphyllon uniflorum Gray. Contrib. Bot. Lab. Univ. Penn. 2: 111-121. pls. 13-15. 1901.

Syith, Arya. Abortive Flower Buds of Trillium. Bot. Gazette 22: 402-403. 1896.

Suith, R. W. A Contribution to the Life History of the Pontederiaceae. Bot. Gazette 25: 324-337. pls. 19-20. 1898.

Solms-Laubach, H. Graf zu. Ueber den Bau der Samen in den Familien der Rafflesiaceae und Hydnoraceae. Bot. Zeit. 32: 337-342, 353-358, 369-374, 355-389. pl. s. 1874.

- Ueber monocotyle Embryonen mit scheitelbürtigen Vegetationspunkt. Bot. Zeit. 36: 65-74, 81-93. figs. 3\%. 1878.

- Cruciferenstudien. 1. Capsella Heegeri Solms, eine neue entstandene Form der deutschen Flora. Bot. Zeit. 581 : 167-190. pl. 7.1900.

Stevens, W. C. The Behavior of the Kinoplasm and Nucleolus in the Division of the Pollen Mother-cells of Asclepias Cornuti. Kansas Univ. Quarterly 7: 77-85. pl. 15. 1898.

Strasburger, E. Befruchtung und Zelltheilung. Jena. 1877.

Ueber Polyembryonie. Jenaisch. Zeitsch. Naturwiss. 12: 647-670. 1878 .

Die Angiospermen und die Gymnospermen. Jena. 1879.

- Ueber Zellbildung und Zelltheilung. Ed. 3. Jena. 1880.

- Einige Bemerkungen über vielkernige Zellen und Embryogenie von Lupinus. Bot. Zeit. 38: 845-854, 857-868. fig. 64. 1880.

—. Ueber den Theilungsvorgang der Zellkerne und das Verhältniss der Kerntheilung zur Zelltheilung. Archiv. Mrikr. Anat. 21: 176-590. pls. 25-27. 1882.

—_. Neue Untersuchungen ïber den Befruchtungsrorgang bei den Phanerogamen. Jena. 18st.

- Ueber Kerntheilung und Zelltheilung im Pflanzenreich. Hist. Beitr. I. Jena. 1858.

\section{——. Histologische Beiträge. III. 1891.}

- The Periodic Reduction of Chromosomes in Living Organisms. Annals of Botany 8: 2\$1-316. 1894.

—. Karyokinetische Probleme. Jahrb. Wiss. Bot. 28: 151-204. pls. 2-3. 1895 .

—. Einige Bemerkungen zur Frage nach der "doppelten Befruchtung" bei den Angiospermen. Bot. Zeit. 58: 293-316. 1900.

- Ueber Reduktionstheilung. Spindelbildung, und Cilienbildner im Pflanzenreich. Hist. Beitr. VI. Jena. 1900.

—. Einige Bemerkungen zu der Pollenbildung bei Asclepias. Ber. Deutsch. Bot. Gesell. 19: 450-161. pl. 24. 1901.

—. Ein Beitrag zur Kenntniss von Ceratophyllum submersum und phylogenetische Erörterungen. Jahrb. Wiss. Bot. 37: 477526. pls. 9-11. 1902 . 
Thomas, Ethel M. On the Presence of Vermiform Nuclei in a Dicotyledon. Annals of Botany 14: 318-319. 1900.

- Double Fertilization in a Dicotyledon-Caltha palustris. Annals of Botany 14: 527-535. pl. 30. 1900.

Tischler, G. Untersuchungen über die Entwicklung des Endospermis und der Samenschale von Corydalis cava. Verhandl. Naturhist.-Ned. Ver. Heidelberg 6: 351-380. pls. ‥ 1900.

Tretjakow, S. Die Betheiligung der Antipoden in Fällen der Polyembryonie bei Allium odorum L. Ber. Deutsch. Bot. Gesell. 13 : 13-17. pl. 2. 1895 .

Treub, M. Notes sur l'embryogénie de quelques Orchilées. Naturkund. Verhandl. Königl. Akad. Deel 21: 1879.

Observations sur les Loranthacées. Amn. Sci. Nat. Bot. VI. 13: 250-282. pls. 13-20. 18s:; reprinted in Ann. Jard. Bot. Buitenzorg 3: 1-12. pls. 1-?. 1883, and 2: 54-76. pls. 8-15. 1885.

Notes sur l'embryon, le sac embryonnaire, et l'ovule. I and II. Ann. Jard. Bot. Buitenzorg 3: 76-87. pls. 13-15. 1883.

Notes sur l'embryon, le sac embryonnaire, et l'ovule. III and IV. Ann. Jard. Bot. Buitenzorg 3: 120-128. pls. 18-19. 1883.

- Observations sur les Loranthacées. IV. Ann. Jard. Bot. Buitenzorg 3: 184-190. pls. 28-29. 1883.

- Notes sur l'embryon, le sac embryonnaire, et l'ovule. V. Ann. Jard. Bot. Buitenzorg 4: 101-106. pl. 8. 1884.

- Sur les Casuarinées et leur place dans le système naturel. Ann. Jard. Bot. Buitenzorg 10: 145-231. pls. 12-32. 1891.

- L'organe femelle et l'apogamie du Balanophora elongata. Ann. Jard. Bot. Buitenzorg 15: 1-22. pls. 1-8. 1898.

- L'organe femelle et l'embryogénèse dans le Ficus hirta Vahl. Ann. Jard. Bot. Buitenzorg II. 3: 124-157. pls. 16-25. 1902.

- and Mellink, J. F. A. Notice sur la développement du sac embryonnaire dans quelques Angiospermes. Archives Néerlandaises 15 : Oct. 1880.

LiNGER. D. F. Die Entwicklung des Embryo's von Hippuris vulgaris. Bot. Zeit. 7 : 329-339. pls. 3-4. 1849.

Vax Tieghem, Ph. Structure du pistil des Primulacées et des Theophrastées. Aun. Sci. Nat. Bot. V. 12: 329-339. 1869.

- Traité de Botanique. Paris. 1891.

- Observations sur la structure et la dehiscence des anthères des Loranthacées, etc. Bull. Soc. Bot. France 42: 363-368. 1895.

- Sur l'organisation florale des Balanophoracées. Bull. Soc. Bot. France 43: 295-309. 1896.

Vesque. J. Développement du sac embryonnaire des Phanérogames Angiospermes. Ann. Sci. Nat. Bot. VI. 6: 237-285. pls. 11-16. 1878. Compt. Rend. 88: 1359-1361. 1879. Bot. Zeit. 37: 505-509. 1879. 
Vesque, J. Nouvelles recherches sur le développement du sac embryonnaire des Phanérogames Angiospermes. Ann. Sci. Nat. Bot. VI. 8: 261-390. pls. 12-21. 1879.

Ward, H. Marshall. On the Embryo-sac and Development of Gymnadenia conopsea. Quart. Jour. Micr. Sci. 20: 1-18. pls. 1-3. 1880.

A Contribution to Our Knowledge of the Embryo-sac in Angiosperms. Jour. Linn. Soc. Bot. London 17: 519-546. pls. 1\%-25. 1880.

Warming, E. Recherches sur la ramification des Phanérogames. Copenhagen. 1872.

Untersuchungen über pollenbildende Phyllome und Kaulome.

Hanstein's Bot. Abhandl. 2: 1-90. pls. 1-6. 1873.

- De l'ovule. Ann. Sei. Nat. Bot. VI. 5: 177-266. pls. $\gamma-13.1877$. WEBB, J. E. A Morphological Study of the Flower and Embryo of Spiraea. Bot. Gazette 33: 451-460. figs. 28. 1902. For correction of names see REHDER in Bot. Gazette 34: 246. 1902.

Webber, H. J. Xenia, or the Immediate Effect of Pollen in Maize. Bulletin 22. Div. Veg. Path. and Phys. U. S. Dept. Agric. pp. 40. pls. 4. 1900.

Westeryaier, M. Zur Embryologie der Phanerogamen, insbesondere über die sogenannten Antipoden. Nova Acta Leopoldina 57: 1890 .

- Zur Physiologie und Morphologie der Angiospermen-Samenknospen. Beitr. Wiss. Bot. 1 : 2. 1896.

WiEgand, K. M. The Development of the Microsporangium and Microspores in Convallaria and Potamogeton. Bot. Gazette 28: 328-359. pls. 24-25. 1899.

- The Development of the Embryo-sac in some Monocotyle-

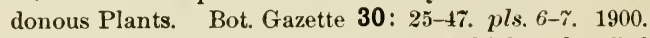

Wille, N. Ueber die Entwickelungsgeschichte der Pollenkörner der Angiospermen und das Wachsthum der Membranen durch Intussusception. Christiania. 1886.

Williaysox and Scotr. Further Observations on the Organization of the Fossil Plants of the Coal-measures. Part. 3. Lyginodendron and Heterangium. Phil. Trans. Roy. Soc. London B. 186: 1896.

Worsdell, W. C. On Transfusion Tissue; its Origin and Function in the Leaves of Gymnospermous Plants. Trans. Linn. Soc. Bot. London II. 5: 301-319. pls. 23-26. 1897.

- The Comparative Anatomy of Certain Species of Encephalartos. Trans. Linn. Soc. Bot. London II. 5: 445-459. pl. 43. 1900.

-. Trans. British Assn. Adv. Sci. 1900.

Wrlie, R. B. A Morphological Study of Elodea canadensis. To be published in Bot. Gazette 36: 1903.

Zivger, N. Beitrïge zur Kenntniss der weiblichen Blüthen und Inflorescenzen bei Camnabineen. Flora 85: 189-2.)3. pls. 6-10. 1898. 


\section{N D E X}

\section{[The italicized numbers refer to figures.]}

Acacia, 85, 203.

Acanthaceae, 176, 177, 256, 269.

Acer, 134, 136, 147; rubrum. 52.

Aceraceae, 20, 97, 104, 110, 248, 278.

Achariaceae, 249.

Aconitum Napellus, 82, 99, 100, 111, $125,221$.

Acorus, 275.

Acrogamy, 150 .

Actinomorphy, 15, 16.

Adiantum pedatum, 297, 303, Fig. 108.

Adoxa, 277.

Adoxaceae. 259.

Aesculus, $14 \pi$.

Agave, 25 ; americana, 34 .

Aglaonema. 192.

Agraphis, 63. 77, 84, 86; nutans, 84.

Agrimonia, 58.

Aizoaceae, 244.

Alchemilla, 87, 93, 96, 104, 151, 211, 218, 219; acutangula, 212; alpestris, 212 ; alpina, 55, 58, 59, 79, 82 . 212; arvensis, 150, 211, 212; " hybrida," 212; pastoralis, 212, 221 ; pubescens, 212; sericata, 93, 212, 221 ; speciosa, 212.

Alisma, $77,136,138,151,152.195$, 196; type of embryo, 188: Plantago, 188.

Alismaceae, $77,97,16 \pi, 171,229$, 230, 263, 265.

Allium, 64, 77: canadense. 218; Cepa, 81; cernuum, 218: fistulosum, 81. 218: odorum, 103, 217. 218. 221: tricoceum, 218: ursinum, 81, 218.

Alnus, 60, 131, 132, 149, 150; glutinosa, 30,147 .
Aloe, 53.

Alopecurus pratensis, 98.

Alsineae, 131.

Alstroemeria, 81 ; psittacea, 81.

Alternation of generations, 288.

Althaea, 39.

Alyssum, 63, 65, 199.

Amarantaceae, 46, 244.

Amarantus retroflexus, 21.

Amaryllidaceae, 157, 178, 236, 238, $264,266$.

Amentaceae, 241.

Amentiferae, 60, 62, 100, 105, 112 , $113,241$.

Ámici, 143, 145.

Amsonia, 103.

Amygdalus, 199, 208.

Anacardiaceae, 248.

Anagallis, 25; arvensis, 46.

Anatomy of Angiosperms, 311; of Dicotyledons, 311 ; of Gymnosperms, 296; of Monocotyledons. 314.

Ancistrocladaceae, 249.

Andrews, F. M., 64, 76, 84, 101.

Androecium, 23.

Anemarrhena, 209, 281.

Anemone, 64: nemorosa. 156, 158. 159; patens Nuttalliana. 15\%.

Anemonella. 100; thalictroides, 60.

Angiosperms, comparative anatomy of, 311: contrasted with Grmnosperms, 1: embryogeny of, 2 ; fossil. 272: gametophyte of. 3 ; gengraphic distribution of. 261: phylogenetic relation to Gymnosperms. 283. to Pteridophytes. 284: phylogeny of. 290: sporophyte of. 2. 
Anoda, 101.

Anona, 131.

Anonaceae, 245.

Antennaria, 101; alpina, 80, 82, 92, 95. $166,170,211,212$; dioica, 80, $82,166,211$.

Anther, 23; dehiscence of, 41.

Anthericum, $7 \pi$.

Antherozoids, 160.

Anthyllis tetraphylla, 203.

Antipodal cells, 94, 98, 111.

Aphyllon uniflorum, 80, 170, 206.

Aplectrum hiemale, 194.

Apocynaceae, 255, 269.

Aponogetonaceae, 229, 263, 266.

Aquifoliaceae, 248.

Aquilegia, 64. 78; canadensis, 99.

Araceae. 10, 41, 48, 56, 77, 98, 103, $174,192,233,263,266,274,275$.

Arachis hypogaea, 203.

Arales, 233, 263, 275, 287.

Aralia, 277, 278; racemosa, 74 .

Araliaceae, 65, 79, 85, 251.

Araucarioxylon, 307 .

Archangelica, 136.

Archesporium of megasporangium, 57 ; of microsporangium, 32.

Archichlamydeae, 97 ; classification of, 240 ; geographic distribution of, 266.

Arctostaphylos, alpina, 42; Uvaursi, \&2.

Aril, 53.

Arisaema, 62, 77, 103 .

Aristolochia, 27\%.

Aristolochiaceae, 176, 244.

Aristolochiales, 244.

Armeria, 103; vulgaris, 172.

Arum, 146, 147, 233.

Arundina, 156.

Arundinites, 275.

Arundo, 275.

Asarum, 101.

Ascherson, P., 196.

Asclepiadaceae, $30,38,41,61,132$, 157, 255. 269.

Asclepias, 37, 55, 74, 102, 109, 122, $124,12 \%, 133,135,146,167,169$; Cornuti, 82, 102, 127, 157, 159, $16 \%$ : Syriaca, 123; tuberosa, 82, $85,12 \%$.

Asparagus officinalis, 125.

Asperula, 82, 202; azurea, 202.
Asphodelus, 53.

Aster novae-angliae, 100, 101.

Astilbe, 19, 37, 39, 59, 87, 103, 108;

japonica, 58 .

Astrapaea, 131.

Astrocarpus, 51.

Atkinson, G. F., 75, 81.

Avena, 80,136 ; fatua, $33,63,78,98$, 192.

Avicennia, 199; officinalis, 80.

Azalea indica, 125, 129.

Baillon, H. E., 42.

Balanophora, 50, 95, 166; dioica, 47 ; elongata, 49, 92, 218, 2?0, 221; globosa, 48, 49, 92, 21s; indica, 49,92 ; polyandra, 47,49 .

Balanophoraceae, $30,48,55,64,65$, $79,92,170,176,201,206,243$.

Balanopsidaceae, 242.

Balanopsidales, 242.

Balfour, I. B., 209.

Balicka-Iwanowska, G. P., 96, 102, $103,106,10 \%$.

Balsaminaceae, 248.

Bambusa, 275.

Barber, C. A., 22.

Barnes, C. R., 24, 103, 104, 131, 136, 146,148 .

Barringtonia Vriesei, 201.

Bartonia, 50.

Basellaceae, 244.

Basigamy, 150.

Batilaceae, 244.

Begonia, 125, 129.

Begoniaceae, 249.

Belajeff, W., 129, 131, 138.

Bennettitales, anatomy of, 306 .

Benson, Margaret, 59, 66, 87, 100, $105,14 \overline{7}, 148,149,151$.

Bentham, G., 227.

Berberidaceae, 64, 245, 278, 282.

Berberis, 41.

Bernard. C. H., 61, 79, 86, 91, 92, $95,103,154,166,218$.

Bessey, C. E., 283.

Betula, 60, 149, 150; alba, 147.

Betulaceae, 243, 278.

Bignoniaceae, 97, 176, 177, 256.

Rillings, F. H., 95, 103, 106, 107, $111,113,148,149,200,201$.

Bixaceae, 249.

Blattiaceae, 250. 
Bombacaceae, 249.

Borraginaceae, 131, 256, 269, 271.

Borraginales, 258.

Borago, 97 .

Boveri, Th., 182.

Bower, F. O., 288.

Brasenia, 5l.

Braun, A., 208, 213, 221, 227.

Bromeliaceae, 235, 264, 266.

Brongniart, A., 143, 227.

Brown. Robert, 143.

Brunelliaceae, 246.

Bruniaceae, 246.

Bryophyllum, 51.

Budding, 210.

Burmannia javanica, 213.

Burmanniaceae, 206, 238, 266.

Burns, G. P., 103, 106, 107, 113, 170 .

Burseraceae, 247 .

Butomaceae, 229, 263, 266, 275.

Butomus, 25, 50, 63, 75, 77, 282.

Buxaceae, 248.

Byblis, 108: gigantea, 107.

Byxbee, Edith, 129.

Cabomba. 51.

Cactaceae, 79, 97, 108, 14i, 151, 250, 268,312 .

Caesalpinia, 247; mimosoides, 203.

Calamus, 233.

Calandrinia compressa, $\{2$.

Calanthe veratrifolia, 30,39 .

Calceolaria, Pavonii, 2 .

Caldwell, O. WT., 30, 3i , 39, 40, 63, 77, $92,103,136,167,193$.

Calendula, 103; lusitanica, 95, 111.

Calla, 233: palustris, 2 .

Callipeltis cuenllaria, 58, 101.

Callitrichaceae, 247.

(allothamnus, 23.

(altha, 64. 78. 137. 157; palustris, (j0, 99, 152, 156. $1 \% 3$.

Calycanthaceae, 245, 267.

Calyceraceae, 259, 270 .

('amassia Fraseri, 138.

Campanales, 259,270 .

Campanula, 25, 95, 103, 104, 131, 136. 146 ; americana, 148 .

Campanulaceae, 102, 106, 110, 176, $259,270$.

Campbell, D. H., 27, 28, 48, 63, 77, $78,84,89,90,98,99,133,135,154$,
$192,195,196,200,242,282,285$, 287,308 .

Candolleaceae, 259, 270.

Canellaceae, 249.

Canna, 110, 179; indica, 64, 73,81 , $105,171,173$; limbata, 14.

Cannabineae, 56, 148, 150.

Cannaceae, 64, 171, 237, 264, 266.

Cannon, W. A., 33, 63, 78, 80, 98, $136,192$.

Capparidaceae, $5 \overline{5}, 246$.

Caprifoliaceae, 259, 269.

Capsella, 18, 61, 65, 94. 157, 196, 199; type of embryo, 199; Bursa-pastoris, $16,19,187,197,198,293$; Heegeri, 293.

Carboniferous Monocotyledons, 273.

Carex acuta, 74, 124, 128.

Caricaceae, 249.

Carlson, G. WV. F.. 293.

Carpel, 24; morphology of, 22.

Carpinus, 60, 66. $87,110,131,148$, 150; Betulus, 105, 147 .

Carum bulbocastanum, 206.

Carya, 148; olivaeformis, 149.

Caryocaraceae, 249.

Caryophyllaceae, $57,97,103,179$, 244,267 .

Cassia lentiva, 12.

Castanea, 60. 102, 109, 110; vulgaris, $100,105$.

Casuarina, 28, 59, 60, 66, 79, 87, 92, $101,102,105,109,149,150,157$, 167,312 ; suberosa, 149 .

Casuarinaceae, $97,242$.

Casuarinales, 242.

Celakovsky, L. F., 8, 9, 52, 288.

Celastraceae. 248.

Celastrales, 248.

Celastrus, 53.

Centrolepidaceae, 235, 264, 276.

Centrosomes. 153.

Centrospermae, 244.

Centrospermales, 244 .

Cephalotaceae, 246.

Cephalotaxus, drupacea, 308, Fig. 112; Fortunei, 308, Fig. 112.

Ceratophyllaceae, 15\%, 176, 245. 267, 282.

Ceratophyllum. 17\%, 208: demersum, 157, 201: submersum, 82. $17 \%$.

Cercis, 203: siliquastrum, 203.

Chalazogamy, 149 . 
Chamberlain, C. J., 28, 30, 31, 52, 58, $60,77,79,81,87,94,95,100,101$, $132,133,134,135,136,138,151$, 199.

Chauveaud, G. L., 55, 123, 217, 221.

Cheiranthus Cheiri, 221.

Chenopodiaceae, 57, 103, 179, 244.

Chlaenaceae, 249.

Chloranthaceae, 242.

Chlorophytum Sternbergianum, 81 .

Chodat, R., 79, 91, 92, 95, 103, 166, 218.

Chromatin, behavior during fusion, 153.

Chromosomes, 128, 211; reduction of, $80,128$.

Chrysanthemum, 38; Leucanthemum, 61 .

Cicer arietinum, 20\%.

Cistaceae, 56, 249.

Citrus, 147, 214; Aurantium, 213, 221.

Cladosiphonic, 298.

Clematis, 64, 84, 99, 122, 156; cirrhosa, 60 .

Clethraceae, 253.

Clintonia borealis, 314, Fig. 113.

Clusia alba, 221.

Cneoraceae, 24i.

Cnicus, 15i; ; arvensis, 17.

Coalescence, 12.

Cochlospermaceae, 249.

Coelebogyne, 214 ; ilicifolia, 213, 221.

Coffea arabica, 221.

Colchicum autumnale, 147.

Columelliaceae, 256.

Combretaceae, 250.

Commelina, 77, 99; stricta, 63.

Commelinaceae, 56, 63, 196, 235, 264, 266.

Compositae, 12, 15, 16, 18, 22, 24, $33,46,58,61,87,95,97,100,101$, $102,103,111,113,131,157,174$, 259, 270, 271.

Conard, H. S., 201, 207.

Conducting tissue, 25.

Coniferales, 286: anatomy of, 308 .

Connaraceae, 246.

Conrad, A. H., 31, 34, 58, 60, 66, 79, 94,147 .

Contortae, 25.5.

Convallaria, $63,64,77,133,136$; majalis, 33, 81; multiflora, 125.
Convolvulaceae, 131, 269.

Conyza, 96, 101.

Cook, M. T., 176.

Corallorbiza multiflora, 195.

Cordaitales, anatomy of, 307 .

Cordaites, Fig. 111.

Coriariaceae, 248.

Corn, xenia, 180.

Cornaceae, 251.

Cornucopiae, 63, 98.

Cornus, 147 ; sanguinea, 125.

Correns, C., 180.

Corry, T. H., 132.

Corydalis, cava, 172, 173, 206; lutea, 206 ; nobilis, 206.

Corylus, 60, 87, 132, 148, 149. 150; americana, 30, 31; Avellana, 105, 147.

Corynocarpaceae, 248.

Coryphanthe, 231.

Costus, 77, 171.

Cotyledon, phylogeny of, 208; single in Dicotyledons, 206; three in Dicotyledons, 208.

Coulter, J. M., 36, 37, 38, 60, 61, 65, $81,87,88,131,135,136,151,169$, $170,193,199,290$.

Crassulaceae, 246.

Crataegus, 199.

Cretaceous Dicotyledons, 276, 278; Monocotyledons, 273.

Crinum, 53 ; capense, 178.

Crocus, 94, 99, 104, 146, 147.

Croomia, 266; japonica, 266 ; pauciflora, 266.

Crossosomataceae, 246.

Crucianella, 82, 85; macrostachya, 86.

Cruciferae, 18, 57, 65, 97, 157, 246, 267.

Cucurbita, 150, 151, 179, 205.

Cucurbitaceae, 131, 174, 259, 270.

Cunoniaceae, 246.

Cuphea, 63, 96, 104.

Cupuliferae, 97, 131, 174, 313.

Cuscuta, 174, 206.

Cycadales, 286; anatomy of, 304 .

Cycadofilices, 109; anatomy of, 300.

Cycads, 301.

Cycas, 305; revoluta, 305, Fig. 111. Cyclamen, europaeum, 42; persicum, 206. 
Cyclanthaceae, 232, 263, 266, 275.

Cyclanthera, 28.

Cyclic series, 12, 228, 234.

Cydonia, 59.

Cymbalaria, 158.

Cynanchum, 55, 124.

Cynocrambaceae, 244.

Cynomoriaceae, 250.

Cynomorium, 76, 147, 201.

Cyperaceae, 122, 230, 265, 275.

Cypripedium, 132, 238, 239, 315; bar-

batum, 81 ; spectabile, 133.

Cyrillaceae, 248.

Cyrtosperma, 263.

Cystisus, 203; Laburnum, 203.

Cytinaceae, 206.

Dadoxylon, 307.

Damascena, 158.

Datiscaceae, 249.

Datura, 38, 15i, 158; laevis, 136, $151,165,178$.

De Candolle, A. P., 9, 227.

Definitive nucleus. See Endosperm nucleus.

De Jussieu, A. L., 227.

Delphinium, 64, 76, 78, 84, 87; elatum, 156; exaltatum, 100 ; tricorne, 60, 8\%, 99, 15. .

Delpino, F., 282.

De Vries, H., 180, 292, 293.

Diapensiaceae, 253, 269.

Dichapetalaceae, 247 .

Dicotyledons, 4, 11; anatomy of, 311: eyclic number of, 5; embryo of, $4,7,196$; fossil, 276 ; leaves of, 5, 6; in Lower Cretaceous, 276; in Tertiary, 278; in Upper Cretaceous, 278; phylogeny of, 281; prophyllum of, 7 ; roots of, 7 : seed germination, 6 ; vascular bundles of, 4 .

Dieffenbachia, 77, 84, 192.

Digitalis, 136.

Dilleniaceae, 249.

Diodia, 104, 111; virginiana, 102.

Dioecism, 20, 21.

Dioscoreaceae, 196, 236, 264, 266, $274,276$.

Dipsaceae, 18, 102, 269.

Dipterocarpaceae, 249.

Dodel, A., 217, 221.

Doronicum, 101; macrophyllum, 32.
Double fertilization, $155,156,160$, 180 ; nature of, 182.

Draba verna, 293.

Dracaena, 237, 285.

Droseraceae, 246.

Ducamp, L., 65, 74, 79, 85.

Duggar, B. M., 31, 37, 136.

Dumée et Malinvaud, 58, 64.

Dunn, Louise B., 100.

Ebenaceae, 254.

Ebenales, 254, 269.

Egg, 93, 145: apparatus, 93 ; rest of, 169.

Ehrarta panicea, 98 .

Eichhornia, 80, 94, 95, 135, 136; crassipes, $73,81,135,170$.

Eichler, A. W., 8, 15, 51, 52, 227, 241.

Elaeagnaceae, 250.

Elaeocarpaceae, 249.

Elatinaceae, 249.

Elatine hexandra, 125.

Elmore, C. J.. 218.

Elodea, 157, 170 .

Elfving, F., 124, 132, 148.

Embryo, 187; Alisma type, 188; Angiosperms and Gymnosperms contrasted, 2; Capsella type, 199: degree of development, 205 ; departures from type, 195; Lilium type, 193; Monocotyledons and Dicotyledons contrasted, 4, 7 ; of Dicotyledons, 196; of Monocotyledons, 188; Orchid type, 194; origin of, 144; Pistia type, 192.

Embryo-sac, chambered, 175, 176; enlargement of, 103, 109; number of, 86; nutritive jacket, 103, 109 ; nutritive mechanism, 108.

Embryonal vesicle, 143.

Empetraceae, 248.

Enantioblastae, 236.

Endlicher, S. L., 52, $22 \bar{\imath}$.

Endosperm, 16.5; continuation of growth. 17s: displaced by embryo, 174; division of, 169 ; feeble development of, 171; function of, 179; morphological character of, 181 ; nature of, 183: nature of tissue, 178; nuclear fusions, 172: nucleus, 89, 166: origin by free nuclear division. 172; origin by wall-formation, 174 . 
Endothecium, 34.

Endymion, 158; nutans, 156.

Engler, A., 8, 10, 11, 25, 30, 32, 227, $2 \cdot 28,233,234,240,212,252,274$.

Epacridaceae, 253, 269.

Epigaea, 53.

Epigyny, 14.

Epilobium, 122.

Epipactis, 194; palustris, 193.

Equisetum, 306; telemateia, 15'.

Erianthis, 99, 281; hiemalis, 206.

Ericaceae, 41, 157, 253.

Ericales, 253, 268, 271.

Erigeron, 151, 156, 158, 169; philadelphicus, 169 .

Eriobotrya, 59, 85, 87, 96, 101.

Eriocaulaceae, 56, 235, 264, 266, 276.

Ernst, A.. 89, 90, 159, 160, 193, 215, $219,222$.

Erodium, 103.

Ervum Errilia, 204.

Erythraea Centaureum, 42.

Erythrina cristagalli. 204.

Erythronium. 25, 53, 64, 77, 135 , 136, 146, 151, 193, 215; albidum, 215; americanum, s1, 21\%, 2.2.; dens-canis. 2:2.

Erythroxylaceae, 247 .

Eucalyptus. 27\%. 278 .

Eucryphiaceae, 249.

Euonymus, 53; americanus, 221 ; latifolius, 213 .

Euphorbia, 94. 136, 151; corollata, 33, 49, 74. 126, 129; dulcis, 217; Lathyrus, 125.

Euphorbiaceae, 63, 97, 247.

Exarch, 300.

Exine, 131.

Fagaceae, 243, 278 .

Fagales, 243, 268.

Fagus, 59, 87, 110, 147, 151; sylvatica, 105,147 .

Familler, I., 8.

Famintzin, A., 18s, 196.

Farinales, 235, 264, 276.

Farinosae, 235.

Fatsia japonica, if.

Faull, J. H., 299.

Female gametophrte, 7 : development of. 87 : tetrad. 71 ; irregularities in, 91: nuclei, 153.

Ferraris, T., 94, 99, 104.
Fertilization, 143; double, 155, 156, $160,180,18.2$; generative and vegetative, 159 .

Ficaria ranunculoides, 125, 1:9.

Ficus, 131; hirta, 212.

Filicales, 28 i.

Filiform apparatus, 94.

Fischer, A., 55, 58, 61, 64, 71, 77, 92, 98.

Flacourtiaceae, 249.

Flagellariaceae, 235, 264.

Floral leaves, origin of, 9 .

Flower, 8; bisporangiate, 21; "coalescence," 12; definition of, 9 ; "dioecious," 20; hypogyny to epigrny, 13; morphology of members, 2.2 ; naked to differentiated calyx and corolla, 10; organogeny, 16; primitive $r s$. reduced, 10 ; spiral to cyclic, 11 ; symmetry, 15.

Focke. WV. O., 179.

Fol, H., 154 .

Forsythia, 103.

Fossil angiosperms, 272.

Fouquieraceae, 249.

Foureroya, 131.

Fovilla, 132.

Fragaria, 199.

Frank, A. B., 309.

Frankeniaceae, 249.

Fritillaria, 77 ; imperialis, 81 ; Meleagris. 81,156 ; persica, 123 ; tenella, 156.

Frye, T. C., 37, 39, 55. 61, 74, 82, 85, 92, 102, 105, 122, 124, 12, 134 , $135,157,159,167,169$.

Fuchsia, 63, 125.

Fullmer, E. L., 33, 74, 126, 135.

Funaria, 246.

Funkia, 64, 7,215 ; ovata, 125, 213, $21\}, 221$; Sieboldiana, 81.

Fusion, behavior of chromatin during. 153; of sexual nuclei, 153; triple, 158.

Fusion nucleus, 166; division of, 169.

Gager, C. S., 124.

Galanthus nivalis, 42.

Galega orientalis, 204.

Galeopsis angustifolia, 42 .

Galieae, 97, 102, 104, 111, 113.

Galium, 108. 
Galtonia. 77; candicans, 81, 82.

Gametoplyte, 4:2; Angrosperms and Gymnosperms contrasted, 2; female, 71 ; male, 121 .

Ganong. W. F., 14, 214. 221.

Garcinia, 42.

Gaura, 30.

Geissolomaceae, 250.

Generative, cell, 133; fertilization, 182; nucleus, 132, division of, 13.5.

Gentiana, 50.

Gentianaceae, 255, 269.

Gentianales, 255, 269.

Geographic distribution, 261.

Geraniaceae, 20, 131, 247.

Geraniales, $24 \%$.

Geranium, 200.

Gesneraceae, 256, 269.

Geum, 5s, 199.

Giltay, E.. 179.

Ginkgo, 307; biloba, Fig. 111.

Ginkgoales, anatomy of, 30 -

Gladiolus, 99, 104.

Glaucium luteum, 221.

Gleichenia, 302: flabellata, 300, Fig. 108.

Globularia, 103, 176: cordifolia, 4?, $10 \%$.

Globulariaceae. 256, 269.

Gloriosa, 31.5.

Glumales. 230, 231, 264, 275.

Glume, 231.

Glumiflorae, 230.

Gnetales, anatomy of, 310.

Gnetum, S8, 90, 91, 283, 284, 28.5, 286, 310; Gnemon, 310, Fig. 113.

Goebel, C., 8, 9, 15, 20, 21, 28, 30, $33,34,43,64,122,131,133,147$, $196,206,221$.

Goldflus, Mlle. M., 111.

Golinski. St. J., 136, 137.

Gomortegaceae, 245.

Gomplirena, 91, 92.

fronyanthes candida, 170, 213.

Conystylaceae, 249.

Coodeniaceae, 259, 270 .

Groodyera, 193, 194.

Grainineae, 57, 63, 77, 98, 104, 109 , $112,113,157,174,205,230,265$, 275 .

Gray, A., 8.

Grebel, Dr., 213.
Grubbiaceae, 243.

Guignard, L.., 30. 33, 38, 39, 59, 60, $61,62,63,64,65,71,77,80,81$, $82,84,85,86,87,89,90,94,95$, $96,97,98,99,101,104,105,12 \cdot 2$, $133,136,147,151,153,154,155$, $156,157.158,159.165,169,170$, $172,178,150,202,203,204,216$, 217. 221 .

Gunnera, 89. 99, 166, 313.

Guttiferae, 249.

Gymnadenia, 77, 92, 94, 95; conopsea, $64,82,148,19 \%, 217,221$.

Grmnosperms, comparative anatony of, 296; contrasted with Angiosperns. 1: embryogeny of, 2: gametophyte of, 3 ; sporophyte of. 2 .

Gynoecium, 24.

Gynostemium, 238.

Habenaria. 315: blephariglottis, 195; tridentata. 195.

Haemodoraceae, 236, 264, 266.

Hall, J. G., 63, 77, 92. 95, 146, 167, $171,175,192.215,216,222$.

Hallier, H., 282.

Haloraghidaceae, 250, 312.

Halsted, B. D.. 136.

Hamamelidaceae, 246.

Hamamelis. 30,41 ; virginiana, $14 i$.

Hanausek. T. F., 221.

Hanstein. J., 18s, 196, 198.

Hartig. Theodore, 145.

Hartog. M., 2.s.

Haustoria, 104, 109. 202.

Hautschicht, 9.5.

Hebenstreitia, 17\%.

Heckeria, 79, 90, 101. 167, 170, 178, $179,201$.

Hedysarum coronarium, 203.

Hegelmaier, F., 102, 178, 192, 206 , $207,217.218,221$.

Heleocharis palustris, 128 .

Helianthemum, 61, 122.

Helianthus annuus. 15.5, 156.

Heliconia. 171 .

Helleborus, 64, 84 : cupreus, 60 ; foetidus, 82. 1.5ti.

Helobiales. 171, 239. 231, 234, 263, $275,287$.

Helosis, $79,95,103$. 16fi: guayanensis, $91,92,218$. 
Hemerocallis, 64, 76, 77, 104, 135 ; fulva, $33,74,125,126,1 \leq 9$.

Hepatica, 30, 38, 53, 94, 99, 100.

Hernandiaceae, 245.

Hesperis, 136.

Heterangium, 300, 301, 302; Grievii, 300, Fig. 109.

Hibiscus, 156.

Hicoria, 148.

Hill, T. G., 99, 192.

Himantoglossum, 156; hircinum, 82 .

Hippeastrum aulicum, 148.

Hippocastanaceae, 248.

Hippocrateaceae, 248.

Hippuris, 55, 64.

Hofmeister, W., Is, $32,47,48,49$, $51,53,71,94,101,106,125,132$, 143, 146, $14 \bar{\tau}, 148,176,178,181$, $206,221,222$.

Holferty, G. M., 63, 76, $77,78,96$, $176,192$.

Holm, Theodore, 282.

Homalomena, 263.

Hooker, J. D., 2:27.

Houstonia, 55, 202.

D'Hubert, E., 79, 108, 147, 151.

Humiriaceae, 247.

Humphrey, J. E., 64, 77, 104, 154, 171. 173, 192.

Hyacinthus orientalis, 74,75 .

Hydnoraceae, 244.

Hydrocaryaceae, 250.

Hydrocharitaceae, 157, 171, 229, 230, $263,265,275$.

Hydrophyllaceae, 176, 256, 269.

Hydrostachyaceae, 246.

Hypericum, 24; calycinum, 18.

Hypogyny, 13, 14.

Hypophysis, 188, 198.

Icacinaceae, 248.

lkeda, T., 77, 96, 99, 104, 111, 112, $153,157,158,174$.

Impatiens, 131, 205.

Integument, 53.

Intine, 131.

Iridaceae, 64, 236, 264, 265, 276.

Iris, $77,99,155$; sibirica, 217, 221; squalens, 81 ; stylosa, 64.

Irmisch, T., 206.

Isobilaterality, 16.

Isoetaceae, 285.

Isoetes, 196, 284, 285, 287.
Jasminum, 95.

Jeffersonia, 64, 76, 84; diphylla, 101. Jeflrey, E. C., 214, 215, 222, 281, $296,297,298,300,301,303,304$, $305,308,309,311,312$.

Johnson, D. S., 79, 89, 90, 101, 104, $105,136,137,153,166,167,168$, 170, 176, 17s, 179, 200, 201, 242.

Johnson, T., 47, 5.5.

Jönsson, B., 221.

Jordan, K. F., 293.

Juel, H. O., 73, 74, 76, 80, 82, 92, $101,124,126,128,129,14 \bar{\imath}, 166$, $170,201,211$.

Juglandaceae, 46, 157, 243, 278, 284. Juglandales, 243, 268.

Juglans, 91, 146, 147, 148, 150, 156, $15 \bar{i}, 158$; cinerea, 149 ; cordiformis, $60,79,84,87$; nigra, 92,96 ; regia, 90,149 .

Juncaceae, 236, 264, 265, 276.

Juncaginaceae, 196，229，230，263, $265,275$.

Juncagineae, 171.

Juncus, 121.

Jurassic Monocotyledons, 273.

Justicia, 131.

Kamienski. F., 206.

Karsten, G., 60, 79, 84, 87, 91, 92, $96,157,158,284$.

Kauffmann, N., 28.

Kerner, A., 42.

Klebs, G., 288, 289.

Koch, L., 80, 206.

Koeberliniaceae, 249.

Kölliker, A., 292.

Körnicke, F., 180.

Koernicke, M., 63, 81, 137.

Korschinsky, S., 292.

Labiatae, 16, 24, 104, 106, 176, 256, 269, 271.

Labiatales, 258.

Lacistemaceae, 242.

Lactoridaceae, 245.

Land. W. J. G.. 29, 82, 151, 155, 156, 160, 169. Figs. 35 and 36 .

Lang, F. X., 107, 108.

Lang. W. H., 288, 289.

Lappa. 122.

Lardizabalaceae, 245, 267.

Larix europaea, 15\%. 
Lathyrus, 136; heterophyllus, 204; odoratus, 204.

Lauraceae, 245,267 .

Laurus, $2 \pi$.

Lawson, A. A., 129.

Leaves, Monocotyledons and Dicotyledons contrasted, 5, 6 .

Leavitt, R. G., 193, 194.

Lecythidaceae, 250 .

Leeuwenhoek, A., 213.

Leguminosae, 15, 16, 20, 55, 65, 97, $174,202,246,267,279$; embryos of, 202 .

Leguminosites, 277 .

Leitneriaceae, 242 .

Leitneriales, 242.

Lemna, $10,30,39,63,7 \tau, 92,95$, $103,136,167,193$; reduced flowers, 10 ; minor, 37,40 .

Lemnaceae, 233, 234, 263, 265.

Le Nonnier, G.. 181, 182.

Lennoaceae, 253.

Lentibulariaceae, 256.

Lepidium, 157 .

Leptosiphon, 103.

Leucojum vernum, 81 .

Lilaea, 28, 46, 99; subulata, 27, 47, $196,285$.

Liliaceae, 64, $76,82,97,103,109$, $157,174,193,209,236,264,265$, $274,276$.

Liliales, 236, 264, 276.

Liliiflorae, 236.

Lilium, 25, 41, 58, 64, 73, 77, 80, $81,84,95,97,104,123,134,135$, $136,137,146,151,157,159,161$, $169,193,195$; type of embryo, 193; auratum, 13\%, 138; candidum, 61, 81, 86, 130, 131, 153, 154; croceum, 81: Martagon, 81, 1?2, $130,15 \%, 156,158,22]$; philadelphicum, 29, 5/, 61, 81, Figs. 35 and $36,88.135,157,160,193$; pyrenaicum, 156; tigrinum, 16, 81, $13 \%, 135,157$.

Limnanthaceae, 248.

Limnocharis, 63, $77,92,95.167,171$, 175. 176, 192; emarginata, 146 , $215,216,222$.

Linaceae. 247 .

Linum. 103.

Liriodendron. 27,27 .

Listera, 194; ovata, 82, 193, 194 .
Lloyd, F. E., 55, 58, 61, 80, 82, 85, 86, 97, 101, 102. 104, 108, 202.

Loasaceae, 176,249 .

Lobelia, 80, 103, 111 .

Lobeliaceae, 24, 30, 48, 58, 106, 110.

Loganiaceae, 25.5, 269.

Longo, B., 150.

Lonicera, S0; coerulea, 125.

Loranthaceae, 55, 65, 97, 104, 110, $176,243$.

Loranthus, 50, 61, 85, 86, 91, 92, 97, 17\%; europaeus, 221, pentandrus, 49, 200\%; sphaerocarpus, 45, $50,199,200$.

Lotsy, J. P., 28, 34, 48, 49, 50, 5l, $79,92,136,166,218$.

Luerssen, C., 131.

Lupinus, 202, 204; luteus, 205 ; mutabilis, 205; pilosus, 205; polyphyllus, 205; subcarnosus, 205; truncatus, 205.

Lychnis, 21.

Lycium, 80.

Lycopodiales, 286.

Lyginodendron, 301，302，303，305, 306; Oldhamium, 301, 302, Fig. 110 ; robustum, 302.

Lygodium, 300.

Lyon, F. M., 49, $74,94,100,126$, $129,136,151$.

Lyon. H. L., 169, 201, 207, 208, 282.

Lysichiton, 63, 192; kamtschatcense, 98, 192 .

Lythraceae, 104, 110, 250.

Magnolia, 277.

Magnoliaceae, 245.

Magnus, P., 28.

Malıonia indica, 64.

Maize, xenia, 180.

Male cells, 136; not concerned in fertilization. 161.

Male gametophyte, 121.

Male nucleus, $136,152,15 \pi, 166$; change in size and form, 152; fusion. 153; its part in fertilization, 160 ; movements of, 157 ; vermiform, 161.

Malesherbiaceae, 249.

Malpighi. M., 143.

Malpighiaceae, 247 .

Malva, 38.

Malvaceae, 33, 131, 15`, 249. 
Malvales, 249, 26i.

Mangifera indica, 221.

Marantaceae, 171, 237, 264, 266.

Marattiaceae, 301.

Maregraviaceae, 249.

Marié, M., 312.

Martyniaceae, 256 .

Massula, 39.

Mayacaceae, 235, 264, 266.

Medicago, 104; falcata, 204.

Medinilla, $\{$ ?

Medullosa, 301, 302; anglica, 301, Fig. 110: Solmsi. 301, Fig. 110; stellata, 301.

Megasporangium, 46; archesporium of, 5\%: cauline, 46 ; mother-cell, 66: parietal cells, 62; time of development, 52.

Megaspore, 71 : germination of, 87 ; number of, $i 6$ : the functional, 84 .

Melastomataceae, 250, 268.

Meliaceae, $24 \overline{6}$.

Melianthaceae, 248.

Melissa officinalis, $\{$ ?

Mellink, J. F. A.. $71,84$.

Menispermaceae, $\mathbf{2 4 5}$.

Menispermites, 2 $\pi$.

Mentha, 38; aquatica, 32, 33.

Menyanthes, 103: trifoliata, 32.

Merrell, W. D., 34. 35, 82, 101, 103, 136, 137, 151, 158, 199.

Mertensia, 136.

Mesembrianthemum, 63.

Metamorphosis, 8, 10, 22.

Mettenius, G. H., 304, 305 .

Microspermae, 238.

Microsporangium, 27: archesporium, 32: cauline, 28: development of, 32 ; mother-cells, 38 ; number of, 29 ; parietal layers, 34 ; tapetum, 36 ; tine of formation. 30.

Microspores, 121: germination of, 132 ; number of, 125; wall of, 131.

Mimosa, 203, 24i, 267, 268, 279; Denhartii, 216. 221.

Mimoseae, 30, 33, 132.

Mirbel, C. F., 56.

Mohl. H. von. 145 .

Monimiaceae. 24.5.

Monocotyledons, 4, 11; anatomy of, 314 ; clasification of. $22 \pi$; cyclic number of, 5 ; embryo of, 4,7 ,
188; fossil, 272; in Carboniferous, 273 ; in Cretaceous, 273 ; in Jurassic, 273; in Tertiary, 275; geographic distribution of, 262 ; leaves of, 5. 6; phylogeny of, 281; prophyllum of, $\tau$; roots of, 7 ; seed germination, 6 ; vascular bundles of, 4 .

Monotropa, 148, 158, 206; Hypopitys, 145. 156; uniflora, 96, 102, $147,153,157,159,167$.

Monotropaceae, 176 .

Moraceae, 243, 278.

Moringaceae, 246.

Morus albus, 221.

Mother-cell, of megasporangia, 38; of microsporangia. 38 .

Mottier. D. M., 52, 60, 61, 62, 76 , $77,78,82,84,87,94.99,101,103$, $124,129,130,134,136,146,153$, 154, 169, 199.

Murbeck, S., 55, 58, 59, 79, 82, 87 , $93,96,104,150,175,196,211,212$, 218, 219, 221, 285.

Musaceae, $171,237,264,266,276$.

Muscari neglectum, 81.

Mutation theory, 292.

Myoporaceae. 256.

Myoporum, 103, 200; serratum, 201.

Myosurus, 64, 99.

Myrica, 277.

Myricaceae, 242.

Myricales, 242.

Myristica, 53.

Myristicaceae, 245.

Myrothamnaceae, 246.

Myrsinaceae, 254. 269.

Myrsinophỵllum, 27T.

Myrtaceae, 201, 250, 268.

Myrtales, 250.

Myzodendraceae, 243.

Myzodendron, 105, 110; punctulatum, $4 \bar{i}, 55$.

Nägeli. C., 32 .

Naiadaceae, 9i, 15i, 171, 229, 230, $263,265$.

Naias, 28, 41, 46,133,171, 192; flexilis, $2 \gamma$; major, $81,15 \%, 165,170,216$, 221.

Nareissus, 77. 99, 156.

Nawaschin, S.. 90, 146, 148, 149, 150, $155,156,180$. 
Nelumbo, 169, 201, 20i, 208.

Nêmec, B., 74, 75 .

Nemophila, 136, 176.

Neottia, 131, 133; nidus-avis, $\$ 2 ., 122$; ovata, 35,39 .

Nepenthaceae, $246,26 \mathrm{~s}$.

Nicotiana, s0, 96, 97, 15i, 15s; Tabacum, 136, 147, 151, 158.

Nigella, 99, 15l, 15s; damascena, 157,159 ; sativa, 156.

Nolanaceae, 256, 269.

Jothoscordon fragrans, 213, 221.

Nuphar, 50, 176; lutea, 208.

Nyctaginaceae. $96,97,244$.

Nyctandra, $\{$.

Nymphaea, 9, 22, 23, 50, 53, 176, 201, 207; alba, 8.2.

Nymphaeaceae, 103, 110, 176, 245, $282,312,313$.

Obolaria. 50.

Ochnaceae, 249.

Oenothera, 104; Lamarckiana, 292; lata. 293.

Olacaceae, 243.

Oleaceae, $9 \overline{7}, 255$.

Oliniaceae, 250.

Oliver, F. WV., 55, 80, 85, 95, 106, $109,111,134,148,169,17 \overline{6}, 178$, 199.

Onagraceae, 30, 97, 131, 250, 267.

Onobrychis petraea, 204.

Ononis, alopecuroides, 204; fruticosa, 204.

Opiliaceae, 243.

Opuntia, tortispina, 214; vulgaris, 214, 2-21.

Opuntiales, 250.

Orange, 213.

Orchid, 195: type of embryo, 194.

Orchidaceae, $1 \overline{5}, 30,58,64,97,103$, $113,132,136,147,157,171,194$, 20ti. 234, 23s, 266.

Orchidales, 23s, 264, 276 .

Orchis, 51, 77,145 . 156; latifolia, $1 \%$, 1.5; maculata, $33,38,39$, 1\%; mascula, 82, 121, 126; Morio, $1 \% \%$ 145, 221; pallens, 64.

Organogeny of flower, 16 .

Ornithogalum, 64, 97. 99; nutans, 91 ; pyrenaicum, 61.

Orobanchaceae, 176, 206, 256, 269.

Orobanche, 80.
Orobus angustifolius, 65, 20.'; aureus, 204 .

Osmunda, 302, 303; cinnamomea, 295, 299, Fig. 109; Claytoniana, 295, Fig. 10s; regalis, 299.

Osterwalder, A., 99, 100, 111, 221.

Osyris, 10.5 .

Ovary, 24, 26.

Overton, E., $71,221$.

Overton, J. B., 63, 64, 81, \$2, 94, $100,170,199,212$.

Ovulary, 24.

Orules, foliar, 50; morphological nature of, 5l; development of, 53; forms of, $\bar{j} 6$.

Oxalidaceae, 247 .

Paeonia spectabilis, 82.

Palet, 231.

Palmaceae, 231, 262, 266, 274, 275.

Palmales, 231, 262, 275.

Pandanaceae, 228, 262, 266, 273, 275.

Pandanales, 228. 231, 262, 275.

Papaver, 136; orientale, 65.

Papaveraceae, 65, 246.

Papilio. 247. 267.

Parietales, 249.

Paris quadrifolia. 159, 160.

Parthenogenesis, 210.

Passiflora, 131.

Passifloraceae. 249.

Payer. J. B., 16, 20.

Péchoutre, F., 59. 199.

Pedaliaceae, $97,106,110,176,177$, 256, 269.

Pedicularis, 106.

Penaeaceae, 250.

Pentaphyllaceae, 248.

Peperomia, 79, 8., 90, 136, 137, 153, $178,179,200$; pellueida, 89, 166, $168,178,200,242.284$.

Pepo macrocarpus, 143.

Perigsny. 13. 14.

Perisperm, 103: function of, 179.

Peristylis grandis. 194.

Personales. 15, 24, 258.

Petasites, 101.

Petit-Thouars, 213.

Peucedanites, $27 \%$.

Pfeffer, W.. 19.

Pfitzer. E., 194.

Phajus. 156.

Phalaenopsis grandiflora, 194. 
Phaseolus, 179, 208; multiflorus, 204.

Philydraceae, 235, 264.

Phlox Drummondii, 113.

Phyllocactus, 108.

Phragmites, 275.

Phrymaceae, 256.

Phylloglossum, 300.

Phyllosiphonic, 298.

Phylogeny of Angiosperms, 280.

Phytelephas, 178, 231, 262.

Phytolacea, 179 .

Phytolaceaceae, 103, 179, 244.

Pinguicula vulgaris, 4 .

Pinus, 160; Strobus, 112, 309.

Piper, 79, 90, 167, 178; medium, 168.

Piperaceae, 46, 56, 79, 103, 178, 179, 201, 242.

Piperales, 242, 28\%.

Pirolaceae, 253.

Pirotta, R., 150.

Pirus Malus, 15, 221.

Pistia, 178, 192, 195, 201, 263, 275; type of embryo, 192.

Pistil, 25.

Pisum sativum, 204.

Pittosporaceae, 246.

Placenta, 25.

Plantaginaceae, 102, 106, 176, 258, 271 .

Plantaginales, 258, 269.

Plantago, 269; lanceolata, $10 \%$.

Platanaceae, 246.

Plumbaginaceae, 254.

Poacites, 275.

Podophyllum, 53, 282, 313; peltatum, 31, 82. 12\%.

Podostemonaceae, 246.

Polar nuclei, 92; fision of, 95.

Polemoniaceae, 103, 256, 269.

Polemoniales, 258.

Pollen mother-cell. division of, 126

Pollen-tube, 143: branching of, 148 ; development of, 146; discharge of, 152: entrance into sac, 151: in cleistogamous flowers, 146: Propfen, 148: time between pollination and fertilization, 146.

Pollination, relation to endosperm, 169.

Pollinium, 132.

Polyembryony, 213.

Polygalaceae, 104, 110, 247.
Polygonaceae, 46, 56, 179, 244, 267.

Polygonales, 244.

Polygonum, y4; divaricatum, 94.

Polypompholyx, 10s.

Polystelic, 297.

Pontederia, 104, 146, 151; cordata, 81.

Pontederiaceae, $34,37,63,77,78$, $97,23.5,264,265$.

Populus, 52, 133, 277, 278; monilifera, 30,31 ; primaeva, 276 ; tremuloides, 60.

Portulaca, 143.

Portulacaceae, 244.

Potamogeton, 63, 76, 77, 96, 97, 104, $136,176,192$; natans, 78 ; foliosils, $33,62,78$.

Potamogetonaceae, 229, 230, 234, 263, 265, 274, 275 .

Potentilla, 18.

Pothos longifolia, 148.

Potonié, H., 300, 303, 308, Fig. 110.

Prantl, K., 8, 56.

Primula farinosa, 312 .

Primulaceae, 19, 103, 254, 269.

Primulales, 254, 269.

Principes, 231.

Pringsheim, N., 285.

Proangiosperms, 27 7 , 281, 283, 286.

Proembryo, 188.

Propfen, 148.

Prophyllum, Monocotyledons and Dicotyledons contrasted, 7 .

Proteaceae, 131, 243, 268, 278.

Proteales, 243.

Proteopliyllum, 277.

Protocorm, 209.

Protolemna, 275.

Protostelic, 297.

Prunus C'erasus, 125.

Pseudo-monocotyledons, 206.

rseudo-polyembryony, 221.

Psilotum triquetrum, 15!.

Pteridophytes, anatomy of, 296.

Pteris aquilina, 29 $\overline{7}, 298,301,303$, Fig. 108.

Punicaceae, 250.

Purkinje, J. E., 34.

Pyrethrum. 85, 87; balsaminatum, 61.

Pyrola rotundifolia, 42; secunda, 206; uniflora, 42.

Pyrolaceae, 176. 
Quereus, 34, 66, 79, 94, 147. 148, 208; Robur, 147; velutina, 31,58 , 60 , 147.

Queva, C., 281, 315.

Quiinaceae, 249.

Rafflesiaceae, 244.

Ramondia pyrenaica, 42 .

Ranales, 245. 28\%.

Ranunculaceae, 21, 60, 64, 7s, 84, 99, $102,111,153,157,158,169,245$, $267,282,312$.

Ranunculus, $11,16,36.37,51,55,64$. 78. 87. 100. 131, 136, 151, 158, 170, 199. 311, 312; flowers of, 11, 16; abortirus, 60: acris, 312, 313. Fif. 11.3; Cymbalaria. 15\%; Ficaria, 206, 207, 282; Flammula, 156; multifidus, 65,88 ; septentrionalis, 61.

Rapateaceae. $235,264$.

Ray, John, 227.

Reichenbach, H. G., 132.

Renault, B., 30 s.

Reseda, 20, 156: odorata, 173 .

Resedaccae, 57, 157, 246.

Restiaceae, 56.

Restionaceae, 235, 264, 276.

Reversion, 22.

Rhamnaceae, 249.

Rhamnales, 249.

Rhinanthus, 106.

Rhizophoraceae, 250.

Rhododendron, 132.

Rhoedales, 246.

Rhopalocnemis, 79. 92, I36; phalloides, $28,34,49,51$.

Ricinns, 24, 179.

Riddle, Lumina C., 63, 65, 199.

Rolsinia, 147.

Rohrbach, P., 28.

Romulea, 94, 99, 104.

Root, Monocotyledons and Dicotyledons contrasted, $\pi$.

Rosa, 18, 84, 87, 221, 247; livida, 58, 221.

Rosaceae, 59, 60, 62, 63, 87, 199, 246, 267,279 .

Rosales, 246.

Rosanoff, S.. 33. 132.

Rose, J. 亡.., 13.̄, 136.

Rosenberg, $0 ., 36,37,74,77,81,122$, 124. liubiaceae, $18,58,61,80,97,102$,

$111,113,20: 2,25 !), 2(i !)$.

Riubiales, 259. 269.

Rubus, 1s, 59.

Rudbeckia speciosa, 156.

Rumex, 21: Patientia. 125.

Ruppia, 196, 285; rostellata, 175.

Ruta, 97; graveolens, 62 .

Rutaceae, 20, 247.

Sabiaceae, 248.

Sachs, J., 15.

Sagittaria, $96,104,135,136,137,169$,

175,176 ; variabilis, $152,154,175$,

185, 189,191 .

Salieaceae. $97,243$.

Salicales, 242.

Salix, 52, 60. 87, 94, 136, 151, 199, 27,278 ; glaucophỵlla, 30, 58, 79 , 9.5 ; petiolaris, $28,5 \pi .95$.

Salvadoraceae. 255. 269.

Salvia, 95, 97: pratensis, 85.

Sambueus, 136.

Sanguisorba, 58 .

Santalaceae, 55, 105. 110, 176, 243.

Santalales, 243.

Santalum, 91. 94. 10.5: album, 221.

Sapindaceae, 20, 245.

Sapindales, 248.

Sarcodes, 25, 80, 97, 134, 169, 178, 199 ; sanguinea, 148.

Sargant, Ethel, 73, 81, 8.2, 15i, 182, $207,20 ! 9,281,282$.

Sarraceniaceae. $246,268$.

Sarraceniales. 246 .

Sassafras, 41,27 .

Saururaceae. 97. 104, 109, 176, 24?.

Saururus, 79, 104, 110, 176, 179; cernums, 10\%. 105.

Saxifraga caespitosa. 125.

Saxifragaceae, 5?. 97. $246,267$.

Seaevola, 103.

Schacht. H., 55, 94, 131, 143, 144. 145. 221.

Schaffner. J. H., 28, 38, 53, 63, it, 77, 81, 88, 96, 121, 126. 133. 135. 136. 137. 138, 146, 151, 152, 153, 154. 169. 175, 18\%, 189, 191. 193, 215.

Sehleiden. II. .T. 9. 52, 55, 144, 145.

Schlotterbeck. M., 106.

Sichmicl. 13.. 201:.

S'chnegg. 11., 89, 90, $1 \mathrm{co}$. 
Schniewind-Thies. .J., $77,81,84$.

schrankia uncinata, 2:21.

Schwere, S., 102, 199, 216, 221.

Scilla, 64, 84, 156; non-scripta, 81; -ibirica, $\$ 1$.

sicitaminales, $237,264,2 ; 6$.

Scitamineae, $5 \overline{7}, 64,77,97,103,104$, $109,171,192,237$.

Scrophularia nodosa. $16,125$.

ficrophulariaceae, 96, 97, 103, 106, $110,176,256,269,271$.

-cleranthus ammus, 125.

scott, D. H., $288,300,301,302,303$, 304, 305, 306, 307, Fig. 110.

Scytopetalaceae, 249.

sedmon, 51.

Seed, Monocotyledors and Dicotyiedons contrasted, 6.

relaginaceae, 176,177 .

Felaginella, 28.5, 28̄; ; laegivata, Fig. 108.

Senecio, 87, 101, 169, 199.

Seward, A. C., 273, 302; aureus, 61.

Sherardia arvensis, 101 .

Shibata, K., 96, 102, 147, 148, 153, $157,159,167$.

Shoemaker, D. N., 30, 147.

sibbaldia procumbens, 42 .

silene, 94.

Silphium, 34, 101, 103, 136, 137, 151, 156, 158, 160, 199; integrifolium, 35, 82; laciniatum, 82, 155.

Simarubaceae, $24 \overline{7}$.

sinningia Lindleyana, 221.

Siphonostelic, 297 .

Sium, 65, 94, 96, 103, 199; cicutaefolimm, 79.

Sisvrinchium, 7 ; ridifolium, 64 .

Smilax, 274; herbacea, Fig. 113.

smith, Amelia C., 80, 170, 206.

smith, Arma, 30.

smith, R. WV., $34,37,63,73,77,78$, $80,81,94,95,135,136,146,151$, 170.

Snow, Laetitia M., 160.

Solanaceae, 136, 157, 176, 256, 269.

Solanum, 4l ; Lycopersicum. 12.

Solms-Laubach, H., 196, 206, 293.

sonneratiaceae, 250.

sparganiaceae, 98, 228, 262, 265, 275.

Sparganium, 112, 133, 192, 228, 229,

233 ; simplex, 47, 98, 135.

Spartium junceum, 203.
Spathe, 232.

spathitlorae, 233.

- pergularia rubra, 46.

spermacoceae, 202.

spermatozoids, $136,160$.

sperms, 136, l60.

spiral series, $11,228$.

spiranthes, 193.

Sporangia, foliar and cauline, $2 \overline{7}, 46$;

in winter, 30 ; periblem origin of, $2 \overline{7}, 46$.

Sporophyte, 4l; Angiosperms and Gymnosperms contrasted, 2.

Stachyuraceae, 249.

Stackhousiaceae, 248.

stamen, 23; morphology of, 22.

Staminodia, 24.

Stangeria paradoxa, 305.

Staphylea, 136, 1/5; pinnata, 172 .

Staphyleaceae, $248,278$.

Stellaria, glauca, 125; Holostea, 84.

Stemona, 266.

stemonaceae, 236, 264, 266.

Sterculiaceae, 249.

Sterzel, J. T., Fig. 110.

Stevens, WV. C., 124.

Stichneuron, 266.

Stigma, 25.

strasburger, E., $38,43,53,58,62,63$, $64,71,73,74,76,77,81,82,83,87$, $92.94,99,104,121,122,123,124$, $126,128,132,133,136,138,145$, $146,148,154,157,158,159,171$, $172,173,17 \%, 181.182,183,201$, $202,208,213,214,215,217,221$. 244, 294. 313.

Strelitzia, 171 .

Strobilus, theory of, 288.

Succisa pratensis, 293.

Suspensor, 113, 190, 192, 193, 194. 202.

Stylidaceae, 103, 106, 108, 110, 170.

Stylidium squamellosmm, 107, 113.

Styracaceae, 254.

Sympetalae, 97; classification of, 252; geographic distribution of, 268 .

Sympetaly, 13.

Symphytum officinale, 125.

Symplocaceae, 254.

Symplocarpus, $31,37,136$; foetidus, 315.

Synanthae, 232. 
Synanthales, 232, 263, 275.

-ynapsis, 126.

iynearpy, 13.

Fynergids, 91, 94; as an haustorium, 111: disorganization of, 151.

srringa, persica, 125; rulgaris, 125.

Taceaceae, 236, 264, 266.

Tamaricaceae, 249.

Tangl, E., 125.

Tapetum, 36 .

Taraxacum, 101, 102, 157, 199; officinale, $216,221$.

Tertiary, Dicotyledons, 278; Monocotyledons, 275.

Tetrads, $71,121,126$.

Tetragonolobus purpureus, 203.

Thalia dealbata, 171 .

Thalictrum, $63,64,78,94,199$; dioicum, 100; Fendleri, 212; purpurascens, $100,170,212$.

Theaceae. 249.

Theobroma Cacao, 42.

Thesium, 61, 105.

Thomas, Ethel M., 137, 152, 156, 157. 158.

Thuja occidentalis, 309, Fig. 112.

Thunbergia, 131.

Thymelaeaceae, 250, 268.

Tiliaceae, 249.

Tischler, G., 172.

Todea barbara, 299.

Torenia, 111, 136; asiatica, 104, 106.

Tovariaceae, $\mathbf{2 4 6 .}$

Tozzia alpina, $\{$.

Tracheid-like cells in nucellus, 100 , 109.

Tradescantia, 81, 135, 136; virginica, 63.

Trapa, 171, 205; natans, 206.

Trapella, 55, 80, 8.5. 95, 106, 110, 111, 177,199 : sinensis, 85.

Tremandiaceae, $24 \bar{\gamma}$.

Tretjakow, S., 217, 218, 221.

Treub. M., 49, 50, 59, 61, 64, 66, 71, 79. 80, 84, 85, 87, 91, 92, 149, 16ti, $16 \bar{i}, 170,193,194,199,200,201$, $212,213,218,221$.

Treviranus, 213.

Tricytis, 64, 77, 96, 99, 104, 158, 174: hirta. $77,111,112,153,157$.

Trifolium. pratense, 221 ; resupinatum, 203.
Triglochin, 63, 192; maritima, 99.

Trigoniaceae, 247.

Trillium, $30,64,77,86,89$; grandiflorum, $81,90,159$; reeurvatum, $52, \tau$ ?, 81 .

Triple fusion, 158,160 , 166; nature of, 182.

Triplochitonaceae, 249.

Triticum, 63, 136, 13i; vulgare, 81 .

Tritonia, $7 \tau$.

Triuridaceae, 229, 263, 266.

Triuridales, 229.

Trochodendraceae, 245.

Tropaeolaceae, $24 \overline{ }$.

Tropaeolum, 39, 171, 207.

Trophophylls, 282.

Tschireh, A., 106.

Tschistiakoff, I., 125.

Tube nucleus, 133; fragmentation of, 135 .

Tubiflorae, 256.

Tubiflorales, 256, 269.

Tulasne, L. R., 106.

Tulipa, 77, 89, 156, 193; Celsiana,

156; Gesneriana, 81, 215, 219, 222;

sylvestris, 90,156 .

Tumboa, 310.

Turneraceae, 249.

Tussilago, 101.

Typha, 28, 38, 63, 74, 77, 104, 121, 131, 133, 229, 233; latifolia, 28, 126.

Typhaceae, $97,228,262,265,275$.

Ulmaceae, 243.

Ulmus, 147, 148, 150, 151; montana, 150 ; pedunculata, 150 .

Umbellales, 251.

Umbelliferae, $15,16,55,65,79,97$, $251,267$.

Umbelliflorae. 251.

Unger, D. F.. 55.

Urticaceae, 56, 243.

Urticales, 243.

Utricularia, 206.

Utriculariaceae, 106.

Uvularia, 84.

Tacciniaceae, $176,177$.

Taceinimm, 80: Oxyeoceus, 12; uliginosum, $\{$ ?

Taillantia, 104, 111; hispida, 102, 202. 
Valerianaceae, 18, 259, 269.

Van Tieghem, Ph., 30, 49, 52, 92, $297,298,309$.

Vaseular bundles, Monocotyledons and Dicotyledons contrasted, 4.

Vegetative, apogamy, 210; fertilization, 182; nucleus, 132.

Velloziaceae, 236, 264, 266.

Verbenaceae, 80, 176, 17i, 256, 269.

Terticillatae, 242.

Tesque, J., 63, 65, 71, 77, 80, 84, 85, 86.

Viburnum, $27 \overline{7}, 27 \mathrm{~s}$.

Vicia narbonnensis, 204.

Tinea, 136.

Vincetoxicum, medium, 221; nigrum, $21 \bar{i}, 221$.

Viola, 25.

Violaceae, 249.

Viscum, 61, 97, 176, 206; album, 221 ; articulatum, 79,87 .

Vitaceae, 249.

Viticella, 156.

Vochysiaceae, 247.

Ward, H. Marshall, 58, 61, 63, 71, $76,77,80,87,92,94,148,194$.

Warming, E., 28, 32, 33, 51, 52, 53, 71 .

Webb, J. E., 19, 37, 39, 58, 59, 87, 108.
Webber, H. J., 180, 181.

Weber. M., Fig. $111 \%$.

Westermaier, M., 98, 99, 111.

Wiegand, K. M., 33, 62, 63, 64, 7 : $77,78,81,133,136,192$.

Wille, N., 121, 123, 124, 125, 15 $129,196$.

Williamson. W.. 301, 302, Fig. 11

Wimmel. Th., 125.

Wolffia, 234.

Worsdell, W. C., 303, 306, 308, 30

Wylie, R. B., 157, 170 .

Xenia, 179.

Xyridaceae, 56, 235, 264, 266.

Yucea, 63, 64, 77, 285; gloric 84.

Zamia, 305, 307; floridana, 304, j 111.

Zannichellia, 27, 28, 46, 51, 192, 285; palustris, 195 .

Zea, 94, 98, 153, 157, 158, 172, 17

Zingiberaceae, 171, 23 $, 264,26^{\circ}$

Zinger, N.. 56, 14s, 150.

Zizania, 315.

Zostera, $3 \bar{i}, 74,7 \pi, 122$; mari $81,124$.

Zygomorphy, 15, 16.

Zygophyllaceae, 20, $24 \overline{\text { }}$. 




\section{PLEASE DO NOT REMOVE CARDS OR SLIPS FROM THIS POCKET}

\section{UNIVERSITY OF TORONTO LIBRARY}


